\author{
Universidade de São Paulo \\ Faculdade de Medicina de Ribeirão Preto \\ Departamento de Biologia Celular e Molecular e Bioagentes Patogênicos \\ Programa de Pós-Graduação em Biologia Celular e Molecular
}

Danielle Pini Alves Mascarenhas

A ativação de caspase-8 no inflamassoma de Naip5/NLRC4 em resposta a infecção por Legionella pneumophila

Ribeirão Preto

2018 


\section{Danielle Pini Alves Mascarenhas}

A ativação de caspase-8 no inflamassoma de Naip5/NLRC4 em resposta a infecção por Legionella pneumophila

Tese apresentada à Faculdade de Medicina de Ribeirão Preto da Universidade de São Paulo para obtenção do título de Doutor em Ciências

Área de Concentração:

Biologia Celular e Molecular

Orientador: Prof. Dr. Dario Simões Zamboni

Ribeirão Preto 
Autorizo a reprodução e divulgação total ou parcial deste trabalho, por qualquer meio convencional ou eletrônico, para fins de estudo e pesquisa, desde que citada a fonte.

Mascarenhas, Danielle Pini Alves

A ativação de caspase-8 no inflamassoma de Naip5/NLRC4 em resposta a infecção por Legionella pneumophila, 2018. 256 p.: il. ; $30 \mathrm{~cm}$

Tese de Doutorado, apresentada à Faculdade de Medicina de Ribeirão Preto/USP. Área de concentração: Biologia Celular e Molecular.

Orientador: Zamboni, Dario Simões.

1. Inflamassoma. 2. NLRC4. 3. Caspase-8. 4. Legionella pneumophila. 5. Controle da replicação. 


\section{FOLHA DE APROVAÇÃO}

Nome: MASCARENHAS, Danielle Pini Alves

Título: A ativação de caspase-8 no inflamassoma de Naip5/NLRC4 em resposta a infecção por Legionella pneumophila

Tese apresentada à Faculdade de Medicina de Ribeirão Preto da Universidade de São Paulo para obtenção do título de Doutor em Ciências.

Aprovada em: 


\section{Agradecimentos}




\section{AGRADECIMENTOS}

Ao Prof. Dr. Dario Simões Zamboni por todos esses anos de ensinamentos e de trabalho juntos. Só tenho a agradecer por tudo que aprendi e vivi nestes anos de laboratório sob sua orientação. Muito obrigada por sempre ter confiado em mim e no meu trabalho.

Aos meus colegas antigos e atuais do Laboratório de Patogenicidade Microbiana e Imunidade Inata: Alexandre, Amanda, Augusto, Catarina, Daiane, Danilo, Djalma, Grace, Graziele, Gustavo (Caju), Fernanda, Jonilson, Juliana Issa, Juliana Magro, Larissa, Laís, Leonardo, Letícia, Leticia Corsi, Liliana, Lincoln, Lívia, Luís Henrique (Bera), Luiza, Maira, Marcelo, Mariana, Marisa, Natalia, Rafael, Renan, Renata, Robson, Talita, Tiago, Victor, Victoria, Vitoria, Warrison (Leitim) e Yasmin por toda ajuda e apoio, pelas discussões científicas e também pelas risadas que tantas vezes demos juntos. Um agradecimento em especial a aqueles que além de tudo me deram a sua amizade.

À Daiane, Marcelo, Fernanda, Talita, Graziele e Larissa por toda a colaboração neste trabalho. Bem como à Luiza por todo o suporte nas técnicas moleculares.

Um agradecimento em especial também à Maira, Catarina, Amanda, Lívia, Letícia Corsi, Laís, Victoria e Vitoria pelo apoio técnico. Nada do nosso trabalho seria possível sem o auxílio de vocês.

Aos professores Dr. José Freire Silva Neto e Dr. Célio Lopes Silva pela infraestrutura cedida para a realização de alguns experimentos.

À Gabriela secretária do Programa de Biologia Celular e Molecular por sempre estar disposta a ajudar.

Ao Domingos, Rubilan, Edir, Adriana e os outros responsáveis por cuidar dos biotérios de maneira tão eficiente e responsável, garantindo qualidade aos nossos experimentos.

À Roberta Costa Rosales e os responsáveis pelo Laboratório Multiusuário de Microscopia Multifóton (LMMM) por todo o apoio técnico e paciência para conseguirmos as melhores imagens.

Um agradecimento especial a todos os envolvidos na estrutura e administração do Departamento de Biologia Celular e Molecular e Bioagentes Patogênicos. Sem toda a infraestrutura deste departamento não teria sido possível a realização deste trabalho. 
Aos meus amigos: André, Gabriela, Flávia, Jéssica e Isa. E aos amigos emprestados: Bruno, Felipe (Alemão), Rodrigo (Camper), Otávio e todo o pessoal da Casa dos Caras. Estar com vocês torna tudo muito melhor, os problemas somem e a vida fica mais alegre e divertida. Obrigada por estarem sempre ao meu lado.

Acima de tudo à minha família, por estarem sempre ao meu lado incondicionalmente. Aos meus avós Djalma e Rosette, por serem um exemplo de integridade e caráter que quero seguir. Aos meus titios Fernando e Rosana, por serem meus segundos pai e mãe. Passei a minha vida me inspirando em vocês e não seria metade do que sou hoje se não fosse por vocês dois. Ao meu irmão Gabriel que me enche de orgulho e me impulsiona e dar sempre o meu melhor. E à minha mãe que sempre esteve ao meu lado, fazendo papel duplo de pai e mãe. Sua criação e amor por mim sempre me deram força para que eu fosse a melhor possível. Obrigada por me ajudar a levantar todas as vezes que cai.

Ao meu companheiro de tantos anos Felipe. Obrigada por fazer eu me sentir especial todos os dias e por compartilhar sua vida comigo. Tenho muita sorte de ter alguém como você ao meu lado.

\section{Agradecimentos à FAPESP - Fundação de Amparo à Pesquisa do Estado de São} Paulo

Agradeço à Fundação de Amparo à Pesquisa do Estado de São Paulo (FAPESP) pelo apoio financeiro concedido durante os quatro anos de desenvolvimento desse trabalho (processo 2014/00794-0). 


\section{$\underline{\text { Resumo }}$}




\section{RESUMO}

Mascarenhas, D. P. A. A ativação de caspase-8 no inflamassoma de Naip5/NLRC4 em resposta a infecção por Legionella pneumophila. 2018. Tese (Doutorado) Faculdade de Medicina de Ribeirão Preto, Universidade de São Paulo, Ribeirão Preto, 2018.

A bactéria Legionella pneumophila é um bacilo Gram-negativo, flagelado causador da doença dos legionários e febre de Pontiac. O inflamassoma mais importante no controle da replicação desta bactéria é o composto por Naip5/NLRC4, que é responsável pelo reconhecimento de flagelina. A ativação do inflamassoma de Naip5/NLRC4 pela flagelina induz a ativação de caspase-1, induzindo a formação de poros na membrana, piroptose e controle da replicação desta bactéria. A participação da proteína adaptadora ASC é essencial para a nucleação deste complexo e secreção de citocinas inflamatórias como IL-1 $\beta$ e IL-18 por esta via. Além do controle da replicação de $L$. pneumophila pelo inflamassoma NLRC4 dependente de caspase-1, foi demonstrado que existe uma via induzida por NLRC4 independente de caspase1/11. Dessa forma, camundongos e células N/rc4\% são mais susceptíveis à infecção por esta bactéria do que as células Casp $1 / 11 \%$. Neste trabalho, nós identificamos que a via independente de caspase-1/11 é composta por Naip5/NLRC4/ASC/Caspase-8 e é essencial para o controle da replicação de Legionella spp. flageladas em macrófagos e in vivo. Através da utilização de BMDMs Casp 1/11\% e Asc/Casp1/11\% transduzidos com NLRC4-GFP ou ASC-GFP, identificamos que a formação de punctas de NLRC4 e ASC dependem do reconhecimento de flagelina e que ASC é essencial para a formação desses punctas. Também foi identificado que a infecção com $L$. pneumophila que expressa flagelina leva à ativação de caspase-8 de maneira dependente de ASC e Naip5, mas independente de caspase-1/11. De acordo com esses dados, o silenciamento de caspase-8 em macrófagos Casp 1/11/ aumentou a susceptibilidade dessas células à infecção com $L$. pneumophila flagelada. Além disso, macrófagos e camundongos Asc/Casp 1/11/ foram tão susceptíveis quanto os N/rc4- e mais susceptíveis que os Casp 1/11\%. Nós observamos que o inflamassoma de NLRC4/ASC/Caspase-8 induz formação de poros e morte celular independente de gasdermina-D (GSDMD). Por meio da utilização de células de camundongos C57BL/6, foi observado que caspase-8 é recrutada para o inflamassoma de Naip5/NLRC4/ASC/Caspase-1. Entretanto, a ativação de caspase-8 só ocorre na 
ausência de caspase-1 ou GSDMD. Nossos dados sugerem que a ativação de caspase-8 no inflamassoma composto por NLRC4/ASC/Caspase-8 representa uma via alternativa que opera para garantir o controle da replicação de bactérias flageladas em situações nas quais ou caspase-1 ou GSDMD estão inibidas.

Palavras-chave: Inflamassoma; NLRC4; Caspase-8; Legionella pneumophila; Controle da replicação. 
Abstract 
ABSTRACT

Mascarenhas, D. P. A. The activation of caspase-8 by Naip5/NLRC4 inflammasome in response to Legionella pneumophila infection. 2018. Tese (Doutorado) - Faculdade de Medicina de Ribeirão Preto, Universidade de São Paulo, Ribeirão Preto, 2018.

Legionella pneumophila is a flagellated Gram-negative bacillus that is the causative agent of the legionnaire's disease and Pontiac fever. The most important inflammasome for the control of $L$. pneumophila replication is the Naip5/NLRC4, responsible for the flagellin recognition. The activation of the Naip5/NLRC4 inflammasome leads to caspase- 1 activation, consequently pore formation, pyroptosis and control of bacterial replication. The participation of the adaptor molecule ASC is essential for this complex nucleation and the secretion of inflammatory cytokines like IL-1 $\beta$ and IL-18 by this pathway. Besides the control of $L$. pneumophila replication by Naip5/NLRC4/Caspase-1 inflammasome, it was demonstrated there are NLRC4 responses independent of caspase-1/11. These explain why mice and macrophages NIrc4 ${ }^{-\%}$ are more susceptible than Casp $1 / 11 \%$. In this work, we identified that the caspase-1/11-independent pathway is composed of Naip5/NLRC4/ASC/Caspase-8 and it is essential for the control of flagellated Legionella spp. replication in macrophages and in vivo. Infection of Casp1/11\% and Asc/Casp1/11\% macrophages, transduced with NLRC4-GFP or ASC-GFP, showed that flagellin-positive bacteria triggered puncta formation that is ASC-dependent. Accordingly, Naip5 and ASC, but not caspase-1/11, were required for caspase- 8 activation in response to flagellated bacteria. Silencing caspase-8 in Casp $1 / 11 \%$ BMDMs increased the susceptibility to $L$. pneumophila infection. Furthermore, the macrophages and mice Asc/Casp $1 / 11 \%$ are as susceptible as $\mathrm{NIrC4}^{-\%}$, but more susceptible than Casp $1 / 11^{-}$. We also found that the NLRC4/ASC/Caspase-8 inflammasome induces GSDMD-independent pore formation and cell death. Using C57BL/6 cells, we observed that caspase-8 is recruited to Naip5/NLRC4/ASC/Caspase-1 inflammasome. However, caspase-8 is just activated in the absence of caspase-1 or GSDMD. Our data suggest that caspase-8 activation in the NLRC4/ASC/Caspase-8 inflammasome represents an alternative pathway that operates to ensure the control of flagellated bacteria replication in situations which either caspase-1 or GSDMD are inhibited. 
Keywords: NLRC4; Inflammasome; Caspase-8; Legionella pneumophila; Control of replication. 


\section{Abreviaturas}




\section{ABREVIATURAS}

AIM2: Absent in melanoma 2

ANOVA: Análise de variância

ASC: Apoptosis-associated speck-like protein containing a caspase recruitment domain

ATP: Adenosine triphosphate

BIR: Baculovirus inhibitor of apoptosis repeat domain

BMDMs: Bone marrow-derived macrophages

CARD: Caspase activation and recruitment domain

CT: Cycle Threshold

CYE: Charcoal yeast extract agar (Meio sólido para cultivo de Legionella spp)

DAMPs: Damage-associated molecular pattern

DNA: Deoxyribonucleic acid

cDNA: Complementary DNA

Dot: Defective in organelle trafficking

ECL: Entry-level peroxidase substrate for enhanced chemiluminescence

ELISA: Enzyme-Linked Immunosorbent Assay

flaA: : Legionella pneumophila deficiente para o gene flaA, que codifica a flagelina.

flir: Legionella pneumophila deficiente para o gene flil, que codifica uma ATPase necessária para a secreção de flagelina na formação do flagelo.

FWD: Primer forward

g: Grama

GFP: Green fluorescent protein 
GSDMA: Gasdermina-A

GSDMC: Gasdermina-C

GSDMD: Gasdermina-D

GSDME: Gasdermina-D

GSDMF: Gasdermina-F

h: Horas

HIN: Hematopoietic IFN-inducible nuclear domain

Icm: Intracellular multiplication

IFNs: Interferon

IL: Interleucina

IRAK: IL-1R-associated kinases

IRF: Interferon Regulators Factors

JNK: JUN N-terminal kinase

LCCM: L929 cell conditioned media

LCV: Legionella-containing vacuole

LDH: Lactate dehydrogenase

Lp: Legionella pneumophila

LPS: Lipopolissacarídeo

LRR: Leucine-rich repeat

Lvh: L. pneumophila vir homologues

MAL/TIRAP: TIR domain containing adaptor protein MAL (Myd88 adaptor-like)

MAMPs: Microbe-associated molecular patterns

MAPK: Mitogen Activated Protein Kinases 
MCSF: Macrophage colony-stimulating factor

$\mu \mathrm{g}:$ Micrograma

$\mu \mathrm{L}:$ Microlitros

$\mu \mathrm{M}:$ Micromolar

mg: Miligrama

ml: Mililitro

mM: Milimolar

MOI: Multiplicity of infection

MyD88: Myeloid differentiation primary response 88

NAIP: NLR family of apoptosis inhibitory protein

NBD: Nucleotide-binding and oligomerization domain

ND: Not detected (Diferença estatística não detectada)

NF-kB: Nuclear Factor- $\kappa B$

ng: Nanograma

NI: Não infectado

NLR: Nucleotide-binding domain leucine-rich repeat-containing protein (Nod like receptor)

NLRC4: NLR family of CARD domain containing protein 4

NLRP3: NLR family of PYRIN domain containing protein 3

nm: Nanômetro

Nod1: Nucleotide binding and oligomerization domain containing 1

Nod2: Nucleotide binding and oligomerization domain containing 2

NT shRNA: Non-target shRNA 
O.D: Optical density

PBS: Phosphate buffered saline

PEI: Polyethylenimine

PI: Propidium iodide

PITs: Pore-induced intracellular traps

PRRs: Pattern recognition receptors

PYD: Pyrin domain

qPCR: Quantitative polymerase chain reaction

REV: Primer reverse

RIPA Buffer: Radio immunoprecipitation assay buffer

Ripk3: Receptor-interacting protein (RIP) family of serine/threonine protein kinases RPMI: Roswell Park Memorial Institute medium

Rpsl: 30 S ribosomal protein $\mathrm{S12}$

RNA: Ribonucleic acid

SBF: Soro Bovino Fetal

SDS: Sodium dodecyl sulfate

shRNA: Small hairpin RNA

T4ASS: Type IVA secretion system

T4BSS: Type IVB secretion system

TBS: Tris buffered saline

TIR: Toll IL-1 receptors

TLR: Toll like receptors

TNF: Tumor necrosis factor 
TRAF: TNF receptor-associated factors

TRAM: TRIF-related adaptor molecule

TRIF: TIR-domain-containing adapter-inducing interferon- $\beta$

UFC: Unidades Formadoras de Colônia

WT: Wild-type 


\section{Lista de Figuras}




\section{LISTA DE FIGURAS}

Figura 1: Estrutura geral dos receptores NLRs.

Figura 2: Estrutura dos inflamassomas ativados em resposta à Legionella pneumophila

Figura 3: Ativação dos inflamassomas por Legionella pneumophila e suas consequências.

Figura 4: Estrutura do poro de membrana formado por gasdermina-D

Figura 5: O controle da replicação de L. pneumophila é dependente de NLRC4 e flagelina, parcialmente dependente de caspase-1 e independente de ASC

Figura 6: L. pneumophila leva à formação de puncta de NLRC4-GFP de maneira dependente de flagelina e ASC e independente de caspase-1/11 .64

Figura 7: ASC e caspase-8, mas não caspase-3 e caspase-7 colocalizam o puncta de NLRC4-GFP em resposta à L. pneumophila contendo flagelina 65

Figura 8: Puncta de ASC-GFP é induzido em resposta à flagelina de L. pneumophila e colocaliza com caspase-8.

Figura 9: Caspase-8 é ativada em resposta à flagelina de L. pneumophila de maneira dependente de ASC e independente de caspase-1/11.

Figura 10: Caspase-8 é importante para o controle da replicação de L. pneumophila mediado por NLRC4 e independente de caspase-1/11

Figura 11: ASC é importante para o controle da infecção de $L$. pneumophila mediado pelo inflamassoma de NLRC4/Caspase-8 e independente de caspase-1/11 . .73

Figura 12: ASC é essencial para o controle da replicação de Legionella flagelada mediado por NLRC4 e independente de caspase-1/11 in vivo. 76

Figura 13: AIM2 não participa da formação dos punctas de NLRC4-GFP e da ativação de caspase-8 em resposta à infecção por L. pneumophila com flagelina 79 
Figura 14: AIM2 não é importante para o controle da infecção mediado por NLRC4 e independente de caspase-1/11 em macrófagos e in vivo.

Figura 15: A ativação do inflamassoma de NLRC4/ASC/Caspase-8 em resposta à infecção por L. pneumophila flagelada é dependente de Naip5.

Figura 16: A via de NLRC4/ASC/Caspase-8 é importante para a formação de poro, mas não secreção de IL-1 $\beta$ em resposta à $L$. pneumophila flagelada na ausência de caspase- $1 / 11$.

Figura 17: Poro induzido por ASC na ausência de caspase-1/11 é dependente de caspase-8. .90

Figura 18: Naip5 é importante para a formação de poro pelo inflamassoma de NLRC4/ASC/Caspase-8 em resposta à L. pneumophila flagelada.

Figura 19: Caspase-8 colocaliza com inflamassoma de NLRC4/ASC/Caspase-1, mas só é ativada na ausência de caspase-1

Figura 20: Inibição ou deleção de gasdermina-D permite a ativação de caspase-8 em células contendo caspase-1...

Figura 21: Gasdermina-D é importante para a formação de poro em BMDMs C57BL/6, mas não em Casp1/11\%

Figura 22: Modelo proposto. 108 
Sumário 


\section{SUMÁRIO}

1 - INTRODUÇÃO

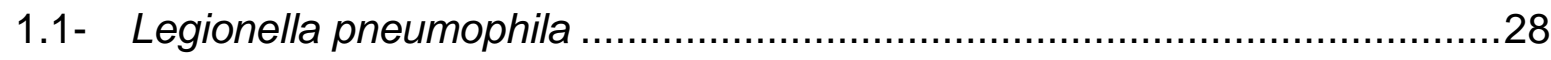

1.2- Reconhecimento de Legionella pneumophila por PRRs ..............................31

1.3- Ativação dos inflamassomas por Legionella pneumophila ............................35

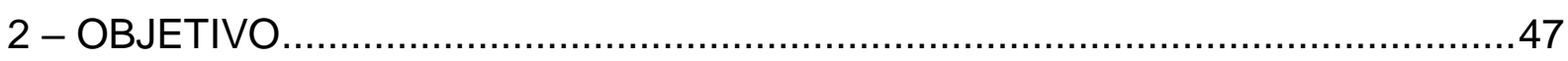

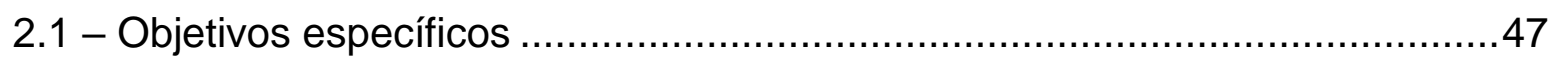

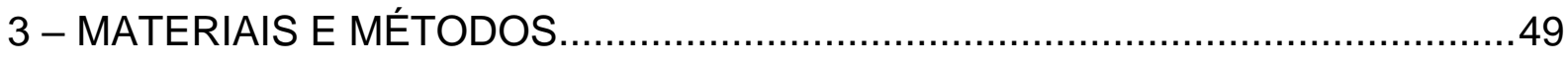

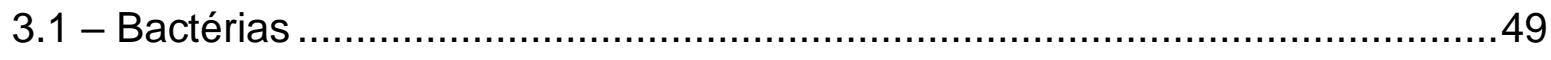

3.2 - Cultura de macrófagos derivados de medula óssea .....................................49

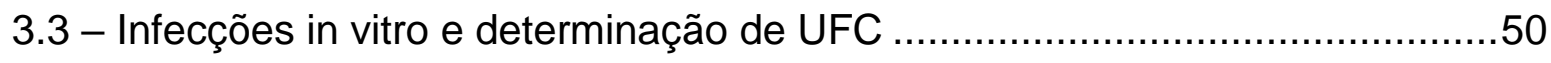

3.4 - Transdução retroviral e quantificação de NLRC4-GFP e ASC-GFP ..............50

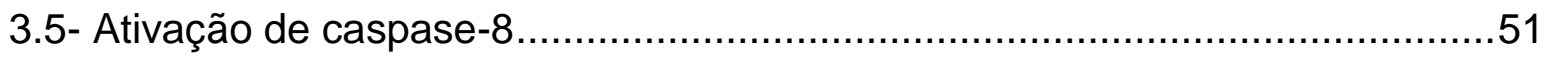

3.6 - Silenciamento retroviral de caspase-8, Naip5 e GSDMD............................52

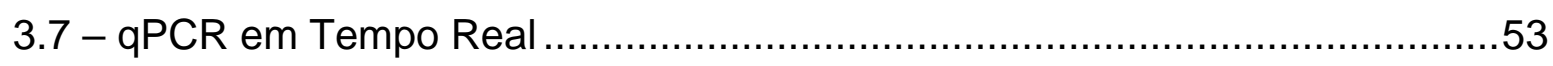

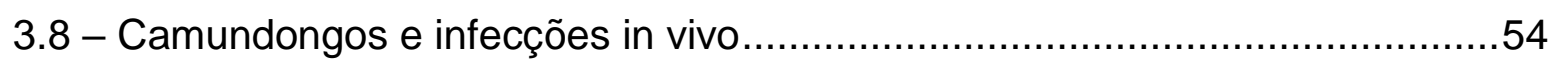

3.9 - Ensaio de formação de poro ……………….......................................5

3.10 - Ensaio de liberação de Lactato desidrogenase (LDH) e ELISA ...................55

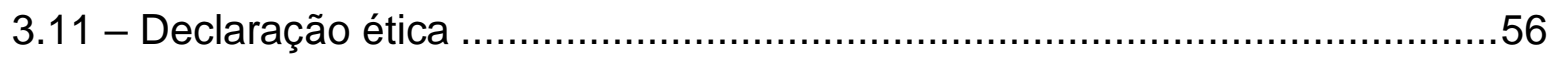

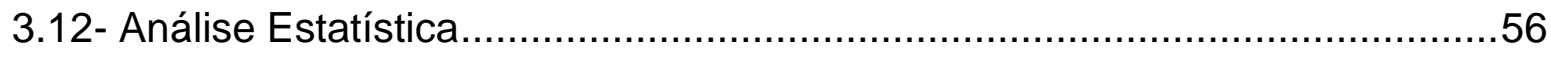

4 - RESULTADOS

4.1 - O controle da replicação de L. pneumophila em BMDMs é dependente do reconhecimento de flagelina e de NLRC4, independente de ASC e parcialmente dependente de caspase-1

4.2- A formação de punctas de NLRC4 por L. pneumophila contendo flagelina é dependente de ASC.... 
4.3- O inflamassoma de NLRC4/ASC/Caspase-8 leva ao controle da replicação de Legionella spp. flageladas na ausência de caspase-1/11 em macrófagos 67

4.4 - ASC é essencial para o controle da replicação de Legionella flagelada mediado pelo inflamassoma de NLRC4/ASC/Caspase-8 in vivo

4.5 - AIM2 não participa no inflamassoma de NLRC4/ASC/Caspase-8 em resposta à infecção por L. pneumophila

4.6 - Naip5 é essencial para a ativação do inflamassoma de

NLRC4/ASC/Caspase-8 em resposta à L. pneumophila flagelada na ausência de caspase- $-1 / 11$

4.7 - A ativação do inflamassoma de Naip5/NLRC4/ASC/Caspase-8 induz a formação de poro, mas não a secreção de IL-1 $\beta$.

4.8- Caspase-8 é recrutada para o inflamassoma de NLRC4/ASC/Caspase-1, mas só é ativada na ausência de caspase-1 ou gasdermina-D..................................92

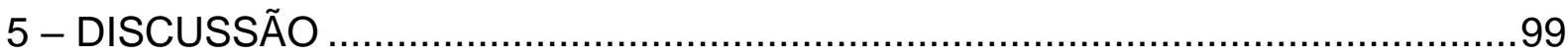

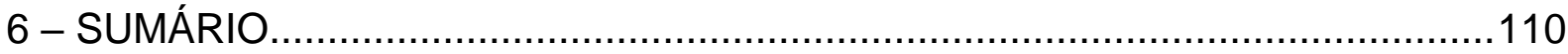

7 - CONCLUSÃO

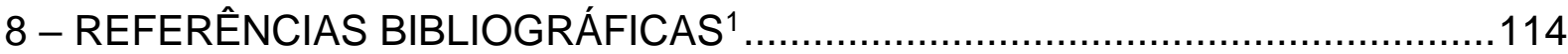

9 - ANEXO I: Trabalhos de primeira autoria *.....................................................144

9.1 - Anexo 1 - Artigo publicado (MASCARENHAS, Danielle PA et al. Plos Pathogens, 2017).

9.2 - Anexo 2 - Artigo publicado (MASCARENHAS, Danielle PA; ZAMBONI, Dario

S. Journal of Leukocyte Biology, 2017).

9.3 - Anexo 3 - Manuscrito enviado por convite da revista (MASCARENHAS,

Danielle PA; ZAMBONI, Dario S. Methods in Molecular Biology/2018)

9.4 - Anexo 4 - Artigo publicado (MASCARENHAS, Danielle PA et al. Journal of Infectious Diseases, 2014)

10 - ANEXO II: Trabalhos de colaboração 233

10.1 - Anexo 5 - Artigo publicado (CUNHA, Larissa D; SILVA, Alexandre LN; RIBEIRO, Juliana M; MASCARENHAS, Danielle PA; QUIRINO, Gustavo FS; 
SANTOS, Leonardo L; FLAVELL, Richard A; ZAMBONI, Dario S. Cell Reports, 2017)

10.2 - Anexo 6 - Artigo publicado (LOPES, Alexandre H; TALBOT, Jhimmy;

SILVA, Rangel L; LIMA, Jonilson B; FRANÇA, Rafael O; VERRI JR, Waldiceu A;

MASCARENHAS, Danielle PA; RYFFEL, Bernhard; CUNHA, Fernando Q;

ZAMBONI, Dario S; CUNHA, Thiago M. Pain, 2015) .247 


\section{Introdução}




\section{1 - INTRODUÇÃO}

\section{1- Legionella pneumophila}

A bactéria $L$. pneumophila foi isolada pela primeira vez em 1976 na Filadélfia EUA, após um surto entre os participantes da "Convenção Americana dos Legionários" que apresentavam sintomas característicos de uma pneumonia. Cerca de 200 pessoas foram infectadas e destas 29 não sobreviveram (Fraser et al., 1977). Após este surto se iniciou uma corrida para a identificação do organismo causador da infecção. O desenvolvimento do meio ideal para o seu isolamento e a utilização das técnicas empregadas nos estudos com Rickettsia, outra bactéria intracelular, foram cruciais para a caracterização dessa bactéria. L. pneumophila foi então identificada como um bacilo Gram-negativo flagelado, e a doença causada por essa bactéria foi então denominada de "doença dos legionários" em referência aos legionários afetados (Mcdade et al., 1977).

Hoje são conhecidas mais de 60 espécies de Legionella, sendo que todas já foram isoladas de amostras ambientais e pelo menos metade delas já foi reportada em infecção em humanos (Yu et al., 2002). Dentre essas, as espécies de Legionella mais comumente isoladas de humanos são $L$. pneumophila e $L$. longbeachae seguidas de L. bonzemanii, L. micdadei e L. dumoffii (Yu et al., 2002). Entretanto, mais de $90 \%$ dos casos de pneumonia relacionada à doença dos legionários, são resultados de infecções por L. pneumophila, dado que pode não ser correto devido à dificuldade de identificação de outras espécies de Legionella nos exames diagnósticos (Fraser et al., 1977; Mcdade et al., 1977; Khodr et al., 2016).

As infecções por Legionella ocorrem principalmente em surtos, durante períodos mais quentes do ano (Phin et al., 2014). Entretanto uma pequena parcela das pessoas exposta à Legionella desenvolve a doença dos legionários. Essa susceptibilidade está relacionada a alguns fatores como: fumo, idade avançada, doenças cardiovasculares crônicas, doenças respiratórias, abuso de álcool, diabetes e outras condições que possam levar a imunodeficiência (Phin et al., 2014; Khodr et al., 2016).

As bactérias do gênero Legionella podem causar dois tipos principais de doença: a doença dos legionários e febre de Pontiac. A doença dos legionários é caracterizada por um período de incubação e 3 a 10 dias e por sintomas de uma broncopneumonia, podendo levar à morte (Kaufmann et al., 1981; Doebbeling e 
Wenzel, 1987). Já a febre de Pontiac é a manifestação mais frequente das infecções por Legionella, com tempo de incubação de 36 horas e sintomas muito parecidos com os da gripe, como por exemplo febre, calafrios, dores de cabeça e mialgia (Kaufmann et al., 1981; Doebbeling e Wenzel, 1987). A febre de Pontiac, foi assim denominada após um surto de infecção em 1968 entre os funcionários do Departamento de Saúde de Pontiac, Michigan - EUA (Glick et al., 1978). Entretanto, somente após o surto da doença dos legionários na Filadélfia, foi identificado que ambas as doenças eram causadas pelas mesma bactéria (Blaser, 1977).

O gênero Legionella apresenta bactérias intracelulares facultativas, que vivem em ambientes de água doce ou em solo (Fliermans et al., 1981). Essas bactérias seguiram a sua evolução infectando protozoários unicelulares, incluindo diversas espécies de amebas de vida livre como Acanthamoeba e Naegleria (Rowbotham, 1980). A infecção em humanos ocorre pela inalação de gotículas de água contendo a bactéria. Essas gotículas de água são oriundas de sistemas de irrigação, fontes, torres de refrigeração ou de aparelhos de ar condicionado onde essa bactéria forma biofilmes (Fraser et al., 1979; Morris et al., 1979; Sethi e Brandis, 1983; Spitalny et al., 1984; Newton et al., 2010; Lucas et al., 2018). Após a inalação das gotículas contaminadas as bactérias são fagocitadas pelos macrófagos alveolares onde apresentam um ciclo de vida muito similar ao que vivem no interior as amebas (Horwitz e Silverstein, 1980).

No meio intracelular, a $L$. pneumophila subverte as funções da célula hospedeira, inibindo a fusão do fagossomo com o lisossomo, impedindo a sua degradação (Horwitz, 1983). Em paralelo, essa bactéria recruta proteínas e organelas da célula hospedeira, como as mitocôndrias e vesículas do retículo endoplasmático, gerando um compartimento ideal para a sua replicação, com características de retículo endoplasmático rugoso, denominado de LCV (Legionella-containing vacuole) (Horwitz, 1983; Swanson e Isberg, 1995). A subversão das funções normais da célula hospedeira pela $L$. pneumophila é dependente do Sistema de Secreção do tipo IVB (T4BSS), denominado de Dot/lcm (Defective in organelle trafficking / Intracellular multiplication) (Marra et al., 1992; Berger e Isberg, 1993; Berger et al., 1994; Roy e Isberg, 1997; Roy et al., 1998). Esse sistema de secreção é composto por 27 genes, importantes para translocar mais de 300 proteínas efetoras que podem agir em diversas vias da célula hospedeira (Coers et al., 2000; Nagai et al., 2002; Newton et 
al., 2010; Khodr et al., 2016). Mutação em genes que formam o Dot/lcm, levam a um defeito na formação do LCV e na replicação intracelular desta bactéria nas células hospedeiras (Newton et al., 2010).

Além do T4BSS, também foi descrito que L. pneumophila expressa um T4ASS, denominado de $L v h$ (L. pneumophila vir homologues) importante para 0 translocamento de DNA e conjugação entre bactérias (Segal et al., 1999). A transferência horizontal de genes entre as bactérias tem sido muito importante durante a história evolucionária desses organismos, gerando mecanismos para parasitar novos nichos, como ocorreu em relação aos humanos, considerados hospedeiros acidentais dessa bactéria (Cazalet et al., 2004; Gomez-Valero e Buchrieser, 2013).

Infecções com $L$. pneumophila passaram a ser mais frequentes em humanos com as mudanças em nosso estilo de vida, como por exemplo o aumento do número de aparelhos de ar condicionado e torres de refrigeração em edifícios, o que possibilita o espalhamento do aerossol desta bactéria (Gomez-Valero e Buchrieser, 2013). Entretanto, a infecção por L. pneumophila, diferente do que ocorre nas amebas, é controlada em células de mamíferos (Yamamoto et al., 1988; Cirillo et al., 1999). Acredita-se que isso ocorra porque durante o seu processo evolutivo, a $L$. pneumophila sofreu pressões seletivas infectando protozoários unicelulares, entretanto o hospedeiro humano é considerado seu hospedeiro acidental (Lau e Ashbolt, 2009; Khodr et al., 2016). Por essa razão L. pneumophila apresenta fatores de virulência para subverter certas vias de células eucarióticas comuns entre as amebas e os humanos (Gomez-Valero e Buchrieser, 2013). Entretanto, essa bactéria falha na inibição de outras vias mais específicas, como as de reconhecimento do sistema imune inato. Assim, em células de mamíferos, L. pneumophila é reconhecida por diversos receptores da imunidade inata, como os TLRs (Toll-like Receptors) e os NLRs (Nod-like Receptors), gerando respostas inflamatórias e sendo rapidamente controlada (Massis e Zamboni, 2011). Consequentemente, L. pneumophila é um excelente modelo para o estudo de novas vias de reconhecimento de MAMPs (Microbe-associated molecular patterns) e DAMPs (Damage-associated molecular patterns) por PRRs (Pattern recognition receptors) (Massis e Zamboni, 2011; Mascarenhas e Zamboni, 2017). 


\section{2- Reconhecimento de Legionella pneumophila por PRRs}

Os receptores do tipo TLR foram identificados pela primeira vez em Drosophila melanogaster (Lemaitre et al., 1996). Em humanos e camundongos foram identificados 10 e 13 receptores do tipo TLR respectivamente (Rock et al., 1998). Esses receptores são proteínas presentes na membrana plasmática das células (TLR1, TLR2, TLR4, TLR5 e TLR6) ou em endossomos (TLR3, TLR4, TLR7, TLR8, TLR9 e TLR13) (O'neill et al., 2013). Como estrutura geral os TLRs contêm um domínio N-terminal LRR (Leucine-rich repeat) extracelular de reconhecimento, um domínio transmembrana e um domínio intracelular C-terminal de sinalização (Medzhitov et al., 1997; Medzhitov, 2001). Já os TLRs endossomais apresentam o domínio N-terminal no interior do endossomo (Creagh e O'neill, 2006; O'neill et al., 2013). A sinalização por esses receptores ocorre por meio de proteínas adaptadoras contendo domínios TIR (Toll IL-1 receptors), também presentes na sinalização via IL1 e IL-18, e são eles: TRAM (TRIF-related adaptor molecule), MAL/TIRAP \{TIR domain containing adaptor protein MAL (Myd88 adaptor-like)\}, MyD88 (Myeloid differentiation primary response gene 88) e TRIF (TIR-domain-containing adapterinducing interferon- $\beta$ ) (Creagh e O'neill, 2006).

Os TLRs podem ser ativados por diversas moléculas de vírus, bactérias, fungos e protozoários (Akira e Takeda, 2004; Kawai e Akira, 2010). Um exemplo é a ativação de TLR5 que ocorre pelo reconhecimento de flagelina, o principal componente do flagelo bacteriano. Já o receptor TLR4 é capaz de reconhecer LPS (lipopolissacarídeo), presente na parede celular de bactérias Gram-negativas. TLR3 é responsável por reconhecer dupla fita de RNA de infecções virais, enquanto TLR2 é capaz de reconhecer lipoproteínas e glicolipidios de diversos patógenos (Akira e Takeda, 2004).

A ativação desses receptores, desencadeia uma cascata sinalizadora com recrutamento de IRAK (IL-1R-associated kinases) e TRAF (TNF receptor-associated factors), levando à ativação das vias de MAPK (Mitogen activated protein kinase), JNK (JUN N-terminal kinase) e p38. Bem como a ativação de fatores de transcrição como NF-kB (Nuclear factor- $\kappa B$ ) e IRF (Interferon regulators factors) (Kawai e Akira, 2010; 
O'neill et al., 2013). De forma geral, a principal consequência da ativação dos TLRs é a indução de citocinas pró-inflamatórias, como TNF e IL-12, bem como de IFNs (Interferons). Além disso, o reconhecimento de moléculas pelos TLRs, bem como por outros PRRs, desencadeia na transcrição de certas proteínas como caspase-1, caspase-11 e NLRP3 (NLR family of PYRIN domain containing protein 3), bem como precursores de outras citocinas como pró-IL-1 $\beta$ e pró-IL-18 em um processo denominado de "priming" (Bauernfeind et al., 2009). Esse processo é essencial para a ativação de outras vias do sistema imune inato importantes de reconhecimento de patógenos, como a dos inflamassomas (Kawai e Akira, 2011; Latz et al., 2013).

Muitos trabalhos têm demonstrados vias envolvendo o reconhecimento de MAMPs de L. pneumophila pelos TLRs. Um exemplo é o papel do receptor TLR2 no controle da infecção ou chamado "clearance" desta bactéria (Mascarenhas et al., 2015). Trabalhos observaram que camundongos deficientes para TIr2 apresentam uma diminuição na secreção de citocinas como IL-12 e IL-10, e são mais susceptíveis à infecção que os camundongos C57BL/6 quando infectados com L. pneumophila (Hemmi et al., 2000; Akamine et al., 2005; Archer e Roy, 2006; Hawn et al., 2006; Newton et al., 2007; Archer et al., 2009). A sinalização por TLR2 no reconhecimento de moléculas bacterianas como peptidoglicano e lipopeptídeos requer sua oligomerização com TLR1 ou TLR6, capazes de reconhecer lipoproteínas (Ahmadishoar e Kariminik, 2017). Um trabalho publicado em 2013 demonstrou que tanto TLR1 como TLR6 são essenciais para o reconhecimento de L. pneumophila por TLR2 e que polimorfismos em TIr6 estão ligados à casos de alto risco à doença dos legionários após a exposição a esta bactéria (Misch et al., 2013).

Além do reconhecimento de $L$. pneumophila por TLR2, também foi demonstrado que a flagelina desta bactéria é reconhecida pelo receptor TLR5, regulando o recrutamento inicial de neutrófilos para o pulmão. Entretanto camundongos $\mathrm{Tr}^{-/}$não apresentam uma susceptibilidade significativa em relação aos C57BL/6 quando infectados com L. pneumophila (Hawn et al., 2007; Archer et al., 2009). Adicionalmente, assim como ocorre com outras bactérias Gram-negativas, o LPS de L. pneumophila, pode ser reconhecido por TLR4, entretanto o reconhecimento por esse receptor também não parece ser essencial o controle da infecção dessa bactéria (Lettinga et al., 2002; Archer e Roy, 2006; Mascarenhas et al., 2015). 
Trabalhos tem demonstrado que camundongos deficientes para Myd88 apresentam uma falha no controle da infecção de L. pneumophila (Archer e Roy, 2006; Hawn et al., 2006). Entretanto, não foi reportado nenhum camundongo deficiente para TLR tão susceptível quanto o $M y d 88 \%$. Mesmo camundongos duplo deficientes para os receptores T/r2/TIr9 e TIr2/TIr5 não são tão susceptíveis quanto os camundongos Myd88\% infectados com L. pneumophila (Archer et al., 2009). Recentemente demonstramos que além dos TLRs, a alta susceptibilidade do Myd88--- também ocorre pelo seu papel na sinalização via IL-1. Já que camundongos $I /-1 r^{-}$são altamente susceptíveis à infecção por $L$. pneumophila e apresentam uma falha no clearance desta bactéria, bem como no recrutamento de neutrófilos para o pulmão (Mascarenhas et al., 2015). Desta maneira, existe uma grande cooperação entre as sinalizações que operam via MyD88, bem como uma grande redundância entre as sinalizações via TLR em resposta à $L$. pneumophila.

Além dos TLRs, uma outra família de PRRs citoplasmáticos foi descrita pela sua grande importância no reconhecimento de MAMPs e DAMPs, os NLRs (Nucleotide-binding domain leucine-rich repeat-containing protein ou Nod-like receptors). Homólogos desses receptores são encontrados em plantas, denominadas de "proteínas R", importantes no reconhecimento de moléculas conservadas de bactérias patogênicas (Dangl e Jones, 2001). Os NLRs apresentam uma estrutura tripartida contendo: um domínio C-terminal LRR que atua como sensor de diferentes estímulos microbianos e de dano, um domínio NBD (Nucleotide-binding and oligomerization domain) responsável pela oligomerização do receptor após a ligação ao ATP e um domínio N-terminal variável, o qual determina a função efetora do receptor (Fig. 1). O domínio N-terminal pode ser um domínio CARD (Caspase activation and recruitment domain), um domínio PYD (Pyrin domain) ou um domínio BIR (Baculovirus inhibitor of apoptosis repeat domain) (Inohara e Nunez, 2003; Akira, 2009). 

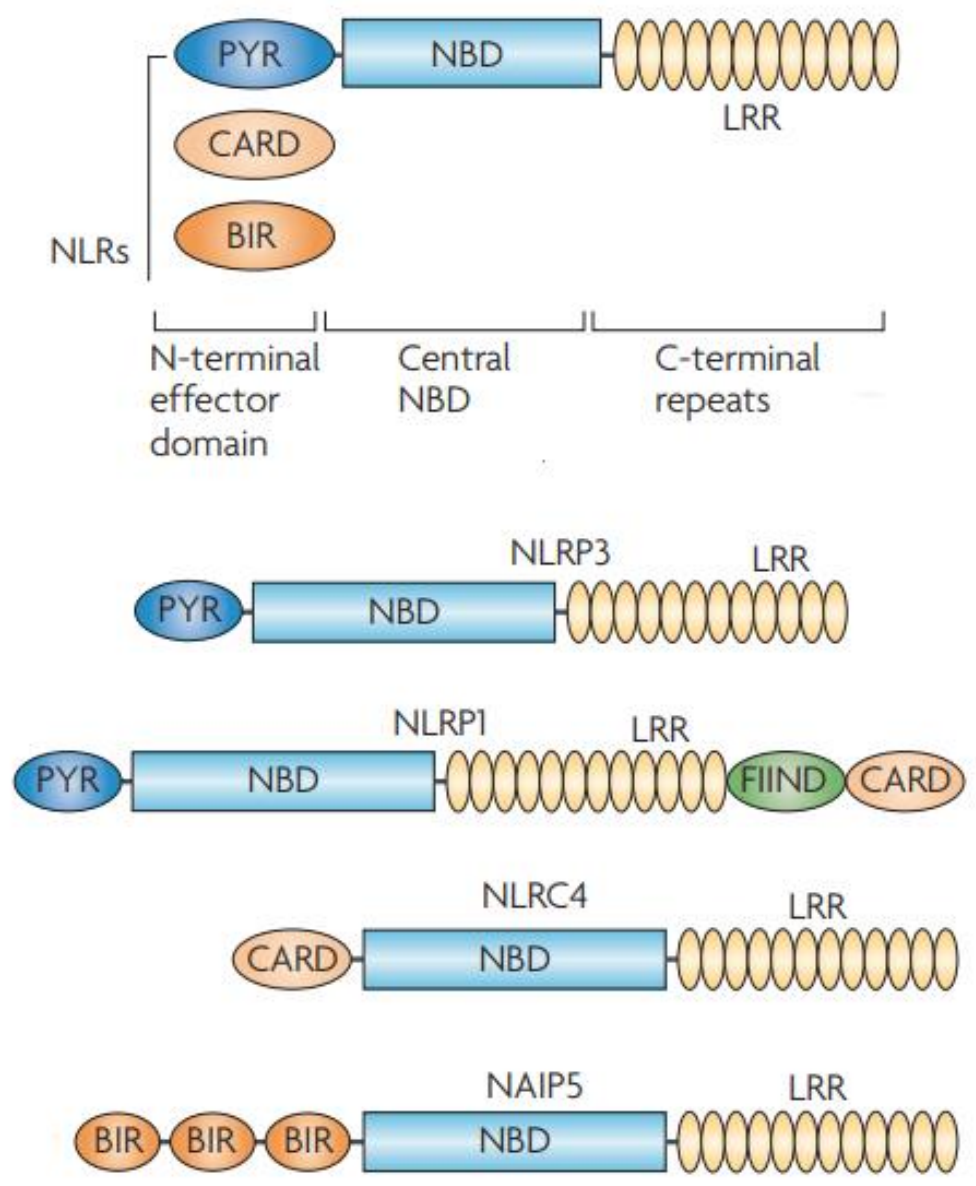

Figura 1: Estrutura geral dos receptores NLRs. De maneira geral os NLRs apresentam uma estrutura tripartida contendo: um domínio C-terminal LRR (Leucine-rich repeat), um domínio NBD (Nucleotidebinding and oligomerization domain) e um domínio N-terminal variável, podendo ser um domínio CARD (Caspase activation and recruitment domain), um domínio PYD (Pyrin domain) ou um domínio BIR (Baculovirus inhibitor of apoptosis repeat domain). Tanto NLRP3 quanto NLRP1 apresentam PYD como domínios N-terminais. Já NLRC4 apresenta um domínio de recrutamento de caspase CARD, e Naip5 apresenta um domínio BIR. Adaptado de: TING, Jenny PY et al. Nature Reviews Immunology, 2008.

Os NLRs são ativados por diversos MAMPs e DAMPs como flagelina, cristais de ácido úrico, peptidoglicano e toxinas bacterianas, sendo de grande importância no controle da infecção de bactérias intracelulares como L. pneumophila (Kufer et al., 2005; Ting et al., 2008; Kim et al., 2016). Como exemplo Naip5 (NLR family of apoptosis inhibitory protein 5), um NLR capaz de reconhecer flagelina bacteriana de L. pneumophila gerando a formação de um complexo intracelular que induz o controle da replicação desta bactéria (Zamboni et al., 2006). Ou também os receptores Nod1 (Nucleotide binding and oligomerization domain containing 1) e Nod2 (Nucleotide binding and oligomerization domain containing 2), que são capazes de sinalizar em resposta à infecção por L. pneumophila, sendo importantes para o clearance e 
recrutamento de células para o pulmão em resposta a esta bactéria (Shin et al., 2008; Berrington et al., 2010; Frutuoso et al., 2010).

Além destes, diversos receptores NLRs são ativados em resposta à infecção por L. pneumophila (Massis e Zamboni, 2011; Mascarenhas e Zamboni, 2017). Após ativados esses NLRs se oligomerizam, levando à ativação de diversas vias como de MAPK, indução de fatores de transcrição como NF-kB, e também a formação de um complexo proteico denominado de inflamassoma com a ativação de caspases (Ting et al., 2008; Guo et al., 2015).

\section{3- Ativação dos inflamassomas por Legionella pneumophila}

Os inflamassomas são caracterizados por um agregado de proteínas que são formados no citoplasma da célula e induzem a ativação e clivagem de caspases inflamatórias como caspase-1 e caspase-11 (Fig. 2) (Martinon et al., 2002). As caspases ativas induzem a formação de poros na membrana celular e uma morte celular característica denominada de piroptose, além da secreção de citocinas próinflamatórias como IL-1 $\beta$ e IL-18 (Cookson e Brennan, 2001; Fink e Cookson, 2006).

Tem sido amplamente estudada a ativação dos inflamassomas pela $L$. pneumophila, sendo essa bactéria um excelente modelo para o estudo destas vias. Um dos mais importantes inflamassomas ativados por esta bactéria é o de Naip5/NLRC4, responsável pelo reconhecimento de flagelina bacteriana e ativação de caspase-1 (Fig. 2) (Ren et al., 2006; Zamboni et al., 2006; Kofoed e Vance, 2011; Zhao et al., 2011). Outro inflamassoma também muito estudado, principalmente pela ampla gama de agonistas pelo qual é ativado é o de NLRP3 (Latz et al., 2013). Esse inflamassoma é ativado por diversos fatores, entretanto todos parecem convergir para efluxo de potássio, que parece ser o principal ativador desta via (Rivers-Auty e Brough, 2015; Ruhl e Broz, 2015). Além dos inflamassomas dependentes dos receptores NLRs, L. pneumophila também ativa vias independentes destes receptores, como o inflamassoma de AIM2 (Absent in melanoma 2) e de caspase-11, responsáveis pelo reconhecimento de dupla fita de DNA e LPS de bactérias Gram-negativas, respectivamente (Mascarenhas e Zamboni, 2017).

A formação da maioria destes inflamassomas depende da proteína adaptadora ASC (Apoptosis-associated speck-like protein containing a caspase activation and recruitment domain). Essa proteína apresenta dois domínios de interação proteína- 
proteína, um domínio PYD que se liga aos receptores NLRs, e um domínio CARD que se liga às caspases, funcionando assim como uma ponte entre elas (Fig. 2) (Masumoto et al., 1999; Motani et al., 2011; Proell et al., 2013). Trabalhos demonstram que ASC facilita a nucleação dos inflamassomas, sendo essencial para a formação de "punctas" ou "specks" (Masumoto et al., 1999; Proell et al., 2013). Essas estruturas são características da ativação dos inflamassomas e podem ser observadas por meio de microscopia óptica. A aproximação das moléculas de caspase nas estruturas dos punctas possibilita o autoprocessamento dessas proteínas, e posteriormente a secreção de citocinas pró-inflamatórias (Boucher et al., 2018). Em 2010 um trabalho utilizando formas mutantes de caspase-1, demonstrou que ASC é importante para a formação dos punctas e autoproteólise das moléculas de caspase-1 (Broz et al., 2010). Entretanto, a forma de caspase-1 ativa e não clivada é capaz de levar à indução de piroptose de maneira independente de ASC. Este estudo sugere que a formação dos inflamassomas ocorrem em duas etapas, a primeira sem a presença de ASC, onde ocorre a ativação das caspases e indução de piroptose. Em um segundo momento ocorre o recrutamento de ASC e formação dos punctas, importante para 0 autoprocessamento das caspases, gerando assim a clivagem e secreção de citocinas pró-inflamatórias como IL-1 $\beta$ e IL-18. 
NAIP/NLRC4 Inflammasome

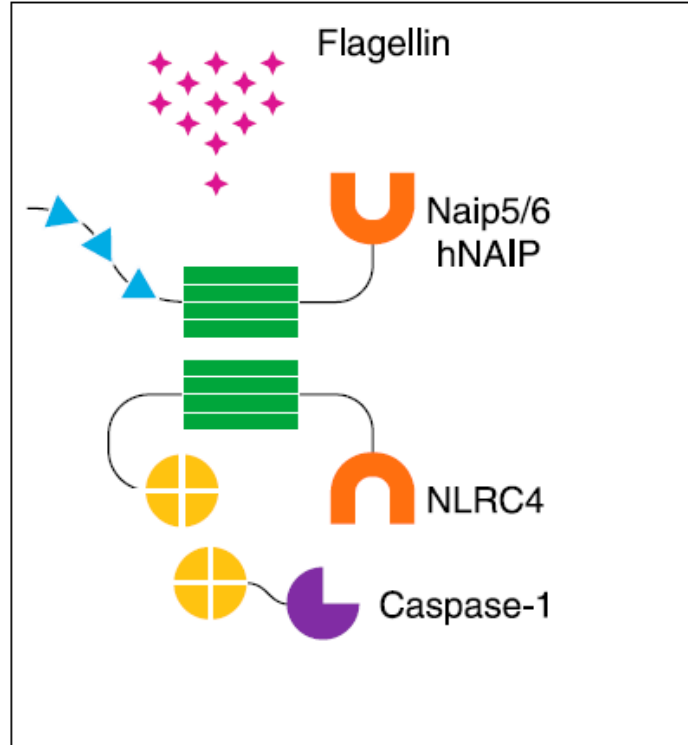

AIM2 Inflammasome

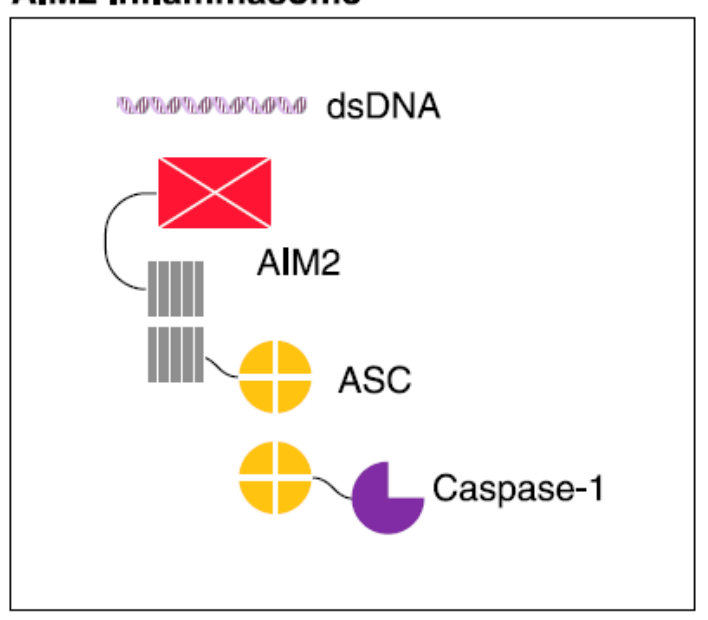

Caspase-11 Inflammasome

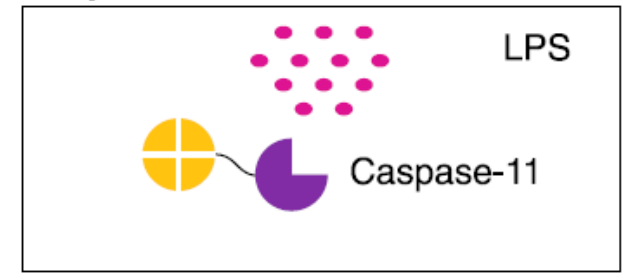

NLRP3 Inflammasome

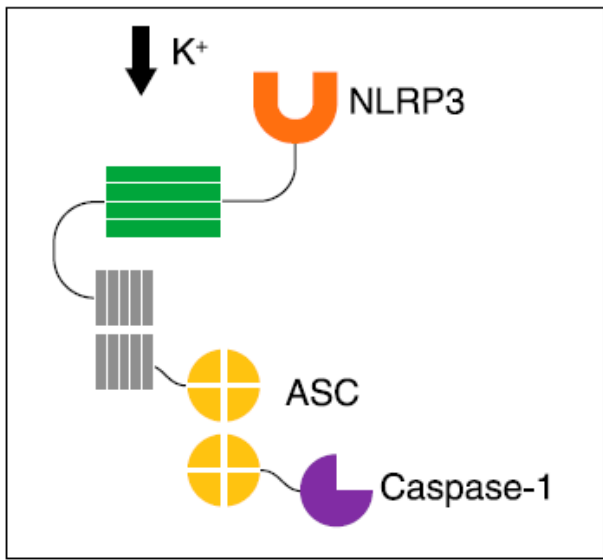

Domains:

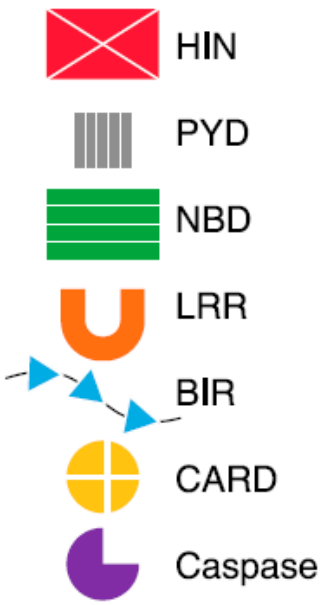

Figura 2: Estrutura dos inflamassomas ativados em resposta à Legionella pneumophila. Nesta figura estão demonstradas as estruturas dos componentes que formam os inflamassomas em resposta à L. pneumophila. O inflamassoma de Naip5/NLRC4/Caspase-1 é ativado em resposta à flagelina bacteriana. O domínio C-terminal da flagelina é reconhecido pelo domínio NBD do Naip5 que se oligomeriza e recruta NLRC4. A ligação entre Naip5 e NLRC4 também ocorre pelo domínio NBD. Após essa interação ocorre o recrutamento e ativação de caspase-1, que se liga à NLRC4 pelo seu domínio CARD. O reconhecimento de flagelina também ocorre pelo receptor Naip6 e pelo único receptor do tipo Naip em humanos. Já o inflamassoma de caspase-11 reconhece LPS de bactérias Gram-negativas, pela ligação direta entre o domínio CARD de caspase-11 e o lipídio A do LPS. A via de AIM2 é ativada pelo reconhecimento de fita dupla de DNA de L. pneumophila pelo domínio HIN do receptor AIM2. Esse inflamassoma é dependente da proteína adaptadora ASC, que se liga ao AIM2 pelo seu domínio PYD, levando ao recrutamento de caspase-1. Por fim o inflamassoma de NLRP3 reconhece reduzidas concentrações de $\mathrm{K}^{+}$na célula levando à ativação do inflamassoma e secreção de citocinas próinflamatórias como IL-18 e IL-1 $\beta$. Esse inflamassoma também necessita da proteína adaptadora ASC. A ligação entre ASC e NLRP3 ocorre pelos seus domínios PYD. Estão indicados os seguintes domínios: HIN, PYD, NBD, LRR, BIR, CARD e caspase. De: MASCARENHAS, Danielle PA; ZAMBONI, Dario S. Journal of leukocyte biology, 2017. 
Caspases são proteases baseadas em cisteína que clivam suas proteínas-alvo em resíduos de ácido aspártico (Creagh, 2014). Elas são classificadas como caspases inflamatórias (caspase-1 e caspase-11 em camundongos e caspase-4 e caspase-5 em humanos) e caspases apoptóticas (iniciadoras: caspase-2, caspase-8, caspase-9 e caspase-10 e efetoras: caspase-3, caspase-6 e caspase-7) de acordo com as vias em que estão envolvidas. Além das caspases inflamatórias, trabalhos têm demonstrado a participação de outras caspases na formação dos inflamassomas, como caspase-3, caspase-7 e principalmente caspase-8 (Masumoto et al., 2003; Hasegawa et al., 2005; Akhter et al., 2009; Kumar et al., 2010; Abdelaziz, Gavrilin, Akhter, Caution, Kotrange, Khweek, Abdulrahman, Hassan, et al., 2011; Motani et al., 2011; Pierini et al., 2012; Man et al., 2013; Sagulenko et al., 2013; Man et al., 2014; Vajjhala et al., 2015; Kawamoto et al., 2017; Rauch et al., 2017; Schneider et al., 2017). A participação dessas caspases parece ser de grande importância na indução de respostas independentes de caspase-1 induzidas pelos inflamassomas, como a secreção de citocinas pró-inflamatórias. Além disso também tem sido demonstrado o papel das vias dependentes de caspase-8 no priming dos inflamassomas, como o de NLRP3 (Gurung et al., 2014). Entretanto, ainda se sabe muito pouco sobre o papel dessas caspases não inflamatórias nos inflamassomas, principalmente no que se refere ao controle de infecção à patógenos como a L. pneumophila.

Grande parte das informações e descobertas acerca dos inflamassomas ocorreu com a utilização de L. pneumophila como modelo (Mascarenhas e Zamboni, 2017). A principal delas foi pela observação de que macrófagos de camundongos $A / J$ são mais susceptíveis a infecção por $L$. pneumophila quando comparados a outras linhagens de camundongos como C57BL/6 e BALB/c (Yamamoto et al., 1988). Por meio da utilização de genética clássica essa resistência foi mapeada em um locus autossômico nomeado de Lgn1 no cromossomo 13, e foi identificado que esses genes correspondiam aos receptores Naip1, Naip3, Naip6, Naip5 e Naip2 expressos em macrófagos (Beckers et al., 1995; Dietrich et al., 1995; Diez et al., 2000). A partir dessas descobertas, foi verificado que Naip5 era o responsável pela resistência contra L. pneumophila em macrófagos, levando à ativação de caspase-1 de maneira dependente de Dot/lcm (Zamboni et al., 2006). Em camundongos A/J o alelo de Naip5 não é funcional, levando à alta susceptibilidade desses camundongos à infecção por L. pneumophila (Diez et al., 2003; Wright et al., 2003). Também foi demonstrando que 
Naip5, interage com NLRC4, após o reconhecimento de flagelina, induzindo a ativação do inflamassoma (Amer et al., 2006; Molofsky et al., 2006; Ren et al., 2006). Entretanto somente após o desenvolvimento do camundongo Naip $5^{-}$, foi confirmado que esse receptor interage com o domínio C-terminal conservado da flagelina de $L$. pneumophila, recruta NLRC4, levando à ativação de caspase-1 (Fig. 3) (Lightfield et al., 2008; Kofoed e Vance, 2011; Zhao et al., 2011). Adicionalmente também foi descrita a participação de Naip6 no reconhecimento de flagelina e interação com NLRC4, entretanto Naip5 é mais efetivo nessa função (Kofoed e Vance, 2011; Zhao et al., 2011; Rauch et al., 2016; Zhao et al., 2016).

Além da interação com Naip5, NLRC4 também interage com os receptores Naip1 e Naip2. O inflamassoma Naip1/NLRC4 reconhece a proteína Prgl (needle protein), já o de Naip2/NLRC4 reconhece a proteína PrgJ (rod protein), ambas do Sistema de Secreção do Tipo III de bactérias (Kofoed e Vance, 2011; Zhao et al., 2011; Rayamajhi et al., 2013; Rauch et al., 2016; Zhao et al., 2016).

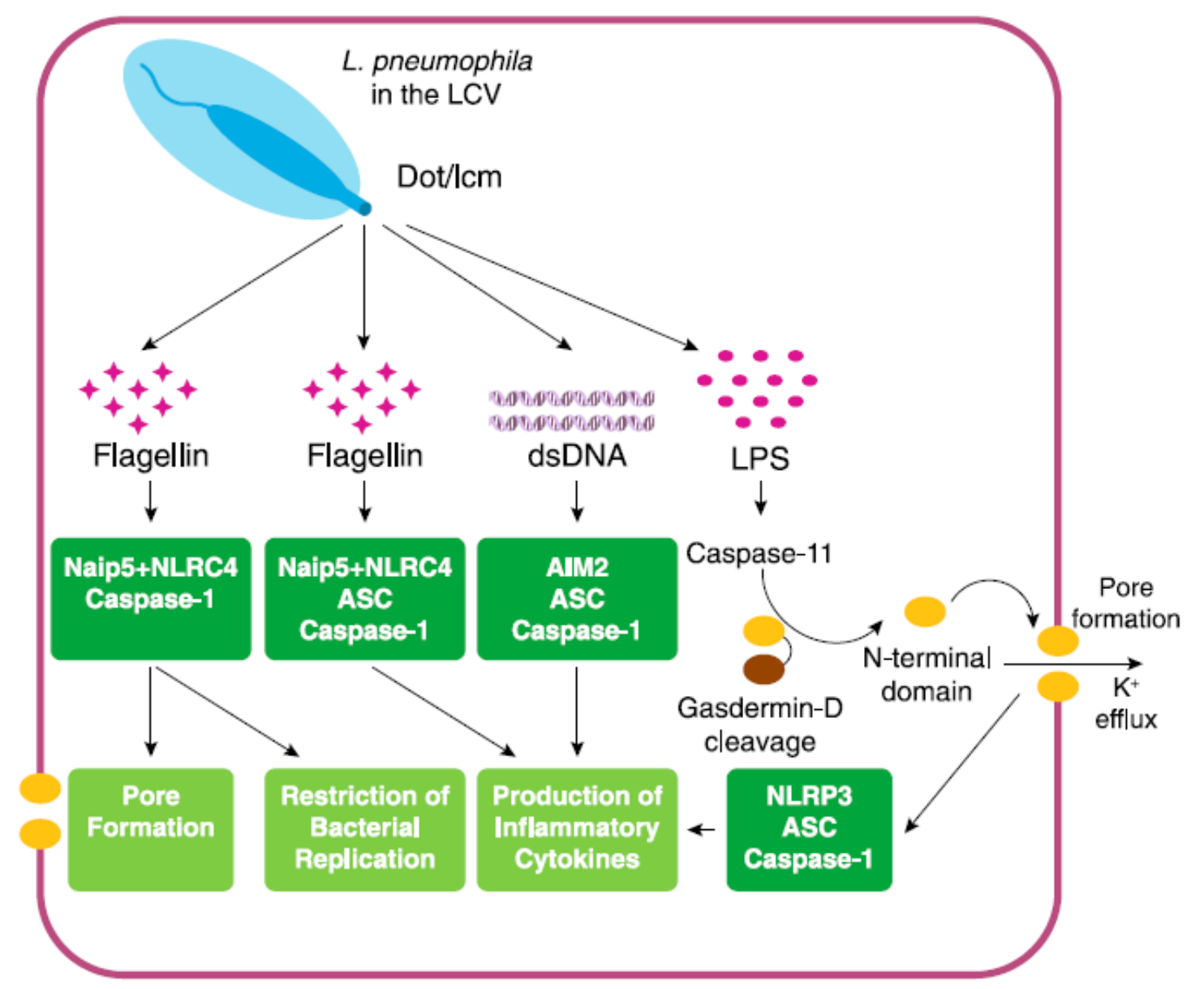


Figura 3: Ativação dos inflamassomas por Legionella pneumophila e suas consequências. $L$. pneumophila é reconhecida por diversos inflamassomas. O reconhecimento de flagelina pela via de Naip5/NLRC4 é dependente de Dot/lcm e induz a formação de dois complexos. O primeiro é independente de ASC e leva à ativação, mas não clivagem de caspase-1, com consequente formação de poros e controle da replicação bacteriana. O segundo complexo é dependente de ASC e induz a formação dos punctas, clivagem de caspase-1 e secreção de citocinas pró-inflamatórias. $L$. pneumophila também é reconhecida pelo inflamassoma de AIM2, pela ligação deste receptor com dupla fita de DNA. AIM2 juntamente com ASC, leva ao recrutamento e ativação de caspase-1, induzindo piroptose e secreção de citocinas pró-inflamatórias. Já caspase-11 reconhece o LPS de $L$. pneumophila, assim como de outras Gram-negativas, levando à clivagem de GSDMD. Após essa clivagem, o domínio N-terminal de GSDMD é transportado para a membrana plasmática interna onde se oligomeriza e forma a estrutura do poro, levando à indução de piroptose. Os poros formados pelos inflamassomas de Naip5/NLRC4, AIM2 e caspase-11 levam a um efluxo de potássio e com isso a ativação do inflamassoma de NLRP3, gerando a secreção de citocinas pró-inflamatórias como IL-18 e IL-1 $\beta$. Adaptado de: MASCARENHAS, Danielle PA; ZAMBONI, Dario S. Journal of leukocyte biology, 2017.

L. pneumophila como modelo possibilitou um grande desenvolvimento na elucidação dessas vias inflamatórias. Além da ativação dos inflamassomas por essa espécie, já foi relatado a ativação do inflamassoma de Naip5/NLRC4/Caspase-1 também por outras espécies de Legionella flageladas como: L. bonzemani, L. gratiana, $L$. micdadei e $L$. jordanis, bem como outras espécies de bactérias contendo flagelina como Salmonella Thyphimurium e Pseudomonas aeruginosa (Franchi et al., 2006; Miao et al., 2006; Molofsky et al., 2006; Franchi et al., 2007; Sutterwala et al., 2007; Suzuki et al., 2007; Pereira, Marques, et al., 2011; Pereira, Morgantetti, et al., 2011).

A ativação do inflamassoma de Naip5/NLRC4/ Caspase-1 é uma das vias mais importantes no controle da replicação de Legionella spp., entretanto os mecanismos responsáveis por esse controle ainda não são completamente conhecidos (Zamboni et al., 2006; Kofoed e Vance, 2011; Pereira, Morgantetti, et al., 2011; Zhao et al., 2011; Cerqueira et al., 2015; Rauch et al., 2016; Zhao et al., 2016). Acredita-se que a alta indução de poros na membrana e consequente morte por piroptose pode ser um dos mecanismos pelos quais as bactérias intracelulares são controladas após a ativação desse inflamassoma (Miao et al., 2010; Silveira e Zamboni, 2010). Já que a morte celular por piroptose lisa as células onde essas bactérias estão se multiplicando e também leva à uma propagação da inflamação, por meio do extravasamento de citocinas e DAMPs, recrutamento assim novas células para o sítio de infecção. Trabalhos recentes demonstraram que a indução de piroptose não leva diretamente à morte das bactérias intracelulares. Entretanto, essas bactérias ficam presas nos restos das células mortas após a piroptose, em uma estrutura denominada de PITs (Pore-induced intracellular traps) (Jorgensen, Lopez, et al., 2016; Jorgensen, Zhang, 
et al., 2016). Os PITs mantêm as bactérias presas no lugar, impedindo que infectem novas células. A indução de piroptose leva à liberação de DAMPs, citocinas próinflamatórias e eicosanoides recrutando novas células para o sítio de infecção como neutrófilos (Barry et al., 2013; Casson et al., 2013; Mascarenhas et al., 2015). Essas células recrutadas fagocitam os restos celulares com as bactérias presas, em um processo denominado de eferocitose (Jorgensen, Lopez, et al., 2016; Jorgensen, Zhang, et al., 2016). Foi demonstrado que essas bactérias após passarem por células que sofreram piroptose, ficam mais susceptíveis à morte por espécies reativas de oxigênio (ROS), antibióticos e apresentam uma menor capacidade de infectar outras células. Desta maneira a piroptose parece ser um mecanismo eficiente de controle da replicação de bactérias intracelulares.

A morte celular por piroptose é caracterizada pela formação inicial de poros na membrana, por onde ocorre o influxo e efluxo de íons, gerando uma lise osmótica da célula com liberação do seu conteúdo no meio extracelular, juntamente com citocinas pró-inflamatórias (Cookson e Brennan, 2001; Fink e Cookson, 2006; Larock e Cookson, 2013; Evavold et al., 2018). Até 2015 não se conhecia os mecanismos pelo qual a ativação do inflamassomas e as caspases induziam a formação de poros nas membranas e morte celular por piroptose. Contudo, através da utilização de "high throughput screening" com CRISPR/Cas9, foi identificada a proteína responsável pela formação dos poros na membrana, denominada de gasdermina-D (GSDMD) (Fig. 4) (Kayagaki et al., 2015; Shi et al., 2015). Tanto a caspase-1 quanto a caspase-11 clivam essa proteína, liberando um fragmento C-terminal e um $\mathrm{N}$-terminal. O fragmento N-terminal da GSDMD migra para a membrana plasmática onde se oligomeriza e se liga à lipídios específicos da membrana plasmática interna, formando a estrutura do poro e desencadeando assim a piroptose (Fig. 4) (Kayagaki et al., 2015; Shi et al., 2015; Aglietti et al., 2016; Ding et al., 2016; Liu et al., 2016; Sborgi et al., 2016). Recentemente, foi demonstrado que a secreção de IL-1 $1 \beta$ e IL-18, que não são liberadas por uma via secretória convencional, ocorre pelos poros de GSDMD (Keller et al., 2008; Evavold et al., 2018). Além do papel de GSDMD na indução de piroptose, também foi demonstrada a participação de outras gasderminas na indução de morte celular, como GSDME, também conhecida como Dfna5 (Deafness Autosomal Dominant 5), após sua clivagem por caspase-3 (Rogers et al., 2017; Wang et al., 2017). 

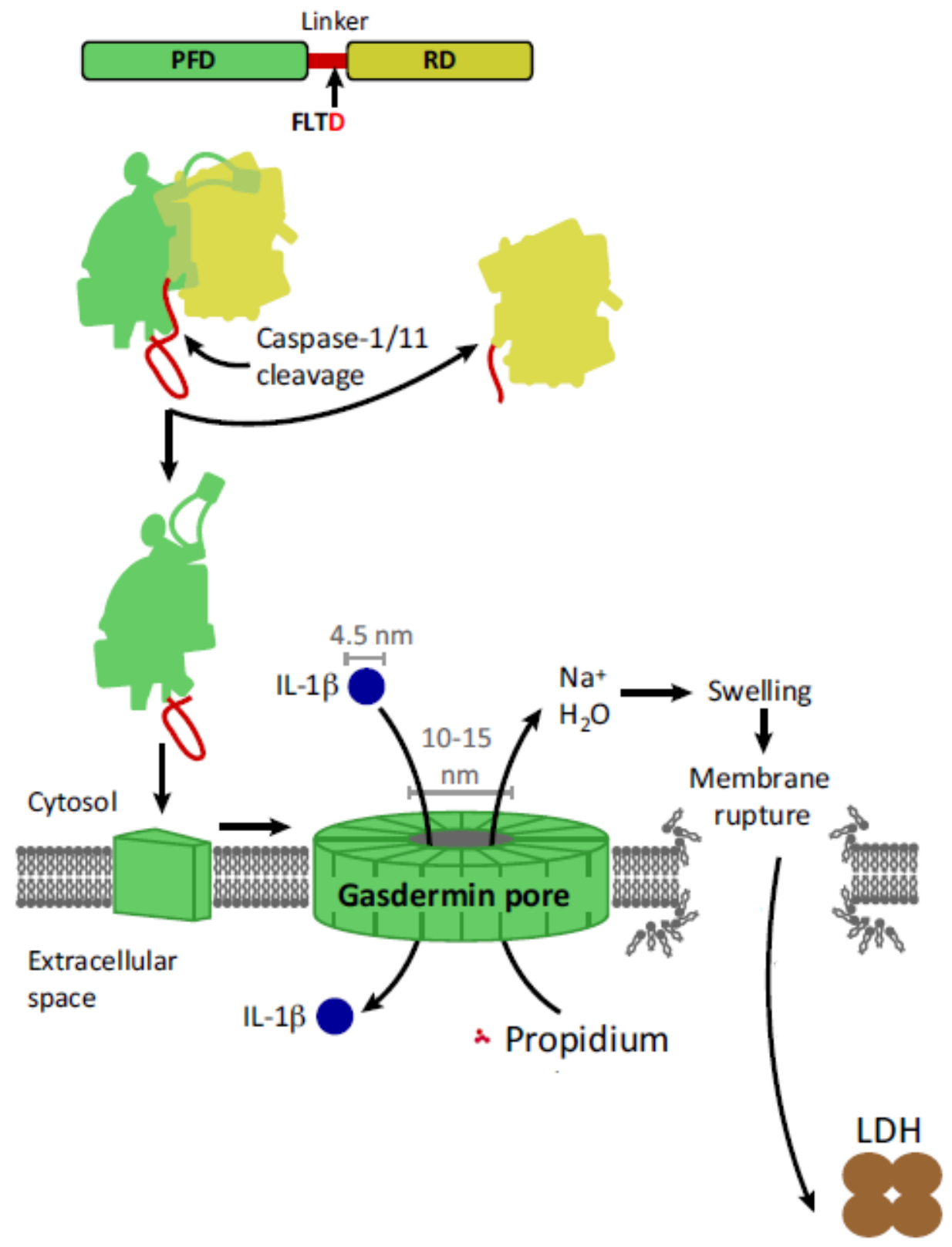

Figura 4: Estrutura do poro de membrana formado por gasdermina-D. Após a ativação das caspases inflamatórias (caspase-1 ou caspase-11 em camundongos e os homólogos de caspase-11, caspase-4 e caspase-5 em humanos) GSDMD é clivada em um ácido aspártico liberando um domínio C-terminal e um $\mathrm{N}$-terminal. $\mathrm{O}$ domínio $\mathrm{N}$-terminal de GSDMD migra para a membrana plasmática, onde se liga à lipídios específicos da membrana plasmática interna. A formação do poro ocorre com a oligomerização de 16 monômeros de GSDMD. O poro formado tem cerca de 10-15nm. Um desbalanço iônico pela formação desse poro causa a entrada de água na célula induzindo a lise celular. Essa lise celular leva à liberação do conteúdo citoplasmático em meio extracelular ativando novas células pelo reconhecimento de DAMPs. Acredita-se que por esse poro são secretadas algumas citocinas com secreção não convencional como IL-1 1 e IL-18. Também são capazes de passar por esse poro outros compostos como iodeto de propídio (PI). Adaptado de: KOVACS, Stephen B; MIAO, Edward A. Trends in Cell Biology, 2017. 
Além da piroptose, em resposta a infecção por $L$. pneumophila, o inflamassoma de Naip5/NLRC4/Caspase-1 também induz a formação de punctas e secreção de citocinas pró-inflamatórias como IL-1 $\beta$ e IL-18, de maneira dependente da molécula adaptadora ASC (Coers et al., 2007; Case et al., 2009; Case e Roy, 2011). Entretanto o papel de ASC no controle da infecção desta bactéria tem sido controverso. Trabalhos utilizando células de humanos demonstraram que ASC é importante no controle da replicação de L. pneumophila (Abdelaziz, Gavrilin, Akhter, Caution, Kotrange, Khweek, Abdulrahman, Grandhi, et al., 2011). Já trabalhos utilizando macrófagos de camundongo demonstraram que ASC não é importante para a indução de piroptose e controle da replicação dessa bactéria. Desta maneira, ainda existe um desacordo em relação ao papel de ASC e o controle da replicação de $L$. pneumophila.

Outros inflamassomas além de Naip5/NLRC4/Caspase-1 também são ativados em resposta à $L$. pneumophila. Um deles é o inflamassoma de AIM2, responsável pelo reconhecimento de fita dupla de DNA (Fig. 2 e 3) (Burckstummer et al., 2009). Esse receptor apresenta dois domínios, um deles denominado de domínio HIN (Hematopoietic IFN-inducible Nuclear Domain) que se oligomeriza após a interação com fita dupla de DNA e um domínio PYD que interage com ASC (Fig. 2) (FernandesAlnemri et al., 2009; Hornung et al., 2009; Roberts et al., 2009). A ativação do inflamassoma de AIM2 por L. pneumophila foi identificado pela observação de que bactérias deficientes para o efetor SdhA geravam uma maior morte celular em macrófagos (Laguna et al., 2006). Alguns anos depois foi demonstrado que $S d h A$ regula a integridade de vacúolo de L. pneumophila (Creasey e Isberg, 2012). A deleção desse gene leva à uma desestabilidade de vacúolo e sua consequente lise, induzindo a liberação do DNA da bactéria no meio citoplasmático onde é reconhecido pelo AIM2. O reconhecimento por esse receptor desencadeia a ativação de caspase1 , secreção de IL-1 $\beta$ e piroptose em células humanas e de camundongos, processos que são independentes de flagelina e da degradação da bactéria no citoplasma (Fig. 3) (Ge et al., 2012).

L. pneumophila, assim como outras bactérias Gram-negativas, também é reconhecida por caspase-11 (Fig. 2 e 3) (Kayagaki et al., 2011). Essa molécula é capaz de reconhecer o LPS (lipopolissacarídeo) dessas bactérias (Shi et al., 2014). A ligação entre essas moléculas ocorre pelo domínio CARD da caspase-11 e o lipídio $A$ do LPS (Shi et al., 2014; Zanoni et al., 2016). Após essa ligação ocorre uma 
oligomerização de caspase-11 e ativação do inflamassoma, desencadeando respostas como piroptose pela clivagem de GSDMD e secreção de IL-1a (Fig. 3) (Case et al., 2013; He et al., 2015; Kayagaki et al., 2015; Shi et al., 2015; Aglietti et al., 2016; Liu et al., 2016; Sborgi et al., 2016). A ativação desse inflamassoma é independente de flagelina e da via de Naip5/NLRC4/Caspase-1, que gera a maior e mais rápida indução de piroptose em resposta à L. pneumophila (Case et al., 2013; Casson et al., 2013; Cunha et al., 2015).

O papel do inflamassoma de caspase- 11 no controle da replicação de $L$. pneumophila é controverso. Entretanto nosso grupo demonstrou através da utilização dos camundongos Casp 1\%Casp1 $11^{\text {tg }}$ e Casp $11^{1-}$ que somente caspase-1, mas não caspase-11 é importante para o controle da replicação de $L$. pneumophila flagelada (Cerqueira et al., 2015). Esse trabalho foi essencial para diferenciar as respostas dependentes de caspase-1 e caspase-11, já que por muito tempo o camundongo Casp $1 / 11^{\text {\% }}$ foi utilizado pelos pesquisadores como sendo deficiente apenas para caspase-1.

Em 2017, um trabalho do nosso grupo demonstrou que camundongos deficientes para Aim2/Casp11 são mais susceptíveis à infecção por L. pneumophila deficiente para flagelina (Cunha et al., 2017). Foi verificado que a ativação dos inflamassomas de AIM2 e caspase-11 induz a formação de poro. Esse dano na membrana gerado pelo poro leva a um efluxo de potássio, e com isso a ativação do inflamassoma de NLRP3 em resposta à infecção por L. pneumophila (Fig. 3).

A ativação de NLRP3, uma molécula que também é membro da família dos NLRs, pode ocorrer por duas vias principais. A via canônica de ativação, que é ativada por diversos componentes como ATP, RNA bacteriano, toxinas que levam à formação de poro (como nigericina) e cristais de urato monossódico (Kanneganti et al., 2006; Mariathasan et al., 2006; Martinon et al., 2006; Sutterwala, Ogura, Szczepanik, et al., 2006; Sutterwala, Ogura, Zamboni, et al., 2006). Já a ativação não canônica depende da ativação prévia de outros inflamassomas, como por exemplo a ativação de caspase-11 por bactérias Gram-negativas (Kayagaki et al., 2011; Case et al., 2013; Casson et al., 2015; Schmid-Burgk et al., 2015). Entretanto, tanto a via canônica quanto a não canônica de ativação do inflamassoma de NLRP3 parecem resultar de um processo comum, que é o efluxo de potássio (Rivers-Auty e Brough, 2015; Ruhl e Broz, 2015; Cunha et al., 2017). 
O inflamassoma de NLRP3 não é importante no controle da infecção de $L$. pneumophila (Case et al., 2009). Entretanto, esse inflamassoma em cooperação com o inflamassoma de Naip5/NLRC4/Caspase-1 são essenciais para a clivagem de caspase-1 e secreção de citocinas pró-inflamatórias como IL-1 $\beta$ e IL-18 ambos de maneira dependente de ASC (Zamboni et al., 2006; Case et al., 2013).

Durante muito tempo acreditou-se que o único inflamassoma realmente efetivo no controle da replicação de L. pneumophila era o de Naip5/NLRC4/Caspase-1 (Yamamoto et al., 1988; Zamboni et al., 2006). Contudo, Pereira, Morgantetti, et al. (2011) demonstraram que além dessa via dependente de NLRC4, flagelina e caspase1 , existe uma via independente de caspase-1/11 que age no controle da replicação de espécies de Legionella flageladas. Foi demonstrado que camundongos $\mathrm{NIrC4}^{-/}$são mais susceptíveis à infecção por $L$. pneumophila flagelada do que camundongos Casp $1 / 11 \%$. Ainda, quando foram utilizadas bactérias deficientes para flagelina $\left(\right.$ fla $\left.A^{-}\right)$ em macrófagos Casp 1/11\%, foi observado uma maior multiplicação bacteriana quando comparado à infecção por bactérias selvagem (WT Lp). Indicando que existe uma via dependente de flagelina e NLRC4 e independente e caspase-1/11 que atua no controle da replicação de $L$. pneumophila. Uma hipótese para esse novo inflamassoma encontrado é de que NLRC4 poderia utilizar uma caspase apoptótica para atuar nesta via. Essa hipótese é corroborada por alguns trabalhos que já detectaram a ativação de caspases não inflamatórias em resposta à infecção por $L$. pneumophila, como caspase-3 e caspase-7 (Gao e Abu Kwaik, 1999; Akhter et al., 2009; Amer, 2010; Abdelaziz, Gavrilin, Akhter, Caution, Kotrange, Khweek, Abdulrahman, Hassan, et al., 2011; Zhu et al., 2013). Entretanto, os mecanismos e os componentes dessa via independente de caspase-1/11 ainda são obscuros, bem como o papel de ASC e dessas caspases não inflamatórias no controle da replicação de L. pneumophila. 
Objetivo 


\section{2 - OBJETIVO}

Determinar e caracterizar da via de sinalização dependente de flagelina/NLRC4 e independente de caspase-1/11 que leva ao controle da infecção de L. pneumophila.

\section{1 - Objetivos específicos}

> Avaliar o papel de ASC no controle da replicação de L. pneumophila.

> Identificação das proteínas que compõe o inflamassoma dependente de NLRC4 e independente de caspase-1/11 em resposta à L. pneumophila flagelada.

> Avaliar o papel de caspases apoptóticas na sinalização induzida por $L$. pneumophila.

> Analisar o papel do reconhecimento de flagelina por Naip5 para a ativação do inflamassoma dependente de NLRC4 e independente de caspase-1/11.

> Avaliar a formação de poro e secreção de citocinas pela via independente de caspase-1/11.

- Caracterizar as respostas independentes de caspase-1/11 no controle da replicação de L. pneumophila. 


\section{Materiais e Métodos}




\section{3 - MATERIAIS E MÉTODOS}

\section{1 - Bactérias}

Neste estudo foram utilizadas as bactérias $L$. pneumophila da cepa selvagem JR32 (WT Lp) e seus mutantes isogênicos deficientes para motilidade (flit) e para flagelina (fla $\left.A^{-}\right)$(Ren et al., 2006; Pereira, Morgantetti, et al., 2011). As bactérias $L$. micdadei (ATCC 33218) e L. gratiana (ATCC 49413) foram utilizadas para gerar cepas resistentes à estreptomicina. Mutantes para Rps/ de L. micdadei e L. gratiana foram isoladas após plaqueadas em placas contendo $100 \mu \mathrm{g} / \mathrm{ml}$ de estreptomicina (Zhu et al., 2015). Todas as bactérias foram cultivadas em placas com meio CYE $\{1 \%$ de extrato de levedura (Oxoid), 1\% MOPS (Sigma-Aldrich), pH 6.9, 3.3 mM de L-cisteína

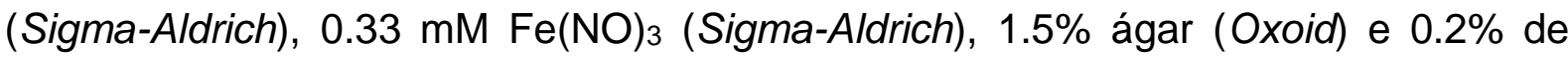
carvão ativado (Sigma-Aldrich)\} (Feeley et al., 1979). Para os experimentos de infecção in vitro e in vivo, todas as bactérias cresceram a $36^{\circ} \mathrm{C}$ por 48 horas. Para a realização das infecções, as bactérias foram ressuspendidas em água estéril e diluídas de acordo com a densidade óptica (O.D) a 600nm.

\section{2 - Cultura de macrófagos derivados de medula óssea}

Para a cultura de macrófagos derivados de medula óssea (BMDMs - Bone marrow-derived macrophages), foram retirados fêmures e tíbias de animais eutanasiados por dose excessiva de anestésico. As células precursoras de macrófagos obtidas da medula óssea de camundongos C57BL/6, $\mathrm{NrC4}^{-/}$, Asc ${ }^{-1}$ Casp1/11\%, Asc/Casp1/11\%, Aim2/Casp1/11\%, Casp1\%Casp11tg, Casp11\% e Gsdmd 1 - foram diferenciadas in vitro durante 7 dias, em estufa a $37^{\circ} \mathrm{C}$ e $5 \%$ de $\mathrm{CO}_{2}$, em meio RPMI 1640 +HEPES (Gibco - Thermo Fisher Scientific) suplementado com 20\% de soro bovino fetal (SBF) (Gibco - Thermo Fisher Scientific), 30\% de meio condicionado por células L929 (LCCM: fonte de M-CSF, importante para diferenciação de células progenitoras em macrófagos), $2 \mathrm{mM}$ L-Glutamina (Sigma-Aldrich), $100 \mathrm{U} / \mathrm{mL}$ de penicilina/estreptomicina (Sigma-Aldrich) (Marim et al., 2010). Após a diferenciação, os macrófagos foram coletados pela lavagem das monocamadas com PBS (phosphate-buffered saline) pH 7.4 gelado (Gibco - Thermo Fisher Scientific), posteriormente, distribuídos em placas de poços tratadas e cultivados em meio RPMI 1640 +HEPES contendo 10\% de SBF e 2 mM L-Glutamina para serem posteriormente infectados. 


\section{3 - Infecções in vitro e determinação de UFC}

Nos experimentos com infecções in vitro as culturas foram infectadas em uma multiplicidade de infecção (MOI) de 0.015, 5 ou 10 bactérias/célula, seguidas de uma centrifugação de $300 \times g$ por 5 minutos a temperatura ambiente e posteriormente incubadas a $37^{\circ} \mathrm{C}$ e $5 \% \mathrm{CO}_{2}$. Para a determinação de UFC (unidades formadoras de colônias), $2 \times 10^{5}$ células foram plaqueadas em placa de 24 poços. Após a adesão das células, a cultura foi infectada com $\mathrm{MOI} 0.015$ ou 10, seguidas de uma centrifugação de $300 \times g$ por 5 minutos a temperatura ambiente. No caso de experimentos com $\mathrm{MOI} 10$, após 1 hora de infecção os poços foram lavados duas vezes com PBS morno e $1 \mathrm{ml}$ de meio RPMl 1640 +HEPES com 10\% de SBF e $2 \mathrm{mM}$ L-Glutamina foi adicionado a cada poço e as placas foram então incubadas a $37^{\circ} \mathrm{C} \mathrm{e}$ $5 \% \mathrm{CO}_{2}$ durante os tempos indicados. Para a determinação de UFC, o sobrenadante de cada poço foi coletado e foi adicionado $1 \mathrm{ml} /$ poço de água estéril. $\mathrm{O}$ lisado celular foi combinado ao sobrenadante do respectivo poço. As combinações de lisado mais sobrenadante de cada poço foram diluídas em água estéril, plaqueadas em meio CYE e incubadas por 4 dias a $36^{\circ} \mathrm{C}$ (Pereira, Morgantetti, et al., 2011; Cerqueira et al., 2015; Mascarenhas et al., 2015).

\section{4 - Transdução retroviral e quantificação de NLRC4-GFP e ASC-GFP}

NLRC4 e ASC murinos foram clonados em vetor pEGFP (N2) (Clontech) usando os sítios de restrição Xhol e BamHI (Case e Roy, 2011). NLRC4-GFP e ASCGFP foram clonados em vetor retroviral específico de murino pMSCV2.2 (Clontech). O sistema de vetor $\mathrm{pCL}$ foi utilizado para o empacotamento dos retrovírus das células Hek Peak transfectadas e posteriormente mantidas em meio contendo $10 \%$ de SBF e $2 \mathrm{mM}$ L-Glutamina. O sobrenadante das células Hek Peak contendo os retrovírus foi coletado após 2 dias da transfecção, filtrado utilizando filtro de $0.45 \mu \mathrm{m}$ e utilizado para a transdução dos BMDMs. BMDMs foram obtidos de camundongos Casp1/11\%, Asc/Casp 1/11\% e Aim2/Casp1/11\% e plaqueados em meio para diferenciação. Após 3 dias de diferenciação o sobrenadante contendo os retrovírus foram adicionados aos BMDMs com 20\% de SBF, 25\% de LCCM e 2 mM L-Glutamina. Após a diferenciação $2 \times 10^{5}$ células/poço foram plaqueadas em placa de 24 poços contendo lamínulas de vidro de $12 \mathrm{~mm}$ e cultivadas em meio suplementado com 10\% de SBF e $2 \mathrm{mM} \mathrm{L}$ Glutamina. Para os experimentos de colocalização com caspases, as culturas foram 
tratadas com $20 \mu \mathrm{M}$ de Z-VAD (Promega) por 1 hora e infectados com MOI 1, 3 e 10. Após a infecção as placas foram centrifugadas a $300 \mathrm{Xg}$ a temperatura ambiente $\mathrm{e}$ incubadas a $37^{\circ} \mathrm{C}$ e $5 \%$ de $\mathrm{CO}_{2}$. Após 1,3 ou 10 horas de infecção as células foram fixadas com paraformaldeído $4 \%$, permeabilizadas e bloqueadas com $0.05 \%$ de saponina mais $10 \%$ de soro de cabra (tampão de bloqueio), as lamínulas foram então montadas em lâminas com Prolong Gold Antifade Reagent contendo DAPI (Molecular probes - Thermo Fisher Scientific). Para os experimentos de colocalização, após a permeabilização e bloqueio as células foram incubadas com anti-caspase-8 (Enzo, diluição de 1:50), anti-caspase-8 clivada (Cell signaling, diluição de 1:800), anticaspase-3 clivada (Cell signaling, diluição de 1:400), anti-caspase-7 clivada (Cell signaling, diluição de 1:400), anti-ASC (Adipogen, diluição de 1:250), anti-ASC (Santa Cruz, 1:50), anti-caspase-1 (Santa Cruz, diluição de 1:500) ou anti-AIM2 (Cell Signaling, diluição de 1:400) diluídos em tampão de bloqueio, por 1 hora. Após incubados com o anticorpo primário, as células foram lavadas três vezes com PBS e então incubadas com os anticorpos secundários conjugados com o fluoróforo Alexa Fluor 594 ou 647 (Molecular probes - Thermo Fisher Scientific, diluição 1:3000), DAPI e as lamínulas foram montadas com Prolong Gold Antifade Reagent. O número de punctas de NLRC4-GFP ou ASC-GFP em relação as células transduzidas e o número de colocalizações foi quantificado em microscópio invertido Leica DMI 4000B com objetiva de 100X (Leica Microsystems). As imagens de microscopia de multifóton foram adquiridas utilizando o sistema LSM 780 Zeiss AxioObserver (Zeiss) com lente de óleo de imersão de aumento de $63 \mathrm{X}$ e analisadas e utilizando o software ImageJ.

\section{5- Ativação de caspase-8}

Para investigar a ativação de caspase-8, $1 \times 10^{5}$ células/poço foram plaqueadas em placas brancas de 96 poços. Após a sua adesão, as células foram infectadas com WT Lp, flit e flaA- (MOI 10) por 8 horas. A ativação de caspase-8 foi medida utilizando o kit de Caspase-8 Glo Assay (Promega) de acordo com o recomendado pelo fabricante. Para a avaliação da ativação de caspase-8 por análise de Western Blotting, foram plaqueados $1 \times 10^{7}$ células/poço em placa de 6 poços e infectados com flit e flaA- (MOI 10). Após 8 horas de infecção as células foram lisadas com tampão RIPA $\{25 \mathrm{mM}$ Tris-HCl (pH 7.6) (J.T.Baker), $150 \mathrm{mM} \mathrm{NaCl}$ (J.T.Baker), $1 \%$ NP-40 (Fluka Biochemika), 1\% deoxicolato de sódio (Sigma- Aldrich), 0.1\% SDS\} 
com inibidor de protease (Roche). Os lisados foram centrifugados a $20.500 \mathrm{X} g$ por 15 minutos a $4^{\circ} \mathrm{C}$ e posteriormente os sobrenadantes foram ressuspendidos em tampão de amostra $\{50 \mathrm{mM}$ Tris (pH 6.8), 2\% SDS (USB Corporation), $0.1 \%$ azul de bromofenol (Synth), 10\% glicerol (Sigma- Aldrich), 2.5\% $\beta$-mercaptoetanol (J.T.Baker )\} e fervidos por 5 minutos. As amostras foram então separadas em gel de SDS-PAGE $15 \%$ e posteriormente transferidas para uma membrana de nitrocelulose de $0.22 \mu \mathrm{m}$ (GE Healthcare), utilizando o sistema de transferência Semidry Transfer Cell (Bio$R a d)$. Após a transferência, as membranas foram bloqueadas por 1 hora a $25^{\circ} \mathrm{C}$ em tampão TBS (Tris buffered saline) $\{60.5 \mathrm{~g} / \mathrm{L}$ de Tris (J.T.Baker) e $87.5 \mathrm{~g} / \mathrm{L}$ de NaCl (J.T.Baker) com pH ajustado para $8.0 \mathrm{com} \mathrm{HCl}$ com $0.01 \%$ de Tween-20 (SigmaAldrich) e 5\% de leite em pó desnatado. $\mathrm{O}$ anticorpo primário anti-caspase-8 (Enzo, diluição 1:500) foi diluído em tampão de bloqueio e incubado na membrana por cerca de $12-14$ horas a temperatura de $4^{\circ} \mathrm{C}$. As membranas foram lavadas três vezes com TBS-Tween e então incubadas com anticorpo secundário anti-rato conjugado a peroxidase (KPL, diluição 1:3000) diluído em tampão de bloqueio por 1 hora a temperatura ambiente. Após a incubação do anticorpo secundário, as membranas foram lavadas novamente três vezes com TBS-Tween e foi utilizado ECL Prime Western Blotting Detection Reagent (GE Healthcare) para a detecção dos anticorpos marcados observados no aparelho Amersham Imager 600 (GE Healthcare).

\section{6 - Silenciamento retroviral de caspase-8, Naip5 e GSDMD}

Para o silenciamento retroviral de caspase-8, Naip5 e gasdermina-D (GSDMD), células Hek Peak foram transfectadas com vetores lentivirais codificando shRNA (small hairpin RNA) para caspase-8 (Sigma-Aldrich - Seq1: TRCN0000231279; Seq2: TRCN0000231281), Naip5 (Sigma-Aldrich - TRCN0000114742) e GSDMD (SigmaAldrich - TRCN0000219619) e o como controle um vetor com uma sequência não relacionada (NT - non-target shRNA) (Franco et al., 2017). A transfecção das células Hek Peak foi realizada com o auxílio de PEI (Polyethylenimine) (Sigma-Aldrich). As células transfectadas foram mantidas em meio RPMl $1640+$ Hepes suplementado com $10 \%$ de SBF e $2 \mathrm{mM} \mathrm{L-Glutamina} \mathrm{a} 37^{\circ} \mathrm{C}$ e $5 \% \mathrm{CO}_{2}$. Após 2 dias de transfecção o sobrenadante das células Hek Peak contendo os retrovírus foi coletado, filtrado utilizando filtro de $0.45 \mu \mathrm{m}$ e utilizado para a transdução dos BMDMs. BMDMs foram obtidos de camundongos C57BL/6, Casp1/11 1 e Asc/Casp $1 / 11^{1 /}$ e plaqueados em 
meio para diferenciação. Após 3 dias de diferenciação o sobrenadante contendo os retrovírus codificando os shRNAs e o NT shRNA foram adicionados aos BMDMs com $20 \%$ de SBF e $30 \%$ de LCCM. Após um dia de transdução as células foram selecionadas com $3 \mu \mathrm{g} / \mathrm{ml}$ de puromicina por 2 dias e então plaqueadas e utilizadas de acordo com cada experimento. Para a confirmação do silenciamento das células foi realizado Western Blotting para observação da pro-caspase-8 (como descrito anteriormente), bem como qPCR em tempo real para caspase-8, Naip5 e GSDMD como descreveremos a seguir.

\section{7 - qPCR em Tempo Real}

RNA total foi extraído de $2 \times 10^{6}$ células utilizando o kit de isolamento de RNA Illustra RNAspin (Ge Healthcare) de acordo com o recomendado pelo fabricante. Após a extração, alíquotas de $2 \mu \mathrm{l}$ foram utilizadas para determinar a concentração de RNA total em equipamento de NanoDrop (Thermo Fisher Scientific) e $1 \mu \mathrm{g}$ do RNA extraído foi utilizado para a conversão em cDNA utilizando o kit iScriptTM cDNA Synthesis (BioRad) e o auxílio do termociclador Mastercycler gradient (Eppendorf) de acordo com o recomendado pelo fabricante. O cDNA $(10 \mu \mathrm{g})$ foi utilizado para a quantificação da expressão de caspase-8 (TaqMan Assay: Casp8 - Mn01255716_m1) (Thermo Fisher Scientific) por PCR em tempo real utilizando TaqMan Fast Advanced Master Mix (Thermo Fisher Scientific) de acordo com o recomendado pelo fabricante. O gene de ß-actina (TaqMan Assay: Actb - Mn00607939_s1) (Thermo Fisher Scientific) foi utilizado com controle para normalização da expressão das amostras. A quantificação de Naip5 e GSDMD foi realizada utilizando $25 \mathrm{ng}$ de cDNA e $10 \mu \mathrm{M}$ de cada primer 1X SYBR Green (Naip5: FWD: GTTGAGATTGGAGAAGACCTCG, REVCACACGTGAAAGCAACCA

TGG; GSDMD: FWD: TCATGTGTCAACCTGTCAATCAAGGACAT, REVCATCGACGACATCAGAGACTTTGAAGGA). A normalização da expressão de Naip5 e GSDMD foi realizada pela expressão do gene Gapdh (glyceraldehyde-3phosphate dehydrogenase) (Gapdh: FWD- AGGTCGGTGTGAACGGATTTG, REVTGTAGACCATGTAGTTGAGGTCA). A reação de PCR em tempo real foi realizada no equipamento Viia 7 Real-Time PCR System (Thermo Fisher Scientific). Os resultados foram analisados utilizando o método $2^{-\Delta \Delta C T}$ e foram expressos em relação ao grupo 
de referência. A porcentagem de silenciamento foi estimada utilizando a equação: $\{1$ $\left.\left(2^{-\triangle \Delta C T}\right) \times 100\right\}$ (Milstein et al., 2013).

\section{8 - Camundongos e infecções in vivo}

Os camundongos utilizados neste estudo foram criados e mantidos nos Biotérios da Universidade de São Paulo no Campus de Ribeirão Preto (Biotério Central, Centro de Criação de Camundongos Especiais, Biotério do Departamento de Biologia Celular e Molecular e Biotério do Departamento de Imunologia e Bioquímica). Foram utilizados os camundongos C57BL/6 (Jax 000664), NIrC4 ${ }^{-/}$, Casp1/11//, AsC ${ }^{-/ \text {, }}$ Casp11\% e Casp1\%Casp11tg (Kuida et al., 1995; Lara-Tejero et al., 2006; Sutterwala, Ogura, Szczepanik, et al., 2006; Kayagaki et al., 2011). Camundongos duplodeficientes foram gerados pelo intercruzamento da progênie F1 dos camundongos parentais. Todos os camundongos foram pareados por sexo e idade (todas as infecções foram feitas com camundongos de pelo menos 8 semanas) e todos os camundongos são do background genético de C57BL/6. Para os experimentos com infecções in vivo, foram utilizados cerca de 5-7 animais/grupo como indicado em cada figura. Anteriormente às infecções, os camundongos foram anestesiados com cetamina e xilazina (50 mg/kg e $10 \mathrm{mg} / \mathrm{kg}$, respectivamente) por via intraperitoneal. Após anestesiados os camundongos foram infectados com $40 \mu \mathrm{l}$ de PBS contendo 1 $X 10^{5}$ bactérias/camundongo por via intranasal. Para a determinação do número de bactérias no pulmão, os camundongos foram sacrificados e seu pulmão retirado, triturado e homogeneizado em $5 \mathrm{ml}$ de água estéril por 30 segundos com homogeneizador de tecidos Power Gen 125 (Thermo Fisher Scientific). Os pulmões homogeneizados foram então diluídos em água e plaqueados em meio CYE para a determinação de UFC/pulmão após 4 dias a $36^{\circ} \mathrm{C}$ (Pereira, Marques, et al., 2011; Pereira, Morgantetti, et al., 2011; Mascarenhas et al., 2015).

\section{9 - Ensaio de formação de poro}

A formação de poro nos BMDMs foi quantificada baseada na incorporação de iodeto de propídio (PI), um corante fluorescente capaz de entrar apenas em células com a membrana danificada (Case et al., 2013; Cerqueira et al., 2015). Para isso, $1 \mathrm{X}$ $10^{5}$ células/poço foram plaqueados em placa preta com o fundo transparente de 96 
poços. Antes da infecção o meio foi substituído por RPMI sem vermelho de fenol (Sigma-Aldrich) contendo $15 \mathrm{mM}$ de Hepes (Sigma-Aldrich), apenas $0.038 \mathrm{~g} / \mathrm{ml} \mathrm{de}$ $\mathrm{NaHCO}_{3}$ (J.T.Baker), suplementado com 2\% de SBF, 2 mM de L-Glutamina, e posteriormente adicionado $6 \mu \mathrm{l}$ de PI e anticorpo anti-L. pneumophila (diluição 1:1000). Os macrófagos foram infectados com $\mathrm{MOI} 10$ e posteriormente a placa foi centrifugada a $300 \times g$ por 5 minutos a temperatura ambiente. Os BMDMs infectados foram mantidos a $37^{\circ} \mathrm{C}$, com o PI sendo excitado a $535 \mathrm{~nm}$. A fluorescência de emissão foi lida a $617 \mathrm{~nm}$ a cada 5 minutos utilizando um fluorímetro de placa Spectra Max i3x (Molecular Devices). A formação total de poro foi determinada pela lise das células com a adição de $34 \mu \mathrm{l} /$ poço (contendo $200 \mu \mathrm{l}$ de meio) de Triton X-100 (Sigma-Aldrich) 9\%.

\subsection{0 - Ensaio de liberação de Lactato desidrogenase (LDH) e ELISA}

Nos ensaios de liberação de Lactato desidrogenase (LDH) e ELISA, $5 \times 10^{5}$ células/poço foram plaqueadas em placa de 24 poços. No ensaio de LDH, antes da infecção o meio foi substituído por RPMI sem vermelho de fenol contendo $15 \mathrm{mM}$ de Hepes, $2 \mathrm{~g} / \mathrm{L}$ de $\mathrm{NaHCO}_{3}$, suplementado com 2\% de SBF e 2 mM de L-Glutamina. As células foram infectadas com MOI 10 seguidas de uma centrifugação de $300 \times \mathrm{g}$ por 5 minutos a temperatura ambiente. Após 8 horas de infecção o sobrenadante das células foi coletado para a dosagem de liberação de LDH com o kit CytoTox 96 LDHrelease (Promega) de acordo com as recomendações do fabricante. O valor do LDH total foi determinado pela lise das células com Triton X-100 9\%. Para a determinação da secreção de citocinas pelo método de ELISA (Enzyme-linked immunosorbent assay) após aderidos os BMDMs foram infectados com MOI 10. Após 1 hora de infecção as culturas foram lavadas duas vezes com PBS morno e o meio foi substituído por um novo meio RPMI 1640 suplementado com 10\% de SBF e 2 mM de L-Glutamina. As células foram incubadas por 24 horas a $37^{\circ} \mathrm{C}$ e $5 \%$ de $\mathrm{CO}_{2}$, e então seus sobrenadantes foram coletados para a dosagem de citocinas utilizando os kits de ELISA de acordo com as recomendações do fabricante (BD Biosciences). 


\subsection{1 - Declaração ética}

Os cuidados com os animais neste trabalho estão de acordo as diretrizes institucionais de ética em experimentação animal e foram aprovadas pela Comissão de Ética em Experimentação Animal da Faculdade de Medicina de Ribeirão Preto (CETEA - Número de protocolo: 218/2014). Para a eutanásia, os camundongos foram tratados com cetamina e xilazina (50 mg/kg e $10 \mathrm{mg} / \mathrm{kg}$, respectivamente) por via intravenosa.

\subsection{2- Análise Estatística}

$\mathrm{Na}$ realização das análises estatísticas do presente estudo, foi utilizado o programa GraphPad Prism 5.0 Para comparar dados entre diferentes grupos experimentais, foi empregado o teste $t$ não paramétrico ou teste de análise de variância ANOVA seguido de análise pós-teste Bonferroni. O teste não-paramétrico Mann-Whitney foi utilizado nas análises dos experimentos in vivo. As diferenças foram consideradas estatisticamente diferentes quando $p<0.05$ e foram indicadas com asteriscos nas figuras. 


\section{$\underline{\text { Resultados }}$}




\section{4 - RESULTADOS}

\section{1 - 0 controle da replicação de L. pneumophila em BMDMs é dependente do reconhecimento de flagelina e de NLRC4, independente de ASC e parcialmente dependente de caspase-1}

Foi demonstrado anteriormente que o controle da replicação de L. pneumophila ocorre pela via já descrita de Naip5/NLRC4/Caspase-1 e por uma via dependente de NLRC4, mas independente de caspase-1/11 (Zamboni et al., 2006; Pereira, Morgantetti, et al., 2011). Entretanto os mecanismos pelos quais essa via atua eram desconhecidos. Com o objetivo de caracterizar as respostas independentes de caspase-1/11 no controle da replicação de $L$. pneumophila, foi utilizada a cepa JR32 WT Lp de L. pneumophila (Wild-type), e seus mutantes isogênicos flit e flaA: A bactéria flit é deficiente para uma ATPase importante para a secreção de flagelina pelo aparato flagelar; conforme foi demonstrado anteriormente, bactérias flit induzem ativação do inflamassoma de Naip5/NLRC4 normalmente (Merriam et al., 1997; Pereira, Morgantetti, et al., 2011). Por outro lado, a bactéria flaA é deficiente para flagelina, e, portanto, não é capaz de ativar o inflamassoma de Naip5/NLRC4 (Amer et al., 2006; Molofsky et al., 2006; Ren et al., 2006). Deste modo, o melhor controle para a bactéria flaA-é a bactéria flit, já que ambas são deficientes para motilidade, mas somente a flit expressa flagelina. Para avaliar o crescimento dessas bactérias na via independente de caspase-1/11, macrófagos derivados de medula óssea (BMDMs - Bone marrow-derived macrophages) de camundongos C57BL/6, NIrc4 ${ }^{-/}$, Casp1/11. - e Asc/- foram infectados com WT Lp, flit, e flaA- com baixo (0.015) e alto (10) MOI e lisados após $0,24,48,72$ e 96 horas para a determinação das unidades formadoras de colônias (UFCs). Em ambos os MOls os macrófagos C57BL/6 e Asc ${ }^{-/}$foram altamente restritivos à replicação de $L$. pneumophila WT Lp e flit (Fig. 5A-D). Confirmando dados anteriores de que ASC não é importante no controle da replicação de L. pneumophila na presença de caspase-1/11 (Zamboni et al., 2006; Case et al., 2009). Por outro lado, macrófagos derivados de camundongos Casp $1 / 1 \%$ infectados com WT Lp e flit apresentaram um controle da replicação intermediário nos dois MOls utilizados. Já os macrófagos derivados de camundongos N/rc4-1 infectados com todas as bactérias foram altamente susceptíveis à infecção (Fig. 5A-F), assim como as células infectadas com a bactéria mutante para flagelina $(f l a A)$, por não ser 
reconhecida pela via de NLRC4 (Fig. 5E-F). Esses dados corroboram com os achados de que além do inflamassoma de Naip5/NLRC4/Caspase-1 existe uma nova via dependente do reconhecimento de flagelina e de NLRC4 e independente de caspase1/11 (Pereira, Morgantetti, et al., 2011). A partir desses dados, nós utilizamos dos macrófagos derivados de camundongos Casp 1/11\% para a caracterização dessa via de controle da replicação de $L$. pneumophila, na ausência de caspase-1/11. 

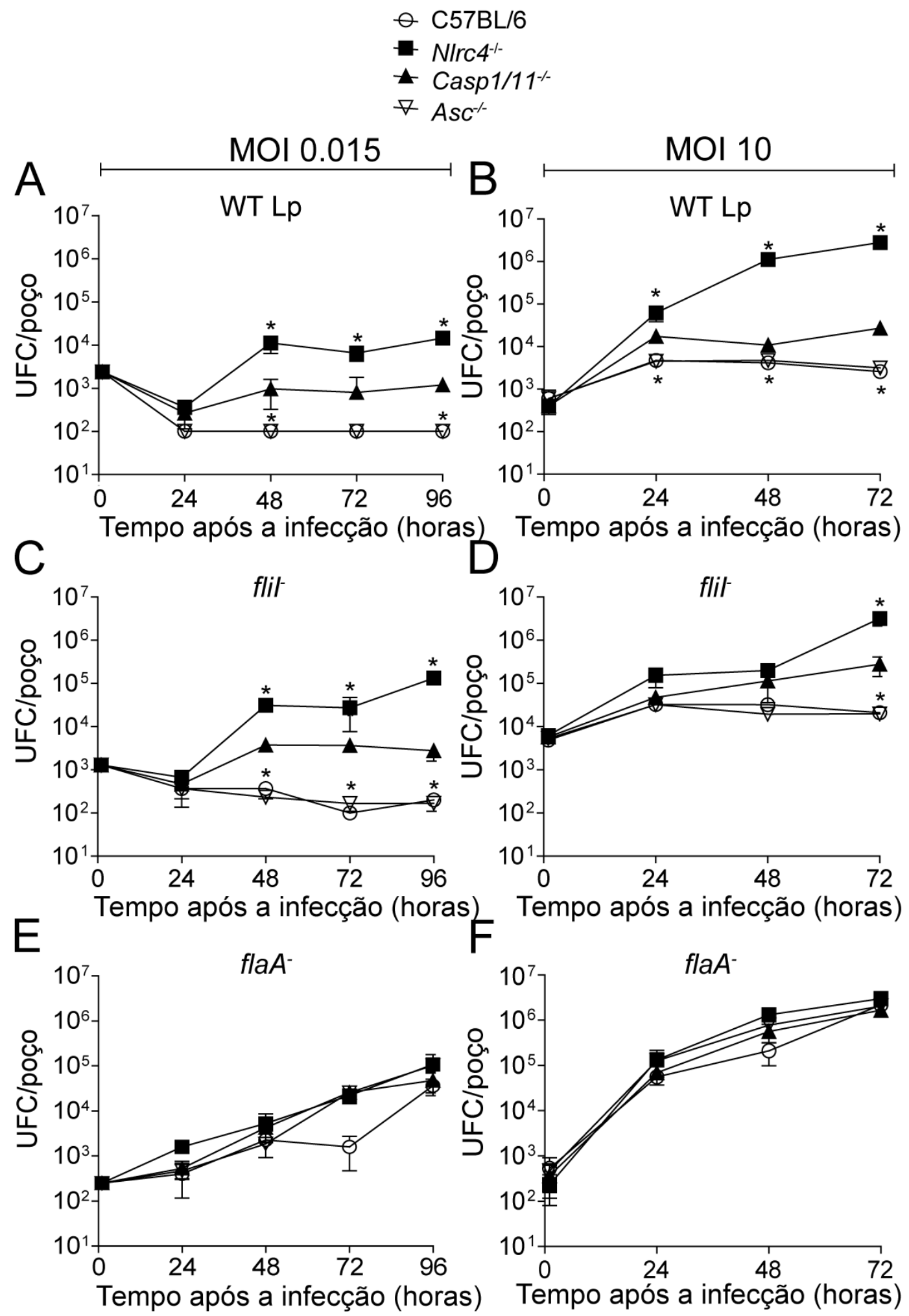

Figura 5: O controle da replicação de $L$. pneumophila é dependente de NLRC4 e flagelina, parcialmente dependente de caspase-1 e independente de ASC. Macrófagos derivados de medula óssea (BMDMs) de C57BL/6 (círculo aberto), N/rc4 $4^{-}$(quadrado fechado), Casp1/11\% (triângulo fechado) e Asc ${ }^{-}$(triângulo invertido aberto) foram infectados com L. pneumophila WT Lp (A-B), flit (CD) e fla $A^{-}(\mathrm{E}-\mathrm{F})$ com MOI de 0.015 (A, C e E) ou 10 (B, D e F). As células foram lisadas após 0, 24, 48, 72 ou 96 horas para a determinação das unidades formadoras de colônias (UFCs). Dados demonstram a média \pm 0 desvio padrão das triplicatas. ${ }^{*}, P<0.05$ comparado com as células Casp1/11\%, ANOVA. Os dados apresentam um experimento representativo de dois experimentos com resultados similares. De: MASCARENHAS, Danielle PA et al. PLoS pathogens, 2017. 


\section{2- A formação de punctas de NLRC4 por L. pneumophila contendo flagelina é dependente de ASC}

A formação e ativação dos inflamassomas gera um agregado citoplasmático muito característico, capaz de ser visto em microscópio óptico, denominado de "puncta" ou "speck" (Proell et al., 2013). A formação dos punctas leva à auto proteólise das caspases, com consequente secreção de citocinas pró-inflamatórias (Martinon et al., 2002). Desta maneira, nosso próximo objetivo foi avaliar como ocorre a formação do inflamassoma dependente de NLRC4 e independente de caspase-1/11 pela observação dos punctas de NLRC4. Para isso utilizamos um sistema retroviral expressando NLRC4 fusionado à GFP já padronizado anteriormente (Case e Roy, 2011). BMDMs derivados de camundongos Casp $1 / 11 \%$ foram transduzidos com NLRC4-GFP e então infectados com WT Lp, flit e flaA (MOI 1, 3 e 10) por 2, 4 e 8 horas. Nós observamos que a quantidade de punctas de NLRC4-GFP aumenta conforme o tempo e a quantidade de bactérias/macrófagos (Fig. 6A). As bactérias WT Lp e flit induziram uma maior formação de punctas em comparação à bactéria flaAque apresentou baixas porcentagens de formação de punctas de NLRC4-GFP. Esse dado indica que há formação de puncta de NLRC4 em resposta à flagelina de $L$. pneumophila mesmo na ausência de caspase-1/11.

Diversos trabalhos têm demostrado o papel essencial da molécula adaptadora ASC na nucleação dos inflamassomas, incluindo o inflamassoma de NLRC4, AIM2 e NLRP3 (Masumoto et al., 1999; Fernandes-Alnemri et al., 2007; Case e Roy, 2011; Pierini et al., 2012; Man et al., 2013; Stutz et al., 2013). Dessa maneira nosso próximo passo foi avaliar o papel de ASC na formação do puncta de NLRC4-GFP em resposta à $L$. pneumophila na ausência de caspase-1/11. Para isso foram cruzados animais Asc ${ }^{-}$e Casp $1 / 11^{\%}$ gerando uma prole $\mathrm{F} 1$ que foi posteriormente cruzada gerando camundongos triplo nocautes para Asc/Casp1/11\% (Cunha et al., 2017). BMDMs desses camundongos, assim como de Casp $1 / 11 \%$ foram transduzidos com NLRC4GFP e posteriormente infectados com flit por 8 horas para a quantificação de punctas de NLRC4-GFP. Não foi possível detectar nenhum puncta de NLRC4-GFP nos macrófagos Asc/Casp1/11\% infectados com flit (Fig. 6B). Entretanto a ausência de caspase-1/11 não afetou a formação dos punctas como demostrado anteriormente (Fig. 6A). Esses dados confirmam que ASC é essencial para a nucleação do 
inflamassoma de NLRC4 em resposta à infecção por L. pneumophila contendo flagelina, mesmo na ausência de caspase-1/11.

A partir desses resultados nosso próximo objetivo foi identificar novos componentes do inflamassoma dependente de NLRC4 e independente de caspase$1 / 11$, como por exemplo outras caspases. Tem sido demonstrado que caspases apoptóticas, como a caspase-3, caspase-7 e caspase-8 podem participar da formação dos inflamassomas por meio da interação com ASC (Masumoto et al., 2003; Hasegawa et al., 2005; Akhter et al., 2009; Kumar et al., 2010; Abdelaziz, Gavrilin, Akhter, Caution, Kotrange, Khweek, Abdulrahman, Hassan, et al., 2011; Motani et al., 2011; Pierini et al., 2012; Man et al., 2013; Sagulenko et al., 2013; Man et al., 2014; Vajjhala et al., 2015; Kawamoto et al., 2017; Rauch et al., 2017). Desta maneira, macrófagos Casp1/11\% foram transduzidos com NLRC4-GFP e infectados com flit por 8 horas. Nesse experimento antes da infecção as células foram tratadas por 1 hora com inibidor de pan-caspase Z-VAD para bloquear a ativação das caspases e facilitar a visualização dos punctas. Após a infecção as células foram fixadas e coradas com anticorpo anti-caspase-3, anti-caspase-7 ou anti-caspase-8. Nós não detectamos um número significativo de punctas de NLRC4-GFP colocalizados com caspase-3 e caspase-7 (Fig. 7A). Entretanto, foi encontrado uma alta taxa de colocalização entre os punctas de NLRC4-GFP e os punctas de caspase-8, indicando que a caspase-8 pode participar da formação do inflamassoma de NLRC4 na ausência de caspase-1/11. Para confirmar esses dados, nós avaliamos a colocalização de caspase-8 e ASC nos punctas de NLRC4-GFP em macrófagos Casp1/11\% infectados com flit. Tanto os punctas de caspase-8 quanto de ASC apresentaram mais de $80 \%$ de colocalização com os punctas de NLRC4-GFP (Fig. 7B). Confirmando esses dados, imagens adquiridas por microscopia de multifóton revelaram que NLRC4, ASC e caspase-8 estão no mesmo puncta, indicando que o inflamassoma independente de caspase-1/11 é composto por NLRC4/ASC/Caspase-8 (Fig. 7C).

A fim de corroborar os dados anteriores foi utilizado um sistema retroviral expressando ASC fusionado a GFP, também já padronizado anteriormente (Case e Roy, 2011). BMDMs derivados de camundongos Casp1/11\% foram transduzidos com ASC-GFP e infectados com WT Lp, flit e flaA- (MOI 10) por 1 e 8 horas de infecção. Nós observamos que a formação dos punctas de ASC-GFP ocorre logo após a infecção com WT Lp ou flit, mas não com flaA-(Fig. 8A). Após 8 horas de infecção 
ocorre um aumento na formação de punctas de ASC-GFP, inclusive nas células infectadas com flaA; , entretanto essas células ainda apresentam uma formação de punctas inferior se comparadas às células infectadas com WT Lp e flit, sendo a formação de punctas em tempos mais tardios parcialmente dependente de flagelina. Para validar a participação de caspase-8 na via independente de caspase-1/11, macrófagos Casp 1/11\% transduzidos com ASC-GFP foram infectadas com flit e incubadas com anticorpo anti-caspase-3, anti-caspase-7 ou anti-caspase-8. Como observado com NLRC4, nas células transduzidas para ASC-GFP a porcentagem de colocalização entre ASC, caspase-3 e caspase-7 não foi significativa (Fig. 8B). Entretanto, foi encontrado uma alta taxa de colocalização entre ASC-GFP e caspase8 (Fig. 8B-C). Em conjunto esses dados indicam que a flagelina de L. pneumophila leva à formação de um inflamassoma independente de caspase-1/11 composto por NLRC4/ASC/Caspase-8. 


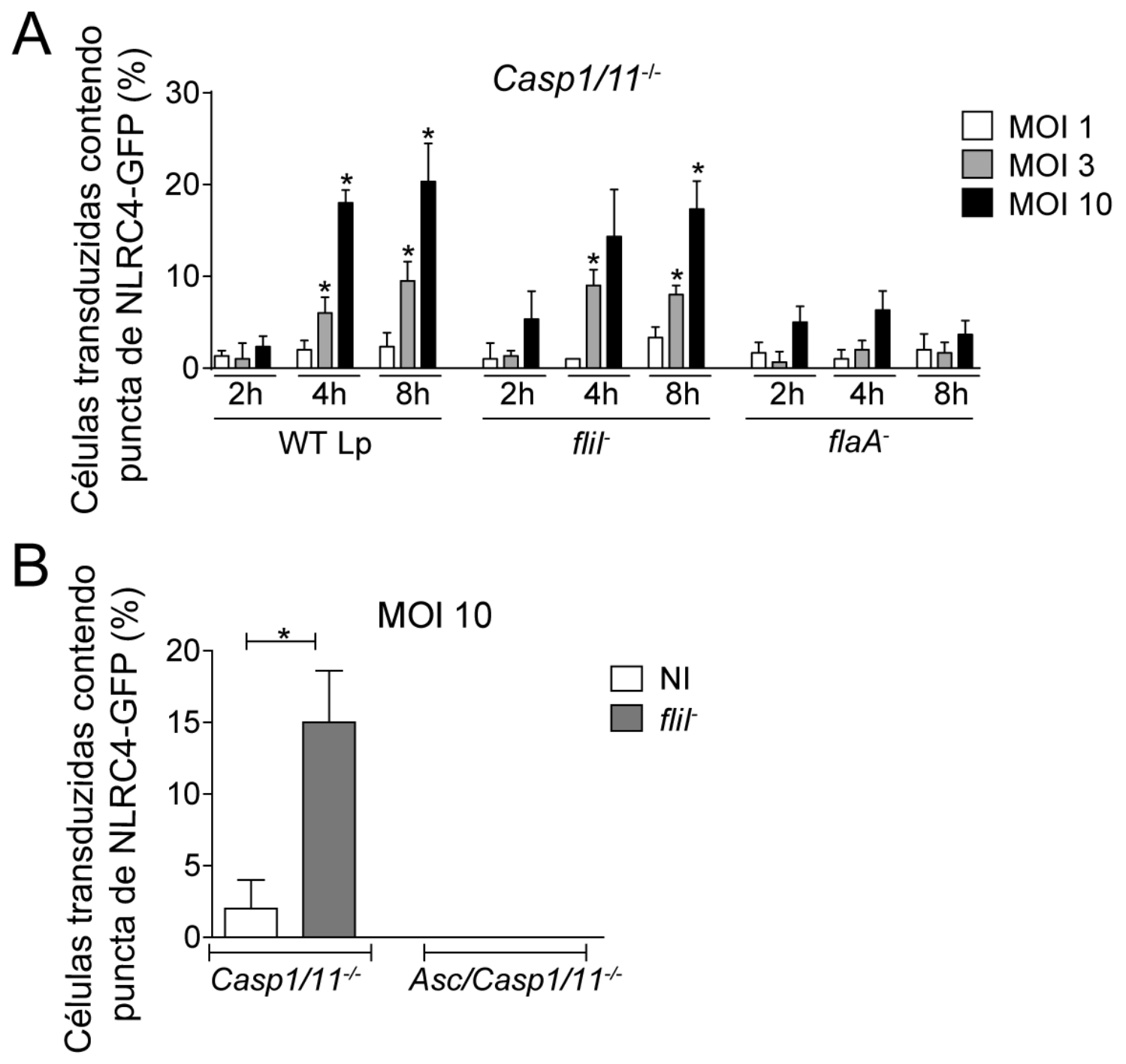

Figura 6: L. pneumophila leva à formação de puncta de NLRC4-GFP de maneira dependente de flagelina e ASC e independente de caspase-1/11. Macrófagos derivados de medula óssea (BMDMs) de Casp1/11\% (A-B) e Asc/Casp1/11\% (B) foram transduzidos com retrovírus expressando NLRC4-GFP e infectados com $L$. pneumophila WT Lp, flit ou flaA- (MOI 1, 3 ou 10). As células foram fixadas após 2 (A), 4 (A) ou 8 (A-B) horas de infecção e a porcentagem de células transduzidas contendo puncta de NLRC4-GFP foi quantificada por meio de microscopia de epifluorescência. Dados demonstram a média \pm 0 desvio padrão das triplicatas. ${ }^{*}, P<0.05$ comparado com as células infectadas com flaA ou como indicado, teste $t$ não paramétrico. Os dados apresentam um experimento representativo de cinco $(A)$ e dois (B) experimentos com resultados similares. Adaptado de: MASCARENHAS, Danielle PA et al. PLoS pathogens, 2017. 

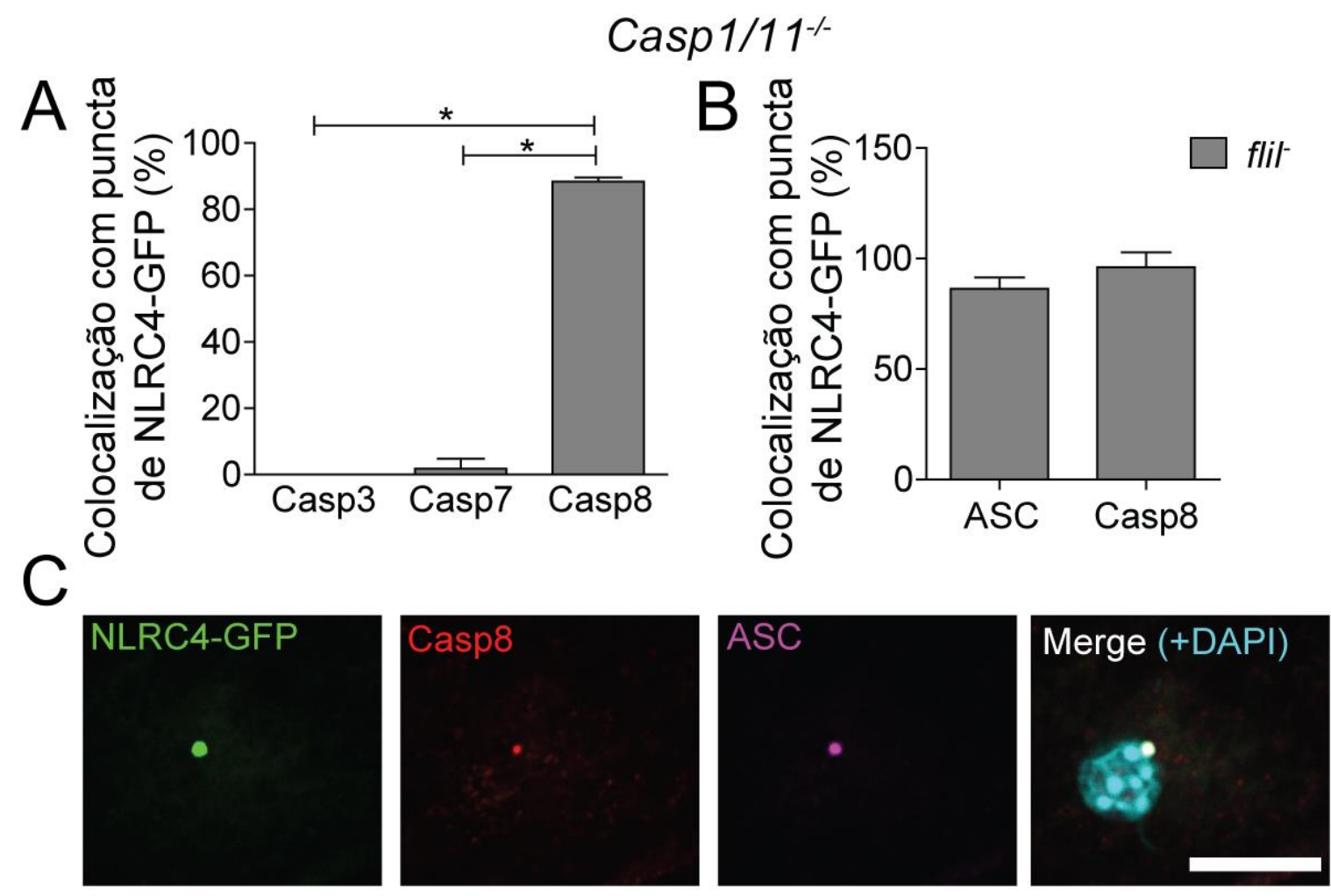

Figura 7: ASC e caspase-8, mas não caspase-3 e caspase-7 colocalizam o puncta de NLRC4GFP em resposta à $L$. pneumophila contendo flagelina. Macrófagos derivados de medula óssea (BMDMs) de Casp1/11\%- foram transduzidos com retrovírus expressando NLRC4-GFP e infectados com L. pneumophila flit (MOI 10). Após 8 horas de infecção as células foram fixadas e incubadas com anticaspase-3 (A), anti-caspase-7 (A), anti-caspase-8 (A-C) ou anti-ASC (B-C). (A-B) A porcentagem de colocalização entre os punctas de NLRC4-GFP, caspase-3, caspase-7, caspase-8 e ASC foi quantificada por meio de microscopia de epifluorescência. (C) Imagens representativas da colocalização entre NLRC4-GFP (verde), caspase-8 (vermelho) e ASC (magenta) em BMDMs Casp 1/11\% transduzidos com NLRC4-GFP e infectados com flit (MOI 10) por 8 horas. As células foram fixadas e marcadas para anti-caspase-8, anti-ASC e o núcleo foi corado com DAPI (ciano). As imagens foram adquiridas por microscopia de multifóton utilizando objetiva de óleo de imersão de aumento de 63X. As imagens foram analisadas utilizando o software ImageJ. Barra de escala, $10 \mu \mathrm{m}$. Dados demonstram a média \pm 0 desvio padrão das triplicatas. ${ }^{*}, P<0.05$, teste $t$ não paramétrico. $\mathrm{NI}$, não infectado. Os dados apresentam um experimento representativo de dois experimentos com resultados similares. Adaptado de: MASCARENHAS, Danielle PA et al. PLoS pathogens, 2017. 


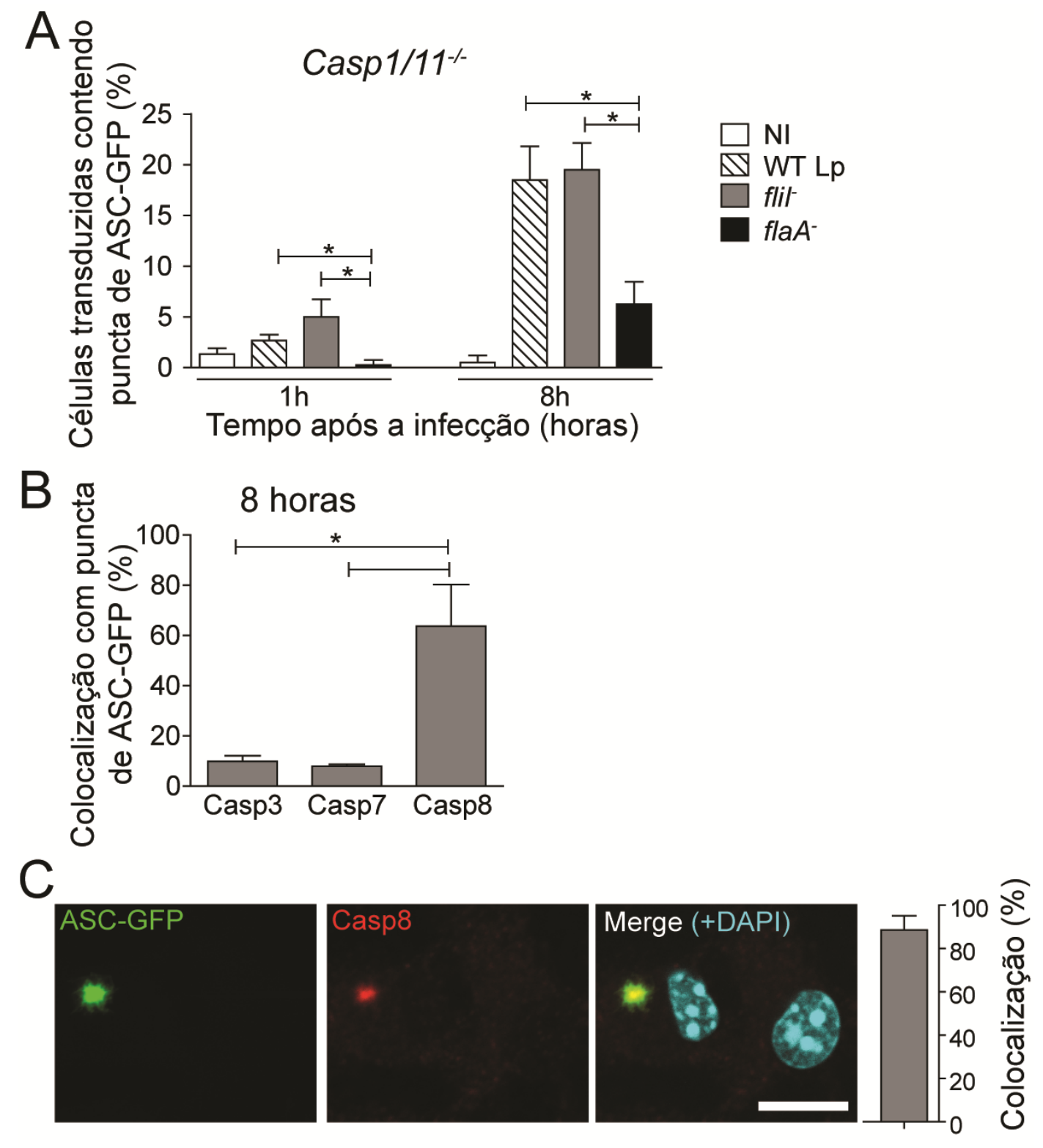

Figura 8: Puncta de ASC-GFP é induzido em resposta à flagelina de $L$. pneumophila e colocaliza com caspase-8. Macrófagos derivados de medula óssea (BMDMs) de Casp1/11/ foram transduzidos com retrovírus expressando ASC-GFP e infectados com L. pneumophila WT Lp (A), flit (A-C) ou flaA (A) (MOI 10). (A) As células foram fixadas após 1 ou 8 horas de infecção e a porcentagem de células transduzidas contendo puncta de ASC-GFP foi quantificada por meio de microscopia de epifluorescência. (B) Após 8 horas de infecção com flit (MOI 10), as células foram fixadas e incubadas com anti-caspase-3, anti-caspase-7 ou anti-caspase-8. A porcentagem de colocalização entre os punctas de ASC-GFP, caspase-3, caspase-7 ou caspase-8 foi quantificada por meio de microscópio de epifluorescência. (C) Imagens representativas da colocalização entre ASC-GFP (verde) e caspase-8 (vermelho) em BMDMs Casp1/11\% transduzidos com ASC-GFP e infectados com flit (MOI 10) por 8 horas. As células foram fixadas e marcadas para anti-caspase-8 e o núcleo foi corado com DAPI (ciano). As imagens foram adquiridas por microscopia de multifóton utilizando objetiva de óleo de imersão de aumento de 63X. As imagens foram analisadas utilizando o software ImageJ. Barra de escala, $10 \mu \mathrm{m}$. Dados demonstram a média \pm 0 desvio padrão das triplicatas. ${ }^{*}, P<0.05$, teste $t$ não paramétrico. $\mathrm{NI}$, não infectado. Os dados apresentam um experimento representativo de três $(A)$ e dois (B-C) experimentos com resultados similares. Adaptado de: MASCARENHAS, Danielle PA et al. PLoS pathogens, 2017. 


\section{3- O inflamassoma de NLRC4/ASC/Caspase-8 leva ao controle da replicação}

de Legionella spp. flageladas na ausência de caspase-1/11 em macrófagos

Anteriormente observamos que NLRC4, ASC e caspase-8 estão no mesmo puncta, sugerindo que caspase-8 participa do inflamassoma independente de caspase-1/11 com NLRC4 e ASC. A partir desses dados, nós avaliamos se caspase8 é ativada em resposta à infecção por L. pneumophila. Com esse objetivo, BMDMs de camundongos Casp $1 / 11^{-/}$e Asc/Casp $1 / 11^{-/}$foram infectados com L. pneumophila flit e flaA- (MOI 10). Após 8 horas foi avaliada a ativação de caspase-8 por meio da adição de um substrato para caspase-8 ativa que quando clivado resulta em um sinal luminescente (Caspase-8 Glo Assay) (Zwolanek et al., 2014). Nós detectamos uma alta ativação de caspase-8 em células Casp1/11\% infectadas com flit, mas não com flaA- (Fig. 9A). Já nas células deficientes para Asc/Casp1/11 a ativação de caspase-8 não foi significativa, indicando que ASC é essencial para a ativação de caspase-8, o que vai de acordo com os dados anteriores indicando que ASC é essencial para a formação deste inflamassoma. Para confirmar esses dados, nós avaliamos a ativação de caspase-8 por Western Blot observando a clivagem da pro-caspase-8 (p55) para a forma clivada (p18). Nós verificamos uma alta clivagem de caspase-8 em p18 nos macrófagos Casp1/11\% infectados com flit, o que também fica evidente pela redução da forma p55 (Fig. 9B). Entretanto, os macrófagos Casp1/11\% infectados com flaA- ou Asc/Casp 1/11\% apresentaram uma baixa clivagem de caspase-8, confirmando que a ativação e clivagem de caspase-8 é dependente de flagelina e ASC.

A partir dos dados de que NLRC4/ASC/Caspase-8 formam um inflamassoma e que caspase-8 é ativada em resposta à flagelina de L. pneumophila, nosso próximo passo foi avaliar o papel de caspase-8 no controle da replicação de $L$. pneumophila independente de caspase-1/11 e mediado por NLRC4 em macrófagos. Com esse objetivo foram utilizados retrovírus expressando duas sequencias independentes de shRNA para o silenciamento de caspase-8 em BMDMs Casp1/11\%. Como controle foram adicionados aos experimentos retrovírus expressando uma sequência não relacionadas (NT - Non-target). Por meio de análises de Western Blot e Real Time qPCR, nós detectamos uma diminuição na expressão de caspase-8 nas células silenciadas com a Seq1 e Seq2 em relação às células não silenciadas (NT) (Fig. 10AB). Também foi possível identificar que a Seq1 apresenta um melhor silenciamento de caspase-8 em comparação com a Seq2. É importante ressaltar que o silenciamento 
dos macrófagos não pode ser completo em relação à caspase-8, já que essa proteína é importante para a sobrevivência das células (Varfolomeev et al., 1998; Kaiser et al., 2011). Para confirmar o silenciamento de caspase-8 por meio de ensaios funcionais, BMDMs silenciados com as duas sequências de shRNA para caspase-8 ou com a sequência NT foram infectados com flit por 8 horas e então foi avaliado o número de punctas e ativação de caspase-8 nessas células. Nós detectamos uma redução significativa tanto na formação de puncta quanto na ativação de caspase-8 nas células silenciadas em comparação às não silenciadas para caspase-8, confirmando assim que nosso sistema de silenciamento funciona corretamente (Fig. 10C-D). A partir desses dados macrófagos silenciados com as duas sequências de shRNA para caspase-8 e a sequência NT, foram infectados com flit e flaA- Após $0,24,48$ ou 72 horas as células foram lisadas e plaqueadas em meio CYE para a determinação das UFCs. Nós observamos que o silenciamento de caspase-8 leva a um aumento da replicação nos macrófagos Casp1/11\% infectados com flir, mas não com flaA; indicando que caspase-8 é importante para o controle da replicação de $L$. pneumophila dependente de flagelina, na ausência de caspase-1/11 (Fig. 10E-F). Esse dado suporta a hipótese de que caspase-8 compõe o inflamassoma de NLRC4, juntamente com ASC e que esse inflamassoma leva ao controle da replicação de $L$. pneumophila de maneira independente de caspase-1/11.

Em seguida nós avaliamos o papel de ASC no controle da infecção mediado por NLRC4, já que nossos dados anteriores indicam que essa proteína adaptadora é essencial para a formação do inflamassoma de NLRC4/ASC/Caspase-8. Para isso BMDMs de camundongos C57BL/6, NIrc4 ${ }^{-}$, Casp1/11\% e Asc/Casp1/11\% foram infectados com L. pneumophila flit e flaA- (MOI 10) e lisados após 0, 24, 48 ou 72 horas para a determinação das UFCs. Nós confirmamos que os macrófagos C57BL/6 são altamente restritivos, os Casp $1 / 11^{\%}$ parcialmente restritivos e os $\mathrm{N} / r \mathrm{rc} 4^{-1}$ susceptíveis em resposta à infecção por L. pneumophila contendo flagelina (flit) (Fig. $11 \mathrm{~A})$. Em paralelo, macrófagos Asc/Casp1/11\% foram altamente susceptíveis à infecção por flit, apresentando um fenótipo muito parecido com o das células N/rc4\%Como observado anteriormente, todos os macrófagos infectados com a bactéria fla $A^{-}$ apresentaram um alto crescimento bacteriano, já que essa bactéria não possui flagelina e não é reconhecida pela via de NLRC4 (Fig. 11B). Para analisar se o inflamassoma de NLRC4/ASC/Caspase-8 seria uma via específica de 
reconhecimento de flagelina de $L$. pneumophila, nós realizamos infecções com outras espécies flageladas de Legionella, como L. gratiana e L. micdadei (Silveira e Zamboni, 2010). Assim como nas infecções com flit, com L. gratiana e L. micdadei, os macrófagos Asc/Casp1/11\%foram tão susceptíveis quanto os N/rc4\%, já os Casp1/11/-foram parcialmente restritivos e os C57BL/6 altamente restritivos (Fig. 11C-D). Esses dados indicam que as células Casp 1/11\% controlam mais a infecção por apresentarem a via de reconhecimento de flagelina NLRC4/ASC/Caspase-8 funcional.

Para confirmar essa hipótese foi realizado o silenciamento de caspase-8 com as suas sequências de shRNA e a sequência não específica (NT) em macrófagos Asc/Casp 1/11\%. O silenciamento foi validado por Western Blot, confirmando uma diminuição da expressão de caspase-8 nas células silenciadas (Fig. 11E). BMDMs transduzidos com as duas sequências de silenciamento de caspase-8 e a sequência NT, foram infectados com flit e fla $A$; e lisados após $0,24,48$ ou 72 horas para a determinação das UFCs. Como observado na figura 10E, o silenciamento de caspase8 em macrófagos Casp1/11\% infectados com flit, leva a um aumento do número de bactérias nessas células (Fig. 11F). Entretanto, o silenciamento de caspase-8 não alterou o crescimento das bactérias flit nas células Asc/Casp1/11\%, ou das bactérias flaA tanto em macrófagos Asc/Casp 1/11\% quanto em Casp $1 / 11 \%$, o que indica que ASC e caspase-8 estão na mesma via (Fig. 11G-I). Em conjunto esses dados confirmam que o inflamassoma de NLRC4/ASC/Caspase-8 leva ao controle da replicação de Legionella spp. em macrófagos, pelo reconhecimento de flagelina e independente das vias de caspase-1/11. 


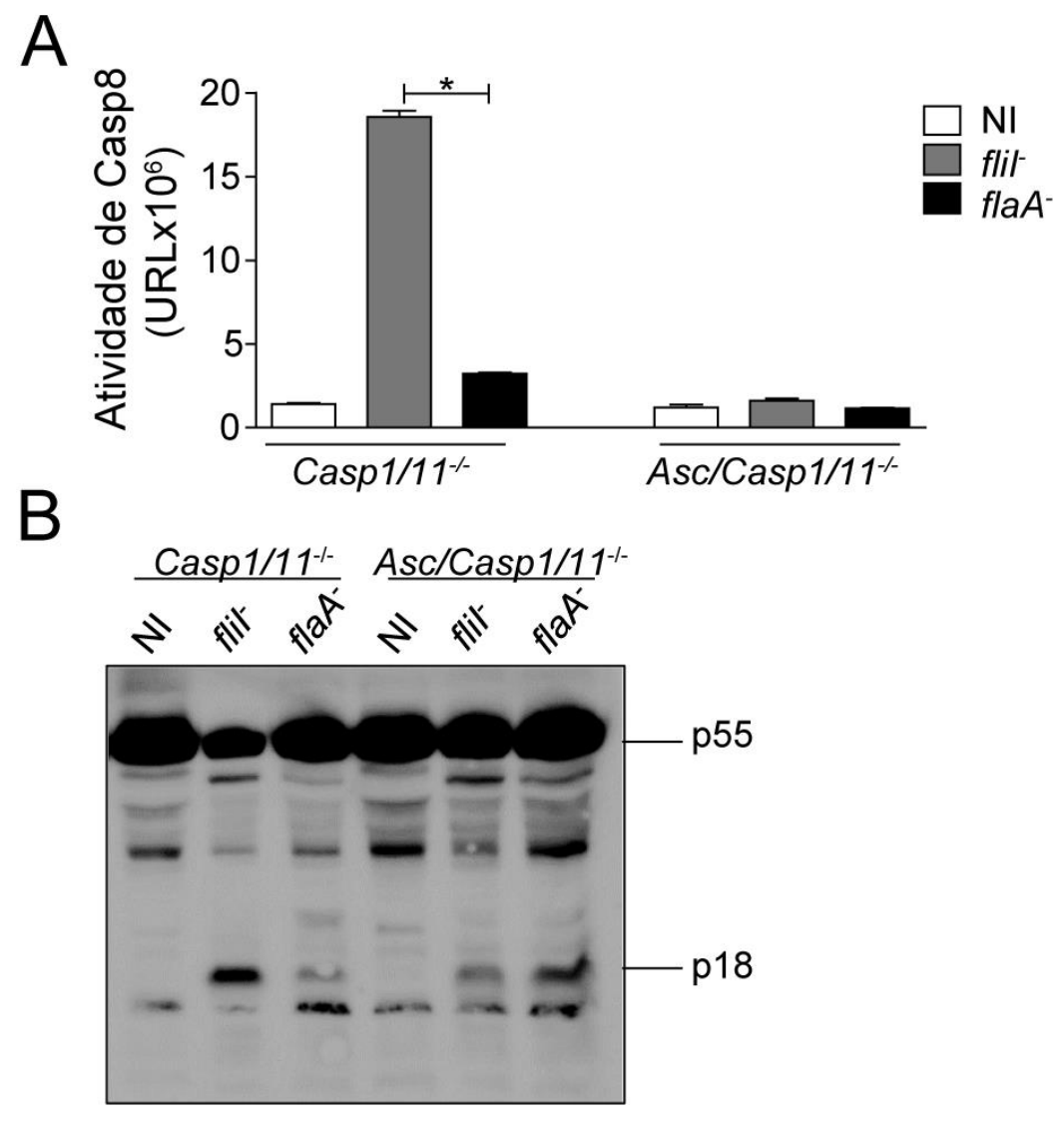

Figura 9: Caspase-8 é ativada em resposta à flagelina de $L$. pneumophila de maneira dependente de ASC e independente de caspase-1/11. Macrófagos derivados de medula óssea (BMDMs) de Casp1/11\% e Asc/Casp1/11\% foram infectados com L. pneumophila flit e flaA com MOI 10. Após 8 horas de infecção a ativação de caspase-8 foi avaliada utilizando um substrato luminescente de caspase-8 (Caspase-8 Glo Assay) (A) ou por Western Blot (B). (B) Após 8 horas de infecção as células foram lisadas com tampão RIPA. Os lisados celulares foram separados em gel SDS-PAGE, transferidos para membrana de nitrocelulose e incubados com anti-caspase-8. A pro-caspase-8 p55 e a forma clivada p18 estão indicadas. Dados demonstram a média \pm 0 desvio padrão das triplicatas. ${ }^{*}, P<0.05$, teste $t$ não paramétrico. $\mathrm{NI}$, não infectado. URL, unidades relativas de luminescência. Os dados apresentam um experimento representativo de três (A) e dois (B) experimentos com resultados similares. De: MASCARENHAS, Danielle PA et al. PLoS pathogens, 2017. 


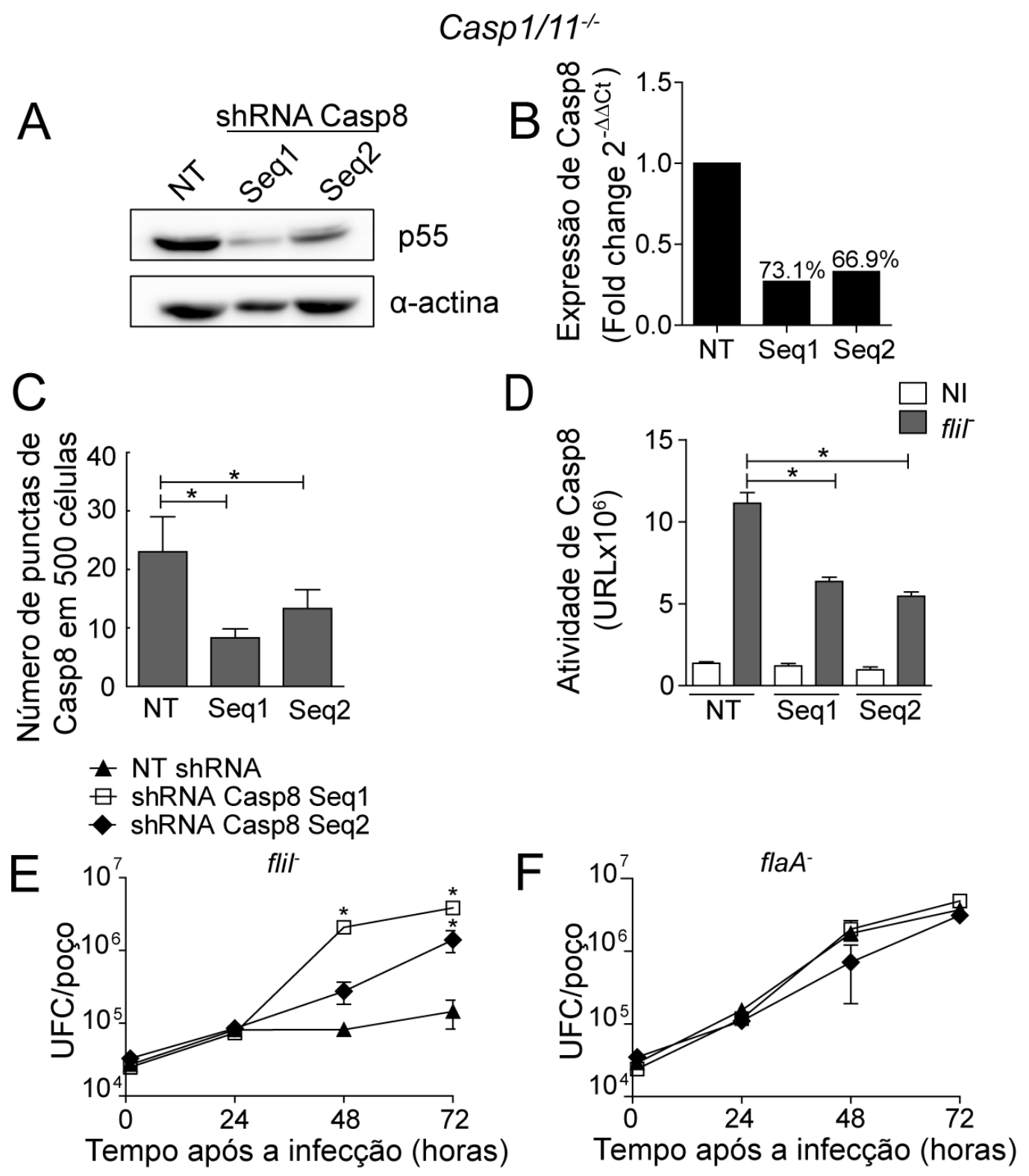

Figura 10: Caspase-8 é importante para o controle da replicação de L. pneumophila mediado por NLRC4 e independente de caspase-1/11. Macrófagos derivados de medula óssea (BMDMs) de Casp $1 / 11^{\%}$ foram transduzidos com retrovírus expressando sequências de shRNA para o silenciamento de caspase-8 (Seq1 e Seq2) e uma sequência não relacionada (NT- non-target). O silenciamento foi confirmado por análises de Western Blot (A) e qPCR em Tempo Real (B). (A) Células não infectadas foram lisadas com tampão RIPA. Os lisados das células foram separados em gel SDS-PAGE, transferidos para membrana de nitrocelulose e incubados com anti-caspase-8 (pro-caspase-8 p55) e anti-a-actina. (B) Quantificação da expressão de caspase-8 por RT-qPCR em macrófagos silenciados para duas sequências de shRNA para caspase-8 e sequência não relacionada. O gene $\beta$-Actina foi utilizado como controle para normalização dos níveis de expressão. Os números acima das barras indicam a porcentagem de silenciamento comparado com a sequência NT pela equação: $\left\{1-\left(2^{-\Delta \Delta C T}\right) X\right.$ 100\}. (C-D) BMDMs Casp1/11\% transduzidos foram infectados com L. pneumophila flit (MOI 10). Após 8 horas de infecção as células foram fixadas e o números de punctas de caspase-8 foram quantificados com auxílio de microscópio de epifluorescência (C), e a ativação de caspase-8 foi avaliada pela adição um substrato luminescente de caspase-8 (Caspase-8 Glo Assay) (D). (E-F) As células transduzidas com a sequência NT (triangulo fechado), shRNA Casp8 Seq1 (quadrado aberto) ou Seq2 (losango fechado) foram infectadas com flit e fla $A^{-}(\mathrm{MOI} 10)$ e lisadas após $0,24,48$ ou 72 horas para a 
determinação das unidades formadoras de colônias (UFCs). Dados demonstram a média \pm o desvio padrão das triplicatas. ${ }^{*}, P<0.05$ comparado com as células transduzidas com a sequência NT ou como indicado, teste $t$ não paramétrico (C-D) e ANOVA (E-F). NI, não infectado. NT, não relacionado (nontarget). Os dados apresentam um experimento representativo de três experimentos com resultados similares. De: MASCARENHAS, Danielle PA et al. PLoS pathogens, 2017. 

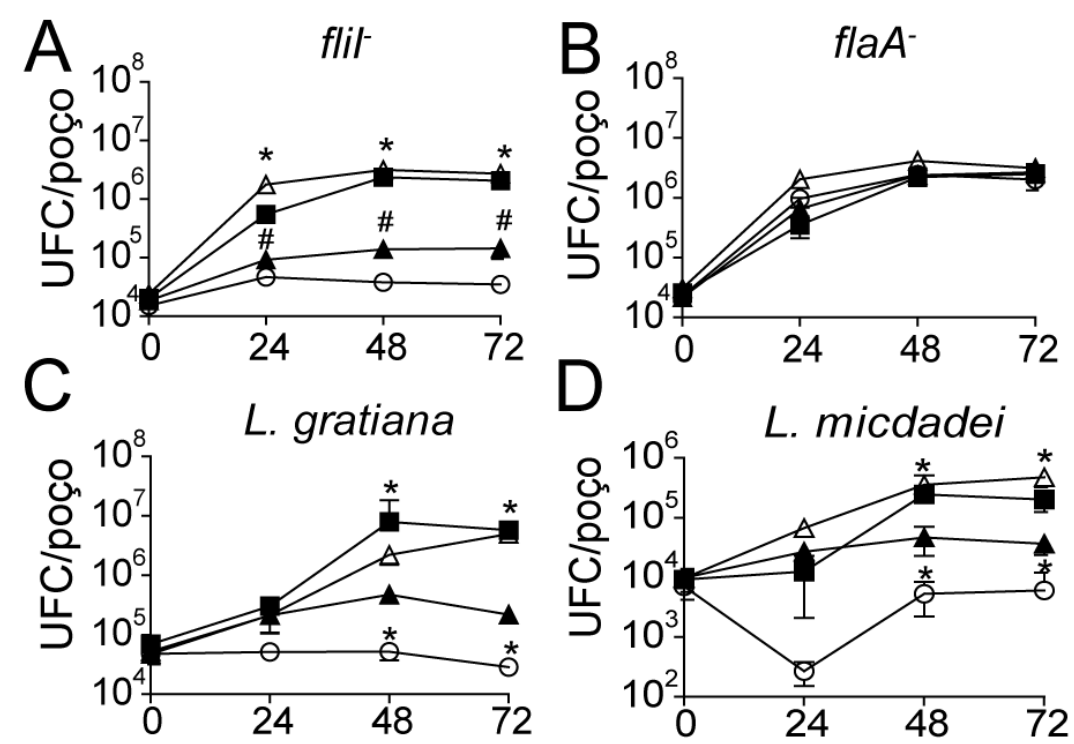

๑ C57BL/6

- NIrc4\%

- Casp1/11\%

$\triangle$ Asc/Casp1/11\%

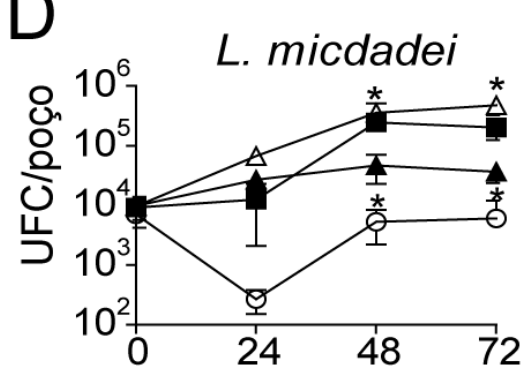

Tempo após a infecção (horas) Tempo após a infecção (horas)

$E$
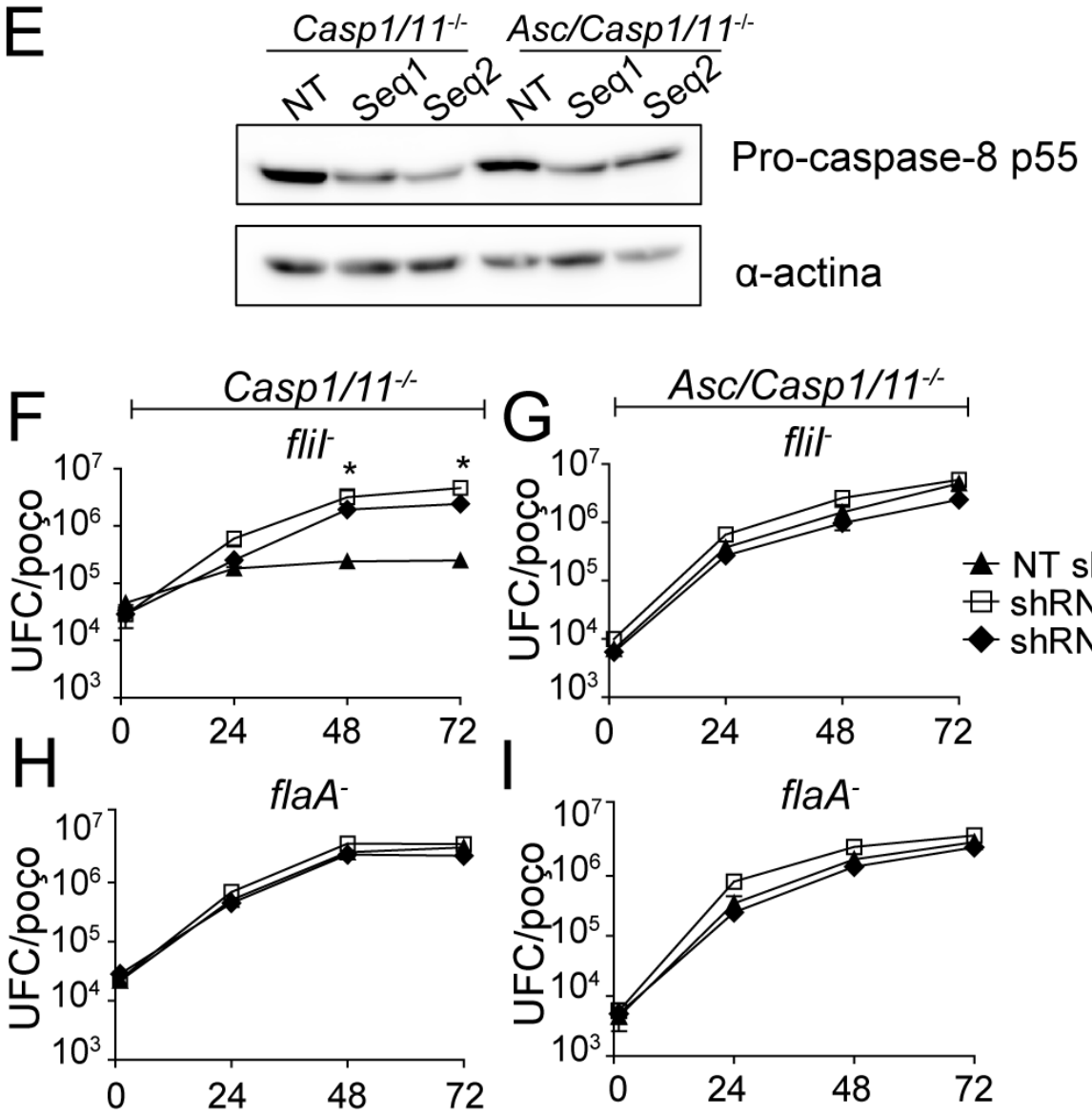

Tempo após a infecção (horas) Tempo após a infecção (horas)

Figura 11: ASC é importante para o controle da replicação de $L$. pneumophila mediado pelo inflamassoma de NLRC4/Caspase-8 e independente de caspase-1/11. (A-D) Macrófagos derivados de medula óssea (BMDMs) de camundongos C57BL/6 (círculo aberto), N/rc4\% (quadrado fechado), Casp1/11\% (triângulo fechado) e Asc/Casp1/11\% (triângulo aberto) foram infectados com $L$. pneumophila flit (A), flaA- (B), L. gratiana (C) e L. micdadei (D) (MOI 10). As células foram lisadas após 
0, 24, 48 ou 72 horas para a determinação das unidades formadoras de colônias (UFCs). (E-I) BMDMs de camundongos Casp1/11\% e Asc/Casp1/11\% foram transduzidos com retrovírus expressando sequências de shRNA para o silenciamento de caspase-8 (Seq1 e Seq2) e uma sequência não relacionada (NT- non-target). (E) O silenciamento foi confirmado por análises de Western Blot. Células não infectadas foram lisadas com tampão RIPA. Os lisados celulares foram separados em gel SDSPAGE, transferidos para membrana de nitrocelulose e incubados com anti-caspase-8 (pro-caspase-8 p55) e anti-a-actina. (F-I) As células transduzidas com a sequência NT (triangulo fechado), shRNA Casp8 Seq1 (quadrado aberto) ou Seq2 (losango fechado) foram infectadas com flit e flaA- (MOI 10) e lisadas após $0,24,48$ ou 72 horas para a determinação das UFCs. Dados demonstram a média \pm 0 desvio padrão das triplicatas. ${ }^{*}, P<0.05$ comparado com as células transduzidas com a sequência NT, ANOVA. NT, não relacionado (non-target). Os dados apresentam um experimento representativo de quatro $(A)$, dois (B-D) ou um (E-I) experimentos com resultados similares. De: MASCARENHAS, Danielle PA et al. PLoS pathogens, 2017. 


\section{4 - ASC é essencial para o controle da replicação de Legionella flagelada mediado pelo inflamassoma de NLRC4/ASC/Caspase-8 in vivo}

Nos dados anteriores nós observamos que a via de NLRC4/ASC/Caspase-8 é importante para o controle da replicação de Legionella spp. em macrófagos. A partir disso, nosso próximo objetivo foi identificar se essa via também é importante para o controle de Legionella flagelada in vivo. Os camundongos Casp8 ${ }^{-/}$são embrionariamente letais, o que nos impede de gerar camundongos Casp1/11/8 (Kaiser et al., 2011). De acordo com os nossos dados ASC é essencial para a formação do inflamassoma de NLRC4/ASC/Caspase-8, a partir disso nós utilizamos como estratégia os animais $A s c / C a s p 1 / 11 \%$ para verificar a importância dessa via no controle da replicação de Legionella spp. in vivo. Com esse objetivo camundongos C57BL/6, NIrc4 $4^{-}$, Casp1/11\% e Asc/Casp1/11\% foram infectados com $10^{5}$ bactérias/camundongo de L. pneumophila flit, L. gratiana e L. micdadei. Após 4, 48 ou 72 horas os pulmões dos animais foram retirados, homogeneizados e plaqueados em meio CYE para a determinação das UFCs/pulmão. Nós observamos que tanto na infecção com flit quanto com L. gratiana e L. micdadei os animais Asc/Casp1/11/foram tão susceptíveis quando os $\mathrm{N} / \mathrm{rc}^{-1}{ }^{-}$(Fig. 12A-C). Como demonstrado nos macrófagos, os camundongos Casp1/11\% foram parcialmente restritivos à infecção por essas bactérias, entretanto os camundongos C57BL/6 foram altamente restritivos. Confirmando nossos dados, camundongos Asc/Casp 1/11\% foram mais susceptíveis que os Casp $1 / 11 \%$ apenas quando infectados com flit, mas não com a fla $A^{-}$que não é reconhecida por nenhuma das vias de NLRC4 (Fig. 12D). Em conjunto esses dados indicam que o inflamassoma de NLRC4/ASC/Caspase-8 é formado em resposta à flagelina de Legionella spp. e opera no controle da sua replicação in vitro e in vivo em uma via independente de caspase-1/11. 
A

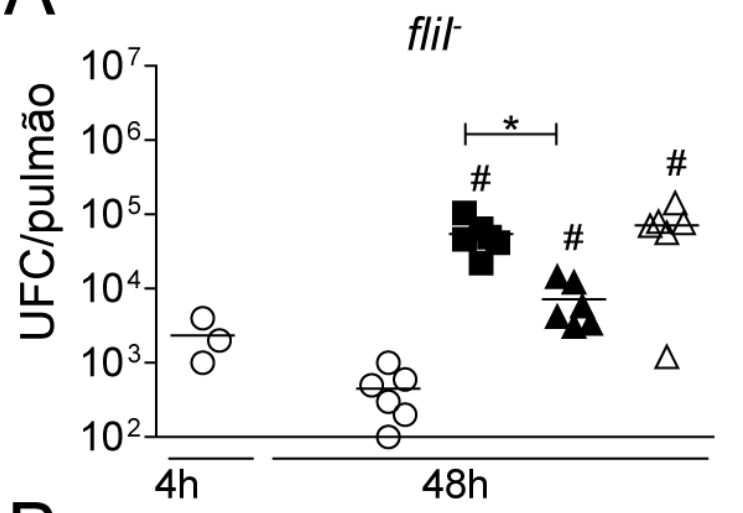

B

L. gratiana

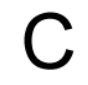

O C57BL/6

- NIrc4 $4^{-1}$

$\Delta$ Casp $1 / 11^{-1}$

$\triangle$ Asc/Casp1/11-

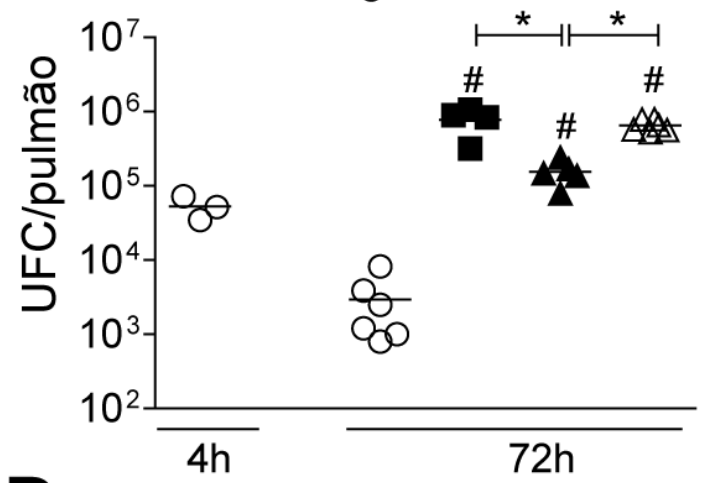

$\mathrm{D}$
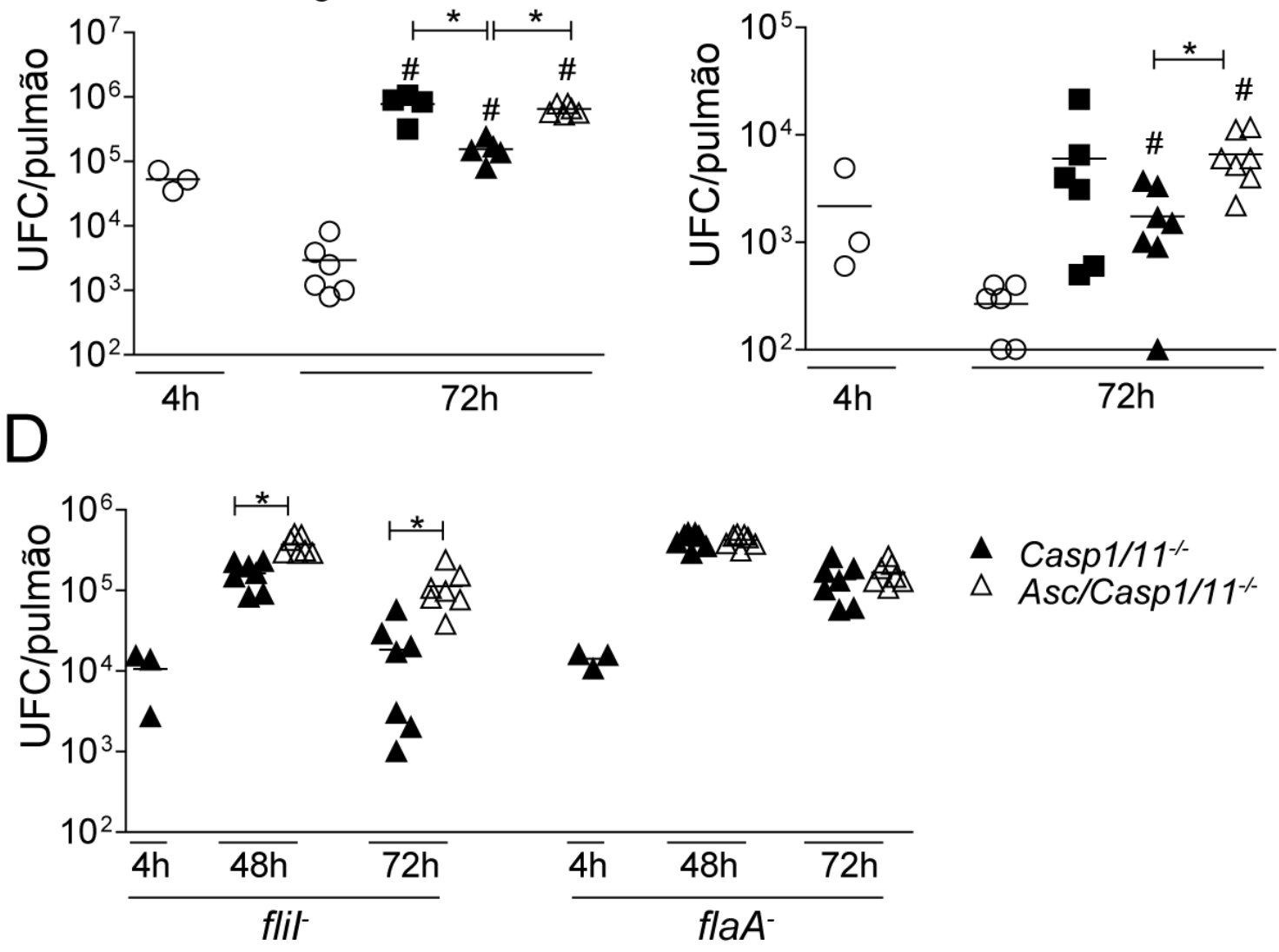

A Casp1/11/-

$\triangle$ Asc/Casp1/111-

Figura 12: ASC é essencial para o controle da replicação de Legionella flagelada mediado por NLRC4 e independente de caspase-1/11 in vivo. Camundongos C57BL/6 (círculo aberto), N/rc4(quadrado fechado), Casp1/11\% (triângulo fechado) e Asc/Casp1/11\% (triângulo aberto) foram infectados por via intranasal com $10^{5}$ bactérias/camundongo de flit (A e D), L. gratiana (B), L. micdadei (C) e flaA- (D). Os animais foram sacrificados após 4,48 ou 72 horas de infecção. Diluições dos pulmões homogeneizados foram plaqueados em meio CYE para a determinação das unidades formadoras de colônias (UFCs). Cada ponto representa um animal, e as linhas horizontais representam as médias dos valores. *, $P<0.05$. \#, indica $P<0.05$ comparado com C57BL/6, Mann Whitney test. Os dados apresentam um experimento representativo de cinco (A), um (B-C) ou dois (D) experimentos com resultados similares. De: MASCARENHAS, Danielle PA et al. PLoS pathogens, 2017. 


\section{5 - AIM2 não participa no inflamassoma de NLRC4/ASC/Caspase-8 em resposta à infecção por L. pneumophila}

Trabalhos tem demonstrado que AIM2, um sensor de dupla fita de DNA, induz a ativação de um inflamassoma pelo recrutamento de ASC, levando à formação de punctas, ativação de caspase-1, piroptose e secreção de citocinas pró-inflamatórias (Muruve et al., 2008; Burckstummer et al., 2009; Fernandes-Alnemri et al., 2009; Hornung et al., 2009; Roberts et al., 2009). Em paralelo tem sido observado a participação de AIM2 em vias independentes de caspase-1 e dependentes de caspase-8 (Pierini et al., 2012; Pierini et al., 2013; Sagulenko et al., 2013). Desta maneira, nós investigamos se AIM2 faz parte do inflamassoma de NLRC4/ASC/Caspase-8 em resposta à L. pneumophila. Para isso BMDMs de camundongos Casp1/11\% foram transduzidos com NLRC4-GFP e infectados com flit (MOI 10). Após 8 horas de infeção as células foram fixadas e marcadas com antiAIM2, para análise da colocalização entre AIM2 e os punctas de NLRC4-GFP. Não foi observada uma colocalização significativa entre os punctas de NLRC4-GFP e AIM2, o que indica que AIM2 não está presente no inflamassoma de NLRC4/ASC/Caspase8 (Fig. 13A). É importante destacar, que foram detectados punctas de AIM2 em resposta à $L$. pneumophila, como demonstrado na Fig. 13A, entretanto a maioria desses punctas não colocalizavam com os de NLRC4-GFP. Para confirmar esses dados, BMDMs de camundongos Casp1/11\% e Aim2/Casp1/11\% transduzidos com NLRC4-GFP foram infectados com WT Lp, flit ou flaA- por 8 horas para a quantificação dos punctas de NLRC4-GFP. Nós não detectamos nenhuma diferença na formação de punctas de NLRC4-GFP entre os macrófagos de camundongos Casp1/11/- e Aim2/Casp1/11\% infectados com WT Lp ou flit (Fig. 13B). O mesmo foi observado quando comparamos a ativação de caspase-8 entre as células Casp1/11\% e Aim2/Casp1/11\%, indicando que AIM2 não é importante para a formação e ativação do inflamassoma de NLRC4/ASC/Caspase-8 (Fig. 13C).

Para corroborar os dados de que AIM2 não participa do inflamassoma de NLRC4/ASC/Caspase-8, nós investigamos o papel desse receptor no controle da replicação de $L$. pneumophila in vitro e in vivo na ausência de caspase-1/11. Para isso BMDMs de camundongos C57BL/6, NIrc4\%, Casp1/11/- e Aim2/Casp1/11\% foram infectados com flit e lisados após 0, 24, 48 ou 72 horas para a determinação das UFCs. Não houve nenhuma diferença no crescimento bacteriano entre as células 
Casp $1 / 11 \%$ e as Aim2/Casp $1 / 11 \%$, indicando que AIM2 não é importante para o controle da replicação de L. pneumophila mediado por NLRC4 na ausência de caspase-1/11 (Fig. 14A). Para validar esses dados in vivo, camundongos C57BL/6, Nirc4 ${ }^{-}$, Casp 1/11\%, Aim2/Casp 1/11\% e Asc/Casp1/11\% foram infectados com flit $\left(10^{5}\right.$ bactérias/camundongo) e após 4,48 ou 72 horas os pulmões dos animais foram retirados, homogeneizados e plaqueados em meio CYE para a determinação das UFCs/pulmão. Como observado nos macrófagos, também in vivo não houve diferença no crescimento de bactérias no pulmão dos camundongos Casp1/11\% e Aim2/Casp1/11\% tanto no tempo de 48 quanto de 72 horas (Fig.14B-C). Entretanto, os camundongos N/rc4\% e Asc/Casp 1/11\% apresentaram uma alta susceptibilidade à infecção por flit, como demostrado anteriormente na figura 12A. Dessa maneira nós concluímos que AIM2 não faz parte do inflamassoma de NLRC4/ASC/Caspase-8. 

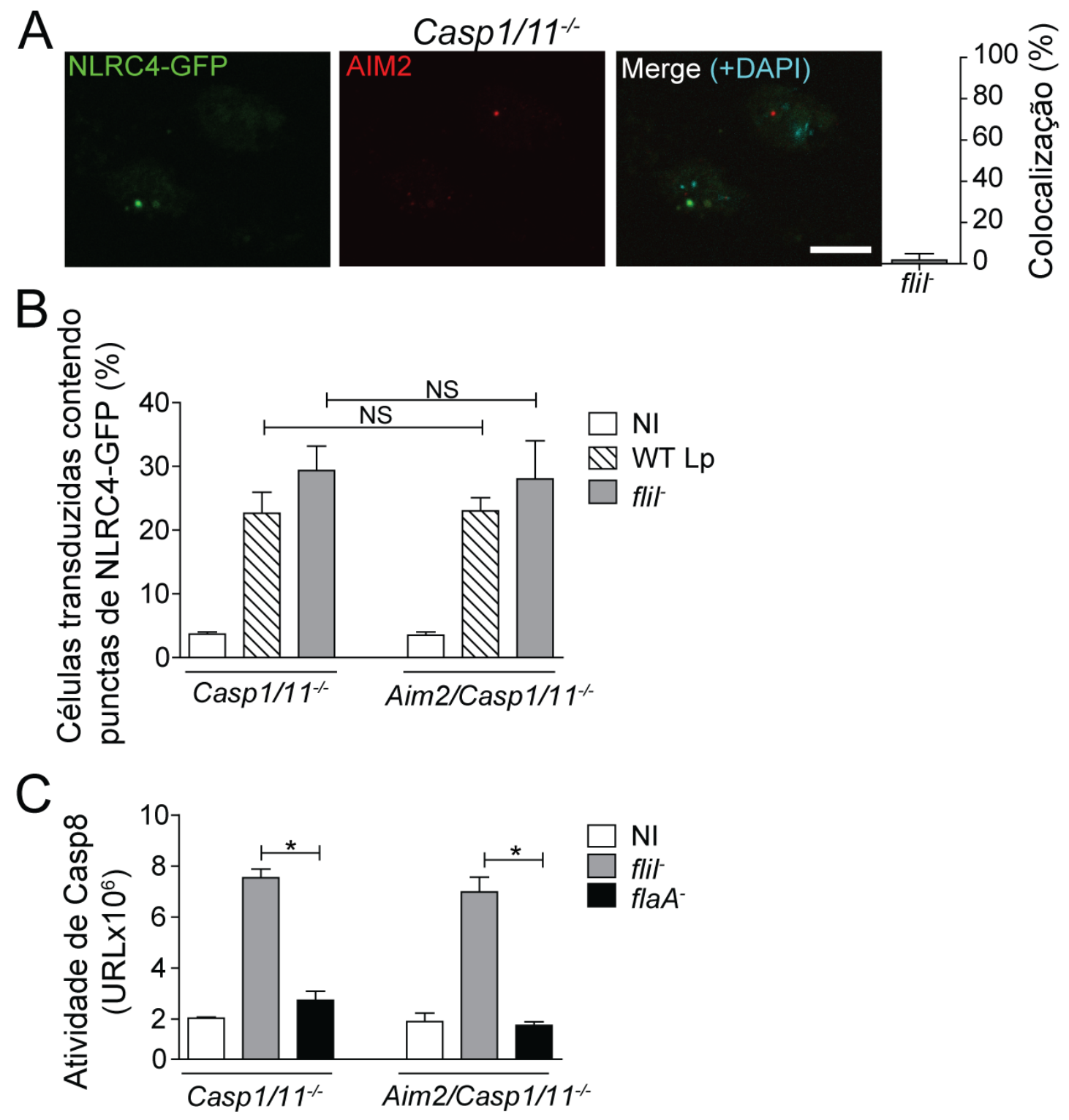

Figura 13: AIM2 não participa da formação dos punctas de NLRC4-GFP e da ativação de caspase8 em resposta à infecção por $L$. pneumophila com flagelina. (A-B) Macrófagos derivados de medula óssea (BMDMs) de Casp1/11\% (A-B) e Aim2/Casp1/11\% (B) foram transduzidos com retrovírus expressando NLRC4-GFP e infectados com L. pneumophila WT Lp (B) e flit (A-B) (MOI 10) por 8 horas. (A) As células foram fixadas e marcadas com anti-AIM2 (vermelho), o núcleo celular com DAPI (ciano) e os punctas de NLRC4-GFP estão representados em verde. A porcentagem de colocalização entre os punctas de NLRC4-GFP e os de AIM2 está representada no gráfico e foi quantificada com auxílio de microscópio de epifluorescência. As imagens foram adquiridas por microscopia de multifóton utilizando objetiva de óleo de imersão de aumento de 63X. As imagens foram analisadas utilizando o software ImageJ. Barra de escala, $10 \mu \mathrm{m}$. (B) A quantificação das células transduzidas contendo punctas de NLRC4-GFP após 8 horas de infecção com WT Lp e flit (MOI 10), foi realizada com auxílio de microscópio de epifluorescência. (C) BMDMs de camundongos Casp1/11\% e Aim2/Casp1/11\% foram infectados com flit e fla $A^{-}$(MOI 10). Após 8 horas de infecção a ativação de caspase-8 foi avaliada utilizando um substrato luminescente de caspase-8 (Caspase-8 Glo Assay). Dados demonstram a média \pm 0 desvio padrão das triplicatas. ${ }^{*}, P<0.05$, teste $t$ não paramétrico. $\mathrm{NI}$, não infectado. URL, unidades relativas de luminescência. NS, não significativo. Os dados apresentam um experimento representativo de dois experimentos com resultados similares. Adaptado de: MASCARENHAS, Danielle PA et al. PLoS pathogens, 2017. 

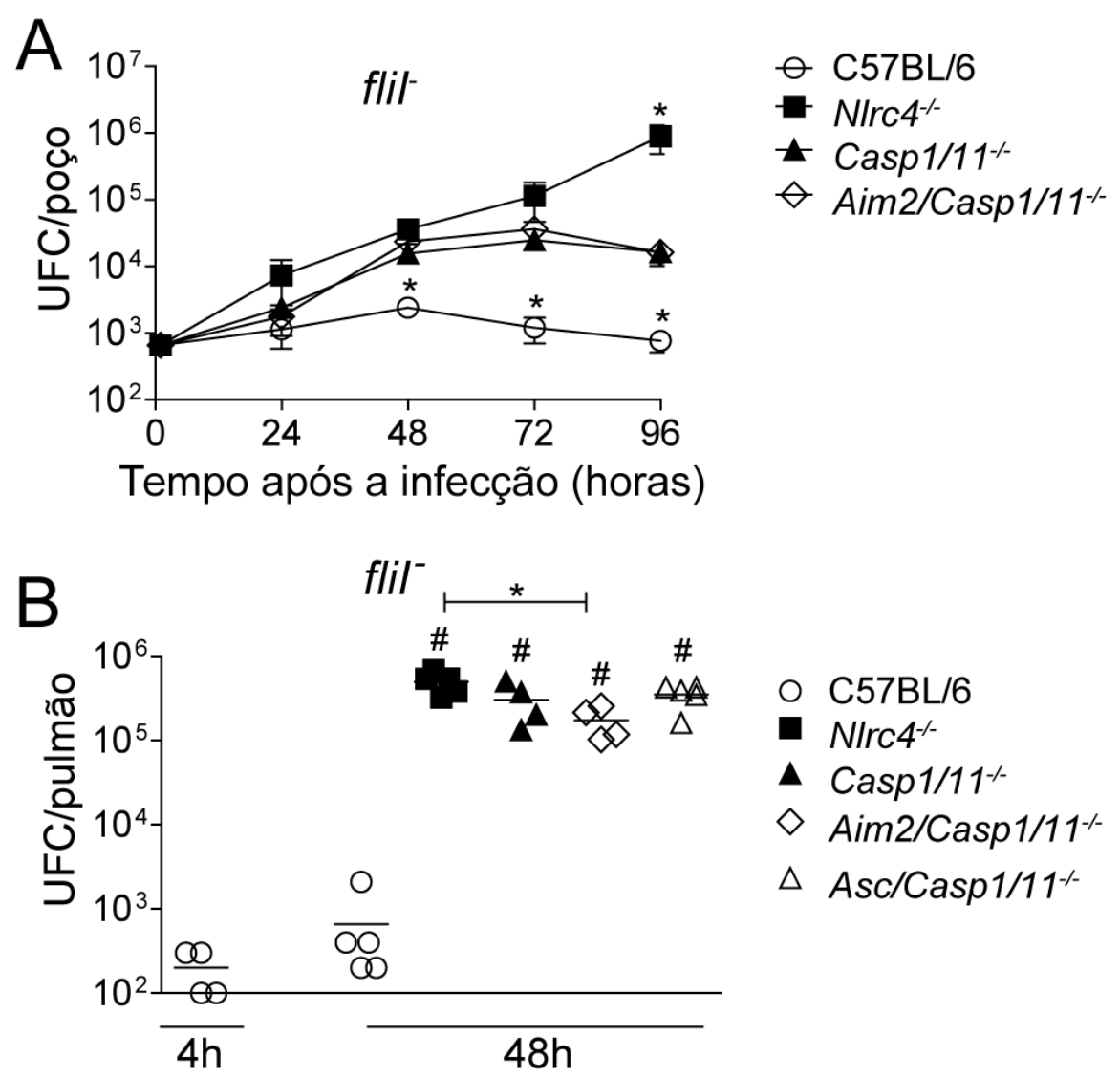

\author{
O C57BL/6 \\ NIrc4 $4^{-/}$ \\ $\Delta$ Casp1/11\% \\ $\diamond$ Aim2/Casp1/11 \\ $\triangle$ Asc/Casp1/11
}

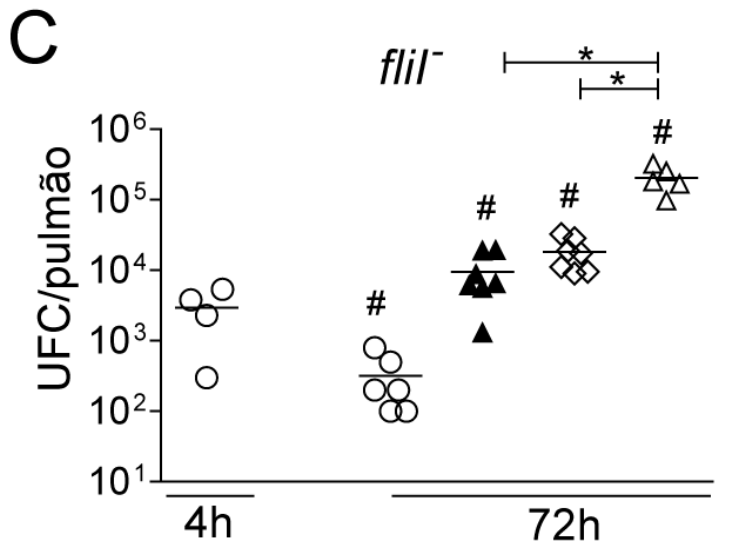

○ C57BL/6

- Casp1/11\%

$\diamond$ Aim2/Casp1/111-

$\triangle$ Asc/Casp1/11\%

Figura 14: AIM2 não é importante para o controle da replicação mediado por NLRC4 e independente de caspase-1/11 em macrófagos e in vivo. (A) Macrófagos derivados de medula óssea (BMDMs) de camundongos C57BL/6 (círculo aberto), NIrc4\% (quadrado fechado), Casp1/11\% (triângulo fechado) e Aim2/Casp1/11\% (losango aberto) foram infectados com flit (MOI 10). As células foram lisadas após $0,24,48$ ou 72 horas para a determinação das unidades formadoras de colônias (UFCs). (B-C) Camundongos C57BL/6 (círculo aberto), N/rc4 ${ }^{-\%}$ (quadrado fechado), Casp1/11\% (triângulo fechado), Aim2/Casp1/11\% (losango aberto) e Asc/Casp1/11\% (triângulo aberto) foram infectados por via intranasal com $10^{5}$ bactérias/camundongo de flit. Os animais foram sacrificados após 4, 48 ou 72 horas de infecção. Diluições dos pulmões homogeneizados foram plaqueados em meio CYE para a determinação das UFCs. Cada ponto representa um animal, e as linhas horizontais representam as médias dos valores. ${ }^{*}, P<0.05$. $\#$, indica $P<0.05$ comparado com C57BL/6, ANOVA (A) Mann Whitney (B-C). Os dados apresentam um experimento representativo de três (A) e dois (B-C) experimentos com resultados similares. Adaptado de: MASCARENHAS, Danielle PA et al. PLoS pathogens, 2017. 


\section{6 - Naip5 é essencial para a ativação do inflamassoma de}

NLRC4/ASC/Caspase-8 em resposta à $L$. pneumophila flagelada na ausência de caspase-1/11

Nossos dados anteriores demonstraram que na ausência de caspase-1/11 o inflamassoma de NLRC4/ASC/Caspase-8 é ativado levando ao controle da replicação de L. pneumophila. Sabe-se que na via de NLRC4 dependente de caspase-1, o reconhecimento de flagelina ocorre pelo sensor Naip5. Esse receptor do tipo NLR reconhece o domínio C-terminal da flagelina, levando ao recrutamento de NLRC4 e ativação de caspase-1 (Amer et al., 2006; Molofsky et al., 2006; Ren et al., 2006; Zamboni et al., 2006; Lightfield et al., 2008; Kofoed e Vance, 2011; Zhao et al., 2011). Para avaliar se na via de NLRC4/ASC/Caspase-8, Naip5 também é o receptor de flagelina, foi utilizado um sistema retroviral expressando uma sequência de shRNA para o silenciamento de Naip5 em BMDMs Casp1/11\% e Asc/Casp1/11\%. Como controle foram adicionados aos experimentos retrovírus expressando uma sequência não relacionada (NT), utilizada anteriormente nos experimentos de silenciamento com caspase-8 (Fig. 10 e 11E-I). Por meio de análises de RT-qPCR, nós confirmamos o silenciamento de Naip5 pela diminuição da sua expressão nas células transduzidas com os retrovírus expressando a sequência de shRNA para Naip5 em comparação com a sequência NT (Fig. 15A). Após a confirmação do silenciamento esses macrófagos foram infectados com $L$. pneumophila WT Lp, flit e flaA- por 8 horas e foi avaliada a ativação de caspase-8 nessas células. Foi detectada uma alta ativação de caspase-8 nos macrófagos Casp1/11\% infectados com WT Lp e flit em comparação com os infectados com flaA', como demonstrado anteriormente nas figuras $9 \mathrm{~A}$ e $13 \mathrm{C}$ (Fig.15B). Entretanto, nas células silenciadas para Naip5 essa ativação foi reduzida, indicando que Naip5 é importante para a ativação de caspase-8 de maneira dependente de flagelina. Como demostrado anteriormente nos macrófagos Asc/Casp 1/11\%, a ativação de caspase-8 não foi significativa.

Para avaliar o papel de Naip5 no controle da replicação de L. pneumophila na via independente de caspase-1/11 os BMDMs Casp1/11\% e Asc/Casp1/11\% silenciados ou não para Naip5 foram infectados com flit e flaA', após 0, 24, 48 ou 72 horas as células foram lisadas para a determinação das UFCs. Nós detectamos um aumento do número de bactérias nas células Casp1/11\% silenciadas infectadas com flit quando comparadas com as células não silenciadas, indicando que Naip5 é 
importante para o controle na replicação mesmo na ausência de caspase-1/11 (Fig. 15C). Entretanto, o silenciamento de Naip5 não alterou o crescimento bacteriano nas células infectadas com flaA- ou nas células Asc/Casp1/11\% infectadas tanto com flit quanto com fla $A^{-}$(Fig. 15D-F). Esses dados indicam que Naip5 participa do inflamassoma de NLRC4/ASC levando à ativação de caspase-8 em resposta à flagelina de $L$. pneumophila em uma via independente de caspase-1/11. 

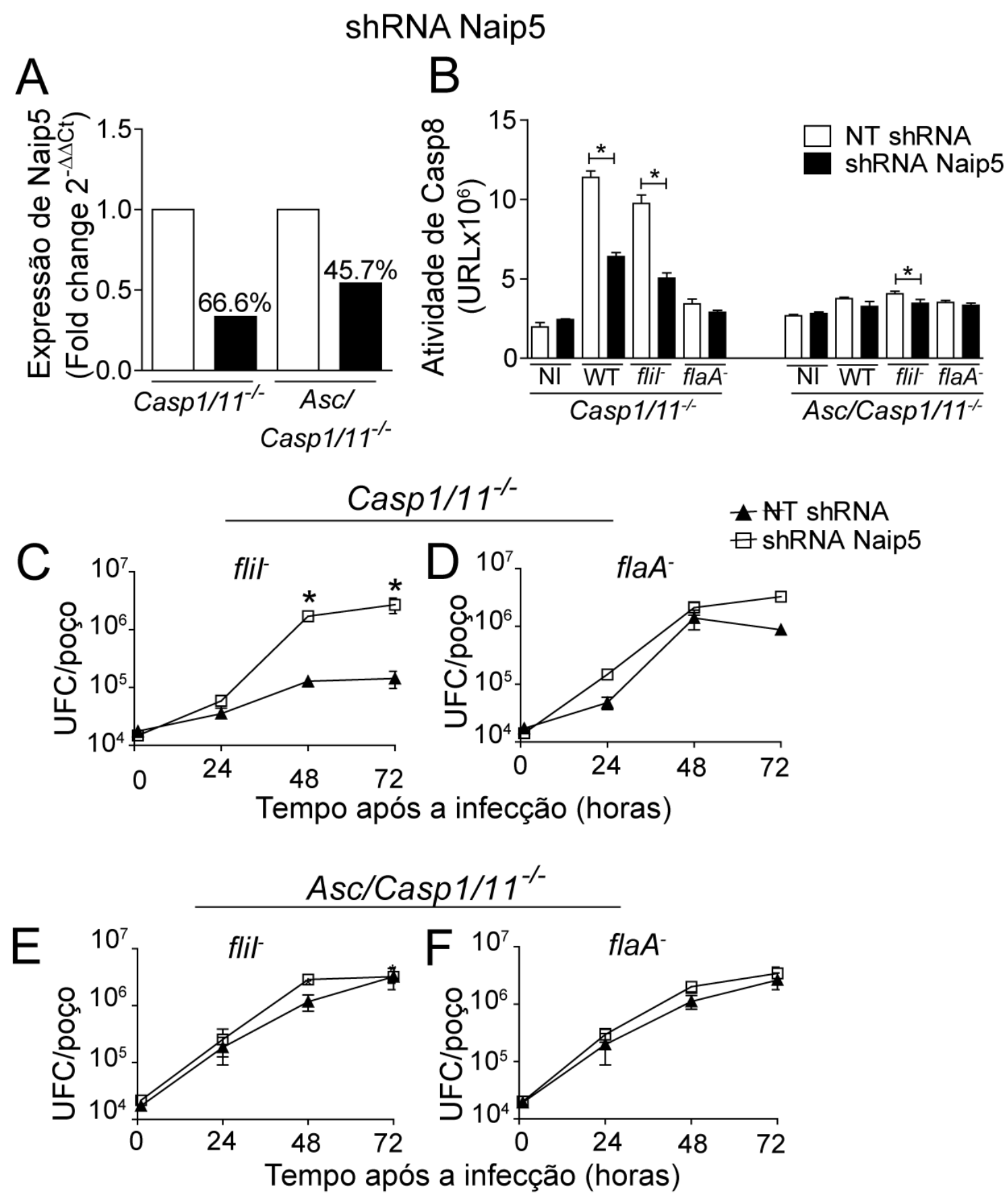

Figura 15: A ativação do inflamassoma de NLRC4/ASC/Caspase-8 em resposta à infecção por $L$. pneumophila flagelada é dependente de Naip5. Macrófagos derivados de medula óssea (BMDMs) de Casp1/11\% e Asc/Casp 1/11\% foram transduzidos com retrovírus expressando uma sequência de shRNA para o silenciamento de Naip5 e uma sequência não relacionada (NT- non-target). (A) $O$ silenciamento foi confirmado por análises de qPCR em Tempo Real. Quantificação da expressão de Naip5 por RT-qPCR em macrófagos transduzidos com retrovírus contendo uma sequência de shRNA para o silenciamento de Naip5 e uma sequência não relacionada. O gene Gapdh foi utilizado como controle para normalização dos níveis de expressão. Os números acima das barras indicam a porcentagem de silenciamento comparado com a sequência NT pela equação: $\left\{1-\left(2^{-\Delta \Delta C T}\right) \times 100\right\}$. (B) BMDMs de Casp1/11\% e Asc/Casp1/11\% transduzidos foram infectados com L. pneumophila flit e flaA (MOI 10). Após 8 horas de infecção a ativação de caspase-8 foi avaliada pela adição um substrato luminescente de caspase-8 (Caspase-8 Glo Assay). (C-F) As células transduzidas com a sequência NT (triangulo fechado) ou shRNA Naip5 (quadrado aberto) foram infectadas com flit e flaA- (MOI 10) e 
lisadas após $0,24,48$ ou 72 horas para a determinação das unidades formadoras de colônias (UFCs). Dados demonstram a média \pm 0 desvio padrão das triplicatas. ${ }^{*}, P<0.05$ comparado com as células transduzidas com a sequência NT ou como indicado, teste $t$ não paramétrico (B) e ANOVA (C-F). NI, não infectado. NT, não relacionado (non-target). URL, unidades relativas de luminescência. Os dados apresentam um experimento representativo de um (B) ou três (C-F) experimentos com resultados similares. Adaptado de: MASCARENHAS, Danielle PA et al. PLoS pathogens, 2017. 


\section{7 - A ativação do inflamassoma de Naip5/NLRC4/ASC/Caspase-8 induz a formação de poro, mas não a secreção de IL-1 $\beta$}

Foi relacionado a formação de poro e indução de piroptose como um mecanismos que desencadeiam o controle da replicação de bactérias intracelulares como Salmonella Thyphimurium, Burkholderia thailandensis e L. pneumophila (Miao et al., 2010; Jorgensen, Lopez, et al., 2016; Jorgensen, Zhang, et al., 2016). Nosso grupo demonstrou que $L$. pneumophila leva à formação de poro pela via de caspase1 e caspase-11, pelo reconhecimento de flagelina e LPS respectivamente (Silveira e Zamboni, 2010; Case et al., 2013; Cerqueira et al., 2015). Mediante esses dados, nosso próximo objetivo foi avaliar se o inflamassoma de NLRC4/ASC/Caspase-8 induz a formação de poro em resposta a infecção por $L$. pneumophila. Para isso foi utilizado um ensaio de formação de poro em tempo real onde a fluorescência liberada pela incorporação de lodeto de Propídio $(\mathrm{PI})$ foi detectada por um fluorímetro de placa. O PI é um corante fluorescente não permeável, ou seja, só é incorporado em células com a membrana danificada, sendo assim uma bom indicador da formação de poros (Case et al., 2013; Cerqueira et al., 2015; Cunha et al., 2015; Cunha et al., 2017). Para esses experimentos foram utilizamos BMDMs C57BL/6, Casp1/11\% e Asc/Casp1/11\% infectados com bactérias flit e flaA- Essas células foram monitoradas por 8 horas de infecção em fluorímetro de placa para a detecção da incorporação de $\mathrm{Pl}$ a cada 5 minutos. Nós não detectamos nenhuma formação de poros nas células não infectadas (Fig. 16A). Entretanto, observamos uma alta taxa de formação de poro nos macrófagos C57BL/6 infectados com flit, em decorrência da ativação do inflamassoma de Naip5/NLRC4/Caspase-1 (Fig. 16B). Essas mesmas células infectadas com fla $A^{-}$apresentaram um poro mais reduzido, resultado da ativação do inflamassoma de caspase-11 (Fig. 16C) (Case et al., 2013). Notavelmente, nós detectamos uma significativa a formação de poro nos BMDMs Casp 1/11\% infectados com flit, entretanto esse poro começou mais tardiamente quando comparado com o poro das células C57BL/6, indicando que existe uma via de morte celular independente de caspase-1/11 (Fig. 16B). Não foi detectada uma significativa formação de poros nas células Casp 1/11\% infectadas com flaA; ou nas células Asc/Casp $1 / 1 \%$ infectadas tanto com flit quanto com flaA: Esses dados indicam que 
que a via NLRC4/ASC/Caspase-8 induz a formação de poros de maneira dependente de flagelina e ASC e independente de caspase-1/11.

Foi demonstrado que a formação de poros na membrana leva a um desbalanço iônico, o que gera entrada de água na célula e assim a sua lise e liberação da enzima lactato desidrogenase (LDH) no sobrenadante (Fink e Cookson, 2006). Para corroborar nossos dados, foi dosado a liberação de LDH no sobrenadante desses macrófagos após 8 horas de infecção. Tanto os BMDMs de camundongos C57BL/6 quanto Casp1/11\% infectados com flit apresentaram uma alta taxa de liberação de $\mathrm{LDH}$, confirmando que existe uma via de morte celular independente de caspase-1/11 (Fig. 16D). Essas mesmas células infectadas com fla $A^{-}$, apresentaram uma liberação de LDH reduzida, em resposta à ativação do inflamassoma de caspase-11 e de AIM2, recentemente demonstrado pelo nosso grupo (Case et al., 2013; Cunha et al., 2017). Não houve diferença na liberação de LDH nas células Asc/Casp1/11-/-infectadas tanto com flit quanto com flaA-, já que a detecção de LDH foi baixa com ambas as infecções. Desta maneira nossos dados indicam que o inflamassoma de NLRC4/ASC/Caspase8 induz a formação de poros e morte celular de maneira independente de caspase$1 / 11$ e dependente do reconhecimento de flagelina.

Tem sido amplamente reportado a participação de caspase-8 e ASC em vias independentes de caspase-1 na secreção de citocinas pró-inflamatórias como IL-18 e IL-1ß (Man et al., 2013; Man et al., 2014; Antonopoulos et al., 2015; Rauch et al., 2017; Schneider et al., 2017). Para avaliar se o inflamassoma de NLRC4/ASC/Caspase-8 também induz a secreção dessas citocinas em resposta à $L$. pneumophila, BMDMs C57BL/6, Casp1/11\% e Asc/Casp1/11\% foram infectados com WT Lp, flit e flaA por 24 horas quando então seus sobrenadantes foram coletados para detecção de IL-1 $\beta$ e IL-12. Nós encontramos uma alta secreção de IL-1 $\beta$ nos macrófagos C57BL/6 infectados tanto com WT Lp quanto com flit. Entretanto, a secreção desta citocina nos BMDMs Casp1/11\% foi muito baixa e nos Asc/Casp1/11\% praticamente não foi detectada (Fig. 16E). A produção de IL-12 foi igual em todas as células infectadas, confirmando que todas estavam primadas e prontas para a responder à infecção (Fig. 16F). Desta maneira, nossos dados indicam que a via majoritária de secreção de IL$1 \beta$ em resposta à flagelina é a de Naip5/NLRC4/Caspase-1. Já a via 
NLRC4/ASC/Caspase-8 não parece ser importante para a secreção desta citocina em resposta à infecção por L. pneumophila.

Nós demonstramos anteriormente que a flagelina de L. pneumophila induz formação de poros e morte celular, mas não a secreção de IL-1 $\beta$ de maneira independente de caspase-1/11 (Figura 16). Para avaliar a participação de caspase-8 nessa formação de poro independente de caspase-1/11, nós utilizamos BMDMs Casp1/11\% e Asc/Casp1/11\% silenciados para caspase-8 e infectados com flit e flaA e analisamos e incorporação de PI por 6 horas. Os macrófagos não infectados não apresentaram formação de poro, confirmando que a transdução não leva à morte celular (Fig. 17A e D). A formação de poros foi evidente nas células Casp1/11\% infectadas com flit em comparação com as Asc/Casp1/11\% (Fig. 17B e E). Em paralelo, nós observamos uma diminuição na formação de poro nas células Casp1/11 /- silenciadas para caspase-8 em relação às não silenciadas (Fig. 17B). Confirmando o papel de flagelina na ativação dessa via, apenas células Casp1/11\% infectadas com flit, mas não com fla $A^{-}$, induziram a formação de poros na membrana (Fig. 17B e C). Corroborando esses dados BMDMs Casp1/11/- tratados com Z-IETD, um inibidor de caspase-8, e infectados com flit apresentaram uma diminuição na formação de poros em relação às células tratadas com DMSO (Fig. 17H). Entretanto não houve diferença na formação de poros nas células tratadas infectadas com flaA-ou não infectadas (Fig. $17 \mathrm{G} \mathrm{e} \mathrm{I).} \mathrm{Esses} \mathrm{dados} \mathrm{indicam} \mathrm{que} \mathrm{caspase-8} \mathrm{é} \mathrm{importante} \mathrm{para} \mathrm{a} \mathrm{formação} \mathrm{de} \mathrm{poros}$ pela via independente de caspase-1/11 em resposta à infecção por L. pneumophila.

Para avaliar a participação de Naip5 na indução de morte celular induzida pela via NLRC4/ASC/Caspase-8 foram utilizados BMDMs Casp1/11\% e Asc/Casp1/11\% transduzidos com shRNA para o silenciamento de Naip5 e a sequência NT, e infectados com WT Lp, flit e flaA- Nós detectamos uma diminuição na formação de poros nas células Casp1/11\% silenciadas para Naip5 e infectadas com WT Lp e flit em relação às não silenciadas (Fig. 18B e C). Entretanto, as células infectadas com fla $A^{-}$, bem como os macrófagos Asc/Casp1/11\% infectados com WT Lp, flit ou fla $A^{-}$ apresentaram uma formação de poros baixa, tanto nas células silenciadas quanto nas não silenciadas para Naip5 (Fig. 18D-H). Esses achados indicam que a flagelina de L. pneumophila desencadeia uma formação de poro e morte celular independente de caspase-1/11 pela via dependente de Naip5/NLRC4/ASC/Caspase-8. 

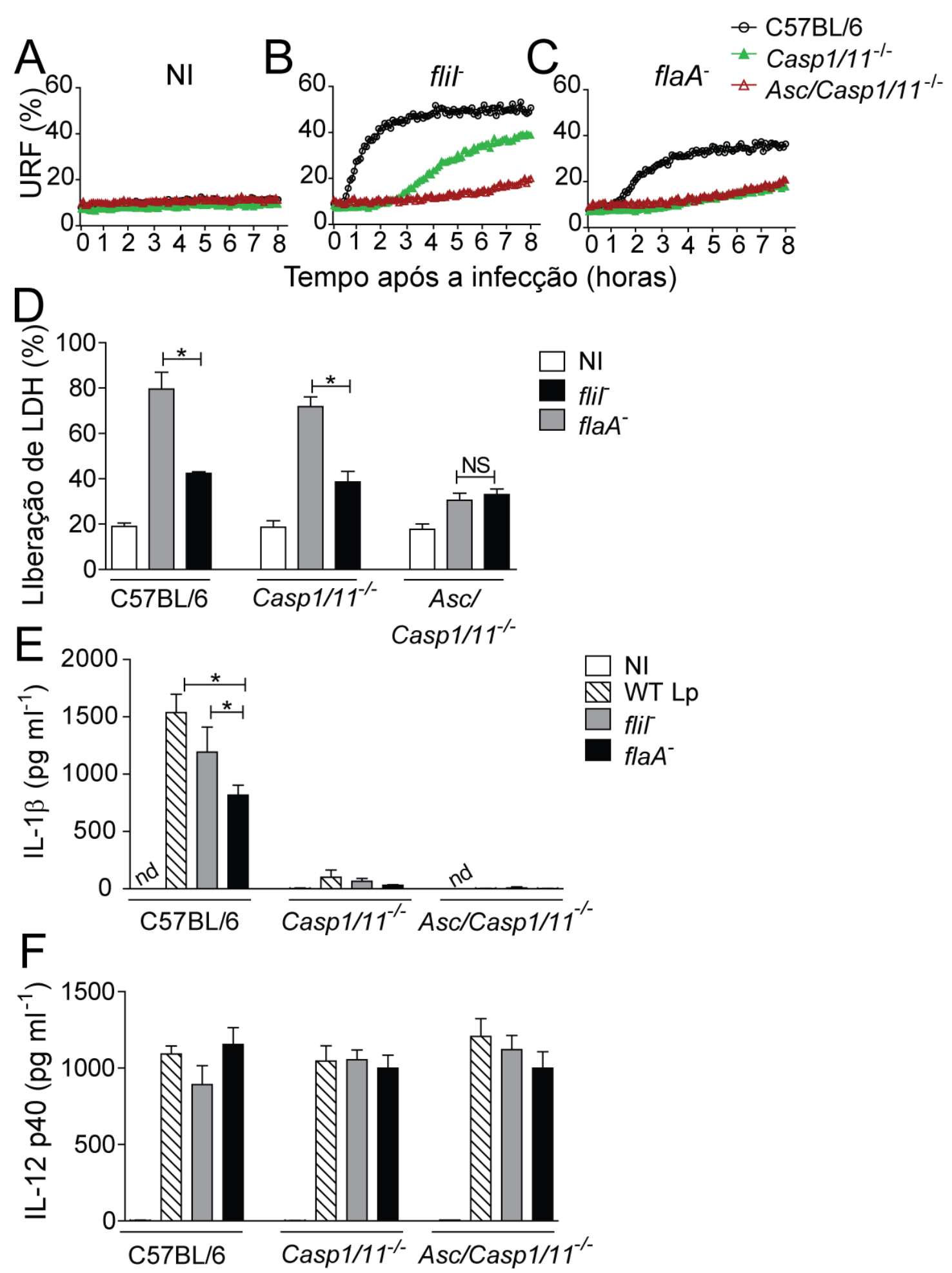

Figura 16: A via de NLRC4/ASC/Caspase-8 é importante para a formação de poro, mas não secreção de IL-1 $\beta$ em resposta à $L$. pneumophila flagelada na ausência de caspase-1/11. (A-C) Macrófagos derivados de medula óssea (BMDMs) de camundongos C57BL/6 (círculo aberto), Casp1/11\% (triângulo fechado) e Asc/Casp1/11\% (triângulo aberto) foram infectados com $L$. pneumophila flit ou flaA- (MOI 10). A formação de poro foi avaliada pela incorporação de iodeto de propídio ( $\mathrm{Pl}$ ) em tempo real com o auxílio de um fluorímetro de placa (a cada 5 minutos). As porcentagens de URF foram estimadas em relação às células lisadas com Triton X-100. (D-F) BMDMs de camundongos C57BL/6, Casp1/11\% e Asc/Casp1/11\% foram infectados com WT Lp (E-F), flit (D-F) 
ou flaA- (D-F) (MOI 10). Após 8 (D) ou 24 (E-F) horas o sobrenadante dessas células foi coletado para a detecção da liberação de lactato desidrogenase (LDH) (D) e citocinas (IL-1ß e IL-12 p40) (E-F), respectivamente. (D) Foi dosada a liberação de LDH no sobrenadante das células utilizando o kit CytoTox96 LDH-release. As porcentagens de liberação de LDH foram estimadas em relação as células lisadas com Triton X-100. (E-F) A produção de IL-1ß (E) e IL-12 p40 (F) na cultura as células foi estimada pelo método de ELISA. Dados demonstram a média \pm 0 desvio padrão das triplicatas. *, $P<0.05$, teste $t$ não paramétrico. NI, não infectado. URF, unidades relativas de fluorescência. ND, não detectado. NS, não significativo. Os dados apresentam um experimento representativo de cinco (A-C), três (D) e dois (E-F) experimentos com resultados similares. Adaptado de: MASCARENHAS, Danielle PA et al. PLoS pathogens, 2017. 

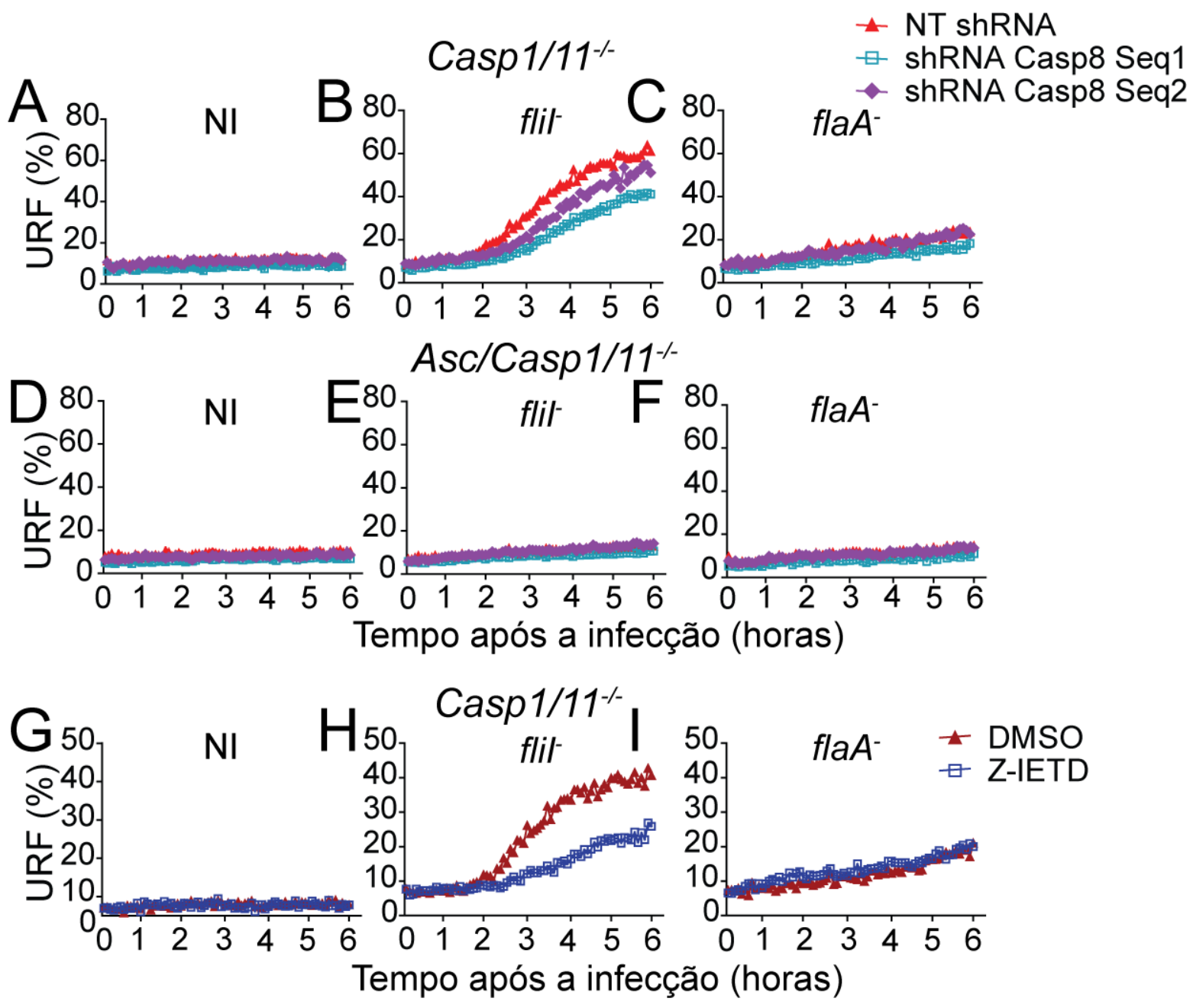

Figura 17: Poro induzido por ASC na ausência de caspase-1/11 é dependente de caspase-8. (AF) Macrófagos derivados de medula óssea (BMDMs) de Casp1/11\% (A-C) e Asc/Casp1/11\%(D-F) foram transduzidos com retrovírus expressando duas sequências independentes de shRNA para o silenciamento de caspase-8 (Seq1 e Seq2) e uma sequência não relacionada (NT-non-target). Os macrófagos transduzidos foram infectados com L. pneumophila flit ou flaA-(MOI 10). (G-I) BMDMs de camundongos Casp1/11\% foram tratados com Z-IETD, um inibidor de caspase-8 ou DMSO e então infectados com flit ou flaA (MOI 10). (A-I) A formação de poro foi avaliada pela incorporação de iodeto de propídio (PI) em tempo real com o auxílio de um fluorímetro de placa (a cada 5 minutos). As porcentagens de URF foram estimadas em relação às células lisadas com Triton X-100. Dados demonstram a média \pm o desvio padrão das triplicatas. $\mathrm{NI}$, não infectado. URF, unidades relativas de fluorescência. Os dados apresentam um experimento representativo de três (A-F) e dois (G-I) experimentos com resultados similares. Adaptado de: MASCARENHAS, Danielle PA et al. PLoS pathogens, 2017. 
\pm NT ShRNA

६ shRNA NAIP5

Casp $1 / 11^{-/-}$

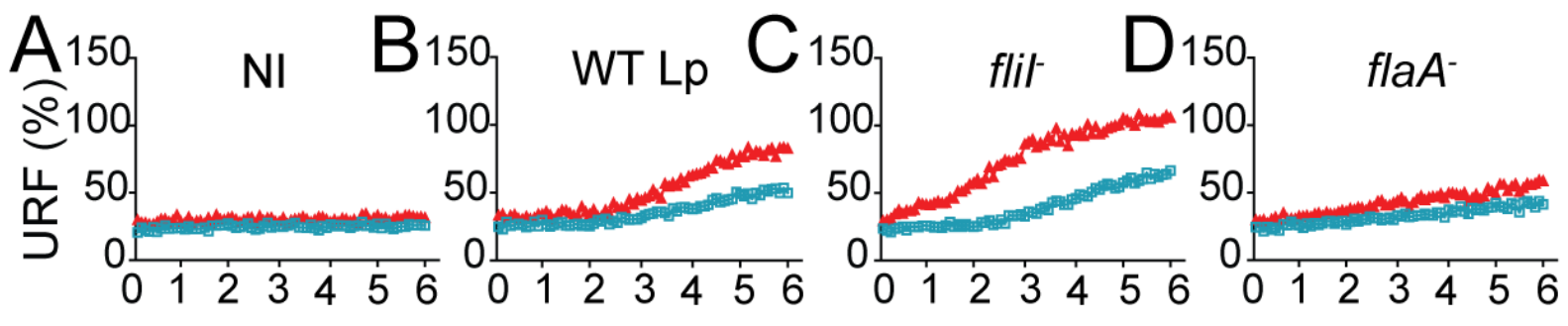
Asc/Casp $1 / 11^{-1}$

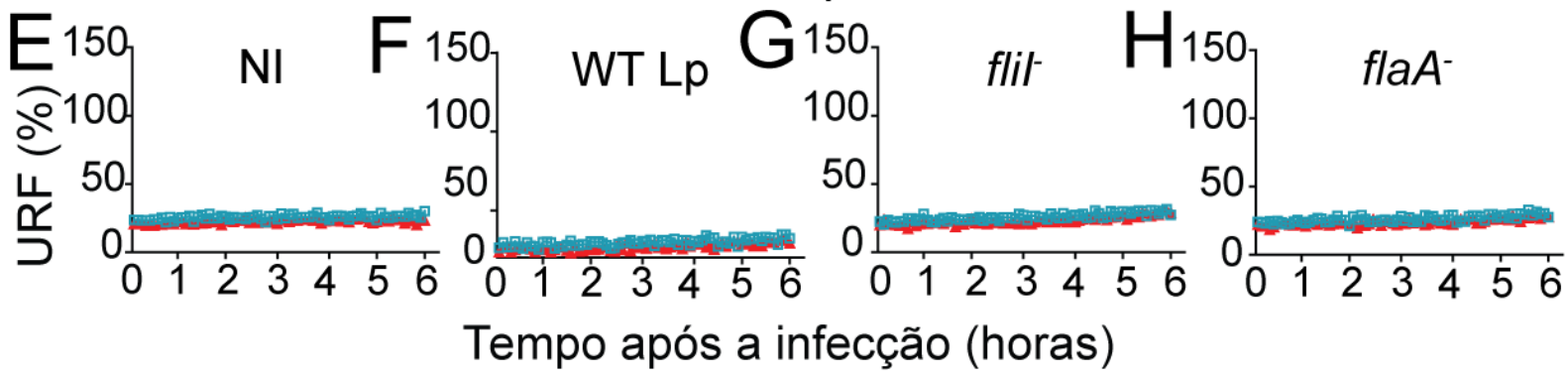

Figura 18: Naip5 é importante para a formação de poro pelo inflamassoma de NLRC4/ASC/Caspase-8 em resposta à $L$. pneumophila flagelada. Macrófagos derivados de medula óssea (BMDMs) de Casp1/11\% (A-D) e Asc/Casp1/11\% (E-H) foram transduzidos com retrovírus expressando uma sequência de shRNA para o silenciamento de Naip5 e uma sequência não relacionada (NT- non-target). Os macrófagos transduzidos foram infectados com $L$. pneumophila WT $\mathrm{Lp}$, flit ou flaA $(\mathrm{MOI} 10)$. A formação de poro foi avaliada pela incorporação de iodeto de propídio (PI) em tempo real com o auxílio de um fluorímetro de placa (a cada 5 minutos). As porcentagens de URF foram estimadas em relação às células lisadas com Triton X-100. Dados demonstram a média \pm 0 desvio padrão das triplicatas. NI, não infectado. URF, unidades relativas de fluorescência. Os dados apresentam um experimento representativo de dois experimentos com resultados similares. Adaptado de: MASCARENHAS, Danielle PA et al. PLoS pathogens, 2017. 


\section{8- Caspase-8 é recrutada para o inflamassoma de NLRC4/ASC/Caspase-1, mas só é ativada na ausência de caspase-1 ou gasdermina-D.}

Anteriormente nós utilizamos como estratégia camundongos deficientes para Casp1/11 para avaliar os mecanismos da via independente dessas proteínas. Entretanto, em condições normais as proteínas caspase-1 e a caspase-11 estão presentes nas células e são ativadas em resposta à L. pneumophila. Desta maneira nós investigamos como caspase-8 participa do inflamassoma de Naip5/NLRC4/ASC na presença de caspase-1/11 em resposta à infecção por L. pneumophila. Com esse objetivo, BMDMs de camundongos C57BL/6 foram infectados com L. pneumophila flit por 8 horas e então incubados com anti-ASC, anti-caspase-8 ou anti-caspase-1 para avaliar o recrutamento dessas proteínas endógenas para o inflamassoma. Nos macrófagos não infectados, a formação de punctas não foi significativa (Fig. 19A). Entretanto, nós detectamos a formação de punctas de ASC e o recrutamento de caspase-8 para esses punctas mesmo nas células C57BL/6 (Fig. 19B). Notavelmente, foi encontrada uma alta taxa de colocalização entre os punctas de caspase-1 e caspase-8 (mais de 60\%), indicando que mesmo na presença de caspase-1, a caspase-8 também é recrutada para o inflamassoma de Naip5/NLRC4/ASC (Fig. 19C).

A partir desses dados, nosso próximo passo foi avaliar a ativação de caspase8 na presença de caspase-1/11. Com essa finalidade, BMDMs de camundongos C57BL/6, Casp1/11/ e Asc/Casp1/11\% foram infectados com flit e flaA por 8 horas para a determinação da ativação de caspase-8 nessas células. Como demonstrado nos dados anteriores, existe uma alta ativação de caspase-8 nos macrófagos Casp1/11\% infectados com flit, mas não nos infectados com fla $A^{-}$ou nos Asc/Casp1/11\%(Fig. 19D). Entretanto, não foi possível identificar ativação de caspase8 nos macrófagos C57BL/6 infectados tanto com flit quanto com fla $A^{-}$, indicando que a caspase-8 não é ativada na presença de caspase-1/11. Para verificar se essa diferença na ativação de caspase-8 não é decorrente de um fundo genético ou microbiota diferentes, camundongos C57BL/6 foram cruzados com Casp1/11\% gerando uma prole F1 que foi então cruzada gerando camundongos F2 (Casp1/11 ${ }^{+/+}$,

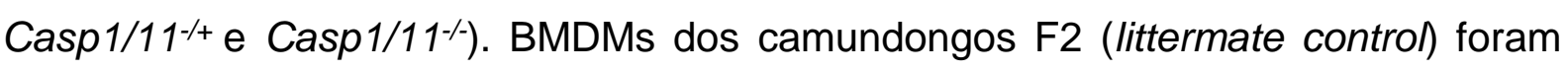
infectados com WT Lp, flit e flaA- para avaliação da ativação de caspase-8 após 8 horas de infecção. Nós detectamos ativação de caspase-8 somente nas células 
Casp1/11/ infectadas com WT Lp e flit, mas não nas Casp1/11//+ e Casp1/11+/, indicando que a presença de caspase-1 ou caspase-11 impede a ativação de caspase-8 (Fig. 19E). Para verificar qual das caspases inflamatórias, caspase-1 ou caspase-11, estaria impedindo a ativação de caspase-8, nós utilizamos BMDMs de camundongos deficientes apenas para caspase-1 (Casp1\%/Casp11tg) ou deficientes apenas para caspase-11 (Casp11--) (Kayagaki et al., 2011). A ativação de caspase8 foi detectada apenas nas células deficientes para caspase-1 expressando caspase11 como um transgene (Casp1\%/Casp11tg) infectadas com WT Lp e flir (Fig. 19F). Entretanto a deficiência apenas na caspase-11 não foi o bastante para possibilitar a ativação de caspase-8 em resposta à infecção por L. pneumophila. Esses dados indicam que a caspase-8 é recrutada para o inflamassoma de NLRC4/ASC/Caspase1 , entretanto só é ativada na ausência de caspase-1.

Recentemente foi demonstrado que a ativação das caspases inflamatórias como caspase-1 e caspase-11 levam à clivagem de gasdermina-D (GSDMD) (He et al., 2015; Kayagaki et al., 2015; Shi et al., 2015). Essa proteína quando clivada libera o seu domínio N-terminal que é o responsável por formar a estrutura do poro na membrana e posteriormente a morte celular por piroptose (Ding et al., 2016; Liu et al., 2016). Desta maneira nós avaliamos se a inibição de GSDMD em BMDMs contendo caspase-1 possibilitaria a ativação de caspase-8. Com esse objetivo, BMDMs C57BL/6 e Casp 1/11\% foram transduzidos com retrovírus expressando duas sequências independentes de shRNA para o silenciamento de GSDMD e a sequência NT (não relacionada). Por meio de análises de qPCR em Tempo Real, nós confirmamos o silenciamento de GSDMD pela diminuição da sua expressão nas células transduzidas com os retrovírus expressando as sequências de shRNA para GSDMD em comparação com a sequência NT (Fig. 20A). Após a confirmação do silenciamento por essas sequências de shRNA, os macrófagos transduzidos foram infectados com WT Lp, flit e flaA- por 8 horas para a detecção da ativação de caspase8. Nós observamos que o silenciamento de GSDMD com as duas sequências de shRNA nas células C57BL/6, possibilitou a ativação de caspase-8 em resposta à $L$. pneumophila contendo flagelina, indicando que caspase-8 só é ativada na ausência de caspase-1 ou GSDMD (Fig. 21B). Não houve diferença na ativação de caspase-8 entre as células Casp1/11/ silenciadas ou não para GSDMD. Para corroborar esses dados nós avaliamos a ativação de caspase-8 em BMDMs de camundongos 
deficientes para Gsdmd. Confirmando nossos dados anteriores nós observamos a ativação de caspase-8 somente em macrófagos Casp1/11\% e não em C57BL/6, Casp11\% e Asc/Casp1/11\% infectados com WT Lp e flit (Fig. 20C). Corroborando a hipótese de que a ausência de GSDMD possibilita a ativação de caspase-8, BMDMs de camundongos Gsdmd $^{-1}$ apresentaram uma ativação de caspase-8 similar aos Casp1/11\% infectados com WT Lp e flit, confirmando assim que caspase-8 só é ativada na ausência de caspase-1 ou GSDMD.

Por fim, nós avaliamos o papel de GSDMD no poro independente de caspase$1 / 11$, induzido pela via NLRC4/ASC/Caspase-8 em resposta à infecção por $L$. pneumophila. Utilizando o sistema de shRNA, nenhuma formação de poro foi detectada nas células não infectadas silenciadas para GSDMD, confirmando que o silenciamento não leva à uma morte celular inespecífica (Fig. 21A e E). Os macrófagos C57BL/6 silenciados para GSDMD e infetados para WT Lp e flit apresentaram uma diminuição na formação de poros, confirmando que GSDMD é importante para a formação do poro pela via Naip5/NLRC4/Caspase-1 (Fig. 21B e C). Entretanto não houve diferença na formação de poros entre as células Casp1/11\% silenciadas ou não para GSDMD, indicando que a formação de poro pela via de NLRC4/ASC/Caspase-8 ocorre por uma via independente de GSDMD (Fig. 21F-H). Em conjunto esses dados demonstram que em resposta à flagelina de Legionella spp. caspase-8 é recrutada para o inflamassoma de NLRC4/ASC/Caspase-1, entretanto só é ativada na ausência de caspase-1 ou GSDMD. O inflamassoma de NLRC4/ASC/Caspase-8 induz a formação de poros independente de GSDMD, possivelmente pela clivagem de outra gasdermina. 

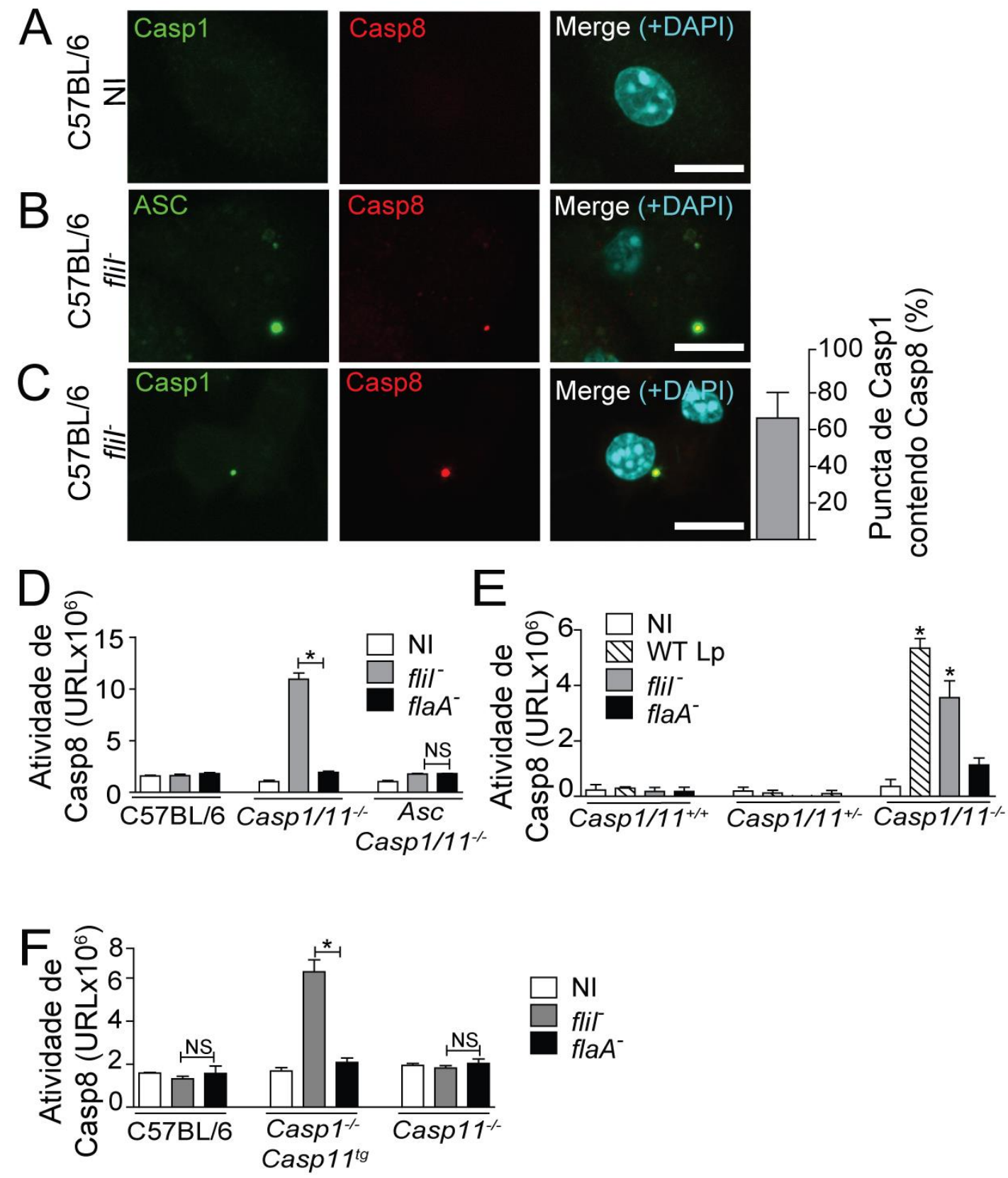

Figura 19: Caspase-8 colocaliza com inflamassoma de NLRC4/ASC/Caspase-1, mas só é ativada na ausência de caspase-1. (A-C) Macrófagos derivados de medula óssea (BMDMs) de C57BL/6 não infectados (NI) ou infectados com L. pneumophila flit (MOI 10) (B-C) por 8 horas foram fixados e marcados com anti-caspase-1 (verde), anti-caspase-8 (vermelho), anti-ASC (verde) e o núcleo celular com DAPI (ciano). A porcentagem de colocalização entre os punctas de caspase-1 e caspase-8 está representada no gráfico e foi quantificada com auxílio de microscópio de epifluorescência. As imagens foram adquiridas por microscopia de multifóton utilizando objetiva de óleo de imersão de aumento de 63X. As imagens foram analisadas utilizando o software ImageJ. Barra de escala, $10 \mu \mathrm{m}$. (D) BMDMs de camundongos C57BL/6, Casp1/11\% e Asc/Casp1/11\% foram infectados com flit e flaA- com MOI 10.

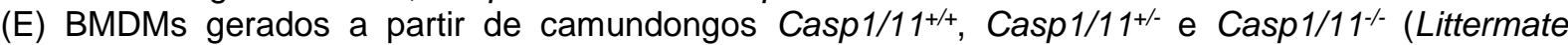
Control) foram infectados com WT Lp, flit e flaA- com MOI 10. (F) BMDMs de camundongos C57BL/6, Casp1/Casp11tg e Casp11\% foram infectados com flit e flaA com MOI 10 (D-F) Após 8 horas de infecção a ativação de caspase-8 foi avaliada utilizando um substrato luminescente de caspase-8 (Caspase-8 Glo Assay). Dados demonstram a média \pm o desvio padrão das triplicatas. ${ }^{*}, P<0.05$, teste $t$ não paramétrico. NI, não infectado. URL, unidades relativas de luminescência. Os dados apresentam um experimento representativo de dois (A-C e E) e cinco (D) experimentos com resultados similares. Adaptado de: MASCARENHAS, Danielle PA et al. PLoS pathogens, 2017. 

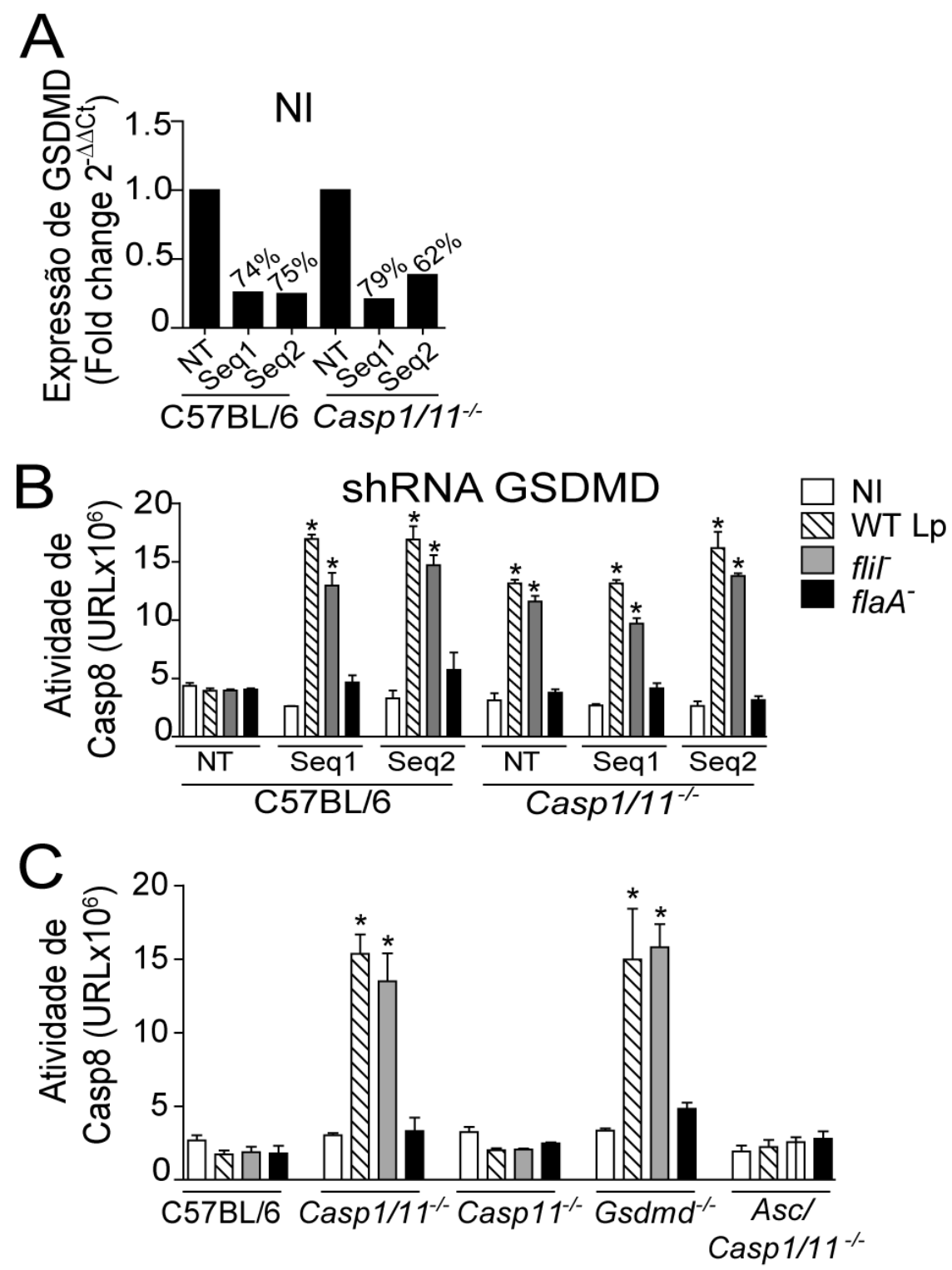

Figura 20: Inibição ou deleção de gasdermina-D permite a ativação de caspase-8 em células contendo caspase-1. Macrófagos derivados de medula óssea (BMDMs) de C57BL/6 e Casp1/11\% foram transduzidos com retrovírus expressando duas sequências independentes de shRNA para o silenciamento de GSDMD (Seq1 e Seq2) e uma sequência não relacionada (NT- non-target). (A) O silenciamento foi confirmado por análises de qPCR em Tempo Real. Quantificação da expressão de GSDMD por RT-qPCR em macrófagos silenciados para duas sequências de shRNA para GSDMD e sequência não relacionada. O gene Gapdh foi utilizado como controle para normalização dos níveis de expressão. Os números acima das barras indicam a porcentagem de silenciamento comparado com a sequência NT pela equação: $\left\{1-\left(2^{-\Delta \Delta C T}\right) \times 100\right\}$. (B) BMDMs C57BL/6 e Casp1/11\% transduzidos foram infectados com L. pneumophila WT Lp, flit e flaA- com MOI 10. Após 8 horas de infecção a ativação de caspase-8 foi avaliada pela adição um substrato luminescente de caspase-8 (Caspase-8 Glo Assay)

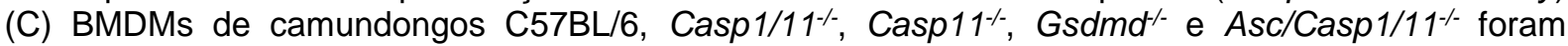
infectados com WT Lp, flit e flaA- com MOI 10. Após 8 horas de infecção a ativação de caspase-8 foi avaliada pela adição um substrato luminescente de caspase-8 (Caspase-8 Glo Assay). Dados demonstram a média \pm 0 desvio padrão das triplicatas. ${ }^{*}, P<0.05$ comparado com as células infectadas $\operatorname{com}$ flaA-, teste $t$ não paramétrico. NI, não infectado. NT, não relacionado (non-target). URL, unidades relativas de luminescência. Os dados apresentam um experimento representativo de dois experimentos com resultados similares. Adaptado de: MASCARENHAS, Danielle PA et al. PLoS pathogens, 2017. Figura C ainda não publicada. 
- NT shRNA

$\because$ shRNA GSDMD Seq1
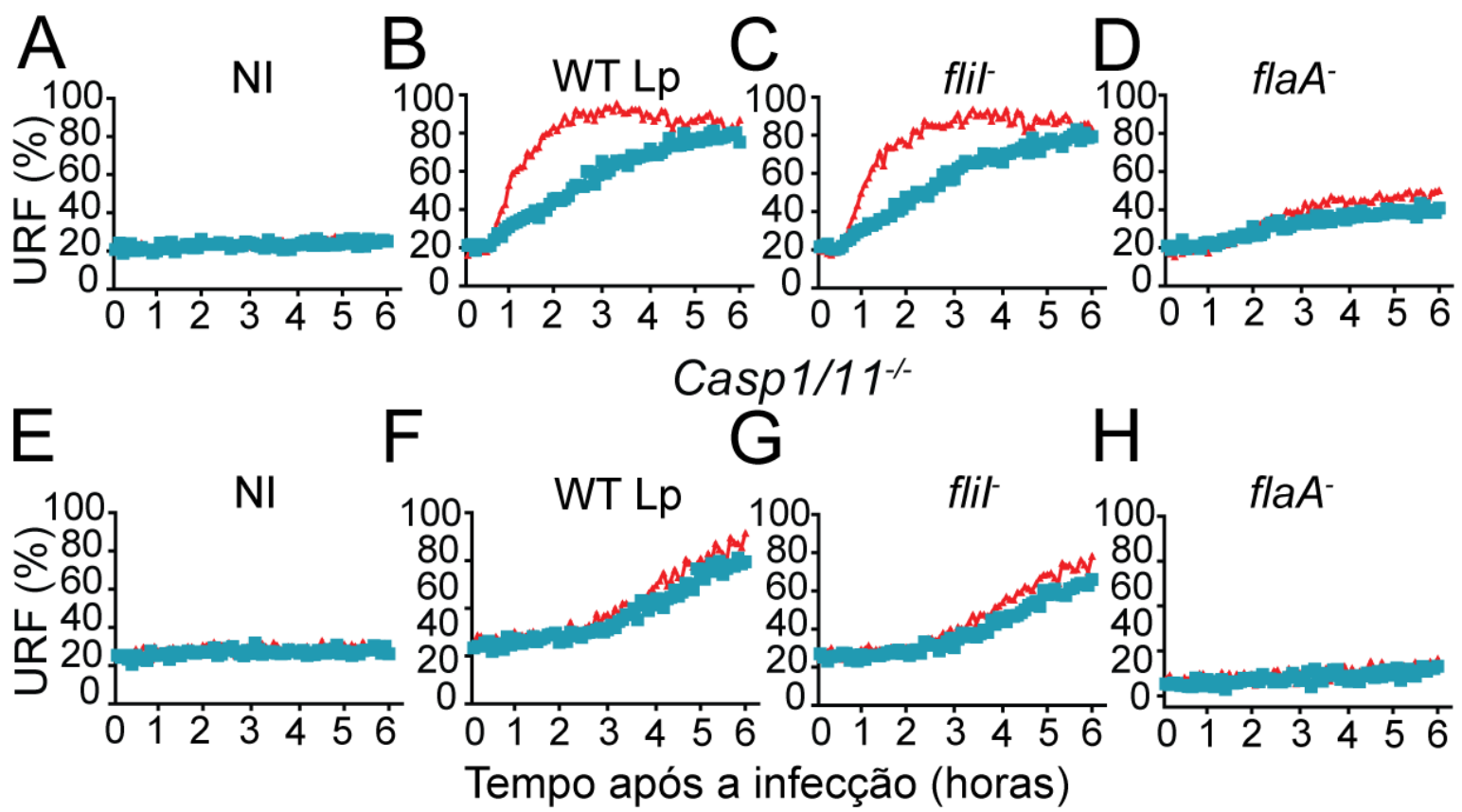

C57BL/6

Figura 21: Gasdermina-D é importante para a formação de poro em BMDMs C57BL/6, mas não em Casp1/11\%. Macrófagos derivados de medula óssea (BMDMs) de C57BL/6 e Casp $1 / 11 \%$ foram transduzidos com retrovírus expressando duas sequências independentes de shRNA para o silenciamento de GSDMD (Seq1 e Seq2) e uma sequência não relacionada (NT- non-target). Os macrófagos transduzidos foram infectados com L. pneumophila WT Lp, flit ou flaA (MOI 10). A formação de poro foi avaliada pela incorporação de iodeto de propídio $(\mathrm{PI})$ em tempo real com o auxílio de um fluorímetro de placa (a cada 5 minutos). As porcentagens de URF foram estimadas em relação às células lisadas com Triton X-100. Dados demonstram a média \pm 0 desvio padrão das triplicatas. NI, não infectado. URF, unidades relativas de fluorescência. Os dados apresentam um experimento representativo de dois experimentos com resultados similares. De: MASCARENHAS, Danielle PA et al. PLoS pathogens, 2017. 
Discussão 


\section{5 - DISCUSSÃO}

L. pneumophila é uma bactéria intracelular Gram-negativa flagelada, causadora da doença dos legionários e febre de Pontiac (Mcdade et al., 1977). Durante sua história evolutiva, esta bactéria seguiu parasitando protozoários intracelulares como amebas de vida livre, entretanto os humanos são considerados seus hospedeiros acidentais (Rowbotham, 1980; Fliermans et al., 1981). Consequentemente, quando é fagocitada por macrófagos alveolares, L. pneumophila é reconhecida por uma série de PRRs, como os TLRs e os NLRs, sendo um excelente modelo de estudo para a ativação das vias do sistema imune inato (Massis e Zamboni, 2011; Mascarenhas e Zamboni, 2017). Diversos TLRs e NLRs são ativados em resposta à $L$. pneumophila (Massis e Zamboni, 2011). A ativação de certos NLRs leva à formação de um complexo proteico citoplasmático denominado de inflamassoma (Ting et al., 2008; Guo et al., 2015). A formação desse complexo, com a proteína adaptadora ASC, leva à ativação e clivagem de caspase-1 com consequente morte celular por piroptose e secreção de citocinas pró-inflamatórias como IL-18 e IL-1 $\beta$ (Martinon et al., 2002).

O inflamassoma mais importante para o controle da replicação de $L$. pneumophila em células de camundongos é o de Naip5/NLRC4/Caspase-1 (Yamamoto et al., 1988; Zamboni et al., 2006). Nesse inflamassoma o receptor Naip5 reconhece a porção C-terminal da flagelina pelo seu domínio NBD (Zamboni et al., 2006; Lightfield et al., 2008; Tenthorey et al., 2014). Após o reconhecimento de flagelina, Naip5 se oligomeriza e recruta NLRC4, levando à ativação de caspase-1 (Lightfield et al., 2008; Kofoed e Vance, 2011; Zhao et al., 2011). A ativação dessa protease leva à morte celular por piroptose e controle da replicação da bactéria (Silveira e Zamboni, 2010; Pereira, Marques, et al., 2011).

Trabalhos reportaram respostas induzidas por NLRC4 de maneira independente de caspase-1, como controle da replicação e indução de morte celular (Gao e Abu Kwaik, 1999; Coers et al., 2007; Akhter et al., 2009; Fortier et al., 2009; Abdelaziz, Gavrilin, Akhter, Caution, Kotrange, Khweek, Abdulrahman, Grandhi, et al., 2011; Abdelaziz, Gavrilin, Akhter, Caution, Kotrange, Khweek, Abdulrahman, Hassan, et al., 2011; Pereira, Morgantetti, et al., 2011; Zhu et al., 2013). Pereira, Morgantetti, et al (2011) demonstraram que além do inflamassoma de Naip5/NLRC4/Caspase-1, existe uma outra via independente de caspase-1/11 e dependente de NLRC4 em 
resposta à flagelina de Legionella spp. Neste trabalho foi verificado que camundongos deficientes para NIrc4 são mais susceptíveis do que camundongos deficientes para Casp1/11 (Pereira, Morgantetti, et al., 2011). Esta foi uma observação muito importante, já que por muito tempo foi considerado que NLRC4 e caspase-1 faziam parte de uma via única de controle da replicação de bactérias flageladas.

Foi demonstrada a participação de caspases apoptóticas, como caspase-3, caspase-7 e caspase-8, nas funções induzidas pelos inflamassomas, induzindo morte celular e secreção de citocinas pró-inflamatórias (Masumoto et al., 2003; Hasegawa et al., 2005; Akhter et al., 2009; Kumar et al., 2010; Abdelaziz, Gavrilin, Akhter, Caution, Kotrange, Khweek, Abdulrahman, Hassan, et al., 2011; Motani et al., 2011; Pierini et al., 2012; Man et al., 2013; Sagulenko et al., 2013; Man et al., 2014; Vajjhala et al., 2015; Kawamoto et al., 2017; Rauch et al., 2017). A partir da hipótese de que alguma dessas caspases poderia fazer parte do inflamassoma independente de caspase-1/11, nós realizamos ensaios de colocalização entre NLRC4-GFP e essas caspases. A partir desses experimentos nós determinamos que esse novo inflamassoma é composto por NLRC4/ASC/Caspase-8 em resposta ao reconhecimento de flagelina de L. pneumophila (Fig. 7 e 8). Nós especulamos que essa via também é ativada em resposta à outras bactérias flageladas, já que foi reportado a interação de NLRC4 e caspase-8 em outras espécies como $S$. Thyphimurium e Listeria monocytogenes (Man et al., 2013; Sagulenko et al., 2013; Uchiyama et al., 2013; Rauch et al., 2017).

Além do recrutamento para o puncta de NLRC4 e ASC em resposta à $L$. pneumophila flagelada, demonstramos que caspase-8 é ativada de maneira independente de caspase-1/11 e dependente de ASC (Fig. 9). Nós observamos a ativação de caspase-8 pela detecção de um substrato luminescente desta protease e também pela sua clivagem em p18 por Western Blot. A utilização destas duas técnicas é importante uma vez que foi demonstrado que, assim como a caspase-1, a caspase-8 também apresenta uma forma ativa e não clivada importante nas respostas contra patógenos (Philip et al., 2016).

Além de caspase-1, trabalhos demonstraram a participação de caspase-3 e caspase-7 em respostas induzidas por L. pneumophila (Gao e Abu Kwaik, 1999; Akhter et al., 2009; Abdelaziz, Gavrilin, Akhter, Caution, Kotrange, Khweek, Abdulrahman, Hassan, et al., 2011; Zhu et al., 2013). Entretanto, nos nossos 
experimentos não observamos nenhuma colocalização entre os punctas de NLRC4GFP, caspase-3 e caspase-7, sugerindo que essas caspases não interagem diretamente com o inflamassoma de NLRC4/ASC. De maneira muito interessante dados preliminares realizados após este trabalho, sugerem que caspase-7 também faz parte deste complexo. Nós especulamos que, como ocorre nos mecanismos de apoptose, na indução de morte celular pelo inflamassoma de NLRC4/ASC/Caspase8, a caspase-8 também atua como uma caspase iniciadora levando à ativação de caspase-7, uma caspase efetora (Shi, 2002; Li e Yuan, 2008; Creagh, 2014). Esses dados não contradizem o que demonstramos nos experimentos de colocalização, já que utilizamos Z-VAD para a inibição da ativação das caspases e melhor visualização dos punctas.

Por meio da utilização de shRNA para o silenciamento de caspase-8 e o camundongo Asc/Casp1/11\%, nós demonstramos que 0 inflamassoma NLRC4/ASC/Caspase-8 é essencial para o controle da replicação de Legionella spp. flagelada in vitro e in vivo (Fig. 10-12). Esses dados são muito relevantes, uma vez que nunca foi demonstrada uma resposta relacionada à caspase-8 e essa bactéria. É importante dar destaque para a estratégia que utilizamos de shRNA para o silenciamento de caspase-8, visto que camundongos deficientes para caspase-8 não sobrevivem pela indução da via de necroptose, sendo necessária a deleção também de Ripk3 nesses animais (Varfolomeev et al., 1998; Kaiser et al., 2011). Além disso, caspase-8 está envolvida em diversas vias e processos celulares, dentre eles a indução das vias de apoptose, o priming pelos TLRs, e a produção de citocinas como TNF e IL-12 (Li e Yuan, 2008; Parrish et al., 2013; Creagh, 2014; Mace et al., 2014; Antonopoulos et al., 2015; Kang et al., 2015; Philip et al., 2016). Desta maneira, a utilização dos camundongos Asc/Casp1/11\% é mais adequada para a avaliação do controle da replicação neste inflamassoma dependente de Naip5/NLRC4.

Trabalhos primordiais no estudo de L. pneumophila identificaram que Naip5 é essencial para controlar a replicação desta bactéria (Yamamoto et al., 1988; Diez et al., 2000; Diez et al., 2003; Wright et al., 2003). Além da via de reconhecimento de flagelina com Naip5 e Naip6, NLRC4 também interage com Naip1 e Naip2 quando ocorre o reconhecimento de proteínas needle e rod (respectivamente) dos sistemas de secreção do Tipo III de bactérias (Kofoed e Vance, 2011; Rayamajhi et al., 2013; Rauch et al., 2016). Entretanto, no controle da replicação de L. pneumophila, o 
receptor Naip5 parece ser o único importante dentre os receptores do tipo Naip (Rauch et al., 2016; Zhao et al., 2016). Por meio do silenciamento de Naip5 por shRNA nós observamos que Naip5 é essencial no controle da replicação de $L$. pneumophila também na via independente de caspase-1/11. Nós detectamos uma diminuição na ativação de caspase-8 e formação de poros em macrófagos silenciados para Naip5, confirmando que o reconhecimento de flagelina por esse receptor é essencial para a ativação do inflamassoma de NLRC4/ASC/Caspase-8 na ausência de caspase-1/11.

Diversos trabalhos sugerem que a morte celular por piroptose pode resultar no controle bacteriano (Miao et al., 2010; Larock e Cookson, 2013). Foi proposto recentemente que a formação de PITs (Pore Intracellular Traps) é importante para o controle da infecção de bactérias intracelulares (Jorgensen, Zhang, et al., 2016). Os PITs são formados de restos de células que passaram por piroptose, onde as bactérias ficam presas, impedindo que infectem novas células. Foi demonstrado que as bactérias que passaram por essas células em piroptose, apresentam uma menor capacidade de infectar novas células, são mais susceptíveis à ROS e antibióticos. Nossos dados sugerem que a flagelina de Legionella spp. induz morte celular tanto pela via dependente quanto independente de caspase-1, pela ativação de caspase8. Tanto as vias dependentes de caspase- 1 ou caspase-8 levam ao controle da replicação de L. pneumophila. Desta maneira nós especulamos que a formação dos PITs é responsável pelo controle da replicação de Legionella spp. flagelada de maneira dependente de caspase-1 e caspase-8.

Foi demonstrado que a piroptose leva à um extravasamento do conteúdo citoplasmático, com liberação de DAMPs, citocinas pró-inflamatórias e mediadores lipídicos recrutando novas células para o sítio de infecção (Jorgensen, Lopez, et al., 2016). Um trabalho publicado pelo nosso grupo em 2014, demonstra que existe uma fase de replicação inicial que pode ser controlada pelo inflamassoma de NLRC4 e uma fase da infecção mais tardia que é controlada pelo recrutamento de células, levando ao "clearance" das bactérias (Mascarenhas et al., 2015). Desta maneira, nós sugerimos que a ativação dos inflamassomas, como o de NLRC4/ASC/Caspase-8, induz piroptose com formação dos PITs, esse mecanismo controla a replicação inicial das bactérias. O recrutamento de novas células para o sítio de infecção, 
principalmente neutrófilos leva a um controle da infecção dessas bactérias ou clearance.

Um trabalho utilizando mutantes de NLRC4 para a região LRR, identificou uma morte celular induzida por NLRC4 independente de caspase-1 e dependente de caspase-8 (Kumar et al., 2010). Neste trabalho os autores identificaram que a proteína Sug1, componente do proteassoma 26S, se liga à NLRC4 levando a sua ubiquitinação e com isso ao recrutamento e ativação de caspase-8. Desta maneira, é muito possível que Sug1 também faça parte do inflamassoma de NLRC4/ASC/Caspase-8 colaborando na indução de morte celular (Raghawan et al., 2017).

Man et al., 2013 observaram a colocalização de ASC e caspase-8 em resposta à infecção por S. Thyphimurium (Man et al., 2013). Contudo, diferente dos nossos achados, a ativação de caspase-8 induz somente a secreção de IL-1ß e não a indução de morte celular em resposta à infecção por $S$. Thyphimurium. Essa diferença de fenótipos pode ser explicada, já que os autores do trabalho utilizaram apenas células de camundongos C57BL/6. Provavelmente a diminuição que observaram nas células Casp8Ripk3-- na indução de IL-1ß é referente à ativação do inflamassoma de NLRP3, já que é bem descrito que caspase-8 é essencial para o priming e ativação deste inflamassoma (Gurung et al., 2014; Antonopoulos et al., 2015; Kang et al., 2015). No presente trabalho utilizamos como estratégia macrófagos de camundongos Casp1/11\% para o estudo desta via independente de caspase-1/11. Esses macrófagos já secretam uma baixa quantidade de IL-1 em resposta à infecção por L. pneumophila, indicando que a via de NLRC4/ASC/Caspase-8 é ineficiente para a secreção desta citocina (Zamboni et al., 2006; Case et al., 2009; Case e Roy, 2011; Kayagaki et al., 2011; Casson et al., 2013; Cerqueira et al., 2015).

AIM2 é caracterizado como um receptor que leva à ativação de caspase-8 em um processo dependente de ASC. Entretanto, nossos dados com AIM2 sugerem que AIM2 não faz parte do inflamassoma composto por NLRC4/ASC/Caspase-8. Observamos que AIM2 não colocaliza com os punctas de NLRC4-GFP e não é importante para a formação dessas estruturas (Fig. 13). Também foi determinado que AIM2 não é importante para o controle da replicação em macrófagos e in vivo em resposta à infecção por L. pneumophila flagelada (Fig. 14). É interessante notar, que foram encontrados punctas de AIM2, já que tem sido reportada a ativação do 
inflamassoma de AIM2 em resposta à L. pneumophila (Ge et al., 2012; Cunha et al., 2017). Entretanto esses punctas não colocalizavam com os de NLRC4-GFP. Este é um dado interessante, pois demonstra que o puncta se forma de maneira específica e não são todas as moléculas ativadas dos inflamassomas em um mesmo puncta. Uma vez que foi reportado que em resposta à infecção por $S$. Thyphimurium os inflamassomas de NLRP3 e NLRC4 são recrutados para o mesmo complexo (Man et al., 2014). Em dados preliminares, nós observamos que os punctas de NLRP3 também não colocalizam com os de NLRC4/ASC/Caspase-8.

Além de verificarmos que o inflamassoma independente de caspase-1/11 é composto por NLRC4/ASC/Caspase-8, também determinamos que neste inflamassoma a formação de punctas e ativação de caspase-8 é dependente da proteína adaptadora ASC (Fig. 6B). Dado que vai de acordo com o demostrado em outros trabalhos de que ASC é essencial para a nucleação dos inflamassomas (Case e Roy, 2011). Um trabalho publicado em 2015 demonstrou que o domínio PYD de ASC interage com o domínio DED da caspase-8 gerando uma estrutura filamentosa muito parecida com o que demonstramos na figura 8C (Vajjhala et al., 2015). A interação entre esses dois domínios é essencial para a nucleação e autoprocessamento da caspase-8. Já a ligação entre ASC e NLRC4 ocorre pelos domínios CARD das duas proteínas (Schroder e Tschopp, 2010). A determinação das funções de ASC no inflamassoma de NLRC4/ASC/Caspase-8 é muito importante para esclarecer a controvérsia por trás do papel de ASC nas funções induzidas por NLRC4.

Trabalhos demostram que ASC não é importante para o controle da infecção de L. pneumophila em células de camundongos (Zamboni et al., 2006; Case et al., 2009). Entretanto, outros trabalhos reportaram que células $A s c^{-/}$são mais susceptíveis à infecção por essa bactéria (Abdelaziz, Gavrilin, Akhter, Caution, Kotrange, Khweek, Abdulrahman, Grandhi, et al., 2011; Abdelaziz, Gavrilin, Akhter, Caution, Kotrange, Khweek, Abdulrahman, Hassan, et al., 2011). Nós iniciamos o trabalho testando os BMDMs $A s c^{-/}$e não detectamos nenhuma diferença em relação ao crescimento bacteriano quando comparados aos $\mathrm{C} 57 \mathrm{BL} / 6$, confirmando que ASC não é importante para o controle da replicação de $L$. pneumophila em condições normais (Fig. 5). Entretanto, na ausência de caspase-1/11 essa proteína adaptadora se mostrou essencial para o controle da replicação desta bactéria, tanto em 
macrófagos quanto in vivo, já que os camundongos Asc/Casp1/11\% foram mais susceptíveis que os Casp1/11\%. Em 2010, um trabalho utilizou formas mutantes de caspase-1 para avaliar as funções de ASC (Broz et al., 2010). Foi observado que existem dois tipos de complexos formados na ativação dos inflamassomas. Um primeiro complexo sem a presença de ASC, que leva apenas à ativação de caspase1 e não sua clivagem. A caspase-1 ativa e não clivada é capaz de induzir a formação de poros, morte celular, e consequentemente controle da replicação. É importante destacar que esse primeiro complexo não leva à uma eficiente clivagem de caspase1 e secreção de citocinas. O recrutamento de ASC para o complexo leva à formação dos punctas, e clivagem das caspases por proximidade, gerando assim a secreção de citocinas pró-inflamatórias como IL-1ß. De maneira muito interessante, após a morte celular por piroptose, são liberados DAMPs para meio extracelular, dentre eles os punctas formados, que parecem ativar novas células, causando uma propagação da inflamação e assim formando novos punctas (Franklin et al., 2014; Franklin et al., 2018). Desta maneira, diferente do que ocorre no inflamassoma dependente de caspase-1 onde ASC só é importante para a formação dos punctas e clivagem de citocinas inflamatórias, na via dependente de caspase-8 a proteína adaptadora ASC também é essencial para a formação de poro e controle da replicação de Legionella spp.

Nossos dados sugerem que em condições normais, na presença de caspase1/11, a caspase-8 é recrutada para este puncta contendo NLRC4/ASC/Caspase-1, inflamassoma que é altamente eficiente na secreção de IL-1ß. Entretanto a caspase8 só é ativada na ausência e/ou inibição de caspase-1 ou GSDMD (Fig. 19 e 20). Um trabalho publicado alguns meses após a publicação do nosso estudo, encontrou dados muito semelhantes (Schneider et al., 2017). Neste trabalho os autores observaram que em resposta à diversos estímulos ocorre a ativação dos inflamassomas de NLRP3, AIM2 e NLRC4, com recrutamento de caspase-1 e caspase-8 para os punctas de ASC. Através da utilização de um mutante enzimaticamente inativo de caspase-1, foi observado que a ativação de caspase-8 só ocorre na ausência de caspase-1 ativa ou de GSDMD. Tudo indica que essa inibição da ativação de caspase-8 é tempo dependente. Isso porque a indução de piroptose pela via de NLRC4/Caspase-1 é muito rápida, começando com menos de uma hora de infecção (Fig. 16B). De acordo com alguns dados preliminares nossos, com 2 
horas de infecção a taxa de ativação de caspase-8 ainda é muito baixa em resposta à L. pneumophila. Além disso, a adição de glicina antes da infecção por essa bactéria, que inibe a lise da célula por piroptose, parece aumentar a ativação de caspase-8 nas células $\mathrm{C} 57 \mathrm{BL} / 6$. Entretanto, os mecanismos pelos quais ocorre essa inibição da ativação de caspase-8 na presença de caspase-1 ou GSDMD ainda precisam ser melhor estudados. Nossos dados indicam que essa via de NLRC4/ASC/Caspase-8 é uma via alternativa de controle da replicação de patógenos quando a via dependente de caspase-1 não pode ser ativada. Essa via alternativa de sinalização abaixo de NLRC4 pode ser muito importante no caso de infecções com vírus ou outros organismos que possam inibir ativação da caspase-1 ou de GSDMD. Inibição que já foi reportada por alguns trabalhos (Callus e Vaux, 2007; Jamieson et al., 2013; Lei et al., 2017).

Além da formação de poro dependente de caspase-1 e caspase-11, nós demonstramos que existe uma formação de poros e morte celular independente de caspase-1/11 com características muito similares as de piroptose. Em contrapartida, diferente do que ocorre nos macrófagos de camundongos C57BL/6, nas células deficientes para Casp1/11 essa morte celular não é dependente de GSDMD, o que também foi observado em outros estudos (Rauch et al., 2017; Schneider et al., 2017). É possível que essa morte celular induzida por caspase-8 é dependente de outra gasdermina, ou até mesmo outra proteína formadora de poro. São conhecidas até hoje dez gasderminas em camundongos: GSDMA (GSDMA1, GSDMA2, GSDMA3), GSDMC (GSDMC1, GSDMC2, GSDMC3 e GSDMC4), GSDMD, GSDME (também conhecida como dfna5) e GSDMF (também conhecida como dfnb59) (Kovacs e Miao, 2017). A maioria dessas gasderminas já teve seu papel descrito ligado à indução de poro e morte celular (Shi et al., 2015). Inclusive já foi demonstrado que GSDME é clivada por caspase-3, levando a indução de piroptose em resposta à drogas quimioterápicas (Rogers et al., 2017; Wang et al., 2017; Wang et al., 2018). Entretanto, ainda não há relatos acerca da resposta à patógenos e a indução de piroptose por outras gasderminas. Neste contexto, estudos futuros acerca do papel de outras gasderminas na morte celular induzida pelo inflamassoma de NLRC4/ASC/Caspase-8 são de extrema importância.

De forma geral os dados deste trabalho em conjunto com o que foi demonstrado por outros estudos, sugere que em resposta à flagelina de Legionella 
spp. é formado um primeiro complexo com Naip5/NLRC4 e sem ASC onde ocorre a ativação de caspase-1 (Fig. 22) (Broz et al., 2010). Essa ativação leva à clivagem de GSDMD, com consequente formação de poro e morte celular por piroptose (He et al., 2015; Kayagaki et al., 2015; Shi et al., 2015; Aglietti et al., 2016; Liu et al., 2016; Sborgi et al., 2016; Kovacs e Miao, 2017). A indução de piroptose tem sido ligada ao controle da replicação dessas bactérias, principalmente pela formação de PITs (Jorgensen, Zhang, et al., 2016). Após o recrutamento de ASC, ocorre a formação dos punctas e o autoprocessamento de caspase-1 levando à secreção de citocinas pró-inflamatórias como IL-1ß e IL-18 (Broz et al., 2010). Nossos dados sugerem que em resposta à infecção por espécies de Legionella flageladas caspase-8 também é recrutada para o puncta contendo NLRC4/ASC/Caspase-1 (Fig. 22). Em caso de inibição de caspase-1 ou degradação de GSDMD por vírus ou outros microrganismos, a caspase-8 é ativada levando à clivagem de uma outra proteína indutora de poro, possivelmente uma gasdermina que não GSDMD (Callus e Vaux, 2007; Jamieson et al., 2013; Lei et al., 2017). Nós sugerimos que essa indução de morte celular pela via NLRC4/ASC/Caspase-8 induz o controle da replicação de L. pneumophila tanto em macrófagos quanto in vivo. Além da ativação do inflamassoma por flagelina também ocorre a ativação do inflamassoma de AIM2 por dupla fita de DNA e de caspase-11 por LPS de L. pneumophila. Em ambos os inflamassomas a clivagem de caspase-1, assim como de caspase-11 induz piroptose dependente de GSDMD e com isso um efluxo de potássio que levará à ativação do inflamassoma de NLRP3 (Cunha et al., 2017). É possível especular que assim como ocorre com os inflamassomas de AIM2, caspase-11 e NLRC4/Caspase-1, a morte celular induzida por NLRC4/ASC/Caspase8 promove o efluxo de potássio que é necessário para a ativação do inflamassoma de NLRP3. Dessa forma, estudos futuros serão necessários para determinar se caspase-8 contribui para ativação de uma via não canônica de ativação de NLRP3. 


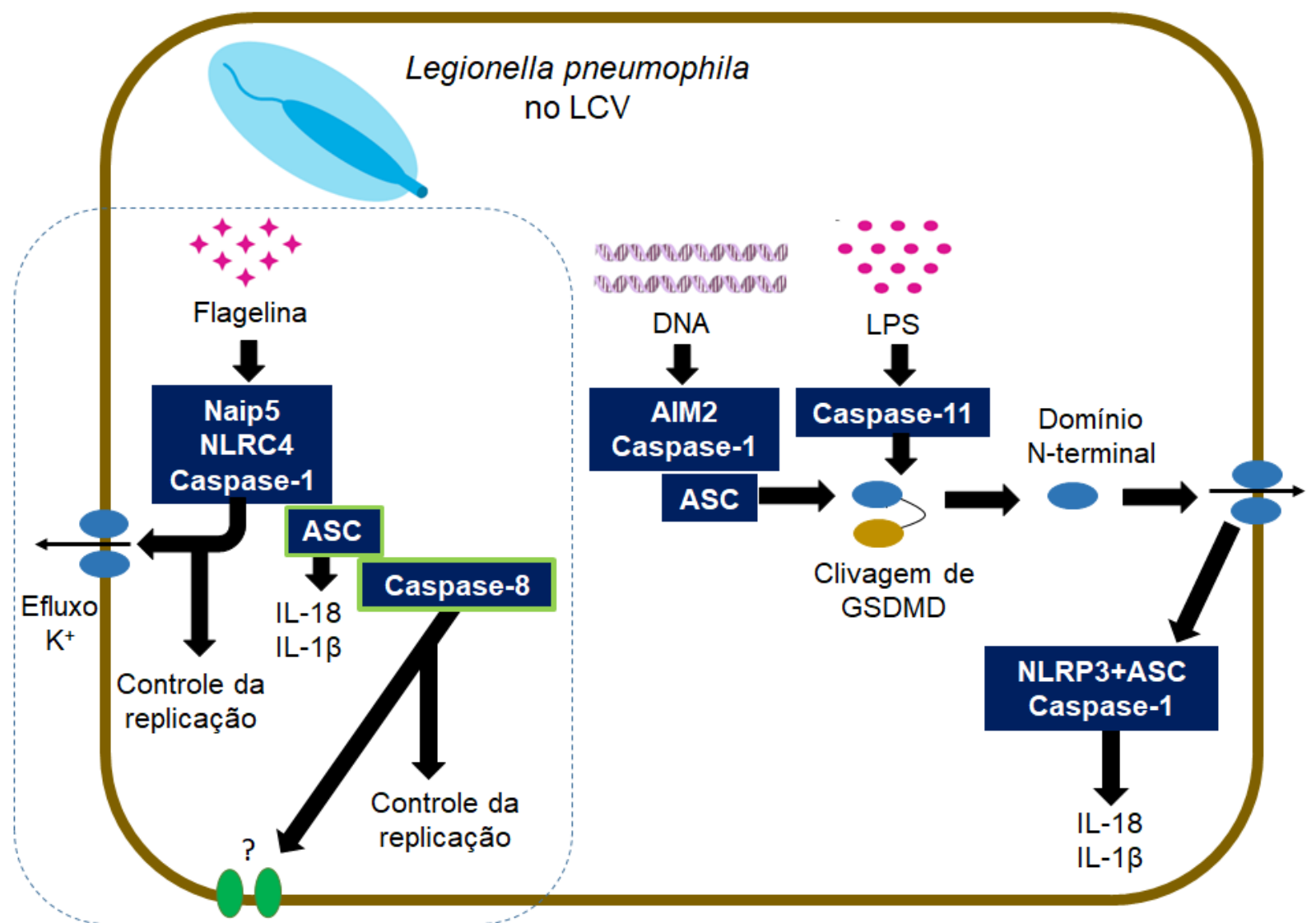

Figura 22: Modelo proposto. O reconhecimento da porção C-terminal da flagelina por Naip5 induz a sua oligomerização e recrutamento de NLRC4 e caspase-1, formando um primeiro complexo. Caspase1 é ativada, levando à clivagem de GSDMD e consequente formação de poro, piroptose e controle da replicação de $L$. pneumophila flagelada. O recrutamento de ASC induz a formação dos punctas e clivagem de caspase-1 por autoprocessamento. A clivagem de caspase-1 gera a secreção de citocinas pró-inflamatórias como IL-1 $\beta$ e IL-18. Nosso trabalho demonstrou que caspase-8 é recrutada para esse complexo (circulado em linhas tracejadas) NLRC4/ASC/Caspase-1. Caspase-8 será ativada caso ocorra a inibição da ativação de caspase-1 ou degradação de GSDMD. Nossos dados indicam que a ativação de caspase-8 induz a formação de poro e morte celular de maneira independente de GSDMD, com a possível participação de outra proteína formadora de poro. A ativação do inflamassoma de NLRC4/ASC/Caspase-8 é essencial para o controle da replicação de $L$. pneumophila independente de caspase-1/11. Além dos inflamassomas ativados por flagelina, o inflamassoma de AIM2 é ativado por fita dupla de DNA e o de caspase-11 por LPS de L. pneumophila e outras bactérias Gram-negativas. A clivagem de caspase-1 e caspase-11 por esses inflamassomas, assim como o de NLRC4/Caspase-1 leva à piroptose, efluxo de potássio com consequente ativação do inflamassoma de NLRP3. 
Sumário 


\section{6 - SUMÁRIO}

> Um puncta de NLRC4, dependente de ASC e independente de caspase-1/11 é formado em resposta à $L$. pneumophila que expressa flagelina.

$>\mathrm{O}$ inflamassoma independente de caspase-1/11 formado em resposta à infecção por $L$. pneumophila contendo flagelina é composto por NLRC4/ASC/Caspase-8.

> ASC é essencial para a ativação de caspase-8 em resposta à infecção por $L$. pneumophila.

> Caspase-8 é importante para o controle da replicação de Legionella flagelada em macrófagos por uma via independente de caspase-1/11.

> ASC é importante para o controle da replicação mediado por NLRC4 de Legionella flagelada in vivo.

> AIM2 não participa do inflamassoma de NLRC4/ASC/Caspase-8 em resposta à L. pneumophila.

$>$ Reconhecimento de flagelina por Naip5 é essencial para os mecanismos efetores do inflamassoma de NLRC4/ASC/Caspase-8.

$>$ L. pneumophila expressando flagelina desencadeia a formação de poro e morte celular independente de caspase-1/11 e dependente da via de Naip5/NLRC4/ASC/Caspase-8.

> A via de NLRC4/ASC/Caspase-8 não contribui de forma significativa para a secreção de IL-1 $\beta$.

> Em resposta à flagelina caspase-8 é recrutada para o inflamassoma de NLRC4/ASC/Caspase-1.

> Caspase-8 está presente no inflamassoma composto por Naip5/NLRC4, mas só é ativada na ausência de caspase-1 ou GSDMD.

> A morte celular induzida pelo inflamassoma composto por NLRC4/ASC/Caspase-8 ocorre de maneira independente de GSDMD. 


\section{Conclusão}




\section{7 - CONCLUSÃO}

A bactéria intracelular flagelada $L$. pneumophila desencadeia a ativação de um inflamassoma contendo Naip5, NLRC4, ASC, caspase-1 e caspase-8. Entretanto, a ativação de caspase-8 ocorre somente na ausência de caspase-1 ou GSDMD, funcionando como uma via alternativa no controle da replicação de L. pneumophila em macrófagos e in vivo. 


\section{Referências}

Bibliográficas 


\section{8 - REFERÊNCIAS BIBLIOGRÁFICAS'1}

${ }^{1}$ De acordo com a Associação Brasileira de Normas Técnicas (ABNT NBR 6023)

ABDELAZIZ, D. H. et al. Apoptosis-associated speck-like protein (ASC) controls Legionella pneumophila infection in human monocytes. J Biol Chem, v. 286, n. 5, p. 3203-8, Feb 4 2011. ISSN 1083-351X (Electronic)

0021-9258 (Linking). Disponível em: < http://www.ncbi.nlm.nih.gov/pubmed/21097506 $>$.

ABDELAZIZ, D. H. et al. Asc-dependent and independent mechanisms contribute to restriction of legionella pneumophila infection in murine macrophages. Front Microbiol, v. 2, p. 18, 2011. ISSN 1664-302X (Electronic)

1664-302X (Linking). Disponível em: < http://www.ncbi.nlm.nih.gov/pubmed/21713115 $>$.

AGLIETTI, R. A. et al. GsdmD p30 elicited by caspase-11 during pyroptosis forms pores in membranes. Proc Natl Acad Sci U S A, v. 113, n. 28, p. 7858-63, Jul 12 2016. ISSN 1091-6490 (Electronic)

0027-8424 (Linking). Disponível em: < http://www.ncbi.nlm.nih.gov/pubmed/27339137 $>$.

AHMADISHOAR, S.; KARIMINIK, A. Toll-like receptor 2 and its roles in immune responses against Legionella pneumophila. Life Sci, v. 188, p. 158-162, Nov 12017. ISSN 1879-0631 (Electronic)

0024-3205 (Linking). Disponível em: < http://www.ncbi.nlm.nih.gov/pubmed/28887059 $>$.

AKAMINE, M. et al. Differential roles of Toll-like receptors 2 and 4 in in vitro responses of macrophages to Legionella pneumophila. Infect Immun, v. 73, n. 1, p. 352-61, Jan 2005. ISSN 0019-9567 (Print)

0019-9567 (Linking). Disponível em: < http://www.ncbi.nlm.nih.gov/pubmed/15618172 $>$.

AKHTER, A. et al. Caspase-7 activation by the Nlrc4/Ipaf inflammasome restricts Legionella pneumophila infection. PLoS Pathog, v. 5, n. 4, p. e1000361, Apr 2009. ISSN 1553-7374 (Electronic)

1553-7366 (Linking). Disponível em: < http://www.ncbi.nlm.nih.gov/pubmed/19343209 $>$.

AKIRA, S. Pathogen recognition by innate immunity and its signaling. Proc Jpn Acad Ser B Phys Biol Sci, v. 85, n. 4, p. 143-56, 2009. ISSN 1349-2896 (Electronic) 
0386-2208 (Linking). Disponível em: < http://www.ncbi.nlm.nih.gov/pubmed/19367086 $>$.

AKIRA, S.; TAKEDA, K. Toll-like receptor signalling. Nat Rev Immunol, v. 4, n. 7, p. 499-511, Jul 2004. ISSN 1474-1733 (Print)

1474-1733 (Linking). Disponível em: < http://www.ncbi.nlm.nih.gov/pubmed/15229469 $>$.

AMER, A. et al. Regulation of Legionella phagosome maturation and infection through flagellin and host Ipaf. J Biol Chem, v. 281, n. 46, p. 35217-23, Nov 17 2006. ISSN 0021-9258 (Print)

0021-9258 (Linking). Disponível em: < http://www.ncbi.nlm.nih.gov/pubmed/16984919 $>$.

AMER, A. O. Modulation of caspases and their non-apoptotic functions by Legionella pneumophila. Cell Microbiol, v. 12, n. 2, p. 140-7, Feb 2010. ISSN 1462-5822 (Electronic)

1462-5814 (Linking). Disponível em: < http://www.ncbi.nlm.nih.gov/pubmed/19863553 $>$.

ANTONOPOULOS, C. et al. Caspase-8 as an Effector and Regulator of NLRP3 Inflammasome Signaling. J Biol Chem, v. 290, n. 33, p. 20167-84, Aug 14 2015. ISSN 1083-351X (Electronic)

0021-9258 (Linking). Disponível em: < http://www.ncbi.nlm.nih.gov/pubmed/26100631 $>$.

ARCHER, K. A. et al. Multiple MyD88-dependent responses contribute to pulmonary clearance of Legionella pneumophila. Cell Microbiol, v. 11, n. 1, p. 21-36, Jan 2009. ISSN 1462-5822 (Electronic)

1462-5814 (Linking). Disponível em: < http://www.ncbi.nlm.nih.gov/pubmed/18782351 $>$.

ARCHER, K. A.; ROY, C. R. MyD88-dependent responses involving toll-like receptor 2 are important for protection and clearance of Legionella pneumophila in a mouse model of Legionnaires' disease. Infect Immun, v. 74, n. 6, p. 3325-33, Jun 2006. ISSN 0019-9567 (Print)

0019-9567 (Linking). Disponível em: < http://www.ncbi.nlm.nih.gov/pubmed/16714560 $>$. 
BARRY, K. C. et al. IL-1alpha signaling initiates the inflammatory response to virulent Legionella pneumophila in vivo. J Immunol, v. 190, n. 12, p. 6329-39, Jun 152013. ISSN 1550-6606 (Electronic)

0022-1767 (Linking). Disponível em: < http://www.ncbi.nlm.nih.gov/pubmed/23686480 $>$.

BAUERNFEIND, F. G. et al. Cutting edge: NF-kappaB activating pattern recognition and cytokine receptors license NLRP3 inflammasome activation by regulating NLRP3 expression. J Immunol, v. 183, n. 2, p. 787-91, Jul 15 2009. ISSN 1550-6606 (Electronic)

0022-1767 (Linking). Disponível em: < http://www.ncbi.nlm.nih.gov/pubmed/19570822 $>$.

BECKERS, M. C. et al. Natural resistance to infection with Legionella pneumophila: chromosomal localization of the Lgn1 susceptibility gene. Mamm Genome, v. 6, n. 8, p. 540-5, Aug 1995. ISSN 0938-8990 (Print)

0938-8990 (Linking). Disponível em: < http://www.ncbi.nlm.nih.gov/pubmed/8589525 $>$.

BERGER, K. H.; ISBERG, R. R. Two distinct defects in intracellular growth complemented by a single genetic locus in Legionella pneumophila. Mol Microbiol, $v$. 7, n. 1, p. 7-19, Jan 1993. ISSN 0950-382X (Print)

0950-382X (Linking). Disponível em: < http://www.ncbi.nlm.nih.gov/pubmed/8382332 $>$.

BERGER, K. H.; MERRIAM, J. J.; ISBERG, R. R. Altered intracellular targeting properties associated with mutations in the Legionella pneumophila $\operatorname{dot} A$ gene. Mol Microbiol, v. 14, n. 4, p. 809-22, Nov 1994. ISSN 0950-382X (Print)

0950-382X (Linking). Disponível em: < http://www.ncbi.nlm.nih.gov/pubmed/7891566 $>$.

BERRINGTON, W. R. et al. NOD1 and NOD2 regulation of pulmonary innate immunity to Legionella pneumophila. Eur J Immunol, v. 40, n. 12, p. 3519-27, Dec 2010. ISSN 1521-4141 (Electronic)

0014-2980 (Linking). Disponível em: < http://www.ncbi.nlm.nih.gov/pubmed/21108472 $>$.

BLASER, M. Hot-bath syndrome, Pontiac fever, and Legionnaires' disease. Lancet, v. 2, n. 8050, p. 1226, Dec 10 1977. ISSN 0140-6736 (Print)

0140-6736 (Linking). Disponível em: < http://www.ncbi.nlm.nih.gov/pubmed/73920 > 
BOUCHER, D. et al. Caspase-1 self-cleavage is an intrinsic mechanism to terminate inflammasome activity. J Exp Med, v. 215, n. 3, p. 827-840, Mar 5 2018. ISSN 15409538 (Electronic)

0022-1007 (Linking). Disponível em: < http://www.ncbi.nlm.nih.gov/pubmed/29432122 $>$.

BROZ, P. et al. Differential requirement for Caspase-1 autoproteolysis in pathogeninduced cell death and cytokine processing. Cell Host Microbe, v. 8, n. 6, p. 471-83, Dec 16 2010. ISSN 1934-6069 (Electronic)

1931-3128 (Linking). Disponível em: < http://www.ncbi.nlm.nih.gov/pubmed/21147462 $>$.

BURCKSTUMMER, T. et al. An orthogonal proteomic-genomic screen identifies AIM2 as a cytoplasmic DNA sensor for the inflammasome. Nat Immunol, v. 10, n. 3, p. 26672, Mar 2009. ISSN 1529-2916 (Electronic)

1529-2908 (Linking). Disponível em: < http://www.ncbi.nlm.nih.gov/pubmed/19158679 $>$.

CALLUS, B. A.; VAUX, D. L. Caspase inhibitors: viral, cellular and chemical. Cell Death Differ, v. 14, n. 1, p. 73-8, Jan 2007. ISSN 1350-9047 (Print)

1350-9047 (Linking). Disponível em: < http://www.ncbi.nlm.nih.gov/pubmed/16946729 $>$.

CASE, C. L. et al. Caspase-11 stimulates rapid flagellin-independent pyroptosis in response to Legionella pneumophila. Proc Natl Acad Sci U S A, v. 110, n. 5, p. 18516, Jan 29 2013. ISSN 1091-6490 (Electronic)

0027-8424 (Linking). Disponível em: < http://www.ncbi.nlm.nih.gov/pubmed/23307811 $>$.

CASE, C. L.; ROY, C. R. Asc modulates the function of NLRC4 in response to infection of macrophages by Legionella pneumophila. MBio, v. 2, n. 4, 2011. ISSN 2150-7511 (Electronic). Disponível em: < http://www.ncbi.nlm.nih.gov/pubmed/21771913 >.

CASE, C. L.; SHIN, S.; ROY, C. R. Asc and Ipaf Inflammasomes direct distinct pathways for caspase-1 activation in response to Legionella pneumophila. Infect Immun, v. 77, n. 5, p. 1981-91, May 2009. ISSN 1098-5522 (Electronic)

0019-9567 (Linking). Disponível em: < http://www.ncbi.nlm.nih.gov/pubmed/19237518 $>$. 
CASSON, C. N. et al. Caspase-11 activation in response to bacterial secretion systems that access the host cytosol. PLoS Pathog, v. 9, n. 6, p. e1003400, 2013. ISSN 1553-7374 (Electronic)

1553-7366 (Linking). Disponível em: < http://www.ncbi.nlm.nih.gov/pubmed/23762026 $>$.

CASSON, C. N. et al. Human caspase-4 mediates noncanonical inflammasome activation against gram-negative bacterial pathogens. Proc Natl Acad Sci U S A, v. 112, n. 21, p. 6688-93, May 26 2015. ISSN 1091-6490 (Electronic)

0027-8424 (Linking). Disponível em: < http://www.ncbi.nlm.nih.gov/pubmed/25964352 $>$.

CAZALET, C. et al. Evidence in the Legionella pneumophila genome for exploitation of host cell functions and high genome plasticity. Nat Genet, v. 36, n. 11, p. 1165-73, Nov 2004. ISSN 1061-4036 (Print)

1061-4036 (Linking). Disponível em: < http://www.ncbi.nlm.nih.gov/pubmed/15467720 $>$.

CERQUEIRA, D. M. et al. Caspase-1 but Not Caspase-11 Is Required for NLRC4Mediated Pyroptosis and Restriction of Infection by Flagellated Legionella Species in Mouse Macrophages and In Vivo. J Immunol, v. 195, n. 5, p. 2303-11, Sep 12015. ISSN 1550-6606 (Electronic)

0022-1767 (Linking). Disponível em: < http://www.ncbi.nlm.nih.gov/pubmed/26232428 $>$.

CIRILLO, J. D. et al. Intracellular growth in Acanthamoeba castellanii affects monocyte entry mechanisms and enhances virulence of Legionella pneumophila. Infect Immun, v. 67, n. 9, p. 4427-34, Sep 1999. ISSN 0019-9567 (Print)

0019-9567 (Linking). Disponível em: < http://www.ncbi.nlm.nih.gov/pubmed/10456883 $>$.

COERS, J. et al. Identification of Icm protein complexes that play distinct roles in the biogenesis of an organelle permissive for Legionella pneumophila intracellular growth. Mol Microbiol, v. 38, n. 4, p. 719-36, Nov 2000. ISSN 0950-382X (Print)

0950-382X (Linking). Disponível em: < http://www.ncbi.nlm.nih.gov/pubmed/11115108 $>$.

COERS, J. et al. Restriction of Legionella pneumophila growth in macrophages requires the concerted action of cytokine and Naip5/lpaf signalling pathways. Cell Microbiol, v. 9, n. 10, p. 2344-57, Oct 2007. ISSN 1462-5814 (Print) 
1462-5814 (Linking). Disponível em: < http://www.ncbi.nlm.nih.gov/pubmed/17506816 $>$.

COOKSON, B. T.; BRENNAN, M. A. Pro-inflammatory programmed cell death. Trends Microbiol, v. 9, n. 3, p. 113-4, Mar 2001. ISSN 0966-842X (Print)

0966-842X (Linking). Disponível em: < http://www.ncbi.nlm.nih.gov/pubmed/11303500 $>$.

CREAGH, E. M. Caspase crosstalk: integration of apoptotic and innate immune signalling pathways. Trends Immunol, v. 35, n. 12, p. 631-640, Nov 10 2014. ISSN 1471-4981 (Electronic)

1471-4906 (Linking). Disponível em: < http://www.ncbi.nlm.nih.gov/pubmed/25457353 $>$.

CREAGH, E. M.; O'NEILL, L. A. TLRs, NLRs and RLRs: a trinity of pathogen sensors that co-operate in innate immunity. Trends Immunol, v. 27, n. 8, p. 352-7, Aug 2006. ISSN 1471-4906 (Print)

1471-4906 (Linking). Disponível em: < http://www.ncbi.nlm.nih.gov/pubmed/16807108 $>$.

CREASEY, E. A.; ISBERG, R. R. The protein SdhA maintains the integrity of the Legionella-containing vacuole. Proc Natl Acad Sci U S A, v. 109, n. 9, p. 3481-6, Feb 28 2012. ISSN 1091-6490 (Electronic)

0027-8424 (Linking). Disponível em: < http://www.ncbi.nlm.nih.gov/pubmed/22308473 $>$.

CUNHA, L. D. et al. Inhibition of inflammasome activation by Coxiella burnetii type IV secretion system effector IcaA. Nat Commun, v. 6, p. 10205, 2015. ISSN 2041-1723 (Electronic)

2041-1723 (Linking). Disponível em: < http://www.ncbi.nlm.nih.gov/pubmed/26687278 $>$.

CUNHA, L. D. et al. AIM2 Engages Active but Unprocessed Caspase-1 to Induce Noncanonical Activation of the NLRP3 Inflammasome. Cell Rep, v. 20, n. 4, p. 794805, Jul 25 2017. ISSN 2211-1247 (Electronic). Disponível em: < http://www.ncbi.nlm.nih.gov/pubmed/28746866 >.

DANGL, J. L.; JONES, J. D. Plant pathogens and integrated defence responses to infection. Nature, v. 411, n. 6839, p. 826-33, Jun 14 2001. ISSN 0028-0836 (Print) 
0028-0836 (Linking). Disponível em: < http://www.ncbi.nlm.nih.gov/pubmed/11459065 $>$.

DIETRICH, W. F. et al. Lgn1, a gene that determines susceptibility to Legionella pneumophila, maps to mouse chromosome 13. Genomics, v. 26, n. 3, p. 443-50, Apr 10 1995. ISSN 0888-7543 (Print)

0888-7543 (Linking). Disponível em: < http://www.ncbi.nlm.nih.gov/pubmed/7607666 $>$.

DIEZ, E. et al. Birc1e is the gene within the Lgn1 locus associated with resistance to Legionella pneumophila. Nat Genet, v. 33, n. 1, p. 55-60, Jan 2003. ISSN 1061-4036 (Print)

1061-4036 (Linking). Disponível em: < http://www.ncbi.nlm.nih.gov/pubmed/12483212 $>$.

DIEZ, E. et al. The neuronal apoptosis inhibitory protein (Naip) is expressed in macrophages and is modulated after phagocytosis and during intracellular infection with Legionella pneumophila. J Immunol, v. 164, n. 3, p. 1470-7, Feb 1 2000. ISSN 0022-1767 (Print)

0022-1767 (Linking). Disponível em: < http://www.ncbi.nlm.nih.gov/pubmed/10640764 $>$.

DING, J. et al. Pore-forming activity and structural autoinhibition of the gasdermin family. Nature, v. 535, n. 7610, p. 111-6, Jul 7 2016. ISSN 1476-4687 (Electronic)

0028-0836 (Linking). Disponível em: < http://www.ncbi.nlm.nih.gov/pubmed/27281216 $>$.

DOEBBELING, B. N.; WENZEL, R. P. The epidemiology of Legionella pneumophila infections. Semin Respir Infect, v. 2, n. 4, p. 206-21, Dec 1987. ISSN 0882-0546 (Print)

0882-0546 (Linking). Disponível em: < http://www.ncbi.nlm.nih.gov/pubmed/3328890 $>$.

EVAVOLD, C. L. et al. The Pore-Forming Protein Gasdermin D Regulates Interleukin1 Secretion from Living Macrophages. Immunity, v. 48, n. 1, p. 35-44 e6, Jan 162018. ISSN 1097-4180 (Electronic)

1074-7613 (Linking). Disponível em: < http://www.ncbi.nlm.nih.gov/pubmed/29195811 $>$. 
FEELEY, J. C. et al. Charcoal-yeast extract agar: primary isolation medium for Legionella pneumophila. J Clin Microbiol, v. 10, n. 4, p. 437-41, Oct 1979. ISSN 00951137 (Print)

0095-1137 (Linking). Disponível em: < http://www.ncbi.nlm.nih.gov/pubmed/393713 >

FERNANDES-ALNEMRI, T. et al. The pyroptosome: a supramolecular assembly of ASC dimers mediating inflammatory cell death via caspase-1 activation. Cell Death Differ, v. 14, n. 9, p. 1590-604, Sep 2007. ISSN 1350-9047 (Print)

1350-9047 (Linking). Disponível em: < http://www.ncbi.nlm.nih.gov/pubmed/17599095 $>$.

FERNANDES-ALNEMRI, T. et al. AIM2 activates the inflammasome and cell death in response to cytoplasmic DNA. Nature, v. 458, n. 7237, p. 509-13, Mar 26 2009. ISSN 1476-4687 (Electronic)

0028-0836 (Linking). Disponível em: < http://www.ncbi.nlm.nih.gov/pubmed/19158676 $>$.

FINK, S. L.; COOKSON, B. T. Caspase-1-dependent pore formation during pyroptosis leads to osmotic lysis of infected host macrophages. Cell Microbiol, v. 8, n. 11, p. 1812-25, Nov 2006. ISSN 1462-5814 (Print)

1462-5814 (Linking). Disponível em: < http://www.ncbi.nlm.nih.gov/pubmed/16824040 $>$.

FLIERMANS, C. B. et al. Ecological distribution of Legionella pneumophila. Appl Environ Microbiol, v. 41, n. 1, p. 9-16, Jan 1981. ISSN 0099-2240 (Print)

0099-2240 (Linking). Disponível em: < http://www.ncbi.nlm.nih.gov/pubmed/7013702 $>$.

FORTIER, A. et al. Restriction of Legionella pneumophila replication in macrophages requires concerted action of the transcriptional regulators Irf1 and Irf8 and nod-like receptors Naip5 and NIrc4. Infect Immun, v. 77, n. 11, p. 4794-805, Nov 2009. ISSN 1098-5522 (Electronic)

0019-9567 (Linking). Disponível em: < http://www.ncbi.nlm.nih.gov/pubmed/19720760 $>$.

FRANCHI, L. et al. Cytosolic flagellin requires Ipaf for activation of caspase-1 and interleukin 1 beta in salmonella-infected macrophages. Nat Immunol, v. 7, n. 6, p. 57682, Jun 2006. ISSN 1529-2908 (Print)

1529-2908 (Linking). Disponível em: < http://www.ncbi.nlm.nih.gov/pubmed/16648852 $>$. 
FRANCHI, L. et al. Critical role for Ipaf in Pseudomonas aeruginosa-induced caspase1 activation. Eur $\mathbf{J}$ Immunol, v. 37, n. 11, p. 3030-9, Nov 2007. ISSN 0014-2980 (Print) 0014-2980 (Linking). Disponível em: < http://www.ncbi.nlm.nih.gov/pubmed/17935074 $>$.

FRANCO, L. H. et al. Autophagy downstream of endosomal Toll-like receptor signaling in macrophages is a key mechanism for resistance to Leishmania major infection. $\mathbf{J}$ Biol Chem, v. 292, n. 32, p. 13087-13096, Aug 11 2017. ISSN 1083-351X (Electronic) 0021-9258 (Linking). Disponível em: < http://www.ncbi.nlm.nih.gov/pubmed/28607148 $>$.

FRANKLIN, B. S. et al. The adaptor ASC has extracellular and 'prionoid' activities that propagate inflammation. Nat Immunol, v. 15, n. 8, p. 727-37, Aug 2014. ISSN 15292916 (Electronic)

1529-2908 (Linking). Disponível em: < http://www.ncbi.nlm.nih.gov/pubmed/24952505 $>$.

FRANKLIN, B. S.; LATZ, E.; SCHMIDT, F. I. The intra- and extracellular functions of ASC specks. Immunol Rev, v. 281, n. 1, p. 74-87, Jan 2018. ISSN 1600-065X (Electronic)

0105-2896 (Linking). Disponível em: < http://www.ncbi.nlm.nih.gov/pubmed/29247990 $>$.

FRASER, D. W. et al. Nonpneumonic, short-incubation-period Legionellosis (Pontiac fever) in men who cleaned a steam turbine condenser. Science, v. 205, n. 4407, p. 690-1, Aug 17 1979. ISSN 0036-8075 (Print)

0036-8075 (Linking). Disponível em: < http://www.ncbi.nlm.nih.gov/pubmed/462175 > .

FRASER, D. W. et al. Legionnaires' disease: description of an epidemic of pneumonia. N Engl J Med, v. 297, n. 22, p. 1189-97, Dec 1 1977. ISSN 0028-4793 (Print)

0028-4793 (Linking). Disponível em: < http://www.ncbi.nlm.nih.gov/pubmed/335244 >.

FRUTUOSO, M. S. et al. The pattern recognition receptors Nod1 and Nod2 account for neutrophil recruitment to the lungs of mice infected with Legionella pneumophila. Microbes Infect, v. 12, n. 11, p. 819-27, Oct 2010. ISSN 1769-714X (Electronic)

1286-4579 (Linking). Disponível em: < http://www.ncbi.nlm.nih.gov/pubmed/20685341 $>$. 
GAO, L. Y.; ABU KWAIK, Y. Activation of caspase 3 during Legionella pneumophilainduced apoptosis. Infect Immun, v. 67, n. 9, p. 4886-94, Sep 1999. ISSN 0019-9567 (Print)

0019-9567 (Linking). Disponível em: < http://www.ncbi.nlm.nih.gov/pubmed/10456945 $>$.

GE, J. et al. Preventing bacterial DNA release and absent in melanoma 2 inflammasome activation by a Legionella effector functioning in membrane trafficking. Proc Natl Acad Sci U S A, v. 109, n. 16, p. 6193-8, Apr 17 2012. ISSN 1091-6490 (Electronic)

0027-8424 (Linking). Disponível em: < http://www.ncbi.nlm.nih.gov/pubmed/22474394 $>$.

GLICK, T. H. et al. Pontiac fever. An epidemic of unknown etiology in a health department: I. Clinical and epidemiologic aspects. Am J Epidemiol, v. 107, n. 2, p. 149-60, Feb 1978. ISSN 0002-9262 (Print)

0002-9262 (Linking). Disponível em: < http://www.ncbi.nlm.nih.gov/pubmed/623097 >

GOMEZ-VALERO, L.; BUCHRIESER, C. Genome dynamics in Legionella: the basis of versatility and adaptation to intracellular replication. Cold Spring Harb Perspect Med, v. 3, n. 6, Jun 1 2013. ISSN 2157-1422 (Electronic)

2157-1422 (Linking). Disponível em: < http://www.ncbi.nlm.nih.gov/pubmed/23732852 $>$.

GUO, H.; CALLAWAY, J. B.; TING, J. P. Inflammasomes: mechanism of action, role in disease, and therapeutics. Nat Med, v. 21, n. 7, p. 677-87, Jul 2015. ISSN 1546170X (Electronic)

1078-8956 (Linking). Disponível em: < http://www.ncbi.nlm.nih.gov/pubmed/26121197 $>$.

GURUNG, P. et al. FADD and caspase-8 mediate priming and activation of the canonical and noncanonical NIrp3 inflammasomes. J Immunol, v. 192, n. 4, p. 183546, Feb 15 2014. ISSN 1550-6606 (Electronic)

0022-1767 (Linking). Disponível em: < http://www.ncbi.nlm.nih.gov/pubmed/24453255 $>$.

HASEGAWA, M. et al. ASC-mediated NF-kappaB activation leading to interleukin-8 production requires caspase-8 and is inhibited by CLARP. J Biol Chem, v. 280, n. 15, p. 15122-30, Apr 15 2005. ISSN $0021-9258$ (Print) 
0021-9258 (Linking). Disponível em: < http://www.ncbi.nlm.nih.gov/pubmed/15701651 $>$.

HAWN, T. R. et al. Altered inflammatory responses in TLR5-deficient mice infected with Legionella pneumophila. J Immunol, v. 179, n. 10, p. 6981-7, Nov 15 2007. ISSN 0022-1767 (Print)

0022-1767 (Linking). Disponível em: < http://www.ncbi.nlm.nih.gov/pubmed/17982089 $>$.

HAWN, T. R. et al. Myeloid differentiation primary response gene (88)- and toll-like receptor 2-deficient mice are susceptible to infection with aerosolized Legionella pneumophila. J Infect Dis, v. 193, n. 12, p. 1693-702, Jun 15 2006. ISSN 0022-1899 (Print)

0022-1899 (Linking). Disponível em: < http://www.ncbi.nlm.nih.gov/pubmed/16703513 $>$.

HE, W. T. et al. Gasdermin D is an executor of pyroptosis and required for interleukin1 beta secretion. Cell Res, v. 25, n. 12, p. 1285-98, Dec 2015. ISSN 1748-7838 (Electronic)

1001-0602 (Linking). Disponível em: < http://www.ncbi.nlm.nih.gov/pubmed/26611636 $>$.

HEMMI, H. et al. A Toll-like receptor recognizes bacterial DNA. Nature, v. 408, n. 6813, p. 740-5, Dec 7 2000. ISSN 0028-0836 (Print)

0028-0836 (Linking). Disponível em: < http://www.ncbi.nlm.nih.gov/pubmed/11130078 $>$.

HORNUNG, V. et al. AIM2 recognizes cytosolic dsDNA and forms a caspase-1activating inflammasome with ASC. Nature, v. 458, n. 7237, p. 514-8, Mar 262009. ISSN 1476-4687 (Electronic)

0028-0836 (Linking). Disponível em: < http://www.ncbi.nlm.nih.gov/pubmed/19158675 $>$.

HORWITZ, M. A. The Legionnaires' disease bacterium (Legionella pneumophila) inhibits phagosome-lysosome fusion in human monocytes. J Exp Med, v. 158, n. 6, p. 2108-26, Dec 1 1983. ISSN 0022-1007 (Print)

0022-1007 (Linking). Disponível em: < http://www.ncbi.nlm.nih.gov/pubmed/6644240 $>$. 
HORWITZ, M. A.; SILVERSTEIN, S. C. Legionnaires' disease bacterium (Legionella pneumophila) multiples intracellularly in human monocytes. J Clin Invest, v. 66, n. 3, p. 441-50, Sep 1980. ISSN 0021-9738 (Print)

0021-9738 (Linking). Disponível em: < http://www.ncbi.nlm.nih.gov/pubmed/7190579 $>$.

INOHARA, N.; NUNEZ, G. NODs: intracellular proteins involved in inflammation and apoptosis. Nat Rev Immunol, v. 3, n. 5, p. 371-82, May 2003. ISSN 1474-1733 (Print) 1474-1733 (Linking). Disponível em:< http://www.ncbi.nlm.nih.gov/pubmed/12766759 $>$.

JAMIESON, A. M. et al. Role of tissue protection in lethal respiratory viral-bacterial coinfection. Science, v. 340, n. 6137, p. 1230-4, Jun 7 2013. ISSN 1095-9203 (Electronic)

0036-8075 (Linking). Disponível em: < http://www.ncbi.nlm.nih.gov/pubmed/23618765 $>$.

JORGENSEN, I. et al. IL-1beta, IL-18, and eicosanoids promote neutrophil recruitment to pore-induced intracellular traps following pyroptosis. Eur J Immunol, Sep 282016. ISSN 1521-4141 (Electronic)

0014-2980 (Linking). Disponível em: < http://www.ncbi.nlm.nih.gov/pubmed/27682622 $>$.

JORGENSEN, I. et al. Pyroptosis triggers pore-induced intracellular traps (PITs) that capture bacteria and lead to their clearance by efferocytosis. J Exp Med, v. 213, n. 10, p. 2113-28, Sep 19 2016. ISSN 1540-9538 (Electronic)

0022-1007 (Linking). Disponível em:< http://www.ncbi.nlm.nih.gov/pubmed/27573815 $>$.

KAISER, W. J. et al. RIP3 mediates the embryonic lethality of caspase-8-deficient mice. Nature, v. 471, n. 7338, p. 368-72, Mar 17 2011. ISSN 1476-4687 (Electronic)

0028-0836 (Linking). Disponível em: < http://www.ncbi.nlm.nih.gov/pubmed/21368762 $>$.

KANG, S. et al. Caspase-8 scaffolding function and MLKL regulate NLRP3 inflammasome activation downstream of TLR3. Nat Commun, v. 6, p. 7515, Jun 24 2015. ISSN 2041-1723 (Electronic)

2041-1723 (Linking). Disponível em: < http://www.ncbi.nlm.nih.gov/pubmed/26104484 $>$. 
KANNEGANTI, T. D. et al. Bacterial RNA and small antiviral compounds activate caspase-1 through cryopyrin/Nalp3. Nature, v. 440, n. 7081, p. 233-6, Mar 92006. ISSN 1476-4687 (Electronic)

0028-0836 (Linking). Disponível em: < http://www.ncbi.nlm.nih.gov/pubmed/16407888 $>$.

KAUFMANN, A. F. et al. Pontiac fever: isolation of the etiologic agent (Legionella pneumophilia) and demonstration of its mode of transmission. Am J Epidemiol, v. 114, n. 3, p. 337-47, Sep 1981. ISSN 0002-9262 (Print)

0002-9262 (Linking). Disponível em: < http://www.ncbi.nlm.nih.gov/pubmed/7304569 $>$.

KAWAI, T.; AKIRA, S. The role of pattern-recognition receptors in innate immunity: update on Toll-like receptors. Nat Immunol, v. 11, n. 5, p. 373-84, May 2010. ISSN 1529-2916 (Electronic)

1529-2908 (Linking). Disponível em: < http://www.ncbi.nlm.nih.gov/pubmed/20404851 $>$.

. Toll-like receptors and their crosstalk with other innate receptors in infection and immunity. Immunity, v. 34, n. 5, p. 637-50, May 27 2011. ISSN 1097-4180 (Electronic)

1074-7613 (Linking). Disponível em: < http://www.ncbi.nlm.nih.gov/pubmed/21616434 $>$.

KAWAMOTO, Y. et al. TNF-alpha inhibits the growth of Legionella pneumophila in airway epithelial cells by inducing apoptosis. J Infect Chemother, v. 23, n. 1, p. 5155, Jan 2017. ISSN 1437-7780 (Electronic)

1341-321X (Linking). Disponível em: < http://www.ncbi.nlm.nih.gov/pubmed/27865699 $>$.

KAYAGAKI, $N$. et al. Caspase-11 cleaves gasdermin $D$ for non-canonical inflammasome signalling. Nature, v. 526, n. 7575, p. 666-71, Oct 29 2015. ISSN 14764687 (Electronic)

0028-0836 (Linking). Disponível em: < http://www.ncbi.nlm.nih.gov/pubmed/26375259 $>$.

KAYAGAKI, N. et al. Non-canonical inflammasome activation targets caspase- 11 . Nature, v. 479, n. 7371, p. 117-21, Nov 3 2011. ISSN 1476-4687 (Electronic)

0028-0836 (Linking). Disponível em: < http://www.ncbi.nlm.nih.gov/pubmed/22002608 $>$. 
KELLER, M. et al. Active caspase- 1 is a regulator of unconventional protein secretion. Cell, v. 132, n. 5, p. 818-31, Mar 7 2008. ISSN 1097-4172 (Electronic)

0092-8674 (Linking). Disponível em: < http://www.ncbi.nlm.nih.gov/pubmed/18329368 $>$.

KHODR, A. et al. Molecular epidemiology, phylogeny and evolution of Legionella. Infect Genet Evol, v. 43, p. 108-122, May 13 2016. ISSN 1567-7257 (Electronic)

1567-1348 (Linking). Disponível em: < http://www.ncbi.nlm.nih.gov/pubmed/27180896 $>$.

KIM, Y. K.; SHIN, J. S.; NAHM, M. H. NOD-Like Receptors in Infection, Immunity, and Diseases. Yonsei Med J, v. 57, n. 1, p. 5-14, Jan 2016. ISSN 1976-2437 (Electronic)

0513-5796 (Linking). Disponível em: < http://www.ncbi.nlm.nih.gov/pubmed/26632377 $>$.

KOFOED, E. M.; VANCE, R. E. Innate immune recognition of bacterial ligands by NAIPs determines inflammasome specificity. Nature, v. 477, n. 7366, p. 592-5, Sep 29 2011. ISSN 1476-4687 (Electronic)

0028-0836 (Linking). Disponível em: < http://www.ncbi.nlm.nih.gov/pubmed/21874021 $>$.

KOVACS, S. B.; MIAO, E. A. Gasdermins: Effectors of Pyroptosis. Trends Cell Biol, v. 27, n. 9, p. 673-684, Sep 2017. ISSN 1879-3088 (Electronic)

0962-8924 (Linking). Disponível em: < http://www.ncbi.nlm.nih.gov/pubmed/28619472 $>$.

KUFER, T. A.; FRITZ, J. H.; PHILPOTT, D. J. NACHT-LRR proteins (NLRs) in bacterial infection and immunity. Trends Microbiol, v. 13, n. 8, p. 381-8, Aug 2005. ISSN 0966842X (Print)

0966-842X (Linking). Disponível em:< http://www.ncbi.nlm.nih.gov/pubmed/15994078 $>$.

KUIDA, K. et al. Altered cytokine export and apoptosis in mice deficient in interleukin1 beta converting enzyme. Science, v. 267, n. 5206, p. 2000-3, Mar 31 1995. ISSN 0036-8075 (Print)

0036-8075 (Linking). Disponível em: < http://www.ncbi.nlm.nih.gov/pubmed/7535475 $>$. 
KUMAR, Y.; RADHA, V.; SWARUP, G. Interaction with Sug1 enables Ipaf ubiquitination leading to caspase 8 activation and cell death. Biochem J, v. 427, n. 1, p. 91-104, Apr 1 2010. ISSN 1470-8728 (Electronic)

0264-6021 (Linking). Disponível em: < http://www.ncbi.nlm.nih.gov/pubmed/20085538 $>$.

LAGUNA, R. K. et al. A Legionella pneumophila-translocated substrate that is required for growth within macrophages and protection from host cell death. Proc Natl Acad Sci U S A, v. 103, n. 49, p. 18745-50, Dec 5 2006. ISSN 0027-8424 (Print)

0027-8424 (Linking). Disponível em: < http://www.ncbi.nlm.nih.gov/pubmed/17124169 $>$.

LARA-TEJERO, M. et al. Role of the caspase-1 inflammasome in Salmonella typhimurium pathogenesis. J Exp Med, v. 203, n. 6, p. 1407-12, Jun 12 2006. ISSN 0022-1007 (Print)

0022-1007 (Linking). Disponível em: < http://www.ncbi.nlm.nih.gov/pubmed/16717117 $>$.

LAROCK, C. N.; COOKSON, B. T. Burning down the house: cellular actions during pyroptosis. PLoS Pathog, v. 9, n. 12, p. e1003793, 2013. ISSN 1553-7374 (Electronic)

1553-7366 (Linking). Disponível em: < http://www.ncbi.nlm.nih.gov/pubmed/24367258 $>$.

LATZ, E.; XIAO, T. S.; STUTZ, A. Activation and regulation of the inflammasomes. Nat Rev Immunol, v. 13, n. 6, p. 397-411, Jun 2013. ISSN 1474-1741 (Electronic)

1474-1733 (Linking). Disponível em: < http://www.ncbi.nlm.nih.gov/pubmed/23702978 $>$.

LAU, H. Y.; ASHBOLT, N. J. The role of biofilms and protozoa in Legionella pathogenesis: implications for drinking water. J Appl Microbiol, v. 107, n. 2, p. 36878, Aug 2009. ISSN 1365-2672 (Electronic)

1364-5072 (Linking). Disponível em: < http://www.ncbi.nlm.nih.gov/pubmed/19302312 $>$.

LEI, X. et al. Enterovirus 71 Inhibits Pyroptosis through Cleavage of Gasdermin D. J Virol, v. 91, n. 18, Sep 15 2017. ISSN 1098-5514 (Electronic)

0022-538X (Linking). Disponível em: < http://www.ncbi.nlm.nih.gov/pubmed/28679757 $>$. 
LEMAITRE, B. et al. The dorsoventral regulatory gene cassette spatzle/Toll/cactus controls the potent antifungal response in Drosophila adults. Cell, v. 86, n. 6, p. 97383, Sep 20 1996. ISSN 0092-8674 (Print)

0092-8674 (Linking). Disponível em: < http://www.ncbi.nlm.nih.gov/pubmed/8808632 $>$.

LETTINGA, K. D. et al. Toll-like receptor 4 is not involved in host defense against pulmonary Legionella pneumophila infection in a mouse model. $\mathbf{J}$ Infect Dis, v. 186, n. 4, p. 570-3, Aug 15 2002. ISSN 0022-1899 (Print)

0022-1899 (Linking). Disponível em: < http://www.ncbi.nlm.nih.gov/pubmed/12195388 $>$.

LI, J.; YUAN, J. Caspases in apoptosis and beyond. Oncogene, v. 27, n. 48, p. 6194206, Oct 20 2008. ISSN 1476-5594 (Electronic)

0950-9232 (Linking). Disponível em: < http://www.ncbi.nlm.nih.gov/pubmed/18931687 $>$.

LIGHTFIELD, K. L. et al. Critical function for Naip5 in inflammasome activation by a conserved carboxy-terminal domain of flagellin. Nat Immunol, v. 9, n. 10, p. 1171-8, Oct 2008. ISSN 1529-2916 (Electronic)

1529-2908 (Linking). Disponível em: < http://www.ncbi.nlm.nih.gov/pubmed/18724372 $>$.

LIU, X. et al. Inflammasome-activated gasdermin D causes pyroptosis by forming membrane pores. Nature, v. 535, n. 7610, p. 153-8, Jul 7 2016. ISSN 1476-4687 (Electronic)

0028-0836 (Linking). Disponível em: < http://www.ncbi.nlm.nih.gov/pubmed/27383986 $>$.

LUCAS, K. D. et al. Outbreak of Legionnaires' disease associated with cooling towers at a California state prison, 2015. Epidemiol Infect, p. 1-6, Feb 1 2018. ISSN 14694409 (Electronic)

0950-2688 (Linking). Disponível em: < http://www.ncbi.nlm.nih.gov/pubmed/29386076 $>$.

MACE, P. D.; RIEDL, S. J.; SALVESEN, G. S. Caspase enzymology and activation mechanisms. Methods Enzymol, v. 544, p. 161-78, 2014. ISSN 1557-7988 (Electronic)

0076-6879 (Linking). Disponível em: < http://www.ncbi.nlm.nih.gov/pubmed/24974290 $>$. 
MAN, S. M. et al. Inflammasome activation causes dual recruitment of NLRC4 and NLRP3 to the same macromolecular complex. Proc Natl Acad Sci U S A, v. 111, n. 20, p. 7403-8, May 20 2014. ISSN 1091-6490 (Electronic)

0027-8424 (Linking). Disponível em: < http://www.ncbi.nlm.nih.gov/pubmed/24803432 $>$.

MAN, S. M. et al. Salmonella infection induces recruitment of Caspase-8 to the inflammasome to modulate IL-1 beta production. J Immunol, v. 191, n. 10, p. 5239-46, Nov 15 2013. ISSN 1550-6606 (Electronic)

0022-1767 (Linking). Disponível em: < http://www.ncbi.nlm.nih.gov/pubmed/24123685 $>$.

MARIATHASAN, S. et al. Cryopyrin activates the inflammasome in response to toxins and ATP. Nature, v. 440, n. 7081, p. 228-32, Mar 9 2006. ISSN 1476-4687 (Electronic) 0028-0836 (Linking). Disponível em: < http://www.ncbi.nlm.nih.gov/pubmed/16407890 $>$.

MARIM, F. M. et al. A method for generation of bone marrow-derived macrophages from cryopreserved mouse bone marrow cells. PLoS One, v. 5, n. 12, p. e15263, 2010. ISSN 1932-6203 (Electronic)

1932-6203 (Linking). Disponível em: < http://www.ncbi.nlm.nih.gov/pubmed/21179419 $>$.

MARRA, A. et al. Identification of a Legionella pneumophila locus required for intracellular multiplication in human macrophages. Proc Natl Acad Sci U S A, v. 89, n. 20, p. 9607-11, Oct 15 1992. ISSN 0027-8424 (Print)

0027-8424 (Linking). Disponível em: < http://www.ncbi.nlm.nih.gov/pubmed/1409673 $>$.

MARTINON, F.; BURNS, K.; TSCHOPP, J. The inflammasome: a molecular platform triggering activation of inflammatory caspases and processing of prolL-beta. Mol Cell, v. 10, n. 2, p. 417-26, Aug 2002. ISSN 1097-2765 (Print)

1097-2765 (Linking). Disponível em: < http://www.ncbi.nlm.nih.gov/pubmed/12191486 $>$.

MARTINON, F. et al. Gout-associated uric acid crystals activate the NALP3 inflammasome. Nature, v. 440, n. 7081, p. 237-41, Mar 9 2006. ISSN 1476-4687 (Electronic) 
0028-0836 (Linking). Disponível em: < http://www.ncbi.nlm.nih.gov/pubmed/16407889 $>$.

MASCARENHAS, D. P. et al. Interleukin 1 receptor-driven neutrophil recruitment accounts to MyD88-dependent pulmonary clearance of legionella pneumophila infection in vivo. J Infect Dis, v. 211, n. 2, p. 322-30, Jan 15 2015. ISSN 1537-6613 (Electronic)

0022-1899 (Linking). Disponível em: < http://www.ncbi.nlm.nih.gov/pubmed/25104770 $>$.

MASCARENHAS, D. P.; ZAMBONI, D. S. Inflammasome biology taught by Legionella pneumophila. J Leukoc Biol, v. 101, n. 4, p. 841-849, Apr 2017. ISSN 1938-3673 (Electronic)

0741-5400 (Linking). Disponível em: < http://www.ncbi.nlm.nih.gov/pubmed/27999148 $>$.

MASSIS, L. M.; ZAMBONI, D. S. Innate immunity to legionella pneumophila. Front Microbiol, v. 2, p. 109, 2011. ISSN 1664-302X (Electronic)

1664-302X (Linking). Disponível em: < http://www.ncbi.nlm.nih.gov/pubmed/21833338 $>$.

MASUMOTO, J. et al. ASC is an activating adaptor for NF-kappa B and caspase-8dependent apoptosis. Biochem Biophys Res Commun, v. 303, n. 1, p. 69-73, Mar 28 2003. ISSN 0006-291X (Print)

0006-291X (Linking). Disponível em: < http://www.ncbi.nlm.nih.gov/pubmed/12646168 $>$.

MASUMOTO, J. et al. ASC, a novel 22-kDa protein, aggregates during apoptosis of human promyelocytic leukemia HL-60 cells. J Biol Chem, v. 274, n. 48, p. 33835-8, Nov 26 1999. ISSN 0021-9258 (Print)

0021-9258 (Linking). Disponível em: < http://www.ncbi.nlm.nih.gov/pubmed/10567338 $>$.

MCDADE, J. E. et al. Legionnaires' disease: isolation of a bacterium and demonstration of its role in other respiratory disease. $\mathbf{N}$ Engl J Med, v. 297, n. 22, p. 1197-203, Dec 1 1977. ISSN 0028-4793 (Print)

0028-4793 (Linking). Disponível em: < http://www.ncbi.nlm.nih.gov/pubmed/335245 >

MEDZHITOV, R. Toll-like receptors and innate immunity. Nat Rev Immunol, v. 1, n. 2, p. 135-45, Nov 2001. ISSN 1474-1733 (Print) 
1474-1733 (Linking). Disponível em: < http://www.ncbi.nlm.nih.gov/pubmed/11905821 $>$.

MEDZHITOV, R.; PRESTON-HURLBURT, P.; JANEWAY, C. A., JR. A human homologue of the Drosophila Toll protein signals activation of adaptive immunity. Nature, v. 388, n. 6640, p. 394-7, Jul 24 1997. ISSN 0028-0836 (Print)

0028-0836 (Linking). Disponível em: < http://www.ncbi.nlm.nih.gov/pubmed/9237759 $>$.

MERRIAM, J. J. et al. Analysis of the Legionella pneumophila flil gene: intracellular growth of a defined mutant defective for flagellum biosynthesis. Infect Immun, v. 65, n. 6, p. 2497-501, Jun 1997. ISSN 0019-9567 (Print)

0019-9567 (Linking). Disponível em: < http://www.ncbi.nlm.nih.gov/pubmed/9169800 $>$.

MIAO, E. A. et al. Cytoplasmic flagellin activates caspase-1 and secretion of interleukin 1 beta via Ipaf. Nat Immunol, v. 7, n. 6, p. 569-75, Jun 2006. ISSN 15292908 (Print)

1529-2908 (Linking). Disponível em: < http://www.ncbi.nlm.nih.gov/pubmed/16648853 $>$.

MIAO, E. A. et al. Caspase-1-induced pyroptosis is an innate immune effector mechanism against intracellular bacteria. Nat Immunol, v. 11, n. 12, p. 1136-42, Dec 2010. ISSN 1529-2916 (Electronic)

1529-2908 (Linking). Disponível em: < http://www.ncbi.nlm.nih.gov/pubmed/21057511 $>$.

MILSTEIN, S. et al. Measuring RNAi knockdown using qPCR. Methods Enzymol, v. 533, p. 57-77, 2013. ISSN 1557-7988 (Electronic)

0076-6879 (Linking). Disponível em: < http://www.ncbi.nlm.nih.gov/pubmed/24182918 $>$.

MISCH, E. A. et al. A TLR6 polymorphism is associated with increased risk of Legionnaires' disease. Genes Immun, v. 14, n. 7, p. 420-6, Oct 2013. ISSN 14765470 (Electronic)

1466-4879 (Linking). Disponível em: < http://www.ncbi.nlm.nih.gov/pubmed/23823019 $>$. 
MOLOFSKY, A. B. et al. Cytosolic recognition of flagellin by mouse macrophages restricts Legionella pneumophila infection. J Exp Med, v. 203, n. 4, p. 1093-104, Apr 17 2006. ISSN 0022-1007 (Print)

0022-1007 (Linking). Disponível em: < http://www.ncbi.nlm.nih.gov/pubmed/16606669 $>$.

MORRIS, G. K. et al. Isolation of the Legionnaires' disease bacterium from environmental samples. Ann Intern Med, v. 90, n. 4, p. 664-6, Apr 1979. ISSN 00034819 (Print)

0003-4819 (Linking). Disponível em: < http://www.ncbi.nlm.nih.gov/pubmed/373549 >.

MOTANI, K. et al. Caspase-1 protein induces apoptosis-associated speck-like protein containing a caspase recruitment domain (ASC)-mediated necrosis independently of its catalytic activity. J Biol Chem, v. 286, n. 39, p. 33963-72, Sep 30 2011. ISSN 1083$351 \mathrm{X}$ (Electronic)

0021-9258 (Linking). Disponível em: < http://www.ncbi.nlm.nih.gov/pubmed/21832064 $>$.

MURUVE, D. A. et al. The inflammasome recognizes cytosolic microbial and host DNA and triggers an innate immune response. Nature, v. 452, n. 7183, p. 103-7, Mar 6 2008. ISSN 1476-4687 (Electronic)

0028-0836 (Linking). Disponível em: < http://www.ncbi.nlm.nih.gov/pubmed/18288107 $>$.

NAGAI, $\mathrm{H}$. et al. A bacterial guanine nucleotide exchange factor activates ARF on Legionella phagosomes. Science, v. 295, n. 5555, p. 679-82, Jan 25 2002. ISSN 10959203 (Electronic)

0036-8075 (Linking). Disponível em: < http://www.ncbi.nlm.nih.gov/pubmed/11809974 $>$.

NEWTON, C. A. et al. Role of Toll-like receptor 9 in Legionella pneumophila-induced interleukin-12 p40 production in bone marrow-derived dendritic cells and macrophages from permissive and nonpermissive mice. Infect Immun, v. 75, n. 1, p. 146-51, Jan 2007. ISSN 0019-9567 (Print)

0019-9567 (Linking). Disponível em: < http://www.ncbi.nlm.nih.gov/pubmed/17060467 $>$.

NEWTON, H. J. et al. Molecular pathogenesis of infections caused by Legionella pneumophila. Clin Microbiol Rev, v. 23, n. 2, p. 274-98, Apr 2010. ISSN 1098-6618 (Electronic) 
0893-8512 (Linking). Disponível em: < http://www.ncbi.nlm.nih.gov/pubmed/20375353 $>$.

O'NEILL, L. A.; GOLENBOCK, D.; BOWIE, A. G. The history of Toll-like receptors redefining innate immunity. Nat Rev Immunol, v. 13, n. 6, p. 453-60, Jun 2013. ISSN 1474-1741 (Electronic)

1474-1733 (Linking). Disponível em: < http://www.ncbi.nlm.nih.gov/pubmed/23681101 $>$.

PARRISH, A. B.; FREEL, C. D.; KORNBLUTH, S. Cellular mechanisms controlling caspase activation and function. Cold Spring Harb Perspect Biol, v. 5, n. 6, Jun 2013. ISSN 1943-0264 (Electronic)

1943-0264 (Linking). Disponível em: < http://www.ncbi.nlm.nih.gov/pubmed/23732469 $>$.

PEREIRA, M. S. et al. The Nlrc4 Inflammasome Contributes to Restriction of Pulmonary Infection by Flagellated Legionella spp. that Trigger Pyroptosis. Front Microbiol, v. 2, p. 33, 2011. ISSN 1664-302X (Electronic)

1664-302X (Linking). Disponível em: < http://www.ncbi.nlm.nih.gov/pubmed/21687424 $>$.

PEREIRA, M. S. et al. Activation of NLRC4 by flagellated bacteria triggers caspase1-dependent and -independent responses to restrict Legionella pneumophila replication in macrophages and in vivo. $\mathbf{J}$ Immunol, v. 187, n. 12, p. 6447-55, Dec 15 2011. ISSN 1550-6606 (Electronic)

0022-1767 (Linking). Disponível em: < http://www.ncbi.nlm.nih.gov/pubmed/22079982 $>$.

PHILIP, N. H. et al. Activity of Uncleaved Caspase-8 Controls Anti-bacterial Immune Defense and TLR-Induced Cytokine Production Independent of Cell Death. PLoS Pathog, v. 12, n. 10, p. e1005910, Oct 2016. ISSN 1553-7374 (Electronic)

1553-7366 (Linking). Disponível em: < http://www.ncbi.nlm.nih.gov/pubmed/27737018 $>$.

PHIN, N. et al. Epidemiology and clinical management of Legionnaires' disease. Lancet Infect Dis, v. 14, n. 10, p. 1011-21, Oct 2014. ISSN 1474-4457 (Electronic)

1473-3099 (Linking). Disponível em: < http://www.ncbi.nlm.nih.gov/pubmed/24970283 $>$. 
PIERINI, R. et al. AIM2/ASC triggers caspase-8-dependent apoptosis in Francisellainfected caspase-1-deficient macrophages. Cell Death Differ, v. 19, n. 10, p. 1709-21, Oct 2012. ISSN 1476-5403 (Electronic)

1350-9047 (Linking). Disponível em: < http://www.ncbi.nlm.nih.gov/pubmed/22555457 $>$.

PIERINI, R. et al. ASC controls IFN-gamma levels in an IL-18-dependent manner in caspase-1-deficient mice infected with Francisella novicida. J Immunol, v. 191, n. 7, p. 3847-57, Oct 1 2013. ISSN 1550-6606 (Electronic)

0022-1767 (Linking). Disponível em: < http://www.ncbi.nlm.nih.gov/pubmed/23975862 $>$.

PROELL, $M$. et al. The CARD plays a critical role in ASC foci formation and inflammasome signalling. Biochem J, v. 449, n. 3, p. 613-21, Feb 1 2013. ISSN 14708728 (Electronic)

0264-6021 (Linking). Disponível em: < http://www.ncbi.nlm.nih.gov/pubmed/23110696 $>$.

RAGHAWAN, A. K. et al. A Disease-associated Mutant of NLRC4 Shows Enhanced Interaction with SUG1 Leading to Constitutive FADD-dependent Caspase-8 Activation and Cell Death. J Biol Chem, v. 292, n. 4, p. 1218-1230, Jan 27 2017. ISSN 1083$351 \mathrm{X}$ (Electronic)

0021-9258 (Linking). Disponível em: < http://www.ncbi.nlm.nih.gov/pubmed/27974463 $>$.

RAUCH, I. et al. NAIP-NLRC4 Inflammasomes Coordinate Intestinal Epithelial Cell Expulsion with Eicosanoid and IL-18 Release via Activation of Caspase-1 and -8. Immunity, v. 46, n. 4, p. 649-659, Apr 18 2017. ISSN 1097-4180 (Electronic)

1074-7613 (Linking). Disponível em: < http://www.ncbi.nlm.nih.gov/pubmed/28410991 $>$.

RAUCH, I. et al. NAIP proteins are required for cytosolic detection of specific bacterial ligands in vivo. J Exp Med, v. 213, n. 5, p. 657-65, May 2 2016. ISSN 1540-9538 (Electronic)

0022-1007 (Linking). Disponível em: < http://www.ncbi.nlm.nih.gov/pubmed/27045008 $>$.

RAYAMAJHI, M. et al. Cutting edge: Mouse NAIP1 detects the type III secretion system needle protein. J Immunol, v. 191, n. 8, p. 3986-9, Oct 15 2013. ISSN 15506606 (Electronic) 
0022-1767 (Linking). Disponível em: < http://www.ncbi.nlm.nih.gov/pubmed/24043898 $>$.

REN, T. et al. Flagellin-deficient Legionella mutants evade caspase-1- and Naip5mediated macrophage immunity. PLoS Pathog, v. 2, n. 3, p. e18, Mar 2006. ISSN 1553-7374 (Electronic)

1553-7366 (Linking). Disponível em: < http://www.ncbi.nlm.nih.gov/pubmed/16552444 $>$.

RIVERS-AUTY, J.; BROUGH, D. Potassium efflux fires the canon: Potassium efflux as a common trigger for canonical and noncanonical NLRP3 pathways. Eur $\mathbf{J}$ Immunol, v. 45 , n. 10, p. 2758-61, Oct 2015. ISSN 1521-4141 (Electronic)

0014-2980 (Linking). Disponível em: < http://www.ncbi.nlm.nih.gov/pubmed/26332156 $>$.

ROBERTS, T. L. et al. HIN-200 proteins regulate caspase activation in response to foreign cytoplasmic DNA. Science, v. 323, n. 5917, p. 1057-60, Feb 20 2009. ISSN 1095-9203 (Electronic)

0036-8075 (Linking). Disponível em: < http://www.ncbi.nlm.nih.gov/pubmed/19131592 $>$.

ROCK, F. L. et al. A family of human receptors structurally related to Drosophila Toll. Proc Natl Acad Sci U S A, v. 95, n. 2, p. 588-93, Jan 20 1998. ISSN $0027-8424$ (Print)

0027-8424 (Linking). Disponível em: < http://www.ncbi.nlm.nih.gov/pubmed/9435236 $>$.

ROGERS, C. et al. Cleavage of DFNA5 by caspase-3 during apoptosis mediates progression to secondary necrotic/pyroptotic cell death. Nat Commun, v. 8, p. 14128, Jan 3 2017. ISSN 2041-1723 (Electronic)

2041-1723 (Linking). Disponível em: < http://www.ncbi.nlm.nih.gov/pubmed/28045099 $>$.

ROWBOTHAM, T. J. Preliminary report on the pathogenicity of Legionella pneumophila for freshwater and soil amoebae. J Clin Pathol, v. 33, n. 12, p. 1179-83, Dec 1980. ISSN 0021-9746 (Print)

0021-9746 (Linking). Disponível em: < http://www.ncbi.nlm.nih.gov/pubmed/7451664 $>$. 
ROY, C. R.; BERGER, K. H.; ISBERG, R. R. Legionella pneumophila DotA protein is required for early phagosome trafficking decisions that occur within minutes of bacterial uptake. Mol Microbiol, v. 28, n. 3, p. 663-74, May 1998. ISSN 0950-382X (Print)

0950-382X (Linking). Disponível em: < http://www.ncbi.nlm.nih.gov/pubmed/9632267 $>$.

ROY, C. R.; ISBERG, R. R. Topology of Legionella pneumophila DotA: an inner membrane protein required for replication in macrophages. Infect Immun, v. 65, n. 2, p. 571-8, Feb 1997. ISSN 0019-9567 (Print)

0019-9567 (Linking). Disponível em: < http://www.ncbi.nlm.nih.gov/pubmed/9009315 $>$.

RUHL, S.; BROZ, P. Caspase-11 activates a canonical NLRP3 inflammasome by promoting $\mathrm{K}(+)$ efflux. Eur J Immunol, v. 45, n. 10, p. 2927-36, Oct 2015. ISSN 15214141 (Electronic)

0014-2980 (Linking). Disponível em: < http://www.ncbi.nlm.nih.gov/pubmed/26173909 $>$.

SAGULENKO, V. et al. AIM2 and NLRP3 inflammasomes activate both apoptotic and pyroptotic death pathways via ASC. Cell Death Differ, v. 20, n. 9, p. 1149-60, Sep 2013. ISSN 1476-5403 (Electronic)

1350-9047 (Linking). Disponível em: < http://www.ncbi.nlm.nih.gov/pubmed/23645208 $>$.

SBORGI, L. et al. GSDMD membrane pore formation constitutes the mechanism of pyroptotic cell death. EMBO J, v. 35, n. 16, p. 1766-78, Aug 15 2016. ISSN 1460-2075 (Electronic)

0261-4189 (Linking). Disponível em: < http://www.ncbi.nlm.nih.gov/pubmed/27418190 $>$.

SCHMID-BURGK, J. L. et al. Caspase-4 mediates non-canonical activation of the NLRP3 inflammasome in human myeloid cells. Eur J Immunol, v. 45, n. 10, p. 29117, Oct 2015. ISSN 1521-4141 (Electronic)

0014-2980 (Linking). Disponível em: < http://www.ncbi.nlm.nih.gov/pubmed/26174085 $>$.

SCHNEIDER, K. S. et al. The Inflammasome Drives GSDMD-Independent Secondary Pyroptosis and IL-1 Release in the Absence of Caspase-1 Protease Activity. Cell Rep, v. 21, n. 13, p. 3846-3859, Dec 26 2017. ISSN 2211-1247 (Electronic). Disponível em: < http://www.ncbi.nlm.nih.gov/pubmed/29281832 >. 
SCHRODER, K.; TSCHOPP, J. The inflammasomes. Cell, v. 140, n. 6, p. 821-32, Mar 19 2010. ISSN 1097-4172 (Electronic)

0092-8674 (Linking). Disponível em: < http://www.ncbi.nlm.nih.gov/pubmed/20303873 $>$.

SEGAL, G.; RUSSO, J. J.; SHUMAN, H. A. Relationships between a new type IV secretion system and the icm/dot virulence system of Legionella pneumophila. Mol Microbiol, v. 34, n. 4, p. 799-809, Nov 1999. ISSN 0950-382X (Print)

0950-382X (Linking). Disponível em: < http://www.ncbi.nlm.nih.gov/pubmed/10564519 $>$.

SETHI, K. K.; BRANDIS, H. Direct demonstration and isolation of Legionella pneumophila (serogroup 1) from bathroom water specimens in a hotel. Zentralbl Bakteriol Mikrobiol Hyg B, v. 177, n. 5, p. 402-5, Jun 1983. ISSN 0174-3015 (Print)

0174-3015 (Linking). Disponível em: < http://www.ncbi.nlm.nih.gov/pubmed/6367308 $>$.

SHI, J. et al. Cleavage of GSDMD by inflammatory caspases determines pyroptotic cell death. Nature, v. 526, n. 7575, p. 660-5, Oct 29 2015. ISSN 1476-4687 (Electronic)

0028-0836 (Linking). Disponível em: < http://www.ncbi.nlm.nih.gov/pubmed/26375003 $>$.

SHI, J. et al. Inflammatory caspases are innate immune receptors for intracellular LPS. Nature, v. 514, n. 7521, p. 187-92, Oct 9 2014. ISSN 1476-4687 (Electronic)

0028-0836 (Linking). Disponível em: < http://www.ncbi.nlm.nih.gov/pubmed/25119034 $>$.

SHI, Y. Mechanisms of caspase activation and inhibition during apoptosis. Mol Cell, v. 9, n. 3, p. 459-70, Mar 2002. ISSN 1097-2765 (Print)

1097-2765 (Linking). Disponível em: < http://www.ncbi.nlm.nih.gov/pubmed/11931755 $>$.

SHIN, S. et al. Type IV secretion-dependent activation of host MAP kinases induces an increased proinflammatory cytokine response to Legionella pneumophila. PLoS Pathog, v. 4, n. 11, p. e1000220, Nov 2008. ISSN 1553-7374 (Electronic)

1553-7366 (Linking). Disponível em: < http://www.ncbi.nlm.nih.gov/pubmed/19043549 $>$. 
SILVEIRA, T. N.; ZAMBONI, D. S. Pore formation triggered by Legionella spp. is an Nirc4 inflammasome-dependent host cell response that precedes pyroptosis. Infect Immun, v. 78, n. 3, p. 1403-13, Mar 2010. ISSN 1098-5522 (Electronic)

0019-9567 (Linking). Disponível em: < http://www.ncbi.nlm.nih.gov/pubmed/20048047 $>$.

SPITALNY, K. C. et al. Pontiac fever associated with a whirlpool spa. Am J Epidemiol, v. 120, n. 6, p. 809-17, Dec 1984. ISSN 0002-9262 (Print)

0002-9262 (Linking). Disponível em: < http://www.ncbi.nlm.nih.gov/pubmed/6391156 $>$.

STUTZ, A. et al. ASC speck formation as a readout for inflammasome activation. Methods Mol Biol, v. 1040, p. 91-101, 2013. ISSN 1940-6029 (Electronic)

1064-3745 (Linking). Disponível em: < http://www.ncbi.nlm.nih.gov/pubmed/23852599 $>$.

SUTTERWALA, F. S. et al. Immune recognition of Pseudomonas aeruginosa mediated by the IPAF/NLRC4 inflammasome. J Exp Med, v. 204, n. 13, p. 3235-45, Dec 24 2007. ISSN 1540-9538 (Electronic)

0022-1007 (Linking). Disponível em: < http://www.ncbi.nlm.nih.gov/pubmed/18070936 $>$.

SUTTERWALA, F. S. et al. Critical role for NALP3/CIAS1/Cryopyrin in innate and adaptive immunity through its regulation of caspase-1. Immunity, v. 24, n. 3, p. 31727, Mar 2006. ISSN 1074-7613 (Print)

1074-7613 (Linking). Disponível em: < http://www.ncbi.nlm.nih.gov/pubmed/16546100 $>$.

SUTTERWALA, F. S. et al. NALP3: a key player in caspase-1 activation. J Endotoxin Res, v. 12, n. 4, p. 251-6, 2006. ISSN 0968-0519 (Print)

0968-0519 (Linking). Disponível em: < http://www.ncbi.nlm.nih.gov/pubmed/16953978 $>$.

SUZUKI, T. et al. Differential regulation of caspase-1 activation, pyroptosis, and autophagy via Ipaf and ASC in Shigella-infected macrophages. PLoS Pathog, v. 3, n. 8, p. e111, Aug 10 2007. ISSN 1553-7374 (Electronic)

1553-7366 (Linking). Disponível em: < http://www.ncbi.nlm.nih.gov/pubmed/17696608 $>$. 
SWANSON, M. S.; ISBERG, R. R. Association of Legionella pneumophila with the macrophage endoplasmic reticulum. Infect Immun, v. 63, n. 9, p. 3609-20, Sep 1995. ISSN 0019-9567 (Print)

0019-9567 (Linking). Disponível em: < http://www.ncbi.nlm.nih.gov/pubmed/7642298 $>$.

TENTHOREY, J. L. et al. Molecular basis for specific recognition of bacterial ligands by NAIP/NLRC4 inflammasomes. Mol Cell, v. 54, n. 1, p. 17-29, Apr 10 2014. ISSN 1097-4164 (Electronic)

1097-2765 (Linking). Disponível em: < http://www.ncbi.nlm.nih.gov/pubmed/24657167 $>$.

TING, J. P.; WILLINGHAM, S. B.; BERGSTRALH, D. T. NLRs at the intersection of cell death and immunity. Nat Rev Immunol, v. 8, n. 5, p. 372-9, May 2008. ISSN 14741741 (Electronic)

1474-1733 (Linking). Disponível em: < http://www.ncbi.nlm.nih.gov/pubmed/18362948 $>$.

UCHIYAMA, R.; YONEHARA, S.; TSUTSUI, H. Fas-mediated inflammatory response in Listeria monocytogenes infection. J Immunol, v. 190, n. 8, p. 4245-54, Apr 152013. ISSN 1550-6606 (Electronic)

0022-1767 (Linking). Disponível em: < http://www.ncbi.nlm.nih.gov/pubmed/23509366 $>$.

VAJJHALA, P. R. et al. The Inflammasome Adaptor ASC Induces Procaspase-8 Death Effector Domain Filaments. J Biol Chem, v. 290, n. 49, p. 29217-30, Dec 4 2015. ISSN 1083-351X (Electronic)

0021-9258 (Linking). Disponível em: < http://www.ncbi.nlm.nih.gov/pubmed/26468282 $>$.

VARFOLOMEEV, E. E. et al. Targeted disruption of the mouse Caspase 8 gene ablates cell death induction by the TNF receptors, Fas/Apo1, and DR3 and is lethal prenatally. Immunity, v. 9, n. 2, p. 267-76, Aug 1998. ISSN 1074-7613 (Print)

1074-7613 (Linking). Disponível em: < http://www.ncbi.nlm.nih.gov/pubmed/9729047 $>$.

WANG, Y. et al. Chemotherapy drugs induce pyroptosis through caspase-3 cleavage of a gasdermin. Nature, v. 547, n. 7661, p. 99-103, Jul 6 2017. ISSN 1476-4687 (Electronic) 
0028-0836 (Linking). Disponível em: < http://www.ncbi.nlm.nih.gov/pubmed/28459430 $>$.

WANG, Y. et al. GSDME mediates caspase-3-dependent pyroptosis in gastric cancer. Biochem Biophys Res Commun, v. 495, n. 1, p. 1418-1425, Jan 12018. ISSN 1090 2104 (Electronic)

0006-291X (Linking). Disponível em: < http://www.ncbi.nlm.nih.gov/pubmed/29183726 $>$.

WRIGHT, E. K. et al. Naip5 affects host susceptibility to the intracellular pathogen Legionella pneumophila. Curr Biol, v. 13, n. 1, p. 27-36, Jan 8 2003. ISSN 0960-9822 (Print)

0960-9822 (Linking). Disponível em: < http://www.ncbi.nlm.nih.gov/pubmed/12526741 $>$.

YAMAMOTO, Y. et al. Growth of Legionella pneumophila in thioglycolate-elicited peritoneal macrophages from A/J mice. Infect Immun, v. 56, n. 2, p. 370-5, Feb 1988. ISSN 0019-9567 (Print)

0019-9567 (Linking). Disponível em: < http://www.ncbi.nlm.nih.gov/pubmed/3257460 $>$.

YU, V. L. et al. Distribution of Legionella species and serogroups isolated by culture in patients with sporadic community-acquired legionellosis: an international collaborative survey. J Infect Dis, v. 186, n. 1, p. 127-8, Jul 12002 . ISSN 0022-1899 (Print)

0022-1899 (Linking). Disponível em: < http://www.ncbi.nlm.nih.gov/pubmed/12089674 $>$.

ZAMBONI, D. S. et al. The Birc1e cytosolic pattern-recognition receptor contributes to the detection and control of Legionella pneumophila infection. Nat Immunol, v. 7, n. 3, p. 318-25, Mar 2006. ISSN 1529-2908 (Print)

1529-2908 (Linking). Disponível em: < http://www.ncbi.nlm.nih.gov/pubmed/16444259 $>$.

ZANONI, I. et al. An endogenous caspase-11 ligand elicits interleukin-1 release from living dendritic cells. Science, v. 352, n. 6290, p. 1232-6, Jun 3 2016. ISSN 1095-9203 (Electronic)

0036-8075 (Linking). Disponível em: < http://www.ncbi.nlm.nih.gov/pubmed/27103670 $>$. 
ZHAO, Y. et al. Genetic functions of the NAIP family of inflammasome receptors for bacterial ligands in mice. J Exp Med, v. 213, n. 5, p. 647-56, May 2 2016. ISSN 15409538 (Electronic)

0022-1007 (Linking). Disponível em: < http://www.ncbi.nlm.nih.gov/pubmed/27114610 $>$.

ZHAO, Y. et al. The NLRC4 inflammasome receptors for bacterial flagellin and type III secretion apparatus. Nature, v. 477, n. 7366, p. 596-600, Sep 29 2011. ISSN 14764687 (Electronic)

0028-0836 (Linking). Disponível em: < http://www.ncbi.nlm.nih.gov/pubmed/21918512 $>$.

ZHU, W. et al. Induction of caspase 3 activation by multiple Legionella pneumophila Dot/lcm substrates. Cell Microbiol, v. 15, n. 11, p. 1783-95, Nov 2013. ISSN 14625822 (Electronic)

1462-5814 (Linking). Disponível em: < http://www.ncbi.nlm.nih.gov/pubmed/23773455 $>$.

ZHU, W. et al. Sensing cytosolic RpsL by macrophages induces lysosomal cell death and termination of bacterial infection. PLoS Pathog, v. 11, n. 3, p. e1004704, Mar 2015. ISSN 1553-7374 (Electronic)

1553-7366 (Linking). Disponível em: < http://www.ncbi.nlm.nih.gov/pubmed/25738962 $>$.

ZWOLANEK, F. et al. The non-receptor tyrosine kinase Tec controls assembly and activity of the noncanonical caspase-8 inflammasome. PLoS Pathog, v. 10, n. 12, p. e1004525, Dec 2014. ISSN 1553-7374 (Electronic)

1553-7366 (Linking). Disponível em: < http://www.ncbi.nlm.nih.gov/pubmed/25474208 $>$. 
Anexos 
9 - ANEXO I: Trabalhos de primeira autoria*

*Trabalhos de primeira autoria em ordem de importância para o entendimento deste trabalho.

9.1 - Anexo 1 - Artigo publicado (MASCARENHAS, Danielle PA et al. Plos Pathogens, 2017)

"Inhibition of caspase-1 or gasdermin-D enable caspase-8 activation in the Naip5/NLRC4/ASC inflammasome"

- Publicado em: agosto de 2017 


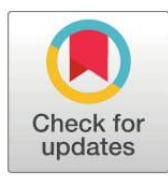

\section{Gopenaccess}

Citation: Mascarenhas DPA, Cerqueira DM, Pereira MSF, Castanheira FVS, Fernandes TD, Manin GZ, et al. (2017) Inhibition of caspase-1 or gasdermin-D enable caspase-8 activation in the Naip5/NLRC4/ ASC inflammasome. PLoS Pathog 13(8): e1006502. https://doi.org/10.1371/journal. ppat.1006502

Editor: H. Steven Seifert, Northwestern University Feinberg School of Medicine, UNITED STATES

Received: March 9, 2017

Accepted: June 30, 2017

Published: August 3, 2017

Copyright: @ 2017 Mascarenhas et al. This is an open access article distributed under the terms of the Creative Commons Attribution License, which permits unrestricted use, distribution, and reproduction in any medium, provided the original author and source are credited.

Data Availability Statement: All relevant data are within the paper and its Supporting Information files.

Funding: This work was supported by grants from Fundação de Amparo à Pesquisa do Estado de São Paulo (FAPESP, grants 2012/09363-6, 2013/ 08216-2 and 2014/04684-4), Conselho Nacional do Desenvolvimento Cientifico e Tecnológico (CNPq) and Coordenação de Aperfeiçoamento de Pessoal de Nivel Superior (CAPES). DSZ is a

\section{RESEARCH ARTICLE \\ Inhibition of caspase- 1 or gasdermin-D enable caspase- 8 activation in the Naip5/NLRC4/ASC inflammasome}

\author{
Danielle P. A. Mascarenhas, Daiane M. Cerqueira, Marcelo S. F. Pereira, Fernanda V. \\ S. Castanheira, Talita D. Fernandes, Graziele Z. Manin, Larissa D. Cunha, Dario \\ S. Zamboni* \\ Department of Cell Biology, School of Medicine of Ribeirão Preto, University of São Paulo. Ribeirão Preto, \\ Brazil \\ *dszamboni@fmrp.usp.br
}

\begin{abstract}
Legionella pneumophila is a Gram-negative, flagellated bacterium that survives in phagocytes and causes Legionnaires' disease. Upon infection of mammalian macrophages, cytosolic flagellin triggers the activation of Naip/NLRC4 inflammasome, which culminates in pyroptosis and restriction of bacterial replication. Although NLRC4 and caspase-1 participate in the same inflammasome, $\mathrm{NIrC4}^{-\%}$ mice and their macrophages are more permissive to $L$. pneumophila replication compared with Casp $1 / 11^{\%}$. This feature supports the existence of a pathway that is NLRC4-dependent and caspase-1/11-independent. Here, we demonstrate that caspase- 8 is recruited to the Naip5/NLRC4/ASC inflammasome in response to flagellin-positive bacteria. Accordingly, caspase-8 is activated in Casp1/11\% macrophages in a process dependent on flagellin, Naip5, NLRC4 and ASC. Silencing caspase-8 in Casp $1 / 11^{-1}$ cells culminated in macrophages that were as susceptible as N/rc4 $4^{-/}$ for the restriction of $L$. pneumophila replication. Accordingly, macrophages and mice deficient in Asc/Casp $1 / 11^{-\%}$ were more susceptible than Casp $1 / 11^{-\%}$ and as susceptible as NIrc $4^{-/}$for the restriction of infection. Mechanistically, we found that caspase-8 activation triggers gasdermin-D-independent pore formation and cell death. Interestingly, caspase- 8 is recruited to the Naip5/NLRC4/ASC inflammasome in wild-type macrophages, but it is only activated when caspase-1 or gasdermin- $D$ is inhibited. Our data suggest that caspase- 8 activation in the Naip5/NLRC4/ASC inflammasome enable induction of cell death when caspase- 1 or gasdermin- $D$ is suppressed.
\end{abstract}

\footnotetext{
Author summary

Legionella pneumophila is the causative agent of Legionnaires' disease, an atypical pneumophila that affects people worldwide. Besides the clinical importance, $L$. pneumophila is a very useful model of pathogenic bacteria for investigation of the interactions of innate immune cells with bacterial pathogens. Studies using $L$. pneumophila demonstrated that Naip 5 and NLRC 4 activate caspase- 1 and this inflammasome is activated by bacterial
} 
research fellow from CNPq, Brazil. The funders had no role in study design, data collection and analysis, decision to publish, or preparation of the manuscript.

Competing interests: The authors have declared that no competing interests exist. flagellin. However, macrophages and mice deficient in NLRC4 are more susceptible for $L$. pneumophila replication than those deficient in caspase-1, indicating that the flagellin/ Naip5/NLRC4 inflammasome triggers responses that are independent on caspase-1. Here, we used L. pneumophila to investigate this novel pathway and found that caspase- 8 interacts with NLRC4 in a process that is dependent on ASC and independent of caspase-1 and caspase-11. Although caspase- 8 is recruited to the Naip5/NLRC4/ASC inflammasome, it is only activated when caspase- 1 or gasdermin-D is inhibited. Our data suggest that caspase-8 activation in the Naip5/NLRC4/ASC inflammasome may favor host responses during infections against pathogens that inhibit components of the pyroptotic cell death including caspase-1 and gasdermin-D.

\section{Introduction}

Legionella pneumophila is the causative agent of Legionnaires' disease. It was identified for the first time in 1976, after an atypical pneumonia affected the participants of the American Legion Convention in Philadelphia, United States [1]. After isolation, L. pneumophila were characterized as Gram-negative, flagellated, intracellular facultative bacteria [2,3]. The species of Legionella were found mainly in freshwater and soil environments, including lakes and irrigation systems [4]. Infection of humans occurs upon inhalation of water droplets derived from these environments containing Legionella [5]. After inhalation, L. pneumophila can subvert the normal vesicle traffic within alveolar macrophages and form LCV (Legionella-containing vacuoles), a process that is mediated by the injection of hundreds of bacterial effectors through a type IV secretion system called Dot/Icm [6-9]. During its evolution, L. pneumophila were selected based on their replication in protozoa but not in humans, which are accidental hosts [10]. Consequently, L. pneumophila can be recognized by many innate immune receptors in mammalian cells, including proteins from the family of the nucleotide-binding domain and leucine-rich repeat-containing proteins (NLRs). These characteristics make L. pneumophila an excellent model for the study of innate immunity, including intracellular signaling pathways and inflammasomes.

The major inflammasome that leads to the restriction of Legionella replication in macrophages is Naip5/NLRC4. This pathway was discovered in mouse cells upon observations that macrophages from the A/J mouse strain, but not cells from other mice strains, are susceptible to L. pneumophila replication [11]. The resistance was mapped to the Lgn1 locus, which encodes several copies of Naip genes, including Naip5 (Birc1e), which is the gene responsible for resistance [12-16]. Successful lines of investigation culminated in the demonstration that Naip5 recognizes bacterial flagellin and interacts with NLRC4 for caspase-1 activation and the restriction of bacterial replication [17-20]. This platform was named the Naip5/NLRC4 inflammasome and triggers pore formation and pyroptosis, which has been considered one of the most important mechanisms for the restriction of intracellular pathogen replication via inflammasomes [21-24]. Host cell death via pyroptosis eliminates intracellular parasite replication and traps intracellular microbes in pyroptotic cells, facilitating microbial destruction by additional phagocytes [23,25-29]. Pyroptosis occurs concomitantly with the secretion of inflammatory cytokines such as IL- $1 \beta$ and IL-18, a process that requires the adaptor molecule ASC and the formation of NLRC4/ASC puncta $[20,30]$. ASC also functions as an adaptor protein for other inflammasomes, including AIM2 and NLRP3, which triggers the processing of caspase-1 and caspase-8 [21,31-34]. Of note, Naip5/NLRC4 appears to be the only inflammasome required for the restriction of L. pneumophila replication. Macrophages that are deficient 
in NLRP3 or AIM2 can efficiently restrict L. pneumophila replication [20,21,23,35]. However, the participation of ASC in the resistance of $L$. pneumophila infection is controversial. In murine macrophages, ASC is dispensable for the induction of pyroptosis and the restriction of bacterial replication $[20,21]$. By contrast, experiments performed with human monocytes indicate that ASC silencing leads to an increase in bacterial replication [36,37]. Thus, the role of ASC in the restriction of L. pneumophila replication is still unclear.

We have previously demonstrated the existence of a pathway that is dependent on flagellin and NLRC4 but independent of caspase-1 [38]. Here, we used macrophages and Casp1/1 $1{ }^{-1}$ mice to systematically assess this pathway. By searching for additional components that operate in the NLRC4 inflammasome independently of caspase-1/11, we found that caspase- 8 interacts with NLRC4 in a process that is dependent on ASC. This pathway effectively accounts for resistance to infection in macrophages and in vivo when caspase- 1 is absent. In wild-type cells, caspase- 8 is recruited to the Naip5/NLRC4/ASC/caspase- 1 inflammasome, but is not activated. Caspase- 8 activation in this platform only occurs when caspase- 1 or gasdermin-D is inhibited, suggesting that this pathway may be important when pyroptosis is inhibited.

\section{Results}

\section{Restriction of $L$. pneumophila replication in BMDMs is flagellin/ NLRC4-dependent, ASC-independent and partially caspase-1/ 11-dependent}

We have previously demonstrated that activation of the flagellin/NLRC4 inflammasome triggers caspase-1-dependent and independent responses to restrict Legionella replication in macrophages and in mouse lungs [38]. However, the caspase-1-independent mechanisms underlying this pathway are unknown. To further characterize this pathway, we performed growth curves using high and very low multiplicity of infections (MOIs) in bone marrowderived macrophages (BMDMs). Macrophages were infected with wild-type L. pneumophila in the JR32 background (WT Lp) and the isogenic mutants flaA $A^{-}$and fliI. FliI is an ATPase that is required for the secretion of flagellin through the flagellar apparatus [39]. Consequently, fliT mutants express flagellin but are non-motile and non-flagellated, making them an appropriate control for fla $\mathrm{A}^{-}$mutants for investigations related to the role of flagellin. We found that BMDMs from C57BL/6 and $A s c^{-1-}$ mice fully restrict the replication of WT Lp and fliT bacteria at low and high MOIs. In contrast, Nlrc $4^{-/-}$cells are permissive and Casp $1 / 11^{-1-}$ cells are partially restrictive (S1 Fig). Bacterial mutants for flagellin bypass NLRC4-mediated growth restriction and replicate in all macrophages as previously described $[17-19,40]$. These data support previous reports showing that ASC is not required for the restriction of L. pneumophila replication in the presence of caspase-1/11 [20,21]. In addition, these data further support our previous assertion that flagellin triggers an uncharacterized pathway that is dependent on NLRC4 and independent of caspase-1 and caspase-11 [38]. We decided to use BMDMs from Casp $1 / 11^{-1-}$ mice to further investigate this NLRC4-dependent and caspase-1/ 11-independent pathway.

\section{Flagellated $L$. pneumophila triggers NLRC4 puncta that associate with caspase- 8 in a process that is ASC-dependent}

The transduction of BMDMs with a retrovirus encoding NLRC4 fused to GFP allows the visualization of NLRC4 puncta in the cytoplasm of macrophages infected with flagellated bacteria [30]. Here, we used this retroviral system to investigate the formation of the NLRC4 inflammasome in the absence of caspase-1/11. BMDMs from Casp $1 / 11^{-/}$mice were transduced with 
NLRC4-GFP and infected with WT Lp, fliI and flaA $^{-}$at different MOIs and time points. We found that WT Lp and fliT triggered the formation of NLRC4 puncta in the absence of caspase-1/11 (Fig 1A). The formation of NLRC4 puncta was influenced by the MOI and significantly diminished in response to fla $\mathrm{A}^{-}$bacteria (Fig $1 \mathrm{~A}$ ). Next, we evaluated the requirement of ASC for the formation of NLRC4 puncta in the absence of caspase-1/11. We constructed a mouse that was deficient in ASC and caspase-1/11 and found that whereas the formation of

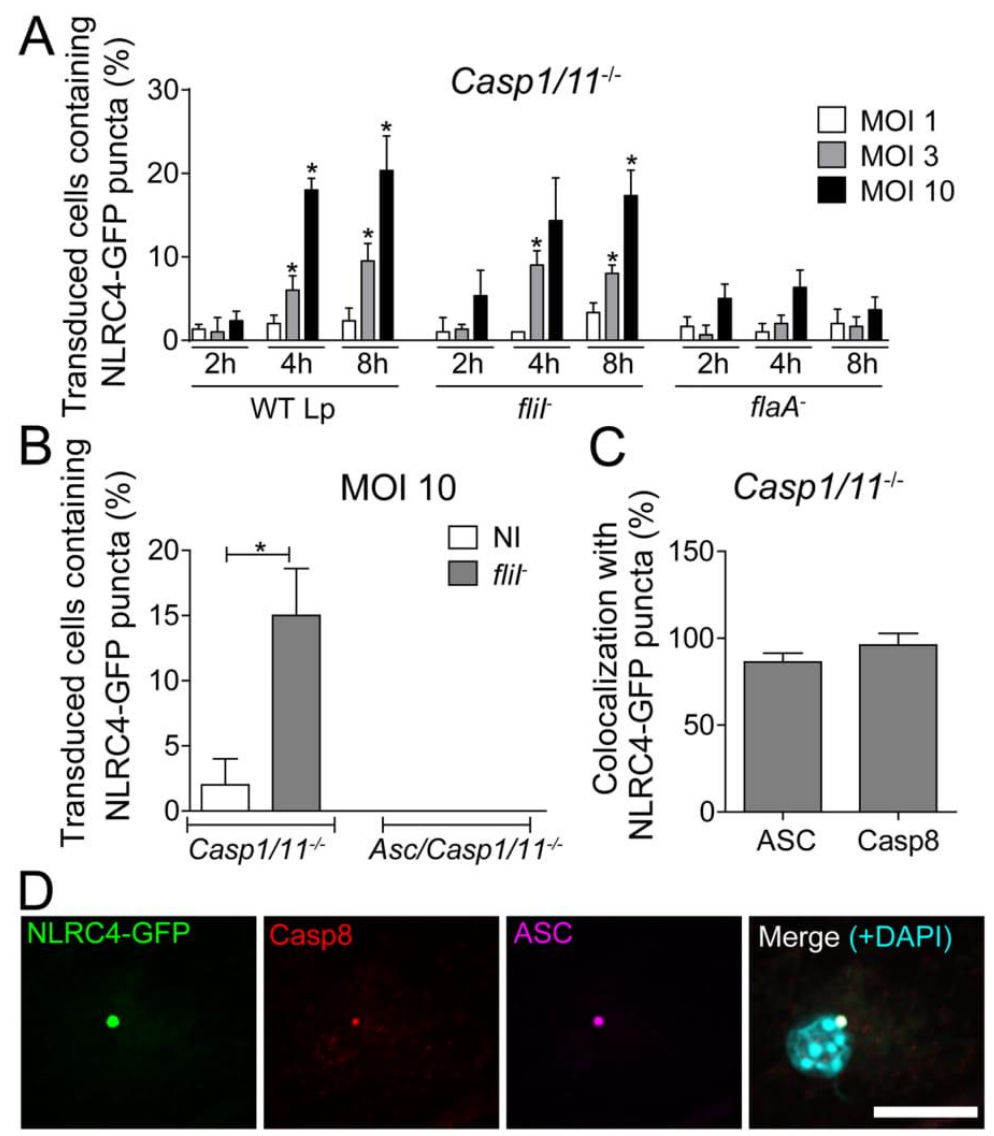

Fig 1. Legionella triggers the formation of NLRC4/caspase-8 puncta in a process that is dependent on ASC and flagellin and independent of caspase-1/11. Bone marrow-derived macrophages (BMDMs) obtained from Casp $1 / 11^{-/}$and $A s c / C a s p 1 / 11^{1 /}$ mice were transduced with retrovirus encoding NLRC4-GFP. Cells were infected with wild-type $L$. pneumophila (WT Lp), motility-deficient mutants expressing flagellin (flir) or with flagellin-deficient mutants ( $f\left(a A^{-}\right)$at a $\mathrm{MOI}$ of 1,3 or 10 . (A) After 2, 4 and 8 hours of infection, the cells were fixed, and the percentage of transduced cells containing NLRC4-GFP puncta were determined using an epifluorescence microscope. ${ }^{*}, P<0.05$ compared with BMDMs infected with fla $A^{-}$, Student's $t$ test. (B-D) Transduced cells were infected with flir (MOI 10) and fixed after 8 hours of infection. (B) The percentages of transduced Casp $1 / 11^{-/}$and Asc/Casp $1 / 11^{-/}$cells containing NLRC4-GFP puncta were determined. (C) The percentages of NLRC4-GFP puncta that colocalized with ASC and caspase-8 were determined. (D) Representative images of a transduced BMDM infected with flir at a MOI of 10 . The cultures were stained with anti-caspase-8 (red) and anti-ASC (purple). The cell nuclei were stained with DAPI (cyan); NLRC4-GFP is shown in green. The images show the colocalization of NLRC4-GFP, ASC and caspase-8 in Casp $1 / 11^{-1}$ BMDMs. The images were acquired by multiphoton microscopy using a $63 \mathrm{x}$ oil immersion objective and analyzed using ImageJ Software. Scale bar, $10 \mu \mathrm{m}$. Data show the average \pm SD of triplicate wells. NI, uninfected. Data are presented for one representative experiment of five (A) and two (B-D) experiments with similar results.

https://doi.org/10.1371/journal.ppat.1006502.g001 
NLRC4 puncta occurred in the absence of caspase-1/11, ASC was essential for formation of the NLRC4 puncta (Fig 1B). These data are in agreement with previous findings indicating that ASC is critical for the nucleation of several inflammasomes, including AIM2, NLRP3 and NLRC4 [30,32,33,41-46]. Our results confirm that ASC is essential to NLRC4 puncta formation formed in the absence of caspase-1/11. Next, we used this NLRC4-GFP system to identify additional components of the NLRC4 inflammasome that operates in the absence of caspase$1 / 11$. Non-inflammatory caspases have been previously shown to participate in the assembly of inflammasomes and to interact with ASC, including caspase-3, caspase-7 and caspase-8 [3234,37,44,46-51]. Thus, we transduced Casp $1 / 11^{-/}$macrophages with a retrovirus encoding NLRC4-GFP and evaluated the colocalization of NLRC4 with these caspases. In this experiment, we used the pan-caspase inhibitor Z-VAD to block caspase activation and to visualize puncta formation. We did not detect significant numbers of NLRC4 or ASC puncta containing caspase- 3 and caspase-7 (S2 Fig). In contrast, caspase-8 and ASC was present in more than $90 \%$ of the NLRC4 puncta (Fig 1C and S2 Fig). These data are in agreement with our findings indicating that ASC is required for NLRC4 puncta formation, accordingly, endogenous ASC colocalizes with NLRC4 and caspase- 8 in the same puncta (Fig 1D). To evaluate the participation of caspase- 8 in the NLRC4 inflammasome, we transduced BMDMs from Casp $1 / 11^{-/}$mice with a retrovirus encoding ASC fused to GFP (ASC-GFP) and analyzed ASC puncta colocalization with caspase- 8 . We found that ASC puncta formed readily after the infection and that this process occurred in response to WT Lp and fliT but not llaA $^{-}$(Fig 2A). After 8 hours of infection, the formation of ASC puncta was partially dependent on flagellin (Fig 2A). We stained caspase- 8 in macrophages transduced with retrovirus encoding ASC-GFP and found that caspase- 8 colocalized with ASC puncta in response to infection with flagellated bacteria (Fig 2B). Collectively, these results indicate that flagellin triggers the assembly of an inflammasome composed of NLRC4 and ASC, which colocalizes with caspase-8.

The double-stranded DNA sensor AIM2 is known to recruit ASC to trigger puncta formation in response to infection, leading to caspase- 1 activation and IL- $1 \beta$ and IL-18 release [31,52-55]. The role of AIM2 inflammasome in the recognition of L. pneumophila has been demonstrated using $s d h A^{-}$deficient bacteria. In the absence of SdhA, bacteria do not maintain vacuole integrity and localize in the macrophage cytoplasm, triggering activation of the AIM2 inflammasome [56,57]. In addition, the AIM2 inflammasome has been shown to trigger caspase- 8 activation independently of caspase- $1[33,34,58]$. Thus, we investigated whether AIM2 is present in the NLRC4/ASC/caspase- 8 inflammasome that is formed in response to flagellinpositive L. pneumophila. We stained AIM2 in macrophages transduced with retrovirus encoding NLRC4-GFP and found no AIM2 in the NLRC4 puncta (S3A Fig). Moreover, we generated Aim $2 /$ Casp $1 / 11^{-/}$mice and found that AIM2 was dispensable for the formation of NLRC4 puncta in response to flagellin-positive bacteria (S3B Fig).

\section{The NLRC4/ASC/caspase-8 inflammasome accounts for flagellin- dependent restriction of Legionella replication in macrophages in the absence of caspase-1/11}

Our data are consistent with the hypothesis that caspase- 8 is a part of the inflammasome composed of NLRC4 and ASC. Thus, we investigated whether caspase- 8 is activated during infection. We found that caspase- 8 was strongly activated in Casp $1 / 11^{-/}$BMDMs in response to $f l i$ but not flaA- bacteria (Fig $3 \mathrm{~A}$ ). In agreement with the requirement of ASC for the assembly of the NLRC4/ASC/caspase- 8 inflammasome, we found that caspase- 8 activation was abolished in Asc/Casp $1 / 11^{-/-}$cells (Fig 3A). Caspase-8 activation occurred normally in Aim $2 /$ Casp $1 / 11^{-1-}$ cells, indicating that AIM2 was not involved in the activation of caspase- 8 through the 
flagellin/NLRC4/ASC inflammasome (S4 Fig). We also evaluated caspase-8 activation by western blot analysis by measuring the cleavage of $\mathrm{p} 55$ and the production of $\mathrm{p} 18$ isoforms. We found that flagellated bacteria triggered caspase-8 activation in Casp $1 / 11^{-1}$ but not in $\mathrm{Asc} /$ Casp $1 / 11^{--}$cells. This phenomenon was evident by the reduction in $\mathrm{p} 55$ and increased production of p18 in Casp1/11 $1^{-/}$BMDMs infected with fliT but not $f l a A^{-}$bacteria (Fig 3B).

Next, we evaluated the participation of caspase-8 in caspase-1/11-independent restriction of L. pneumophila replication in macrophages, a process that was dependent on flagellin and NLRC4. Endogenous caspase- 8 was silenced in Casp $1 / 11^{-/-}$BMDMs using two independent retrovirus encoding shRNA to target caspase-8. A non-target sequence was used as a control (NT). By western blotting, we detected reduced caspase-8 expression in Casp1/11 $1^{-/}$transduced cells. The shRNA Casp8 Seq1 was more efficient than Seq2 for silencing caspase-8 as determined by western blot (Fig 4A and S5 Fig) and RT-PCR (Fig 4B). Importantly, complete silencing of caspase- 8 cannot be achieved because caspase- 8 expression is required for macrophage survival $[59,60]$. Nonetheless, using the described silencing conditions, we did not detect signs of cell death or LDH in the supernatant of the transduced macrophages. To evaluate the efficiency of caspase-8 silencing, we quantified caspase-8-containing puncta formation and caspase- 8 activation in macrophages infected with flagellated L. pneumophila. We found that the frequency of puncta containing caspase- 8 and caspase- 8 activation was reduced in caspase-

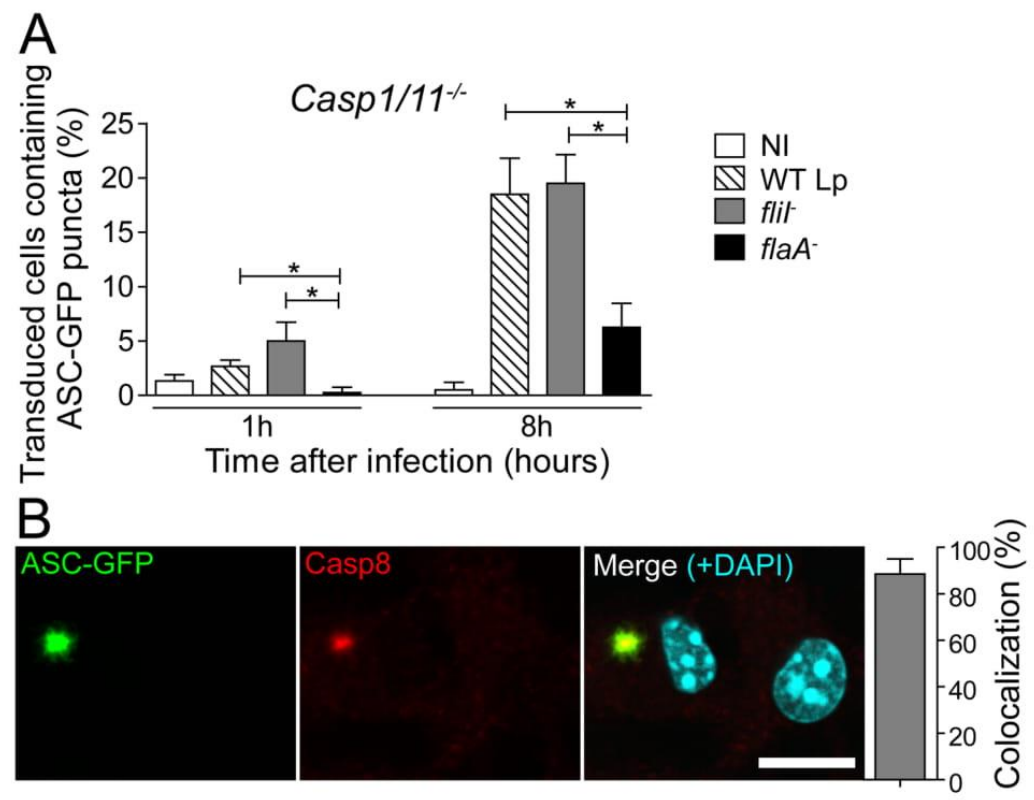

Fig 2. ASC puncta are induced in response to flagellated bacteria and colocalize with caspase-8. Bone marrow-derived macrophages (BMDMs) from Casp $1 / 11^{-\%}$ mice were transduced with retrovirus encoding ASC-GFP. (A) Cells were infected with wild-type L. pneumophila (WT Lp), motility-deficient mutants expressing flagellin (flir) or with flagellin-deficient mutants ( $f l a A^{-}$) at a MOI of 10 . After 1 or 8 hours of infection, the cells were fixed, and the number of transduced cells containing ASC-GFP puncta was determined using an epifluorescence microscope. (B) Representative images of a transduced BMDM infected with flir at a MOI of 10 . The cultures were stained with anti-caspase- 8 (red), cell nuclei were stained with DAPI (cyan) and ASC-GFP is shown in green. The images show the colocalization between ASC-GFP and caspase- 8 in Casp $1 / 11^{-/}$BMDMs infected for 8 hours. The images were acquired by multiphoton microscopy with a $63 x$ oil immersion objective and analyzed using ImageJ Software. Scale bar, 10 $\mu \mathrm{m}$. Data show the average \pm SD of triplicate wells. ${ }^{*}, P<0.05$, Student's $t$ test. $\mathrm{NI}$, uninfected. Data are presented for one representative experiment of three $(A)$ and two $(B)$ experiments with similar results.

https://doi.org/10.1371/journal.ppat.1006502.g002 
8 -silenced cells (Fig 4C and 4D). Next, we evaluated the effect of caspase-8 for the restriction of L. pneumophila replication in Casp 1/11 $11^{-1}$ BMDMs. We found that silencing caspase- 8 culminated in increased replication of fli but not flaA $A^{-}$bacteria (Fig $4 \mathrm{E}$ and $4 \mathrm{~F}$ ). These data indicated that caspase- 8 contributed to the restriction of bacterial replication in a process that was dependent on flagellin, supporting the hypothesis that caspase- 8 functionally participates in responses that are NLRC4/ASC-dependent and caspase-1/11-independent.

\section{ASC is required for NLRC4/caspase-8-mediated restriction of Legionella} replication in the absence of caspase-1/11

Our data indicate that caspase- 8 is part of the NLRC4/ASC inflammasome and that ASC is essential for the assembly of this inflammasome. Thus, we reasoned that in the absence of
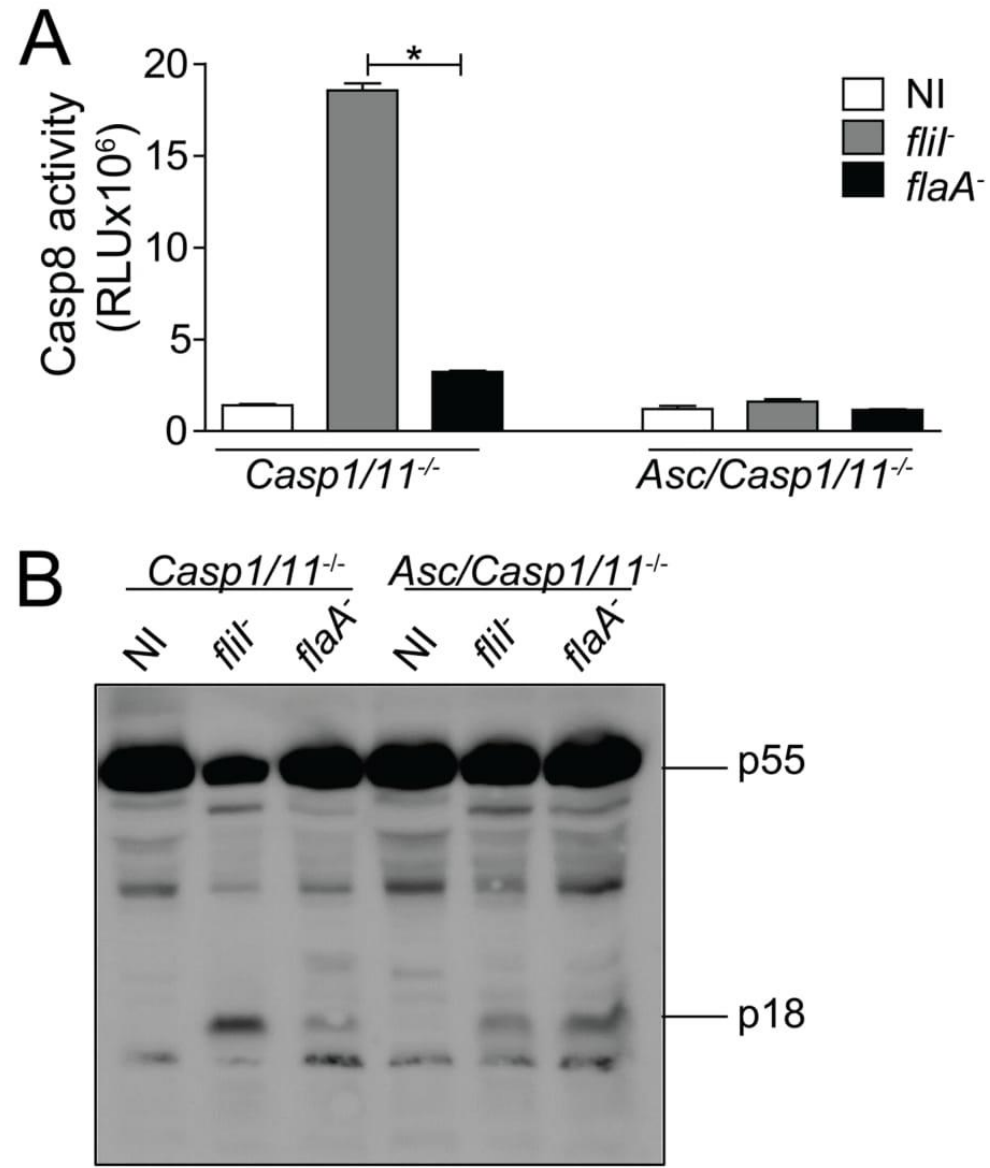

Fig 3. Caspase-8 is activated in response to flagellated bacteria in a process that is ASC-dependent and caspase-1/11-independent. Bone marrow-derived macrophages (BMDMs) from Casp $1 / 11^{\%}$ and Asc/ Casp $1 / 11^{-/}$mice were infected with motility-deficient $L$. pneumophila mutants expressing flagellin $(f l i r)$ or with flagellin-deficient bacteria $\left(f l a A^{-}\right)$at a $\mathrm{MOI}$ of 10 for 8 hours. The activity of caspase- 8 was measured using the Caspase-8 Glo Assay (A) or by western blot analysis (B). The pro-caspase-8 p55 and the processed form of caspase- 8 p18 are indicated. Data show the average $\pm S D$ of triplicate wells. *, $P<0.05$, Student's $t$ test. RLU, relative luminescence units; $\mathrm{NI}$, uninfected. Data are presented for one representative experiment of three $(A)$ and two (B) experiments with similar results.

https://doi.org/10.1371/journal.ppat.1006502.g003 
A

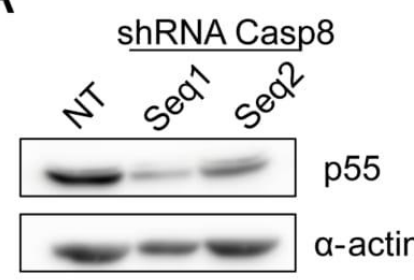

C

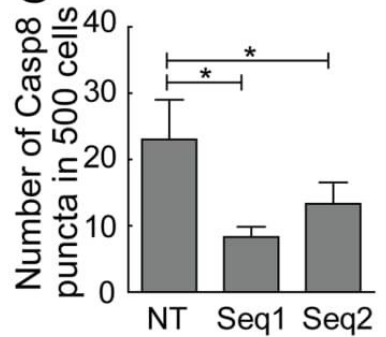

NT Seq1 Seq2

^ NT shRNA

$\square$ ShRNA Casp8 Seq1

- shRNA Casp8 Seq2

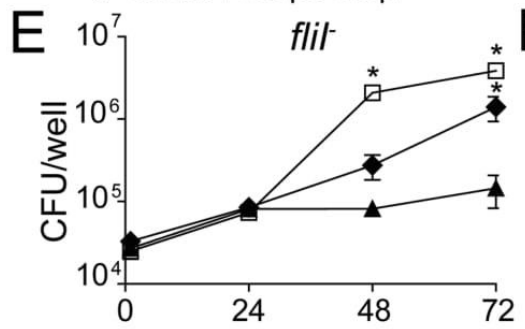

Time after Infection (hours)

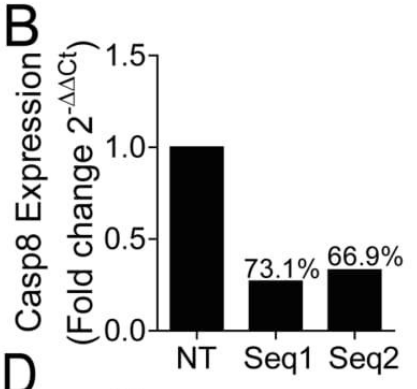

D

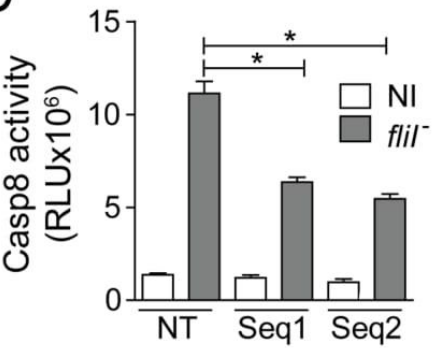

Fig 4. Caspase-8 is important for NLRC4-mediated restriction of $L$. pneumophila replication independently of caspase-1/11. Bone marrow-derived macrophages (BMDMs) generated from Casp 1/11\% mice were transduced with a retrovirus encoding shRNA sequences to target caspase-8 (Seq1, Seq2) and a non-target shRNA sequence (NT). (A) The silencing was confirmed by western blot analysis and Real Time qPCR. (A) Cell lysates were separated by SDS-PAGE, blotted and probed with anti-caspase-8 (pro-caspase8 p55) and anti- $\alpha$-actin. (B) Quantification of the casp8 gene expression by Real Time qPCR. Actin beta gene was used as a control for normalization of expression levels. The number above the bars indicates the percentage of silencing compared to the NT sequence. (C-D) The transduced Casp $1 / 11^{1 /}$ BMDMs were infected with motility-deficient $L$. pneumophila mutants expressing flagellin (flir) at a MOI of 10 . After 8 hours the cells were fixed, the number of caspase- 8 puncta was quantified using an epifluorescence microscope (C) and the activity of caspase- 8 was measured using the Caspase-8 Glo Assay (D). (E-F) The transduced Casp $1 / 11^{-1}$ BMDMs were infected with flir $(\mathrm{E})$ and $f\left(a A^{-}(\mathrm{F})\right.$ at a $\mathrm{MOI}$ of 10 to evaluate bacterial replication. The cells were incubated for 24,48 and 72 hours for CFU determination. Data show the average \pm SD of triplicate wells. ${ }^{*} P<0.05$, compared with NT. (C-D) Student's $t$ test, (E-F) ANOVA. RLU, relative luminescence units; $\mathrm{NI}$, uninfected. Data are presented for one representative experiment of three experiments with similar results.

https://doi.org/10.1371/journal.ppat.1006502.g004

ASC, the NLRC4/ASC/caspase-8 inflammasome would not be functional. If this hypothesis is correct, Asc/Casp $1 / 11^{-/}$macrophages should be more permissive than Casp $1 / 11^{-/}$and as per-

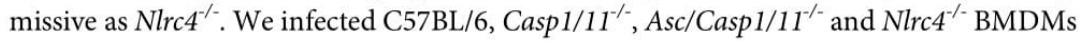


with $f l i \Gamma$ and $f l a A^{-}$, and evaluated bacterial replication after 24,48 and 72 hours. Using flagellin-positive bacteria, we confirmed that C57BL/6 BMDMs were restrictive to bacterial growth, $\mathrm{NlrC4}^{-/}$were permissive and Casp $1 / 11^{-/}$were partially restrictive (Fig 5A). Importantly, Asc/
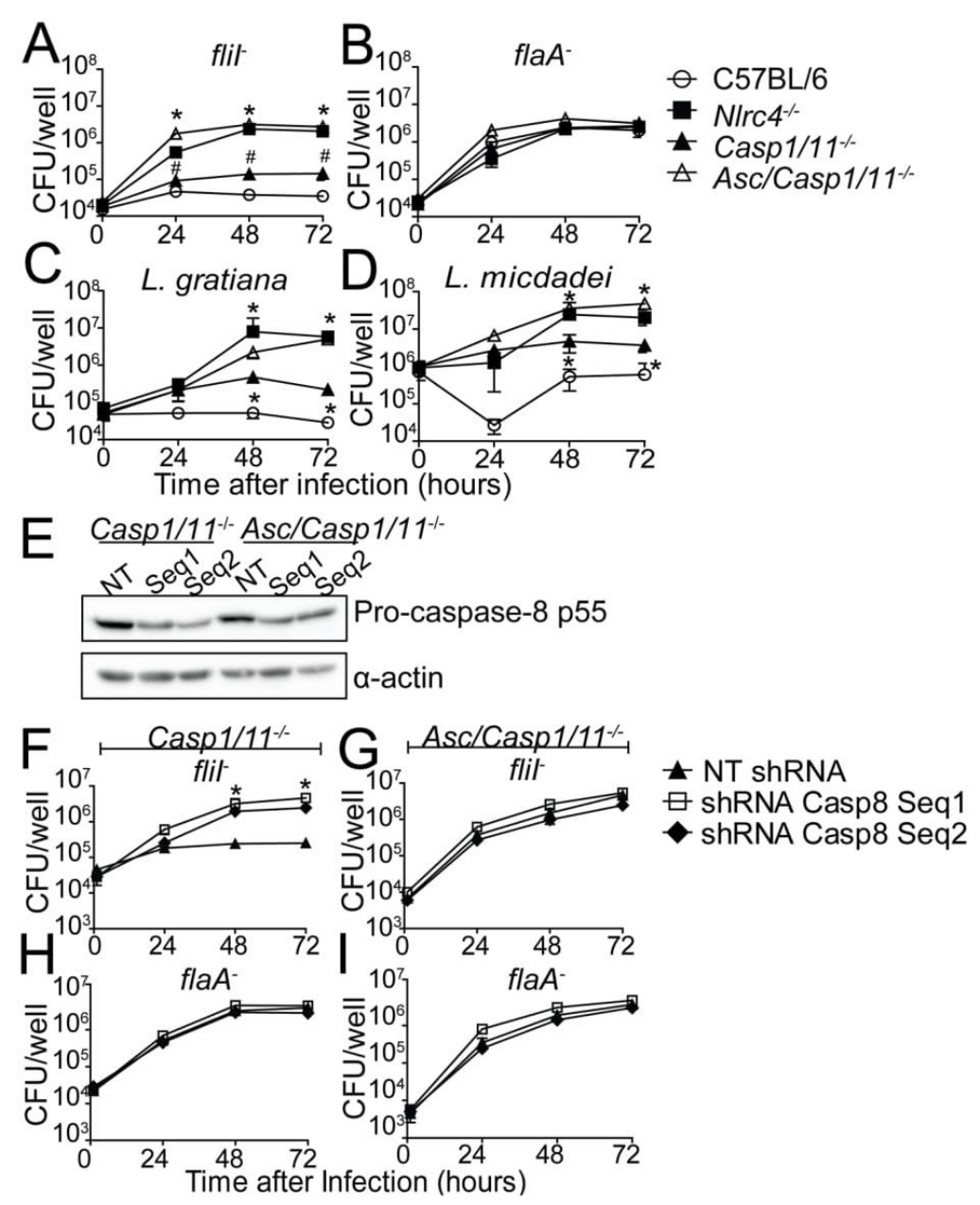

Fig 5. ASC is important for NLRC4/caspase-8-mediated restriction of $L$. pneumophila replication independently of caspase-1/11. (A-D) Bone marrow-derived macrophages (BMDMs) from C57BL/6 (open

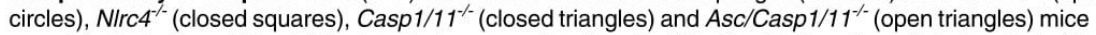
were infected with motility-deficient mutants expressing flagellin (flir, A), with flagellin-deficient mutants $\left(\right.$ fla $A^{-}$ $B)$, L. gratiana (C) or with $L$. micdadei (D) at a MOI of 10 . The cells were incubated for 24,48 and 72 hours for CFU determination. Data show the average \pm SD of triplicate wells. ${ }^{*}, P<0.05$ compared with Casp-1/11\% BMDMs. ", P<0.05 compared with C57BL/6 BMDMs, ANOVA. (E-I) BMDMs from Casp 1/11 ${ }^{-/}$and Asc/Casp1/ $11^{\%}$ mice were transduced with a retrovirus encoding shRNA sequences to target caspase-8 (Seq1, Seq2) and a non-target shRNA sequence (NT). (E) Caspase-8 silencing was confirmed by western blot analysis. Cell lysates were separated by SDS-PAGE, blotted and probed with anti-caspase-8 (pro-caspase-8 p55) and

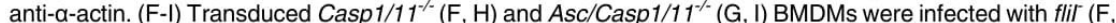
$\mathrm{G})$ or fla $A^{-}(\mathrm{H}, \mathrm{I})$ at a $\mathrm{MOI}$ of 10 and incubated for 24,48 and 72 hours for CFU determination. Data show the average \pm SD of triplicate wells. ${ }^{*}, P<0.05$ compared with NT shRNA, ANOVA. NT, non-target shRNA. Data are presented for one representative experiment of four (A), two (B-D) and one (F-I) experiments performed with similar results.

https://doi.org/10.1371/journal.ppat.1006502.g005 
Casp $1 / 11^{-/}$cells were highly permissive and phenocopied the Nlrc4 $4^{-/}$cells (Fig 5A). As predicted, flagellin mutants bypassed the NLRC4 and replicated in all macrophages evaluated (Fig 5B). These data further confirmed that Casp $1 / 11^{-1}$ cells were more restrictive than $N l r c 4^{-1-}$ macrophages, possibly due to the presence of the NLRC4/ASC/caspase-8 inflammasome. We also used non-pneumophila species to compare bacterial replication in $\mathrm{NlrC}^{-/-}$and $\mathrm{Asc} /$ Casp $1 / 11^{-/}$macrophages. Infections performed with L. gratiana and L. micdadei indicated that $\mathrm{Asc} / \mathrm{Casp} 1 / 11^{-/}$macrophages were as susceptible as $\mathrm{Nlrc}^{-/}$, whereas Casp $1 / 11^{-/-}$cells were partially restrictive (Fig 5C and 5D). Similar experiments performed with Aim $2 /$ Casp $1 / 11^{-1-}$ macrophages did not support the role of AIM2 in the NLRC4/ASC-dependent growth restriction that occurred in the absence of caspase-1/11 (S6 Fig). These data indicate that flagellated species of Legionellae trigger NLRC4 responses that are independent of caspase-1/11 but dependent on ASC. To further confirm the participation of caspase-8 in this NLRC4/ASC inflammasome, we silenced caspase-8 in Casp $1 / 11^{-/-}$and Asc/Casp $1 / 11^{-/}$macrophages. We confirmed the silencing by western blot analysis (Fig 5E and S7 Fig) and found that the reduction in caspase-8 expression impaired the restriction of bacterial replication in Casp 1/1 $11^{-1}$ infected with fliI (Fig 5F). Inhibition of caspase-8 expression affected neither the replication of fliT in Asc/Casp1/11 $1^{-/}$cells (Fig 5G) nor the replication of $\mathrm{flaA}^{-}$in Casp $1 / 11^{-/-}$and in Asc/ Casp $1 / 11^{--}$cells (Fig $5 \mathrm{H}$ and $5 \mathrm{I}$ ). Collectively, these data are consistent with the hypothesis that flagellin activates a response that is dependent on NLRC4, ASC and caspase-8 and occurs in the absence of caspase-1/11.

Casp $8^{-/}$mice are embryonic lethal [59], and we were not able to generate Casp $8 / 1 / 11^{1-}$ mice. Since the deletion of ASC impairs the assembly of the NLRC4/ASC/caspase- 8 inflammasome and caspase- 8 activation, we used Asc/Casp $1 / 11^{-/}$mice to assess the role of the NLRC4/ ASC/caspase-8 inflammasome in the restriction of Legionella replication in vivo. Using flagellin-positive bacteria such as L. pneumophila, L. gratiana and L. micdadei, we demonstrated that $A s c / C a s p 1 / 11^{--}$mice were highly permissive to bacterial replication and phenocopied infection of Nlrc4 $4^{-/}$mice (Fig 6A-6C). Casp $1 / 11^{-/}$mice were more permissive than C57BL/6, but they were less permissive than $\mathrm{Nlrc}^{-/}$mice (Fig 6A-6C). Experiments performed with $\mathrm{fliI}$ and $\mathrm{flaA} \mathrm{A}^{-}$indicated that $\mathrm{Asc} / \mathrm{Casp} 1 / 11^{-/}$were more permissive than Casp $1 / 11^{-/}$when infected with fli but not flaA (Fig 6D). To determine whether AIM2 accounted for the restriction of bacterial replication in the absence of caspase-1/11, we compared infection of Aim2/Casp1/ $11^{-/}$with Casp $1 / 11^{-/}$. We found that Aim $2 /$ Casp $1 / 11^{-/}$and Casp $1 / 11^{-/}$supported similar replication levels of fliT L. pneumophila in the lungs. In contrast, Asc/Casp $1 / 11^{-/-}$and $\mathrm{Nlrc}^{-/-}$mice were significantly more permissive to bacterial replication (S8 Fig). Collectively, these data indicate that AIM2 is dispensable for the functions of the NLRC4/ASC/caspase- 8 inflammasome. This molecular platform is assembled in response to flagellin-positive bacteria and operates to restrict bacterial replication in vitro and in vivo in a process that is independent of both caspase- 1 and caspase- 11 .

\section{Activation of the NLRC4/ASC/caspase-8 inflammasome triggers pore formation and cell death}

Activation of caspase-1 inflammasomes induces pyroptosis and contributes to the restriction of infection by flagellated bacteria such as L. pneumophila, Salmonella typhimurium and Burkholderia thailandensis [23]. Accordingly, we have previously demonstrated that L. pneumophila trigger pyroptosis in a process mediated by caspase- 1 and caspase-11, which are activated in response to flagellin and LPS, respectively $[20,24,35,61]$. Thus, we investigated whether activation of the NLRC4/ASC/caspase-8 inflammasome could trigger cell death in Casp1/11 ${ }^{-1}$ macrophages. We assessed membrane permeabilization fluorometrically in real time via the 


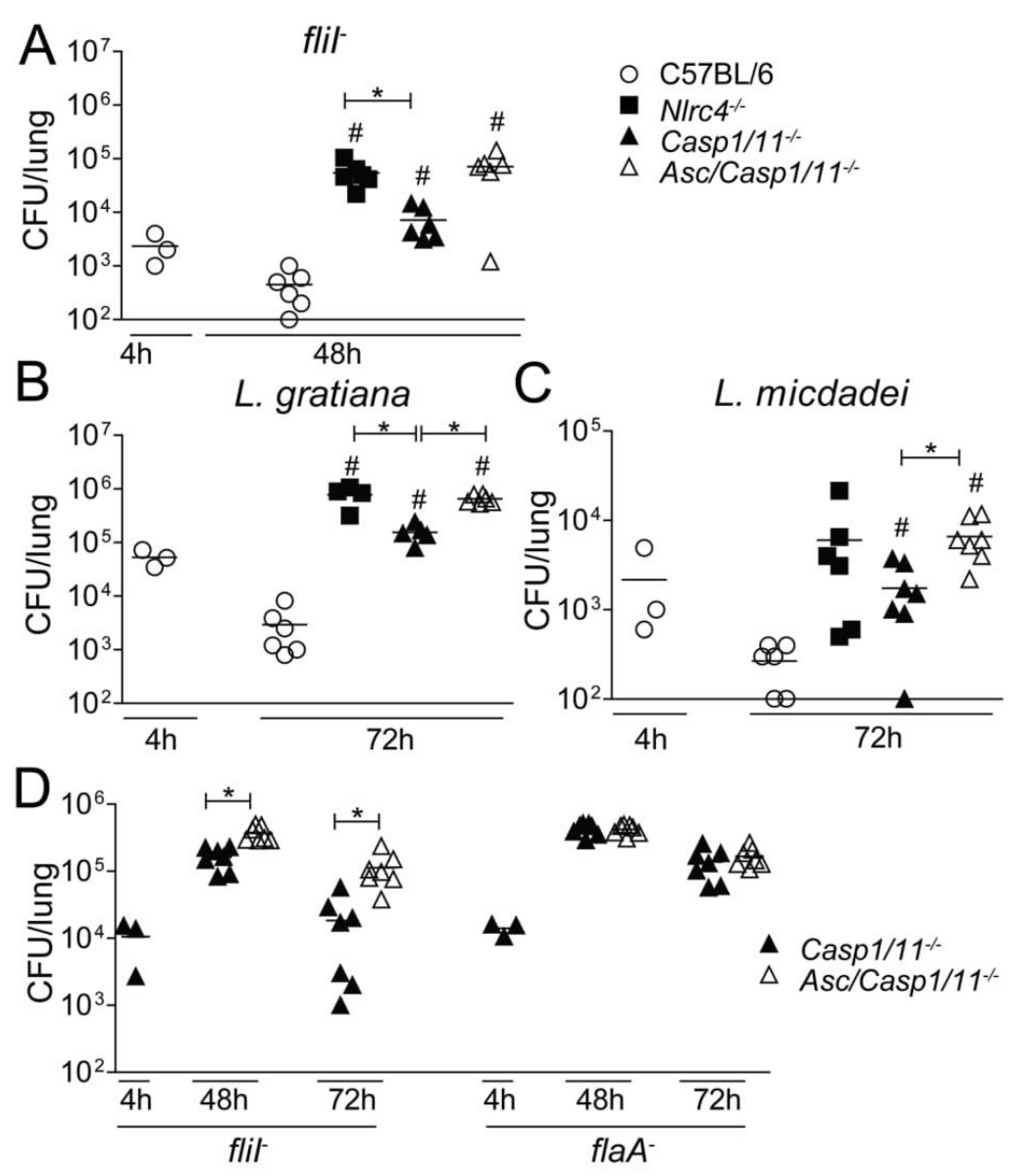

Fig 6. ASC is essential for NLRC4-mediated restriction of $L$. pneumophila replication independently

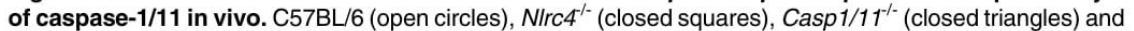
Asc $/$ Casp $1 / 11^{-1 /}$ (open triangles) mice were infected with motility-deficient $L$. pneumophila mutants expressing flagellin (flir, A, D), with flagellin-deficient $L$. pneumophila (fla $\left.A^{-}, \mathrm{D}\right)$, with $L$. gratiana (B) or with $L$. micdadei (C) at a dose of $10^{5}$ bacteria/mice. The mice were euthanized at 4,48 or 72 hours after infection. Dilutions of the lung homogenates were added to charcoal-yeast extract agar plates for colony-forming unit determination. Each dot represents a single animal, and the horizontal lines represent the averages. ${ }^{*}, P<0.05 .{ }^{\#}$, indicates $P<0.05$ compared with C57BL/6, Mann Whitney test. Data are presented for one representative experiment of five $(A)$, one $(B-C)$ and two $(D)$ experiments performed with similar results.

https://doi.org/10.1371/journal.ppat.1006502.g006

uptake of propidium iodide. Macrophages were infected with $f l i \Gamma$ or $f l a A$, and pore formation was monitored in real time for 6 hours. C57BL/6 macrophages triggered robust pore formation in response to infection with $f l i \Gamma$ and reduced pore formation in response to $\mathrm{flaA}^{-}$(Fig $7 \mathrm{~A}-7 \mathrm{C}$ ). The pore formation observed in C57BL/6 macrophages infected with $\mathrm{flaA}$ - mutants was dependent on caspase-11 [61] and will not be addressed herein. Importantly, despite the absence of both caspase- 1 and caspase-11, we detected significant pore formation in Casp1/ $11^{-/}$cells infected with fliI (Fig 7B). This response was not detected in Casp $1 / 11^{-/}$cells infected

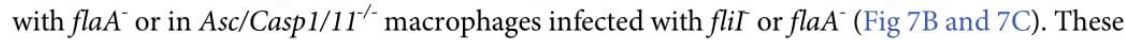
data support the hypothesis that NLRC4/ASC/caspase-8 induces pore formation. Experiments 

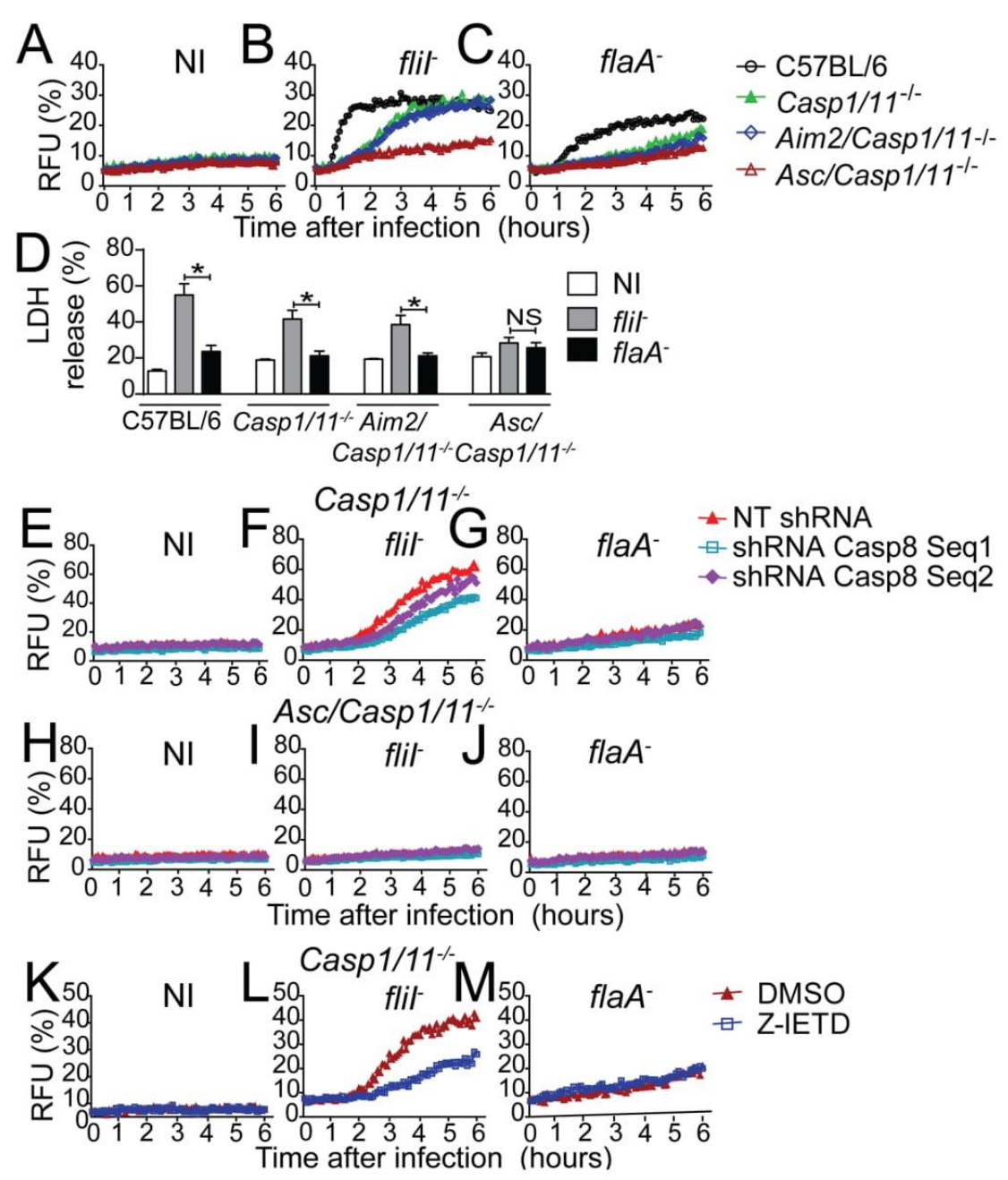

Fig 7. The NLRC4/ASC/caspase-8 inflammasome is important for pore formation and cell death independently of caspase-1/11. (A-D; K-M) Bone marrow-derived macrophages (BMDMs) were generated from C57BL/6, Casp 1/11 ${ }^{-/}$, Aim2/Casp $1 / 11^{-/}$and Asc/Casp $1 / 11^{-/}$mice and infected with motility-deficient $L$. pneumophila mutants expressing flagellin ( $f l i r)$ or with flagellin-deficient bacteria $\left(f l a A^{-}\right)$at a $\mathrm{MOI}$ of 5 . (E-J) BMDMs were transduced with retrovirus encoding shRNA sequences to target caspase-8 (Seq1, Seq2) and a non-target shRNA sequence (NT) and infected with flir or flaA at a MOI of 5. (A-C; E-J) Pore formation was assessed fluorometrically in real time by the uptake of propidium iodide. RFU (\%) represents the percentage of RFU estimated with cells lysed with Triton X-100. (D) LDH release was measured using the CytoTox 96 $\mathrm{LDH}$-release kit. The $\mathrm{LDH}$ release (\%) represents the percentage of $\mathrm{LDH}$ release estimated with cells lysed with Triton X-100. (K-M) BMDMs were treated with $50 \mu \mathrm{M}$ of Z-IETD or DMSO for 1 hour and infected with (L) flir or (M) flaA at a $\mathrm{MOI}$ of 5 . Pore formation was assessed fluorometrically in real time by the uptake of propidium iodide. Data show the average \pm SD of triplicate wells. ${ }^{*}, P<0.05$, Student's t test. NS, not significant; RFUs, relative fluorescence units; NI, uninfected. Data are presented for one representative experiment of five (A-C), three (E-J) and two (D and K-M) experiments with similar results.

https://doi.org/10.1371/journal.ppat.1006502.g007

performed using Aim2/Casp1/11/- macrophages corroborate our previous findings, indicating that AIM2 is not required for the activities of the NLRC4/ASC/caspase- 8 inflammasome (Fig $7 \mathrm{~B}$ and $7 \mathrm{C})$. Pore formation induced in response to caspase- 1 and caspase-11 activation 
culminates with the induction of macrophage lysis, a process that can be assessed by the presence of LDH in tissue culture supernatants $[24,61,62]$. Thus, we measured LDH release in the supernatants of macrophages infected with fliT and flaA for 8 hours. By comparing Casp1/ $11^{-1}$ and $A s c / C a s p 1 / 11^{-1}$ cells, we found that macrophage lysis occurred despite the absence of caspase-1/11 (Fig 7D). Cell death was flagellin-dependent because infections with fli but not $\mathrm{flaA}^{-}$induced LDH release (Fig 7D). The participation of caspase-8 in pore formation and cell death induced in caspase-1/11-deficient macrophages was evident using both MOI 5 (Fig 7) and MOI 10 (S9 Fig). Importantly, cell death was not observed in $\mathrm{Asc} / \mathrm{Casp} 1 / 11^{-/}$, a feature that corroborates the pore formation studies and indicates that the NLRC4/ASC/caspase-8 inflammasome triggers pore formation and lysis of infected cells. We also assessed whether the NLRC4/ASC/caspase-8 inflammasome was important for the activation of inflammatory cytokines. We found that whereas C57BL/6 macrophages readily triggered the production of IL-1 $\beta$ after 24 hours of infection with flagellated bacteria, the Casp $1 / 11^{-/}$or $A s c / C a s p 1 / 11^{-1}$ deficient cells do not trigger a IL-1 $\beta$ production (S10A Fig). The production of IL-12p40 by these cells confirmed that all macrophages were primed and could respond to L. pneumophila infection (S10B Fig). To evaluate the participation of caspase- 8 in cell death induced by the NLRC4/ ASC/caspase- 8 inflammasome, we silenced endogenous caspase- 8 using shRNA. Macrophages that were transduced with retrovirus encoding shRNA did not exhibit pore formation before infection, indicating that transduction itself did not trigger cell death (Fig $7 \mathrm{E}$ and $7 \mathrm{H}$ ). In contrast, pore formation was evident in Casp1/1 $11^{-/}$but not in Asc/Casp $1 / 11^{-/}$macrophages in response to $\mathrm{fliT}$ infection (Fig $7 \mathrm{~F}$ and $7 \mathrm{I}$ ). Pore formation induced in Casp $1 / 11^{-/}$was diminished in caspase-8-silenced cells (Fig 7F). In support of the role of flagellin for triggering these responses, we did not detect pore formation in cells infected with $\mathrm{flaA}^{-}$(Fig $7 \mathrm{G}$ and 7J). To further evaluate the participation of caspase- 8 in pore formation induced by flagellin, we performed pore formation assays using Z-IETD, a cell permeable peptide that binds irreversibly to the catalytic site of caspase-8 [63-65]. We found that treatment of Casp $1 / 11^{-/-}$macrophages with DMSO or Z-IETD did not cause pore formation in uninfected cells (Fig 7K). However, Z-IETD treatment reduced the pore formation induced by fli (Fig 7L) but not by flaA (Fig $7 \mathrm{M}$ ). Collectively, these data indicate that flagellin-positive bacteria trigger pore formation and cell death-independent of caspase-1/11 via a process that requires ASC and caspase-8.

\section{Naip5 is required for NLRC4/ASC/caspase-8 inflammasome activation in response to flagellated Legionella}

Our data reveal that the NLRC4/ASC/caspase- 8 inflammasome is activated in Casp $1 / 11^{-/-}$macrophages in response to infection with flagellated Legionella. To evaluate if Naip5 is required for activation of this inflammasome, we used shRNA to silence endogenous Naip5. In Naip5 silenced Casp $1 / 11^{-1-}$ macrophages, we detected a reduced activation of caspase- 8 in response to WT Lp and fliT bacteria (Fig 8A). Naip 5 silencing was confirmed by RT-PCR (Fig 8B). We also tested if Naip5 is important for pore formation induced via caspase- 8 in Casp $1 / 11^{-/-}$macrophages. By evaluating pore formation, we found that Naip5 is important for efficient pore formation in response to WT Lp and fliT bacteria (Fig 8D-8E). As previously reported, no pore formation was detected in response to $\mathrm{flaA}^{-}$bacteria (Fig 8F) or in Asc/Casp1/11 $1^{-1}$ macrophages (Fig 8G-8J). Finally, we tested if Naip5 is important for restriction of L. pneumophila replication in Casp $1 / 11^{-1-}$ macrophages. We found that Naip5 is important for restriction of flagellin-positive L. pneumophila replication in Casp1/11 $1^{-/}$macrophages (Fig $8 \mathrm{~K}$ ). Naip5 silencing did not affect the replication of fla $A^{-}$bacteria in Casp $1 / 11^{-1}$ macrophages (Fig 8L). As predicted, Asc/Casp $1 / 11^{-/}$macrophages were permissive to replication of both flaA and fli bacteria and Naip5 did not influenced this process (Fig $8 \mathrm{M}$ and $8 \mathrm{~N}$ ). Taken together, these 


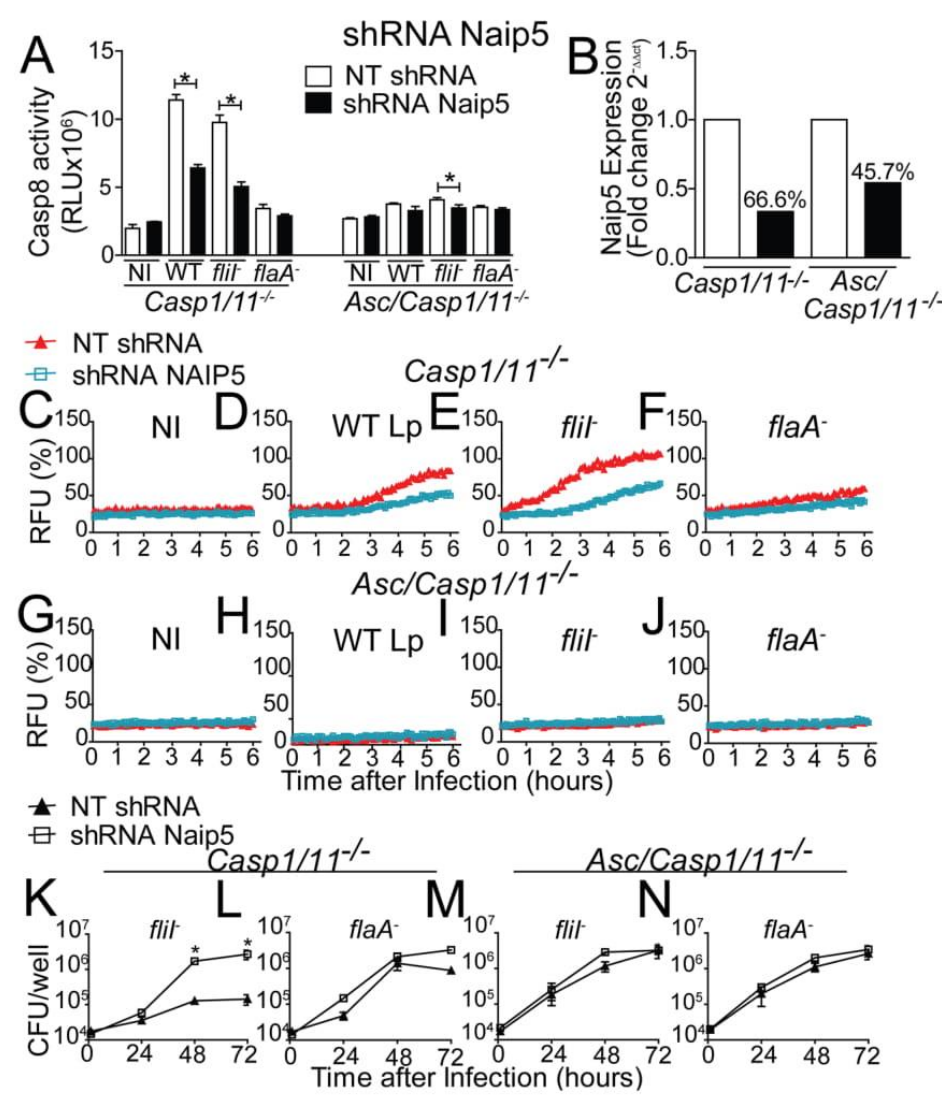

Fig 8. Naip5 is required for the functions of the NLRC4/ASC/Caspase-8 inflammasome independently of caspase-1/11. Bone marrow-derived macrophages (BMDMs) generated from Casp $1 / 11^{-/}$and Asc/Casp1/ $11 \%$ mice were transduced with a retrovirus encoding shRNA sequence to target Naip5 and a non-target shRNA sequence (NT). Transduced BMDMs were infected with wild-type $L$. pneumophila (WT Lp), motilitydeficient mutants expressing flagellin ( $f(i r)$ or with flagellin-deficient mutants ( $f l a A$ ) at a MOI of 10 . (A) 8 hours after infection the activity of caspase- 8 was measured using the Caspase- 8 Glo Assay. (B) Quantification of the Naip5 gene expression by Real Time qPCR. Gapdh gene was used as a control for normalization of expression levels. The number above the bars indicates the percentage of silencing compared to the NT shRNA (open bars). (C-J) Pore formation was assessed fluorometrically in real time by the uptake of propidium iodide. The RFU (\%) represents the percentage of RFU estimated with cells lysed with Triton X100. (K-N) The cells were infected with flir or fla $A^{-}$for 24,48 and 72 hours for CFU determination. Data show the average \pm SD of triplicate wells. ${ }^{*}, P<0.05$, Student's t test $(A)$ and ANOVA (K-N). NS, not significant; $\mathrm{RFU}$, relative fluorescence units; $\mathrm{NI}$, uninfected. Data are presented for one representative experiment of two (A-J) and three (K-N) experiments with similar results.

https://doi.org/10.1371/journal.ppat.1006502.g008

data indicates that Naip5 participate of the NLRC4/ASC inflammasome that trigger caspase- 8 activation in the absence of caspase-1/11.

Caspase- 8 is recruited to the NLRC4/ASC/caspase-1 inflammasome but it is only activated when caspase-1 or gasdermin-D is suppressed

In the experiments shown thus far, we used Casp $1 / 11^{-1-}$ macrophage as a tool to assess the caspase- 8 effects without the interference of caspase-1. However, because caspase- 1 is present in natural conditions, we tested if caspase-8 participates in the NLRC4/ASC inflammasome in 
the presence of caspase-1. First, we infected C57BL/6 macrophages with flagellin-positive $L$. pneumophila to assess if endogenous caspase- 8 colocalizes with the Naip5/NLRC4/ASC inflammasome. In uninfected conditions, we detected no significant puncta formation (Fig 9A). However, in response to fliI bacteria, caspase-8 colocalizes with ASC (Fig 9B) and caspase-1 (Fig 9C). We determined that caspase- 8 is present in more than $60 \%$ puncta containing caspase-1 (Fig 9C). These data indicates that regardless to the presence of caspase-1, the caspase- 8 is recruited to the inflammasome during activation.

Next, we evaluated caspase- 8 activation in wild-type macrophages. We found that caspase- 8 activation does not occur in C57BL/6 macrophages infected with L. pneumophila. As expected caspase-8 is readily activated in Casp $1 / 11^{-/}$, but not in Asc/Casp $1 / 11^{-/-}$macrophages infected with fliT bacteria (Fig 9D). To ensure similar genetic background, we intercrossed a F1 progeny of Casp $1 / 11^{-1}$ x C57BL/6 to obtain F2 littermate controls. Infections in macrophages from littermate control mice indicated that caspase- 8 activation occur in Casp $1 / 11^{-/}$, but not in Casp $1 / 11^{+/-}$and Casp $1 / 11^{+/+}$macrophages (Fig 9E). To further test whether the deficiency in caspase- 1 or caspase- 11 enable caspase- 8 activation, we performed experiments using mice single deficient in caspase- 1 or caspase- 11 as previously described $[35,66]$. We found that caspase-11 deficiency alone is not sufficient to enable caspase- 8 activation in response to L. pneumophila infection (Fig 9F). In contrast, caspase-1-deficient cells expressing caspase-11 as a transgene $\left(\mathrm{Casp}^{-/-}\right.$Casp $\left.11^{\text {tg }}\right)$ effectively trigger caspase- 8 activation in response to fli L. pneumophila (Fig 9F). These data indicate that caspase- 1 but not caspase-11 is required to prevent caspase- 8 activation.

Caspase-1 activation via the NLRC4 inflammasome is known to trigger activation of gasdermin-D (GSDMD) to induce cell death $[67,68]$. Thus, we tested if inhibition of GSDMD is sufficient to enable caspase- 8 activation in the presence of caspase- 1 . To achieve this, we inhibited endogenous GSDMD using shRNA and found that despite the presence of caspase-1, caspase- 8 is robustly activated when GSDMD is inhibited (Fig 9G). RT-PCR was used to confirm the silencing of the two different sequences of shRNA used (Fig 9H). To further confirm the GSDMD silencing, we performed pore formation assay in C57BL/6 macrophages infected with L. pneumophila. We found that GSDMD silencing inhibited the caspase-1-mediated pore formation induced by WT Lp and fliT L. pneumophila (S11A-S11D Fig). However, GSDMD did not participate of pore formation induced via caspase- 8 that occurs in Casp $1 / 11^{-1 /}$ macrophages (S11E-S11H Fig). Collectively, these data indicates that despite the presence of caspase-1, caspase-8 activation occur in the Naip5/NLRC4/ASC inflammasome when GSDMD is inhibited.

\section{Discussion}

The recognition of Legionella flagellin by the Naip5/NLRC4 inflammasome in macrophages is a major mechanism for the restriction of bacterial replication in mouse cells $[17-20,22,69,70]$. It is well accepted in the field that not all NLRC4 functions require caspase-1 [29,38,71,72]. This conclusion is supported by the observation that $\mathrm{Nlr}_{\mathrm{C}}{ }^{-/-}$mice (and their macrophages) are significantly more permissive to L. pneumophila replication than Casp $1 / 11^{-/}$mice $[29,38]$. Here, we unraveled this caspase-1/11-independent pathway and characterized an inflammasome composed of Naip5, NLRC4, ASC and caspase-8, which operates in the absence of caspase- 1 and caspase-11. This inflammasome effectively participates in the mechanisms involved in the restriction of bacterial replication in macrophages and in vivo. Previous biochemistry studies using yeast two-hybrid screening showed that NLRC4 is ubiquitinated by Sug1, a process that facilitates the activation of caspase-8 [51]. Thus, it is possible that Sug1 is also a component of this NLRC4 inflammasome. In addition, previous studies using the Salmonella 

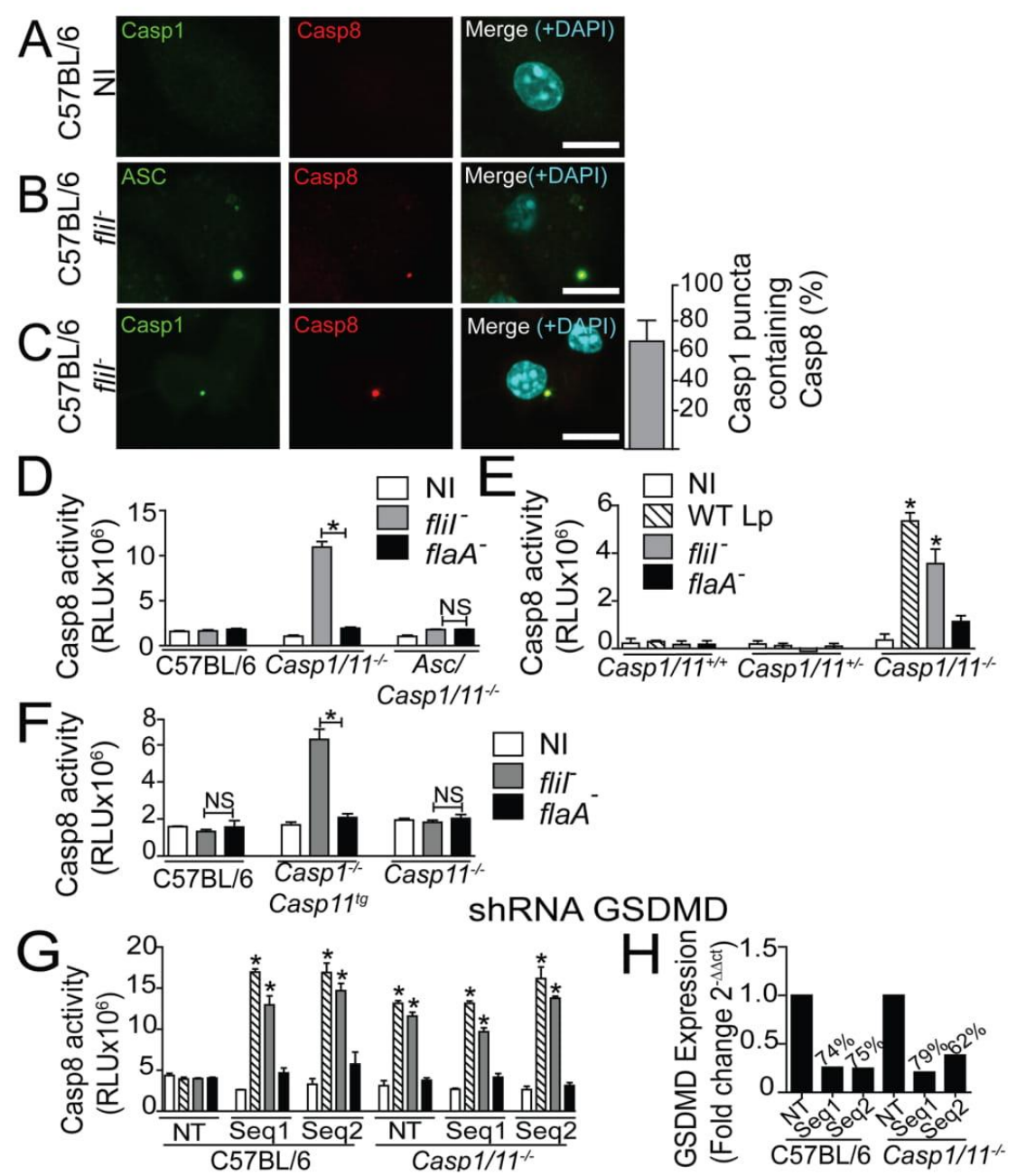

Fig 9. Caspase-8 colocalizes with the NLRC4/ASC/Caspase-1 inflammasome, but it is only activated if caspase-1 or gasdermin-D is inhibited. (A-C) Bone marrow-derived macrophages (BMDMs) generated from C57BL/6 mice were infected with motility-deficient $L$. pneumophila mutants expressing flagellin (flir) at a $\mathrm{MOI}$ of 10 for $8 \mathrm{~h}$. The cultures were stained with anti-caspase-1 (green) (A, C) or anti-ASC (green) (B), anticaspase-8 (red). Cell nuclei were stained with DAPI (cyan). Images were acquired by multiphoton microscopy with a $63 x$ oil immersion objective and analyzed using ImageJ software. The images are the maximal projection of a $z$ project. Scale bars, $10 \mu \mathrm{m}$. (C) The percentage of the caspase-1 puncta containing caspase- 8 was determined using an epifluorescence microscope. (D) BMDMs were generated from C57BL/6, Casp1/ $11^{\%}$ and $A s c / C a s p 1 / 11^{\%}$ mice and infected with flit or flaA ${ }^{*}$. (E) BMDMs were generated from Casp $1 / 11^{+/+}$ Casp $1 / 11^{+/}$and Casp $1 / 11^{-\%}$ littermate control mice and infected with WT, flir and flaA'. (F) BMDMs were generated from C57BL/6, Casp $1^{-1-}$ Casp $11^{t g}$ and Casp $11^{1 /}$ mice and infected with WT, flir and flaA . (G-H) BMDMs generated from C57BL/6 and Casp $1 / 11^{-1 /}$ mice were transduced with a retrovirus encoding shRNA sequences to target Gasdermin D (GSDMD) (Seq1, Seq2) and a non-target shRNA sequence (NT). (G) Transduced cells were infected with WT Lp, flit and flaA'. (D-G) Cells were infected with an MOI of 10 and after 8 hours the activity of caspase- 8 was measured using the Caspase- 8 Glo Assay. (H) GSDMD silencing was confirmed by Real Time qPCR. Gapdh gene was used as a control for normalization of expression levels. The numbers above the bars indicate the percentage of silencing compared to the NT sequence. Data show the average \pm SD of triplicate wells. ${ }^{*}, P<0.05$, Student's test in relation to $f l a A$. RLU, relative luminescence units; NI, non-infected. Data are presented for one representative experiment of two $(A-C$ and $E-H)$ and five (D) experiments with similar results.

https://doi.org/10.1371/journal.ppat.1006502.g009 
enterica serovar Typhimurium have indicated that both caspase- 8 and caspase- 1 are recruited to the ASC puncta in response to infection. However, caspase- 8 is involved in the synthesis of pro-IL-1 $\beta$ and is dispensable for Salmonella-induced cell death [32]. These data contrast with published data using L. pneumophila, which indicate that in the absence of caspase-1/11, no inflammatory cytokines are produced $[20,21,25,30,35,66]$. Accordingly, our data indicates that this Naip5/NLRC4/ASC/Caspase-8 inflammasome is very inefficient to trigger IL-1 $\beta$ maturation when caspase-1 is not present.

Importantly, AIM2 is not part of this NLRC4/ASC/caspase- 8 inflammasome. AIM2 is wellknown to trigger caspase- 8 activation via ASC $[33,34,58]$. Our data unequivocally demonstrate that AIM2 is neither a component of this inflammasome, nor is it required for inflammasome functions. AIM2 did not colocalize with the NLRC4/ASC/caspase-8 puncta, it was dispensable for the activation of caspase- 8 in response to flagellated L. pneumophila and for the induction of cell death and restriction of L. pneumophila replication. The pyrin domain of ASC can bind to the death domain of caspase-8 [46]. Thus, it is possible that the interactions of the ASC pyrin domain with the caspase- 8 dead domain are critical for the recruitment of caspase- 8 to the complex. Consistent with this hypothesis, our studies unequivocally show that ASC is required for the assembly and function of this NLRC4 inflammasome. Importantly, the characterization of this NLRC4/ASC/caspase-8 inflammasome accounted to clarify a controversy in the field concerning the participation of ASC in the NLRC4 inflammasome. Studies utilizing biochemistry and cells from gene-deficient mice have demonstrated that ASC is dispensable for NLRC4 functions, including pyroptosis and the restriction of L.pneumophila replication $[20,21,29]$. However, ASC is essential for caspase- 1 cleavage and the processing of inflammatory cytokines in response to flagellated L. pneumophila, a process that is NLRC4-dependent and NLRP3-independent $[20,21,25,30]$. In addition, ASC participates in the restriction of intracellular replication of L. pneumophila under certain circumstances [36,37]. Our studies provide data that help to consolidate these data in a cohesive model. NLRC4 can operate to form an inflammasome in absence of ASC that triggers pore formation and the restriction of bacterial replication $[20,21,25,30]$. This platform does not form puncta and is ineffective for triggering caspase-1 cleavage and processing inflammatory cytokines. When ASC is present, NLRC4 inflammasome associates with ASC and recruit caspase- 1 and caspase- 8 to the puncta. This inflammasome is very efficient to cleave caspase- 1 and inflammatory cytokines such as IL-1 $\beta$. Interestingly, our data indicate that caspase- 8 is not activated when caspase- 1 is present. However, when caspase-1 is missing or when Gasdermin-D is inhibited, we detected a robust caspase-8 activation. These data suggest that activation of caspase- 8 in the Naip5/NLRC4/ASC inflammasome functions as a backup strategy to guarantee cell death when key components of the pyroptotic cell death are inhibited. Interestingly, our data and previously published data indicate that gasdermin-D is dispensable for caspase-8-induced cell death [73]. Therefore, when gasdermin-D is inhibited, caspase- 8 engages gasdermin- $\mathrm{D}$-independent cell death. It is possible that caspase- 8 induces caspase- 3 and caspase- 7 to targed gasdermin-E (also known as DFNA5) to induce pore formation and cell death independent of gasdermin-D [74,75]. This may guarantee appropriate responses to pathogens that inhibit canonical components of pyroptotic cell death such as caspase-1 or gasdermin-D.

\section{Materials and methods}

\section{Bacterial culture}

The L. pneumophila bacteria used were JR32 and isogenic clean deletion mutants for motility (fli ) and flagellin (flaA ${ }^{-}$) [19,38]. L. micdadei (ATCC 33218) and L. gratiana (ATCC 49413) were used to generate streptomycin-resistant strains. RpsL mutants of $L$. micdadei and $L$. 
gratiana were isolated by plating these strains on CYE agar containing $100 \mu \mathrm{g} / \mathrm{ml}$ of streptomycin. All bacteria were grown on buffered charcoal-yeast extract (CYE) agar plates [ $1 \%$ yeast extract, $1 \%$ MOPS, $3.3 \mathrm{mM}$ L-cysteine, $0.33 \mathrm{mM} \mathrm{Fe}(\mathrm{NO} 3) 3,1.5 \%$ Bacto agar and $0.2 \%$ activated charcoal, $\mathrm{pH}$ 6.9] [76].

\section{Macrophages}

Bone Marrow derived macrophages (BMDMs) were generated from mice as previously described [77]. Briefly, bone marrow cells were harvested from femurs and differentiated with RPMI 1640 (Gibco) containing 20\% fetal bovine serum (FBS-Invitrogen) and 30\% L-929 cell-conditioned medium (LCCM), 2 mM L-glutamine (Sigma-Aldrich), $15 \mathrm{mM}$ Hepes (Gibco) and $100 \mathrm{U} / \mathrm{ml}$ penicillin-streptomycin (Sigma-Aldrich) at $37^{\circ} \mathrm{C}$ with $5 \% \mathrm{CO}_{2}$ [77]. BMDMs were seeded at $2 \times 10^{5}$ cells/well in 24-well plates and cultivated in RPMI 1640 medium (Gibco) supplemented with 10\% FBS, 5\% LCCM, 2 mM L-glutamine and $15 \mathrm{mM}$ Hepes.

\section{In vitro infections and CFU determination}

For the in vitro infections, the cultures were infected at a multiplicity of infection of $0.015,5$ or 10 followed by centrifugation for 5 minutes at $300 \mathrm{X} g$ at room temperature and incubation at $37^{\circ} \mathrm{C}$ in a $5 \% \mathrm{CO}_{2}$ atmosphere. In the colony-forming units (CFU) experiments, cultures infected at a MOI of 10 were washed two times with PBS, and $1 \mathrm{ml}$ of medium was added to each well. For CFU determination, the cultures were lysed in sterile water, and the cell lysates were combined with the cell culture supernatant from the respective wells. Lysates plus supernatants from each well were diluted in water, plated on CYE agar plates, and incubated for 4 days at $37^{\circ} \mathrm{C}$ for $\mathrm{CFU}$ determination as described previously $[28,38]$.

\section{Retroviral transduction and quantification of NLRC4-GFP and ASC-GFP puncta}

Murine Nlrc4 or Asc were cloned into the pEGFP (N2) vector (Clontech) using XhoI and BamHI restriction sites as previously described [30]. NLRC4-GFP or ASC-GFP and GFP were cloned into the pMSCV2.2 murine-specific retroviral vector (Clontech). The pCL vector system 51 was used to package the retroviruses in transfected monolayers of Hek Peak cells (ATCC CRL-2828), which were maintained in RPMI with 10\% FBS. The supernatant from the Hek Peak cells containing retrovirus was collected three days after transfection, filtered using a $0.45-\mu \mathrm{m}$ filter and used for BMDM transduction. BMDMs were obtained from Casp $1 / 11^{-1}$, Asc/Casp $1 / 11^{-1-}$ and Aim2/Casp $1 / 11^{-1-}$ mice and seeded in differentiation medium. On day 3 of differentiation, the supernatants containing retroviral were added to BMDMs in $20 \%$ FBS and $25 \%$ LCCM. After differentiation, the BMDMs were seeded at $2 \times 10^{5}$ cells/well in 24 -well plates containing 12-mm glass cover slides and cultivated in RPMI 1640 medium supplemented with 10\% FBS and 5\% LCCM. For the caspase colocalization experiments, the cultures were treated with $20 \mu \mathrm{m}$ of Z-VAD for 1 hour and infected at a MOI of 1,3 or 10 . After infection, the plates were centrifuged for 5 minutes at $300 \mathrm{Xg}$ at room temperature and incubated at $37^{\circ} \mathrm{C}$ in a $5 \% \mathrm{CO}_{2}$ atmosphere. At 1,2, 4 and 8 hours after infection, the cells were fixed with $4 \%$ paraformaldehyde, permeabilized with $0.05 \%$ saponin, stained with DAPI and mounted on glass slides using Prolong Gold Antifade Reagent (Invitrogen). For the colocalization assay, the cells were stained with rat anti-caspase-8 (Enzo- 1G12; 1:50), rabbit anti-cleaved caspase-8 (Cell signaling- 8592; 1:800), rabbit anti-cleaved caspase-3 (Cell signaling- 9664; 1:400); rabbit anti-cleaved caspase-7 (Cell signaling-8438; 1:400), anti-ASC (Adipogen- AL177; 1:250), goat anti-ASC (Santa Cruz-sc33958; 1:50), rabbit anti-caspase-1 (Santa Cruz- sc514; 
1:500) or anti-AIM2 (Cell signaling- 13095; 1:400), followed by Alexa 594-conjugated goat anti-rabbit secondary $\mathrm{Ab}$ (Invitrogen; 1:3000), Alexa 594-conjugated goat anti-rat secondary $\mathrm{Ab}$ (Invitrogen; 1:3000) or Alexa 647-conjugated chicken anti-rabbit secondary Ab (Invitrogen; 1:2000) and DAPI and mounted on glass slides using Prolong Gold Antifade Reagent (Invitrogen). The images were processed using LAS AF software (Leica Microsystems) and analyzed under fluorescence using a Leica DMI 4000B inverted microscope with a 100X oil objective. The number of NLRC4-GFP or ASC-GFP puncta in the transduced cells and the colocalization were quantified. Bacteria were not stained. Therefore, the whole cell population was scored. Multiphoton microscopy images were acquired using an LSM 780 Zeiss AxioObserver microscope equipped with a $63 \mathrm{X}$ oil immersion objective and analyzed using ImageJ software.

\section{Retroviral silencing of caspase-8, Naip5 and GSDMD}

For retroviral silencing of caspase-8, Naip5 and GSDMD (Gasdermin D), Hek Peak cells were transfected with lentiviral vectors encoding a small hairpin RNA (shRNA) targeting caspase-8 [Sigma- Seq1: TRCN0000231279 (Sequence- CCGGTCATCTCACAAGAACTATATTCTCG AGAATATAGTTCTTGTGAGATGATTTTTG); Seq2: TRCN0000231281 (Sequence-CCGG TCCTGACTGGCGTGAACTATGCTCGAGCATAGTTCACGCCAGTCAGGATTTTTG)], Naip5 [Sigma- TRCN0000114742 (Sequence-CCGGCGCTTGATTATCTTCTGGAAACT CGAGTTTCCAGAAGATAATCAAGCGTTTTTG)], GSDMD [Sigma- TRCN0000219619 (Sequence-CCGGGATTGATGAGGAGGAATTAATCTCGAGATTAATTCCTCCTCATC AATCTTTTTG); TRCN0000219620 (Sequence-CCGGCCTAAGGCTGCAGGTAGAATC CTCGAGGATTCTACCTGCAGCCTTAGGTTTTTG)] and a negative control vector that included a non-target shRNA sequence (NT). The plates were treated with polyethylenimine (Sigma-Aldrich) (Corning). Transduced cells were maintained in RPMI 1640 medium supplemented with $10 \% \mathrm{FBS}$ at $37^{\circ} \mathrm{C}$ and $5 \% \mathrm{CO}_{2}$. Lentiviruses expressing shRNAs were collected, filtered using a $0.45-\mu \mathrm{m}$ filter and added to the BMDMs. After selection with puromycin, the resistant cells were seeded at $2 \times 10^{5}$ cells/well in 24 -well plates and infected with fli or $_{\text {flaA }}{ }^{-}$ for CFU determination. The caspase- 8 silencing efficiency was measured by immunoblotting: $1 \mathrm{X} 10^{6}$ cells were lysed in RIPA buffer ( $10 \mathrm{mM}$ Tris-HCl, pH 7.4, 1 mM EDTA, $150 \mathrm{mM}$ $\mathrm{NaCl}, 1 \%$ Nonidet P- $40,1 \%$ deoxycholate, and $0.1 \%$ SDS) in the presence of a protease inhibitor cocktail (Roche). The lysates were suspended in $4 \mathrm{X}$ Laemmli buffer, boiled for 5 minutes, resolved by $15 \%$ SDS PAGE and transferred (Semidry Transfer Cell, Bio-Rad) to $0.22-\mu \mathrm{m}$ nitrocellulose membranes (GE Healthcare). The membranes were blocked in Tris-buffered saline (TBS) with $0.01 \%$ Tween-20 and 5\% non-fat dry milk for 1 hour. Rat anti-caspase-8 p55 (Enzo-1G12; 1:500) and anti-rat peroxidase-conjugated antibody (KPL, 1:3000) were diluted in blocking buffer for the incubations (overnight for anti-caspase- 8 and 1 hour for the secondary antibody). The ECL luminol reagent (GE Healthcare) was used for antibody detection. For evaluation of caspase- 8 silencing by immunoblots, Image J software were used to estimate the ratio of caspase- 8 p 55 to $\alpha$-actin.

\section{Caspase-8 activation}

To assess caspase- 8 activation, BMDMs were infected with $f l i T$ or $f l a A^{-}$for 8 hours, and the activity of caspase- 8 was measured using the Caspase- 8 Glo Assay (Promega) according to manufacturer's recommendations. To evaluate caspase- 8 activation by western blot analysis, 1 $\mathrm{X} 10^{7}$ cells were infected at a MOI of 10 and lysed 8 hours after infection in RIPA buffer with protease inhibitor, as previously described. The lysates were suspended in $4 \mathrm{X}$ Laemmli buffer, boiled for 5 minutes, resolved by $15 \%$ SDS PAGE and transferred to $0.22-\mu \mathrm{m}$ nitrocellulose 
membranes. The membranes were blocked in Tris-buffered saline (TBS) with $0.01 \%$ Tween20 and $5 \%$ non-fat dry milk or for 1 hour. The mouse anti-caspase-8 (Enzo- 1G12) and antirabbit peroxidase-conjugated antibody (KPL; 1:3000) were diluted in blocking buffer for the incubations (overnight for anti-cleaved caspase- 8 and 1 hour for the secondary antibody). ECL luminol reagent (GE Healthcare) was used for antibody detection.

\section{Real Time q-PCR}

Total RNA was extracted from $2 \times 10^{6}$ macrophages using total RNA isolation kit (illustra RNAspin, GE Healthcare, UK), according to manufacturer's instructions. After extraction, an aliquot of $2 \mu$ was used to determine the RNA concentration in NanoDrop (Thermo Fisher Scientific) and $1 \mu \mathrm{g}$ of the extracted RNA was used for the cDNA conversion using the iScriptTM cDNA Synthesis kit (BIO-RAD) in a thermal cycler. The cDNA (10 ng) was used for the quantification of the Caspase 8 gene expression (TaqMan Assay: Casp 8-Mm01255716_m1) by realtime PCR using TaqMan Fast Advanced Master Mix, according to the manufacturer's instruction (Applied Biosystems). Actin beta (Actb) gene (TaqMan Assay: Actb-Mm00607939_s1) was used as a control for normalization of expression levels. The quantification of GSDMD and Naip 5 were performed using $25 \mathrm{ng}$ of cDNA and $10 \mu \mathrm{M}$ of each primer, $1 \mathrm{X}$ SYBR Green (Applied Biosystems), and was normalized using the housekeeping gene glyceraldehyde-3phosphate dehydrogenase (Gapdh). The specificity of the PCR products was assessed by melting curve analysis for all samples. The following primers were used: Gapdh, FWD- AGGTCGGTG TGAACGGATTTG, REV-TGTAGACCATGTAGTTGAGGTCA, GSDMD, FWD-TCATGT GTCAACCTGTCAATCAAGGACAT, REV- CATCGACGACATCAGAGACTTTGAAGGA, NAIP5, FWD- GTTGAGATTGGAGAAGACCTCG, REV-CACACGTGAAAGCAACCATGG. The real-time quantitative reaction was performed in the Viia 7 Real-Time PCR System (Applied Biosystems). The results were analyzed using the $2^{-\Delta \Delta C T}$ method and are expressed in relation to the reference group. The percentage of silencing knockdown was estimated using the $\left[1-\left(2^{-\Delta \Delta C T}\right)\right.$ $\mathrm{x}$ 100] equation [78].

\section{Mice and in vivo infections}

Mice used in this study were breed and maintained in institutional animal facilities. Mice used

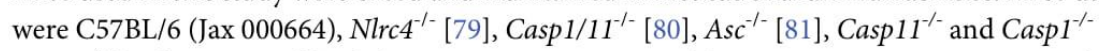
Casp $11^{\text {tg }}[66]$ were. Double-deficient mice were generated by intercrossing a F1 progeny of the parental strains. All mice were matched by sex and age (all were at least 8 weeks old at the time of infection) and were in a C57BL/6 mouse genetic background. For the in vivo experiments, approximately 5-7 mice per group were used, as indicated in the figures. For in vivo infections, the mice were anesthetized with ketamine and xylazine $(50 \mathrm{mg} / \mathrm{kg}$ and $10 \mathrm{mg} / \mathrm{kg}$, respectively) by intraperitoneal injection followed by intranasal inoculation with $40 \mu \mathrm{l}$ of phosphate-buffered saline (PBS) containing 1 X $10^{5}$ bacteria per mouse. For CFU determination, the lungs were harvested and homogenized in $5 \mathrm{ml}$ of sterile water for 30 seconds using a tissue homogenizer (Power Gen 125; Thermo Scientific). Lung homogenates were diluted in sterile water and plated on CYE agar plates for CFU determination as previously described [28,38].

\section{Pore formation assay}

Pore formation in BMDMs was quantified based on the permeability to propidium iodide (PI) in damaged cells as previously described [61]. BMDMs were seeded in a black, clear-bottom 96-well plate ( 1 X $10^{5}$ cells/well). Before infection, the medium was replaced with $10 \%$ RPMI without phenol red, $0.038 \mathrm{~g} / \mathrm{ml} \mathrm{NaHCO} 3,6 \mu \mathrm{l} / \mathrm{ml}$ PI and anti-L. pneumophila (1:1000). Infected BMDMs were maintained at $37^{\circ} \mathrm{C}$, and PI was excited at $538 \mathrm{~nm}$. The fluorescence 
emission was read at $617 \mathrm{~nm}$ every 5 minutes using a plate fluorometer (SpectraMax i3x, Molecular Devices). Total pore formation was determined by lysing cells with Triton X-100.

\section{Lactate dehydrogenase release assay and ELISA}

BMDMs were seeded in 24-well plates ( $5 \times 10^{5}$ cells/well). Infections were performed in RPMI1640 medium without phenol red, $15 \mathrm{mM}$ HEPES and $2 \mathrm{~g} / 1 \mathrm{NaHCO}_{3}$ supplemented with $10 \%$ FBS. After 8 hours of infection, the supernatants were collected for analysis of lactate dehydrogenase $(\mathrm{LDH})$ release. Total $\mathrm{LDH}$ was determined by lysing the cultures with Triton $\mathrm{X}-100$. LDH was quantified using the CytoTox $96 \mathrm{LDH}-$ release kit (Promega). For cytokine determination, enzyme-linked immunosorbent assay (ELISA) were used. BMDMs were seeded into 24 -well plates ( $5 \times 10^{5}$ cells/well) and infected with WT Lp, fliI and flaA- (MOI 10) for 24 hours. BMDMs supernatant was assessed using ELISA kits according to manufacturer's recommendations (BD Biosciences).

\section{Ethics statement}

The care of the mice was in compliance with the institutional guidelines on ethics in animal experiments; approved by CETEA (Comissão de Ética em Experimentação Animal da Faculdade de Medicina de Ribeirão Preto, approved protocol number 218/2014). CETEA follow the Brazilian national guidelines recommended by CONCEA (Conselho Nacional de Controle em Experimentação o Animal). For euthanasia, the mice were treated with ketamine and xylazine (50 $\mathrm{mg} / \mathrm{kg}$ and $10 \mathrm{mg} / \mathrm{kg}$, respectively) by intravenous injection.

\section{Statistical analysis}

The data were plotted and analyzed using GraphPad Prism 5.0 software. The statistical significance was calculated using the Student's t-test or analysis of variance (ANOVA). Nonparametric test Mann-Whitney $\mathrm{U}$ test were used for analysis of in vivo experiments. Differences were considered statistically significant when $P$ was $<0.05$, as indicated by an asterisk in the figures.

\section{Supporting information}

S1 Fig. Restriction of L. pneumophila replication is fully dependent on NLRC4 and flagellin, and partially dependent on caspase-1/11. Bone marrow-derived macrophages (BMDMs) from C57BL/6 (open circles), Nlrc4 $4^{-/-}$(closed squares), Casp $1 / 11^{-/}$(closed triangles) and $\mathrm{Asc}^{-1-}$ (open inverted triangles) mice were infected with L. pneumophila for CFU determination. (A, B) Cells were infected with wild-type L. pneumophila (WT LP). (C, D) Cells were infected with motility-deficient mutants expressing flagellin $(f l i T)$. (E, F) Cells were infected with flagellindeficient mutants $\left(f l a A^{-}\right)$. BMDMs were infected with $3 \times 10^{3}$ (MOI 0.015 ) or $2 \times 10^{5}$ (MOI 10) bacteria per well and incubated for $24,48,72$ and 96 hours for CFU determination. Data show the average \pm SD of triplicate wells. ${ }^{*}, P<0.05$ compared with Casp $1 / 11^{-/-}$BMDMs, ANOVA. Data are presented for one representative experiment of two experiments with similar results. (TIF)

S2 Fig. Caspase- 8 but not caspase- 3 and caspase-7 colocalize with NLRC4-GFP and ASC-GFP puncta. Bone marrow-derived macrophages (BMDMs) generated from Casp 1/11 1 mice were transduced with retrovirus encoding NLRC4-GFP (A) or ASC-GFP (B) and infected with motility-deficient $L$. pneumophila mutants expressing flagellin (fliI) at a MOI of 10 for $8 \mathrm{~h}$. (A-B) The percentage of colocalization of caspase- 3 , caspase- 7 and caspase- 8 with NLRC4-GFP and ASC-GFP was determined using an epifluorescence microscope. (C-E) BMDMs generated from Casp $1 / 11^{-/-}$mice were infected with fliT at a MOI of 10 for $8 \mathrm{~h}$. The 
cultures were fixed and stained with anti-ASC (green), anti-caspase-3 (red) (C), anti-caspase-7 (red) (D), anti-caspase-8 (red) (E). Cell nuclei were stained with DAPI (cyan). Images were acquired by multiphoton microscopy with a $63 \mathrm{x}$ oil immersion objective and analyzed using ImageJ software. The images are the maximal projection of a z project. Scale bar, $10 \mu \mathrm{m}$. Data show the average \pm SD of triplicate wells. ${ }^{*}, P<0.05$, Student's $t$ test. Data are presented for one representative experiment of two experiments with similar results.

(TIF)

S3 Fig. AIM2 does not colocalize and is not required for NLRC4-GFP puncta formation. Bone marrow-derived macrophages (BMDMs) generated from Casp $1 / 11^{-/-}$and Aim2/Casp1/ $11^{-/}$mice were transduced with retrovirus encoding NLRC4-GFP and infected with wild-type L. pneumophila (WT) or with motility-deficient L. pneumophila mutants expressing flagellin (fliI) at a MOI of 10 for $8 \mathrm{~h}$. (A) The cultures were stained with anti-AIM2 (red), the cell nuclei were stained with DAPI (cyan) and the NLRC4-GFP puncta is shown in green. The percentage of colocalization of AIM2 with NLRC4-GFP is shown. Images were acquired by multiphoton microscopy with a $63 \mathrm{x}$ oil immersion objective and analyzed using ImageJ software. Scale bar, $10 \mu \mathrm{m}$. (B) Quantification of the number of transduced cells containing NLRC4-GFP in response to WT or fliT infection was estimated in Casp $1 / 11^{-/-}$and Aim2/Casp $1 / 11^{-1-}$ BMDMs. Data show the average \pm SD of triplicate wells. NS, not significant, Student's t test. NI, uninfected. Data are presented for one representative experiment of two experiments with similar results.

S4 Fig. AIM2 is not required for caspase-8 activation in response to flagellated L. pneumophila. Bone marrow-derived macrophages (BMDMs) generated from Casp $1 / 11^{-/}$and Aim $2 /$ Casp $1 / 11^{-/}$mice were infected with motility-deficient $L$. pneumophila mutants expressing flagellin $(f l i \Gamma)$ or with flagellin-deficient bacteria $\left(f l a A^{-}\right)$at a MOI of 10 for 8 hours. The activity of caspase- 8 was measured using the Caspase- 8 Glo Assay. Data show the average \pm SD of triplicate wells. ${ }^{*}, P<0.05$, Student's $t$ test. NI, uninfected. Data are presented for one representative experiment of two experiments with similar results.

S5 Fig. Caspase-8 quantification in the western blot shown in Fig 4A. Bone marrow-derived macrophages (BMDMs) generated from Casp $1 / 11^{-1}$ mice were transduced with a retrovirus encoding shRNA sequences to target caspase-8 (Seq1, Seq2) and a non-target shRNA sequence (NT). The silencing was confirmed by western blot analysis (Fig 4A). Cell lysates were separated by SDS-PAGE, blotted and probed with anti-caspase- 8 (pro-caspase- 8 p55) and anti- $\alpha$-actin. Immunoblots were analyzed in Image J software and the caspase- 8 p55 to $\alpha$-actin ratio is shown. (TIF)

S6 Fig. AIM2 is not required for NLRC4-mediated restriction of $L$.pneumophila replication in macrophages. Bone marrow-derived macrophages (BMDMs) from C57BL/6, $\mathrm{NlrC}^{-/}$, Casp $1 / 11^{-/}$and Aim2/Casp $1 / 11^{-/-}$mice were infected with motility-deficient L. pneumophila mutants expressing flagellin ( $f l i T$ ) at a MOI of 0.015 . The cultures were incubated for $24,48,72$ and 96 hours after infection for CFU determination. Data show the averages \pm SD of triplicate wells. ${ }^{*}, P<0.05$, compared with Casp $1 / 11^{-/}$cells. Student's t test. Data are presented for one representative experiment of three experiments with similar results.

S7 Fig. Caspase-8 quantification in the western blot shown in Fig 5E. Bone marrow-derived macrophages (BMDMs) generated from Casp $1 / 11^{-1-}$ and Asc/Casp $1 / 11^{-/}$mice were transduced with a retrovirus encoding shRNA sequences to target caspase- 8 (Seq1, Seq2) and a non-target 
shRNA sequence (NT). The silencing was confirmed by western blot analysis (Fig 5E). Cell lysates were separated by SDS-PAGE, blotted and probed with anti-caspase- 8 (pro-caspase- 8 p55) and anti- $\alpha$-actin. Immunoblots were analyzed in Image J software and the caspase- 8 p 55 to $\alpha$-actin ratio is shown.

(TIF)

S8 Fig. AIM2 is not required for NLRC4-mediated restriction of $L$. pneumophila infection in vivo. C57BL/6 (open circles), $\mathrm{Nlrc}^{-/-}$(closed squares), Casp1/11 $1^{-/-}$(closed triangles), Aim $2 /$ Casp $1 / 11^{-/}$(open diamond) and Asc/Casp $1 / 11^{-/-}$(closed triangles) mice were infected intranasally with $1 \times 10^{5}$ motility-deficient $L$. pneumophila mutants expressing flagellin $(f l i I)$. The mice were euthanatized at 4 and 48 hours after infection. Dilutions of the lung homogenates were added to charcoal-yeast extract agar plates for colony-forming unit determination. Each dot represents a single animal, and the horizontal lines represent averages. ${ }^{*}, P<0.05$, Student's t test. NS, not significant.

(TIF)

S9 Fig. The NLRC4/ASC/caspase-8 inflammasome is important for pore formation and cell death independently of caspase-1/11. Bone marrow-derived macrophages (BMDMs) were generated from C57BL/6, Casp $1 / 11^{-/}$and Asc/Casp $1 / 11^{--}$mice and infected with motility-deficient $L$. pneumophila mutants expressing flagellin $(f l i I)$ or with flagellin-deficient bacteria $\left(f l a A^{-}\right)$ at a MOI of 10. (A-C) Pore formation was assessed fluorometrically in real time by the uptake of propidium iodide. RFU (\%) represents the percentage of RFU estimated with cells lysed with Triton X-100. (D) After 8 hours the LDH release was measured using the CytoTox 96 LDHrelease kit. The $\mathrm{LDH}$ release (\%) represents the percentage of $\mathrm{LDH}$ released compared with cells lysed with Triton X-100. Data show the average \pm SD of triplicate wells. ${ }^{*}, P<0.05$, Student's t test. NS, not significant; RFU, relative fluorescence units; NI, uninfected. Data are presented for one representative experiment of five (A-C) and two (D) experiments with similar results. (TIF)

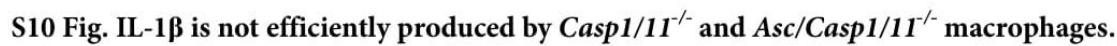
Bone marrow-derived macrophages (BMDMs) were generated from C57BL/6, Casp1/11 $1^{-1}$ and Asc/Casp $1 / 11^{-1-}$ mice and infected with wild-type L. pneumophila (WT Lp), motility-deficient mutants expressing flagellin $(f l i \Gamma)$ or with flagellin-deficient mutants $\left(\right.$ flaA $\left.^{-}\right)$at a MOI of 10. The production of IL-1 1 (A) and IL-12p40 (B) in the tissue culture supernatants was estimated by ELISA at 24 hours after infection. Data show the average \pm SD of triplicate wells. ${ }^{*}, P<0.05$, Student's t test. nd, not detected; RFU, relative fluorescence units; NI, uninfected. Data are presented for one representative experiment of two experiments with similar results. (TIF)

S11 Fig. Gasdermin-D is important for pore formation in C57BL/6 but not in Casp1/11 ${ }^{-/}$ macrophages. BMDMs generated from C57BL/6 (A-D) and Casp $1 / 11^{-/-}(\mathrm{E}-\mathrm{H})$ mice were transduced with a retrovirus encoding shRNA sequence to target Gasdermin D (GSDMD) (Seq1) and a non-target shRNA sequence (NT). Transduced cells were infected with wild-type L. pneumophila (WT Lp) (B and F), motility-deficient mutants expressing flagellin (fliI) (C and $\mathrm{G})$ or with flagellin-deficient mutants $\left(f l a A^{-}\right)(\mathrm{D}$ and $\mathrm{H})$ at a $\mathrm{MOI}$ of 10 . Pore formation was assessed fluorometrically in real time by the uptake of propidium iodide. The RFU (\%) represents the percentage of RFU compared with cells lysed with Triton X-100. Data show the average \pm SD of triplicate wells. RFU, relative fluorescence units; NI, uninfected. Data are presented for one representative experiment of two experiments with similar results.

(TIF) 


\section{Acknowledgments}

We are grateful to Maira Nakamura, Catarina Horta, Leticia Corsi and Victoria dos Santos for their technical assistance. We also thank Roberta Ribeiro Rosales for technical assistance in the institutional facility of the Multiphoton Microscopy. We thank Richard Flavell (Yale University) for providing the Casp $1 / 11^{-1-}$ mice and Vishva Dixit (Genentech) for providing the Casp $11^{--}$and Casp $^{-1-}$ Casp $11^{\text {tg }}$ mice.

\section{Author Contributions}

Conceptualization: Danielle P. A. Mascarenhas, Dario S. Zamboni.

Data curation: Danielle P. A. Mascarenhas.

Formal analysis: Danielle P. A. Mascarenhas, Daiane M. Cerqueira, Marcelo S. F. Pereira. Funding acquisition: Dario S. Zamboni.

Investigation: Danielle P. A. Mascarenhas, Daiane M. Cerqueira, Marcelo S. F. Pereira, Fernanda V. S. Castanheira, Talita D. Fernandes, Graziele Z. Manin, Larissa D. Cunha.

Methodology: Danielle P. A. Mascarenhas, Graziele Z. Manin, Larissa D. Cunha.

Project administration: Dario S. Zamboni.

Resources: Dario S. Zamboni.

Supervision: Dario S. Zamboni.

Validation: Danielle P. A. Mascarenhas, Daiane M. Cerqueira, Marcelo S. F. Pereira.

Visualization: Danielle P. A. Mascarenhas, Dario S. Zamboni.

Writing - original draft: Danielle P. A. Mascarenhas, Dario S. Zamboni.

Writing - review \& editing: Danielle P. A. Mascarenhas, Dario S. Zamboni.

\section{References}

1. Fraser DW, Tsai TR, Orenstein W, Parkin WE, Beecham HJ, et al. (1977) Legionnaires' disease: description of an epidemic of pneumonia. N Engl J Med 297: 1189-1197. https://doi.org/10.1056/ NEJM197712012972201 PMID: 335244

2. Horwitz MA (1983) The Legionnaires' disease bacterium (Legionella pneumophila) inhibits phagosomelysosome fusion in human monocytes. J Exp Med 158: 2108-2126. PMID: 6644240

3. McDade JE, Shepard CC, Fraser DW, Tsai TR, Redus MA, et al. (1977) Legionnaires' disease: isolation of a bacterium and demonstration of its role in other respiratory disease. N Engl J Med 297: 11971203. https://doi.org/10.1056/NEJM197712012972202 PMID: 335245

4. Newton HJ, Ang DK, van Driel IR, Hartland EL (2010) Molecular pathogenesis of infections caused by Legionella pneumophila. Clin Microbiol Rev 23: 274-298. https://doi.org/10.1128/CMR.00052-09 PMID: 20375353

5. Khodr A, Kay E, Gomez-Valero L, Ginevra C, Doublet P, et al. (2016) Molecular epidemiology, phylogeny and evolution of Legionella. Infect Genet Evol 43: 108-122. https://doi.org/10.1016/j.meegid.2016. 04.033 PMID: 27180896

6. Berger KH, Isberg RR (1993) Two distinct defects in intracellular growth complemented by a single genetic locus in Legionella pneumophila. Mol Microbiol 7: 7-19. PMID: 8382332

7. Berger KH, Merriam JJ, Isberg RR (1994) Altered intracellular targeting properties associated with mutations in the Legionella pneumophila dotA gene. Mol Microbiol 14: 809-822. PMID: 7891566

8. Isberg RR, O'Connor TJ, Heidtman M (2009) The Legionella pneumophila replication vacuole: making a cosy niche inside host cells. Nat Rev Microbiol 7: 13-24. https://doi.org/10.1038/nrmicro1967 PMID: 19011659 
9. Roy CR, Berger KH, Isberg RR (1998) Legionella pneumophila DotA protein is required for early phagosome trafficking decisions that occur within minutes of bacterial uptake. Mol Microbiol 28: 663-674. PMID: 9632267

10. Swanson MS, Hammer BK (2000) Legionella pneumophila pathogesesis: a fateful journey from amoebae to macrophages. Annu Rev Microbiol 54: 567-613. https://doi.org/10.1146/annurev.micro.54.1. 567 PMID: 11018138

11. Yamamoto Y, Klein TW, Newton CA, Widen R, Friedman $H$ (1988) Growth of Legionella pneumophila in thioglycolate-elicited peritoneal macrophages from A/J mice. Infect Immun 56: 370-375. PMID: 3257460

12. Beckers MC, Yoshida S, Morgan K, Skamene E, Gros $P$ (1995) Natural resistance to infection with Legionella pneumophila: chromosomal localization of the Lgn1 susceptibility gene. Mamm Genome 6: 540-545. PMID: 8589525

13. Dietrich WF, Damron DM, Isberg RR, Lander ES, Swanson MS (1995) Lgn1, a gene that determines susceptibility to Legionella pneumophila, maps to mouse chromosome 13. Genomics 26: 443-450. PMID: 7607666

14. Diez E, Yaraghi Z, MacKenzie A, Gros $P(2000)$ The neuronal apoptosis inhibitory protein (Naip) is expressed in macrophages and is modulated after phagocytosis and during intracellular infection with Legionella pneumophila. J Immunol 164: 1470-1477. PMID: 10640764

15. Diez E, Lee SH, Gauthier S, Yaraghi Z, Tremblay M, et al. (2003) Birc1e is the gene within the Lgn1 locus associated with resistance to Legionella pneumophila. Nat Genet 33: 55-60. https://doi.org/10. 1038/ng1065 PMID: 12483212

16. Wright EK, Goodart SA, Growney JD, Hadinoto V, Endrizzi MG, et al. (2003) Naip5 affects host susceptibility to the intracellular pathogen Legionella pneumophila. Curr Biol 13:27-36. PMID: 12526741

17. Amer A, Franchi L, Kanneganti TD, Body-Malapel M, Ozoren N, et al. (2006) Regulation of Legionella phagosome maturation and infection through flagellin and host Ipaf. J Biol Chem 281: 35217-35223. https://doi.org/10.1074/jbc.M604933200 PMID: 16984919

18. Molofsky AB, Byrne BG, Whitfield NN, Madigan CA, Fuse ET, et al. (2006) Cytosolic recognition of flagellin by mouse macrophages restricts Legionella pneumophila infection. J Exp Med 203: 1093-1104. https://doi.org/10.1084/jem.20051659 PMID: 16606669

19. Ren T, Zamboni DS, Roy CR, Dietrich WF, Vance RE (2006) Flagellin-deficient Legionella mutants evade caspase-1- and Naip5-mediated macrophage immunity. PLoS Pathog 2: e18. https://doi.org/10. 1371/journal.ppat.0020018 PMID: 16552444

20. Zamboni DS, Kobayashi KS, Kohlsdorf T, Ogura Y, Long EM, et al. (2006) The Birc1e cytosolic patternrecognition receptor contributes to the detection and control of Legionella pneumophila infection. Nat Immunol 7: 318-325. https://doi.org/10.1038/ni1305 PMID: 16444259

21. Case CL, Shin S, Roy CR (2009) Asc and Ipaf Inflammasomes direct distinct pathways for caspase-1 activation in response to Legionella pneumophila. Infect Immun 77: 1981-1991. https://doi.org/10. 1128/IAI.01382-08 PMID: 19237518

22. Lightfield KL, Persson J, Brubaker SW, Witte CE, von Moltke J, et al. (2008) Critical function for Naip5 in inflammasome activation by a conserved carboxy-terminal domain of flagellin. Nat Immunol 9: 11711178. https://doi.org/10.1038/ni.1646 PMID: 18724372

23. Miao EA, Leaf IA, Treuting PM, Mao DP, Dors M, et al. (2010) Caspase-1-induced pyroptosis is an innate immune effector mechanism against intracellular bacteria. Nat Immunol 11: 1136-1142. https:// doi.org/10.1038/ni.1960 PMID: 21057511

24. Silveira TN, Zamboni DS (2010) Pore formation triggered by Legionella spp. is an Nlrc4 inflammasomedependent host cell response that precedes pyroptosis. Infect Immun 78: 1403-1413. https://doi.org/ 10.1128/IAI.00905-09 PMID: 20048047

25. Casson CN, Copenhaver AM, Zwack EE, Nguyen HT, Strowig T, et al. (2013) Caspase-11 activation in response to bacterial secretion systems that access the host cytosol. PLoS Pathog 9: e1003400. https://doi.org/10.1371/journal.ppat.1003400 PMID: 23762026

26. Jorgensen I, Lopez JP, Laufer SA, Miao EA (2016) IL-1beta, IL-18, and eicosanoids promote neutrophil recruitment to pore-induced intracellular traps following pyroptosis. Eur J Immunol.

27. LaRock CN, Cookson BT (2013) Burning down the house: cellular actions during pyroptosis. PLoS Pathog 9: e1003793. https://doi.org/10.1371/journal.ppat.1003793 PMID: 24367258

28. Mascarenhas DP, Pereira MS, Manin GZ, Hori JI, Zamboni DS (2015) Interleukin 1 receptor-driven neutrophil recruitment accounts to MyD88-dependent pulmonary clearance of legionella pneumophila infection in vivo. J Infect Dis 211: 322-330. https://doi.org/10.1093/infdis/jiu430 PMID: 25104770 
29. Pereira MS, Marques GG, Dellama JE, Zamboni DS (2011) The NIrc4 Inflammasome Contributes to Restriction of Pulmonary Infection by Flagellated Legionella spp. that Trigger Pyroptosis. Front Microbiol 2: 33. https://doi.org/10.3389/fmicb.2011.00033 PMID: 21687424

30. Case CL, Roy CR (2011) Asc modulates the function of NLRC4 in response to infection of macrophages by Legionella pneumophila. MBio 2.

31. Hornung V, Ablasser A, Charrel-Dennis M, Bauernfeind F, Horvath G, et al. (2009) AIM2 recognizes cytosolic dsDNA and forms a caspase-1-activating inflammasome with ASC. Nature 458: 514-518. https://doi.org/10.1038/nature07725 PMID: 19158675

32. Man SM, Tourlomousis P, Hopkins L, Monie TP, Fitzgerald KA, et al. (2013) Salmonella infection induces recruitment of Caspase- 8 to the inflammasome to modulate IL-1beta production. J Immunol 191: 5239-5246. https://doi.org/10.4049/jimmunol.1301581 PMID: 24123685

33. Pierini R, Juruj C, Perret M, Jones CL, Mangeot P, et al. (2012) AIM2/ASC triggers caspase-8-dependent apoptosis in Francisella-infected caspase-1-deficient macrophages. Cell Death Differ 19: 17091721. https://doi.org/10.1038/cdd.2012.51 PMID: 22555457

34. Sagulenko V, Thygesen SJ, Sester DP, Idris A, Cridland JA, et al. (2013) AIM2 and NLRP3 inflammasomes activate both apoptotic and pyroptotic death pathways via ASC. Cell Death Differ 20: 11491160. https://doi.org/10.1038/cdd.2013.37 PMID: 23645208

35. Cerqueira DM, Pereira MS, Silva AL, Cunha LD, Zamboni DS (2015) Caspase-1 but Not Caspase-11 Is Required for NLRC4-Mediated Pyroptosis and Restriction of Infection by Flagellated Legionella Species in Mouse Macrophages and In Vivo. J Immunol 195: 2303-2311. https://doi.org/10.4049/jimmunol. 1501223 PMID: 26232428

36. Abdelaziz DH, Gavrilin MA, Akhter A, Caution K, Kotrange S, et al. (2011) Apoptosis-associated specklike protein (ASC) controls Legionella pneumophila infection in human monocytes. J Biol Chem 286 3203-3208. https://doi.org/10.1074/jbc.M110.197681 PMID: 21097506

37. Abdelaziz DH, Gavrilin MA, Akhter A, Caution K, Kotrange S, et al. (2011) Asc-dependent and independent mechanisms contribute to restriction of legionella pneumophila infection in murine macrophages. Front Microbiol 2: 18. https://doi.org/10.3389/fmicb.2011.00018 PMID: 21713115

38. Pereira MS, Morgantetti GF, Massis LM, Horta CV, Hori JI, et al. (2011) Activation of NLRC4 by flagellated bacteria triggers caspase-1-dependent and -independent responses to restrict Legionella pneumophila replication in macrophages and in vivo. J Immunol 187: 6447-6455. https://doi.org/10.4049/ jimmunol.1003784 PMID: 22079982

39. Merriam JJ, Mathur R, Maxfield-Boumil R, Isberg RR (1997) Analysis of the Legionella pneumophila fli gene: intracellular growth of a defined mutant defective for flagellum biosynthesis. Infect Immun 65 : 2497-2501. PMID: 9169800

40. Franchi L, Amer A, Body-Malapel M, Kanneganti TD, Ozoren N, et al. (2006) Cytosolic flagellin requires Ipaf for activation of caspase-1 and interleukin 1 beta in salmonella-infected macrophages. Nat Immunol 7: 576-582. https://doi.org/10.1038/ni1346 PMID: 16648852

41. Stutz A, Horvath GL, Monks BG, Latz E (2013) ASC speck formation as a readout for inflammasome activation. Methods Mol Biol 1040: 91-101. https://doi.org/10.1007/978-1-62703-523-1_8 PMID: 23852599

42. Masumoto J, Taniguchi S, Ayukawa K, Sarvotham H, Kishino T, et al. (1999) ASC, a novel 22-kDa protein, aggregates during apoptosis of human promyelocytic leukemia HL-60 cells. J Biol Chem 274: 33835-33838. PMID: 10567338

43. Fernandes-Alnemri T, Wu J, Yu JW, Datta P, Miller B, et al. (2007) The pyroptosome: a supramolecular assembly of ASC dimers mediating inflammatory cell death via caspase-1 activation. Cell Death Differ 14: 1590-1604. https://doi.org/10.1038/sj.cdd.4402194 PMID: 17599095

44. Hasegawa M, Imamura R, Kinoshita T, Matsumoto N, Masumoto J, et al. (2005) ASC-mediated NFkappaB activation leading to interleukin-8 production requires caspase- 8 and is inhibited by CLARP. J Biol Chem 280: 15122-15130. https://doi.org/10.1074/jbc.M412284200 PMID: 15701651

45. Broz P, von Moltke J, Jones JW, Vance RE, Monack DM (2010) Differential requirement for Caspase-1 autoproteolysis in pathogen-induced cell death and cytokine processing. Cell Host Microbe 8: 471483. https://doi.org/10.1016/j.chom.2010.11.007 PMID: 21147462

46. Vajjhala PR, Lu A, Brown DL, Pang SW, Sagulenko V, et al. (2015) The Inflammasome Adaptor ASC Induces Procaspase-8 Death Effector Domain Filaments. J Biol Chem 290: 29217-29230. https://doi. org/10.1074/jbc.M115.687731 PMID: 26468282

47. Masumoto J, Dowds TA, Schaner P, Chen FF, Ogura $Y$, et al. (2003) ASC is an activating adaptor for NF-kappa B and caspase-8-dependent apoptosis. Biochem Biophys Res Commun 303: 69-73. PMID: 12646168 
48. Akhter A, Gavrilin MA, Frantz L, Washington S, Ditty C, et al. (2009) Caspase-7 activation by the Nirc4/ Ipaf inflammasome restricts Legionella pneumophila infection. PLoS Pathog 5: e1000361. https://doi. org/10.1371/journal.ppat.1000361 PMID: 19343209

49. Man SM, Hopkins LJ, Nugent E, Cox S, Gluck IM, et al. (2014) Inflammasome activation causes dua recruitment of NLRC4 and NLRP3 to the same macromolecular complex. Proc Natl Acad Sci U S A 111: 7403-7408. https://doi.org/10.1073/pnas.1402911111 PMID: 24803432

50. Motani K, Kushiyama H, Imamura R, Kinoshita T, Nishiuchi T, et al. (2011) Caspase-1 protein induces apoptosis-associated speck-like protein containing a caspase recruitment domain (ASC)-mediated necrosis independently of its catalytic activity. J Biol Chem 286: 33963-33972. https://doi.org/10.1074/ jbc.M111.286823 PMID: 21832064

51. Kumar Y, Radha V, Swarup G (2010) Interaction with Sug1 enables Ipaf ubiquitination leading to caspase 8 activation and cell death. Biochem J 427: 91-104. https://doi.org/10.1042/BJ20091349 PMID: 20085538

52. Muruve DA, Petrilli V, Zaiss AK, White LR, Clark SA, et al. (2008) The inflammasome recognizes cytosolic microbial and host DNA and triggers an innate immune response. Nature 452: 103-107. https:// doi.org/10.1038/nature06664 PMID: 18288107

53. Roberts TL, Idris A, Dunn JA, Kelly GM, Burnton CM, et al. (2009) HIN-200 proteins regulate caspase activation in response to foreign cytoplasmic DNA. Science 323: 1057-1060. https://doi.org/10.1126/ science.1169841 PMID: 19131592

54. Burckstummer T, Baumann C, BlumI S, Dixit E, Durnberger G, et al. (2009) An orthogonal proteomicgenomic screen identifies AIM2 as a cytoplasmic DNA sensor for the inflammasome. Nat Immunol 10: 266-272. https://doi.org/10.1038/ni.1702 PMID: 19158679

55. Fernandes-Alnemri T, Yu JW, Datta P, Wu J, Alnemri ES (2009) AIM2 activates the inflammasome and cell death in response to cytoplasmic DNA. Nature 458: 509-513. https://doi.org/10.1038/nature07710 PMID: 19158676

56. Aachoui Y, Leaf IA, Hagar JA, Fontana MF, Campos CG, et al. (2013) Caspase-11 protects against bacteria that escape the vacuole. Science 339: 975-978. https://doi.org/10.1126/science.1230751 PMID: 23348507

57. Ge J, Gong YN, Xu Y, Shao F (2012) Preventing bacterial DNA release and absent in melanoma 2 inflammasome activation by a Legionella effector functioning in membrane trafficking. Proc Natl Acad Sci U S A 109: 6193-6198. https://doi.org/10.1073/pnas.1117490109 PMID: 22474394

58. Pierini R, Perret M, Djebali S, Juruj C, Michallet MC, et al. (2013) ASC controls IFN-gamma levels in an IL-18-dependent manner in caspase-1-deficient mice infected with Francisella novicida. J Immunol 191: 3847-3857. https://doi.org/10.4049/jimmunol.1203326 PMID: 23975862

59. Kaiser WJ, Upton JW, Long AB, Livingston-Rosanoff D, Daley-Bauer LP, et al. (2011) RIP3 mediates the embryonic lethality of caspase-8-deficient mice. Nature $471: 368-372$. https://doi.org/10.1038/ nature09857 PMID: 21368762

60. Varfolomeev EE, Schuchmann M, Luria V, Chiannilkulchai N, Beckmann JS, et al. (1998) Targeted disruption of the mouse Caspase 8 gene ablates cell death induction by the TNF receptors, Fas/Apo1, and DR3 and is lethal prenatally. Immunity 9: 267-276. PMID: 9729047

61. Case CL, Kohler LJ, Lima JB, Strowig T, de Zoete MR, et al. (2013) Caspase-11 stimulates rapid flagellin-independent pyroptosis in response to Legionella pneumophila. Proc Natl Acad Sci U S A 110: 1851-1856. https://doi.org/10.1073/pnas.1211521110 PMID: 23307811

62. Fink SL, Cookson BT (2006) Caspase-1-dependent pore formation during pyroptosis leads to osmotic lysis of infected host macrophages. Cell Microbiol 8: 1812-1825. https://doi.org/10.1111/j.1462-5822. 2006.00751.x PMID: 16824040

63. Talanian RV, Quinlan C, Trautz S, Hackett MC, Mankovich JA, et al. (1997) Substrate specificities of caspase family proteases. J Biol Chem 272: 9677-9682. PMID: 9092497

64. Thornberry NA, Rano TA, Peterson EP, Rasper DM, Timkey T, et al. (1997) A combinatorial approach defines specificities of members of the caspase family and granzyme B. Functional relationships established for key mediators of apoptosis. J Biol Chem 272: 17907-17911. PMID: 9218414

65. Garcia-Calvo M, Peterson EP, Leiting B, Ruel R, Nicholson DW, et al. (1998) Inhibition of human caspases by peptide-based and macromolecular inhibitors. J Biol Chem 273: 32608-32613. PMID: 9829999

66. Kayagaki N, Warming S, Lamkanfi M, Vande Walle L, Louie S, et al. (2011) Non-canonical inflammasome activation targets caspase-11. Nature 479: 117-121. https://doi.org/10.1038/nature10558 PMID: 22002608 
67. Kayagaki N, Stowe IB, Lee BL, O'Rourke K, Anderson K, et al. (2015) Caspase-11 cleaves gasdermin D for non-canonical inflammasome signalling. Nature 526: 666-671. https://doi.org/10.1038/ nature15541 PMID: 26375259

68. Shi J, Zhao Y, Wang K, Shi X, Wang Y, et al. (2015) Cleavage of GSDMD by inflammatory caspases determines pyroptotic cell death. Nature 526: 660-665. https://doi.org/10.1038/nature15514 PMID: 26375003

69. Kofoed EM, Vance RE (2011) Innate immune recognition of bacterial ligands by NAIPs determines inflammasome specificity. Nature 477: 592-595. https://doi.org/10.1038/nature10394 PMID: 21874021

70. Zhao Y, Yang J, Shi J, Gong YN, Lu Q, et al. (2011) The NLRC4 inflammasome receptors for bacterial flagellin and type III secretion apparatus. Nature 477: 596-600. https://doi.org/10.1038/nature10510 PMID: 21918512

71. Coers J, Vance RE, Fontana MF, Dietrich WF (2007) Restriction of Legionella pneumophila growth in macrophages requires the concerted action of cytokine and Naip5/Ipaf signalling pathways. Cell Microbiol 9: 2344-2357. https://doi.org/10.1111/j.1462-5822.2007.00963.x PMID: 17506816

72. Fortier A, Doiron K, Saleh M, Grinstein S, Gros P (2009) Restriction of Legionella pneumophila replication in macrophages requires concerted action of the transcriptional regulators Irf1 and Irf8 and nod-like receptors Naip5 and Nlrc4. Infect Immun 77: 4794-4805. https://doi.org/10.1128/IAI.01546-08 PMID: 19720760

73. Rauch I, Deets KA, Ji DX, von Moltke J, Tenthorey JL, et al. (2017) NAIP-NLRC4 Inflammasomes Coordinate Intestinal Epithelial Cell Expulsion with Eicosanoid and IL-18 Release via Activation of Caspase1 and -8. Immunity 46: 649-659. https://doi.org/10.1016/j.immuni.2017.03.016 PMID: 28410991

74. Rogers C, Fernandes-Alnemri T, Mayes L, Alnemri D, Cingolani G, et al. (2017) Cleavage of DFNA5 by caspase-3 during apoptosis mediates progression to secondary necrotic/pyroptotic cell death. Nat Commun 8: 14128. https://doi.org/10.1038/ncomms14128 PMID: 28045099

75. Wang Y, Gao W, Shi X, Ding J, Liu W, et al. (2017) Chemotherapy drugs induce pyroptosis through caspase-3 cleavage of a Gasdermin. Nature.

76. Feeley JC, Gibson RJ, Gorman GW, Langford NC, Rasheed JK, et al. (1979) Charcoal-yeast extract agar: primary isolation medium for Legionella pneumophila. J Clin Microbiol 10: 437-441. PMID: 393713

77. Marim FM, Silveira TN, Lima DS Jr., Zamboni DS (2010) A method for generation of bone marrowderived macrophages from cryopreserved mouse bone marrow cells. PLoS One 5: e15263. https://doi. org/10.1371/journal.pone.0015263 PMID: 21179419

78. Milstein S, Nguyen M, Meyers R, de Fougerolles A (2013) Measuring RNAi knockdown using qPCR Methods Enzymol 533: 57-77. https://doi.org/10.1016/B978-0-12-420067-8.00006-4 PMID: 24182918

79. Lara-Tejero M, Sutterwala FS, Ogura Y, Grant EP, Bertin J, et al. (2006) Role of the caspase-1 inflammasome in Salmonella typhimurium pathogenesis. J Exp Med 203: 1407-1412. https://doi.org/10. 1084/jem.20060206 PMID: 16717117

80. Kuida K, Lippke JA, Ku G, Harding MW, Livingston DJ, et al. (1995) Altered cytokine export and apoptosis in mice deficient in interleukin-1 beta converting enzyme. Science 267: 2000-2003. PMID: 7535475

81. Sutterwala FS, Ogura Y, Szczepanik M, Lara-Tejero M, Lichtenberger GS, et al. (2006) Critical role for NALP3/CIAS1/Cryopyrin in innate and adaptive immunity through its regulation of caspase-1. Immunity 24: 317-327. https://doi.org/10.1016/j.immuni.2006.02.004 PMID: 16546100 
Supplementary Fig.1 Mascarenhas et al.

๑ C57BL/6

- Nirc4-1-

^- Casp1/11/

$\nabla \mathrm{Asc}^{--}$
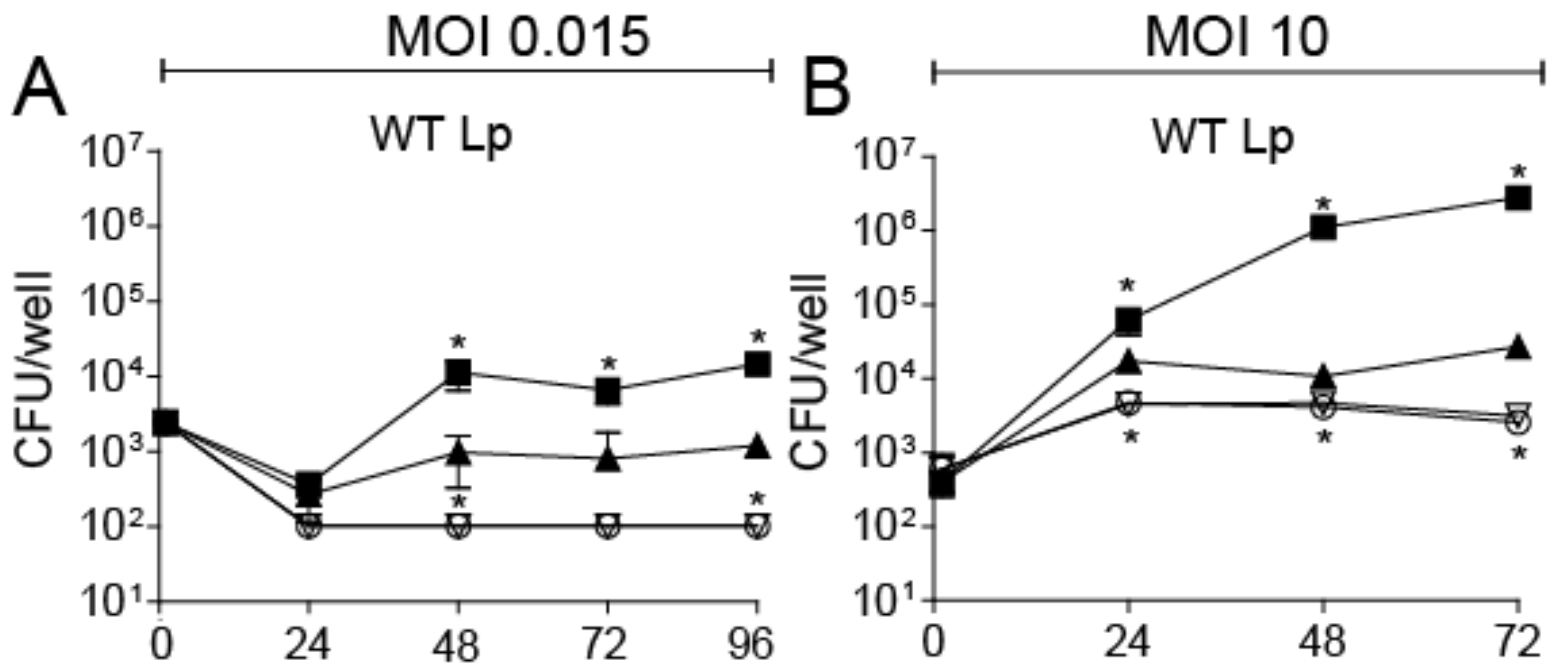

Time after infection (hours)

C

96
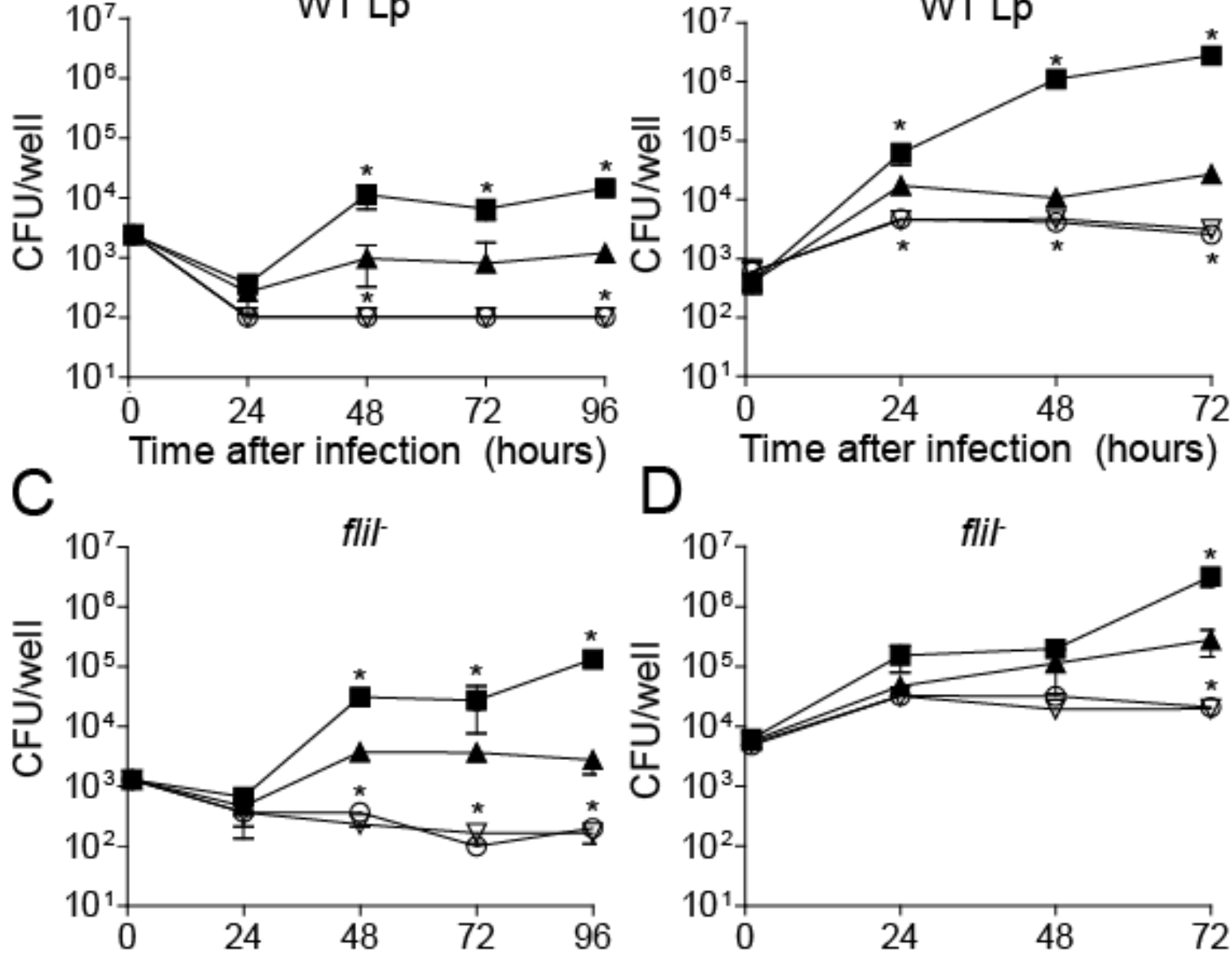

D

Time after infection (hours)
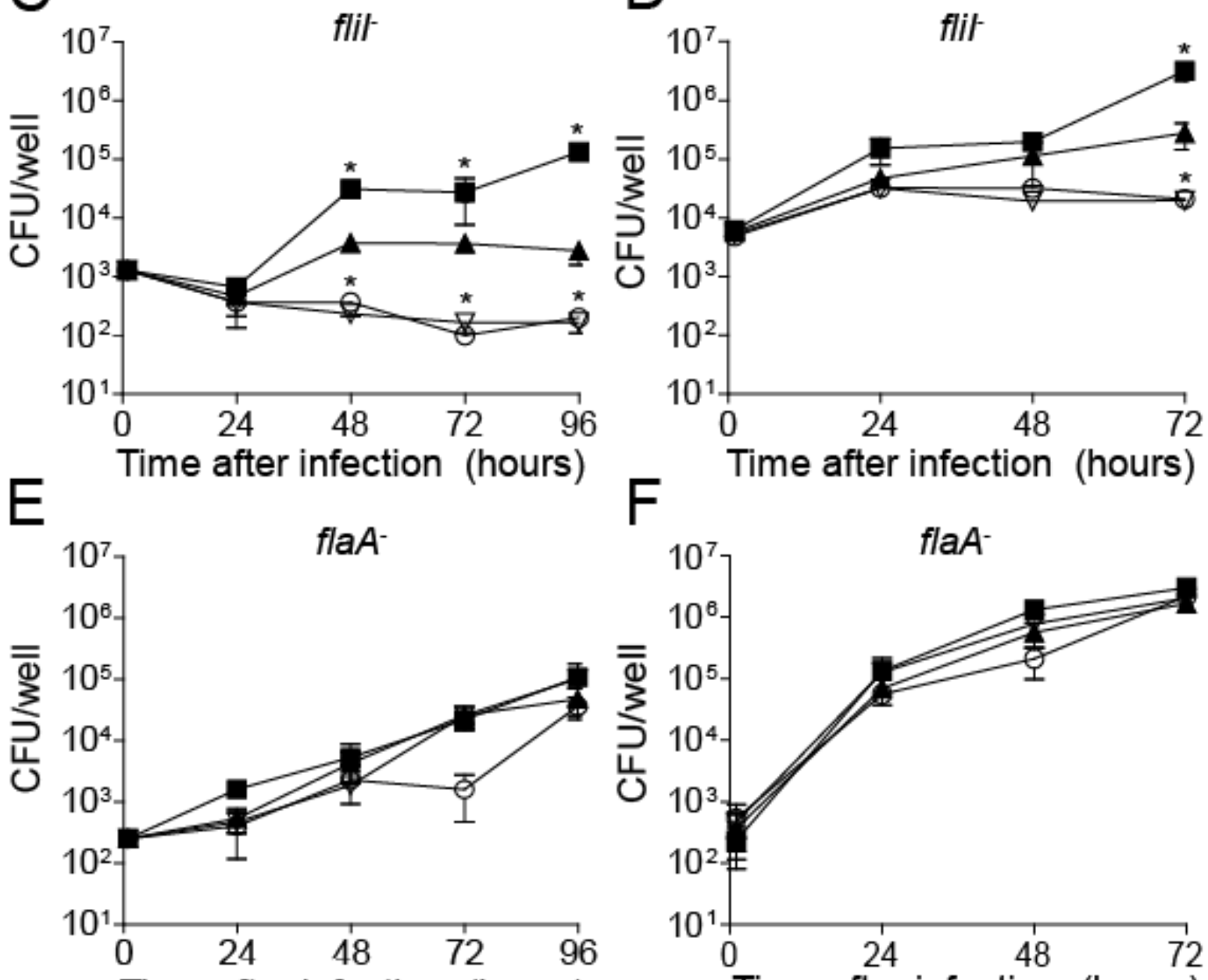

Time after infection (hours)
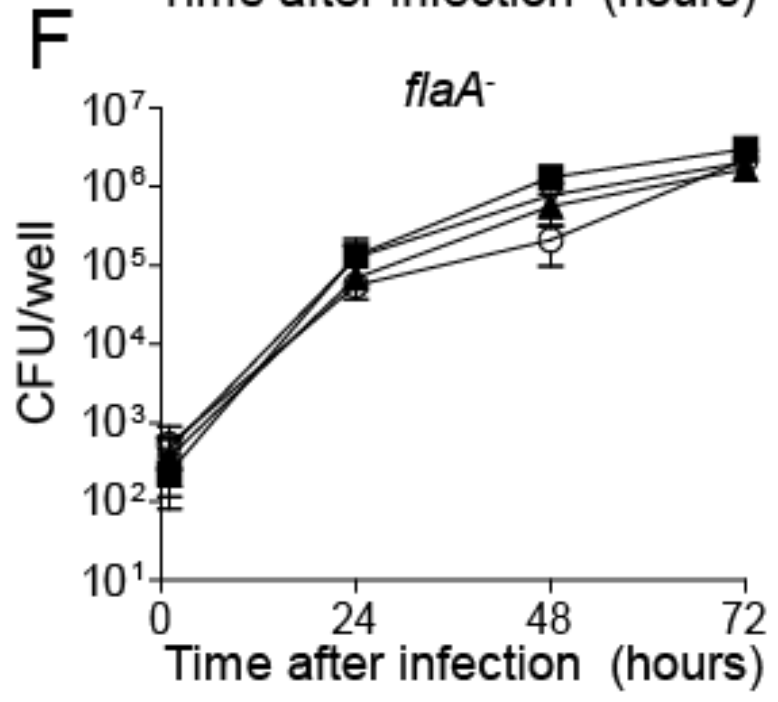
Supplementary Fig.2. Mascarenhas et al.
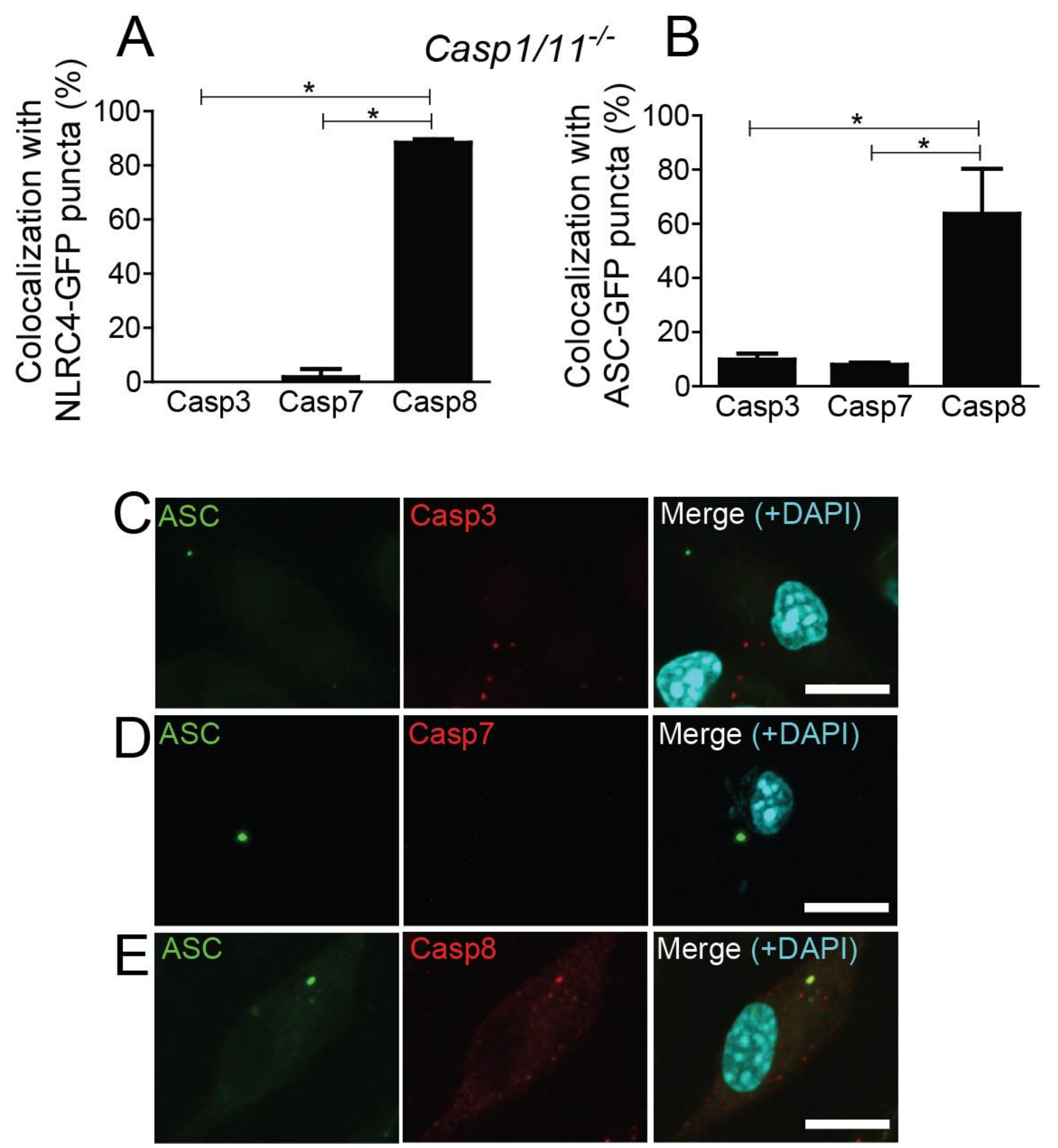
Supplementary Fig.3. Mascarenhas et al .

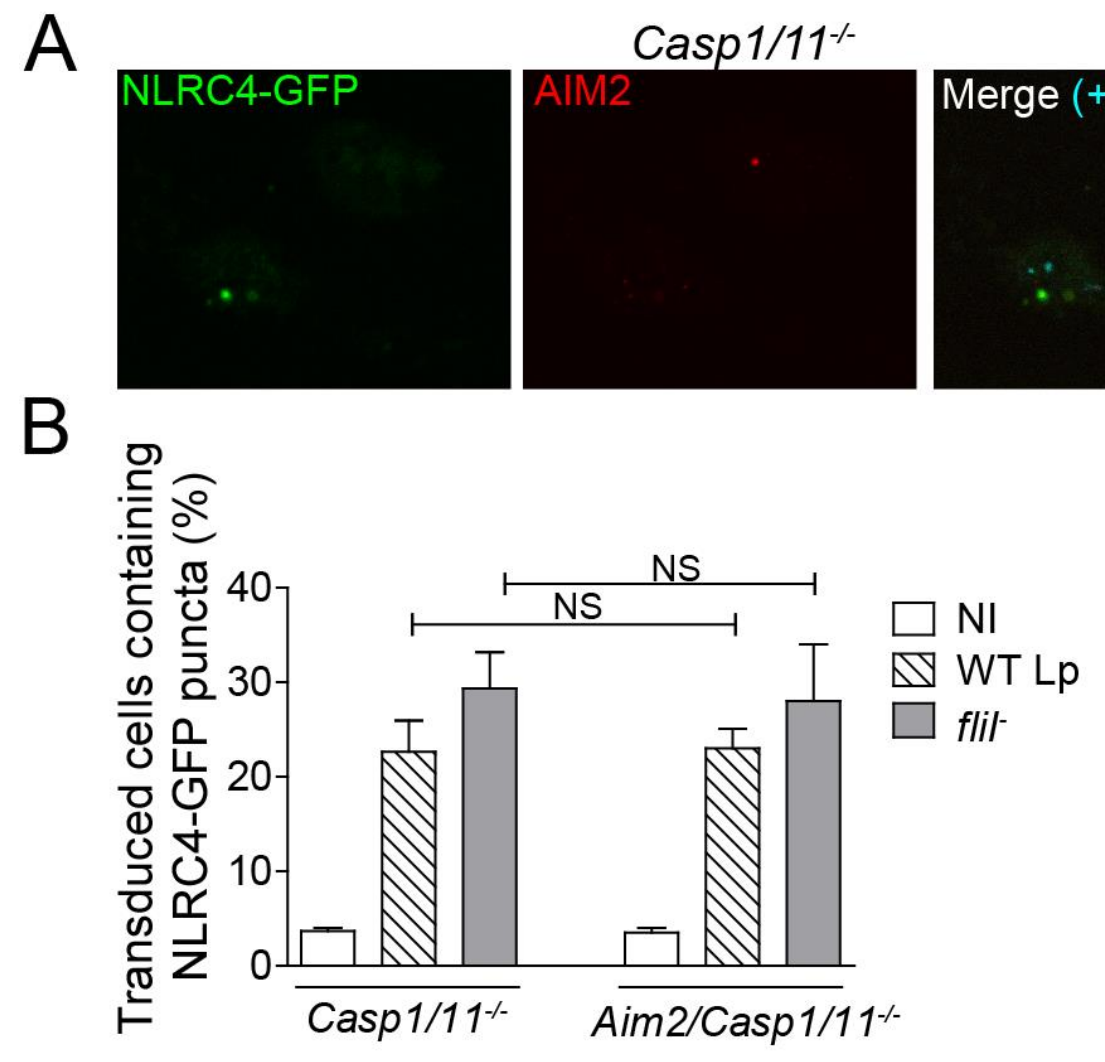

Supplementary Fig.4. Mascarenhas et al.

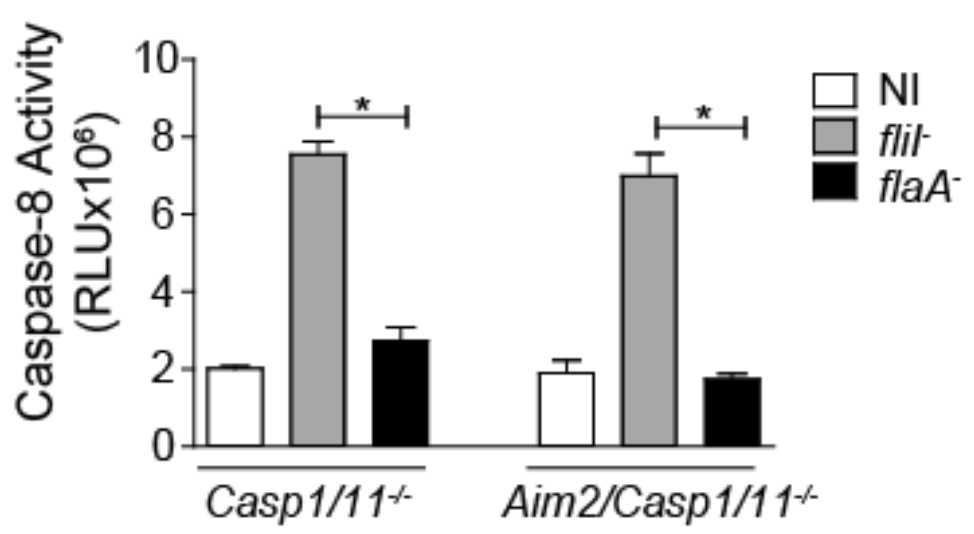


Supplementary Fig.5. Mascarenhas et al.

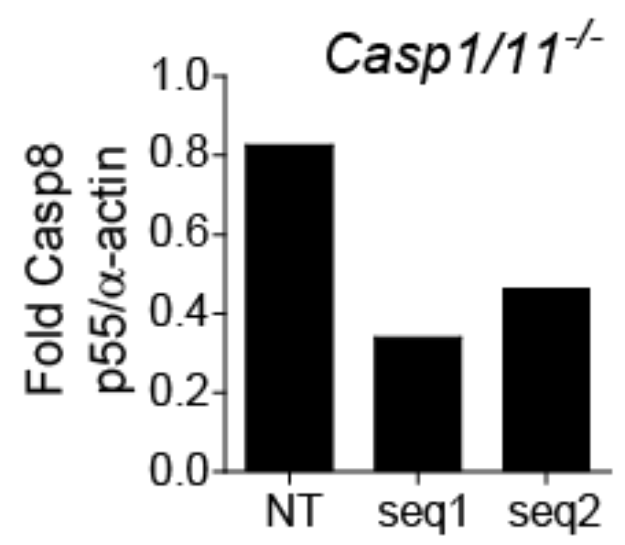

Supplementary Fig.6. Mascarenhas et al.

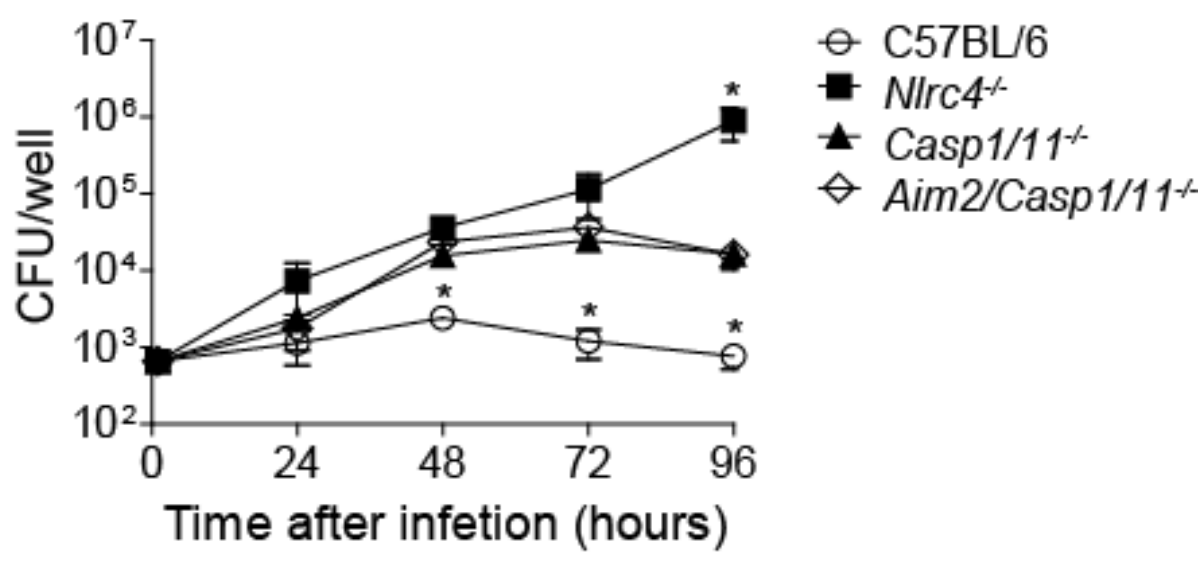

Supplementary Fig.7. Mascarenhas et al.

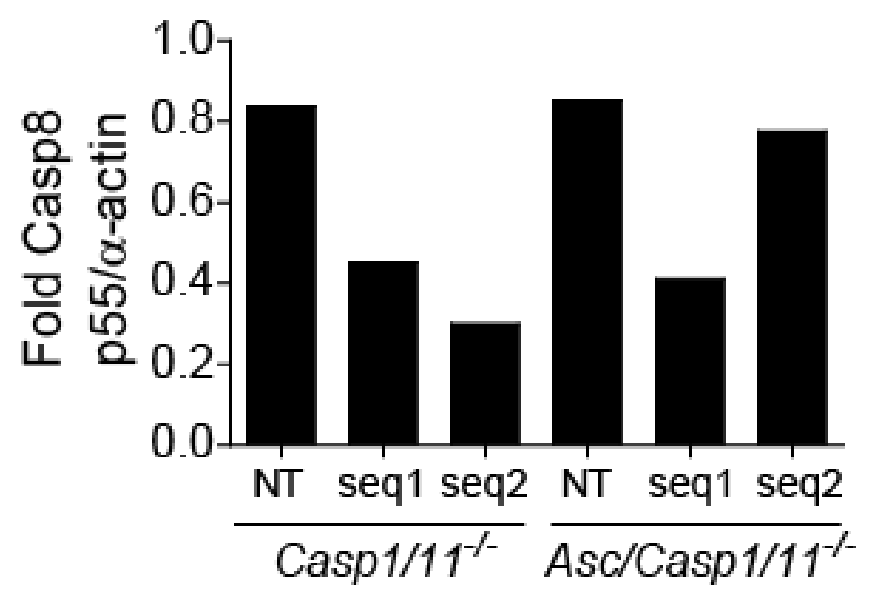


Supplementary Fig. 8. Mascarenhas et al.

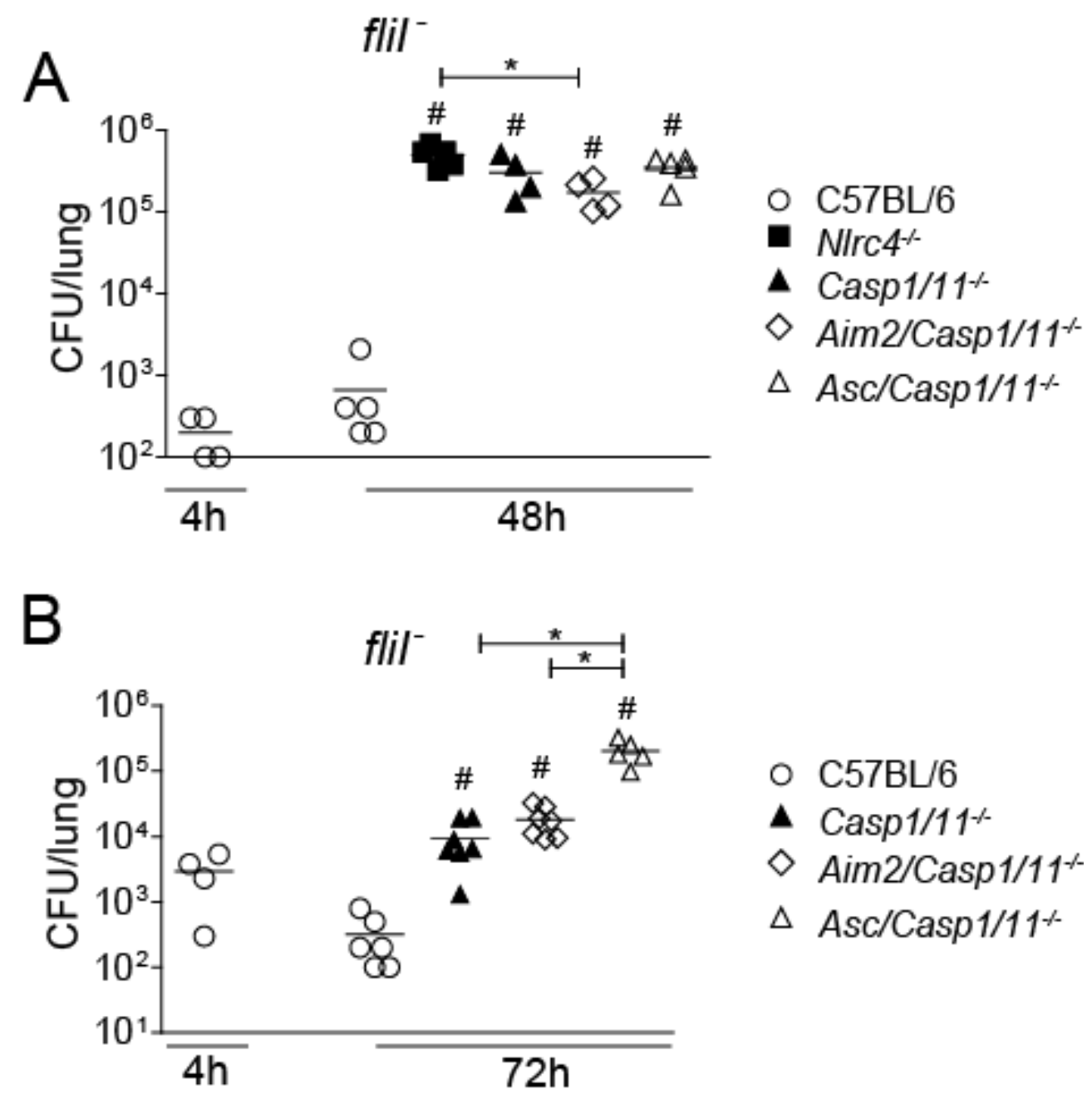


Supplementary Fig.9 Mascarenhas et al.
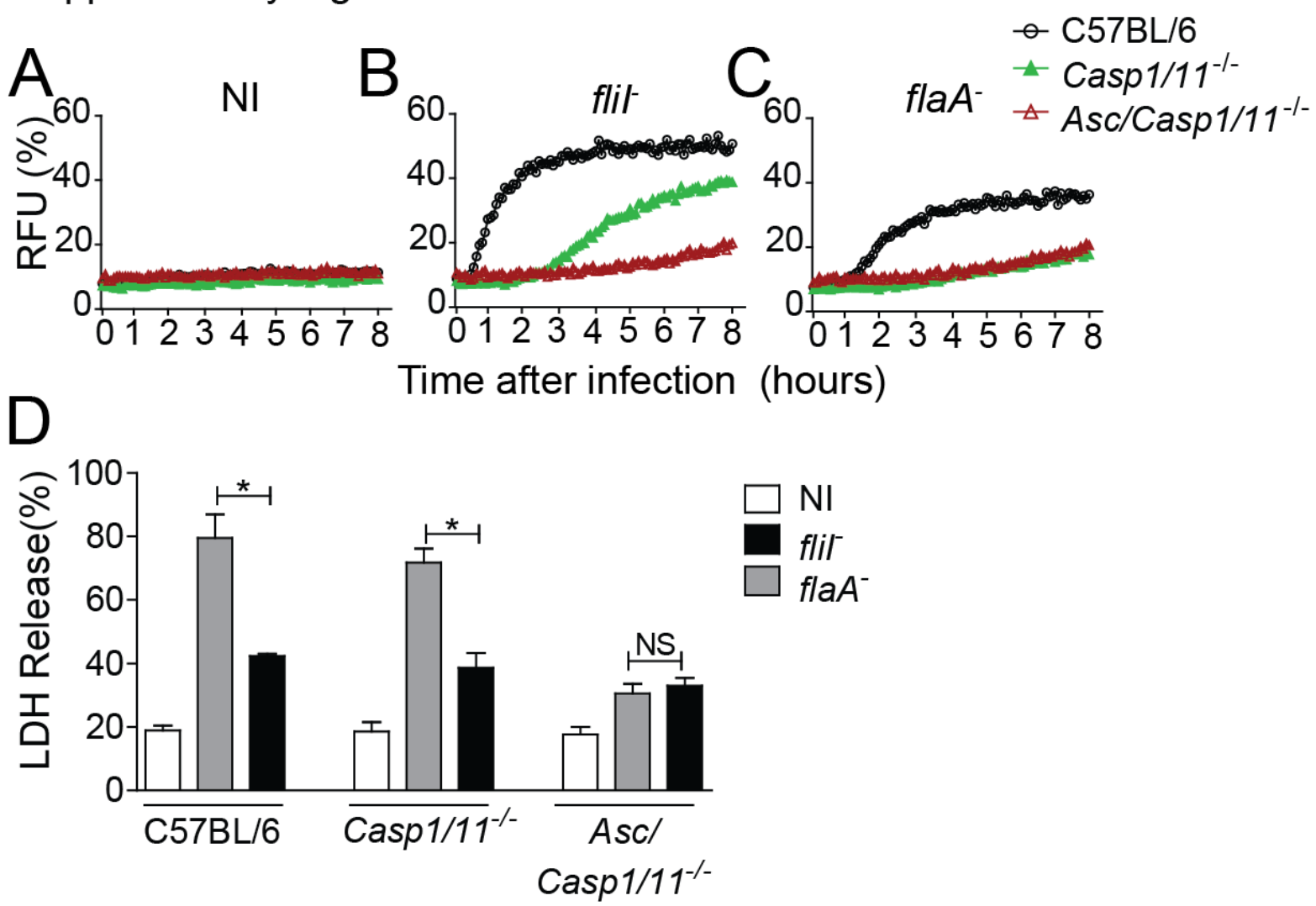

Supplementary Fig.10 Mascarenhas et al.

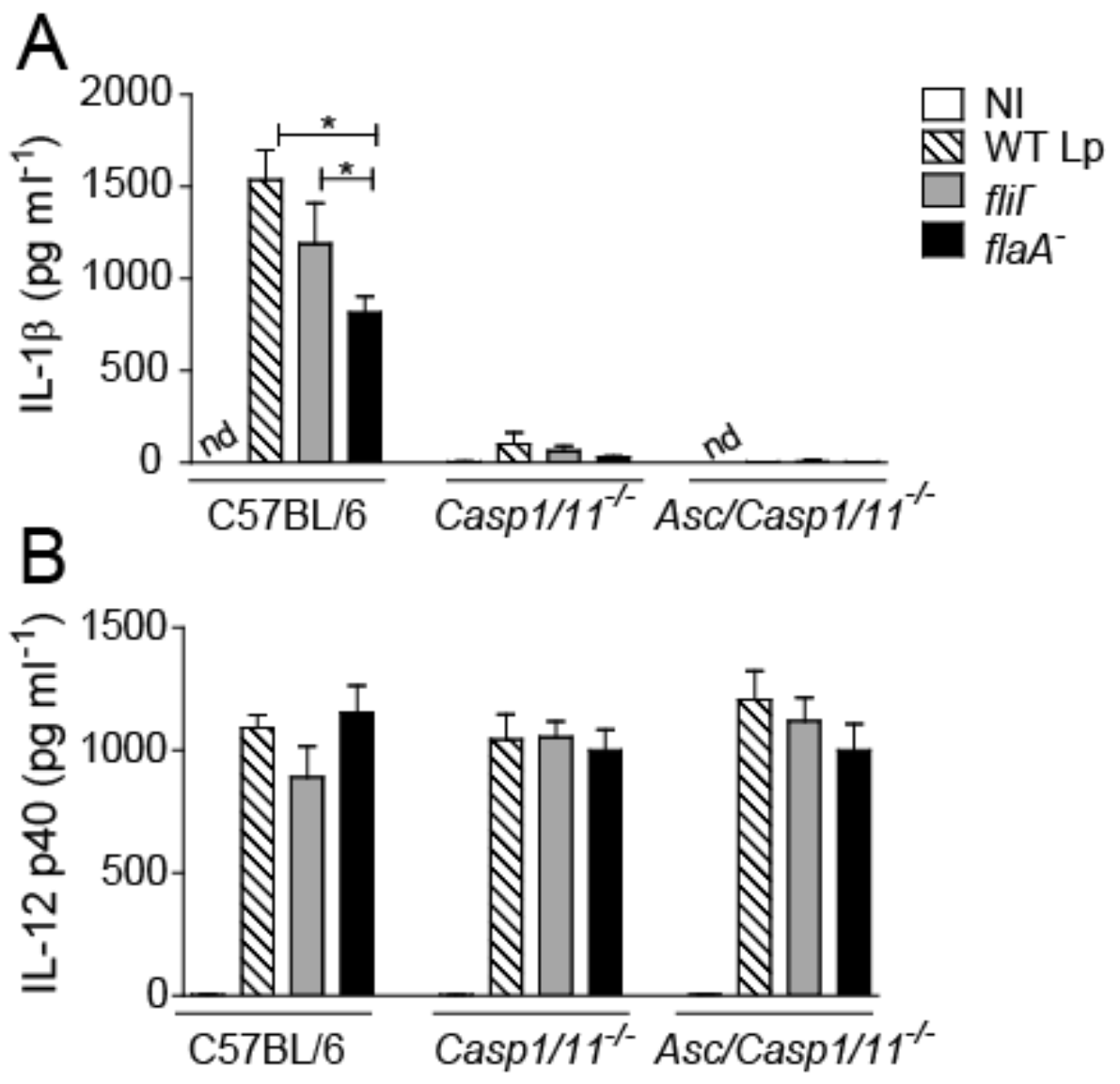


Supplementary Fig.11 Mascarenhas et al.

$\star$ NT ShRNA

— ShRNA GSDMD Seq1

* shRNA GSDMD Seq2

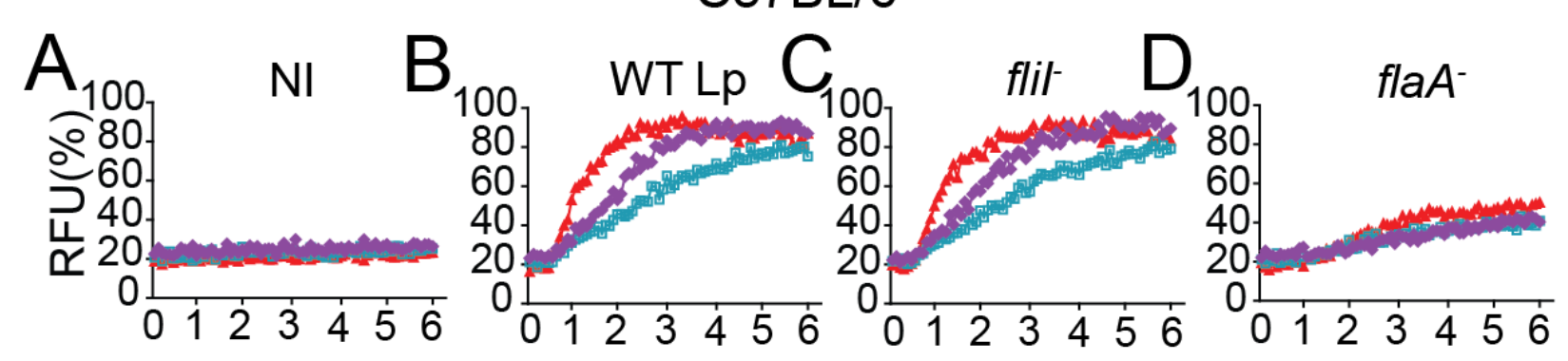

Casp1/11-/-

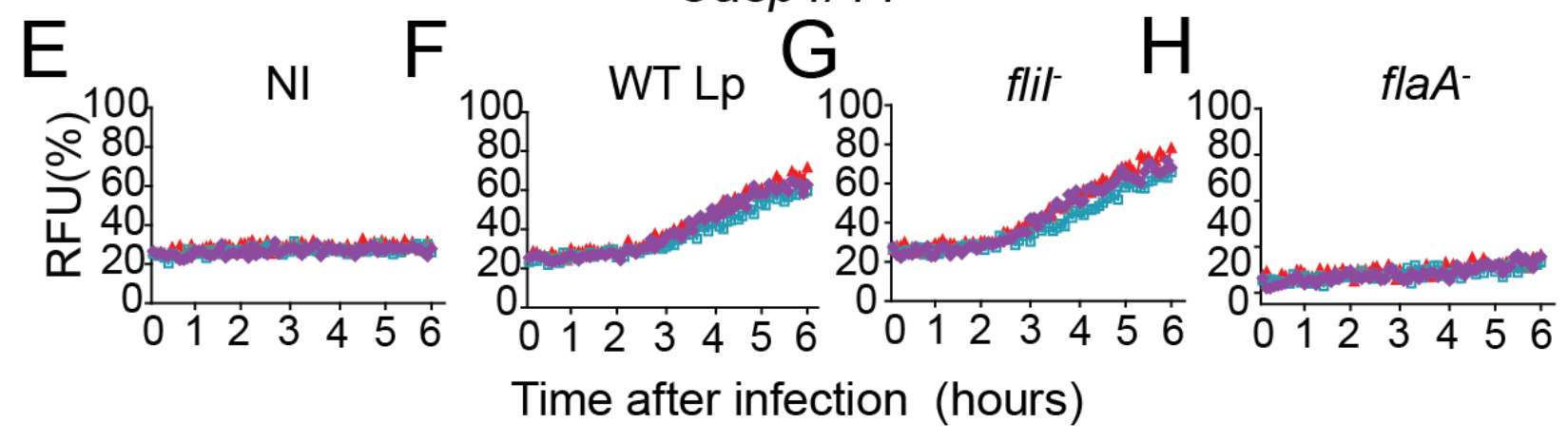


9.2 - Anexo 2 - Artigo publicado (MASCARENHAS, Danielle PA; ZAMBONI, Dario

S. Journal of Leukocyte Biology, 2017)

"Inflammasome biology taught by Legionella pneumophila"

- Publicado em: abril de 2017 


\title{
JLB \\ Inflammasome biology taught by Legionella pneumophila
}

\author{
Danielle P. A. Mascarenhas and Dario S. Zamboni ${ }^{1}$ \\ Department of Cell Biology, School of Medicine of Ribeirão Preto, University of São Paulo, São Paulo, Brazil \\ RECEIVED SEPTEMBER 8, 2016; REVISED OCTOBER 26, 2016; ACCEPTED NOVEMBER 17, 2016. DOI: 10.1189/jlb.3MR0916-380R
}

\begin{abstract}
Inflammasomes are multimeric protein complexes that assemble in the cytosol of many types of cells, including innate immune cells. The inflammasomes can be activated in response to infection or in response to stress signals that induce damage in the host cell membranes. These platforms trigger inflammatory processes, cell death, and the control of microbial replication. Many inflammasomes have been described so far, including NLRP3, NAIP/NLRC4, caspase-11, and AIM2. The ligand for NLRP3 is still unidentified, but the efflux of $\mathrm{K}^{+}$is essential for NLRP3 activation. By contrast, inflammasomes, such as those composed of NAIP/NLRC4, caspase-11, and AIM2, can be activated by bacterial flagellin, LPS, and dsDNA. The knowledge of inflammasome biology has advanced tremendously in the last decade, fostered by the use of model organisms, such as Legionella pneumophila. This bacterium evolved, infecting unicellular protozoa in freshwater environments, and the human infection is accidental. Thus, L. pneumophila did not evolve sophisticated mechanisms to inhibit mammalian innate immunity. For this reason, it has emerged as a very appropriate model of a pathogenic microbe for the investigation of inflammasome biology. In this review, we highlight the current information regarding the biology of inflammasomes and emphasize the advances achieved using $L$. pneumophila. We also describe the inflammasomes activated in response to $L$. pneumophila infection and discuss the effector mechanisms that operate to clear the infection. J. Leukoc. Biol. 101: 000-000; 2017.
\end{abstract}

\section{INTRODUCTION TO LEGIONELLA}

L. pneumophila is an intracellular bacteria that was first identified in 1976 after an outbreak of pneumonia occurred in Philadelphia, PA, USA, among the participants of an American Legion convention [1]. The development of an axenic media favored

Abbreviations: ${ }^{-/-}=$deficient, $\mathrm{AlM} 2=$ absent in melanoma 2, ASC = apoptosis-associated speck-like protein containing a caspase activation and recruitment domain, $\mathrm{BIR}$ = baculovirus inhibitor of apoptosis repeat, $\mathrm{CARD}=$ caspase activation and recruitment domain, Casp $1 / 7 / 11=$ caspase 1/7/11, DAMP = damage-associated molecular pattern, Dot/lcm = defect in organelle trafficking/intracellular multiplication, GSDMD = gasdermin-D, the isolation of many species of legionellae $[2,3]$. The subsequent investigation characterized $L$. pneumophila as a Gramnegative, flagellated organism that is the causative agent of 2 forms of disease in humans, Legionnaire's disease, and Pontiac fever [4-6]. Legionnaire's disease is a severe form of pneumonia. This condition has an incubation period of $2-10 \mathrm{~d}$, followed by lung damage, and affects mainly immunocompromised individuals $[6,7]$. Pontiac fever is the most common clinical manifestation and causes typical symptoms with characteristics of influenza infection, including fever, chills, and headache following a short incubation period $[5,8]$.

This bacterium is found in freshwater and soil environments, where it infects various species of unicellular protozoa, including several species of free-living amoebae [9]. Currently, $>60$ species of the genus Legionella have been isolated from environmental samples, and approximately half of these have been isolated from human samples at least once $[4,10]$. Human infection occurs upon the inhalation of contaminated water droplets or soil aerosols. After inhalation, Legionella can infect and multiply in alveolar macrophages. The bacteria inhabit a vacuole, called the LCV, and replicate intracellularly. Legionella can replicate by subverting the intracellular traffic of vesicles to impair the fusion of the LCV with endocytic vesicles, including lysosomes (reviewed in ref. [11]). This process is strictly dependent on the T4BSS, called Dot/Icm, which translocates hundreds of effector proteins directly into the cytoplasm of the host cell. These effector proteins are responsible for the development of an intracellular compartment that supports the Legionella replication in mammalian macrophages and in amoebae [11-13].

L. pneumophila evolved by replicating within unicellular protozoa in freshwater environments. Thus, in the absence of interaction with mammalian hosts during the evolutionary process, L. pneumophila did not encounter selective pressure for the development of mechanisms to inhibit or bypass the PRRs in mammalian cells. For this reason, L. pneumophila serves as an excellent model of infection for the assessment of the biology of such mammalian receptors. Indeed, much information

1. Correspondence: Dept. of Cell Biology, School of Medicine of Ribeirão Preto, University of São Paulo FMRP/USP, Av. Bandeirantes 3900, Ribeirão Preto, SP 14049-900, Brazil. E-mail: dszamboni@fmrp.usp.br; Twitter: http://www.twitter.com/ds_zamboni 


\section{JLB}

regarding the biology and functions of the intracellular receptors has been revealed in studies using $L$. pneumophila.

\section{INTRODUCTION TO INTRACELLULAR PRRs}

PRRs are central molecules of innate immunity that facilitate the recognition of conserved molecules of microbes (called PAMPs). PRRs also recognize stress- and damage-induced molecules (called DAMPs) $[14,15]$. A family of intracellular molecules that contains a NBD and LRR has a major role in the recognition of intracellular pathogens. This family of sensors exhibits 3 main characteristic domains: 1) LRR in the C-terminus that regulates the receptor activation; 2) a centrally located NBD that causes oligomerization in response to ATP; and 3) a variable $\mathrm{N}$-terminal domain that is important for signaling and/or the recruitment of additional molecules. Among the N-terminal domains of the NLRs are the CARD, PYD, and BIRs [16-19].

The stimulation of certain NLRs by PAMPs and DAMPs leads to the activation and oligomerization of the sensor protein, which in turn, induces the formation of a cytosolic platform of proteins, called the inflammasome [20,21]. This complex can facilitate the activation and cleavage of caspase- 1 and in some cases, caspase-8. Many inflammasomes have been described (reviewed in ref. [22]), most of which require the presence of an adaptor protein, known as ASC, which contains 2 death domains that are important for the homologous protein-protein interactions: the PYD of ASC binds to the PYD of the NLRPs, whereas the CARD of ASC binds to the CARD of caspases [23]. Therefore, ASC facilitates the nucleation of a multimeric complex, the inflammasome, which contains inflammatory caspases. These complexes can be visualized by light microscopy and are called "puncta" or "specks" [24]. The formation of the inflammasome leads to the autoprocessing of caspase-1, a process that leads to the cleavage and activation of IL-1 $\beta$ and IL-18 and to a specific inflammatory form of cell death, called "pyroptosis" [21, 24-28]. Inflammasome activation has been demonstrated to play a critical role in the control of the replication of many pathogens, including the Gram-negative bacteria L. pneumophila. As previously mentioned, $L$. pneumophila has become a very useful model of infection for assessment of the biology of such mammalian PRRs. Much information regarding the biology and functions of the intracellular receptors and inflammasomes has been revealed by studies using $L$. pneumophila. Herein, we review the current information related to the biology of inflammasomes that has been revealed using $L$. pneumophila. In addition, we highlight the inflammasomes that are activated in response to

(continued from previous page)

$H \mathbb{N}$ = hematopoietic IFN-inducible nuclear domain, hNAP = human nucleotidebinding domain leucine-rich repeat-containing protein family of apoptosis inhibitory protein, $L C V=$ Legionella-containing vacuole, $L R R=$ leucine-rich repeat NAP = nucleotide-binding domain leucine-rich repeat-containing protein family of apoptosis inhibitory protein, NBD = nucleotide-binding and oligomerization domain, NLR = nucleotide-binding domain leucine-rich repeat-containing protein, NLRC4 = nucleotide-binding domain leucine-rich repeat-containing protein family caspase activation and recruitment domain-containing protein 4, NLRP = nucleotide-binding domain leucine-rich repeat-containing protein family pyrin domain-containing protein, $\mathrm{PAMP}=$ pathogen-associated molecular pattern PRR = pattern recognition receptor, PYD = pyrin domain, T3/4SS = type $3 / 4$ secretion system
L. pneumophila and discuss the effector mechanisms that operate to control and resolve the infection.

\section{NAIP5/NLRC4 INFLAMMASOME TAUGHT BY LEGIONELLA}

Early studies performed in the 1980s using macrophages and L. pneumophila launched a successful series of investigations that culminated in the revelation of the biology and functions of the NAIP5/NLRC4 inflammasome (Fig. 1). In 1988, it was reported that macrophages from most strains of mice, with the exception of A/J mice, are highly restrictive to L. pneumophila replication [29]. Through classic genetics, the resistance was mapped to an autosomal locus, named $\operatorname{Lgn} 1$ on chromosome 13 [30, 31]. In 2000, it was reported that the genes contained in $\operatorname{Lgn} 1$ are expressed in macrophages. These genes included Naip1, Naip3, Naip6, Naip5, and Naip2, but only Naip1, Naip2, Naip5, and Naip6 are functional in C57BL/6 mice [32]. In 2003, 2 important articles defined Naip5 as the gene within $\operatorname{Lgn} 1$ that is responsible for the macrophage resistance to L. pneumophila [33, 34]. The function of Naip5 was finally demonstrated in 2006 [35]. Naip5 was reported to sense $L$. pneumophila in a Dot/Icm-dependent manner and trigger caspase-1 activation (Fig. 2). Naip5 was also shown to interact with NLRC4. Accordingly, macrophages and mice that expressed the defective Naip5 allele from the A/J strain were permissive for $L$. pneumophila replication. In contrast, the expression of the restrictive C57BL/6 Naip5 impaired the bacterial replication in macrophages and in mouse lungs [35]. Interestingly, mice in the $\mathrm{C} 57 \mathrm{BL} / 6$ genetic background that were genetically deficient in NLRC4 or caspase-1 were susceptible to L. pneumophila infection [35]. The development of the Naip5 mice unequivocally confirmed the important role for Naip5 in the activation of caspase-1 in response to L. pneumophila [36]. After the demonstration that Naip5 activates caspase-1, 3 independent groups used L. pneumophila to demonstrate that flagellin is required for the activation of Naip5, NLRC4, and caspase-1 [37-39]. In 2008, it was demonstrated that the same C-terminal region of flagellin is required for the activation of Naip5 and NLRC4 signaling [36], which supported the hypothesis that 1 of these proteins was the receptor and that the other was required for signaling. The final demonstration that Naip5 is the flagellin sensor was published in 2011, when 2 independent groups demonstrated that Naip5 is the flagellin sensor and requires NLRC4 to activate caspase-1 $[40,41]$. These articles also reported that although Naip5 is a sensor of flagellin, Naip2 senses the rod (PrgJ) proteins from the bacterial T3SS [40, 41]. Furthermore, Naip1 was reported to be a cytoplasmic receptor of the T3SS needle protein (PrgI) and also to use NLRC4 as an adaptor to activate caspase-1 $[42,43]$. Thus, Naip1, Naip2, and Naip5 are receptors that require NLRC4 to trigger caspase-1 activation. L. pmeumophila does not encode a T3SS; therefore, only Naip5 operates to activate NLRC4 in response to this bacterium (Fig. 3). Nonetheless, Naip6 has also been shown to function as a flagellin receptor, and thus, both Naip5 and Naip6 sense L. pneumophila flagellin, with Naip5 being more effective [40, 41]. The recent development of a mouse deficient in several Naips further confirmed that Naip6 (although it is significantly less efficient than Naip5) also accounts for flagellin 


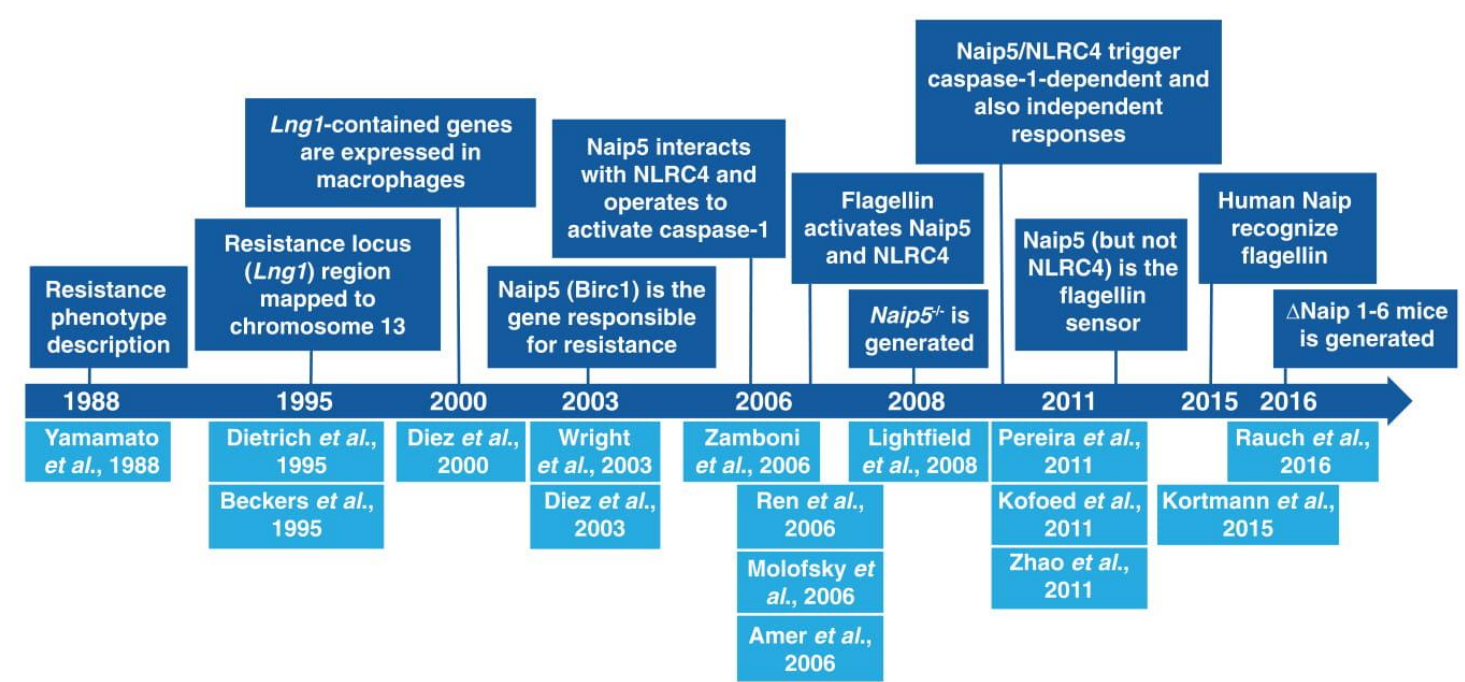

Figure 1. Timeline for the $L$. pneumophila investigations that culminated with the discovery of the Naip5/NLRC4 inflammasome. The indicated references are as follows: Yamamoto et al., 1988 [29]; Dietrich et al., 1995 [31]; Beckers et al., 1995 [30]; Diez et al., 2000 [32]; Wright et al., 2003 [34]; Diez et al., 2003 [33]; Zamboni et al., 2006 [35]; Ren et al., 2006 [38]; Molofsky et al., 2006 [39]; Amer et al., 2006 [37]; Lightfield et al., 2008 [36]; Pereira et al., 2011 [53]; Kofoed and Vance, 2011 [40]; Zhao et al., 2011 [41]; Kortmann et al., 2015 [78]; Rauch et al., 2016 [44].

recognition $[44,45]$. It is worth mentioning that chimeric Naip2 and Naip5 constructs were produced, and it was determined that the ligand specificity was not mediated by the LRR domain but by a region present in the internal NBD [46]. In addition, it was demonstrated that the NBD is important for the Naip oligomerization and its interactions with the adaptor protein NLRC4 during inflammasome activation [46]

The recognition of intracellular flagellin during the responses to intracellular pathogens has been studied extensively since the initial description of the Naip5/NLRC4 inflammasome. As previously mentioned, the original demonstration that flagellin is recognized by the Naip5/NLRC4 inflammasome emerged in 2006 from the work published by several groups using $L$. pneumophila [37-39]. Many studies using various additional bacteria, such as Salmonella enterica, Pseudomonas aeruginosa, and Shigella flexneri, have confirmed the important roles for Naip5 and NLRC4 in the recognition of bacterial flagellin [39, 47-51]. In addition, the flagellin from nonpneumophila Legionella species, including

L. bonzemani, L. gratiana, L. micdadei, $L$. jordanis, and L. rubrilucens, is also able to trigger this pathway [52-54].

\section{NAIP5/NLRC4 INFLAMMASOME AND THE EFFECTOR MECHANISMS FOR THE CONTROL OF LEGIONELLA REPLICATION}

The activation of the Naip5/NLRC4 inflammasome triggers a robust, autonomous cellular process that culminates with the suppression of L. pneumophila replication in macrophages [29, 35]. The effector mechanisms underlying this Naip5/NLRC4-mediated control of the L. pneumophila replication in macrophages are not completely understood. It has been demonstrated that this inflammasome plays an important role in the regulation of the LCV maturation [37, 55]. On the other hand, work published in 2004 proposed that the mechanisms for resistance are multifactorial and involve the regulation of phagosome maturation, lysis, and cell death in response to infection [56]. Autophagy has also been shown to be important for the control of $L$. pneumophila replication by Naip5/NLRC4 [57, 58]. In this context, it is interesting that some strains of L. pneumophila inhibit autophagy through specific Dot/ Icm effector proteins $[59,60]$. Another hypothesis to explain the mechanism underlying the Naip5/NLRC4-mediated suppression of the growth emerged from the observation that $L$. pneumophila leads to an inflammatory cell death. Pyroptosis is defined as an inflammatory form of cell death that is characterized by the formation of pores in the membrane, swelling, and osmotic lysis that results in the release of inflammatory cytokines, such as IL-1 $\beta$ and IL-18 [25, 26, 61]. The mechanism underlying the inflammasomemediated control of infection by pyroptosis involves the death of the host cells, followed by phagocytosis by neutrophils, in a process that involves reactive oxygen species [62]. Very likely, the effector mechanisms that are involved in the control of infection are dependent on the cytokine production induced by PRRs and the recruitment of neutrophils to the infection sites [63-66].

\section{ADDITIONAL FUNCTIONS OF NAIP5/ NLRC4 IN RESPONSE TO L. PNEUMOPHILA}

Although caspase-1 activation is a major consequence of Naip5 NLRC4 activation, caspase-1-independent responses have also been described [67-71]. Pereira et al. [53] demonstrated that activation of the Naip5/NLRC4 inflammasome triggers responses that are independent of caspase-1/11. This explain why

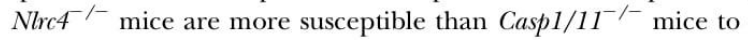




\section{JLB}

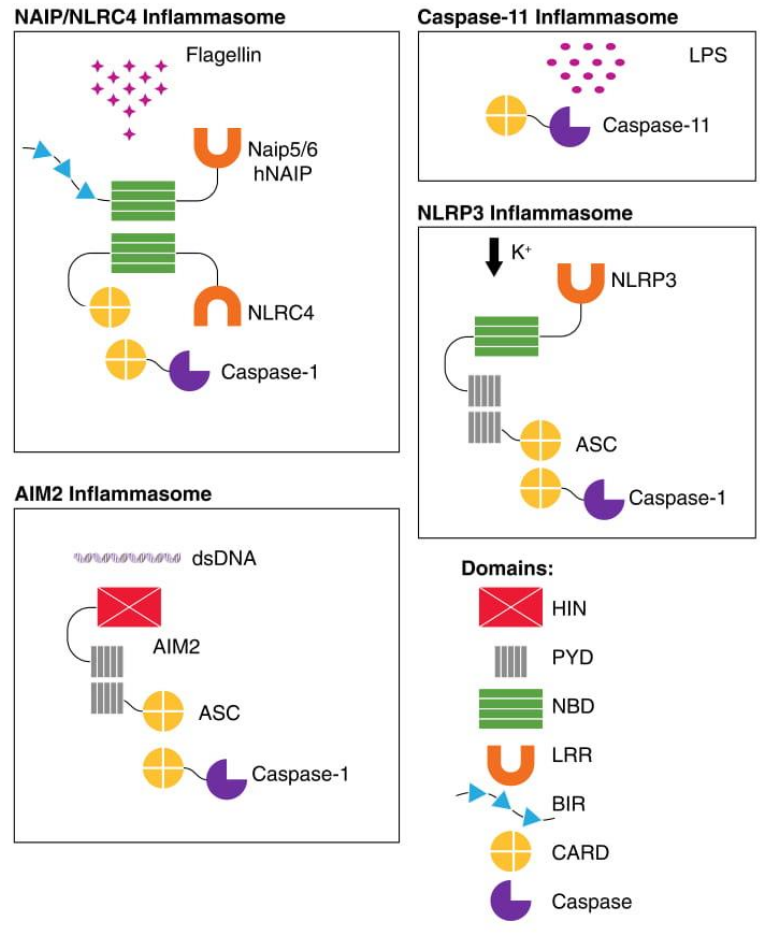

Figure 2. Inflammasomes activated in response to $L$. pneumophila. Various inflammasomes are activated in response to $L$. pneumophila. (Upper left) NAIP/NLRC4 is activated by cytosolic flagellin. Murine Naip5 and Naip6 or hNAIP sense flagellin and recruit NLRC4 to activate caspase-1. This process leads to pyroptosis, the cleavage of caspase-1, the production of IL- $1 \beta$, and the restriction of $L$. pneumophila in macrophages. (Upper right) L. pneumophila LPS binds and activates caspase-11. The active caspase-11 triggers pore formation and partially accounts for the IL-1 $\alpha$ secretion. The pore formation induced by caspase-11 facilitates the efflux of $\mathrm{K}^{+}$and the noncanonical activation of NLRP3. (Lower left) The AIM2 inflammasome is activated in response to dsDNA from L. pneumophila. AIM2 binds ASC to activate caspase-1. This process leads to pyroptosis and IL-1 $\beta$ secretion. (Lower right) The canonical NLRP3 inflammasome requires a pore-forming agent or a molecule that damages the host cell membranes (such as a crystal) to trigger $\mathrm{K}^{+}$efflux. The reduced concentration of cytosolic $\mathrm{K}^{+}$activates NLRP3, which recruits ASC to activate caspase-1. This process leads to pyroptosis and the induction of inflammatory cytokines, such as IL-1 $\beta$ and IL-18. During an L. pneumophila infection, the NLRP3 inflammasome is activated only via the noncanonical pathway, which requires caspase-11 activation by LPS. This process leads to pore formation and the activation of the NLRP3 inflammasome. The indicated domains are as follows: HIN, PYD, NBD, LRR, BIR, CARD, and Caspase.

the replication of $L$. pneumophila in macrophages and in vivo [53]. The mechanisms that underlie the caspase-1/11independent suppression of $L$. pneumophila replication via the flagellin/Naip5/Nlrc4 inflammasome are still unknown. In addition, one study reported an important role for caspase-7 in the activation of caspase-1 via the Naip5/NLRC4 inflammasome [67]. Accordingly, the Casp $7^{-1}$ macrophages had a higher bacterial load, which suggested that caspase-7 is involved in suppression of L. pneumophila replication [67].
Another question that is still unanswered involves the participation of ASC in the Naip5/NLRC4 inflammasome. Studies of $L$. pneumophila replication in human cells have demonstrated that ASC is important for the control of the bacterial replication [72]. However, this contrasts with studies that used mouse macrophages, which indicated that ASC is not required for some functions of the NLRC4 inflammasome, including induction of pore formation, pyroptosis, and the suppression of L. pneumophila replication [35, 52, 53, 73] (Fig. 3). Furthermore, it was demonstrated that ASC is essential for certain NLRC4 functions, including puncta formation, as well as the cleavage and release of caspase-1, IL-1 $\beta$, and IL-18 [73, 74]. An elegant study demonstrated that the formation of ASC puncta is critical for caspase-1 autoproteolysis. Moreover, cleaved caspase-1 is responsible for the release of IL-1 $\beta$ and IL-18. On the other hand, an active but uncleaved form of caspase-1 can induce pore formation and pyroptosis, a process that does not require ASC [75]. Therefore, ASC is important for the recruitment of the additional molecules to the inflammasome in the puncta-like structure, and this process leads to the cleavage and secretion of caspase-1 and inflammatory cytokines, such as IL-1 $\beta$ and IL-18 [73-75]. In conclusion, the published data are consistent with the hypothesis that ASC can be part of the Naip5/NLRC4 inflammasome that induces caspase-1 cleavage and cytokine

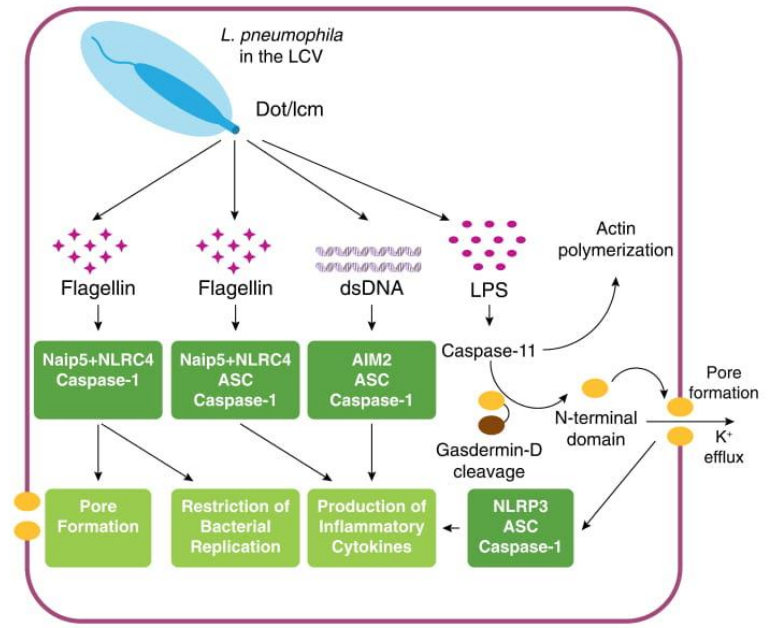

Figure 3. Functional consequences of the inflammasome activation induced by $\boldsymbol{L}$. pneumophila. The recognition of flagellin by the Naip5/ NLRC4 inflammasome is a Dot/Icm-dependent process and induces the formation of 2 platforms. One is ASC independent and leads to pore formation and the suppression of bacterial replication. The other is ASC dependent and induces caspase-1 cleavage and the production of inflammatory cytokines. dsDNA from $L$. pneumophila is recognized by AIM2 and recruits ASC to trigger the activation of the AIM2 inflammasome. The L. pmeumophila LPS is recognized by caspase-11 in a process that induces pore formation and $\mathrm{K}^{+}$efflux and leads to the noncanonical activation of the NLRP3/ASC. Caspase-11 cleaves GSDMD in response to LPS. The N-terminal domain of GSDMD binds to lipids in the inner part of the plasma membrane to promote the formation of pores that are essential for $\mathrm{K}^{+}$efflux and pyroptosis induction. 
production (Fig. 3). Nonetheless, the function of Naip5/NLRC4 is independent of ASC with respect to the activation of caspase-1 (without cleavage) to induce pyroptosis and the suppression of L. pmeumophila replication. These data are very clear in that $A s c^{-1-}$ macrophages are fully sufficient to induce pyroptosis and suppression of $L$. pneumophila replication via the flagellin/Naip5/ NLRC4 inflammasome [35, 52, 74].

\section{THE hNAIP}

Human macrophages, in contrast to the mouse cells, are highly permissive for L. pneumophila replication and only express 1 NAIP gene (hNAIP) [33]. Murine Naip5 is the gene responsible for flagellin recognition and the suppression of L. pneumophila replication in mouse cells; therefore, it was believed that the homologous hNAIP does not recognize flagellin. This hypothesis was supported by the demonstration that the hNAIP recognizes PrgI, a needle protein from the bacterial T3SS [41-43]. In addition, immortalized monocytic-derived cell lines, such as THP-1 and U937, do not respond to flagellin, which argues that hNAIP is not involved in flagellin recognition. However, previous reports indicated that hNAIP and NLRC4 are involved in the restriction of $L$. pneumophila replication in human cells [76]. Consistent with this view, certain human populations express several copies of hNAIP, and the level of expression inversely correlates with the resistance to L. pneumophila [77]. A recently published article clarified this issue and supported the important role of hNAIP in flagellin sensing [78]. This study demonstrated that flagellin detection requires a full-length isoform of hNAIP, which is highly expressed in primary human macrophages but not in immortalized human cell lines, such as THP-1 and U937. Thus, these cell lines are insensitive to flagellin, whereas hNAIP is able to sense flagellin in primary human macrophages [78]. Notably, hNAIP has several annotated transcript variants that encode several NAIP isoforms, and 1 specific transcript encodes an isoform with a high level of identity with murine Naip5 [78] Thus, although humans encode only a single Naip gene, different isoforms may guarantee the ability to recognize both flagellin and bacterial T3SS effectors.

\section{RESPONSES OF THE NLRP3 INFLAMMASOME TO LEGIONELLA}

NLRP3 (previously known as Nalp3/cryopyrin/cold-induced autoinflammatory syndrome 1) is a member of the NLRP class of intracellular sensors and is characterized by the PYD in its $\mathrm{N}$-terminal domain. This domain is important for its interaction with ASC, which leads to activation of caspase-1 [79]. The first study that addressed the role of the NLRP3 inflammasome in the recognition of and responses to $L$. pneumophila was published in 2006. Macrophages deficient in ASC were defective in the induction of inflammatory cytokines, such as IL-1 $\beta$, but were fully competent for the induction of pyroptosis and the suppression of the $L$. pneumophila replication [35]. In the same year, several groups demonstrated that the NLRP3 inflammasome is activated in response to various compounds, including monosodium urate crystals, bacterial RNA, ATP, toxins that lead to pore formation (nigericin and maitotoxin), and calcium pyrophosphate dehydrate [80-84]. Surprisingly, although ASC is essential for the inflammasome-mediated induction of inflammatory cytokines [35], NLRP3 ${ }^{-/-}$macrophages produced IL-1 $\beta$ normally in response to $L$. pneumophila [84]. Further investigation indicated that NLRP3 is indeed unnecessary for caspase-1 activation and the suppression of $L$. pneumophila replication in macrophages and in mouse lungs [73]. However, the NLRP3-independent caspase-1 cleavage in response to $L$. pneumophila occurred in response to only flagellin-positive $L$. pneumophila. Studies comparing wild-type and flagellin-deficient $L$. pneumophila strains demonstrated that NLRP3 is essential for caspase-1 cleavage in the absence of the NLRC4 inflammasome [85]. Activation of the NLRC4 inflammasome by flagellin leads to caspase-1 cleavage and IL-1 $\beta$ production in a process that is ASC dependent and NLRP3 independent [85]. In contrast, in the absence of flagellin, caspase-1 cleavage and IL-1 $\beta$ production are dependent on caspase-11 and NLRP3 [64, 85-87]. This process is the so-called noncanonical pathway for the activation of the NLRP3 inflammasome.

\section{CASPASE-11 AND NONCANONICAL ACTIVATION OF THE NLRP3 INFLAMMASOME}

In 2011, an elegant study performed by Dixit and colleagues [88] demonstrated that caspase-11 is required for caspase-1 activation in certain conditions. It was demonstrated that caspase- $11^{-/-}$ mice fail to activate caspase- 1 and to secrete IL- $1 \beta$ in response to gram-negative bacteria, but the response to canonical NLRP3 activators, such as ATP and nigericin, is normal. In addition, caspase-11 was demonstrated to trigger responses that are independent of NLRP3, including pore formation, cell death, and the release of $\mathrm{IL}-1 \alpha[85,88]$. Investigations using L. pneumophila demonstrated that caspase- 11 is required for the activation of NLRP3 in response to this organism $[64,85]$. Caspase-11 activation in response to L. pneumophila is flagellin independent; accordingly, the caspase-11 pathway cooperates with the flagellin/NLRC4 pathway to induce caspase-1 cleavage and IL-1 $\beta$ production $[64,85]$. Caspase-11 studies performed using $L$. pneumophila indicated that caspase-11 promoted the fusion of the L. pneumophila vacuole with lysosomes by modulating actin polymerization through cofilin $[89,90]$. However, the role of caspase-11 in the suppression of L. pneumophila replication is still controversial. Experiments performed with caspase- $11^{-/-}$mice in various mouse genetic backgrounds indicated that caspase-11 is not required for the suppression of L. pneumophila replication in macrophages and in vivo [91].

The mechanism by which L. pneumophila LPS reaches the host cytoplasm to trigger caspase-11 activation is also unclear. This process is certainly dependent on the bacterial T4BSS, Dot/Icm $[64,85]$. One hypothesis is that LPS leaks via the Dot/Icm. In addition, it was reported that guanylate-binding proteins promote vacuolar lysis, which releases the LPS into the macrophage cytoplasm [92, 93]. It is also possible that bacterial outermembrane vesicles fuse with the host cells and deliver LPS into the cytosol to induce caspase-11 activation [94]. Regardless of 


\section{JLB}

how LPS reaches the cytoplasm, it is clear that murine caspase-11 (and human caspase-4) is activated in response to L. pneumophila LPS and facilitates pore formation. This process is important in triggering $\mathrm{K}^{+}$efflux, a feature that is critical to enable NLRP3 activation $[64,85,93,95]$. Thus, the "noncanonical pathway for the activation of the NLRP3 inflammasome" occurs when activated caspase-11 induces pore formation, enabling $\mathrm{K}^{+}$efflux and NLRP3 activation [96-98].

Until 2015, the mechanism by which caspase-11 triggers pore formation and cell death was unclear, but independent studies using genetic screening identified GSDMD as a mediator for pyroptosis and caspase- 1 activation via the noncanonical activation of the NLRP3 inflammasome. These studies demonstrated that caspase-11 leads to GSDMD cleavage, which results in an N-terminal fragment that is responsible for the downstream signaling [99, 100]. Recently, new studies demonstrated that the cleaved N-terminal fragment (p30) of GSDMD is localized in the lipid bilayer, whereas the C-terminal fragment remains intracellular. This $\mathrm{N}$-terminal fragment forms a ring-like structure where $\mathrm{Ca}^{2+}$ secretion occurs, suggesting that p30 forms pores in the membranes [101-104]. Whether GSDMD is activated in response to L. pneumophila and facilitates pore formation and pyroptosis in response to infection is a matter for future investigation.

\section{THE AIM2 INFLAMMASOME IN RESPONSE TO LEGIONELLA}

Four independent groups reported in 2009 that a cytosolic protein containing an HIN/helicase domain oligomerizes upon the interaction with dsDNA in the cytosol of innate immune cells [20, 105-107]. This HIN-containing protein is AIM2, which contains a PYD and HIN. The latter binds dsDNA in a lengthdependent manner and exposes the PYD, which binds to the PYD of ASC through a homotypic domain interaction. ASC clustering allows procaspase-1 recruitment via a CARD-CARD interaction. This complex of proteins is the AIM2 inflammasome, which is activated in response to dsDNA (Fig. 2).

A few years before the AIM2 inflammasome was identified, a study performed with $L$. pneumophila reported that a Dot/Icm effector protein, called SdhA, is important in the prevention of macrophage cell death and thus, facilitates bacterial replication [108]. In 2012, SdhA was shown to regulate the vacuole integrity on the basis that infections performed with $s d h A^{-/-}$bacteria lead to vacuole destabilization and disruption with the consequent induction of host cell death [109]. This process was shown to be independent of flagellin and bacterial degradation. Moreover, it was demonstrated that the secreted phospholipase, PlaA, another Dot/Icm effector, regulates vacuole rupture and cell death in the absence of SdhA [109]. Notably, a strain of L. pneumophila with a mutation in the $s d h A$ gene localizes in the cytosol and triggers multiple responses, including the induction of type I IFN and the activation of caspase-1 [109, 110]. Additional evidence that the effector protein SdhA is critical to the maintenance of vacuolar integrity, bacterial replication, and prevention of the host cell death was provided by subsequent studies that reported that the expression of SdhA inhibits the activation of the AIM2 inflammasome. Ge and colleagues [111] demonstrated that
L. pneumophila DNA is released into the host cytoplasm, and this was increased in the infection with $s d h A^{-/-}$bacteria. Subsequently, the bacterial DNA is recognized by the AIM2 inflammasome, a process that leads to caspase- 1 activation, IL-1 $\beta$ release, and the pyroptosis of mouse and human cells [111]. The activation of caspase-1 via the AIM2 inflammasome is independent of type I IFN and TNF- $\alpha$, in contrast to the activation of AIM2 in response to Francisella tularensis [111-113].

Notably, SdhA regulates the vacuolar integrity in various hosts [114], regardless of the presence or absence of the AIM2 inflammasome. This is consistent with the fact that $L$. pneumophila evolved in freshwater environments in which it infected protozoa, and human infection is incidental. We speculate that the evolutionary pressure to maintain SdhA expression is likely related to the essential requirement to regulate vacuolar integrity in the unicellular protozoa, rather than a mechanism that evolved to evade innate immune activation and inflammasomes in higher eukaryotes.

\section{CONCLUDING REMARKS}

Over the last decade, $L$. pneumophila has been used very successfully to reveal specific aspects of PRR signaling and inflammasome activation in response to infection. These studies using $L$. pneumophila revealed relevant information regarding the mechanisms of the function of the inflammasomes and also generated important information that contributed to our understanding of the mechanisms used by innate immune cells to recognize and fight infectious diseases, including those caused by Legionella species. We envisage that additional future studies will provide exciting information regarding the function of uncharacterized or poorly characterized inflammasomes and their intracellular sensors. In addition, future investigations involving $L$. pneumophila may help to answer open questions regarding the biology of well-studied inflammasomes, including NLRP3, NLRC4, and AIM2.

\section{AUTHORSHIP}

D.P.A.M. and D.S.Z. wrote the manuscript and prepared the figures.

\section{ACKNOWLEDGMENTS}

Work in our laboratory is supported by grants (2013/08216-2, 2014/50268-2, and 2014/04684-4) from the Fundação de Amparo à Pesquisa do Estado de São Paulo (FAPESP), Conselho Nacional do Desenvolvimento Cientifico e Tecnológico (CNPq), Coordenação de Aperfeiçoamento de Pessoal de Nível Superior (CAPES), and Fundação de Amparo ao Ensino, Pesquisa e Assistência do Hospital das Clínicas da Faculdade de Medicina de Ribeirão Preto/Universidade de São Paulo (FAEPA). D.P.A.M. is supported by a Ph.D. fellowship (2014/00794-0) from FAPESP. D.S.Z. is a research fellow from $\mathrm{CNPq}$, Brazil. The authors are grateful to Maira C. Nakamura, Leticia A. Corsi, and Victoria M. dos Santos for technical assistance in the work performed in their laboratory. 


\section{DISCLOSURES}

The authors declare no conflicts of interest related to this work.

\section{REFERENCES}

1. Fraser, D. W., Tsai, T. R., Orenstein, W., Parkin, W. E., Beecham, H. J. Sharrar, R. G., Harris, J., Mallison, G. F., Martin, S. M., McDade, J. E., Shepard, C. C., Brachman, P. S. (1977) Legionnaires' disease:
description of an epidemic of pneumonia. N. Enol. J. Med. 297, description

2. Feeley, J. C., Gibson, R. J., Gorman, G. W., Langford, N. C., Rasheed, J. K., Mackel, D. C., Baine, W. B. (1979) Charcoal-yeast extract agar: primary isolation medium for Legionella pneumophila. J. Clin. Microbiol. 10, $437-441$

3. Swanson, M. S., Hammer, B. K. (2000) Legionella pneumophila pathogesesis: a fateful journey from amoebae to macrophages. Annu. Rev. Microbiol. 54, 567-613.

4. Brenner, D. J. (1987) Classification of the legionellae. Semin. Respir. Infect. 2, 190-205.

5. Doebbeling, B. N., Wenzel, R. P. (1987) The epidemiology of Legionella pneumophila infections. Semin. Respir. Infect. 2, 206-221.

6. Horwitz, M. A., Silverstein, S. C. (1980) Legionnaires' disease bacterium (Legionella pneumophila) multiples intracellularly in human monocytes. (Legionella preumophila) mo.

7. Stout, J. E., Yu, V. L (1997) Legionellosis. N. Engl. J. Med. 337, 682-687.

7. Stout, J. E., Yu, V. L. (1997) Legionellosis. N. Engl. J. Med. 337, 682-687. the family Legionellaceae. Arch. Immunol. Ther. Exp. (Warsz.) 57, the family

9. Newton, H. J., Ang, D. K., van Driel, I. R., Hartland, E. L. (2010) Molecular pathogenesis of infections caused by Legionella pneumophila. Clin. Microbiol. Reu. 23, 274-298.

10. Khodr, A., Kay, E., Gomez-Valero, L., Ginevra, C., Doublet, P., Buchrieser, C., Jarraud, S. (2016) Molecular epidemiology, phylogeny and evolution of Legionella. Infect. Genet. Evol. 43, 108-122.

11. Isberg, R. R., O'Connor, T. J., Heidtman, M. (2009) The Legionella pneumophila replication vacuole: making a cosy niche inside host cells. Nat. Rev. Microbiol. 7, 13-24.

12. Berger, K. H., Merriam, J. J., Isberg, R. R. (1994) Altered intracellular targeting properties associated with mutations in the Legionella pneumophila dotA gene. Mol. Microbiol. 14, 809-822.

13. Marra, A., Blander, S. J., Horwitz, M. A., Shuman, H. A. (1992) Identification of a Legionella pneumophila locus required for intracellula multiplication in human macrophages. Proc. Natl. Acad. Sci. USA 89, 9607-9611.

14. Chovatiya, R., Medzhitov, R. (2014) Stress, inflammation, and defense of homeostasis. Mol. Cell 54, 281-288.

15. Janeway, C. A., Jr., Medzhitov, R. (2002) Innate immune recognition. Annu. Rev. Immunol. 20, 197-216.

16. Akira, S. (2009) Pathogen recognition by innate immunity and its signaling. Proc. Jpn. Acad., Ser. B, Phys. Biol. Sci. 85, 143-156.

17. Kumar, H., Kawai, T., Akira, S. (2011) Pathogen recognition by the Kumar, H., Kawai, T., Akira, S. (2011) Pathogen recogr

18. Massis, L. M., Zamboni, D. S. (2011) Innate immunity to Legionella pneumophila. Front. Microbiol. 2, 109.

19. Takeuchi, O., Akira, S. (2010) Pattern recognition receptors and inflammation. Cell 140, 805-820.

20. Bürckstümmer, T., Baumann, C., Blüml, S., Dixit, E., Dürnberger, G., Jahn, H., Planyavsky, M., Bilban, M., Colinge, J., Bennett, K. L., SupertiFurga, G. (2009) An orthogonal proteomic-genomic screen identifies AIM2 as a cytoplasmic DNA sensor for the inflammasome. Nat. Immunol. 10, 266-272.

21. Martinon, F., Burns, K., Tschopp, J. (2002) The inflammasome: a molecular platform triggering activation of inflammatory caspases and processing of proIL-beta. Mol. Cell 10, 417-426.

22. Zamboni, D. S., Lima-Junior, D. S. (2015) Inflammasomes in host response to protozoan parasites. Immunol. Rev. 265, 156-171.

23. Masumoto, J., Taniguchi, S., Ayukawa, K., Sarvotham, H., Kishino, T., Niikawa, N., Hidaka, E., Katsuyama, T., Higuchi, T., Sagara, J. (1999) ASC, a novel 22-kDa protein, aggregates during apoptosis of human

promyelocytic leukemia HL-60 cells. J. Biol. Chem. 274, 33835-33838. Proell, M., Gerlic, M., Mace, P. D., Reed, J. C., Riedl, S. J. (2013) The CARD plays a critical role in ASC foci

25. Cookson, B. T., Brennan, M. A. (2001) Pro-inflammatory programmed cell death. Trends Microbiol. 9, 113-114.

26. Fink, S. L., Cookson, B. T. (2006) Caspase-1-dependent pore formation during pyroptosis leads to osmotic lysis of infected host macrophages.

27. Qu, Y., Misaghi, S., Newton, K., Maltzman, A., Izrael-Tomasevic, A., Arnott, D., Dixit, V. M. (2016) NLRP3 recruitment by NLRC4 during Salmonella infection. J. Exp. Med. 213, 877-885.
28. Man, S. M., Hopkins, L. J., Nugent, E., Cox, S., Glück, I. M. Tourlomousis, P., Wright, J. A., Cicuta, P., Monie, T. P., Bryant, C. E.
(2014) Inflammasome activation causes dual recruitment of NLRC4 and NLRP3 to the same macromolecular complex. Proc. Natl. Acad. Sci. USA 111, 7403-7408.

29. Yamamoto, Y., Klein, T. W., Newton, C. A., Widen, R., Friedman, H. (1988) Growth of Legionella pneumophila in thioglycolate-elicited

peritoneal macrophages from A/J mice. Infect. Immun. 56, 370-375. Beckers, M. C., Yoshida, S., Morgan, K., Skamene, E., Gros, P. (1995)
Natural resistance to infection with Legionella pneumophila: chromosomal localization of the Lgn1 susceptibility gene. Mamm. Genome 6, 540-545.

31. Dietrich, W. F., Damron, D. M., Isberg, R. R., Lander, E. S., Swanson, M. S. (1995) Lgn1, a gene that determines susceptibility to Legionella pneumophila, maps to mouse chromosome 13. Genomics 26, 443-450.

32. Diez, E., Yaraghi, Z., MacKenzie, A., Gros, P. (2000) The neuronal apoptosis inhibitory protein (Naip) is expressed in macrophages and is modulated after phagocytosis and during intracellular infection with Legionella pneumophila. J. Immunol. 164, 1470-1477.

33. Diez, E., Lee, S. H., Gauthier, S., Yaraghi, Z., Tremblay, M., Vidal, S., Gros, P. (2003) Bircle is the gene within the Lgn1 locus associated with resistance to Legionella pneumophila. Nat. Genet. 33, 55-60.

34. Wright, E. K., Goodart, S. A., Growney, J. D., Hadinoto, V., Endrizzi, M. G., Long, E. M., Sadigh, K., Abney, A. L., Bernstein-Hanley, I., Dietrich, W. F. (2003) Naip5 affects host susceptibility to the intracellular pathogen Legionella pneumophila. Curr. Biol. 13, 27-36.

35. Zamboni, D. S., Kobayashi, K. S., Kohlsdorf, T., Ogura, Y., Long, E. M. Vance, R. E., Kuida, K., Mariathasan, S., Dixit, V. M., Flavell, R. A., Dietrich, W. F., Roy, C. R. (2006) The Bircle cytosolic patternDietrich, W. F., Roy, C. R. (2006) The Bircle cytosolic pattern-
recognition receptor contributes to the detection and control of recognition receptor contributes to the detection and con
Legionella pneumophila infection. Nat. Immunol. 7, 318-325.

36. Lightfield, K. L., Persson, J., Brubaker, S. W., Witte, C. E., von Moltke, J. Dunipace, E. A., Henry, T., Sun, Y. H., Cado, D., Dietrich, W. F., Monack, D. M., Tsolis, R. M., Vance, R. E. (2008) Critical function fo Naip5 in inflammasome activation by a conserve
domain of flagellin. Nat. Immunol. 9, 1171-1178.

37. Amer, A., Franchi, L., Kanneganti, T. D., Body-Malapel, M., Ozören, N. Brady, G., Meshinchi, S., Jagirdar, R., Gewirtz, A., Akira, S., Núñez, G. (2006) Regulation of Legionella phagosome maturation and infection through flagellin and host Ipaf. J. Biol. Chem. 281, 35217-35223.

38. Ren, T., Zamboni, D. S., Roy, C. R., Dietrich, W. F., Vance, R. E. (2006 Flagellin-deficient Legionella mutants evade caspase-1- and Naip5mediated macrophage immunity. PLoS Pathog. 2, e18.

39. Molofsky, A. B., Byrne, B. G., Whitfield, N. N., Madigan, C. A., Fuse, E. T., Tateda, K., Swanson, M. S. (2006) Cytosolic recognition of flagellin by mouse macrophages restricts Legionella pneumophila infection. J. Exp. Med. 203, 1093-1104.

40. Kofoed, E. M., Vance, R. E. (2011) Innate immune recognition of bacterial ligands by NAIPs determines inflammasome specificity. Nature 477, 592-595.

41. Zhao, Y., Yang, J., Shi, J., Gong, Y. N., Lu, Q., Xu, H., Liu, L., Shao, F (2011) The NLRC4 inflammasome receptors for bacterial flagellin and type III secretion apparatus. Nature 477, 596-600.

42. Ravamajhi, M., Zak, D. E., Chavarria-Smith, J., Vance, R. E., Miao, E. A. (2013) Cutting edge: mouse NAIP1 detects the type III secretion system (2013) Cutting edge: mouse NAIP1 detects

43. Yang, J., Zhao, Y., Shi, J., Shao, F. (2013) Human NAIP and mouse NAIP1 recognize bacterial type III secretion needle protein for inflammasome activation. Proc. Natl. Acad. Sci. USA 110, 14408-14413.

44. Rauch, I., Tenthorey, J. L., Nichols, R. D., Al Moussawi, K., Kang, J. J. Kang, C., Kazmierczak, B. I., Vance, R. E. (2016) NAIP proteins are required for cytosolic detection of specific bacterial ligands in vivo. J. Exp. Med. 213, 657-665.

45. Zhao, Y., Shi, J., Shi, X., Wang, Y., Wang, F., Shao, F. (2016) Genetic functions of the NAIP family of inflammasome receptors for bacterial ligands in mice. J. Exp. Med. 213, 647-656.

46. Tenthorey, J. L., Kofoed, E. M., Daugherty, M. D., Malik, H. S., Vance, R. E. (2014) Molecular basis for specific recognition of bacterial ligands by NAIP/NLRC4 inflammasomes. Mol. Cell 54, 17-29.

47. Franchi, L., Amer, A., Body-Malapel, M., Kanneganti, T. D., Ozören, N., Jagirdar, R., Inohara, N., Vandenabeele, P., Bertin, J., Coyle, A., Grant, E. P., Núñez, G. (2006) Cytosolic flagellin requires Ipaf for activation of caspase-1 and interleukin lbeta in salmonella-infected macrophages. Nat. Immunol. 7, 576-582.

48. Franchi, L., Stoolman, J., Kanneganti, T. D., Verma, A., Ramphal, R., Núñez, G. (2007) Critical role for Ipaf in Pseudomonas aeruginosa-

49. Miao, E. A., Alpuche-Aranda, C. M., Dors, M., Clark, A. E., Bader, M. W. Miller, S. I., Aderem, A. (2006) Cytoplasmic flagellin activates caspase-1 and secretion of interleukin 1 beta via Ipaf. Nat Immunol. 7, 569-

50. Sutterwala, F. S., Mijares, L. A., Li, L., Ogura, Y., Kazmierczak, B. I., Flavell, R. A. (2007) Immune recognition of Pseudomonas aeruginos mediated by the IPAF/NLRC4 inflammasome. J. Exp. Med. 204 3235-3245. 


\section{JLB}

51. Suzuki, T., Franchi, L., Toma, C., Ashida, H., Ogawa, M., Yoshikawa, Y, Mimuro, H., Inohara, N., Sasakawa, C., Nuñez, G. (2007) Differential regulation of caspase-1 activation, pyroptosis, and autophagy via Ipaf and ASC in Shigella-infected macrophages. PLoS Pathog. 3, el11.

52. Pereira, M. S., Marques, G. G., Dellama, J. E., Zamboni, D. S. (2011) The Nlrc4 inflammasome contributes to restriction of pulmonary infection by flagellated Legionella spp. that trigger pyroptosis. Front. Microbiol. 2, 33 .

53. Pereira, M. S., Morgantetti, G. F., Massis, L. M., Horta, C. V., Hori, J. I. Zamboni, D. S. (2011) Activation of NLRC4 by flagellated bacteria triggers caspase-1-dependent and -independent responses to restrict Legionella pneumophila replication in macrophages and in vivo. J. Immunol. 187, 6447-6455.

54. Silveira, T. N., Zamboni, D. S. (2010) Pore formation triggered by Legionella spp. is an Nlrc4 inflammasome-dependent host cell response that precedes pyroptosis. Infect. Immun. 78, 1403-1413.

55. Watarai, M., Derre, I., Kirby, J., Growney, J. D., Dietrich, W. F., Isberg, R. R. (2001) Legionella pneumophila is internalized by a macropinocytotic uptake pathway controlled by the Dot/Icm system and the mouse Lgn locus. J. Exp. Med. 194, 1081-1096.

56. Derré, I., Isberg, R. R. (2004) Macrophages from mice with the restrictive Lgnl allele exhibit multifactorial resistance to Legionell a pneumophila. Infect. Immun. 72, 6221-6229.

57. Amer, A. O., Swanson, M. S. (2005) Autophagy is an immediate macrophage response to Legionella pneumophila. Cell. Microbiol. 7 , macroph $765-778$.

58. Byrne, B. G., Dubuisson, J. F., Joshi, A. D., Persson, J. J., Swanson, M. S. (2013) Inflammasome components coordinate autophagy and pyroptosis as macrophage responses to infection. MBio 4 , e0660-12.

59. Choy, A., Dancourt, J., Mugo, B., O'Connor, T. J., Isberg, R. R., Melia, T. J., Roy, C. R. (2012) The Legionella effector RavZ inhibits host autophagy through irreversible Atg8 deconjugation. Science 338,

60. Rolando, M., Escoll, P., Buchrieser, C. (2016) Legionella pmeumophila restrains autophagy by modulating the host's sphingolipid metabolism. Autophagy 12, 1053-1054

61. Fink, S. L., Cookson, B. T. (2005) Apoptosis, pyroptosis, and necrosis mechanistic description of dead and dying eukaryotic cells. Infect. Immun. 73, 1907-1916.

62. Miao, E. A., Leaf, I. A., Treuting, P. M., Mao, D. P., Dors, M., Sarkar, A Warren, S. E., Wewers, M. D., Aderem, A. (2010) Caspase-1-induced pyroptosis is an innate immune effector mechanism against intracellula bacteria. Nat. Immunol. 11, 1136-1142.

63. Barry, K. C., Fontana, M. F., Portman, J. L., Dugan, A. S., Vance, R. E. (2013) IL-1 $\alpha$ signaling initiates the inflammatory response to virulent Legionella pmeumophila in vivo. J. Immunol. 190, 6329-6339.

64. Casson, C. N., Copenhaver, A. M., Zwack, E. E., Nguyen, H. T., Strowig, T., Javdan, B., Bradley, W. P., Fung, T. C., Flavell, R. A., Brodsky, I. E. Shin, S. (2013) Caspase-11 activation in response to bacterial secretion Shin, S. (2013) Caspase-11 activation in response to bacterial
systems that access the host cytosol. PLoS Pathog. 9, e1003400.

65. Coers, J. Vance, R. E., Fontana, M. F. Dietrich, W. F. (2007) Restriction of Legionella pneumophila growth in macrophages requires the concerted action of cytokine and Naip5/Ipaf signalling pathways. Cell. Microbiol. 9, action of cy

66. Mascarenhas, D. P., Pereira, M. S., Manin, G. Z., Hori, J. I., Zamboni, D. S. (2015) Interleukin 1 receptor-driven neutrophil recruitmen accounts to MyD88-dependent pulmonary clearance of legionella pneumophila infection in vivo. J. Infect. Dis. 211, 322-330.

67. Akhter, A., Gavrilin, M. A., Frantz, L., Washington, S., Ditty, C., Limoli, D., Day, C., Sarkar, A., Newland, C., Butchar, J., Marsh, C. B., Wewers, M. D., Tridandapani, S., Kanneganti, T. D., Amer, A. O. (2009) Caspase7 activation by the Nlrc4/Ipaf inflammasome restricts Legionell pneumophila infection. PLoS Pathog. 5, e1000361.

68. Abdelaziz, D. H., Gavrilin, M. A., Akhter, A., Caution, K., Kotrange, S., Khweek, A. A., Abdulrahman, B. A., Hassan, Z. A., El-Sharkawi, F. Z., Bedi, S. S., Ladner, K., Gonzalez-Mejia, M. E., Doseff, A. I., Mostafa, M., Kanneganti, T. D., Guttridge, D., Marsh, C. B., Wewers, M. D., Amer, A. O. (2011) Asc-dependent and independent mechanisms contribute to restriction of Legionella pmeumophila infection in murine macrophages. Front. Microbiol. 2, 18.

69. Amer, A. O. (2010) Modulation of caspases and their non-apoptotic functions by Legionella pneumophila. Cell. Microbiol. 12, 140-147.

70. Gao, L. Y., Abu Kwaik, Y. (1999) Activation of caspase 3 during Legionella pneumophila-induced apoptosis. Infect. Immun. 67, 4886-4894.

71. pneumophila-induced apoptosis. Infect. Immun. 67, 4886-4894. of caspase 3 activation by multiple Legionella pneumophila Dot/Icm

72. Abdelaziz, D. H., Gavrilin, M. A., Akhter, A., Caution, K., Kotrange, S. Khweek, A. A., Abdulrahman, B. A., Grandhi, J., Hassan, Z. A., Marsh, C., Wewers, M. D., Amer, A. O. (2011) Apoptosis-associated speck-like protein (ASC) controls Legionella preumophila infection in human monocytes. J. Biol. Chem. 286, 3203-3208.
73. Case, C. L., Shin, S., Roy, C. R. (2009) Asc and Ipaf inflammasome direct distinct pathways for caspase-1 activation in response to Legionelle pmeumophila. Infect. Immun. 77, 1981-1991.

74. Case, C. L., Roy, C. R. (2011) Asc modulates the function of NLRC4 in response to infection of macrophages by Legionella pneumophila. MBio 2 , e00117-11.

75. Broz, P., von Moltke, J., Jones, J. W., Vance, R. E., Monack, D. M. (2010) Differential requirement for caspase-1 autoproteolysis in pathogeninduced cell death and cytokine processing. Cell Host Microbe 8, 471-483.

76. Vinzing, M., Eitel, J., Lippmann, J., Hocke, A. C., Zahlten, J., Slevogt, H., N'guessan, P. D., Günther, S., Schmeck, B., Hippenstiel, S., Flieger, A., Suttorp, N., Opitz, B. (2008) NAIP and Ipaf control Legionella pmeumophila replication in human cells. J. Immunol. 180, 6808-6815.

77. Boniotto, M., Tailleux, L., Lomma, M., Gicquel, B., Buchrieser, C., Garcia, S., Quintana-Murci, L. (2012) Population variation in NAIP functional copy number confers increased cell death upon Legionella pneumophila infection. Hum. Immunol. 73, 196-200.

78. Kortmann, J., Brubaker, S. W., Monack, D. M. (2015) Cutting edge: inflammasome activation in primary human macrophages is dependen on flagellin. J. Immunol. 195, 815-819.

79. Martinon, F., Hofmann, K., Tschopp, J. (2001) The pyrin domain: possible member of the death domain-fold family implicated in apoptosis and inflammation. Curr. Biol. 11, R118-R120.

80. Kanneganti, T. D., Ozören, N., Body-Malapel, M., Amer, A., Park, J. H. Franchi, L., Whitfield, J., Barchet, W., Colonna, M., Vandenabeele, P., Bertin, J., Coyle, A., Grant, E. P., Akira, S., Núñez, G. (2006) Bacterial RNA and small antiviral compounds activate caspase-1 through cryopyrin/Nalp3. Nature 440, 233-236.

81. Mariathasan, S., Weiss, D. S., Newton, K., McBride, J., O'Rourke, K., Roose-Girma, M., Lee, W. P., Weinrauch, Y., Monack, D. M., Dixit, V. M. (2006) Cryopyrin activates the inflammasome in response to toxins and (2006) Cryopyrin activates

82. Martinon, F., Pétrilli, V., Mayor, A., Tardivel, A., Tschopp, J. (2006) Gout-associated uric acid crystals activate the NALP3 inflammasome. Nature 440, 237-241

83. Sutterwala, F. S., Ogura, Y., Szczepanik, M., Lara-Tejero, M., Lichtenberger, G. S., Grant, E. P., Bertin, J., Coyle, A. J., Galán, J. E., Askenase, P. W., Flavell, R. A. (2006) Critical role for NALP3/CiAS1/ cryopyrin in innate and adaptive immunity through its regulation of caspase-1. Immunity 24, 317-327.

84. Sutterwala, F. S., Ogura, Y., Zamboni, D. S., Roy, C. R., Flavell, R. A. (2006) NALP3: a key player in caspase-1 activation. J. Endotoxin Res. 12, 251-256.

85. Case, C. L., Kohler, L. J., Lima, J. B., Strowig, T., de Zoete, M. R., Flavell, R. A., Zamboni, D. S., Roy, C. R. (2013) Caspase-11 stimulates rapid flagellin-independent pyroptosis in response to Legionella pneumophila. Proc. Natl. Acad. Sci. USA 110, 1851-1856.

86. Aachoui, Y., Leaf, I. A., Hagar, J. A., Fontana, M. F., Campos, C. G., Zak, D. E., Tan, M. H., Cotter, P. A., Vance, R. E., Aderem, A., Miao, E. A. (2013) Caspase-11 protects against bacteria that escape the vacuole. 39, 975-978.

87. Cunha, L. D., Ribeiro, J. M., Fernandes, T. D., Massis, L. M., Khoo, C. A Moffatt, J. H., Newton, H. J., Roy, C. R., Zamboni, D. S. (2015) Inhibition of inflammasome activation by Coxiella burnetii type IV Inhibition of inflammasome activation by Coxiella burne

88. Kayagaki, N., Warming, S., Lamkanfi, M., Vande Walle, L., Louie, S., Dong, J., Newton, K., Qu, Y., Liu, J., Heldens, S., Zhang, J., Lee, W. P. Roose-Girma, M., Dixit, V. M. (2011) Non-canonic
activation targets caspase-11. Nature 479, 117-121.

89. Akhter, A., Caution, K., Abu Khweek, A., Tazi, M., Abdulrahman, B. A. Abdelaziz, D. H., Voss, O. H., Doseff, A. I., Hassan, H., Azad, A. K., Schlesinger, L. S., Wewers, M. D., Gavrilin, M. A., Amer, A. O. (2012 Caspase-11 promotes the fusion of phagosomes harboring pathogenic bacteria with lysosomes by modulating actin polymerization. Immunit $37,35-47$.

90. Caution, K., Gavrilin, M. A., Tazi, M., Kanneganti, A., Layman, D., Hoque, S., Krause, K., Amer, A. O. (2015) Caspase-11 and caspase-1 differentially modulate actin polymerization via RhoA and Slingshot proteins to promote bacterial clearance. Sci. Rep. 5, 18479.

91. Cerqueira, D. M., Pereira, M. S., Silva, A. L., Cunha, L. D., Zamboni, D. S. (2015) Caspase-1 but not caspase-11 is required for NLRC4mediated pyroptosis and restriction of infection by flagellated Legionelle mediated pyroptosis and restriction of infection by flagellated Legionella
species in mouse macrophages and in vivo. J. Immunol. 195, 2303-2311.

92. Meunier, E., Dick, M. S., Dreier, R. F., Schürmann, N., Kenzelmann Broz, D., Warming, S., Roose-Girma, M., Bumann, D., Kayagaki, N. Broz, D., Warming, S., Roose-Girma, M., Bumann, D., Kayagaki, N .,
Takeda, K., Yamamoto, M., Broz, P. (2014) Caspase-11 activation Takeda, K., Yamamoto, M., Broz, P. (2014) Caspase-11 activation
requires lysis of pathogen-containing vacuoles by IFN-induced GTPases.

93. Pilla, D. M., Hagar, J. A., Haldar, A. K., Mason, A. K., Degrandi, D. Pfeffer, K., Ernst, R. K., Yamamoto, M., Miao, E. A., Coers, J. (2014) Guanylate binding proteins promote caspase-11-dependent pyroptosis in response to cytoplasmic LPS. Proc. Natl. Acad. Sci. USA 111,
$6046-6051$. 
94. Vanaja, S. K., Russo, A. J., Behl, B., Banerjee, I., Yankova, M., Deshmukh, S. D., Rathinam, V. A. (2016) Bacterial outer membrane vesicles
mediate cytosolic localization of LPS and caspase-11 activation. Cell 165, mediate cy $1106-1119$.

95. Casson, C. N., Yu, J., Reyes, V. M., Taschuk, F. O., Yadav, A. Copenhaver, A. M., Nguyen, H. T., Collman, R. G., Shin, S. (2015) Human caspase-4 mediates noncanonical inflammasome activation against gram-negative bacterial pathogens. Proc. Natl. Acad. Sci. USA 112 $6688-6693$

96. Rivers-Auty, J., Brough, D. (2015) Potassium efflux fires the canon: potassium efflux as a common trigger for canonical and noncanonical NLRP3 pathways. Eur. J. Immunol. 45, 2758-2761.

97. Rühl, S., Broz, P. (2015) Caspase-11 activates a canonical NLRP3 inflammasome by promoting $\mathrm{K}(+)$ efflux. Eur. J. Immunol. 45, 2927-2936.

98. Schmid-Burgk, J. L., Gaidt, M. M., Schmidt, T., Ebert, T. S., Bartok, E., NLR3 inflammasome is 4 mediates non-canonical activation of the 2911-2917.

99. Kayagaki, N., Stowe, I. B., Lee, B. L., O'Rourke, K., Anderson, K., Warming, S., Cuellar, T., Haley, B., Roose-Girma, M., Phung, Q. T., Liu, P. S., Lill, J. R., Li, H., Wu, J., Kummerfeld, S., Zhang, J., Lee, W. P. Snipas, S. J., Salvesen, G. S., Morris, L. X., Fitzgerald, L., Zhang, Y., Bertram, E. M., Goodnow, C. C., Dixit, V. M. (2015) Caspase-11 cleaves gasdermin D for non-canonical inflammasome signalling. Nature 526, gasdermi

100. Shi, J., Zhao, Y., Wang, K., Shi, X., Wang, Y., Huang, H., Zhuang, Y., Cai, T., Wang, F., Shao, F. (2015) Cleavage of GSDMD by inflammatory caspases determines pyroptotic cell death. Nature 526, 660-665.

101. Aglietti, R. A., Estevez, A., Gupta, A., Ramirez, M. G., Liu, P. S., Kayagaki, N., Ciferri, C., Dixit, V. M., Dueber, E. C. (2016) GsdmD p30 elicited by caspase-11 during pyroptosis forms pores in membranes. Proc. Natl. Acad. Sci. USA 113, 7858-7863.

102. Ding, J., Wang, K., Liu, W., She, Y., Sun, Q., Shi, J., Sun, H., Wang, D. C. Shao, F. (2016) Pore-forming activity and structural autoinhibition of the gasdermin family. Nature $\mathbf{5 3 5}, 111-116$

103. Liu, X., Zhang, Z., Ruan, J., Pan, Y., Magupalli, V. G., Wu, H., Lieberman, J. (2016) Inflammasome-activated gasdermin D causes pyroptosis by forming membrane pores. Nature 535, 153-158.

104. Sborgi, L., Rühl, S., Mulvihill, E., Pipercevic, J., Heilig, R., Stahlberg, H., Farady, C. J., Müller, D. J., Broz, P., Hiller, S. (2016) GSDMD membrane pore formation constitutes the mechanism of pyroptotic cell death. EMBO J. 35, 1766-1778.
105. Fernandes-Alnemri, T., Yu, J. W., Datta, P., Wu, J., Alnemri, E. S. (2009) AIM2 activates the inflammasome and cell death in response to AIM2 activates the inflammasome and
cytoplasmic DNA. Nature 458, 509-513.

106. Hornung V, Ablasser, A Charrel-Dennis, M. Bauernfeind, F Horvath, G., Caffrey, D. R., Latz, E., Fitzgerald, K. A. (2009) AIM2 recognizes cytosolic dsDNA and forms a caspase-1-activating inflammasome with ASC. Nature 458,514-518.

107. Roberts, T. L., Idris, A., Dunn, J. A., Kelly, G. M., Burnton, C. M. Hodgson, S., Hardy, L. L., Garceau, V., Sweet, M. J., Ross, I. L., Hume, D. A., Stacey, K. J. (2009) HIN-200 proteins regulate caspase activatio in response to foreign cytoplasmic DNA. Science 323, 1057-1060.

108. Laguna, R. K., Creasey, E. A., Li, Z., Valtz, N., Isberg, R. R. (2006) A Legionella pneumophila-translocated substrate that is required for growth within macrophages and protection from host cell death. Proc. Natl. Acad. Sci. USA 103, 18745-18750.

109. Creasey, E. A., Isberg, R. R. (2012) The protein SdhA maintains the integrity of the Legionella-containing vacuole. Proc. Natl. Acad. Sci. USA 109, 3481-3486

110. Monroe, K. M., McWhirter, S. M., Vance, R. E. (2009) Identification of host cytosolic sensors and bacterial factors regulating the type interferon response to Legionella pneumophila. PLoS Pathog. 5, e1000665.

111. Ge, J., Gong, Y. N., Xu, Y., Shao, F. (2012) Preventing bacterial DNA release and absent in melanoma 2 inflammasome activation by a Legionella effector functioning in membrane trafficking. Proc. Natl. Acad. Sci. USA 109, 6193-6198.

112. Fernandes-Alnemri, T., Yu, J. W., Juliana, C., Solorzano, L., Kang, S., Wu, J., Datta, P., McCormick, M., Huang, L., McDermott, E., Eisenlohr, L., Landel, C. P., Alnemri, E. S. (2010) The AIM2 inflammasome is critical for innate immunity to Francisella tularensis. Nat. Immunol. 11, critical for

113. Jones, J. W., Kayagaki, N., Broz, P., Henry, T., Newton, K., O’Rourke, K. Chan, S., Dong, J., Qu, Y., Roose-Girma, M., Dixit, V. M., Monack, D. M. (2010) Absent in melanoma 2 is required for innate immune recognition of Francisella tularensis. Proc. Natl. Acad. Sci. USA 107, 9771-9776

114. Harding, C. R., Stoneham, C. A., Schuelein, R., Newton, H., Oates, C. V., Hartland, E. L., Schroeder, G. N., Frankel, G. (2013) The Dot/Icm effector SdhA is necessary for virulence of Legionella pneumophila in Galleria mellonella and A/J mice. Infect. Immun. 81, 2598-2605.

\section{KEY WORDS:}

caspase-1 $\cdot$ caspase-11 $\cdot$ NLRC4 $\cdot$ NLRP3 $\cdot$ ASC $\cdot$ AIM2 
9.3 - Anexo 3 - Manuscrito enviado por convite da revista (MASCARENHAS, Danielle PA; ZAMBONI, Dario S. Methods in Molecular Biology/2018)

"Inflammasome activation in Legionella-infected macrophages" 
1 Title: Inflammasome Activation in Legionella-infected Macrophages

2

3 Authors:

4 Danielle P. A. Mascarenhas ${ }^{1}$ and Dario S. Zamboni ${ }^{1 *}$

5

6 Affiliations:

$7{ }^{1}$ Department of Cell Biology, School of Medicine of Ribeirão Preto, University of São

8 Paulo. Ribeirão Preto, SP 14049-900, Brazil.

9

10 Short Running title: Legionella-induced inflammasome activation

12 Correspondence:

Dario S. Zamboni: Department of Cell Biology, School of Medicine of Ribeirão Preto,

14 University of São Paulo FMRP/USP, Av. Bandeirantes 3900, Ribeirão Preto, SP 14049-

15 900, Brazil. Phone: (55) (16) 3315-3265. Fax: (55) (16) 3633-1786. E-mail:

16 dszamboni@fmrp.usp.br

17 Keywords: Macrophages, Inflammasome, Caspase-1, Caspase-11, Legionella

Word count: 5227

19

Figures: 1 


\section{Abstract:}

22 Legionella pneumophila is a gram-negative bacterium that infects many species of

23 unicellular protozoa in freshwater environments. The human infection is accidental and the

24 bacteria may not evolved strategies to bypass innate immune signaling in mammalian

25 macrophages. Thus, L. pneumophila triggers many innate immune pathways including

26 inflammasome activation. The inflammasomes are multimolecular platform assembled in

27 the host cell cytoplasm that leads to activation of inflammatory caspases. Inflammasome

28 activation leads to secretion of inflammatory cytokines, such as IL-1 $\beta$ and IL-18, and an

29 inflammatory form of cell death called pyroptosis, which initiates with the induction of a

30 pore in the macrophage membranes. In this chapter we provide detailed protocols to

31 evaluate Legionella-induced inflammasome activation in macrophages, including real-time

32 pore formation assay, western blotting to detect activation of inflammatory caspases

33 (cleavage and pull-down) and the measurement of inflammatory cytokines. 


\section{1- Introduction}

37 Legionella pneumophila has been widely used as a model of intracellular pathogen to assess inflammasome biology (reviewed in [17]). Legionellae evolved infecting various species of unicellular protozoa in freshwater environments and the infection in mammalians

40 is accidental [21, 26]. Therefore, the bacteria did not evolved mechanisms to bypass or

41 inhibit activation of mammalian innate immune signaling, a feature that is consistent with

42 the fact that Legionella triggers many innate immune pathways (reviewed in [19]). For this reason, L. pneumophila emerged as an excellent model for investigating the innate immune

44 pathways in mammalian cells including inflammasome activation.

46 Inflammasomes are multimeric protein complexes formed in the host cell cytoplasm in

47 response to specific stimuli. It culminates with activation and cleavage of inflammatory

48 caspases and the release of inflammatory cytokines [16]. In the case of L. pneumophila

49 infection, upon the inhalation, the bacteria are phagocytosed by alveolar macrophages and

50 can subvert the normal vesicular trafficking by injecting hundreds of effectors proteins via

51 the Dot/Icm type IV secretion system [2, 3, 13, 24]. Although the Dot/Icm is critical for

52 survival of the bacteria in macrophages, it allows the activation of multiple immune

53 pathways including the inflammasome activation [28].

55 The most important inflammasome for restriction of L. pneumophila replication is the

56 NAIP5/NLRC4 inflammasome. The NAIP5 receptor can recognize Legionella flagellin and 
induces activation and oligomerization of NLRC4, which leads to caspase-1 activation [1, $14,20,23,27,28]$. The activation and cleavage of caspase-1 leads to pore formation and a specific form of cell death called pyroptosis, resulting in the restriction of Legionella replication in macrophages $[20,23,25,28]$. The real time analysis of pore formation by the incorporation of iodide propidium, a non-permeable fluorescent dye, and the western blot of cleaved caspase- 1 are easy and fast methods to measure the activation of this inflammasome $[4,6,18]$. Beyond pore formation, the activation of caspase-1 also leads the cleavage and release of IL-1 $\beta$ and IL-18, which provides additional readouts to assess inflammasome activation in macrophages.

In addition to NAIP5/NLRC4 inflammasome, others inflammasome pathways are activated in response to L. pneumophila and others species of Legionella. Caspase-11 is also highly activated by the recognition of $L$. pneumophila LPS (Lipopolysaccharide), a process that leads to pore formation, efflux of $\mathrm{K}+$ and the non-canonical pathway for activation of the NLRP3 inflammasome [4, 5, 6]. Furthermore, activation of the AIM2 inflammasome in response to L. pneumophila has also been shown $[8,11]$. Both the NAIP5/NLRC4, AIM2 and caspase- 11 activation can be measured by pore formation assay and analysis of caspase cleavage. Using this strategy, it was recently demonstrated that pore formation and pyroptosis are also induced by caspase- 8 in response to $L$. pneumophila infection, a process that is flagellin and NAIP5/NLRC4-dependent and caspase-1/11-independent ([18, 22] and Figure 1). Here, we provide detailed protocols for measurements of inflammasome activation in infected macrophages, including real-time pore formation assay, western blot 
79 of cleaved caspases, western blot for pull-down of active caspase-1/11 and detection of

80 inflammatory cytokine release.

81

82

2- Materials

83 2.1- Bone marrow-derived macrophages (BMDMs)

84 1. Sterile endo-free phosphate-buffered saline (PBS) for cell culture.

85 2. RPMI endo-free for cell culture.

86 3. RPMI $20 / 30$ :

$87 \checkmark$ RPMI endo-free for cell culture;

$88 \quad \checkmark \quad 15$ mM Hepes;

$89 \checkmark 2 \mathrm{mM} \mathrm{L}$-glutamine;

$90 \quad \checkmark \quad 100 \mathrm{U} / \mathrm{ml}$ penicillin-streptomycin;

$91 \checkmark \checkmark 20 \%$ of fetal bovine serum (FBS);

$92 \checkmark 30 \%$ of L929 cell-conditioned medium (see Note 2).

93 4. RPMI $10 \%$ :

$94 \checkmark$ RPMI endo-free for cell culture;

$95 \checkmark 15$ mM Hepes;

$96 \checkmark 2 \mathrm{mM}$ L-glutamine;

$97 \checkmark 10 \%$ FBS. 
6. Sterile scissors and tweezers.

100

7. Ethanol $70 \%$.

101

8. Pieces of gauze.

9. $2 \mathrm{ml}$ sterile endo-free microcentrifuge tube.

103

10. Ice.

104

11. Laminar flow cabinet.

105

12. 15 and $50 \mathrm{ml}$ sterile endo-free conical centrifuge tubes.

106 13. Sterile syringe and needles (we recommended the needle of $0.45 \times 13 \mathrm{~mm}$ for tibia and $107 \quad 0.70 \mathrm{~mm} \times 25 \mathrm{~mm}$ for femur).

108 14. Centrifuge for conical tubes.

109 15. Untreated endo-free cell culture plates $100 \mathrm{~mm}$ x $20 \mathrm{~mm}$ (see Note 4).

110 16. Sterile $5 \mathrm{ml}, 10 \mathrm{ml}$ and $25 \mathrm{ml}$ serological pipette.

111 17. Micropipettes (p20: 2-20 $\mu 1$, p200: 20-200 $\mu 1$ and p1000: 100-1000 $\mu 1$ ).

112 18. Sterile tips for $\mathrm{p} 20$, p200, and p1000 micropipettes.

113 19. Cell incubator at $36^{\circ} \mathrm{C}$ and $5 \% \mathrm{CO}_{2}$.

114 20. Vacuum pump.

115

116 2.2- Preparation of L. pneumophila inoculum 
117

1. L. pneumophila.

118 2. CYE (Charcoal-yeast extract) agar plate [10]:

$119 \checkmark \quad 1 \%$ MOPS or ACES;

120

121

122

123

124

125

126

127

128

129

130

131

132

133

134

\section{3- Pore formation assay}

$\checkmark 1 \%$ yeast extract;

$\checkmark$ pH 6.9

$\checkmark \quad 3.3 \mathrm{mM}$ L-cysteine;

$\checkmark 0.33 \mathrm{mM} \mathrm{Fe}\left(\mathrm{NO}_{3}\right)_{3} ;$

$\checkmark \quad 1.5 \%$ bacto agar;

$0.2 \%$ activated charcoal.

3. $37^{\circ} \mathrm{C}$ bacterial incubator.

4. Spectrometer

5. Sterile distilled water.

6. $1.5 \mathrm{ml}$ sterile endo-free microcentrifuge tube.

7. Micropipettes (p20: 2-20 $\mu 1$, p200: 20-200 $\mu \mathrm{l}$ and p1000: 100-1000 $\mu \mathrm{l}$ ).

8. Sterile tips for $\mathrm{p} 20$, p200, and p1000 micropipettes.

9. Vortex. 
135 1. 96 well cell culture plate (Treated, Black with clear-bottom).

136 2. RPMI $10 \%$ :

$137 \checkmark$ RPMI endo-free for cell culture;

$138 \checkmark 15$ mM Hepes;

$139 \checkmark 2 \mathrm{mM}$ L-glutamine;

$140 \checkmark \quad \checkmark \quad 10 \%$ fetal bovine serum (FBS).

141 3. Pore medium (see Note 5):

$142 \checkmark$ RPMI endo-free without phenol red containing just $0.038 \mathrm{~g} / \mathrm{ml} \mathrm{NaHCO}_{3}$;

$143 \quad \checkmark \quad 15$ mM Hepes;

$144 \quad \checkmark \quad 2$ mM L-glutamine;

$145 \checkmark 2 \%$ of FBS.

146 4. Lipopolysaccharide (LPS).

147 5. L. pneumophila inoculum.

148 6. Laminar flow cabinet.

149 7. Centrifuge for plates.

$1508.2 \mathrm{ml}$ sterile endo-free microcentrifuge tube.

1519.15 and $50 \mathrm{ml}$ sterile endo-free conical centrifuge tubes.

152 10. Sterile $5 \mathrm{ml}, 10 \mathrm{ml}$ and $25 \mathrm{ml}$ serological pipette. 
153 11. Micropipettes (p20: 2-20 $\mu 1$, p200: 20-200 $\mu 1$ and p1000: 100-1000 $\mu 1$ ).

154 12. Sterile tips for $\mathrm{p} 20, \mathrm{p} 200$, and $\mathrm{p} 1000$ micropipettes.

155 13. Cell incubator at $36^{\circ} \mathrm{C}$ and $5 \% \mathrm{CO}_{2}$.

156 14. Vacuum pump.

157 15. Iodide propidium $1 \mathrm{mg} / \mathrm{ml}(\mathrm{PI})$

158 16. Antibody anti-L. pneumophila.

159 17. Triton X-100 9\%.

160 18. Fluorometer.

161

162

2.4- Active caspase-1 and caspase-11 immunoblot assay

163

1. 48 well cell culture plate (tissue culture-treated).

164

2. RPMI $10 \%$ :

165

RPMI endo-free for cell culture;

$166 \checkmark 15$ mM Hepes;

$167 \checkmark 2$ mM L-glutamine;

$168 \checkmark \quad \checkmark \quad 10 \%$ fetal bovine serum (FBS).

169 3. Lipopolysaccharide (LPS).

170 4. L. pneumophila inoculum. 
5. Laminar flow cabinet.

6. Centrifuge for plates.

7. $2 \mathrm{ml}$ sterile endo-free microcentrifuge tube.

174

8. 15 and $50 \mathrm{ml}$ sterile endo-free conical centrifuge tubes.

9. Sterile $5 \mathrm{ml}, 10 \mathrm{ml}$ and $2 \mathrm{ml}$ serological pipette.

176

10. Micropipettes (p20: 2-20 $\mu 1$, p200: 20-200 $\mu 1$ and p1000: 100-1000 $\mu 1$ ).

177 11. Sterile tips for $\mathrm{p} 20$, p200, and p1000 micropipettes.

178 12. Cell incubator at $36^{\circ} \mathrm{C}$ and $5 \% \mathrm{CO}_{2}$.

179 13. Vacuum pump.

180 14. Ultra-low temperature freezer (-70 to -80$)$.

181 15. RIPA buffer:

182

$150 \mathrm{mM} \mathrm{NaCl}$;

183

$0.5 \%$ DOC (Deoxycholic acid - deoxycholate);

184

$\checkmark \quad 1 \%$ NP-40;

185

$0.1 \% \mathrm{SDS}$

186

$50 \mathrm{mM}$ Tris $\mathrm{pH}$ 8.0.

187

16. Protease inhibitor (stock $25 \mathrm{X}$ )

188

17. Laemmli $4 \mathrm{X}$ buffer: 
$190 \quad \checkmark \quad 2,4 \mathrm{ml} 1 \mathrm{M}$ Tris $\mathrm{HCl} \mathrm{pH} 6.8 ;$

$191 \quad \checkmark \quad 0.8 \mathrm{~g}$ SDS (Sodium Dodecyl Sulfate);

$192 \checkmark 4 \mathrm{ml}$ glycerol;

$193 \checkmark \quad 1 \mathrm{ml} \beta$-mercaptoethanol;

$194 \checkmark 200 \mu$ l blue bromophenol $2 \%$.

195

196 2.4.1- Western Blot

197 1. Electrophoresis vertical system.

198 2. Gel system with combs, short plate and spacer plate.

$1993.50 \mathrm{ml}$ conical centrifuge tubes.

$2004.5 \mathrm{ml}, 10 \mathrm{ml}$ and $25 \mathrm{ml}$ serological pipette.

201 5. Micropipettes (p20: 2-20 $\mu 1, \mathrm{p} 200: 20-200 \mu 1$ and p1000: 100-1000 $\mu$ ).

202 6. Tips for $\mathrm{p} 20, \mathrm{p} 200$, and $\mathrm{p} 1000$ micropipettes.

203 7. Distilled $\mathrm{H}_{2} \mathrm{O}$;

204 8. Polyacrylamide mix:

205

29 g Acrylamide;

206

$\checkmark 1 \mathrm{~g}$ Bis-acrylamide; 
$100 \mathrm{ml}$ distilled $\mathrm{H}_{2} \mathrm{O}$.

9. $1.5 \mathrm{M}$ Tris $\mathrm{HCl} \mathrm{pH} 8.8$.

209

10. $1 \mathrm{M}$ Tris $\mathrm{HCl} \mathrm{pH} 6.8$.

$210 \quad 11$. SDS $10 \%$

211 12. Ammonium persulfate $10 \%$.

212 13. TEMED.

213 14. Ethanol 100\%.

214 15. Protein ladder.

215 16. Running Buffer 10X:

$216 \checkmark \quad 1 \mathrm{~L}$ distilled $\mathrm{H}_{2} \mathrm{O}$;

$217 \checkmark \quad \checkmark 30.2$ g Tris-base;

$218 \quad \checkmark \quad 188$ g glycine;

$219 \checkmark \quad 10 \mathrm{~g}$ SDS.

220 17. Western Blot transfer system.

221 18. Transfer Buffer (specific for the transfer system).

222 19. Power Supply.

223 20. Nitrocellulose membrane $0.22 \mu \mathrm{m}$.

224 21. Tris-buffered saline 10X (TBS 10X): 
Adjust the $\mathrm{pH}$ to 8.0 with $\mathrm{HCl}$.

229 22. Tween 20.

230 23. Non-fat dry milk or bovine serum albumin (BSA) (according with the primary 231 antibody).

232 24. Primary antibody for cleaved caspase-1 or caspase-11.

233 25. Secondary antibody conjugated with peroxidase (HRP).

234 26. Chemiluminescent Luminol Reagent.

235 27. Gel imaging system.

236

237 2.5- Active caspase-1/11 pull-down assay

238 1. 6 wells cell culture plate (tissue culture-treated).

239 2. RPMI $10 \%$ :

$240 \checkmark$ RPMI endo-free for cell culture;

$241 \quad \checkmark \quad 15$ mM Hepes;

242 2 mM L-glutamine;

$243 \quad \checkmark \quad 10 \%$ fetal bovine serum (FBS). 
245 4. Biotin-VAD-FMK or biotin-YVAD-FMK (specific for caspase-1).

246 5. L. pneumophila inoculum.

247 6. Laminar flow cabinet.

248 7. Centrifuge for plates.

249 8. $2 \mathrm{ml}$ sterile endo-free microcentrifuge tube.

2509 9. 15 and $50 \mathrm{ml}$ sterile endo-free conical centrifuge tubes.

251 10. Sterile $5 \mathrm{ml}, 10 \mathrm{ml}$ and $2 \mathrm{ml}$ serological pipette.

252 11. Micropipettes (p20: 2-20 $\mu 1$, p200: 20-200 $\mu \mathrm{l}$ and p1000: 100-1000 $\mu \mathrm{l}$ ).

253 12. Sterile tips for $\mathrm{p} 20, \mathrm{p} 200$, and $\mathrm{p} 1000$ micropipettes.

254 13. Cell incubator at $36^{\circ} \mathrm{C}$ and $5 \% \mathrm{CO}_{2}$.

255 14. Vacuum pump.

256 15. RIPA buffer:

257

$150 \mathrm{mM} \mathrm{NaCl}$;

258

$0.5 \%$ DOC (Deoxycholic acid - deoxycholate);

$259 \checkmark \quad 1 \%$ NP-40;

$260 \quad \checkmark \quad 0.1 \%$ SDS;

261

$50 \mathrm{mM}$ Tris $\mathrm{pH}$ 8.0. 
16. Protease inhibitor (stock $25 \mathrm{X}$ ).

263 17. Protein quantification method.

264 18. Streptavidin-agarose beads.

265 19. Laemmli $4 X$ buffer:

$266 \checkmark \checkmark 2.8 \mathrm{ml}$ distilled $\mathrm{H}_{2} \mathrm{O}$;

$267 \checkmark \quad 2,4 \mathrm{ml} 1 \mathrm{M}$ Tris $\mathrm{HCl} \mathrm{pH}$ 6.8;

$268 \checkmark \quad 0.8 \mathrm{~g}$ SDS (Sodium Dodecyl Sulfate);

$269 \quad \checkmark \quad 4$ ml glycerol;

$270 \quad \checkmark \quad 1 \mathrm{ml} \beta$-mercaptoethanol;

$271 \checkmark \checkmark 200 \mu$ l blue bromophenol $2 \%$.

272 20. Materials from step 2.4.1.

273

274 2.6- Release of IL-1 $1 \beta$ or IL-18

275 1. 24 well cell culture plate (tissue culture-treated).

276 2. RPMI $10 \%$ :

$277 \checkmark$ RPMI endo-free for cell culture;

$278 \checkmark 15 \mathrm{mM}$ Hepes;

279 2 mM L-glutamine; 
281 3. Lipopolysaccharide (LPS).

282 4. L. pneumophila inoculum.

5. Laminar flow cabinet

6. Centrifuge for plates.

7. $2 \mathrm{ml}$ sterile endo-free microcentrifuge tube.

286

8. 15 and $50 \mathrm{ml}$ sterile endo-free conical centrifuge tubes.

9. Sterile $5 \mathrm{ml}, 10 \mathrm{ml}$ and $25 \mathrm{ml}$ serological pipette.

288

10. Micropipettes (p20: 2-20 $\mu$ l, p200: 20-200 $\mu 1$ and p1000: 100-1000 $\mu$ l).

289 11. Sterile tips for $\mathrm{p} 20$, p200, and p1000 micropipettes.

290 12. Cell incubator at $36^{\circ} \mathrm{C}$ and $5 \% \mathrm{CO}_{2}$.

291 13. Vacuum pump.

292 14. Ultra-low temperature freezer (-70 to -80$)$.

15. ELISA kits for IL-1 $\beta$ and/or IL-18.

294

295

3- Methods 
1. Remove femur and tibias of the mouse and store in $2 \mathrm{ml}$ microcentrifuge tube with

$2981.5 \mathrm{ml}$ of PBS 1X on ice. You can use a peace of gauze with ethanol $70 \%$ to help clean

299 the bones.

300 2. In laminar flow cabinet, prepare the materials to remove the bone marrow:

- $15 \mathrm{ml}$ tube with $4 \mathrm{ml}$ of ethanol $70 \%$;

302

- $15 \mathrm{ml}$ tube with $4 \mathrm{ml}$ of RPMI or PBS;

303

- $50 \mathrm{ml}$ tube with ethanol $70 \%$ with a sterile scissor and tweezer;

- Syringe with RPMI (usually 3-5 ml/bone) and needle.

- $15 \mathrm{ml}$ conical centrifuge tube to collect the bone marrow (one for each group).

3. Quickly wash the bones in ethanol 70\% and transfer it to the tube with RPMI or PBS.

4. Open the syringe and the collect tube for the removal of the bone marrow. Next, cut the

308 both ends of the bone, insert the syringe needle into one end and remove the bone

309 marrow by flushing RPMI through the bone. Store in ice or refrigerator at $4^{\circ} \mathrm{C}$.

310 5. Centrifuge at $200 \mathrm{xg}$ for 5 minutes.

311 6. Discard the supernatant and suspend bone marrow in RPMI 20/30.

312 7. Distribute the supernatant with the cells into non-tissue culture-treated plates with a

313 final volume of $10 \mathrm{ml}$ (1 femur renders approximately 2-3 plates and 1 tibia renders

314 approximately $1-2$ plates with at least $1 \times 10^{7}$ cells).

315 8. Incubate at $36^{\circ} \mathrm{C}$ and $5 \% \mathrm{CO}_{2}$.

316 9. After 4 days in culture add $10 \mathrm{ml}$ of RPMI $20 / 30$ (the RPMI must be at $36-37^{\circ} \mathrm{C}$ ). 
10. On the seventh day of culture, the cells are ready to be released from the plate for use in

318 the experiments. For this, aspirate the plate supernatant with a sterile tip and vacuum $319 \quad$ pump or with a pipette.

320 11. Wash the plate with $10 \mathrm{ml}$ of sterile endo-free PBS $1 \mathrm{X}$ (avoid throwing the PBS

321 directly into the cells, just in the wall of the plate). Discard the PBS.

12. Add $10 \mathrm{ml}$ of sterile endo-free PBS and place the plate on ice or refrigerator $4^{\circ} \mathrm{C}$ for 10 minutes.

13. Store the plate in room temperature for 5 minutes.

14. Remove the cell pipetting PBS in the cells and collect in $15 \mathrm{ml}$ or $50 \mathrm{ml}$ conical tube.

15. Centrifuge at $200 \mathrm{x}$ g for 5 minutes.

16. Discard the supernatant and suspend cells in RPMI $10 \%$ FBS.

17. Determine the number of the cells/ml and dilute the cell suspension in RPMI $10 \%$ FBS to reach the desired cell concentration $/ \mathrm{ml}$.

330 18. Distribute cell suspension in the appropriate plates for the experiments and incubate at $36^{\circ} \mathrm{C}$ in a $95 \%$ air, $5 \% \mathrm{CO}_{2}$ incubator for at least 4 hours before the experiment starts.

\section{2- Preparation of $L$. pneumophila inoculum}

1. Defrost the L. pneumophila 2 days after starting macrophage differentiation. For this, scrape with a sterile tip or inoculation loop the frozen Legionella stock and streak in 
336 CYE agar plate to isolate single colonies. Incubate the plate at $37^{\circ} \mathrm{C}$ for 4 days to isolate 337 single colonies $[10,12]$.

338 2. After 4 days pick up a single colony and inoculate in CYE agar plate doing a "heavy 339 patch" of about $1 \times 1 \mathrm{~cm}$ and incubate at $37^{\circ} \mathrm{C}$ for 2 days.

3403 . On the day of the infection, scrape a little of the " 2 days heavy patch" with a sterile tip 341 and add in a $1.5 \mathrm{ml}$ microcentrifuge tube with $1 \mathrm{ml}$ of sterile distilled water

342 Homogenize the bacterial suspension using a vortex mix.

343 4. Measure the optical density (O.D.) at $600 \mathrm{~nm}$ using a spectrometer. Note that each 344 spectrometer has an optimum O.D. range, therefore, if the bacterial concentration is 345 high it will be necessary to dilute the bacteria in water for appropriate measurements.

346 5. Estimate the final bacteria concentration (an O.D. of 1.0 corresponds to $10^{9}$ bacteria).

347 6. Calculate how much of each bacteria should be added to each well of the experiment:

\section{3- Pore formation assay}

1. Plate $1 \times 10^{5}$ cells/well in a black, clear-bottom 96 well treated plate with $200 \mu 1 /$ well of RPMI 10\% FBS (see Note 6).

2. Incubate at $36^{\circ} \mathrm{C}$ and $5 \% \mathrm{CO}_{2}$ for 1 day.

3. This assay can be performed with or without priming with LPS or another TLR agonist (see Note 7). In the case of LPS, sonicate the LPS for 10 minutes and then add in the plate $1 \mu \mathrm{g} / \mathrm{ml}$ for 3-4 hours (see Note 8 ). 
356 4. In the moment of the infection, replace the medium for the "pore medium" without

357 phenol red containing propidium iodide (PI) and anti-L. pneumophila (200 $\mu 1 /$ well) (see $358 \quad$ Note 5).

- Make a mix of pore medium with PI $(6 \mu 1 / \mathrm{ml})$ and anti-L. pneumophila for all the wells.

- Make the L. pneumophila inoculum as described in the step 3.2.

3615 . Aspirate the well medium with a sterile tip (it is important not to leave any RPMI with 362 phenol red in the well).

363 6. Add $200 \mu \mathrm{l}$ of the medium of the step 4 and the medium containing the bacteria in the 364 specific wells.

365 7. Centrifuge at $200 \mathrm{x}$ g for 5 minutes at room temperature.

366 8. Add $34 \mu \mathrm{l}$ of Triton X-100 9\% in the specific wells .

367 9. Place the plate in a fluorometer and setup with:

- Temperature: $36^{\circ} \mathrm{C}$.

- Excitation reading: $535 \mathrm{~nm}$.

- Emission reading: $617 \mathrm{~nm}$.

- Reading from the bottom.

- Time interval of your choice. 
2. Incubate at $36^{\circ} \mathrm{C}$ and $5 \% \mathrm{CO}_{2}$ for 1 day.

3. This assay can be performed with or without priming with LPS or another TLR agonist (see Note 7). In the case of LPS, sonicate the LPS for 10 minutes and then add in the plate $1 \mu \mathrm{g} / \mathrm{ml}$ (with $100 \mu \mathrm{l} /$ well of RPMI 10\% FBS) for 3-4 hours (see Note 8).

4. Replace the medium for RPMI $10 \%$ FBS $(100 \mu 1 /$ well $)$.

5. Make the L. pneumophila inoculum as shown in step 3.2 and add the bacteria into each specific well.

6. Centrifuge at $200 \mathrm{xg}$ for 5 minutes at room temperature.

7. Incubate at $36^{\circ} \mathrm{C}$ and $5 \% \mathrm{CO}_{2}$ for 2 hours for samples with priming or 9 hours for samples without priming with LPS.

8. Collect the supernatant in microcentrifuge tube or well plates and store at $-70^{\circ} \mathrm{C}$ (if you do not have a $-70^{\circ} \mathrm{C}$ available go to step 9 ).

9. Add Laemmli $4 \mathrm{X}$ buffer $(25 \mu \mathrm{l})$ in the supernatant of the step 8 , boil for 5 minutes and store in $-20^{\circ} \mathrm{C}$.

10. For the cell lysate samples, put the plate on the ice and add $50 \mu$ of RIPA buffer with protease inhibitor 25X in each well (See Note 9).

11. With a sterile tip scrape the well for the cells release and collect in a microcentrifuge tube.

12. Centrifuge at $20.500 \mathrm{x} \mathrm{g} 4^{\circ} \mathrm{C}$ for 15 minutes and collect the supernatant. 


\subsection{1- Western Blot}

398

1. Mount the gel system with the short plate and spacer plate.

399 2. Prepare the lower gel, in a $50 \mathrm{ml}$ tube add:

400 - Lower gel (15\% polyacrylamide-SDS gel):

$401 \quad \checkmark \quad 2.3 \mathrm{ml}$ distilled $\mathrm{H}_{2} \mathrm{O}$;

$402 \checkmark 5.0$ ml Polyacrylamide mix;

$403 \quad \checkmark \quad 2.5 \mathrm{ml} 1.5 \mathrm{M}$ Tris $\mathrm{HCl} \mathrm{pH} \mathrm{8.8;}$

$404 \checkmark 100 \mu$ l SDS $10 \%$;

$405 \checkmark \quad \checkmark 100 \mu$ l Ammonium persulfate 10\% (add last)

$406 \quad \checkmark \quad 4 \mu 1$ TEMED (add last).

407 3. After vortex, put the mix in the gel space and complete with ethanol $100 \%$ or distilled 408 water.

409 4. Wait 20 minutes for the gel solidification.

410 5. Discard the ethanol $100 \%$ and wash 3 times the free space with distilled $\mathrm{H}_{2} \mathrm{O}$.

411 6. Prepare the upper gel, in a $50 \mathrm{ml}$ tube:

412 - Upper part:

413 $2.7 \mathrm{ml}$ distilled $\mathrm{H}_{2} \mathrm{O}$; 
$416 \quad \checkmark \quad 40 \mu 1 \operatorname{SDS} 10 \%$;

$417 \quad \checkmark \quad 40 \mu$ 1 Ammonium persulfate 10\% (add last);

$418 \quad \checkmark \quad 4 \mu 1$ TEMED (add last);

419 7. After vortex, put the mix in the free gel space and add the comb.

420 8. After 20 minutes, mount the electrophoresis system with the running buffer $1 \mathrm{X}$.

421 9. Apply the samples and the protein ladder.

10. Run the gel for around $80 \mathrm{~V}$ until the samples reach the upper gel, and then it is possible to run by $100-150 \mathrm{~V}$.

11. Run the gel until the $10 \mathrm{kDa}$ band reach in the edge (be careful not run out the sample of the gel, the band of active caspase- 1 and caspase- 11 that has around $20 \mathrm{kDa}$ ).

12. Transfer the gel for a $0.22 \mu \mathrm{m}$ nitrocellulose membrane with a transfer system of your choice.

13. Block the membrane for 1-2 hours with a block buffer (TBS $1 \mathrm{X}$ with $0.01 \%$ Tween and $5 \%$ non-fat dry milk or BSA, according with the primary antibody).

14. Discard the block buffer in the membrane.

15. Add the primary antibody for caspase- 1 or caspase- 11 diluted with a block buffer and incubated overnight at $4^{\circ} \mathrm{C}$ or the best time for your primary antibody according with the datasheet. 

with the datasheet.

18. Wash 3 times the membrane with TBS $0.01 \%$ Tween for 5 minutes.

19. Add chemiluminescent luminol reagent.

20. Revel in a gel imaging system of your choice.

2. Incubate at $36^{\circ} \mathrm{C}$ and $5 \% \mathrm{CO}_{2}$ for 1 day.

3. This assay can be performed with or without priming with TNF- $\alpha$ or a TLR agonist (see Note 7). In the case of Pam3Cys, use $500 \mathrm{ng} / \mathrm{ml}$ (with $2 \mathrm{ml} /$ well of RPMI 10\% FBS) for 3-4 hours (see Note 10).

5. Make the L. pneumophila inoculum as shown in step 3.2 and add the bacteria in each specific well. 
6. Centrifuge at $200 \mathrm{xg}$ for 5 minutes at room temperature.

7. Incubate at $36^{\circ} \mathrm{C}$ and $5 \% \mathrm{CO}_{2}$ for 2 hours for samples with priming or 6-9 hours for samples without priming with Pam3Cys (for MOI 10).

8. Discard the supernatant.

9. Put the plate on the ice and lyse the cells with $500 \mu \mathrm{l} /$ condition ( 3 wells together) of RIPA buffer with protease inhibitor.

10. Centrifuge at $20.500 \mathrm{x} \mathrm{g} 4^{\circ} \mathrm{C}$ for 15 minutes and collect the supernatant.

11. Measure the protein number by the method of your choice.

12. Save $30 \mu 1$ of the sample for the Western Blot control. This will be the "input".

13. Wash $100 \mu 1$ of streptavidin-agarose beads for each sample, 3 times with cold RIPA

\section{Apply in the Western Blot assay as shown in step 3.4.1.} buffer (centrifuge at $11.000 \mathrm{x}$ g for 2 minutes and $4^{\circ} \mathrm{C}$ ). In all the washings, carefully remove the supernatant.

14. Incubate the sample with the beads for $3-4$ hours at $4^{\circ} \mathrm{C}$ and low rotation.

15. Wash sample with beads 3 times with cold RIPA buffer (centrifuge at $11.000 \mathrm{x} \mathrm{g}$ for 2 minutes and $\left.4^{\circ} \mathrm{C}\right)$.

16. After the last wash, suspend the supernatant in Laemmli $4 \mathrm{X}$ buffer $(30 \mu 1)$, boil the sample for 5 minutes.

17. Centrifuge at $11.000 \mathrm{x}$ g for 2 minutes and collect the supernatant. 
1. Plate $5 \times 10^{5}$ cells/well in a 24 well cell treated plate with a total of $1 \mathrm{ml}$ of RPMI $10 \%$ FBS

2. Incubate at $36^{\circ} \mathrm{C}$ and $5 \% \mathrm{CO}_{2}$ for 1 day.

479

3. This assay can be performed with or without priming with LPS or another TLR agonist (see Note 7). In the case of LPS, sonicate the LPS for 10 minutes and then add in the plate $1 \mu \mathrm{g} / \mathrm{ml}(500 \mu \mathrm{l} /$ well of RPMI $10 \%$ FBS) for 3-4 hours (see Note 8$)$.

4. Replace the medium for RPMI $10 \%$ FBS $(500 \mu 1 /$ well $)$.

5. Make the L. pneumophila inoculum as shown step 3.2 and add the bacteria in each specific well.

6. Centrifuge at $200 \mathrm{x} \mathrm{g}$ for 5 minutes at room temperature.

7. Incubate at $37^{\circ} \mathrm{C}$ and $5 \% \mathrm{CO}_{2}$ for 2 hours for samples with priming or 9 hours for samples without priming (MOI 10).

8. Centrifuge at $200 \mathrm{x} \mathrm{g}$ for 5 minutes at room temperature.

9. Collect the supernatant in microcentrifuge tube or well plates and store at $-70^{\circ} \mathrm{C}$

10. Use the supernatant for the measurement of IL-1 $\beta$ and IL-18 using ELISA kits according to manufacturer's recommendations. 


\section{4- Notes}

1. It is important for BMDMs differentiation to work with endo-free reagents. Any endotoxin contamination, such as with LPS, can alter the experimental results.

2. The supernatant of L929 cells is rich in MCSF (mouse colony-stimulating factor) which leads to the development of precursor cells in BMDMs [9].

3. The protocols must be in compliance and approved by the local institutional guidelines on ethics for animal experiments.

4. BMDMs are adherent cells, therefore it is recommended for its differentiation the use of non-tissue culture-treated plates (not treated) as described [15].

5. It is very important replace the medium for the "Pore medium" without phenol red and with a low ratio of FBS, in pore formation assay. This is important because phenol red and FBS cause a background of fluorescence and can interfere in the result of the experiment.

6. In the pore formation assay, it is recommended to add at least 3 wells for each group of BMDM or bacteria, including the non-infected wells and wells for Triton X-100 samples. The Triton X-100 can be used for normalize the experiment for the total of cell death (the wells with Triton X-100 should not be next to the other samples, because they spread to adjacent wells) [18].

7. Some inflammasome components like caspase-1, caspase-11, pro-IL-1 $\beta$ and pro-IL-18 have a low expression in BMDMs not stimulated or not primed. As such, macrophage treatment with Tumor necrosis factor (TNF) or TLRs agonists provides the "first signal" to induce the expression of these molecules thought the activation of NF- $\mathrm{kB}$ 
515 pathway. In the case of Gram-negative bacteria, such as L. pneumophila, their own LPS 516 lead to "priming" and activation of NF-кB pathway [4].

517 8. For ultrapure LPS add $500 \mathrm{ng} / \mathrm{ml}$.

518 9. Cleaved caspase-1 and caspase-11 will be found in cells supernatant. Meanwhile, the 519 cell lysate can be collected for detection of pro-caspase-1 and pro-caspase-11 [6, 7].

520 10. In the active caspase-11 pull-down assay, we not recommended the priming with LPS, 521 because it leads to the detection of a non-specific activation. 


\section{Figure Captions}

526 Fig.1. Pore formation in macrophages infected with Legionella pneumophila. Bone

527

528

529

530 marrow-derived macrophages (BMDMs) generated from C57BL/6 (blue squares) and Casp $1 / 11^{-/}$(red circles) mice were infected with L. pneumophila at an MOI of 10 bacteria per cell (filled symbols). Pore formation was assessed fluorometrically in real time by the uptake of propidium iodide. Data show the average \pm SD of triplicate wells. RFUs, relative fluorescence units; NI, uninfected (open symbols). 


\section{References}

2. 1. Amer A, Franchi L, Kanneganti TD et al. (2006) Regulation of Legionella phagosome maturation and infection through flagellin and host Ipaf. J Biol Chem 281:35217-35223

3. 2. Berger KH, Isberg RR (1993) Two distinct defects in intracellular growth complemented by a single genetic locus in Legionella pneumophila. Mol Microbiol 7:7-19

4. 3. Berger KH, Merriam JJ, Isberg RR (1994) Altered intracellular targeting properties associated with mutations in the Legionella pneumophila dotA gene. Mol Microbiol 14:809-822

5. 4. Case CL, Kohler LJ, Lima JB et al. (2013) Caspase-11 stimulates rapid flagellin-independent pyroptosis in response to Legionella pneumophila. Proceedings of the National Academy of Sciences of the United States of America 110:1851-1856

6. 5. Casson CN, Copenhaver AM, Zwack EE et al. (2013) Caspase-11 activation in response to bacterial secretion systems that access the host cytosol. PLoS Pathog 9:e1003400

7. 6. Cerqueira DM, Pereira MS, Silva AL et al. (2015) Caspase-1 but Not Caspase-11 Is Required for NLRC4-Mediated Pyroptosis and Restriction of Infection by Flagellated Legionella Species in Mouse Macrophages and In Vivo. J Immunol 195:2303-2311

8. 7. Cunha LD, Ribeiro JM, Fernandes TD et al. (2015) Inhibition of inflammasome activation by Coxiella burnetii type IV secretion system effector IcaA. Nat Commun 6:10205

9. 8. Cunha LD, Silva ALN, Ribeiro JM et al. (2017) AIM2 Engages Active but Unprocessed Caspase-1 to Induce Noncanonical Activation of the NLRP3 Inflammasome. Cell reports 20:794-805

10. 9. Englen MD, Valdez YE, Lehnert NM et al. (1995) Granulocyte/macrophage colony-stimulating factor is expressed and secreted in cultures of murine L929 cells. J Immunol Methods 184:281-283

11. 10. Feeley JC, Gibson RJ, Gorman GW et al. (1979) Charcoal-yeast extract agar: primary isolation medium for Legionella pneumophila. J Clin Microbiol 10:437-441

12. 11. Ge J, Gong YN, Xu Y et al. (2012) Preventing bacterial DNA release and absent in melanoma 2 inflammasome activation by a Legionella effector functioning in membrane trafficking. Proceedings of the National Academy of Sciences of the United States of America 109:6193-6198 
13. 12. Hori JI, Zamboni DS (2013) The mouse as a model for pulmonary legionella infection. Methods Mol Biol 954:493-503

14. 13. Isberg RR, O'connor TJ, Heidtman M (2009) The Legionella pneumophila replication vacuole: making a cosy niche inside host cells. Nat Rev Microbiol 7:1324

15. 14. Lightfield KL, Persson J, Brubaker SW et al. (2008) Critical function for Naip5 in inflammasome activation by a conserved carboxy-terminal domain of flagellin. Nat Immunol 9:1171-1178

16. 15. Marim FM, Silveira TN, Lima DS, Jr. et al. (2010) A method for generation of bone marrow-derived macrophages from cryopreserved mouse bone marrow cells. PLoS One 5:e15263

17. 16. Martinon F, Burns K, Tschopp J (2002) The inflammasome: a molecular platform triggering activation of inflammatory caspases and processing of proILbeta. Mol Cell 10:417-426

18. 17. Mascarenhas DP, Zamboni DS (2017) Inflammasome biology taught by Legionella pneumophila. J Leukoc Biol 101:841-849

19. 18. Mascarenhas DPA, Cerqueira DM, Pereira MSF et al. (2017) Inhibition of caspase-1 or gasdermin-D enable caspase- 8 activation in the Naip5/NLRC4/ASC inflammasome. PLoS Pathog 13:e1006502

20. 19. Massis LM, Zamboni DS (2011) Innate immunity to legionella pneumophila. Frontiers in microbiology 2:109

21. 20. Molofsky AB, Byrne BG, Whitfield NN et al. (2006) Cytosolic recognition of flagellin by mouse macrophages restricts Legionella pneumophila infection. $\mathrm{J}$ Exp Med 203:1093-1104

22. 21. Newton HJ, Ang DK, Van Driel IR et al. (2010) Molecular pathogenesis of infections caused by Legionella pneumophila. Clin Microbiol Rev 23:274-298

23. 22. Pereira MS, Morgantetti GF, Massis LM et al. (2011) Activation of NLRC4 by flagellated bacteria triggers caspase-1-dependent and -independent responses to restrict Legionella pneumophila replication in macrophages and in vivo. J Immunol 187:6447-6455

24. 23. Ren T, Zamboni DS, Roy CR et al. (2006) Flagellin-deficient Legionella mutants evade caspase-1- and Naip5-mediated macrophage immunity. PLoS Pathog 2:e18

25. 24. Roy CR, Berger KH, Isberg RR (1998) Legionella pneumophila DotA protein is required for early phagosome trafficking decisions that occur within minutes of bacterial uptake. Mol Microbiol 28:663-674

26. 25. Silveira TN, Zamboni DS (2010) Pore formation triggered by Legionella spp. is an Nlrc4 inflammasome-dependent host cell response that precedes pyroptosis. Infect Immun 78:1403-1413

27. 26. Swanson MS, Hammer BK (2000) Legionella pneumophila pathogesesis: a fateful journey from amoebae to macrophages. Annu Rev Microbiol 54:567-613 
621

622
28. 27. Tenthorey JL, Haloupek N, Lopez-Blanco JR et al. (2017) The structural basis of flagellin detection by NAIP5: A strategy to limit pathogen immune evasion. Science 358:888-893

29. 28. Zamboni DS, Kobayashi KS, Kohlsdorf T et al. (2006) The Bircle cytosolic pattern-recognition receptor contributes to the detection and control of Legionella pneumophila infection. Nat Immunol 7:318-325 
9.4 - Anexo 4 - Artigo publicado (MASCARENHAS, Danielle PA et al. Journal of Infectious Diseases, 2014)

"Interleukin 1 Receptor-Driven Neutrophil Recruitment Accounts to MyD88dependent Pulmonary Clearance of Legionella pneumophila Infection In Vivo"

- Publicado em: setembro de 2014 


\section{Interleukin 1 Receptor-Driven Neutrophil Recruitment Accounts to MyD88-Dependent Pulmonary Clearance of Legionella pneumophila Infection In Vivo}

Danielle P. A. Mascarenhas, ${ }^{a}$ Marcelo S. F. Pereira, ${ }^{a}$ Graziele Z. Manin, Juliana I. Hori, and Dario S. Zamboni

Department of Cell Biology, School of Medicine of Ribeirão Preto, University of São Paulo, Brazil

Legionella pneumophila, the etiological agent of Legionnaires' disease, triggers activation of multiple innate immune pathways that lead to the restriction of bacterial replication in vivo. Despite the critical role for MyD88 in infection clearance, the receptors and mechanisms responsible for MyD88-mediated pulmonary bacterial clearance are still unclear. Here, we used flagellin mutants of $L$. pneumophila, which bypass the NAIP5/NLRC4mediated restriction of bacterial replication, to assess the receptors involved in MyD88-mediated pulmonary bacterial clearance. By systematically comparing pulmonary clearance of L. pneumophila in C57BL/6

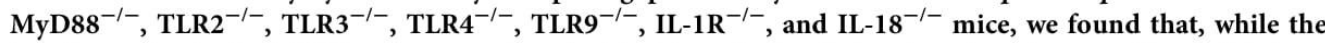
knockout of a single Toll-like receptor or interleukin 18 resulted only in minor impairment of bacterial clearance, deficiency in the interleukin 1 (IL-1) receptor led to a significant impairment. IL-1/MyD88-mediated pulmonary bacterial clearance occurs via processes involving the recruitment of neutrophils. Collectively, our data contribute to the understanding of the effector mechanisms involved in MyD88-mediated pulmonary bacterial clearance.

Keywords. Legionella pneumophila; pulmonary bacterial clearance; neutrophils; MyD88; IL-1 receptor.

Legionella pneumophila is a gram-negative, facultative, intracellular bacterium that is the main cause of a severe form of pneumonia called Legionnaires' disease $[1,2]$. This bacterium survives in freshwater environments and multiplies intracellularly in different species of unicellular protozoa. When droplets of water contaminated by this bacterium are inhaled by humans, L. pneumophila is able to infect and replicate within alveolar macrophages, a process that may culminate in the development of Legionnaires' disease if an innate immune response is not readily triggered $[1,3-5]$. The inter-

Received 18 June 2014; accepted 22 July 2014.

${ }^{\mathrm{a} D}$. P. A. M. and M. S. F. P. contributed equally to this work.

Correspondence: Dario S. Zamboni, PhD, Department of Cell Biology, School of Medicine of Ribeirão Preto, University of São Paulo FMRP/USP, Av. Bandeirantes 3900, Ribeirão Preto, SP 14049-900, Brazil (dszamboni@fmrp.usp.br).

The Journal of Infectious Diseases

(c) The Author 2014. Published by Oxford University Press on behalf of the Infectious Diseases Society of America. All rights reserved. For Permissions, please e-mail: journals.permissions@oup.com

DOl: 10.1093/infdis/iu430 action of L. pneumophila with mammalian alveolar macrophages readily triggers the activation of multiple innate immune signaling pathways that are important for the early restriction of bacterial replication and for the recruitment of additional phagocytes to the infection sites [6-12]. Among the recruited phagocytes are the neutrophils, which are critical for infection control. Recruitment of neutrophils to pulmonary sites has been extensively reported during human infection and in animal models of Legionnaires' disease [6-10, 13-15]. The importance of neutrophils for human resistance to this disease is also corroborated by data indicating that neutropenia is a risk factor for the development of Legionnaires' disease [16-18]. Neutrophil recruitment has been reported to be triggered when microbial molecules trigger innate immune receptors, such as Nod-like receptors (NLRs) and Toll-like receptors (TLRs), and also via novel and unidentified pathways $[6,7,9,13,15,19,20]$.

Unlike human macrophages, mouse macrophages are highly restrictive for the replication of $L$. pneumophila. 
In mice, restriction of bacterial replication is triggered when bacterial flagellin gains access to the host macrophage cytoplasm, possibly via the Dot/Icm type IV secretion system. This leads to the activation of a molecular platform composed of the NLRs NAIP5 and NLRC4, which triggers caspase-1 activation [21-27]. We and others have reported that the use of flagellin mutants of $L$. pneumophila in mice leads to an efficient pulmonary infection, in which Legionella is able to freely replicate in the lungs during the first 2 days of infection but is restricted and cleared from the lungs $2-5$ days after infection by mechanisms that may operate similarly in nonimmunocompromised infected humans $[6,11,21,28,29]$.

Infections using WT $L$. pneumophila have been previously performed in mice deficient in single or multiple TLRs. In vitro and ex vivo studies have demonstrated that TLR2, TLR5, and TLR9 effectively participate in bacterial recognition $[10,28$, 30-37]. TLR5 has been proposed to play an important role in human infection, although TLR5 ${ }^{-/-}$mice show no defects in cytokine production and restriction of pulmonary bacterial infection $[8,10,28,34]$. Similar to that reported with TLR5, the deletion of mouse TLR4, which senses bacterial lipopolysaccharide, does not interfere with cytokine production or with pulmonary bacterial replication $[30,31]$. Infections performed in mice deficient in TLR2 or TLR9 or in mice double-deficient in TLR2 and TLR9 indicate that these molecules are partially required for cytokine production $[28,31,33,35,36]$ However, the absence of these molecules results in only a modest increase in bacterial replication in mouse lungs, compared with that in WT animals $[28,31,32,35]$. In contrast, several independent groups have shown that loss of the TLR-adaptor protein MyD88 in mice results in impaired cytokine production, failure in triggering pulmonary neutrophil recruitment, and impaired ability to restrict bacterial replication [14, 28, 31 , 35]. Notably, the striking susceptibility of MyD88-deficient mice to infection was observed neither in mice deficient in individual TLRs nor in those deficient in multiple TLRs. These observations raise the possibility that additional receptors besides TLRs account for MyD88-mediated resistance to L. pneumophila infection.

Here, we used a virulent strain of $L$. pneumophila deficient in flagellin to dissect MyD88-mediated clearance of L. pneumophila in mouse models of infection. We found that while the deficiency in TLR2 and TLR9 results in only a minor impairment in bacterial clearance, the deficiency in the interleukin 1 receptor (IL-1R) signaling led to a significant impairment in bacterial clearance in the later stages of infection. IL-1R-mediated bacterial clearance is dependent on recruitment of neutrophils to mouse lungs. Collectively, our data provide a basis for understanding MyD88-mediated processes that lead to the restriction of bacterial replication during the acute replication phase and the effector mechanisms involved in pulmonary bacterial clearance.

\section{MATERIALS AND METHODS}

\section{Bacterial Cultures}

The L. pneumophila bacteria used were JR32 (WT) and isogenic, clean deletion mutants for the flagellin $\left(\mathrm{flaA}^{-}\right)$gene [25]. All bacteria were grown on buffered charcoal-yeast extract (CYE) agar as described [38].

\section{Mice and in vivo Infections}

Mice were matched by sex and age (all were at least 8 weeks old at the time of infection) and had a C57BL/6 mouse genetic background. C57BL/6 and IL-1 $\mathrm{R}^{-/-}$mice were from Jackson (stock numbers 000664 and 003245 , respectively). MyD88 $8^{-/-}$ [39], $\mathrm{TLR}^{-1-}$ [40], $\mathrm{TLR}^{-1-}$ [41], $\mathrm{TLR}^{-1-}$ [42], TLR9 ${ }^{-1-}$ [43], and IL-18 ${ }^{-1-}$ [44] mice were previously described. For in vivo experiments, approximately 6-8 mice per group were used, as indicated in the figure legends. The care of mice was in compliance with the institutional guidelines on ethics in animal experiments approved by CETEA (Comissão de Ética em Experimentação Animal da Faculdade de Medicina de Ribeirão Preto; approved protocol number 084/2013). For in vivo infections, the mice were anesthetized with ketamine and xylazine ( $90 \mathrm{mg} / \mathrm{kg}$ and $5 \mathrm{mg} / \mathrm{kg}$, respectively) by intraperitoneal injection, followed by intranasal inoculation with $40 \mu \mathrm{L}$ of phosphate-buffered saline (PBS) containing $1 \times 10^{5}$ bacteria per mouse. For determination of the number of colony-forming units (CFU), the lungs were harvested and homogenized in 5 $\mathrm{mL}$ of sterile water for 30 seconds, using a tissue homogenizer (Power Gen 125; Thermo Scientific, Waltham, MA). Lung homogenates were diluted in sterile water and plated on CYE agar plates for CFU determination.

\section{Macrophages and Infections}

C57BL/6, MyD88 ${ }^{-/-}$, IL-1 $\mathrm{R}^{-/-}$, and TLR2 ${ }^{-/-}$mice were used to generate bone-marrow-derived macrophages (BMDMs) in vitro, using L929 cell-conditioned medium as previously described [45]. BMDMs were seeded at $2 \times 10^{5}$ cells/well in 24 well plates and cultivated in Roswell Park Memorial Institute 1640 medium supplemented with $10 \%$ fetal bovine serum and 5\% L929 cell-conditioned medium. Cultures were infected at a multiplicity of infection of 0.015 , centrifuged for 5 minutes at $200 \times g$ at room temperature, and incubated at $37^{\circ} \mathrm{C}$ in an atmosphere of $5 \% \mathrm{CO}_{2}$. For CFU determinations, cultures were exposed to sterile water for cell lysis, and cell lysates were combined with cell culture supernatant from the respective well. Lysates plus supernatants from each well were diluted in water, plated on CYE agar plates, and incubated for 4 days at $37^{\circ} \mathrm{C}$ for $\mathrm{CFU}$ determination.

Determination of Leukocyte Recruitment and Myeloperoxidase (MPO) Activity and Depletion of Neutrophils

One milliliter of PBS containing $5 \mathrm{mM}$ ethylenediaminetetraacetic acid was injected in the trachea of each mouse, and the

2 - JID • Mascarenhas et al 


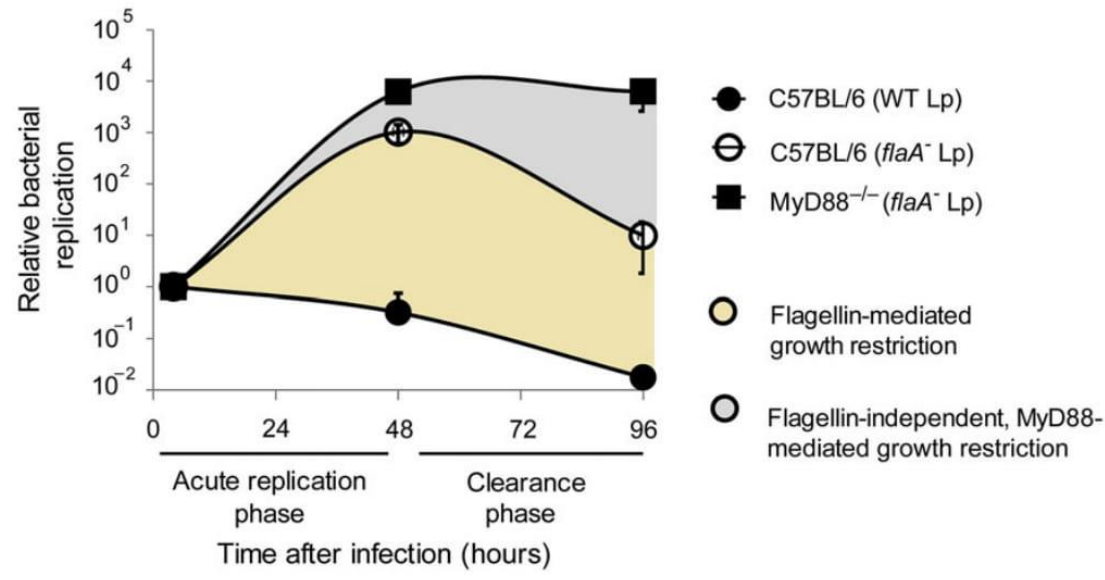

Figure 1. The use of a flagellin-mutant strain of Legionella pneumophila supports the assessment of the critical role for MyD88 in bacterial clearance in the latter stages of infection. C57BL/6 mice were infected intranasally with $1 \times 10^{5}$ wild-type (WT; closed circles) or fla $A^{-}$L. pneumophila (open circles).

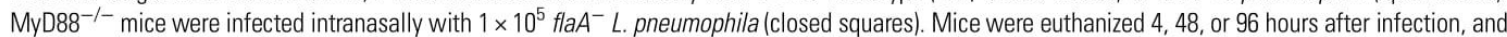
dilutions of the lung homogenates were added to charcoal-yeast extract agar plates for colony-forming units determination. Uniquely for this figure, the data represent a pool of 2 independent experiments, which include 7 mice per group. For appropriate comparisons, data are plotted as fold-change. Abbreviation: Lp, Legionella pneumophila.

bronchoalveolar lavage (BAL) fluid was used for determination of the total number of cells, using a Cell Counter (Mindray Coulter). The percentages of monocytes and neutrophils were estimated by microscopic enumeration of cells in the BAL fluid that were stained by hematoxylin and eosin. Neutrophils (NE) accumulation in the lung tissue was evaluated by assaying MPO activity as previously described [9]. Neutrophil depletions were preformed with $100 \mu \mathrm{g}$ anti-Grl antibody (clone RB6$8 \mathrm{C} 5$ ) in a volume of $200 \mu \mathrm{L}$ injected intraperitoneally. The first injection was 24 hours before infection and was performed on alternate days during the course of infection.

\section{Statistical Analysis}

Statistical significance was calculated using the unpaired Student $t$ test or analysis of variance. Differences were considered statistically significant when $P<.05$.

\section{RESULTS}

\section{Use of flaA- L. pneumophila Reveals a Role for MyD88 in Pulmonary Bacterial Clearance in Mice}

By using WT and fla $A^{-}$L. pneumophila for in vivo infections, we found that use of flaA $A^{-}$but not WT L. pneumophila results in at least 2 logs of bacterial replication during the first 48 hours of infection (indicated as acute replication phase). The acute replication phase is followed by the elimination of bacteria from the infected lungs (indicated as clearance phase). In contrast, infection of $\mathrm{MyD} 8^{-/-}$mice with $f l a A^{-}$L. pneumophila results in a much more robust bacterial replication during the replication phase that cannot be eliminated during the clearance phase (Figure 1). The use of $f l a A^{-} L$. pneumophila for infections in C57BL/6 mice supports previous findings demonstrating an essential role of MyD88 in pulmonary clearance of L. pneumophila and provides us with an appropriate model to assess host components involved in MyD88-mediated clearance of L.pneumophila infection in vivo.

\section{Deficiency in Individual TLRs in Mice Does Not Affect Efficiency of Pulmonary Bacterial Clearance}

We used mice with a C57BL/6 genetic background that were deficient in individual TLRs to evaluate the participation of individual TLRs in flagellin/NLRC4-independent pulmonary bacterial clearance. To this end, we used $f l a A^{-} L$. pneumophila to systematically infect mice strains deficient in TLRs. Age- and sex-matched WT (C57BL/6) and MyD88 ${ }^{-1-}$ mice were used in all experiments for appropriate comparisons of MyD88-mediated bacterial clearance. We assessed bacterial replication and clearance by evaluating the bacterial loads in mouse lungs 4,48 , and 96 hours after infection. By assessing the CFUs at 4 and 48 hours, we found that $f l a A^{-}$L. pneumophila replicated effectively and similarly during the replication phase in the lungs of C57BL/6 mice and in the lungs of mice deficient in MyD88, TLR2, TLR3, TLR4, or TLR9. Notably, we found that TLR2 ${ }^{-/-}$,

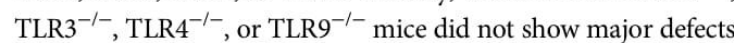
to clear pulmonary bacteria, as assessed by enumeration of CFUs at 48 and 96 hours of infection (Figure 2). Mice deficient in TLR2 and TLR9 were partially able to clear pulmonary bacteria; statistically significant differences from C57BL/6 mice were found at 96 
A

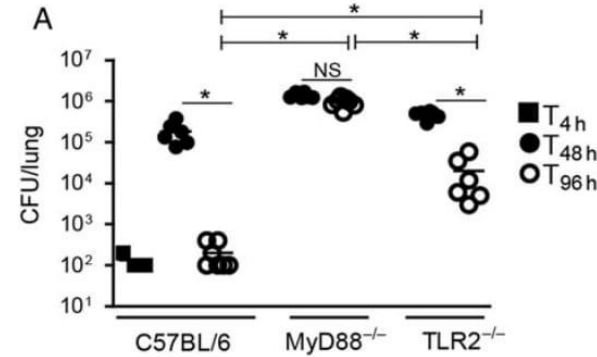

C

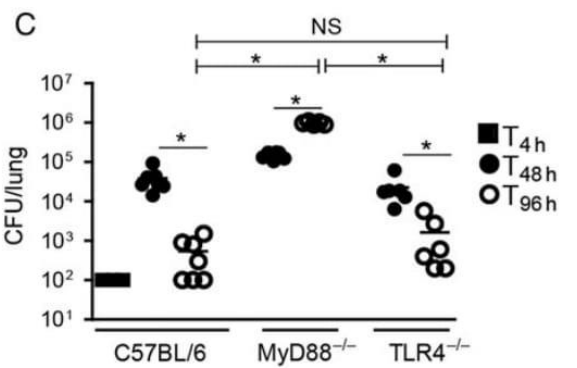

B
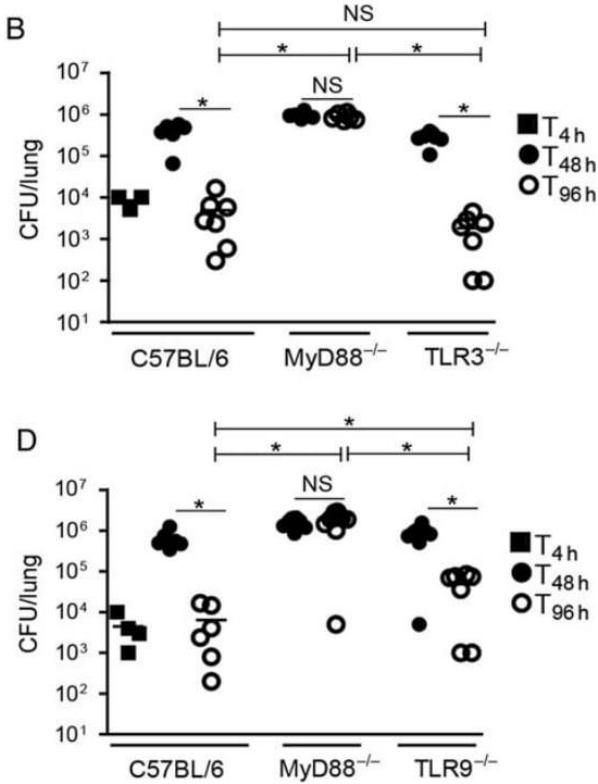

Figure 2. Mice deficient in Toll-like receptor 2 (TLR2), TLR3, TLR4, and TLR9 but not in MyD88 are effective in triggering pulmonary bacterial clearance C57BL/6, MyD88 ${ }^{-/-}$, and TLR2 ${ }^{-1-}$ mice $(A)$, TLR3 ${ }^{-/}$mice $(B)$, TLR4 ${ }^{-1-}$ mice $(C)$, and $\mathrm{TLRg}^{-/-}$mice $(D)$ were infected intranasally with $1 \times 10^{5} \mathrm{flaA}{ }^{-}$ Legionella pneumophila. Mice were euthanized 4 hours (closed squares), 48 hours (closed circles), or 96 hours (open circles) after infection. Dilutions of the lung homogenates were added to charcoal-yeast extract agar plates for colony-forming units determination. Each dot represents a single animal, and the horizontal lines represent the averages. Data are representative of those found in 1-3 independent experiments for each of the TLR-deficient mice strain. ${ }^{*} P<.05$, by the Student $t$ test. Abbreviation: NS, not significant.

hours of infection (Figure $2 A$ and $2 D$ ). The minor deficiencies of $\mathrm{TLR}^{-/-}$or TLR9 ${ }^{-/-}$mice in restricting pulmonary replication of L. pneumophila are consistent with data previously published using infections with flagellated bacteria $[28,30,31,35]$.

\section{Mice Deficient in IL-1R but Not in Interleukin 18 (IL-18) Fail to} Trigger Pulmonary Bacterial Clearance

We investigated the involvement of additional receptors that are not TLR members but signal via MyD88. Initially, we evaluated the clearance of $f l a A^{-}$L. pneumophila in mice deficient in the gene for IL-18, which signals via MyD88 and was previously reported to be important for interferon $\gamma$ production by natural killer cells in response to infection with WT L. pneumophila $[28,39]$. By infecting IL- $18^{-/-}$mice, we found that, despite the absence of IL-18, the mice were fully able to trigger bacterial clearance by 96 hours of infection (Figure $3 A$ ). Similar to IL-18 signaling, IL-1R signaling is also dependent on MyD88 [46]. Thus, we investigated the effect of IL-1R signaling on the flagellin-independent clearance of $L$. pneumophila infection. By infecting IL-1 $\mathrm{R}^{-/-}$mice with $f l a A^{-}$L. pneumophila, we found that, in the absence of IL-1R signaling, the mice showed severely impaired pulmonary bacterial clearance, as the bacterial loads found in the lungs of $\mathrm{IL}_{-1 \mathrm{R}^{-/-}}$mice were similar to those found in $\mathrm{MyD}^{-1-} 8^{-1}$ mice (Figure 3B), a feature not previously detected in TLR-deficient mice. These results support the hypothesis that IL-1R signaling is critical for the clearance of $L$. pneumophila and may provide a mechanistic explanation for the impaired MyD88-mediated pulmonary bacterial clearance.

IL-1R Signaling Is Not Required for Macrophage Restriction of Bacterial Replication but Favors Recruitment of Neutrophils to Mouse Lungs

Next, we investigated whether the impaired bacterial clearance in the lungs of mice deficient in MyD88 and IL-1R was caused by an intrinsic macrophage defect in the restriction of bacterial replication. To test this hypothesis, we generated BMDMs from

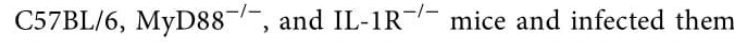
with a flagellin-deficient strain of $L$. pneumophila. Macrophages deficient in TLR2 were also used because TLR2-deficient mice were partially able to clear pulmonary bacteria, compared with C57BL/6 mice (Figure 2A). We found that $\mathrm{IlaA}^{-}$L. pneumophila effectively replicate in the BMDMs regardless of the presence of TLRs, MyD88, or IL-1R signaling (Figure 4A). Accordingly,

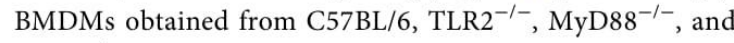
$\mathrm{IL}-1 \mathrm{R}^{-/-}$mice effectively restricted the replication of flagellated L. pneumophila (Figure 4B). These data support the finding that 

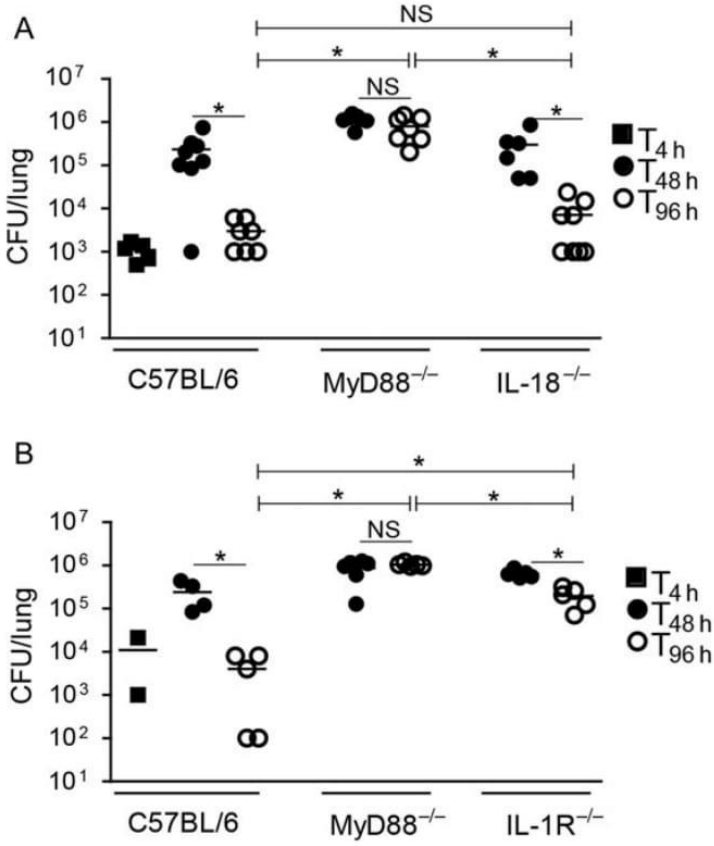

Figure 3. Mice deficient in interleukin 1 receptor (IL-1R), but not those deficient in interleukin 18 (IL-18), fail to trigger pulmonary bacterial clear-

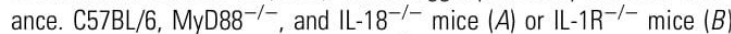
were infected intranasally with $1 \times 10^{5} \mathrm{flaA}^{-}$Legionella pneumophila. Mice were euthanized 4 hours (closed squares), 48 hours (closed circles), or 96 hours (open circles) after infection, and dilutions of the lung homogenates were added to charcoal-yeast extract agar plates for colony-forming units determination. Each dot represents a single animal, and the horizontal lines represent the averages. Data are representative of those found in 2 $(A)$ and $5(B)$ independent experiments. ${ }^{*} P<.05$, by the Student $t$ test. Abbreviation: NS, not significant.

MyD88-dependent signaling pathways are not required for NAIP5/NLRC4-mediated restriction of bacterial replication in macrophages.

Since MyD88-dependent restriction of bacterial replication was not associated with an intrinsic macrophage activity, we investigated the effect of MyD88 signaling on the total cell population obtained from the BAL fluid of mice infected for 24 and 48 hours with $\mathrm{flaA}^{-}$L. pneumophila. We found that mice deficient in MyD88 and IL-1R but not those deficient in TLR2 contain a reduced amount of cells in the pulmonary cavity at 48 hours of infection, compared with WT mice (Figure $5 \mathrm{~A}$ ). Microscopy of these cells indicated that, while the macrophage

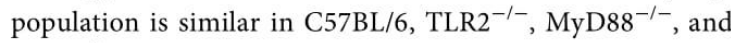
$\mathrm{IL}-1 \mathrm{R}^{-/-}$mice, the neutrophil population is highly reduced in

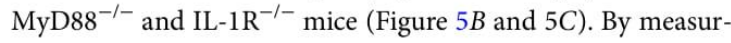
ing the neutrophil MPO activity in the lung tissue, we found an accumulation of neutrophils in the pulmonary tissue 48 hours
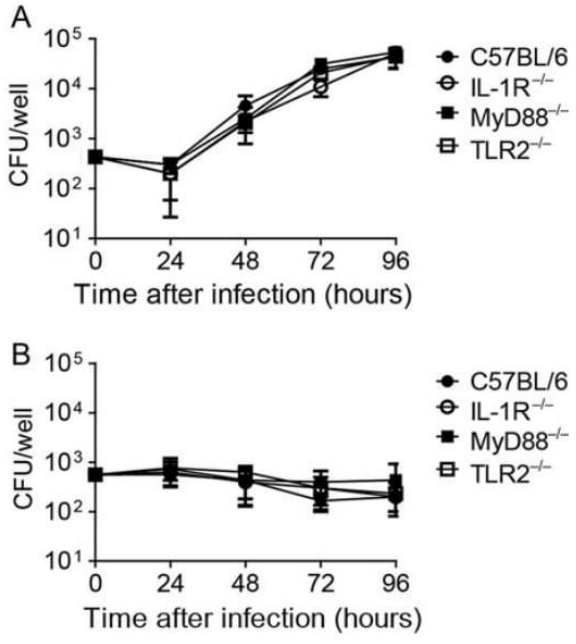

Figure 4. Interleukin 1 receptor (IL-1R)/MyD88-mediated restriction of Legionella pneumophila replication is not detectable in isolated macrophages. Bone-marrow-derived macrophages were generated from $\mathrm{C} 57 \mathrm{BL} /$ 6 mice (closed circles), MyD88 ${ }^{-1-}$ mice (closed squares), TLR2 ${ }^{-1-}$ mice (open squares), and IL-1 $\mathrm{R}^{-/-}$mice (open circles). Cells were plated in 24-well plates and infected with fla $A^{-}$mutants $(A)$ or wild-type $L$. pneumophila $(B)$. Each well was infected with 3000 bacteria and further incubated at $37^{\circ} \mathrm{C}$ for $24,48,72$, and 96 hours for colony-forming units (CFU) determination. The data show the averages \pm standard deviation of triplicate wells. Data are representative of those found in 3 independent experiments. ${ }^{*} P<.05$, by analysis of variance.

after infection and a decrease 96 hours after infection, which is consistent with the increase in neutrophils in the BAL fluid at 48 hours (Figure $5 C$ and $5 D$ ). Accordingly, mice deficient in MyD88 and IL-1R but not those deficient in TLR2 had reduced neutrophil counts in the lung tissue 48 hours after infection (Figure 5C). Collectively, these data indicate that the IL-1/ MyD88-signaling pathway contributes to neutrophil recruitment to the mouse lungs in response to infection with $\mathrm{flaA}^{-}$mutants of L. pneumophila.

\section{IL-1/MyD88-Mediated Neutrophil Recruitment Accounts for Pulmonary Bacterial Clearance}

To evaluate the effect of neutrophil recruitment in the IL-1/ MyD88-dependent bacterial clearance, we used anti-granulocyte receptor-1 $(\alpha-\mathrm{GR} 1)$ neutralizing antibodies for neutrophil

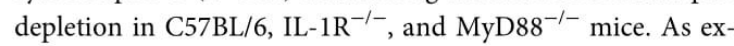
pected, $\alpha$-GR1 treatment resulted in a decrease in the numbers of neutrophils in the lungs of both C57BL/6 and IL-1 $\mathrm{R}^{-1-}$ mice, whereas it did not influence the macrophage population in pulmonary cavities (Figure 6A and 6B). By measuring bacterial replication in neutrophil-depleted mice, we found that neutrophils play a minor role during the acute replication phase, as the CFU loads were similar 48 hours infection (Figure $6 C$ ). In 


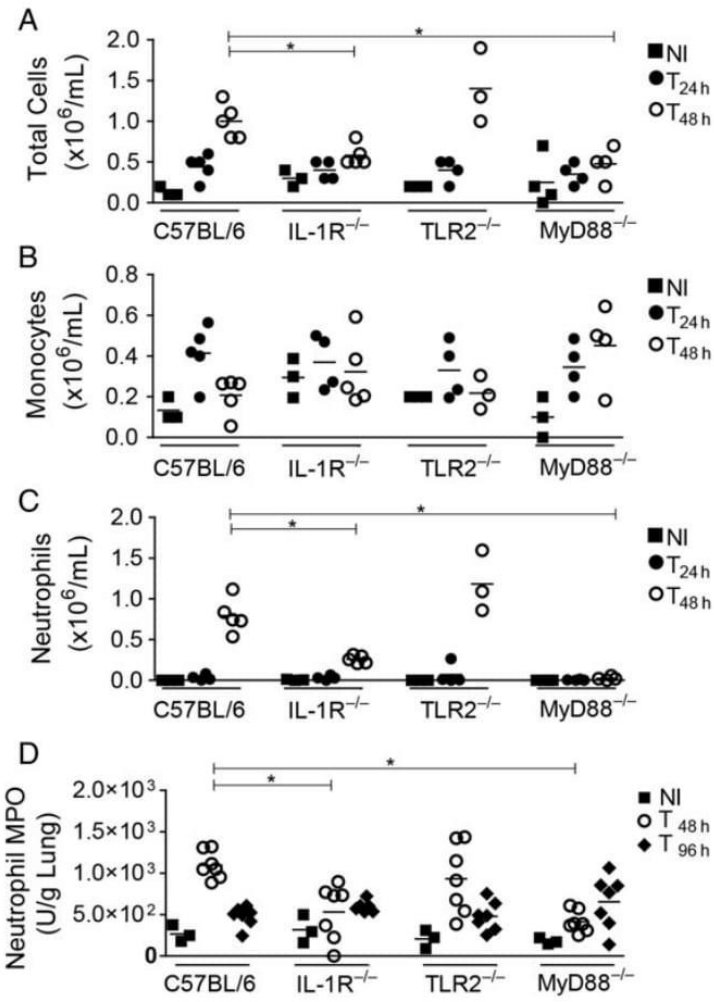

Figure 5. Interleukin 1 receptor signaling is required for MyD88-mediated neutrophil recruitment to the lungs of Legionella pneumophila-infected mice. C57BL/6, MyD88 ${ }^{-/-}$, TLR2 ${ }^{-1-}$, and IL-1 $\mathrm{R}^{-/-}$mice were infected intranasally with $1 \times 10^{5} \mathrm{flaA}^{-}$L. pneumophila. Mice were euthanized, and the lungs and bronchoalveolar fluid lavage (BAL) fluid were collected 24 hours (closed circles) and 48 hours (open circles) after infection for evaluation of cell recruitment to the lungs. Total cells $(A)$, monocytes $(B)$, and neutrophils $(C)$ were microscopically scored from BAL fluid. The activity of neutrophil myeloperoxidase enzyme (MPO) was measure in lung tissue homogenates $(D)$. Each dot represents a single animal, and the horizontal lines represent the averages. Data are representative of those found in 3 independent experiments. ${ }^{*} P<.05$, by the Student $t$ test. Abbreviation: $\mathrm{NI}$, not infected.

contrast, at 96 hours of infection, the CFU loads were significantly higher in neutrophil-depleted mice, thus suggesting that neutrophils may play an important role during the clearance phase (Figure $6 C$ ). Notably, the reduced bacterial clearance observed in neutrophil-depleted mice was less pronounced in $\mathrm{IL}-1 \mathrm{R}^{-/-}$mice, compared with C57BL/6 mice, a result that is consistent with the requirement for IL-1R signaling in neutrophil recruitment in response to pulmonary L. pneumophila infection (Figure $6 C$ ). Taken together, these data indicate that IL-1R signaling effectively contributes to MyD88-mediated bacterial clearance by mechanisms involving the recruitment of neutrophils to the infection sites.

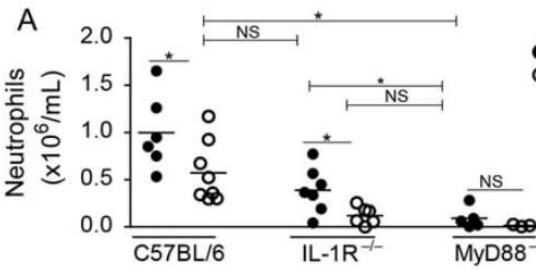

- Without a-GR1 With a-GR1

B
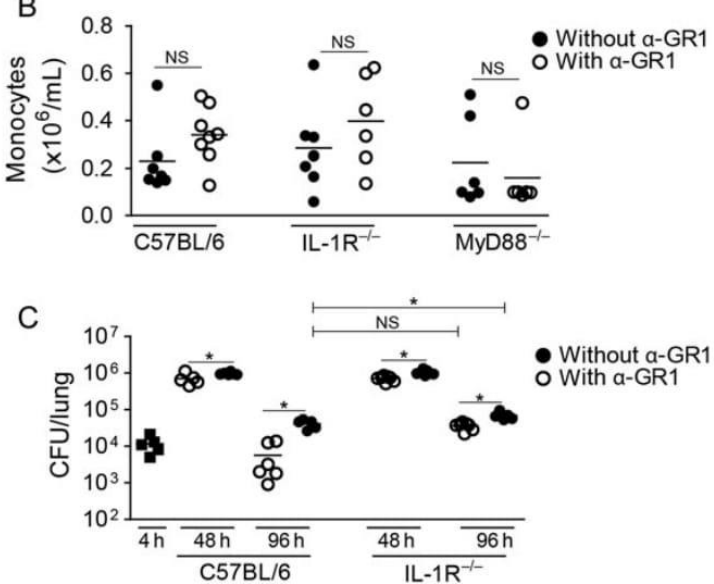

Figure 6. Neutrophil recruitment is required for interleukin 1 receptormediated pulmonary bacterial clearance. $\mathrm{C} 57 \mathrm{BL} / 6, \mathrm{IL}-1 \mathrm{R}^{-/-}$, and $\mathrm{MyD} 88^{-/-}$ mice were infected intranasally with $1 \times 10^{5} \mathrm{flaA}^{-}$Legionella pneumophila. When indicated, mice were treated with $100 \mu \mathrm{g}$ of $\alpha$-GR1 on alternate days during the course of infection. $A$ and $B$, Mice were euthanized, and bronchoalveolar lavage (BAL) fluid was collected 48 hours after infection for evaluation of the recruitment of neutrophils and monocytes to the lungs of infected mice. Neutrophils $(A)$ and monocytes $(B)$ were microscopically scored from BAL fluid. $C$, Mice were euthanized 4, 48, or 96 hours after infection, and dilutions of the lung homogenates were added to charcoal-yeast extract agar plates for colony-forming units determination. Each dot represents a single animal, and the horizontal lines represent the averages. Data are representative of those found in 2 independent experiments. ${ }^{*} P<.05$, by the Student $t$ test. Abbreviation: NS, not significant.

Although experiments comparing the bacterial clearance in IL- $1 \mathrm{R}^{-/-}$and MyD88 ${ }^{-/-}$mice often reveal similar bacterial CFU counts during the clearance phase (assessed here at 96 hours), we investigated whether, at later time points, IL-1 $\mathrm{R}^{-/-}$ and $\mathrm{MyD} 88^{-/-}$mice were similar in their bacterial clearance capability. Thus, we infected a large cohort of C57BL/6, IL-1 $\mathrm{R}^{-1-}$,

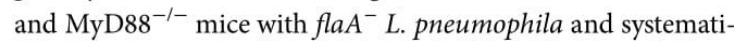
cally measured the CFU counts at 24, 48, 72, 96, 120, and 144 hours. We found that although IL-1R is clearly required for efficient bacterial clearance, IL-1R signaling does not solely explain MyD88-mediated restriction of pulmonary bacterial clearance (Figure 7). Taken together, our data indicate that, while IL-1R signaling effectively contributes to MyD88-

6 J JID • Mascarenhas et al 


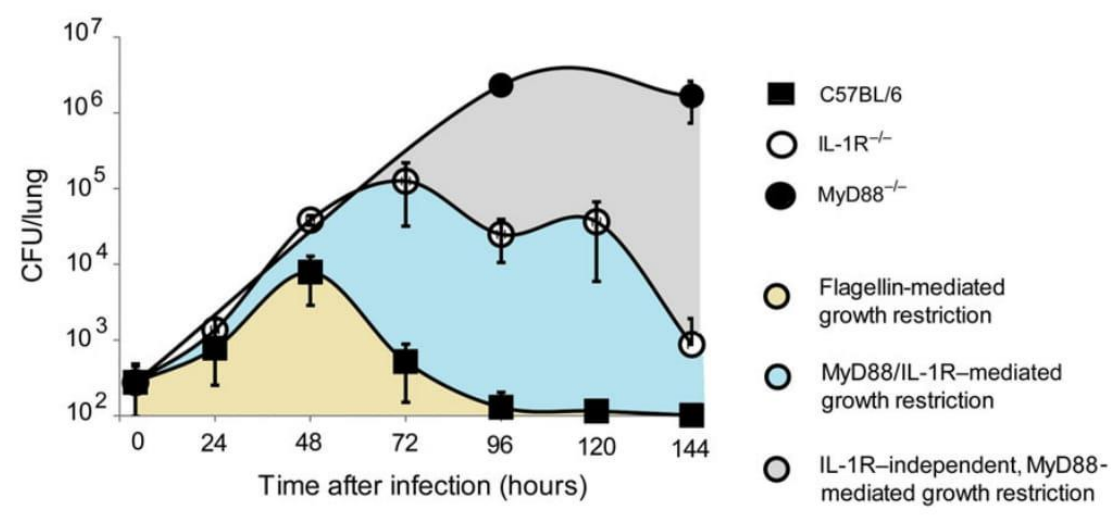

Figure 7. The interleukin 1 receptor (IL-1R) signaling effectively accounts for pulmonary bacterial clearance, but IL-1R-independent mechanisms also operate in MyD88-mediated resistance to Legionella pneumophila infection. C57BL/6 mice (closed squares), IL-1R ${ }^{-/-}$mice (open circles), and MyD88-/mice (closed circles) were infected intranasally with $1 \times 10^{5} \mathrm{fla} A^{-}$L. pneumophila. Mice were euthanized 4, 24, 48, 72, 96, 120, or 144 hours after infection, and dilutions of the lung homogenates were added to charcoal-yeast extract agar plates for colony-forming units (CFU) determination. The averages \pm standard deviation of CFU/lung of approximately 5 mice per group are shown. ${ }^{*} P<.05$, by analysis of variance.

mediated bacterial clearance by mechanisms dependent on neutrophil recruitment, additional receptors, possibly consisting of a combination of multiple TLRs, also account for MyD88mediated clearance of pulmonary bacterial replication.

\section{DISCUSSION}

Infections in mice with WT strains of L. pneumophila culminate with flagellin-mediated activation of the NAIP5/NLRC4 inflammasome. This process readily triggers the restriction of bacterial replication during the acute phase of infection in mice. Although identification of this flagellin-sensing platform effectively contributed to our understanding of the mechanistic functions of Naip genes, the flagellin/NAIP5/NLRC4-mediated growth restriction does not appear to operate in humans, a feature that explains the reports that mice are not an appropriate animal model for Legionnaires' disease. In this study, we used flagellin mutants of L. pneumophila for infections in mice from the C57BL/6 background. By systematically infecting several knockout mice from the C57BL/6 background with flaA mutants of $L$. pneumophila, we studied the previously reported MyD88-mediated resistance to infection [14, 28, 31, 35]. We detected a key role for IL-1R signaling in MyD88-mediated pulmonary bacterial clearance in the later stages of infection. The mechanism underlying IL-1R-mediated resistance involves neutrophil recruitment to the lungs of the infected mice. Our data are consistent with recent reports showing that IL- $1 \alpha$ is important for neutrophil recruitment and mouse resistance in response to WT L. pneumophila infection $[19,47]$. Thus, our data showing that $\mathrm{IL}-1 \mathrm{R}^{-/-}$mice fail to recruit neutrophils support the hypothesis that MyD88-dependent neutrophil recruitment is mediated by IL-1R signaling, which is known to occur via MyD88 $[46,48]$. In addition, by counting the pulmonary CFUs at later time points after infection in neutrophil-depleted mice, we provided data in support of the role of neutrophils in the IL-1R-mediated resistance to infection. These data provide a mechanistic explanation for the well-described MyD88mediated pulmonary bacterial clearance.

The comparisons of mice deficient in MyD88 to those deficient in IL-1R for up to 6 days after infection indicated that MyD88mediated host resistance is only partially dependent on IL-1R (Figure 7). This is in agreement with previous results showing that MyD88-dependent responses involving TLRs are effectively triggered in mice infected with L. pneumophila $[10,28,30-33,35-$ 37]. Although it is known that $L$. pneumophila triggers activation of TLR2, TLR4, TLR5, and TLR9, deletion of these genes has little influence on resistance of the mice to infection in vivo. Among the TLR-deficient mice that are significantly more permissive to L. pneumophila infection are TLR2 $2^{-/-}$and $\mathrm{TLR}^{-/-}$mice $[28,31,35]$. However, although these TLR-deficient mice are slightly more permissive than the WT mice, their reduced restriction of bacterial replication are considerably different from those observed in ${\mathrm{MyD} 88^{-/-}}^{-}$mice $[28,31]$. It is possible that the redundancy among TLRs would compensate for the deficiency in a single TLR. In a massive effort to overcome this redundancy, mice double deficient in TLR5 and TLR2 and mice deficient in TLR2 along with either TLR5 or TLR9 were generated and infected with $L$. pneumophila. It was concluded that even in the absence of functional TLR1, TLR2, TLR5, TLR6, and TLR9 signaling, the mice were overall competent in controlling bacterial replication and had no apparent defects in cytokine production when compared with control mice [28]. It is possible that IL-1R signaling, 
which requires MyD88, will compensate for the absence of individual TLRs during the infections. According to this hypothesis, our data indicate that IL1R signaling does not fully account for MyD88-mediated resistance (Figure 7). It is possible that signaling via multiple TLRs together with signaling via IL-1R and IL-18 will account for the total MyD88-mediated resistance. In this context, CRISPR-mediated multiple gene deletion may provide us with appropriate tools to further identify the individual molecules that contribute to MyD88-mediated host resistance. Regardless of the complex cooperation between these genes, the deletion of a single gene (illr) results in mice that are significantly more susceptible to L. pneumophila infection than any singleTLR- or multiple-TLR-deficient mice generated so far.

Regardless of the receptors accounting for MyD88-mediated host resistance, our data effectively contribute to the elucidation of the host cell processes that lead to neutrophil-mediated resistance in Legionnaires' disease. IL-1R is unique in that it is activated both by IL- $1 \beta$ and IL- $1 \alpha$ [49]; neither IL- $1 \beta$ nor IL- $1 \alpha$ functions as a chemokine for direct neutrophil recruitment. It was recently shown that hematopoietic cells are required for IL- $1 \alpha$ production in response to $L$. pneumophila infection in vivo [19]. It is possible that these cytokines are secreted when the infected alveolar macrophages are targeted by virulent L. pneumophila $[19,47,50]$. In this scenario, the macrophageinduced IL-1 $\alpha$ may target specific host cells for the production of specific chemokines, which may ultimately facilitate neutrophil recruitment. Although the mechanisms involved in IL-1 $\alpha$ secretion by infected macrophages and the processes underlying IL- $1 \alpha$-mediated neutrophil recruitment remain obscure, our data provide a mechanistic explanation for the 2 process that have long been known to be important for host resistance in Legionnaires' disease: MyD88-mediated host resistance to infection and recruitment of neutrophils to the lungs of infected individuals. Further investigation into these processes will be important for a comprehensive understanding of the mechanisms governing health and disease during Legionnaires' disease.

\section{Notes}

Financial support. This work was supported by the Instituto Nacional de Ciência e Tecnologia em Vacinas, the Fundação de Amparo à Pesquisa do Estado de São Paulo (grants 2012/09363-6, 2013/08216-2, and 2014/046844 to D. S. Z.), Fundação de Amparo ao Ensino, Pesquisa e Assistência do Hospital das Clínicas da Faculdade de Medicina de Ribeirão Preto da Universidade de São Paulo and the Conselho Nacional de Desenvolvimento Científico e Tecnológico (research fellowship to D. S. Z.).

Potential conflicts of interest. All authors: No potential conflicts.

All authors have submitted the ICMJE Form for Disclosure of Potential Conflicts of Interest. Conflicts that the editors consider relevant to the content of the manuscript have been disclosed.

\section{References}

1. Horwitz MA, Silverstein SC. Legionnaires' disease bacterium (Legionella pneumophila) multiples intracellularly in human monocytes. J Clin Invest 1980; 66:441-50.
2. McDade JE, Shepard CC, Fraser DW, Tsai TR, Redus MA, Dowdle WR Legionnaires' disease: isolation of a bacterium and demonstration of its role in other respiratory disease. N Engl J Med 1977; 297:1197-203.

3. Diederen BM. Legionella spp. and Legionnaires' disease. J Infect 2008; 56:1-12.

4. Fields BS. The molecular ecology of legionellae. Trends Microbiol 1996 4:286-90.

5. Newton HJ, Ang DK, van Driel IR, Hartland EL. Molecular pathogenesis of infections caused by Legionella pneumophila. Clin Microbiol Rev 2010; 23:274-98.

6. Archer KA, Ader F, Kobayashi KS, Flavell RA, Roy CR. Cooperation between multiple microbial pattern recognition systems is important for host protection against the intracellular pathogen Legionella pneumophila. Infect Immun 2010; 78:2477-87.

7. Berrington WR, Iyer R, Wells RD, Smith KD, Skerrett SJ, Hawn TR. NOD1 and NOD2 regulation of pulmonary innate immunity to Legionella pneumophila. Eur J Immunol 2010; 40:3519-27.

8. Berrington WR, Smith KD, Skerrett SJ, Hawn TR. Nucleotide-binding oligomerization domain containing-like receptor family, caspase recruitment domain (CARD) containing 4 (NLRC4) regulates intrapulmonary replication of aerosolized Legionella pneumophila. BMC Infect Dis 2013; 13:371.

9. Frutuoso MS, Hori JI, Pereira MS, et al. The pattern recognition receptors Nod1 and Nod2 account for neutrophil recruitment to the lungs of mice infected with Legionella pneumophila. Microbes Infect 2010; 12:819-27.

10. Hawn TR, Berrington WR, Smith IA, et al. Altered inflammatory responses in TLR5-deficient mice infected with Legionella pneumophila. J Immunol 2007; 179:6981-7.

11. Pereira MS, Morgantetti GF, Massis LM, Horta CV, Hori JI, Zambon DS. Activation of NLRC4 by flagellated bacteria triggers caspase-1 dependent and -independent responses to restrict Legionella pneumophila replication in macrophages and in vivo. J Immunol 2011; 187:6447-55.

12. Schuelein R, Ang DK, van Driel IR, Hartland EL. Immune control of legionella infection: an in vivo perspective. Front Microbiol 2011; 2:126

13. LeibundGut-Landmann S, Weidner K, Hilbi H, Oxenius A. Nonhema topoietic cells are key players in innate control of bacterial airway infection. J Immunol 2011; 186:3130-7.

14. Sporri R, Joller N, Hilbi H, Oxenius A. A novel role for neutrophils as critical activators of NK cells. J Immunol 2008; 181:7121-30.

15. Tateda K, Moore TA, Deng JC, et al. Early recruitment of neutrophils determines subsequent T1/T2 host responses in a murine model of Legionella pneumophila pneumonia. J Immunol 2001; 166:3355-61.

16. Carratala J, Gudiol F, Pallares R, et al. Risk factors for nosocomial Legionella pneumophila pneumonia. Am J Respir Crit Care Med 1994; 149:625-9.

17. Gutzeit MF, Lauer SJ, Dunne WM Jr, Kelly KJ, Chusid MJ. Fatal Legionella pneumonitis in a neutropenic leukemic child. Pediatr Infect Dis J 1987; 6:68-9.

18. Winn WC Jr, Myerowitz RL. The pathology of the Legionella pneumonias. A review of 74 cases and the literature. Hum Pathol 1981; $12: 401-22$.

19. Barry KC, Fontana MF, Portman JL, Dugan AS, Vance RE. IL-1alph signaling initiates the inflammatory response to virulent Legionella pneumophila in vivo. J Immunol 2013; 190:6329-39.

20. Mariathasan S, Monack DM. Inflammasome adaptors and sensors: intracellular regulators of infection and inflammation. Nat Rev Immunol 2007; 7:31-40.

21. Amer A, Franchi L, Kanneganti TD, et al. Regulation of Legionella phagosome maturation and infection through flagellin and host Ipaf. J Biol Chem 2006; 281:35217-23.

22. Kofoed EM, Vance RE. Innate immune recognition of bacterial ligands by NAIPs determines inflammasome specificity. Nature 2011; 477:592-5.

23. Lightfield KL, Persson J, Brubaker SW, et al. Critical function for Naip5 in inflammasome activation by a conserved carboxy-terminal domain of flagellin. Nat Immunol 2008; 9:1171-8. 
24. Molofsky AB, Byrne BG, Whitfield NN, et al. Cytosolic recognition of flagellin by mouse macrophages restricts Legionella pneumophila infec tion. J Exp Med 2006; 203:1093-104.

25. Ren T, Zamboni DS, Roy CR, Dietrich WF, Vance RE. Flagellin-deficient Legionella mutants evade caspase-1- and Naip5-mediated macrophage immunity. PLoS Pathog 2006; 2:e18.

26. Zamboni DS, Kobayashi KS, Kohlsdorf T, et al. The Bircle cytosolic pattern-recognition receptor contributes to the detection and contro of Legionella pneumophila infection. Nat Immunol 2006; 7:318-25.

27. Zhao Y, Yang J, Shi J, et al. The NLRC4 inflammasome receptors for bacterial flagellin and type III secretion apparatus. Nature 2011 477:596-600.

28. Archer KA, Alexopoulou L, Flavell RA, Roy CR. Multiple MyD88dependent responses contribute to pulmonary clearance of Legionella pneumophila. Cell Microbiol 2009; 11:21-36.

29. Pereira MS, Marques GG, Dellama JE, Zamboni DS. The Nlrc4 inflammasome contributes to restriction of pulmonary infection by flagellated Legionella spp. that trigger pyroptosis. Front Microbiol 2011; 2:33.

30. Akamine M, Higa F, Arakaki N, et al. Differential roles of Toll-like receptors 2 and 4 in in vitro responses of macrophages to Legionella pneumophila. Infect Immun 2005; 73:352-61.

31. Archer KA, Roy CR. MyD88-dependent responses involving toll-like receptor 2 are important for protection and clearance of Legionella pneumophila in a mouse model of Legionnaires' disease. Infect Immun 2006 74:3325-33.

32. Bhan U, Trujillo G, Lyn-Kew K, et al. Toll-like receptor 9 regulates the lung macrophage phenotype and host immunity in murine pneumonia caused by Legionella pneumophila. Infect Immun 2008; 76:2895-904.

33. Fuse ET, Tateda K, Kikuchi Y, et al. Role of Toll-like receptor 2 in recognition of Legionella pneumophila in a murine pneumonia model. J Med Microbiol 2007; 56:305-12.

34. Hawn TR, Verbon A, Lettinga KD, et al. A common dominant TLR5 stop codon polymorphism abolishes flagellin signaling and is associated with susceptibility to Legionnaires' disease. J Exp Med 2003; 198:1563-72.

35. Hawn TR, Smith KD, Aderem A, Skerrett SJ. Myeloid differentiation primary response gene (88)- and toll-like receptor 2-deficient mice are susceptible to infection with aerosolized Legionella pneumophila. J Infect Dis 2006; 193:1693-702.

36. Newton CA, Perkins I, Widen RH, Friedman H, Klein TW. Role of Tolllike receptor 9 in Legionella pneumophila-induced interleukin-12 p40 production in bone marrow-derived dendritic cells and macrophages from permissive and nonpermissive mice. Infect Immun 2007; 75:146-51.
37. Shim HK, Kim JY, Kim MJ, Sim HS, Park DW, Sohn JW. Legionella lipoprotein activates toll-like receptor 2 and induces cytokine production and expression of costimulatory molecules in peritoneal macrophages. Exp Mol Med 2009; 41:687-94.

38. Feeley JC, Gibson RJ, Gorman GW, et al. Charcoal-yeast extract agar: primary isolation medium for Legionella pneumophila. J Clin Microbio 1979; 10:437-41.

39. Adachi O, Kawai T, Takeda K, et al. Targeted disruption of the MyD88 gene results in loss of IL-1- and IL-18-mediated function. Immunity 1998; 9:143-50

40. Takeuchi O, Hoshino K, Kawai T, et al. Differential roles of TLR2 and TLR4 in recognition of gram-negative and gram-positive bacterial cell wall components. Immunity 1999; 11:443-51.

41. Yamamoto M, Sato S, Hemmi H, et al. Role of adaptor TRIF in the MyD88-independent toll-like receptor signaling pathway. Science 2003; 301:640-3.

42. Hoshino K, Takeuchi O, Kawai T, et al. Cutting edge: Toll-like recepto 4 (TLR4)-deficient mice are hyporesponsive to lipopolysaccharide: evidence for TLR4 as the Lps gene product. J Immunol 1999; 162 3749-52.

43. Hemmi H, Takeuchi O, Kawai T, et al. A Toll-like receptor recognize bacterial DNA. Nature 2000; 408:740-5.

44. Takeda K, Tsutsui $\mathrm{H}$, Yoshimoto $\mathrm{T}$, et al. Defective NK cell activity and Th1 response in IL-18-deficient mice. Immunity 1998; 8:383-90.

45. Marim FM, Silveira TN, Lima DS Jr, Zamboni DS. A method for generation of bone marrow-derived macrophages from cryopreserved mouse bone marrow cells. PLoS One 2010; 5:e15263.

46. O'Neill LA, Bowie AG. The family of five: TIR-domain-containing adaptors in Toll-like receptor signalling. Nat Rev Immunol 2007; 7:353-64.

47. Casson CN, Copenhaver AM, Zwack EE, et al. Caspase-11 activation in response to bacterial secretion systems that access the host cytosol. PLoS Pathog 2013; 9:e1003400.

48. Muzio M, Ni J, Feng P, Dixit VM. IRAK (Pelle) family member IRAK-2 and MyD88 as proximal mediators of IL-1 signaling. Science 1997 278:1612-5.

49. Sims JE, March CJ, Cosman D, et al. cDNA expression cloning of the IL1 receptor, a member of the immunoglobulin superfamily. Science 1988; $241: 585-9$.

50. Shin S, Case CL, Archer KA, et al. Type IV secretion-dependent activation of host MAP kinases induces an increased proinflammatory cytokine response to Legionella pneumophila. PLoS Pathog 2008; 4 e1000220. 
10 - ANEXO II: Trabalhos de colaboração

10.1 - Anexo 5 - Artigo publicado (CUNHA, Larissa D; SILVA, Alexandre LN; RIBEIRO, Juliana M; MASCARENHAS, Danielle PA; QUIRINO, Gustavo FS; SANTOS, Leonardo L; FLAVELL, Richard A; ZAMBONI, Dario S. Cell Reports, 2017)

"AIM2 Engages Active but Unprocessed Caspase-1 to Induce Noncanonical Activation of the NLRP3 Inflammasome"

- Publicado em: julho de 2017 


\section{Cell Reports}

\section{AlM2 Engages Active but Unprocessed Caspase-1 to Induce Noncanonical Activation of the NLRP3 Inflammasome}

Graphical Abstract

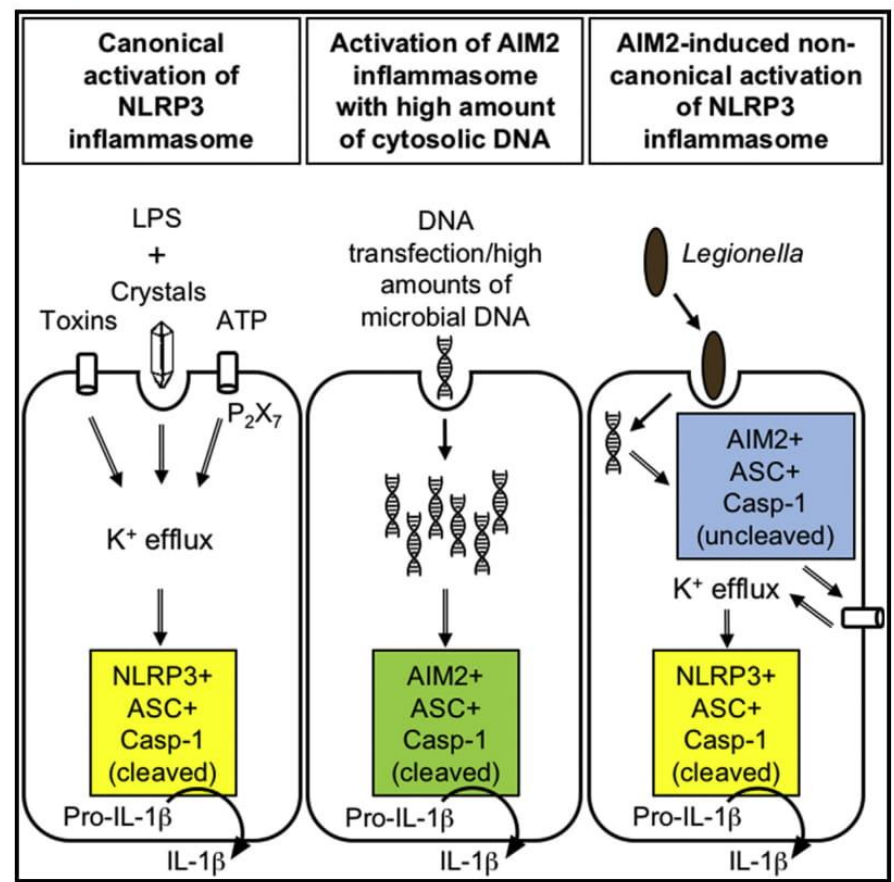

Highlights

- AIM2 triggers caspase-1 activation, but not cleavage, in response to Legionella infection

- AIM2 engages active but unprocessed caspase-1 to induce pore formation and $\mathrm{K}^{+}$efflux

- AIM2 amplifies infection signals to trigger activation of the NLRP3 inflammasome

- AIM2 and caspase-11 cooperate to induce host resistance to Legionella infection

\section{Authors}

Larissa D. Cunha, Alexandre L.N. Silva, Juliana M. Ribeiro, ..., Leonardo L. Santos, Richard A. Flavell, Dario S. Zamboni

\section{Correspondence}

dszamboni@fmrp.usp.br

In Brief

Cunha et al. find that the AIM2

inflammasome is activated in response to Legionella and cooperates with caspase-11 to trigger host resistance. Mechanistically, AIM2 engages active but unprocessed caspase- 1 to trigger pore formation and $\mathrm{K}^{+}$efflux, which also converges into NLRP3 activation. Thus, the AIM2 inflammasome cooperates with caspase-11 to amplify the signals of infection and triggers noncanonical activation of the NLRP3 inflammasome. 


\title{
AlM2 Engages Active but Unprocessed Caspase-1 to Induce Noncanonical Activation of the NLRP3 Inflammasome
}

\author{
Larissa D. Cunha, ${ }^{1,4,5}$ Alexandre L.N. Silva, ${ }^{1,4}$ Juliana M. Ribeiro, ${ }^{1,4}$ Danielle P.A. Mascarenhas, ${ }^{1}$ Gustavo F.S. Quirino, \\ Leonardo L. Santos, ${ }^{1}$ Richard A. Flavell, ${ }^{2,3}$ and Dario S. Zamboni, ${ }^{1,6, *}$ \\ ${ }^{1}$ Department of Cell Biology, Medical School of Ribeirão Preto, University of São Paulo (FMRP/USP), Ribeirão Preto SP 14049-900, Brazil \\ ${ }^{2}$ Department of Immunobiology, Yale University School of Medicine, New Haven, CT 06520, USA \\ ${ }^{3}$ Howard Hughes Medical Institute, Yale University, New Haven, CT 06520, USA \\ ${ }^{4}$ These authors contributed equally \\ ${ }^{5}$ Present address: Department of Immunology, St. Jude Children's Research Hospital, Memphis, TN 38105, USA \\ 'Lead Contact \\ ${ }^{*}$ Correspondence: dszamboni@fmrp.usp.br \\ http://dx.doi.org/10.1016/j.celrep.2017.06.086
}

\section{SUMMARY}

Inflammasomes are multimeric protein complexes that initiate inflammatory cascades. Their activation is a hallmark of many infectious or inflammatory diseases. Their composition and activity are specified by proinflammatory stimuli. For example, the NLRP3 inflammasome is activated in response to cell damage and $\mathrm{K}^{+}$efflux, whereas the AIM2 inflammasome is activated in response to cytosolic DNA. We used Legionella pneumophila, an intracellular bacterial pathogen that activates multiple inflammasomes, to elucidate the molecular mechanisms regulating inflammasome activation during infection. Upon infection, the AIM2 inflammasome engaged caspase-1 to induce pore formation in the cell membrane, which then caused $\mathrm{K}^{+}$-efflux-mediated activation of NLRP3. Thus, the AIM2 inflammasome amplifies signals of infection, triggering noncanonical activation of NLRP3. During infection, AIM2 and caspase-11 induced membrane damage, which was sufficient and essential for activating the NLRP3 inflammasome. Our data reveal that different inflammasomes regulate one another's activity to ensure an effective immune response to infection.

\section{INTRODUCTION}

Inflammation is a protective response triggered by the innate immune system in response to pathogens or damage caused by potentially harmful stimuli. A key contributor to the inflammatory response is the intracellular activation of inflammasomes, which are large multimeric protein complexes that serve primarily as an activating scaffold for caspase-1. Upon sensing harmful stimuli such as pathogens or irritants, pattern-recognition receptors assemble distinct inflammasome structures that recruit and activate caspase-1. Activated caspase- 1 then initiates a large proinflammatory cascade by cleaving various molecules, including inflammatory cytokines, into their bioactive forms. Inflammasome function and activity is dictated by the particular pattern-recognition receptor sensing the stimulus. Although the mechanisms leading to activation of inflammasomes are well characterized, the mechanisms by which distinct inflammasome types are able to compartmentalize their activity are not.

Inflammasomes are often studied in genetically engineered mice lacking a single gene. High concentrations of synthetic or purified molecules that activate distinct inflammasome types are also used. This approach provides valuable information about the specific functions of different inflammasome types; however, it does not provide a comprehensive understanding of the cooperation between inflammasomes during infection or the effect of one inflammasome type on the regulation of another. In this context, the use of relevant pathogens that target inflammasomes to model the physiologic response to infection is essential to assess the role of inflammasomes in infection and immunity. This is particularly important for activation of the pattern-recognition receptor absent in melanoma 2 (AIM2), which recruits the adaptor protein apoptosis-associated speck-like protein containing a CARD (ASC) to promote caspase-1 activation in response to cytosolic DNA (Bürckstümmer et al., 2009; Fernandes-Alnemri et al., 2009; Hornung et al., 2009; Roberts et al., 2009). The AIM2 inflammasome is broadly involved in pathogen recognition, but the physiologic functions of this inflammasome type remain obscure.

Legionella pneumophila is a gram-negative bacterium that causes a severe form of pneumonia called Legionnaires disease. L. pneumophila evolved in freshwater environments, where it replicates in several protozoa species. Mammalian infection is inadvertent and considered a "dead end" for the bacteria. Therefore, $L$. pneumophila has not adapted a mechanism to bypass/inhibit innate immune signaling pathways that are not present in amoeba. Because L. pneumophila initiates the activation of multiple infllammasome types, it is an appropriate model of pathogenic microbial infection to investigate functions of the innate immune system (Cunha and Zamboni, 2014; Fontana and Vance, 2011; Massis and Zamboni, 2011). 
L. pneumophila expresses Dot/lcm, a type IV secretion system that delivers bacterial proteins into the cytoplasm of host cells. Dot/lcm is essential for bacterial replication in macrophages, which also enables the innate immune system to identify pathogens and activate multiple innate immune pathways (Shin 2012; Vance, 2010). Dot/lcm facilitates the delivery of bacterial flagellin into the cytoplasm, which is an agonist that stimulates intracellular Nod-like receptors (NLRs) such as NAIP5 that initiate the assembly an inflammasome composed of NLRC4 and caspase-1 (Amer et al., 2006; Molofsky et al., 2006; Ren et al., 2006). L. pneumophila flagellin mutants ( $f l a A^{-}$) bypass NAIP5/NLRC4 inflammasome-mediated growth restriction and freely multiply in restrictive macrophages. Therefore, NAIP5 and NLRC4 inflammasomes are required to restrict bacteria replication in macrophages (Amer et al., 2006; Molofsky et al., 2006; Ren et al., 2006; Zamboni et al., 2006).

The AIM2 inflammasome is also activated in response to L. pneumophila infection, which also depends on Dot/lcm. SdhA, an effector protein secreted by Dot/lcm, stabilizes L. pneumophila-containing vacuoles and consequently reduces AIM2 activation (Creasey and Isberg, 2012; Ge et al., 2012). Deletion of the sdhA gene strongly activates AIM2-mediated cell death. Nevertheless, AIM2 is activated in wild-type (WT) L. pneumophila containing SdhA (Ge et al., 2012).

Caspase-11 is activated in response to $L$. pneumophila infection (Aachoui et al., 2013; Akhter et al., 2012; Case et al., 2013 Casson et al., 2013; Pilla et al., 2014) through a mechanism independent of bacterial flagellin, NLRC4, or caspase-1. However, this occurs after NLRC4 inflammasome activation (Case et al., 2013) most likely because caspase-11 activation requires macrophage priming to trigger its transcriptional upregulation (Kayagaki et al., 2011). Once activated, caspase-11 triggers macrophage pyroptosis (i.e., inflammation-associated programmed cell death) and noncanonical activation of the NACHT-, LRR-, and PYD-domain-containing protein 3 (NLRP3) inflammasome. Caspase-11-induced NLRP3 inflammasome formation requires $\mathrm{ASC}$ and culminates in caspase-1 activation and inflammatory cytokine secretion (Case et al., 2013; Casson et al., 2013; Kayagaki et al., 2011).

Lipopolysaccharide (LPS), flagellin, and bacterial DNA are agonists for caspase-11, NAIP5/NLRC4/caspase-1, and AIM2/ ASC/caspase-1 inflammasomes, respectively. However, the specific agonist and mechanisms underlying the activation of NLRP3/ASC/caspase-1 remain obscure, which is surprising given that NLRP3 is the most thoroughly studied inflammasome type. NLRP3 is also involved in the pathogenesis of several inflammatory and infectious diseases (reviewed in Wen et al., 2012). Although several molecules activate NLRP3 (e.g., reactive oxygen species, lysosomal cathepsins, bacterial RNA, and mitochondrial DNA), $\mathrm{K}^{+}$efflux appears to be essential for NLRP3 activation (Baker et al., 2015; Muñoz-Planillo et al., 2013; Perregaux and Gabel, 1994; Pétrilli et al., 2007; Rühl and Broz, 2015; Schmid-Burgk et al., 2015).

We used the bacterial pathogen $L$. pneumophila as a relevant model of infection to assess the coordination of inflammasome functions during infection. We hypothesize that the AIM2 inflammasome does not directly cooperate with NLRP3 to trigger caspase-1 activation. Instead, AIM2 indirectly activates the
NLRP3 inflammasome during the physiologic response to infection by inducing membrane damage and $\mathrm{K}^{+}$efflux, thereby amplifying the signals of infection. Thus, AIM2 induces noncanonical activation of the NLRP3 inflammasome, a process that ensures robust activation of inflammasomes and an effective innate immune response to infection.

\section{RESULTS}

Pore Formation Can Occur Independently of Flagellin/ NLRC4 and LPS/Caspase-11 Inflammasomes in

L. pneumophila-Infected Macrophages

Infection of mouse macrophages with WT L. pneumophila activates the NAIP5/NLRC4 inflammasome, which induces pore formation via mechanisms dependent on caspase-1 and flagellin (Case et al., 2009; Silveira and Zamboni, 2010; Zamboni et al., 2006). In addition, caspase-11 mediates pore formation and pyroptosis independently of flagellin/NLRC4 and caspase-1 but requires upregulation of Casp11 through macrophage priming (Case et al., 2013). To assess the role of caspase-1 and caspase-11 in pyroptosis, we examined pore formation by evaluating the loss of membrane integrity in Legionella-infected bone-marrow-derived macrophages (BMDMs) using a real-time fluorimetric assay of propidium iodide (PI) uptake. We primed the cells with LPS and observed that pore formation induced by WT L. pneumophila (JR32 WT) partially depended on caspase-1 and was abolished in BMDMs derived from Casp1/11-deficient mice (Figures $1 \mathrm{~A}$ and 1C). As previously reported (Case et al., 2013), pore formation was reduced overall and depended on caspase-11, but not caspase-1, in response to fla $A^{-}$L. pneumophila (Figure 1B). Experiments performed using $L$. pneumophila $\operatorname{dot} A^{-}$mutants, which have a defective Dot/lcm system, indicated that the bacterial type IV secretion system is essential for pore formation in macrophages (Figure 1D). We obtained similar results for BMDMs primed with tumor necrosis factor alpha (TNF- $\alpha$ ), indicating that regardless of the molecule used for priming, caspase-1 activation requires flagellin and caspase-11 does not (Figures $1 \mathrm{E}-1 \mathrm{G})$. Furthermore, flaA $A^{-}$L. pneumophila triggered pore formation in Casp $11^{-1-}$ BMDMs, suggesting that a pathway independent of flagellin/NLRC4 and caspase-11 can mediate pore formation (Figures $1 \mathrm{~B}$ and $1 \mathrm{~F}$ ). This unidentified pore-formation pathway presumably depends on caspase-1, because it was abolished in Casp1/11-deficient BMDMs and reduced in Casp $1^{-1-}$ BMDMs compared to WT BMDMs (C57BL/6) (Figures $1 \mathrm{~B}$ and $1 \mathrm{~F}$ ).

These data support the idea that Legionella-induced pore formation and pyroptosis involve multiple pathways. One pathway depends on flagellin/NLRC4 and caspase-1, another depends on caspase-11, but not flagellin, and a third is independent of flagellin and caspase-11.

The AIM2 Inflammasome Promotes Pore Formation, Pyroptosis, and Caspase-1 Activation in Response to L. pneumophila

We determined the molecules comprising the pathway that functions independently of flagellin/NLRC4 and LPS/caspase-11 with $\mathrm{flaA}^{-}$L. pneumophila. The AIM2 inflammasome is activated 
A

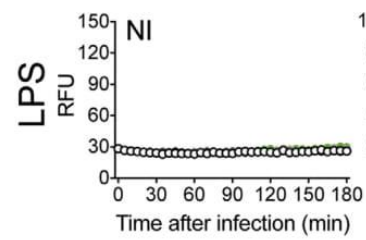

E

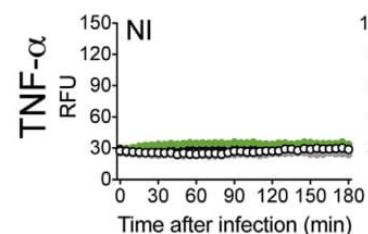

B

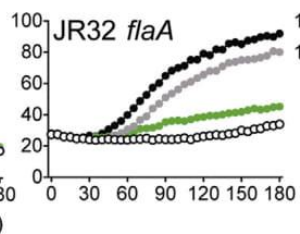

c

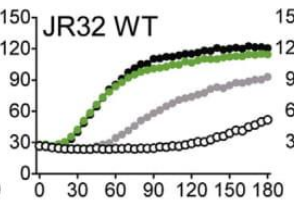

F

\section{G}

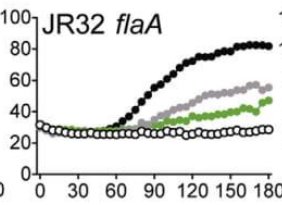

${ }_{120}^{150} \mathrm{JR} 32 \mathrm{WT}$

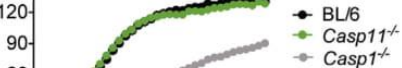

$60-20$ Casp $1 / 11^{1}$
JR32 dotA

- BL/6

- Casp1 1

- Casp $1 / 11$

H
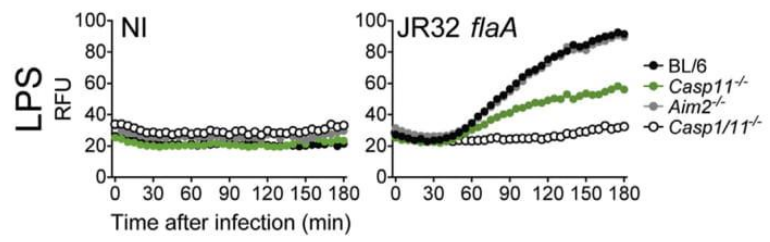

J

K
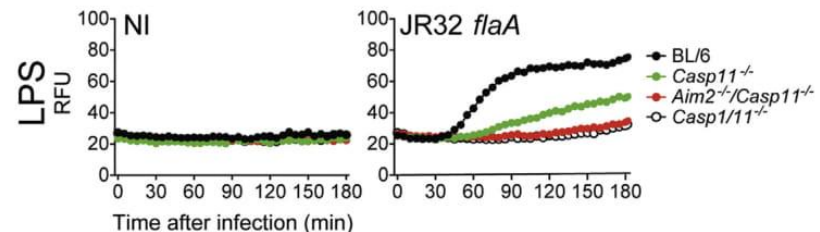

L

M
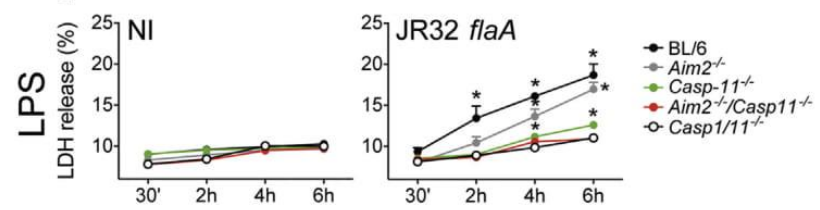

Time after infection

Figure 1. AIM2 Induces NLRC4 and Caspase-11-Independent Pore Formation and Pyroptosis in Response to L. pneumophila Infection (A-K) Fluorometric quantification of PI uptake over time, expressed in relative fluorescence units (RFUs). BMDMs BL/6, Casp $11^{-1-}$, Casp $1^{-1-}$, and Casp $1 / 11^{-1-}$ pretreated with LPS $(500 \mathrm{ng} / \mathrm{mL})$ for $3 \mathrm{hr}$ were either not infected (NI) (A) or infected at MOI20 with fla $A^{-}$mutant strain of L. pneumophila (JR32 flaA) (B), WT

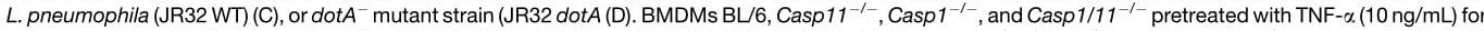

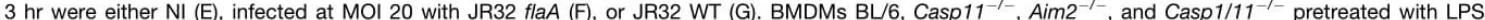
$(500 \mathrm{ng} / \mathrm{mL})$ for $3 \mathrm{hr}$ were $\mathrm{NI}(\mathrm{H})$ or infected at MOI 20 with JR32 flaA (I). BMDMs BL/6, Casp $11^{-1-}$, Aim2 $2^{-1-} /$ Casp $11^{-1-}$ and Casp $1 / 11^{-1-}$ pretreated with LPS $(500 \mathrm{ng} / \mathrm{mL})$ for $3 \mathrm{hr}$ were $\mathrm{NI}(\mathrm{J})$ or infected at MOI 20 with JR32 flaA $(\mathrm{K})$. Data are representative of four independent experiments and are expressed as the average of triplicate wells.

( $\mathrm{L}$ and M) Cytotoxicity was measured in an LDH-release assay. BMDMs pretreated with LPS ( $500 \mathrm{ng} / \mathrm{mL}$ ) for $3 \mathrm{hr}$ were either NI (L) or infected with JR32 flaA at $\mathrm{MOI} 20$ (M). Data are representative of three independent experiments and are expressed as the mean of triplicate wells. Error bars depict $\mathrm{SEM}$. ${ }^{*} \mathrm{p}<0.05$ versus Casp $1 / 11^{-1-}$ BMDMs.

See also Figure S1. 
A

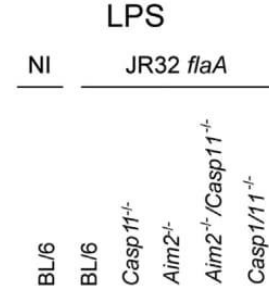

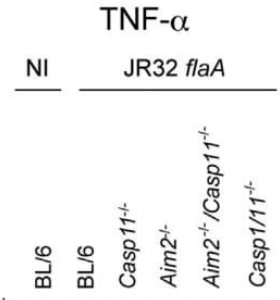

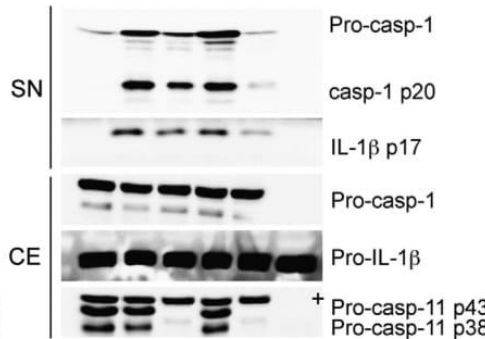

Figure 2. AIM2 and Caspase-11 Cooperate to Trigger Caspase-1 Cleavage in Response to $L$. pneumophila Infection

(A and B) Immunoblots of caspase-1, IL-1B, and caspase-11 in the supernatant (SN) and cell extract (CE) of BMDMs. BMDMs pretreated for $3 \mathrm{hr}$ with LPS $(500 \mathrm{ng} / \mathrm{mL})$ (A) or TNF- $\alpha$. (10 ng/mL) (B) were either not infected (NI) or infected for $2 \mathrm{~h}$ with JR32 flaA (MOI 20). Data are representative of three independent experiments.

(C and $\mathrm{D}) \mathrm{IL}-1 \beta$ released in BMDM SN, as measured by ELISA. BMDMs pretreated for $3 \mathrm{hr}$ with LPS $(500 \mathrm{ng} / \mathrm{mL})(C)$ or TNF- $\alpha$ ( $10 \mathrm{ng} / \mathrm{mL})$ (D) were infected for $4 \mathrm{hr}$ with JR32 flaA (MOI 20). Data are representative of three independent experiments and are expressed as the mean of triplicate wells. Error bars depict \pm SEM. ${ }^{*} p<0.05$ versus NI. See also Figure S2.

nase (LDH) release to assess macrophage pyroptosis in response to $\mathrm{fla}^{-}$ L. pneumophila. In agreement with our pore-formation findings, AIM2 and caspase-11 induced pyroptosis in response to $L$. pneumophila (Figures $1 \mathrm{~L}$ and $1 \mathrm{M}$ ). In immortalized C57BL/6 macrophages that express an AIM2-citrine fusion construct, flaA $A^{-}$, but not $\operatorname{dot} A^{-}$, L. pneumophila induced AIM2 oligomerization (Figures S1C and S1D). This corroborates previous reports of AIM2 activation in response to $L$. pneumophila infections (Ge et al., 2012).

Caspase-11 activates the noncanonical pathway of NLRP3 inflammasome activation (Kayagaki et al., 2011; Rathinam et al., 2012). Therefore, we tested whether AIM2 cooperates with cas-

in response to $L$. pneumophila via a process that requires Dot/lcm and activates caspase-1 (Ge et al., 2012). Therefore, we tested whether AIM2 was required for $L$. pneumophilainduced pore formation. We found that the absence of AIM2 in BMDMs from Aim2 $2^{-1-}$ mice generated in a C57BL/6 background did not affect caspase-11-dependent pore formation in response to L. pneumophila (Figures $1 \mathrm{H}$ and $1 \mathrm{I}$ ). The caspase-1-dependent, LPS/caspase-11-independent, and flagellin/NLRC4-independent pathway was evident, as fla $A^{-} L$. pneumophila triggered pore for-

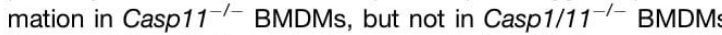
(Figures $1 \mathrm{H}$ and $1 \mathrm{I}$ ). To further test whether AIM2 operates in this pathway, we used mice double deficient for Aim2 and Casp11. Caspase-11-independent pore formation was abolished in these macrophages (Figures $1 \mathrm{~J}$ and $1 \mathrm{~K}$ ). Similar results were obtained by infection with Lp01, a widely used laboratory strain of $L$. pneumophila that was isolated from a historic outbreak of Legionnaires disease in Philadelphia in 1976 (Figures S1A and S1B).

L. pneumophila-induced pore formation culminates in macrophage pyroptosis. Therefore, we measured lactate dehydroge-

pase-11 to trigger the noncanonical pathway, which induces caspase- 1 proteolysis and proteolytic maturation and secretion of interleukin-1 beta (IL-1ß). Compared to that in WT C57BL/6 BMDMs, Casp $11^{-1-}$ BMDMs exhibited reduced caspase-1 cleavage in response to infection with $\mathrm{flaA}^{-}$L. pneumophila in cells primed with LPS or TNF- $\alpha$ (Figures $2 \mathrm{~A}$ and 2B). Deficiency of Aim2 alone had little effect on caspase-1 processing; however, caspase-1 proteolysis was strongly reduced in BMDMs that were double deficient in Aim2 and Casp11 (Figures $2 \mathrm{~A}$ and $2 \mathrm{~B}$ ). Similar results were observed for IL-1 $\beta$ processing and secretion by BMDMs, both of which depend on caspase- 1 activation and proteolysis (Figures 2C and 2D). To ensure that these results were not caused by differences in microbiota or mouse genetic backgrounds, we performed experiments with littermate controls. BMDMs from Aim2 ${ }^{-1-}$, Casp $1^{+/-}$mice displayed no defects in caspase-1 processing or IL-1 $\beta$ secretion, but those derived from Aim2 $2^{+/-} /$Casp $11^{-/-}$ mice were partially defective, and BMDMs derived from Aim2 $2^{-1-} /$ Casp $11^{-1-}$ mice displayed severe impairment in both processes (Figure S2). 
A

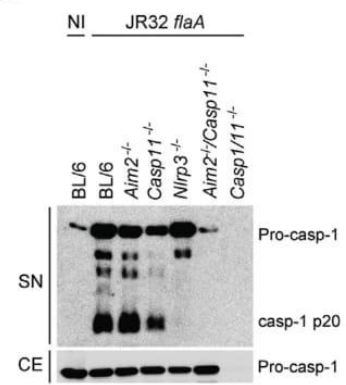

C

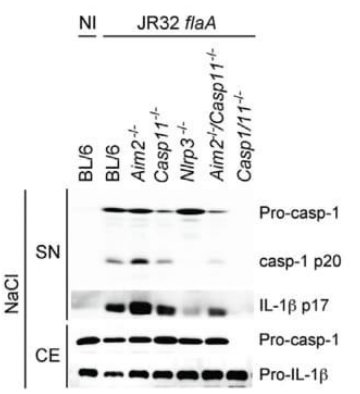

E

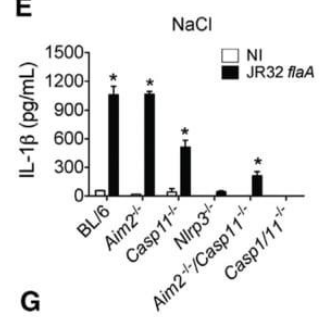

B

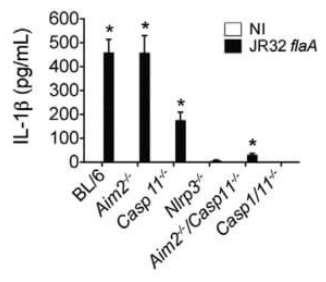

D

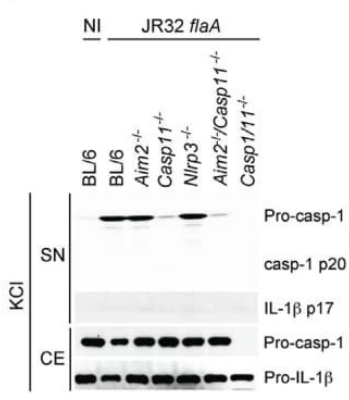

$\mathbf{F}$

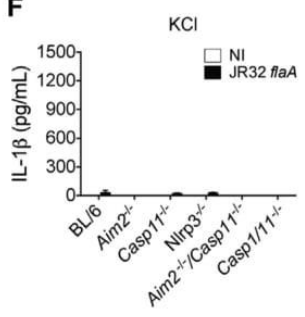

$\circ \mathrm{NI}$

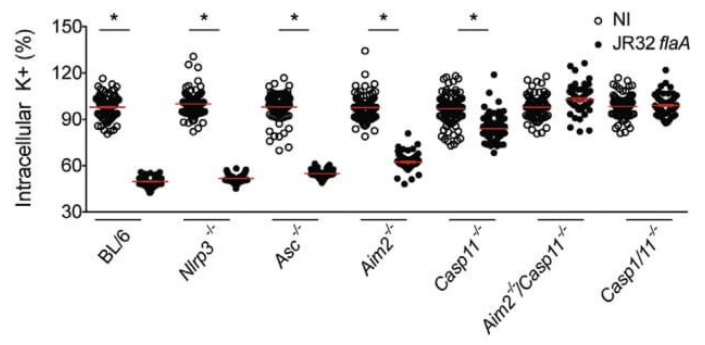

Figure 3. AIM2 and Caspase-11 Cooperate to Induce $\mathrm{K}^{+}$Efflux that Enables NLRP3-Induced Cleavage of Caspase-1 in Response to Infection

(A) Immunoblot of caspase-1 in the supernatant (SN) and cell extract (CE) of BMDMs. BMDMs pretreated for $3 \mathrm{hr}$ with LPS $(500 \mathrm{ng} / \mathrm{mL})$ were either not infected (NI) or infected for $2 \mathrm{hr}$ with JR32 flaA (MOI 20). Data are representative of three independent experiments.

(B) IL- $1 \beta$ released in BMDM SN, as measured by ELISA. BMDMs pretreated for $3 \mathrm{hr}$ with LPS ( $500 \mathrm{ng} / \mathrm{mL}$ ) were infected for $4 \mathrm{hr}$ with JR32 flaA (MOI 20). Data shown are representative of three independent experiments and are expressed as the mean of triplicate wells. Error bars depict \pm SEM. ${ }^{*} p<0.05$ versus NI.

NLRP3 Activation and $\mathrm{K}^{+}$Efflux Are Required for Caspase-1 Proteolysis, but Not Pore Formation, in Response to L. pneumophila

Caspase-11 activation facilitates the maturation of caspase-1 and the secretion of IL-1 $\beta$ in response to $\mathrm{fla}^{-} \mathrm{L}$. pneumophila (Case et al., 2013). This suggests that caspase-11 plays a role in mediating the noncanonical activation of NLRP3, a process that culminates with caspase- 1 cleavage and IL-1 $\beta$ secretion in response to gram-negative bacteria (Kayagaki et al., 2011; Rathinam et al., 2012). Our findings indicated that AIM2 or caspase-11 is required for caspase- 1 proteolysis. Therefore, we tested whether AIM2 participates in the noncanonical pathway to activate NLRP3. We initially used flaA $A^{-}$L. pneumophila to assess whether NLRP3 inflammasome activation was required for caspase-1 proteolysis in response to infection in the presence of AIM2 and caspase-11. NLRP3 activation was essential for caspase- 1 proteolysis and IL-1 $\beta$ secretion, regardless of the presence of caspase-11 and AIM2 (Figures 3A and 3B). In the absence of both, caspase- 1 proteolysis and IL-1 $\beta$ secretion were abolished, regardless of the presence of NLRP3. These results are consistent with a model in which caspase-11 or AIM2 is required to activate NLRP3. To determine whether AIM2 and NLRP3 function in two independent inflammasome types or in the same type, we infected BMDMs with $\mathrm{flaA}^{-}$ L. pneumophila and performed immunostaining for endogenous NLRP3 and AIM2. Both AIM2 and NLRP3 foci formed in response to infection, but they did not colocalize (Figure S3). Therefore, AIM2 and NLRP3 function in discrete molecular complexes. These results support the hypothesis that AIM2 mediates a process resulting in noncanonical activation of NLRP3 via a mechanism similar to yet distinct from that of caspase-11.

To investigate whether the AIM2 inflammasome is sufficient to trigger caspase-1 proteolysis in the absence of NLRP3, we evaluated caspase-1 proteolysis in high extracellular $\mathrm{K}^{+}$conditions, which inhibits the activation of NLRP3, but not that of AIM2. Caspase-1 proteolysis and IL-1 $\beta$ maturation and secretion were abrogated in the presence of $\mathrm{KCl}$, but not $\mathrm{NaCl}$, in all BMDMs tested (Figures 3C-3F). These data support a model in which NLRP3 is a key factor in caspase- 1 proteolysis and IL- $1 \beta$ secretion. According to this model, caspase-11 or AIM2 is required to trigger NLRP3-mediated caspase-1 cleavage and IL-1 $\beta$

(C and D) Immunoblot of caspase- 1 and IL-1 13 in the SN and CE of BMDMs. BMDMs pretreated for $3 \mathrm{hr}$ with LPS $(500 \mathrm{ng} / \mathrm{mL})$ were NI or infected for $2 \mathrm{hr}$ with JR32 flaA (MOI 20), in the presence of $\mathrm{NaCl}(\mathrm{C})$ or $\mathrm{KCl}(\mathrm{D})$. Data shown are representative of three independent experiments.

( $\mathrm{E}$ and $\mathrm{F}$ ) $\mathrm{L}-1 \mathrm{~B}$ released in BMDM SN, as measured by ELISA. BMDMs pretreated for $3 \mathrm{hr}$ with LPS ( $500 \mathrm{ng} / \mathrm{mL}$ ) were infected for $4 \mathrm{hr}$ with JR32 flaA (MOI 20 ), in the presence of $\mathrm{NaCl}(\mathrm{E})$ or $\mathrm{KCl}(\mathrm{F})$. Data shown are representative of three independent experiments and are expressed as the mean of triplicate wells. Error bars depict \pm SEM. ${ }^{*} p<0.05$ versus NI.

(G) Assessment of intracellular $\mathrm{K}^{+}$levels, as measured by the fluorescent $\mathrm{K}^{+}$ probe APG-2. BMDMs were NI or were infected for $2 \mathrm{hr}$ with JR32 flaA (MOI 5) Each dot represents the percentage of APG-2 fluorescence intensity in relation to the average fluorescence of control cells, and the bars represent the mean of all analyzed cells. Error bars depict \pm SEM. ${ }^{*} p<0.05$ versus NI. Data shown are representative of three independent experiments.

See also Figures $\mathrm{S} 3$ and $\mathrm{S} 4$. 


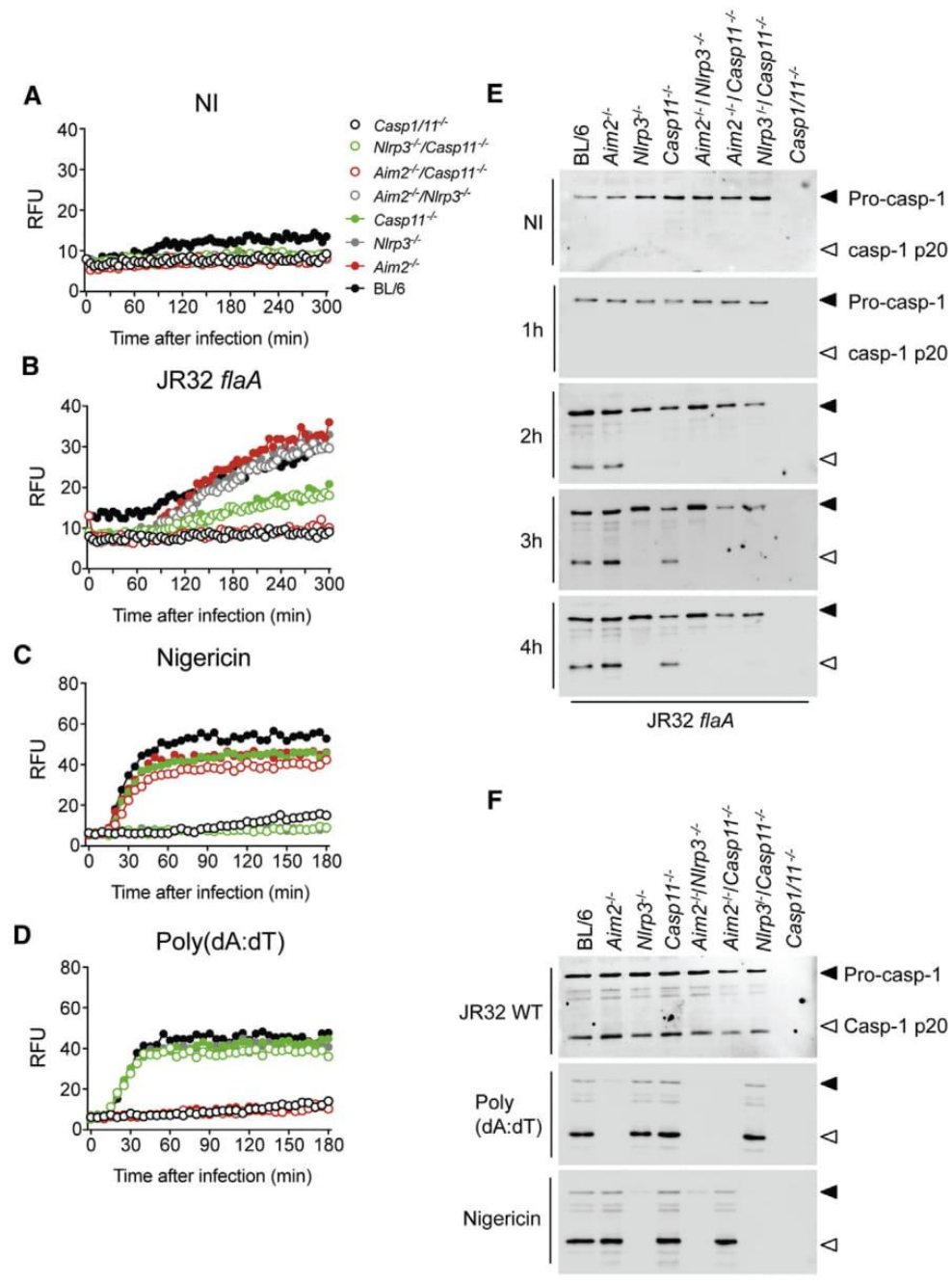

Figure 4. AIM2 Triggers Caspase-1 Cleavage Independent of NLRP3 in Response to Cytosolic DNA, but NLRP3 Is Essential for AIM2-Induced Caspase-1 Cleavage in Response to $L$. pneumophila Infection

(A-D) Fluorometric quantification of $\mathrm{Pl}$ uptake ove time, expressed in RFUs. BMDMs pretreated with LPS $(500 \mathrm{ng} / \mathrm{mL})$ for $3 \mathrm{hr}$ were either not infected (NI) (A), infected with JR32 flaA (MOI 20) (B), stimulated with $20 \mu \mathrm{M}$ nigericin $(C)$, or stimulated with $500 \mathrm{ng} / \mathrm{mL}$ poly(dA:dT) (D). Data are representative of three independent experiments and are expressed as the average of triplicate wells.

( $E$ and F) Immunoblots of caspase-1 in the supernatant (SN) of BMDMs. BMDMs pretreated for $3 \mathrm{hr}$ with LPS $(500 \mathrm{ng} / \mathrm{mL})$ were $\mathrm{NI}$ or infected at the different time points with JR32 flaA (MOI 20) (E). As a control, BMDMs were infected with JR32 WT (MOI 20), treated with $20 \mu \mathrm{M}$ nigericin, or stimulated with $500 \mathrm{ng} / \mathrm{mL}$ poly(dA:dT) (F). Data shown are representative of three independent experiments.

(Figures S4A and S4B). Conversely, attenuating $\mathrm{K}^{+}$efflux did not affect pore formation in response to infection in either WT or Casp11 $11^{-1-}$ BMDMs (Figures S4CS4F), which confirmed that NLRP3 is not required for this process. In agreement with these findings, pyroptosis was not affected by the absence of NLRP3, as $\mathrm{LDH}$ levels and $\mathrm{K}^{+}$efflux were unaffected in NIrp3 ${ }^{-1-}$ BMDMs (Figures S4G-S4I). These findings also support the hypothesis that caspase-11- or AIM2-mediated pore formation does not require NLRP3. Finally, reducing $\mathrm{K}^{+}$efflux did not affect the induction of the AIM2 inflammasome, as indicated by AIM2-citrine oligomerization in response to infection with fla $A^{-}$ L. pneumophila or transfection with double-stranded DNA (Figures $\mathrm{S} 4 \mathrm{~J}$ and S4K). Collectively, our data support a

secretion. To further test this hypothesis, we determined whether AIM2 and caspase- 11 are required for $\mathrm{K}^{+}$efflux in macrophages infected with fla $A^{-} L$. pneumophila. The intracellular $\mathrm{K}^{+}$ concentration decreased in response to infection, and this was independent of ASC and NLRP3 and partially dependent on AIM2 and caspase-11 (Figure $3 \mathrm{G}$ ). We detected no $\mathrm{K}^{+}$efflux in

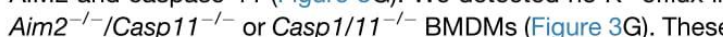
data are consistent with the hypothesis that AIM2 or caspase-11 is required for pore formation, leading to the noncanonical activation of NLRP3 via $\mathrm{K}^{+}$efflux.

Our data demonstrate that NLRP3 is required to induce caspase-1 proteolysis via either AIM2 or caspase-11. Therefore, we investigated whether NLRP3 is likewise required for the functions of caspase-11 and AIM2 inflammasomes (i.e., pore formation, pyroptosis, and inflammasome assembly) in infected BMDMs. NLRP3 was not required for pore formation model in which AIM2 or caspase-11 is required to induce pore formation and activate NLRP3. Conversely, NLRP3 is dispensable for the functions of AIM2 and caspase-11.

Activation of AIM2 Inflammasome Preferentially Induces Pore Formation, and NLRP3 Is Essential for Caspase-1 Cleavage

To evaluate the requirement of NLRP3 for caspase-1 cleavage and pore formation, we established mouse strains that are double deficient for NIrp3 and Casp11 or NIpr3 and Aim2. Measuring pore formation in response to fla $A^{-} L$. pneumophila, we found that $\mathrm{NIrp3}^{-1-} / \mathrm{Casp} 11^{-1-}$ BMDMs phenocopied Casp $11^{-1-}$ cells, confirming that NIrp3 does not affect pore formation in response to infection (Figures $4 \mathrm{~A}$ and $4 \mathrm{~B}$ ). We treated BMDMs with nigericin or transfected them with poly $(\mathrm{dA}: \mathrm{dT})$ to confirm that pore formation is induced by canonical activation 
of NLRP3 (Figure 4C) or AIM2 (Figure 4D), as previously established (Kayagaki et al., 2011). We also confirmed that caspasecleavage in response to infection depends on NLRP3. NIrp3 ${ }^{-1-}$, Casp $11^{-1-}$ and Aim2 $2^{-1-} / \mathrm{NIrp3}^{-1-}$ BMDMs did not process caspase-1 (Figure 4E), whereas NLRC4 activation triggered caspase-1 cleavage in WT BMDMs (Figure 4F). Furthermore, caspase- 1 cleavage induced by nigericin depended only on NLRP3, whereas cleavage induced by poly(dA:dT) depended only on AIM2 (Figure 4F). These data support the hypothesis that AIM2 inflammasome promotes the activation and cleavage of caspase-1 in the presence of high amounts of cytosolic DNA. However, during the physiologic response to infection, AIM2 preferentially triggers pore formation to induce caspase-1 cleavage by NLRP3.

AIM2-Induced Pore Formation Requires Caspase-1 Activity, but Not Proteolysis

NLRP3 is essential for caspase-1 proteolysis in the physiologic response to $L$. pneumophila infection. AIM2-mediated pore formation requires caspase- 1 but occurs in the absence of NLRP3. Therefore, we hypothesized that AIM2 requires caspase- 1 but triggers pyroptosis independently of caspase- 1 proteolysis. An uncleavable yet catalytically active variant of caspase-1 (Casp1 6DN) is sufficient to induce pyroptosis (Broz et al., 2010). To test the hypothesis that AIM2 employs an active but uncleaved form of caspase-1 to trigger pore formation independently of caspase-11, we transduced Casp $1 / 11^{-1-}$ BMDMs with a lentivirus encoding WT caspase-1 (Casp1 WT), Casp1 $6 \mathrm{DN}$, or empty virus (vector) and then assayed pore formation. Western blot analysis confirmed that Casp1 WT, but not Casp1 $6 \mathrm{DN}$ or Casp $1 \mathrm{C} 285 \mathrm{~A}$, underwent autoproteolysis in response to infection with fla $A^{-} L$. pneumophila (Figure $5 \mathrm{~A}$ ). We then verified the caspase- 1 requirements for pore formation in immortalized Casp $1 / 11^{-1-}$ BMDMs that stably overexpress Casp-1 WT or Casp-1 6DN. Overexpression of either variant failed to induce spontaneous pore formation in uninfected cells. Likewise, infection with $\operatorname{dot} A^{-} L$. pneumophila did not trigger pore formation (Figures 5B-5D). In contrast, infection with WT or fla $A^{-}$ $L$. pneumophila readily induced pore formation in BMDMs expressing Casp1 WT or Casp16DN, but not empty virus (Figures 5B-5D). Similar results were obtained when we used a lentivirus to express Casp1 WT and Casp1 6DN in primary macrophages from Casp1/11 ${ }^{-1-}$ mice (Figures S5A-S5D). Overexpression of Casp1 WT or Casp1 6DN did not restore pore formation in Asc/Casp1/Casp11 $11^{-1-}$ triple-knockout BMDMs in response to infection, suggesting that the activation of uncleavable caspase-1 requires ASC (Figures S5E-S5G).

To determine whether AIM2 engages unprocessed caspase-1 to trigger pore formation in the absence of caspase-11, we transduced BMDMs from Casp $1 / 11^{-1-}$ or Aim2 $2^{-1-}$ Casp $1 / 11^{-1-}$ mice with a lentivirus encoding Casp 1 WT, Casp $16 \mathrm{DN}$, or vector and then assayed the cells for pore formation. We also included a lentivirus encoding the catalytically inactive form of caspase-1 (Casp1 C285A) (Figure 5A). Overexpression of Casp1 WT and Casp1 6DN restored pore formation in Casp1/11 ${ }^{-1-}$ BMDMs infected with fla $A^{-}$L. pneumophila (Figures $5 \mathrm{E}-5 \mathrm{G}$ ). In contrast, Casp1/11 $1^{-1-}$ BMDMs expressing Casp1 C285A did not trigger pore formation (Figure 5F). Therefore, cleavage is dispensable, but the C285 active site is essential for caspase-1-induced pore formation.

When we used Aim2 $2^{-1-} /$ Casp $1 / 11^{-1-}$ BMDMs, no pores formed in response to fla $A^{-}$L. pneumophila (Figures $5 \mathrm{H}$ and 5I). In this experiment, we included infections with WT L. pneumophila as a positive control, because the NLRC4 inflammasome triggers caspase-1-dependent pore formation. WT L. pneumophila induced pore formation in Casp1/Casp11 $11^{-1}$ and Aim2 $2^{-1-} /$ Casp $1 /$ Casp $11^{-/-}$BMDMs when the cells expressed Casp1 WT or Casp1 6DN, but not Casp1 C285A (Figure $5 \mathrm{~J}$ ). These results indicate that AIM2 is dispensable for NLRC4-induced pore formation, and caspase-1 activation without proteolysis is sufficient to induce pore formation via AIM2 or NLRC4 inflammasomes. These results imply that these inflammasomes engage an active, uncleaved form of caspase- 1 to trigger pore formation. This process is also necessary and sufficient to induce the noncanonical activation of the NLRP3 inflammasome.

AIM2- and Caspase-11-Induced Pore Formation Contributes to the Restriction of Pathogen Replication In Vivo

We next evaluated the consequences of activating inflammasomes on the infection ability of $L$. pneumophila in macrophages and in vivo. In Legionnaires disease, NAIP5/NLRC4 (but not NLRP3) inflammasome mediates resistance to pulmonary infection (Amer et al., 2006; Case et al., 2009; Molofsky et al., 2006; Pereira et al., 2011; Zamboni et al., 2006). Therefore, we used $f l a A^{-} L$. pneumophila to evaluate whether mice deficient in the signaling pathways that mediate pore formation are more susceptible to infection. WT and Aim2 ${ }^{-1-} /$ Casp $11^{-1-}$ mice were infected with fla $A^{-} L$. pneumophila at a very low $\mathrm{MOI}\left(10^{3}\right.$ per mouse). Bacterial replication was higher in Aim2 ${ }^{-1-} /$ Casp $11^{-1}$ mice than in WT mice (Figure 6A). Although loss of AIM2 or caspase-11 individually in littermate control mice did not influence the restriction of $L$. pneumophila replication, Aim2 $2^{-/-} /$Casp $11^{-/-}$ mice were more susceptible than WT mice (Figure 6B). Because the innate immune pathways that restrict $L$. pneumophila infections in vivo are extensively redundant, these data indicate that pore formation induced by caspase- 11 and AIM2 contributes to the restriction of pulmonary bacterial replication in a murine model of Legionnaires disease.

\section{DISCUSSION}

L. pneumophila is a genetically tractable bacterial pathogen that targets multiple inflammasome types. We determined that the activation of NLRP3 by L. pneumophila is regulated by other inflammasome types. Cell damage induced by at least one inflammasome type (NLRC4, caspase-11, or AIM2) is required and sufficient to engage NLRP3 and to independently mediate resistance to $L$. pneumophila infection.

Membrane-disrupting pathogens (e.g., Listeria, Shigella, Francisella, and Rickettsia) and many toxin-producing bacteria damage host cell membranes. Likewise, certain fungi and the protozoan parasite Trypanosoma cruzi cause cell damage (Silva et al., 2013; Wellington et al., 2014; Zamboni and Lima-Junior, 2015). Therefore, these pathogens may activate NLRP3 via a 
A

Casp1/11\% Aim2 ${ }^{-/}$Casp 1/11\% $\quad$ Casp1/11\% Aim2 ${ }^{-/ C a s p 1 / 11 \%}$

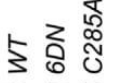

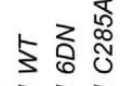

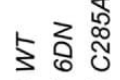

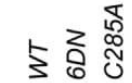

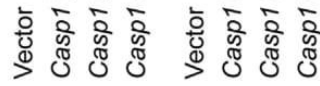

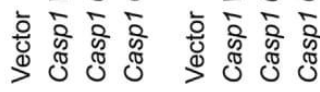

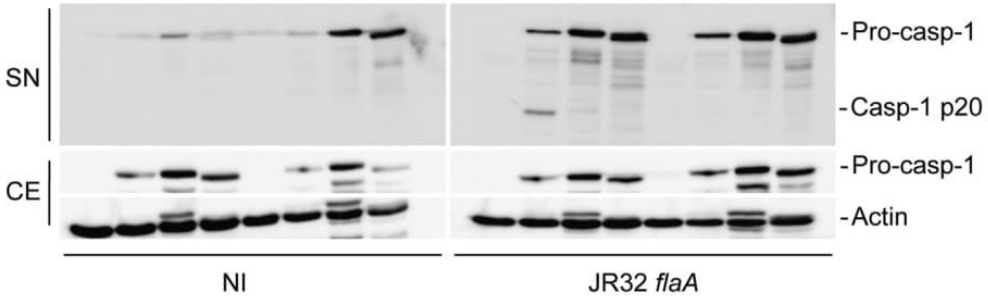

B

C

D
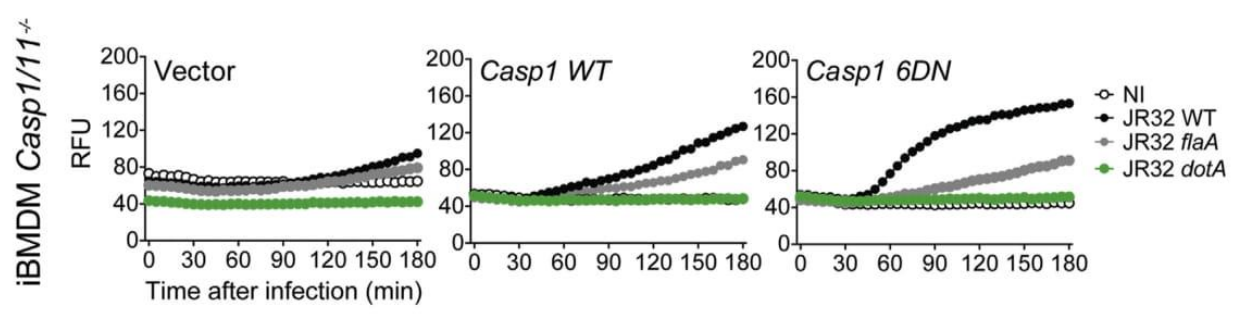

E

F

G
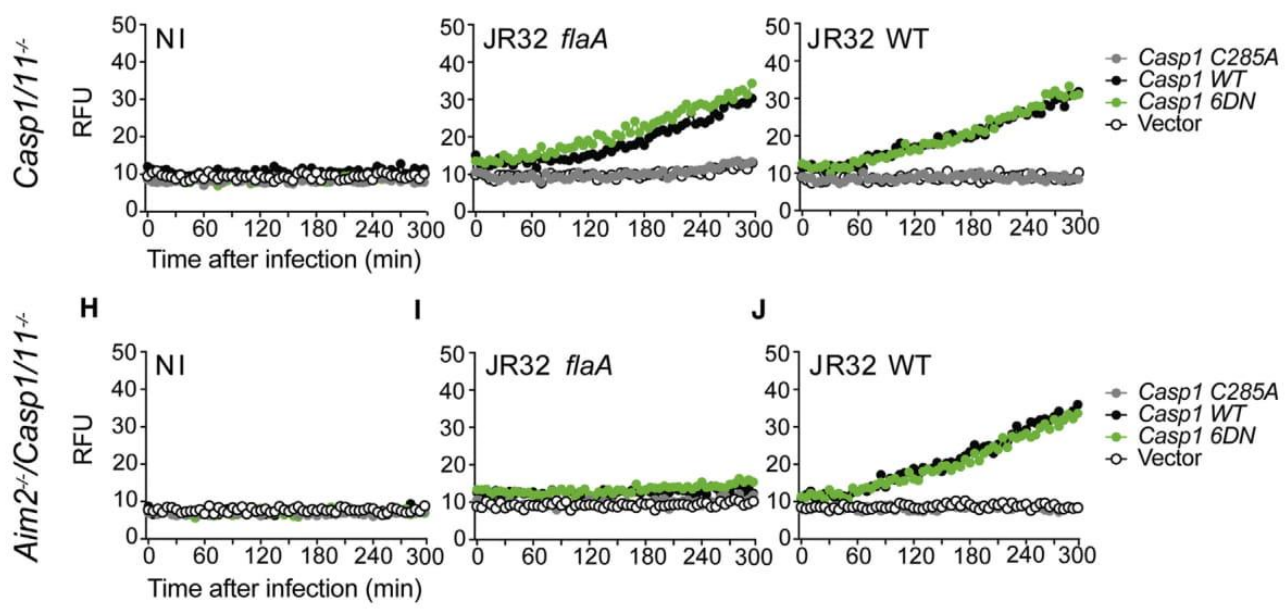

Figure 5. Caspase-1 Activity, but Not Proteolysis, Is Necessary and Sufficient to Trigger AIM2-Dependent Pore Formation in Response to L. pneumophila Infection

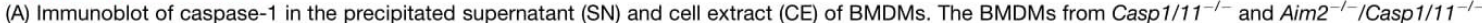
mice were transduced with viruses encoding empty vector (Vector), WT caspase-1 (Casp1 WT), 6DN mutant (Casp1 6DN), or catalytically inactive C285A mutant (Casp1 C285A). Cells pretreated for $3 \mathrm{hr}$ with LPS $(500 \mathrm{ng} / \mathrm{mL})$ were either not infected (NI) or infected for $2 \mathrm{hr}$ with JR32 flaA (MOI 20).

(legend continued on next page) 
A

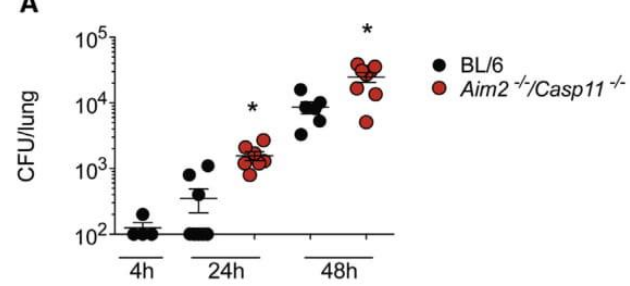

B

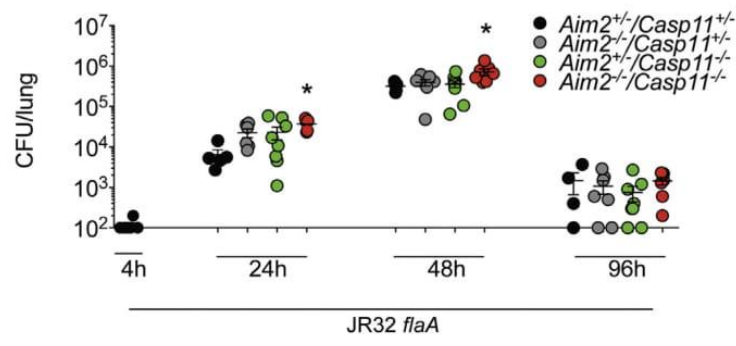

Figure 6. Caspase-11 and AIM2 Inflammasomes Contribute to Restriction of $L$. pneumophila Infection in Mouse Lungs

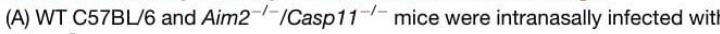
$1 \times 10^{3} \mathrm{flaA}$. Mice were euthanized at the indicated time points postinfection, and dilutions of lung homogenates were added to charcoal yeast extract aga plates for CFU determination. Data shown are representative of two independent experiments.

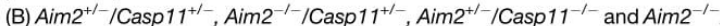
Casp $11^{-1-}$ mice were infected as in (A). Each symbol represents a single animal, and the horizontal lines represent mean of all animals. Error bars depict \pm SEM ${ }^{*} \mathrm{p}<0.05$. Data shown are representative of two independent experiments.

process that does not first require inflammasomes to damage host cells. This hypothesis is consistent with the fact that crystals and pore-forming molecules are bona fide activators of NLRP3. Of note, the crystal- and toxin-mediated canonical activation of the NLRP3 inflammasome requires host cell priming to regulate the transcription of NIrp3 and the pro-forms of inflammatory cytokines (e.g., //1b and //18), in addition to the posttranscriptional mechanisms of NLRP3 degradation (Bauernfeind et al., 2009; Ghonime et al., 2014; Juliana et al., 2012; Mariathasan et al., 2004; Perregaux et al., 2000). Therefore, host cell priming in combination with a membrane-disrupting agent may mimic host cell infection by virulent pathogens by damaging membranes. In contrast, bona fide intracellular pathogens are usually nonlytic to host cells and may even protect cells from damage (Ashida et al., 2011; Cunha and Zamboni, 2013; Galluzzi et al., 2008; Rodrigues et al., 2012). In this case, innate immune cells may employ additional cellular components to induce cell damage and $\mathrm{K}^{+}$efflux, which is essential to activate NLRP3. As shown in this study, additional inflammasome types are activated by intracellular pathogen-associated molecular patterns and can trigger pore formation, thereby facilitating the engagement of the NLRP3 inflammasome. We have shown previously and here that flagellin/NLRC4, LPS/caspase-11, and DNA AIM2 can induce cell damage, which enables $\mathrm{K}^{+}$efflux and activates NLRP3 and caspase-1 proteolysis (Baker et al., 2015; Rühl and Broz, 2015; Schmid-Burgk et al., 2015). We found that caspase-11, NLRC4, AIM2, or a combination thereof is necessary and sufficient to trigger NLRP3 inflammasome in response to L. pneumophila infection. Therefore, several inflammasome types provide innate immune cells with multiple platforms from which to detect distinct cytosolic pathogens and trigger the canonical activation of NLRP3, a process that culminates in caspase-1 cleavage and inflammatory cytokine induction.

Cell membrane permeabilization and consequent pyroptosis is required for inflammasome-mediated restriction of infection by intracellular pathogens (Miao et al., 2010). Although recognition of flagellin by NAIP/NLRC4 is the main pathway triggering pyroptosis and control of $L$. pneumophila replication, NLRP3 is dispensable for restricting bacterial replication in vivo (Case et al., 2009). Our data reveal a role for AIM2 and caspase-11 in control of infection by $L$. pneumophila in vivo, suggesting that the induction of pyroptosis by these inflammasomes ensures bacterial restriction independently of their role in the downstream activation of NLRP3 (Figure 7).

Our results suggest that AIM2 operates via a different multiprotein platform than does NLRP3. We did not detect colocalization of NLRP3 and AIM2 in infected cells, indicating that two distinct inflammasome types are assembled in response to infection. These data are consistent with the fact that NLRP3 is dispensable for either the assembly of AIM2 inflammasome or AIM2-induced pore formation. Recent reports have shown the colocalization of proteins from different inflammasome types (Karki et al., 2015; Man et al., 2014). Therefore, the lytic activities of pathogens may simultaneously activate the two types of inflammasomes, leading to the colocalization of AIM2 and NLRP3. In contrast, L. pneumophila did not activate NLRP3 in the absence of caspase-11, AIM2, or NLRC4, which suggests that at least one of these inflammasome types is required to activate NLRP3. This temporal delay in inflammasome activation may not favor the recruitment of AIM2 and NLRP3 in the same protein complex. Therefore, our data support a model in which AIM2 and NLRP3 are assembled in two distinct inflammasome types.

An important aspect of caspase- 1 activation that we have demonstrated here and others have shown is that caspase-1 can function in an active but uncleaved form (Broz et al., 2010; Guey et al., 2014; Van Opdenbosch et al., 2014). Active,

(B-J) Fluorometric quantification of PI uptake over time, expressed in RFUs. Casp 1/11 ${ }^{-1-}$ immortalized bone-marrow-derived macrophages (iBMDMs) transduced with vector (B), Casp1 WT (C), or Casp1 6DN (D) and pretreated with LPS (500 ng/mL) for $3 \mathrm{hr}$ were not infected (NI) or were infected with JR32 WT, JR32 flaA, or JR32 dotA (MOI 20). Casp1/11 ${ }^{-1-}$ BMDMs transduced with the different caspase-1 constructs were pretreated with LPS (500 ng/mL) and either NI (E) or were infected at MOI 20 with JR32 flaA (F), or JR32 WT (G). Aim2 ${ }^{-1-} /$ Casp $1 / 11^{-1-}$ BMDMs transduced with the different caspase-1 constructs were pretreated with LPS $(500 \mathrm{ng} / \mathrm{mL})$ and either $\mathrm{NI}(\mathrm{H})$ or were infected at MOI 20 with JR32 flaA (I) or JR32 WT (J). Data shown are representative of three independent experiments.

See also Figure S5. 


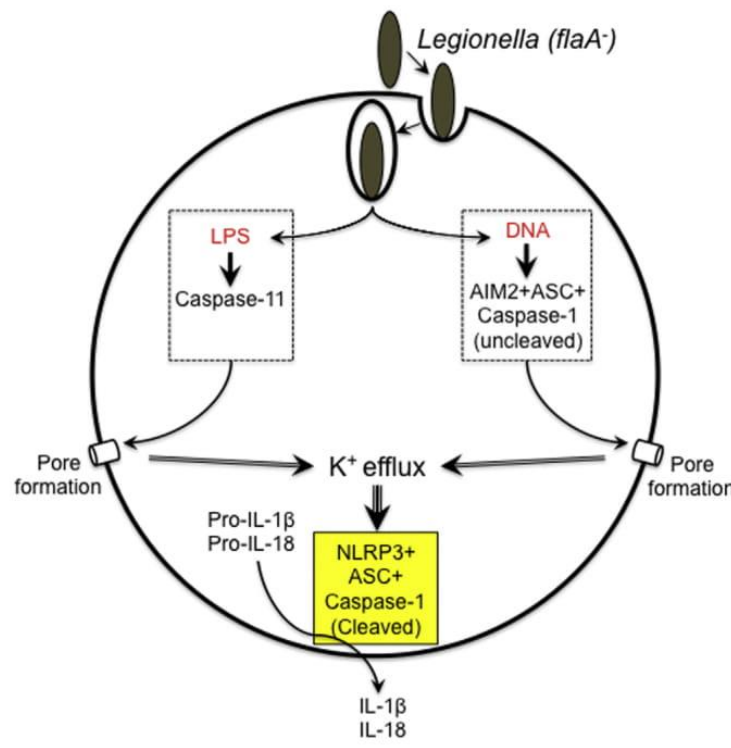

Figure 7. AIM2 Engages Active but Uncleaved Caspase-1 to Trigger the Noncanonical Activation of NLRP3 Inflammasome Schematic of noncanonical activation of the NLRP3 inflammasome, which occurs via membrane damage caused by upstream inflammasomes, including the AIM2 and caspase-11. Activation of AIM2 inflammasome during infection leads to pore formation via a process that requires the activation, but no cleavage of caspase-1. Pore formation and pyroptosis lead to infection control. The membrane damage that is induced by the AIM2 inflammasome further triggers $\mathrm{K}^{+}$-efflux-mediated activation of NLRP3 inflammasome, a process that culminates in caspase-1 proteolysis and the secretion of the inflammatory cytokines IL-1 $\beta$ and IL-18.

uncleaved caspase- 1 is recruited by NLRC4 and AIM2 to trigger pore formation and pyroptosis. These inflammasomes function in cells that express a catalytically null form of caspase-1. In contrast, once recruited by the NLRP3 inflammasome, cas pase- 1 undergoes proteolytic cleavage and may become less available to AIM2. In addition to producing inflammatory cytokines, NLRP3 may negatively regulate the activation of AIM2, which is important for the induction of pyroptosis. Therefore, NLRP3 may represent a key regulator of the balance between the induction of inflammatory cell death and that of inflammatory cytokines.

\section{EXPERIMENTAL PROCEDURES}

Further details and an outline of resources used in this work can be found in Supplemental Experimental Procedures.

\section{Experimental Model Details} Institutional Permission

All mice were bred and maintained under specific-pathogen-free conditions in the Animal Facilities of the Medical School Ribeirão Preto (FMRP-USP). The care of the mice was in compliance with institutional guidelines on ethics in animal experiments approved by CETEA (Comissão de Ética em Experimentação Animal da Faculdade de Medicina de Ribeirão Preto; protocol number 130/2014

\section{Mice}

We used male and female 8- to 12-week-old C57BL/6 mice, including WT (Jackson Laboratory, stock number 000664), Casp11-1- (Kayagaki et al., 2011), Casp1/11 ${ }^{-1-}$ (Kuida et al., 1995), Casp1/11 ${ }^{-1-} /$ Casp11 ${ }^{\text {Tg }}$ (Kayagaki et al., 2011) (herein called Casp $1^{-1-}$ ), Aim2 $2^{-1-}$ (Jones et al., 2010), Aim2 $2^{-1-}$ Casp11 ${ }^{-1-}$ (Rathinam et al., 2010), Asc ${ }^{-1-}$ (Sutterwala et al., 2006), Nirc4 ${ }^{-1}$ (Lara-Tejero et al., 2006), and Nirp3 ${ }^{-1-}$ (Mariathasan et al., 2006) mice in these experiments. Asc ${ }^{-1-} /$ Casp $1 / 11^{-1-}$, Aim2 ${ }^{-1-} /$ Casp $1 / 11^{-1-}, \mathrm{NIrp3} 3^{-1-}$ Casp $11^{-1-}$, and Aim2 $2^{-1-} / \mathrm{NIrp}^{-1-}$ mice were generated in-house by intercrosses. To ensure a similar genetic background between experimental mice, we crossed Aim2 $2^{-1-} /$ Casp $11^{-1-}$ mice with C57BL/6 mice and with Aim2 $2^{-1-}$ and $\mathrm{Casp}_{111^{-1-}}$ mice to obtain $\mathrm{Aim2}^{+/-} / \mathrm{Casp}_{11^{+/-}}$, Aim2 ${ }^{-1-}$ Casp $11^{+/-}$, and Aim2 $2^{+/-} /$Casp $11^{-/-}$mice, respectively.

Bone-Marrow-Derived Macrophages

BMDMs were obtained as previously described (Marim et al., 2010). Briefly, mice were euthanized and bone marrow cells were harvested from the femurs and differentiated in RPMI 1640 (Sigma) containing 20\% fetal bovine serum (FBS), 30\% L-929 cell-conditioned media (LCCM), 1\% L-glutamin (200 mM), and 1\% penicillin-streptomycin (100 U/mL; Sigma). BMDMs were harvested and seeded on tissue culture plates 1 day before infection and maintained in RPMI 1640 media containing 10\% FBS and 5\% LCCM. All cells used in this study were cultivated at $37^{\circ} \mathrm{C}$ with $5 \% \mathrm{CO}_{2}$ In Vivo Infections

For $L$. pneumophila infections, mice were anesthetized with ketamine and xylazine $(50 \mathrm{mg} / \mathrm{kg}$ and $10 \mathrm{mg} / \mathrm{kg}$, respectively) by intraperitoneal injection, followed by intranasal inoculation with $40 \mu \mathrm{L}$ PBS containing $10^{3} \mathrm{JR} 32 \mathrm{flaA}$ per mouse. To determine the number of colony-forming units, mice were euthanized, the lungs harvested and homogenized in sterile water. Lung homogenates were then diluted in sterile water and plated on CYE agar plates for colony-forming unit (CFU) determination.

Quantification and Statistical Analysis

Data were plotted and analyzed with GraphPad Prism 7.0 software. Statistical significance was determined using a two-tailed, unpaired $t$ test. An $F$ test was performed to evaluate significant difference in variance between the compared groups. The number of replicate wells and the number of experiments performed are described in the figure legends. Differences were considered statistically significant when the $p$ value was less than 0.05 .

\section{SUPPLEMENTAL INFORMATION}

Supplemental Information includes Supplemental Experimental Procedures and five figures and can be found with this article online at http://dx.doi.org/ 10.1016/j.celrep.2017.06.086

\section{AUTHOR CONTRIBUTIONS}

L.D.C. and D.S.Z. designed the experiments. L.D.C., A.L.N.S., and J.M.R. performed the experiments and analyzed the data. D.P.A.M., G.F.S.Q., and L.L.S. performed and analyzed specific experiments. R.A.F. provided reagents and discussed hypotheses. L.D.C. and D.S.Z wrote the manuscript, and all authors reviewed and approved the final text.

\section{ACKNOWLEDGMENTS}

We thank Maira Nakamura and Victoria Santos for technical assistance. We are grateful to Kate Fitzgerald (University of Massachusetts Medical School) and Vishva Dixit (Genentech) for providing mice and the antibody to caspase-1 p20 (Genentech) used in this study. We thank Denise Monack (Stanford University) for the vectors encoding Casp1 WT, Casp1 C285A, and Casp1 $6 \mathrm{DN}$. This work was supported by the PEW Program in Biomedical Sciences and by grants from the Fundação de Amparo à Pesquisa do Estado de São Paulo (FAPESP; grants 2013/08216-2 and 2014/04684-4), the Conselho Nacional de Desenvolvimento Científico e Tecnológico Ciência (CNPq; grants 401577/2014-7 and 445881/2014-3), the Instituto Nacional de Ciência e Tecnologia de Vacinas (INCTV/CNPq), and the Núcleo de Apoio à Pesquisa 
research fellow of the Conselho Nacional de Desenvolvimento Científico e Tecnológico (CNPq), Brazil.

Received: December 29, 2016

Revised: May 10, 2017

Accepted: June 28, 2017

Published: July 25, 2017

\section{REFERENCES}

Aachoui, Y., Leaf, I.A., Hagar, J.A., Fontana, M.F., Campos, C.G., Zak, D.E., Tan, M.H., Cotter, P.A., Vance, R.E., Aderem, A., and Miao, E.A. (2013). Caspase-11 protects against bacteria that escape the vacuole. Science 339 975-978.

Akhter, A., Caution, K., Abu Khweek, A., Tazi, M., Abdulrahman, B.A., Abdelaziz, D.H., Voss, O.H., Doseff, A.I., Hassan, H., Azad, A.K., et al. (2012). Caspase-11 promotes the fusion of phagosomes harboring pathogenic bacteria with lysosomes by modulating actin polymerization. Immunity 37, 35-47.

Amer, A., Franchi, L., Kanneganti, T.D., Body-Malapel, M., Ozören, N., Brady, G., Meshinchi, S., Jagirdar, R., Gewirtz, A., Akira, S., and Núñez, G. (2006). Regulation of Legionella phagosome maturation and infection through flagellin and host Ipaf. J. Biol. Chem. 281, 35217-35223.

Ashida, H., Mimuro, H., Ogawa, M., Kobayashi, T., Sanada, T., Kim, M., and Sasakawa, C. (2011). Cell death and infection: a double-edged sword for host and pathogen survival. J. Cell Biol. 195, 931-942.

Baker, P.J., Boucher, D., Bierschenk, D., Tebartz, C., Whitney, P.G., D'Silva, D.B., Tanzer, M.C., Monteleone, M., Robertson, A.A., Cooper, M.A., et al. (2015). NLRP3 inflammasome activation downstream of cytoplasmic LPS recognition by both caspase-4 and caspase-5. Eur. J. Immunol. 45, 29182926.

Bauernfeind, F.G., Horvath, G., Stutz, A., Alnemri, E.S., MacDonald, K., Speert, D., Fernandes-Alnemri, T., Wu, J., Monks, B.G., Fitzgerald, K.A., et al. (2009). Cutting edge: NF-kappaB activating pattern recognition and cytokine receptors license NLRP3 inflammasome activation by regulating NLRP3 expression. J. Immunol. 183, 787-791.

Broz, P., von Moltke, J., Jones, J.W., Vance, R.E., and Monack, D.M. (2010). Differential requirement for Caspase-1 autoproteolysis in pathogen-induced cell death and cytokine processing. Cell Host Microbe 8, 471-483.

Bürckstümmer, T., Baumann, C., Blüml, S., Dixit, E., Dürnberger, G., Jahn, H., Planyavsky, M., Bilban, M., Colinge, J., Bennett, K.L., and Superti-Furga, G. (2009). An orthogonal proteomic-genomic screen identifies AIM2 as a cytoplasmic DNA sensor for the inflammasome. Nat. Immunol. 10, 266-272.

Case, C.L., Shin, S., and Roy, C.R. (2009). Asc and Ipaf Inflammasomes direc distinct pathways for caspase-1 activation in response to Legionella pneumophila. Infect. Immun. 77, 1981-1991.

Case, C.L., Kohler, L.J., Lima, J.B., Strowig, T., de Zoete, M.R., Flavell, R.A., Zamboni, D.S., and Roy, C.R. (2013). Caspase-11 stimulates rapid flagellin-independent pyroptosis in response to Legionella pneumophila. Proc. Natl. Acad. Sci. USA 110, 1851-1856.

Casson, C.N., Copenhaver, A.M., Zwack, E.E., Nguyen, H.T., Strowig, T., Javdan, B., Bradley, W.P., Fung, T.C., Flavell, R.A., Brodsky, I.E., and Shin, S. (2013). Caspase-11 activation in response to bacterial secretion systems that access the host cytosol. PLoS Pathog. 9, e1003400.

Creasey, E.A., and Isberg, R.R. (2012). The protein SdhA maintains the integrity of the Legionella-containing vacuole. Proc. Natl. Acad. Sci. USA 109, 3481-3486.

Cunha, L.D., and Zamboni, D.S. (2013). Subversion of inflammasome activation and pyroptosis by pathogenic bacteria. Front. Cell. Infect. Microbiol. 3, 76. Cunha, L.D., and Zamboni, D.S. (2014). Recognition of Legionella pneumophila nucleic acids by innate immune receptors. Microbes Infect. 16, 985-990. Fernandes-Alnemri, T., Yu, J.W., Datta, P., Wu, J., and Alnemri, E.S. (2009). AIM2 activates the inflammasome and cell death in response to cytoplasmic DNA. Nature 458, 509-513.
Fontana, M.F., and Vance, R.E. (2011). Two signal models in innate immunity. Immunol. Rev. 243, 26-39.

Galluzzi, L., Brenner, C., Morselli, E., Touat, Z., and Kroemer, G. (2008). Viral control of mitochondrial apoptosis. PLoS Pathog. 4, e1000018.

Ge, J., Gong, Y.N., Xu, Y., and Shao, F. (2012). Preventing bacterial DNA release and absent in melanoma 2 inflammasome activation by a Legionella effector functioning in membrane trafficking. Proc. Natl. Acad. Sci. USA 109, 6193-6198.

Ghonime, M.G., Shamaa, O.R., Das, S., Eldomany, R.A., Fernandes-Alnemri, T., Alnemri, E.S., Gavrilin, M.A., and Wewers, M.D. (2014). Inflammasome priming by lipopolysaccharide is dependent upon ERK signaling and proteasome function. J. Immunol. 192, 3881-3888.

Guey, B., Bodnar, M., Manié, S.N., Tardivel, A., and Petrilli, V. (2014). Caspase-1 autoproteolysis is differentially required for NLRP1b and NLRP3 inflammasome function. Proc. Natl. Acad. Sci. USA 111, 17254-17259.

Hornung, V., Ablasser, A., Charrel-Dennis, M., Bauernfeind, F., Horvath, G., Caffrey, D.R., Latz, E., and Fitzgerald, K.A. (2009). AIM2 recognizes cytosolic dsDNA and forms a caspase-1-activating inflammasome with ASC. Nature $458,514-518$

Jones, J.W., Kayagaki, N., Broz, P., Henry, T., Newton, K., O'Rourke, K., Chan, S., Dong, J., Qu, Y., Roose-Girma, M., et al. (2010). Absent in melanoma 2 is required for innate immune recognition of Francisella tularensis. Proc. Natl. Acad. Sci. USA 107, 9771-9776.

Juliana, C., Fernandes-Alnemri, T., Kang, S., Farias, A., Qin, F., and Alnemri, E.S. (2012). Non-transcriptional priming and deubiquitination regulate NLRP3 inflammasome activation. J. Biol. Chem. 287, 36617-36622.

Karki, R., Man, S.M., Malireddi, R.K., Gurung, P., Vogel, P., Lamkanfi, M., and Kanneganti, T.D. (2015). Concerted activation of the AIM2 and NLRP3 inflammasomes orchestrates host protection against Aspergillus infection. Cell Host Microbe 17, 357-368.

Kayagaki, N., Warming, S., Lamkanfi, M., Vande Walle, L., Louie, S., Dong, J., Newton, K., Qu, Y., Liu, J., Heldens, S., et al. (2011). Non-canonical inflammasome activation targets caspase-11. Nature 479, 117-121.

Kuida, K., Lippke, J.A., Ku, G., Harding, M.W. Livingston, D.J., Su, M.S., and Flavell, R.A. (1995). Altered cytokine export and apoptosis in mice deficient in interleukin-1 beta converting enzyme. Science 267, 2000-2003.

Lara-Tejero, M., Sutterwala, F.S., Ogura, Y., Grant, E.P., Bertin, J., Coyle, A.J. Flavell, R.A., and Galán, J.E. (2006). Role of the caspase-1 inflammasome in Salmonella typhimurium pathogenesis. J. Exp. Med. 203, 1407-1412.

Man, S.M., Hopkins, L.J., Nugent, E., Cox, S., Glück, I.M., Tourlomousis, P., Wright, J.A., Cicuta, P., Monie, T.P., and Bryant, C.E. (2014). Inflammasome activation causes dual recruitment of NLRC4 and NLRP3 to the same macromolecular complex. Proc. Natl. Acad. Sci. USA 111, 7403-7408.

Mariathasan, S., Newton, K., Monack, D.M., Vucic, D., French, D.M., Lee W.P., Roose-Girma, M., Erickson, S., and Dixit, V.M. (2004). Differential activation of the inflammasome by caspase-1 adaptors ASC and Ipaf. Nature 430 , 213-218.

Mariathasan, S., Weiss, D.S., Newton, K., McBride, J., O'Rourke, K., RooseGirma, M., Lee, W.P., Weinrauch, Y., Monack, D.M., and Dixit, V.M. (2006). Cryopyrin activates the inflammasome in response to toxins and ATP. Nature 440, 228-232.

Marim, F.M., Silveira, T.N., Lima, D.S., Jr., and Zamboni, D.S. (2010). A method for generation of bone marrow-derived macrophages from cryopreserved mouse bone marrow cells. PLoS ONE 5, e15263.

Massis, L.M., and Zamboni, D.S. (2011). Innate immunity to legionella pneumophila. Front. Microbiol. 2, 109.

Miao, E.A., Leaf, I.A., Treuting, P.M., Mao, D.P., Dors, M., Sarkar, A., Warren, S.E., Wewers, M.D., and Aderem, A. (2010). Caspase-1-induced pyroptosis is an innate immune effector mechanism against intracellular bacteria. Nat. Immunol. 11, 1136-1142.

Molofsky, A.B., Byrne, B.G., Whitfield, N.N., Madigan, C.A., Fuse, E.T., Tateda, K., and Swanson, M.S. (2006). Cytosolic recognition of flagellin by mouse 
macrophages restricts Legionella pneumophila infection. J. Exp. Med. 203 1093-1104.

Muñoz-Planillo, R., Kuffa, P., Martínez-Colón, G., Smith, B.L., Rajendiran, T.M., and Núnez, G. (2013). $\mathrm{K}^{+}$efflux is the common trigger of NLRP3 inflammasome activation by bacterial toxins and particulate matter. Immunity 38 $1142-1153$

Pereira, M.S., Morgantetti, G.F., Massis, L.M., Horta, C.V., Hori, J.I., and Zamboni, D.S. (2011). Activation of NLRC4 by flagellated bacteria triggers caspase-1-dependent and -independent responses to restrict Legionella pneumophila replication in macrophages and in vivo. J. Immunol. 187, $6447-6455$

Perregaux, D., and Gabel, C.A. (1994). Interleukin-1 beta maturation and release in response to ATP and nigericin. Evidence that potassium depletion mediated by these agents is a necessary and common feature of their activity. J. Biol. Chem. 269, 15195-15203.

Perregaux, D.G., McNiff, P., Laliberte, R., Conklyn, M., and Gabel, C.A. (2000). ATP acts as an agonist to promote stimulus-induced secretion of IL-1 beta and IL-18 in human blood. J. Immunol. 165, 4615-4623.

Pétrilli, V., Papin, S., Dostert, C., Mayor, A., Martinon, F., and Tschopp, J. (2007). Activation of the NALP3 inflammasome is triggered by low intracellula potassium concentration. Cell Death Differ. 14, 1583-1589.

Pilla, D.M., Hagar, J.A., Haldar, A.K., Mason, A.K., Degrandi, D., Pfeffer, K, Ernst, R.K., Yamamoto, M., Miao, E.A., and Coers, J. (2014). Guanylate binding proteins promote caspase-11-dependent pyroptosis in response to cytoplasmic LPS. Proc. Natl. Acad. Sci. USA 111, 6046-6051.

Rathinam, V.A., Jiang, Z., Waggoner, S.N., Sharma, S., Cole, L.E., Waggoner L., Vanaja, S.K., Monks, B.G., Ganesan, S., Latz, E., et al. (2010). The AIM2 inflammasome is essential for host defense against cytosolic bacteria and DNA viruses. Nat. Immunol. 11, 395-402.

Rathinam, V.A., Vanaja, S.K., Waggoner, L., Sokolovska, A., Becker, C., Stuart, L.M., Leong, J.M., and Fitzgerald, K.A. (2012). TRIF licenses caspase-11-dependent NLRP3 inflammasome activation by gram-negative bacteria. Cell 150, 606-619.

Ren, T., Zamboni, D.S., Roy, C.R., Dietrich, W.F., and Vance, R.E. (2006). Flagellin-deficient Legionella mutants evade caspase-1- and Naip5-mediated macrophage immunity. PLoS Pathog. 2, e18.

Roberts, T.L., Idris, A., Dunn, J.A., Kelly, G.M., Burnton, C.M., Hodgson, S. Hardy, L.L., Garceau, V., Sweet, M.J., Ross, I.L., et al. (2009). HIN-200 protein regulate caspase activation in response to foreign cytoplasmic DNA. Science $323,1057-1060$.
Rodrigues, V., Cordeiro-da-Silva, A., Laforge, M., Ouaissi, A., Silvestre, R., and Estaquier, J. (2012). Modulation of mammalian apoptotic pathways by intracellular protozoan parasites. Cell. Microbiol. 14, 325-333.

Rühl, S., and Broz, P. (2015). Caspase-11 activates a canonical NLRP3 inflammasome by promoting K(+) efflux. Eur. J. Immunol. 45, 2927-2936.

Schmid-Burgk, J.L., Gaidt, M.M., Schmidt, T., Ebert, T.S., Bartok, E., and Hornung, V. (2015). Caspase-4 mediates non-canonical activation of the NLRP3 inflammasome in human myeloid cells. Eur. J. Immunol. 45, 2911-2917.

Shin, S. (2012). Innate Immunity to Intracellular Pathogens: Lessons Learned from Legionella pneumophila. Adv. Appl. Microbiol. 79, 43-71.

Silva, G.K., Costa, R.S., Silveira, T.N., Caetano, B.C., Horta, C.V., Gutierrez, F. Guedes, P.M., Andrade, W.A., De Niz, M., Gazzinelli, R.T., et al. (2013). Apoptosis-associated speck-like protein containing a caspase recruitment domain inflammasomes mediate IL-1 $\beta$ response and host resistance to Trypanosoma cruzi infection. J. Immunol. 191, 3373-3383.

Silveira, T.N., and Zamboni, D.S. (2010). Pore formation triggered by Legionella spp, is an Nirc4 inflammasome-dependent host cell response that precedes pyroptosis. Infect. Immun. 78, 1403-1413.

Sutterwala, F.S., Ogura, Y., Szczepanik, M., Lara-Tejero, M., Lichtenberger, G.S., Grant, E.P., Bertin, J., Coyle, A.J., Galán, J.E., Askenase, P.W., and Flavell, R.A. (2006). Critical role for NALP3/CIAS1/Cryopyrin in innate and adaptive immunity through its regulation of caspase-1. Immunity 24, 317-327.

Van Opdenbosch, N., Gurung, P., Vande Walle, L., Fossoul, A., Kanneganti, T.D., and Lamkanfi, M. (2014). Activation of the NLRP1b inflammasome independently of ASC-mediated caspase-1 autoproteolysis and speck formation. Nat. Commun. 5, 3209.

Vance, R.E. (2010). Immunology taught by bacteria. J. Clin. Immunol. 30 , 507-511.

Wellington, M., Koselny, K., Sutterwala, F.S., and Krysan, D.J. (2014). Candida albicans triggers NLRP3-mediated pyroptosis in macrophages. Eukaryot. Cel $13,329-340$

Wen, H., Ting, J.P., and O'Neill, L.A. (2012). A role for the NLRP3 inflammasome in metabolic diseases-did Warburg miss inflammation? Nat. Immunol. $13,352-357$

Zamboni, D.S., and Lima-Junior, D.S. (2015). Inflammasomes in host response to protozoan parasites. Immunol. Rev. 265, 156-171.

Zamboni, D.S., Kobayashi, K.S., Kohlsdorf, T., Ogura, Y., Long, E.M., Vance, R.E., Kuida, K., Mariathasan, S., Dixit, V.M., Flavell, R.A., et al. (2006). The Birc1e cytosolic pattern-recognition receptor contributes to the detection and control of Legionella pneumophila infection. Nat. Immunol. 7, 318-325. 
10.2 - Anexo 6 - Artigo publicado (LOPES, Alexandre H; TALBOT, Jhimmy; SILVA, Rangel L; LIMA, Jonilson B; FRANÇA, Rafael O; VERRI JR, Waldiceu A; MASCARENHAS, Danielle PA; RYFFEL, Bernhard; CUNHA, Fernando Q; ZAMBONI, Dario S; CUNHA, Thiago M. Pain, 2015)

"Peripheral NLRC4 inflammasome participates in the genesis of acute inflammatory pain"

- Publicado em: março de 2015 


\title{
Peripheral NLCR4 inflammasome participates in the genesis of acute inflammatory pain
}

Alexandre H. Lopes ${ }^{\mathrm{a}}$, Jhimmy Talbott ${ }^{\mathrm{a}}$, Rangel L. Silva ${ }^{\mathrm{a}}$, Jonilson B. Lima ${ }^{\mathrm{a}}$, Rafael O. França ${ }^{\mathrm{a}}$, Waldiceu A. Verri Jr ${ }^{\mathrm{b}}$, Danielle P. Mascarenhas ${ }^{c}$, Bernhard Ryffel ${ }^{\mathrm{d}}$, Fernando Q. Cunha ${ }^{\mathrm{a}}$, Dario S. Zambonic, Thiago M. Cunha ${ }^{\mathrm{a}, *}$

\begin{abstract}
Inflammatory hyperalgesia is a complex process that depends on the sensitization of primary nociceptive neurons triggered by proinflammatory mediators, such as interleukin $1 \beta(\mathrm{IL}-1 \beta)$. Recently, the peripheral activation of caspase- 1 (previously known as IL$1 \beta$-converting enzyme) was implicated in the induction of acute inflammatory pain by promoting the processing of IL-1 $\beta$ from its precursor form, pro-IL-1 $\beta$. Caspase-1 activation in several systems requires the assembly of an intracellular molecular platform called an inflammasome. Inflammasomes consist of 1 nucleotide-binding oligomerization domain-like receptor (NLR), the adapter molecule apoptosis-associated speck-like protein containing a C-terminal caspase recruitment domain (ASC), and caspase-1. NLRP3 and NLRC4 inflammasomes are well described. However, the identity of the inflammasome that is involved in the peripheral activation of caspase- 1 that accounts for acute inflammatory hyperalgesia has not been described. The present findings demonstrated that mice deficient in NLRC4 or ASC, but not in NLRP3, present reduced mechanical and thermal acute inflammatory hyperalgesia induced by carrageenan. The reduced hyperalgesia was accompanied by significant impairments in the levels of mature forms of $\mathrm{IL}-1 \beta$ ( $\mathrm{p} 17$ ) and caspase-1 (p20) compared to wild-type mice at the inflammatory site. Therefore, these results identified the inflammasome components NLRC4 and ASC as the molecular platform involved in the peripheral activation of caspase-1 and IL-1 $\beta$ maturation, which are responsible for the induction of acute inflammatory pain. In conclusion, our study provides new therapeutic targets for the control of acute inflammatory pain.
\end{abstract}

Keywords: Inflammatory pain, Inflammasome, IL-1ß, Caspase-1, NLRC4, NLRP3

\section{Introduction}

Inflammatory pain is a common clinical symptom of inflammatory diseases characterized by hyperalgesia due to the sensitization of primary nociceptive neurons (PNN). ${ }^{43}$ It is well established that mediators (eg, prostaglandins and sympathomimetic amines) released into the inflammatory site are responsible for the direct sensitization of PNN. ${ }^{18,32,43}$

The production of prostaglandins and sympathomimetic amines is preceded by the release of several pronociceptive cytokines. ${ }^{10,53}$ Among the pronociceptive cytokines, tumor necrosis factor- $\alpha$ $(\mathrm{TNF}-\alpha)$, keratinocyte-derived chemokine $(\mathrm{KC} / \mathrm{CXCL} 1)^{10}$ and interleukin $1 \beta(\mathrm{IL}-1 \beta)$ seem to be the most relevant in the induction of prostaglandin production. ${ }^{10}$ Furthermore, chemokines are responsible for the stimulation of the sympathomimetic component

Sponsorships or competing interests that may be relevant to content are disclosed at the end of this article.

a Department of Pharmacology, Ribeirao Preto Medical School, University of São Paulo, Ribeirao Preto, São Paulo, Brazil, ${ }^{b}$ Departamento de Ciências Patológicas, Universidade Estadual de Londrina, Centro de Ciências Biológicas, Londrina,

Paraná, Brazil, ' Department of Cell Biology, Ribeirao Preto Medical School, University of São Paulo, Ribeirao Preto, São Paulo, Brazil, ${ }^{d}$ University of Orleans and CNRS UMR7355, Experimental and Molecular Immunology and Neurogenetics, Orleans, France

*Corresponding author. Address: Department of Pharmacology, Ribeirao Preto Medical School, University of São Paulo, Ave Bandeirantes 3900, 14049-900, Ribeirao Preto, São Paulo, Brazil. Tel.: + $55163602-0199$, fax: + 55 163633-0021. E-mail address: thicunha@fmrp.usp.br (T. M. Cunha).

PAIN 156 (2015) 451-459

(C) 2015 International Association for the Study of Pain

http://dx.doi.org/10.1097/01.j.pain.0000460322.72396.53 of inflammatory hyperalgesia. ${ }^{10}$ Notably, peripheral TNF- $\alpha$ and KC/ CXCL1 mediate inflammatory hyperalgesia due to their ability to promote neutrophil recruitment to inflammatory sites whereas IL$1 \beta$ seems to act on neutrophils to induce the production of prostaglandins that ultimately sensitize PNN. ${ }^{11-13}$ Notwithstanding, these cytokines can act directly on receptors expressed by PNN causing their sensitization. $3,27,56$

As mentioned above, $\mathbb{L}-1 \beta$ is an important pronociceptive cytokine that is responsible for the induction of inflammatory hyperalgesia. ${ }^{19}$ Therefore, the control of IL-1 $\beta$ production/release is a promising therapeutic target of great relevance. ${ }^{53} \mathrm{~L}-1 \beta$ is synthesized intracellularly as the inactive cytokine pro-IL-1 $\beta$ (p35; 35 $\mathrm{kDa})$. Pro-IL-1 $\beta$ requires cleaving by cysteine protease to yield the biological active form, IL-1 $1 \beta(p 17 ; 17 \mathrm{kDa}){ }^{7}$ Caspase- 1 is the wellknown cysteine protease involved in the processing of $\mathrm{LL}-1 \beta \mathrm{s}^{7,55}$

Caspase- 1 is synthesized as an inactive zymogen (procaspase-1 p45; $45 \mathrm{kDa}$ ), and it becomes proteolytically active when the controlled oligomerization of several different molecules occur. ${ }^{42}$ This assembly process generates an intracellular molecular platform called an inflammasome, which promotes the auto-cleavage of pro-caspase- 1 to generate active caspase-1 (p20; $20 \mathrm{kDa}){ }^{4,15}$ Inflammasome complexes are composed of intracellular nucleotide-binding oligomerization domain-like receptors (NLRs), the adapter molecule apoptosis-associated speck-like protein containing a C-terminal caspase recruitment domain (ASC), and caspase-1. NLRP3 and NLRC4 inflammasomes are well described. ${ }^{39,41}$ NLRP3 seems to be activated primarily by microbes and cell stress products, and NLRC4 has been described to operate when neuronal apoptosis inhibitory proteins (Naip) sense bacterial-derived products such as flagellin. ${ }^{41,39,38}$ 
Recently, we have shown that caspase- 1 is involved in the peripheral processing of IL-1 $1 \beta$, and it accounts for the genesis of carrageenan-induced acute inflammatory hyperalgesia. ${ }^{14} \mathrm{How}-$ ever, the identity of the inflammasome that is involved in the peripheral activation of caspase- 1 and $\mathrm{IL}-1 \beta$ maturation and accounts for the induction of acute inflammatory hyperalgesia induced by carrageenan has not been investigated.

The hypothesis that caspase-1 participates in the genesis of inflammatory hyperalgesia was based primarily on the use of mice deficient in caspase-1. ${ }^{14}$ Nevertheless, further studies described that these mice are also deficient in caspase- $11 .{ }^{29}$ Based on this evidence, this study investigated the participation of the NLRP3 and NLRC4 inflammasomes in the genesis of acute inflammatory hyperalgesia and focused on their role in the peripheral maturation of $\mathrm{IL}-1 \beta$. The dependence of inflammatory pain on caspase-1 and/or caspase-11 was also investigated.

\section{Materials and methods}

\subsection{Animals}

The experiments were performed using male C57BL/6 mice (wild type, WT, 20-25 g) and mice deficient in the following proteins:

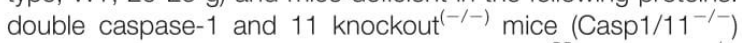
(previously described as caspase-1 null mice), ${ }^{29}$ Casp $1 / 11^{-1-}$ that had caspase-11 transgenically introduced to become caspase-1 single knockout mice (Casp $1^{-1-} / \mathrm{Tg}$ Casp11), ${ }^{29}$ single Caspase- $11^{-1-}$ mice (Casp11 $1^{-1-}$ ), interleukin 1 receptor type 1 $\left(\mathrm{IL}-1 \mathrm{R} 1^{-/-}\right), \mathrm{NLRP3}\left(\mathrm{NLRP3}^{-/-}\right), \mathrm{NLRC} 4\left(\mathrm{NLRC}^{-/-}\right)$, and ASC $\left(\mathrm{ASC}^{-1-}\right)$. Casp $1 / 11^{-1-31}$ and $\mathrm{NLRC}^{-1-33}$ mice were previously described and backcrossed to C57BL/6 mice for 8 generations. $\mathrm{ASC}^{-1-}$ mice were previously described and backcrossed to C57BL/6 mice for 9 generations. ${ }^{33}$ These deficient mice were backcrossed until 10 generations to the C57BL/6 at the animal facilities at the Medical School of Ribeirao Preto. NLRP3 ${ }^{-1-}$ mice were constructed in the C57BL/6 background. ${ }^{40}$ The Casp $1^{-1-} / \mathrm{Tg}$ Casp11 mice were created by the introduction of a Casp11 BAC transgene into Casp1/11 ${ }^{-1}$ embryos. ${ }^{54}$ The mice were housed in the animal care facility of the Ribeirao Preto Medical School and taken to the testing room at least 1 hour before experiments. Food and water were available ad libitum. All behavioral tests were performed between 9:00 AM and 5:00 PM. Animal care and handling procedures were in accordance with the guidelines of the International Association for the Study of Pain (IASP) on the use of animals in pain research. Approval for ethical animal care and use was obtained before this study commenced (Process No. 149/2011).

\subsection{Mechanical nociceptive paw test}

Mechanical hyperalgesia was tested using an electronic version of the von Frey test in mice as reported previously. ${ }^{9}$ Mice were placed in acrylic cages $(12 \times 10 \times 17 \mathrm{~cm})$ with wire grid floors in a quiet room 15 to 30 minutes before the start of testing. The test consisted of evoking a hind paw flexion reflex with a handheld force transducer (electronic esthesiometer; IITC Life Science, Woodland Hills, CA) adapted with a $0.5-\mathrm{mm}^{2}$ polypropylene tip. The investigator (blinded to group allocation) was trained to apply the tip perpendicularly to the central area of the plantar hind paw with a gradual increase in pressure. The gradual increase in pressure was manually performed in blinded experiments. The upper limit pressure was $15 \mathrm{~g}$. The end point was characterized by the removal of the paw followed by clear flinching movements. The intensity of the pressure that elicited paw withdrawal was automatically recorded, and the final value for the response was obtained by averaging 3 measurements. The animals were tested before and after treatments. The results are expressed as the nociceptive withdrawal threshold (in grams, mean of 3 measurements) before and at the indicated times after drug or solvent (control) injections. The nociceptive withdrawal threshold of naive mice was $8.5 \pm 0.2 \mathrm{~g}$ (mean $\pm \mathrm{SEM} ; \mathrm{n}=30$ ) before injection of the solvent or hypernociceptive agents.

\subsection{Thermal nociceptive paw test (Hargreaves test)}

The latency of paw withdrawal to a radiant heat stimulus was measured using a plantar test (model 400; IITC Life Science) as described previously. ${ }^{25}$ Mice can move freely in this apparatus in which plastic boxes are placed on an elevated glass surface. Mice were acclimated for 1 hour before testing until they became calm and motionless. A calibrated infrared light source of high intensity was applied perpendicularly to the plantar surface of the hind paw of each mouse. The end point was characterized by the removal of the paw followed by clear flinching movements. Latency to paw withdrawal was automatically recorded. Each hind paw was tested alternately with an interval of 5 minutes for 4 trials.

\subsection{Reagents}

The following drugs were used in this study: prostaglandin E2 (PGE2) (P5640 from Sigma-Aldrich, St. Louis, MO), nigericin (N7143 from Sigma-Aldrich), IL-1 $\beta$ (NIBSC; South Mimms, Hertfordshire, United Kingdom), and carrageenan (FMC, Philadelphia, PA). A stock solution of PGE2 $(1 \mu \mathrm{g} / \mu \mathrm{L})$ was prepared in $10 \%$ ethanol, and dilutions were made in $0.9 \% \mathrm{NaCl}$ (saline); the final concentration of ethanol was $1 \%$.

\subsection{Cytokine measurements using enzyme-linked immunosorbent assays}

Animals were terminally anesthetized 3 hours after an intraplantar (i.pl.) injection of carrageenan or saline, and the skin tissues of the plantar region were removed from the injected and control paws (saline). The samples were triturated and homogenized in $500 \mu \mathrm{L}$ of the appropriate buffer (phosphate-buffered saline containing 0.05\% Tween 20, $0.1 \mathrm{mM}$ phenylmethylsulphonyl fluoride, 0.1 $\mathrm{mM}$ benzethonium chloride, $10 \mathrm{mM}$ EDTA, and 20 kallikrein international units of aprotinin A) followed by a 10-minute centrifugation at $2000 \mathrm{~g}$. The supernatants were used to determine the levels of IL-1 $\beta$, TNF- $\alpha$, and CXCL1/KC using ELISA Duo-Set R\&D Systems following the manufacturer's instructions (Mouse IL-1 beta/IL-1F2 DY401; Mouse TNF- $\alpha$ DY210; Mouse CXCL1/KC DY453). The results are expressed as picograms (pg) of each cytokine per paw.

\subsection{Determination of tissue myeloperoxidase activity}

Neutrophil migration to the hind paw plantar tissues of mice was evaluated using a myeloperoxidase (MPO) kinetic colorimetric assay as previously described. ${ }^{13,52}$ Samples of subcutaneous plantar tissue were collected in $50 \mathrm{mM} \mathrm{K}_{2} \mathrm{HPO}_{4}$ buffer (pH 6.0) containing $0.5 \%$ hexadecyltrimethylammonium bromide and kept at $-80^{\circ} \mathrm{C}$ until use. Samples were homogenized using a Polytron (PT3100) and centrifuged at 16,100g for 4 minutes. The resulting supernatant was assayed for MPO activity spectrophotometrically at $450 \mathrm{~nm}$ (SpectraMax, Molecular Devices, San Francisco, CA), with 3 readings in 1 minute. The MPO activity of samples was compared with a standard curve of neutrophils. Briefly, $10 \mu \mathrm{L}$ of the sample was mixed with $200 \mu \mathrm{L}$ of $50 \mathrm{mM}$ phosphate buffer, $\mathrm{pH}$ 
6.0, containing $0.167 \mathrm{mg} / \mathrm{mL}$ o-dianisidine dihydrochloride and $0.0005 \%$ hydrogen peroxide. The results are presented as MPO activity (number of neutrophils per milligram of tissue).

\subsection{Western blot analysis}

Mice were terminally anesthetized 5 hours after an i.pl. injection of carrageenan or saline, and skin tissues were removed from the plantar region of paws. The samples were homogenized, and the expression of the immature form of pro-IL-1 $\beta(\sim 35 \mathrm{kD})$, the mature form of IL-1 $\beta(\sim 17 \mathrm{kDa})$, the immature form of pro-caspase-1 ( 45 $\mathrm{kDa})$, and the mature form of caspase-1 ( $20 \mathrm{kDa}$ ) were evaluated using Westem blot analyses. Briefly, samples were homogenized in a lysis buffer containing a mixture of proteinase inhibitors (Tris- $\mathrm{HCl}$ 50 mM, pH 7.4; NP-40 1\%; Na-deoxycholate, 0.25\%; NaCl, 150 mM; EDTA, $1 \mathrm{mM}$; PMSF, $1 \mathrm{mM}$; aprotinin, leupeptin, and pepstatin, $1 \mu \mathrm{g} / \mathrm{mL}$ each). Proteins were separated using SDSpolyacrylamide gel electrophoresis (SDS-PAGE-15\%) and transblotted onto nitrocellulose membranes (Amersham Pharmacia Biotech, Little Chalfont, United Kingdom). The membranes were blocked with $5 \%$ dry milk (overnight) and incubated overnight at $4^{\circ} \mathrm{C}$ with a rabbit polyclonal antibody against caspase-1 (1:300; Sigma-Aldrich, Saint Louis, MO), goat polyclonal antibody against IL-1 $\beta$ (1:200, I3767; Sigma-Aldrich), and anti-ASC, pAb (AL177) (1: 1000; Adipogen, San Diego, CA). The membranes were washed and incubated for 2 hours at room temperature with an HRP-conjugated secondary antibody (1:10,000; Jackson ImmunoResearch, Philadelphia, PA). Immunodetection was performed using an enhanced chemiluminescence light-detecting kit (Amersham Pharmacia Biotech) for 1 minute. A mouse monoclonal antibody against $\beta$-actin (1:10,000; Sigma-Aldrich) was used for loading controls. Western blot runs were performed with protein samples from saline-injected WT mouse paws and carrageenaninjected paws of WT, NLRC4 ${ }^{-1-}, \mathrm{ASC}^{-1-}, \mathrm{NLRP}^{-1-}$, and Casp1/ $11^{-1-}$ mice. Images were used as representative blots. Densitometric data were measured after normalization to the control (house-keeping gene) using Scientific Imaging Systems (Image Lab 3.0 software; Biorad Laboratories, Hercules, CA).

\subsection{Statistical analysis}

Data are reported as the mean \pm SEM and are representative of 2 separate experiments. Two-way analysis of variance followed by Bonferroni $t$ test was used to compare groups when the hyperalgesic responses were measured at different times after the stimulus injection. Alternatively, when the responses (thermal hyperalgesia, neutrophil migration and cytokine production, western blotting) were measured once after the stimulus injection, the differences were evaluated by 1-way analysis of variance followed by Bonferroni $t$ test (for 3 or more groups) comparing al pairs of columns. The $P$ values $<0.05$ were considered significant. Statistical analysis was performed with GraphPad Prism (GraphPad Software, San Diego, CA).

\section{Results}

\subsection{IL-1R1 and caspase-1 mediates mechanical inflammatory hyperalgesia}

It was shown previously that the local or systemic treatment of experimental animals with an IL-1 receptor antagonist (IL-1ra) reduced acute inflammatory hyperalgesia. ${ }^{8,14}$ The current results confirmed the importance of $\mathrm{LL}-1 \beta$ in the genesis of acute inflammatory hyperalgesia because the mechanical hyperalgesia induced by carrageenan was reduced in $\mathrm{IL}-1 \mathrm{R} 1^{-/-}$mice compared with WT mice (Fig. 1A).

As mentioned before, our previous study that described the involvement of caspase- 1 in the induction of acute inflammatory hyperalgesia used Casp $1 / 11^{-1-}$ mice. ${ }^{14}$ Herein, inflammatory hyperalgesia induced by carrageenan was induced in Casp $1^{-1-}$ Tg Casp11 mice in an attempt to elucidate whether caspase-1 is indeed involved in the genesis of inflammatory hyperalgesia or whether this phenotype was because of the lack of caspase-11. Corroborating our previous study, ${ }^{14}$ carrageenan-induced mechanical inflammatory hyperalgesia was reduced in Casp $1 / 11^{-1-}$ mice when compared with WT mice (Fig. 1B). Furthermore, carrageenaninduced mechanical inflammatory hyperalgesia was also reduced in Casp $1^{-1-} / \mathrm{Tg}$ Casp11 mice to the same level compared with Casp $1 / 11^{-1-}$ mice (Fig. 1B). In agreement, it was observed that single Casp $11^{-1-}$ mice developed similar mechanical inflammatory hyperalgesia compared with WT mice (Fig. 1C). Altogether, these results confirm the specific involvement of caspase- 1 in the induction of acute inflammatory hyperalgesia induced by carrageenan.

\subsection{Acute inflammatory hyperalgesia is not dependent on the NLRP3 inflammasome}

Next, we investigated the identity of the inflammasomes that are involved in the peripheral activation of caspase-1, which
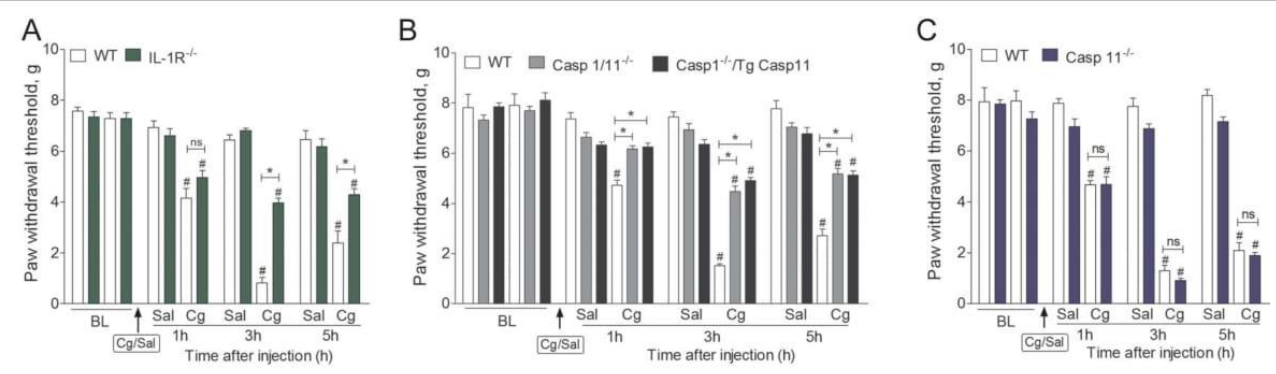

Figure 1. Acute inflammatory hyperalgesia depends on IL 1-R and caspase-1 but not caspase-11. (A) Mechanical nociceptive threshold was measured before (BL) and after $\left(1,3\right.$, and 5 hours) intraplantar injection of carrageenan $\left(\mathrm{Cg}: 100 \mu \mathrm{g} / \mathrm{paw}\right.$ ) or vehicle (Sal-saline) in wild type (WT) or IL-1 $\mathrm{R}^{-1-}$ mice. (B) Mechanical nociceptive threshold was measured before (BL) and after ( 1,3 , and 5 hours) intraplantar injection of $\mathrm{Cg}\left(100 \mu \mathrm{g} / \mathrm{paw}\right.$ ) or vehicle in WT, Casp $1 / 11^{-1-}$ or Casp $1^{-1-}$, $\mathrm{Tg}$ Casp 11 mice. (C) Mechanical nociceptive threshold was measured before (BL) and after (1, 3, and 5 hours) intraplantar injection of Cg (100 $\mu \mathrm{g} / \mathrm{paw})$ or vehicle in WT or Casp $11^{-I-}$ mice. Data are expressed as mean \pm SEM, 5 mice per group. \#Indicates statistical significance $(P<0.05)$ compared with the saline paw injected group. *Indicates statistical significance $(P<0.05)$ compared with the WT group injected with $\mathrm{Cg}$. Two-way analysis of variance followed by the Bonferron test. ns $=$ no significance.

Copyright (c) 2015 by the International Association for the Study of Pain. Unauthorized reproduction of this article is prohibited. 
accounts for the genesis of acute inflammatory hyperalgesia. The NLRP3 inflammasome was tested first. The mechanical nociceptive threshold of $\mathrm{NLRP}^{-1-}$ naive mice did not differ from the threshold of WT naive mice (Fig. 2A). NLRP3 ${ }^{-1-}$ mice also presented mechanical hyperalgesia induced by carrageenan similarly to WT mice (Fig. 2A). The thermal inflammatory hyperalgesia induced by carrageenan was also similar in $\mathrm{NLRP3}^{-1-}$ mice compared with WT mice (Fig. 2B). Neutrophil migration triggered by carrageenan is not altered in $\mathrm{NLRP}^{-1-}$ mice compared with WT mice (Fig. 2C). Furthermore, the expression of active caspase-1 (p20 kDa; Fig. 2D) and mature $\mathrm{L}-1 \beta$ (p17 kDa; Fig. 2E) induced by i.pl. carrageenan was similar in NLRP3 ${ }^{-1-}$ and WT mice. These results indicate that the NLRP3 inflammasome is not involved in the peripheral activation of caspase- 1 and IL-1 $\beta$ maturation, and consequently, it did not participate in the induction of carrageenaninduced inflammatory hyperalgesia.

\subsection{Acute inflammatory hyperalgesia depends on the NLRC4/ASC inflammasome}

The observation that the NLRP3 inflammasome is not involved in the induction of the acute inflammatory hyperalgesia prompted us to consider whether another important inflammasome, NLRC4 and its adapter molecule ASC, might play a role. The mechanical nociceptive threshold of $\mathrm{NLRC}^{-1-}$ naive mice was similar to $\mathrm{WT}$ naive mice (Fig. 3A). However, mechanical inflammatory hyperalgesia induced by carrageenan was reduced in $\mathrm{NLRC}^{-1-}$ mice compared with WT mice (Fig. 3A). The mechanical nociceptive threshold of $\mathrm{ASC}^{-1-}$ naive mice was similar to the WT mice, but carrageenan-induced acute mechanical inflammatory pain was reduced in $\mathrm{ASC}^{-1-}$ mice compared with WT mice (Fig. 3B). Importantly, thermal inflammatory hyperalgesia induced by carrageenan was also reduced in $\mathrm{NLRC}^{-1-}$ and $\mathrm{ASC}^{-1-}$ mice compared with WT mice (Fig. 3C). Interestingly, paw injection of carrageenan upregulated ASC expression in a time-dependent manner (Fig. 3D). Paw tissue samples from $\mathrm{ASC}^{-/-}$mice were used as a negative control.
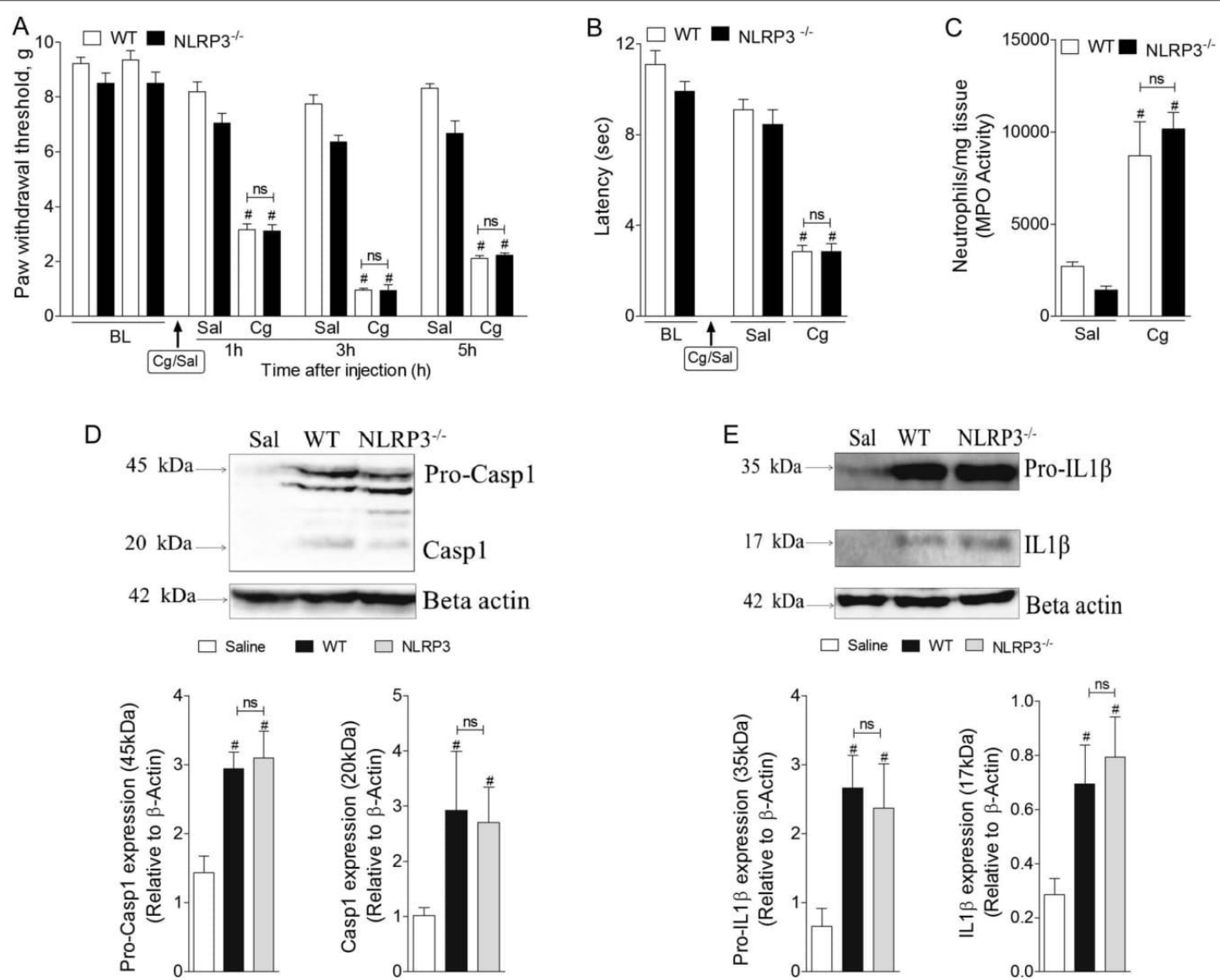

Figure 2. The NLRP3 inflammasome is not involved in the induction of acute inflammatory hyperalgesia. (A) Mechanical nociceptive threshold was measured before (BL) and after (1, 3, and 5 hours) intraplantar injection of carrageenan (Cg: $100 \mu \mathrm{g} / \mathrm{paw}$ ) or vehicle (Sal-saline) in wild-type (WT) or NLRP3 ${ }^{-1-}$ mice. (B) Thermal nociceptive threshold was measured before (BL) and after (3 hours) intraplantar injection of $\mathrm{Cg}$ (100 $\mu \mathrm{g} / \mathrm{paw}$ ) or vehicle (Sal-saline) in WT or NLRP3 ${ }^{-1-}$ mice. (C) MPO activity was determined in the WT or NLRP3 ${ }^{-1-}$ mice plantar tissue 5 hours after $\mathrm{Cg}$ or saline injection. (D and E) WT and NLRP3 ${ }^{-1-}$ mice received an intraplantar injection of carrageenan (100 $\mu \mathrm{g} / \mathrm{paw})$ or saline. At 5 hours after $\mathrm{Cg}$ injection, plantar tissue samples were collected, and the level of mature $(\sim 20$ $\mathrm{kDa})$ and immature forms $(\sim 45 \mathrm{kDa})$ of caspase-1 and mature $(\sim 17 \mathrm{kDa})$ and immature forms $(\sim 35 \mathrm{kDa})$ of IL-1 $1 \beta$ were determined using Western blot analysis. Representative blot and relative quantification. Beta actin levels were used as an internal control. Data are expressed as mean \pm SEM, 5 mice per group. \#Indicates statistical significance $(P<0.05)$ compared with the saline paw injected group. No statistical significance $(n s ; P<0.05)$ was identified between WT and $\mathrm{NLRP}^{-1-}$ mice groups that received $\mathrm{Cg}$. Two-way or 1 -way analysis of variance followed by Bonferroni test.

Copyright (c) 2015 by the International Association for the Study of Pain. Unauthorized reproduction of this article is prohibited. 

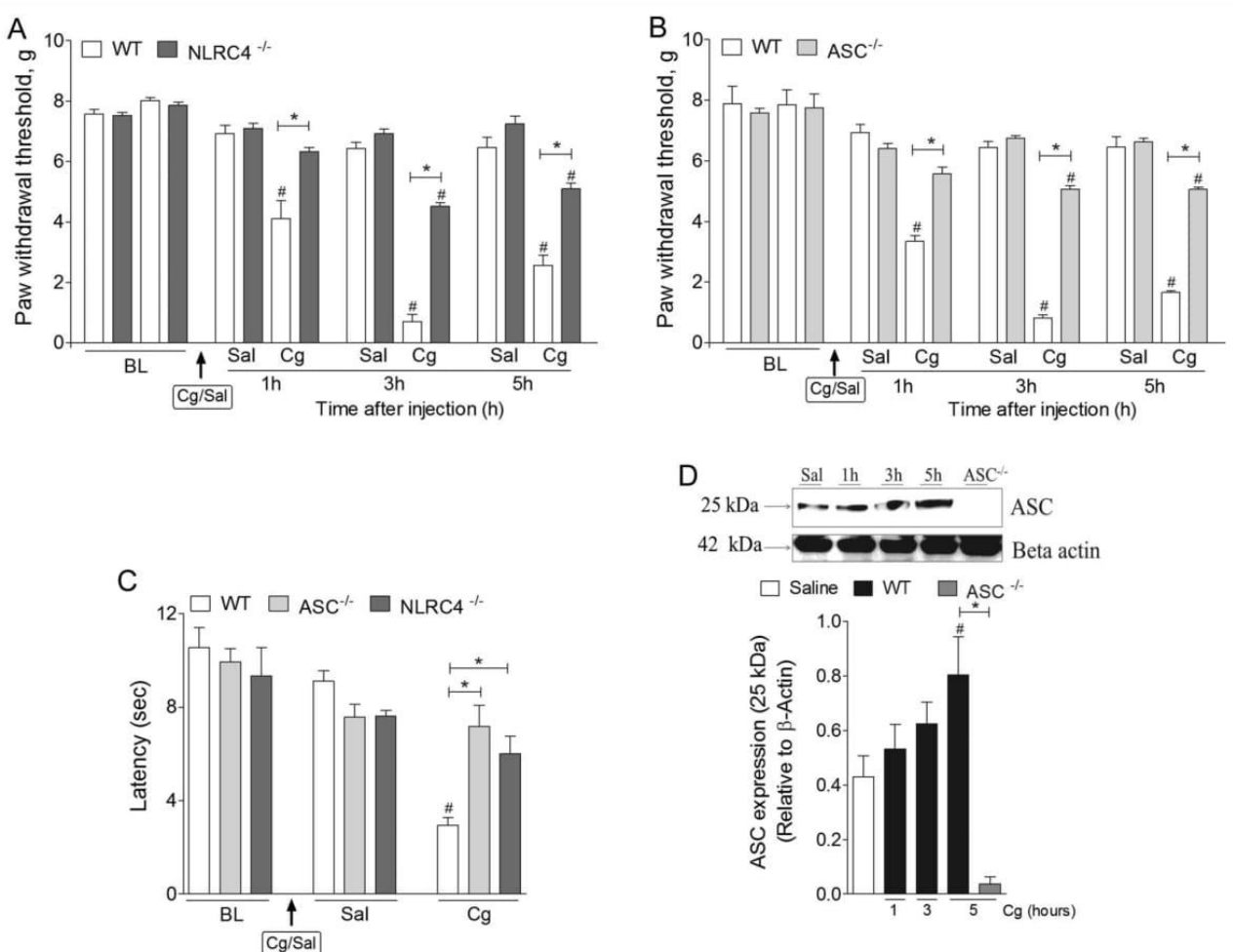

Figure 3. The NLRC4 inflammasome and its adapter molecule ASC participate in acute inflammatory hyperalgesia. (A) Mechanical nociceptive threshold was measured before (BL) and after (1, 3, and 5 hours) intraplantar injection of carrageenan (Cg: $100 \mu \mathrm{g} / \mathrm{paw}$ ) or vehicle (Sal-saline) in wild-type (WT) or NLRC4 mice. (B) Mechanical nociceptive threshold was measured before (BL) and after (1,3, and 5 hours) intraplantar injection of carrageenan (Cg: $100 \mu \mathrm{g} / \mathrm{paw}$ ) or vehicle (Sal-saline) in wild-type (WT) or ASC ${ }^{-1-}$ mice. (C) Thermal nociceptive threshold was measured before (BL) and after ( 3 hours) intraplantar injection of Cg (100 $\mu \mathrm{g} /$ paw) or vehicle (Sal-saline) in WT, NLRC4 ${ }^{-1-}$, or $\mathrm{ASC}^{-1-}$ mice. (D) ASC $(25 \mathrm{kDa})$ expression was determined in the paw samples from WT (1, 3, and 5 hours) and $\mathrm{ASC}^{-1-}$ (5 hour) mice after intraplantar injection of $\mathrm{Cg}(100 \mu \mathrm{g} / \mathrm{paw})$ or saline. Beta-actin levels were used as an internal control. Representative blot and relative quantification. Data are expressed as mean \pm SEM of 5 animals per group. \#lndicates statistical significance $(P<0.05)$ compared with the group injected with saline. *Indicates statistical significance $(P<0.05)$ compared with the WT group injected with $\mathrm{Cg}$. Two-way or 1 -way analysis of variance followed by Bonferroni test.

\subsection{The NLRC4/ASC inflammasome is neither involved in the peripheral production of pronociceptive cytokines (TNF- $\alpha$ and CXCL1/KC) nor neutrophil migration during acute inflammation}

We investigated the role of the NLRC4/ASC inflammasome in the production of pronociceptive cytokines, TNF- $\alpha$, and KC/CXCL1 and in the recruitment of neutrophils to inflammatory sites to delineate the mechanisms by which the NLRC4/ASC inflammasome mediates carrageenan-induced acute inflammatory hyperalgesia. The intraplantar injection of carrageenan increased the levels of TNF- $\alpha, \mathrm{KC} / \mathrm{CXCL} 1$ and the infiltration of neutrophils into WT mice paws; these results were not different in $\mathrm{NLRC}^{-/-}$and $\mathrm{ASC}^{-1-}$ mice (Figs. 4A-C).

\subsection{The NLRC4/ASC/caspase-1 inflammasome mediates the peripheral maturation of IL-1 $\beta$ during acute inflammation}

We tested the hypothesis that the NLRC4/ASC inflammasome mediates acute inflammatory hyperalgesia through its role in caspase- 1 activation and IL-1 $\beta$ processing. Western blotting analyses of paw samples showed that the expression of the active form of caspase- 1 (caspase-1 p20) and mature IL-1 $\beta$ ( $p 17$;

$\sim 17 \mathrm{kDa}$ ) increased in WT mice after carrageenan injection and was reduced in $\mathrm{NLRC}^{-1-}$ and $\mathrm{ASC}^{-/-}$mice (Figs. 5A and $\mathrm{B}$ ). The increase in the production of mature $\mathrm{IL}-1 \beta$ was also reduced in Casp $1 / 11^{-1-}$ mice, which confirms our previous results. ${ }^{14}$ Notably, the increase in the production of pro-IL-1 $\beta$ (p35; 35 $\mathrm{kDa}$ ) triggered by peripheral acute inflammation appeared similar in $\mathrm{NLRC4}^{-1-}, \mathrm{ASC}^{-1-}$, and Casp $1 / 11^{-1-}$ mice compared with WT mice (Fig. 5A). Supernatants of LPS-primed macrophages activated with nigericin ${ }^{44}$ were used as a positive control for the mature form of caspase-1 (Fig. 5B).

The intraplantar injection of $\mathrm{IL}-1 \beta$ and PGE2 produced mechanical hyperalgesia in $\mathrm{ASC}^{-/-}$and $\mathrm{NLRC}^{-/-}$mice, and these mice exhibited similar intensities and durations as WT mice (Figs. 6A and B). These results support the hypothesis that the NLRC4/ASC inflammasome mediates carrageenan-induced acute inflammatory hyperalgesia through a mechanism that is dependent on peripheral caspase- 1 activation and IL-1 $\beta$ maturation.

\section{Discussion}

The production of proinflammatory cytokines at the inflammatory site mediates inflammatory hyperalgesia. ${ }^{53}$ Among the peripheral pronociceptive cytokines, $\mathrm{IL}-1 \beta$ is one of the most important. ${ }^{10,53}$ This study established the molecular mechanisms involved in the

Copyright (c) 2015 by the International Association for the Study of Pain. Unauthorized reproduction of this article is prohibited. 


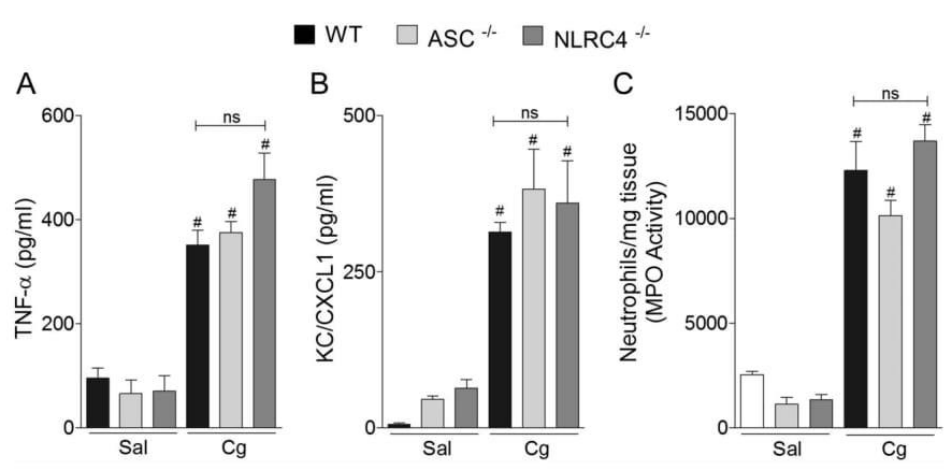

Figure 4. Carrageenan-induced pronociceptive cytokines production and neutrophil infiltration are not mediated by NLRC4/ASC inflammasome. Wild-type (WT), $\mathrm{NLRC}^{-/-}$, or $\mathrm{ASC}^{-1-}$ mice received an intraplantar injection of carrageenan (Cg: $100 \mu \mathrm{g} / \mathrm{paw}$ ) or saline. At 3 hour after Cg injection, plantar tissue samples were collected, and the levels of (A) TNF- $\alpha$ and (B) KC/CXCL1 were determined using enzyme-linked immunospecific assay. (C) MPO activity was determined in mice plantar tissue 3 hours after $\mathrm{Cg}\left(100 \mu \mathrm{g} /\right.$ paw) injection in WT, NLRC4 ${ }^{-1-}$, or $\mathrm{ASC}^{-1-}$. Data are expressed as mean \pm SEM of 5 animals per group. \#Indicates statistical significance $(P<0.05)$ compared with the group injected with saline. No statistical significance $(n s ; P<0.05)$ was identified between WT, ASC ${ }^{-1-}$, or $\mathrm{NLRC}^{-1-}$ mice groups that received $\mathrm{Cg}$. One-way analysis of variance followed by Bonferroni test.

production of the mature form of $\mathrm{IL}-1 \beta$ that accounted for the genesis of acute inflammatory hyperalgesia. For example, the peripheral stimulation of the NLRC4/ASC inflammasome platform, but not the NLRP3 inflammasome, was involved in the cascade of events that finally promoted the production of the active form of $\mathrm{IL}-1 \beta$ and acute inflammatory hyperalgesia. Additionally, the NLRC4/ASC inflammasome assembly triggered specific caspase-1-dependent inflammatory hyperalgesia, but the caspase-11-dependent noncanonical pathway was not involved.

$\mathrm{IL}-1 \beta$ was the first cytokine implicated in the genesis of pain processes. ${ }^{19}$ The peripheral injections of small doses of $\mathrm{LL}-1 \beta$ induce mechanical hyperalgesia in the rat paw through a prostaglandin-dependent mechanism. ${ }^{19}$ In this context, IL-1 $\beta$ became an interesting target in the control of inflammatory diseases, including inflammatory hyperalgesia. In fact, the pharmacologic blockade of $\mathrm{IL}-1 \mathrm{R} 1$ with $\mathrm{IL}-1$ ra reduces inflammatory hyperalgesia. ${ }^{8,10}$ The results of this study confirmed previous studies because IL-1R1 null mice presented reduced inflammatory hyperalgesia compared with their littermates. Notably, IL-1 $\beta$-targeting therapies are clinically effective in different inflammatory conditions associated with severe pain, such as rheumatoid arthritis, gout, and other autoimmune diseases. ${ }^{21}$

The discovery that the production of the biologically active form of $\mathrm{IL}-1 \beta$ from pro- $\mathrm{IL}-1 \beta$ cleavage is dependent on intracellular
A

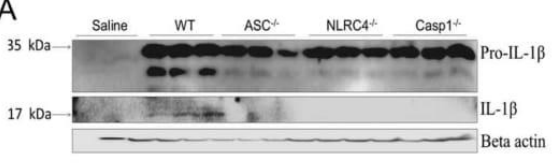

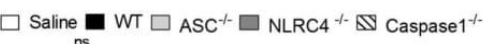

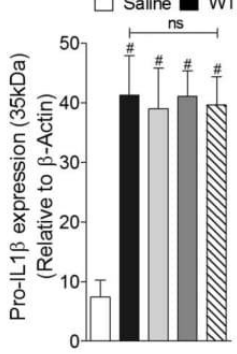

B

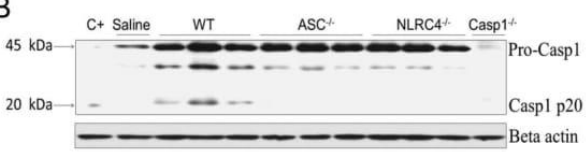

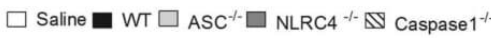
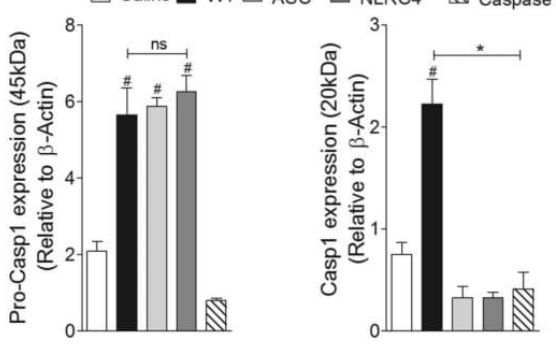

Figure 5. The NLRC4/ASC inflammasome is involved in caspase- 1 activation and peripheral maturation of IL-1 $\beta$ in carrageenan-induced paw inflammation. Wildtype (WT), $\mathrm{ASC}^{-1-}$, or NLRC4 ${ }^{-1-}$ mice received an intraplantar injection of carrageenan (Cg: $100 \mu \mathrm{g} / \mathrm{paw}$ ) or saline. At 5 hours after Cg injection, plantar tissue samples were collected, and the levels of the $(A)$ mature $(\sim 17 \mathrm{kDa})$ and immature forms $(\sim 35 \mathrm{kDa})$ of $l \mathrm{~L}-1 \beta$ and the $(B)$ mature $(\sim 20 \mathrm{kDa})$ and immature forms $(\sim 45$ $\mathrm{kDa}$ ) of caspase- 1 were determined using Western blot analyses. Representative blot and relative quantification. Beta-actin levels were used as an internal control. Samples from casp $1 / 11^{-1-}$ mice were also used as a negative control. Supernatant samples from LPS plus nigericin-stimulated macrophages were used as a positive control of mature caspase- $1\left(C^{+}\right)$. Data are expressed as mean \pm SEM, 5 mice per group. \#Indicates statistical significance $(P<0.05)$ compared with the group injected with saline. "Indicates statistical significance $(P<0.05)$ compared with the WT group injected with $\mathrm{Cg}$. One-way analysis of variance followed by the Bonferroni test.

Copyright @ 2015 by the International Association for the Study of Pain. Unauthorized reproduction of this article is prohibited. 

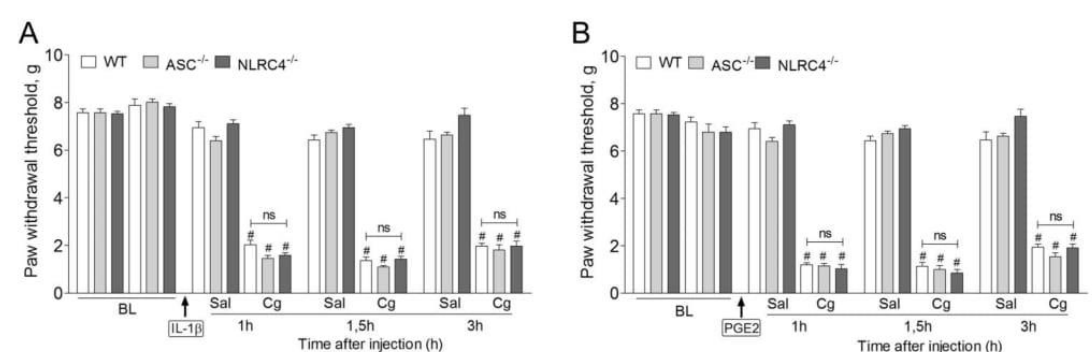

Figure 6. IL-1 $\beta$ and PGE2 induced mechanical hyperalgesia in $\mathrm{NLRC4}^{-/-}$and $\mathrm{ASC}^{-/-}$mice similar to wild-type (WT) mice. Mechanical nociceptive threshold was measured before (BL) and after (1, 1.5, and 3 hours) intraplantar injection of (A) IL-1 3 (1 ng/paw). (B) PGE2 (100 ng/paw) or vehicle (Sal-saline) in WT, NLRC4 ${ }^{-/-}$, or $\mathrm{ASC}^{-1-}$ mice. Data are expressed as mean \pm SEM, 5 mice per group. \#Indicates statistical significance $(P<0.05)$ compared with the saline paw injected group. No statistical significance $(P<0.05)$ was identified between WT, ASC ${ }^{-1-}$, and NLRC4 $4^{-/-}$mice groups that received Cg. Two-way analysis of variance followed by No statistical signic
Bonferroni test.

cysteine protease, caspase-1, prompted the development of caspase-1-targeting therapies. ${ }^{16,24,35}$ We have shown that peripheral caspase- 1 activation mediates acute inflammatory pain through the maturation of $\mathrm{IL}-1 \beta .^{14}$ This conclusion was based on data obtained with caspase-1 null mice. However, subsequent studies have shown that these mice also have the caspase-11 gene removed. ${ }^{29,54}$ Nevertheless, the present results confirmed that acute inflammatory hyperalgesia is controlled specifically by caspase- 1 but not caspase- 11 because Casp $1 / 11^{-1-}$ and Casp $1^{-1-} / \mathrm{Tg}$ Casp11 mice exhibited similar reductions in carrageenan-induced acute inflammatory hyperalgesia. Moreover, single Casp $11^{-1-}$ mice developed similar inflammatory hyperalgesia when compared with WT mice. Corroborating these findings is the fact that a selective inhibitor of caspase-1 also reduced acute inflammatory hyperalgesia in our previous study. ${ }^{14}$ These results strongly support the peripheral participation of caspase-1 in the mediation of carrageenan-induced acute inflammatory hyperalgesia.

Knowledge of the mechanisms related to caspase- 1 activation and the maturation of $\mathrm{IL}-1 \beta$ has increased in the last years. Currently, it is described that caspase- 1 activation and IL-1 $\beta$ processing require the assembling of inflammasome platforms, which subsequently promotes caspase- 1 activation. ${ }^{51}$ The NLRP3 inflammasome is the best characterized inflammasome that has been most implicated as a sensor of sterile injury. ${ }^{51,6}$ NLRP3 is proposed as the sensor of a wide range of structurally diverse DAMPs. ${ }^{49}$ For example, both monosodium urate and calcium pyrophosphate crystals, which are inflammatory drivers of gout and pseudogout, activate NLRP3 inflammasome. ${ }^{41}$ These crystals are also suggested to be a general inflammatory signal that is released from dead and dying cells. ${ }^{17}$ Based on these data, NLRP3 was suggested to play an important role in carrageenan-induced acute inflammatory hyperalgesia. Surprisingly, $\mathrm{NLRP}^{-1-}$ mice present similar acute inflammatory hyperalgesia as WT mice. The behaviora data were further supported by the similar expression of mature caspase- 1 and IL-1 $\beta$ in samples from NLRP3 ${ }^{-1-}$ and WT mice.

In contrast, the peripheral NLRC4 inflammasome assembly was implicated in the genesis of carrageenan-induced acute mechanical and thermal inflammatory hyperalgesia. Peripheral NLRC4 inflammasomes seem to mediate this process through the activation of caspase- 1 and the maturation of IL-1 $\beta$. In fact, the mature forms of caspase- 1 and IL-1 $\beta$ did not increase in the inflamed NLRC4 ${ }^{-1-}$ and $\mathrm{ASC}^{-/-}$mice paws compared with WT mice, but the production of pro-IL-1 $\beta$ was not changed. The production of TNF- $\alpha$ and $C X C L 1 / K C$ chemokine and the recruitment of neutrophils were similar in NLRC4 ${ }^{-/-}$and $\mathrm{ASC}^{-/-}$ mice during acute inflammation, which confirmed IL-1 $\beta$ maturation as the mechanism by which the NLRC4 inflammasome participated in carrageenan-induced inflammatory pain. Remarkably, the release of TNF- $\alpha$ and CXCL1/KC is an upstream event related to $\mathrm{IL}-1 \beta$ production in the cascade of cytokines that mediate carrageenan-induced inflammatory pain in mice. ${ }^{10}$ Furthermore, TNF- $\alpha$ and $\mathrm{CXCL} 1 / \mathrm{KC}$ chemokines mediate acute inflammatory pain because they are involved in the recruitment of neutrophils to the inflammatory site, but $\mathrm{LL}-1 \beta$ seems to act on recruited neutrophils to promote their activation and to stimulate the production of prostaglandins. ${ }^{10,13,14}$ These data are consistent with a recent finding showing that caspase- 1 does not control the release of TNF- $\alpha$ and $C X C L 1 / K C$ and neutrophil migration to the inflammatory site. ${ }^{14}$ Finally, NLRC4 $4^{-1-}$ and $\mathrm{ASC}^{-1-}$ mice developed similar intensities of hyperalgesia triggered by $\mathrm{IL}-1 \beta$ and PGE2 as WT mice, which indicated that the NLRC4 inflammasome is the upstream of these mediators and that $\mathrm{NLRC}^{-1-}$ and $\mathrm{ASC}^{-1-}$ mice did not have intrinsic problems with presenting inflammatory hyperalgesia. The importance of peripheral caspase- 1 activation was also identified in a rat fracture model of complex regional pain syndrome. ${ }^{36}$ However, caspase-1 action is triggered by NLRP1 in this model, ${ }^{36}$ which suggests differences in the activated inflammasome depending on the stimuli that trigger pain.

Important questions emerging from our results are the mechanisms involved in the peripheral activation of the NLRC4 inflammasome and in which cell type this activation occurs. Classically, NLRC4 is an important cytosolic member of the NLR family, which is an indirect sensor of bacterial flagellin and bacterial type III secretion systems, and responds by assembling an inflammasome complex that promotes caspase- 1 activation and interacts with ASC. ${ }^{39,57}$ The activation of NLRC4 by bacterial products seems to be dependent on apoptosis inhibitory proteins (NAIPs), which engage NLRC4 after interacting directly with flagellin or T3SS components, such as PrgJ. ${ }^{30,57}$ In certain cases, NLRC4 activation requires Naip5 because Naip5 ${ }^{-1-}$ mice fail to activate NLRC4 or caspase-1 in response to infection with Legionella pneumophila or the C-terminus of flagellin. ${ }^{37,38}$ Nevertheless, acute inflammatory hyperalgesia developed similar to $\mathrm{C} 57 \mathrm{BL} / 6$ mice in $\mathrm{A} / \mathrm{J}$ mice, which have a defective Naip5 signaling (data not shown). Therefore, it is plausible that NLRC4 might be activated by endogenous stimuli because our experimental model did not include infectious stimuli.

One alternative explanation for NLRC4 activation in the present experimental model could be that extracellular stimuli might trigger intracellular signaling pathways that culminate with NLRC4 activation. Data in the literature showed that NLRC4 is

Copyright (c) 2015 by the International Association for the Study of Pain. Unauthorized reproduction of this article is prohibited. 
activated by phosphorylation at the Ser533 residue. ${ }^{45}$ Furthermore, screening with kinase inhibitors identified $\mathrm{PKC} \delta$ as a candidate for NLRC4 phosphorylation. ${ }^{45}$ Therefore, it is plausible that extracellular signaling through $\mathrm{PKC} \delta$ could be involved in the activation of NLRC4 that accounts for acute inflammatory pain.

Regarding the resident paw cells responsible for carrageenaninduced $\mathrm{LL}-1 \beta$ production and maturation, there is evidence showing that in mice paws, keratinocytes are the main source of caspase- $1 .{ }^{36}$ Thus, they could be involved in carrageenan-induced IL-1 $\beta$ production and inflammatory hyperalgesia. Nevertheless, these processes could be mediated by more than 1 cell type. For instance, there are data showing that inflammasome complex can be secreted and process IL-1 $\beta$ in the extracellular space. ${ }^{2,20}$ Thus, we could not discard the possibility that, in carrageenan-induced paw inflammation, inflammasome components can be produced by 1 cell type and pro-IL-1 $\beta$ by another one.

Although the present results suggest that the peripheral NLRC4 assembly is important for the induction of carrageenaninduced inflammatory pain, we cannot exclude the possibility that central NLRC4 might play a role. Indeed, inflammatory pain is mediated by the production of IL-1 $\beta$ at the level of the dorsal root ganglion and spinal cord. ${ }^{34,47,48}$ In addition, functional NLRC4 inflammasome has been shown in microglia of the central nervous system. ${ }^{26}$ Therefore, further studies are necessary to elucidate whether central inflammasomes also play a role in the genesis of inflammatory pain.

Although the present findings might be specific for carrageenaninduced inflammatory hyperalgesia, they are important because IL-1 $\beta$ processing could be mediated in an inflammasomeindependent way including metalloproteases, elastases, and proteinases. ${ }^{50,21,22,28}$ Furthermore, there are data showing that mutations in inflammasomes components (including NLRC4) might trigger autoinflammatory diseases in which pain is an important symptom. ${ }^{5,46,1,23}$ In addition, carrageenan is one of the most well-described models of inflammatory pain and a model that is often used for the development of novel analgesic and antiinflammatory drugs. Therefore, knowledge of the pathophysiologic mechanisms of this model potentionally could be quite helpful in the development of novel analgesic drugs.

In summary, this study provides novel evidence that the peripheral assembly of the NLRC4/ASC inflammasome, but not NLRP3, participates in the genesis of carrageenan-induced acute inflammatory hyperalgesia. Furthermore, the NLRC4/ASC inflammasome mediates this process through the activation of caspase-1 and the maturation of $\mathrm{IL}-1 \beta$, but it is not involved in the production of proinflammatory cytokines (TNF- $\alpha, \quad$ CXCL $1 / K C$ ) or in the recruitment of neutrophils. These results add new information about the physiopathologic mechanisms of inflammatory pain. Finally, from a prospective point of view, this study suggests that inhibition of NLRC4 assembly or caspase-1 might be effective in the control of acute inflammatory hyperalgesia without affecting other protective mechanisms of inflammation such as the production of proinflammatory cytokines and neutrophil migration.

\section{Conflict of interest statement}

The authors have no conflicts of interest to declare.

\section{Acknowledgements}

The research leading to these results received funding from the European Union Seventh Framework Programme (FP7-2007-2013) under Grant Agreement No. HEALTH-F4-2011-281608 (TIMER), the São Paulo Research Foundation (FAPESP) under Grant Agreement Nos. 2011/19670-0 (Thematic Project) and 2013/ 08216-2 (Center for Research in Inflammatory Disease), from the University of São Paulo NAP-DIN under Grant Agreement No. 11.1.21625.01.0 and a CNPq Grant no. 477242/2012-0.

\section{Article history:}

Received 17 June 2014

Received in revised form 3 December 2014

Accepted 3 December 2014

Available online 13 January 2015

\section{References}

[1] Agostini L, Martinon F, Burns K, McDermott MF, Hawkins PN, Tschopp J. NALP3 forms an IL-1beta-processing inflammasome with increased activity in Muckle-Wells autoinflammatory disorder. Immunity 2004;20: 319-25.

[2] Baroja-Mazo A, Martín-Sánchez F, Gomez Al, Martínez CM, AmoresIniesta J, Compan V, Barberà-Cremades M, Yagüe J, Ruiz-Ortiz E, Antón J, Buján S, Couillin I, Brough D, Arostegui JI, Pelegrín P. The NLRP3 inflammasome is released as a particulate danger signal that amplifies the inflammatory response. Nat Immunol 2014;15:738-48.

[3] Binshtok AM, Wang H, Zimmermann K, Amaya F, Vardeh D, Shi L, Brenner GJ, Ji RR, Bean BP, Woolf CJ, Samad TA. Nociceptors are interleukin-1 $\beta$ sensors. J Neurosci 2008;28:14062-73.

[4] Broz P, Monack DM. Molecular mechanisms of inflammasome activation during microbial infections. Immunol Rev 2011;243:174-90.

[5] Canna SW, de Jesus AA, Gouni S, Brooks SR, Marrero B, Liu Y, DiMattia MA, Zaal KJ, Sanchez GA, Kim H, Chapelle D, Plass N, Huang Y, Villarino AV, Biancotto A, Fleisher TA, Duncan JA, O'Shea JJ, Benseler S, Grom A, Deng Z, Laxer RM, Goldbach-Mansky R. An activating NLRC4 inflammasome mutation causes autoinflammation with recurrent macrophage activation syndrome. Nat Genet 2014;46:1140-6.

[6] Cassel SL, Sutterwala FS. Sterile inflammatory responses mediated by the NLRP3 inflammasome. Eur J Immunol 2010;40:607-11.

[7] Cerretti DP, Kozlosky CJ, Mosley B, Nelson N, Van Ness K, Greenstreet TA, March C J, Kronheim SR, Druck T, Cannizzaro LA. Molecular cloning of the interleukin-1 $\beta$ converting enzyme. Science 1992;256:97-100.

[8] Cunha JM, Cunha FQ, Poole S, Ferreira SH. Cytokine-mediated inflammatory hyperalgesia limited by interleukin-1 receptor antagonist. Br J Pharmacol 2000;130:1418-24.

[9] Cunha TM, Verri WA Jr, Vivancos GG, Moreira IF, Reis S, Parada CA, Cunha FQ, Ferreira SH. An electronic pressure-meter nociception paw test for mice. Braz J Med Biol Res 2004;37:401-7.

[10] Cunha TM, Verri WA Jr, Silva JS, Poole S, Cunha FQ, Ferreira SH. A cascade of cytokines mediates mechanical inflammatory hypernociception in mice. Proc Natl Acad Sci U S A 2005;102:1755-60.

[11] Cunha TM, Barsante MM, Guerrero AT, Verri WA Jr, Ferreira SH, Coelho FM, Bertini R, Di Giacinto C, Allegretti M, Cunha FQ, Teixeira M. Treatment with DF 2162, a non-competitive allosteric inhibitor of CXCR1/2, diminishes neutrophil influx and inflammatory hypernociception in mice. Br J Pharmacol 2008:154:460-70.

[12] Cunha TM, Dal-secco D, Verri WA Jr, Guerrero AT, Souza GR, Vieira SM, Lotufo CM, Neto AF, Ferreira SH, Cunha FQ. Dual role of hydrogen sulfide in mechanical inflammatory hypernociception. Eur J Pharmacol 2008; 590:127-35.

[13] Cunha TM, Verri WA Jr, Schivo IR, Napimoga MH, Parada CA, Poole S, Teixeira MM, Ferreira SH, Cunha FQ. Crucial role of neutrophils in the development of mechanical inflammatory hypernociception. J Leukoc Biol 2008;83:824-32.

[14] Cunha TM, Talbot J, Pinto LG, Vieira SM, Souza GR, Guerrero AT, Sonego F, Verri WA Jr, Zamboni DS, Ferreira SH, Cunha FQ. Caspase-1 is involved in the genesis of inflammatory hypernociception by contributing to peripheral IL-1beta maturation. Mol Pain 2010;6:63.

[15] Davis BK, Wen H, Ting JP. The inflammasome NLRs in immunity, inflammation, and associated diseases. Annu Rev Immunol 2011;29: 707-35

[16] Dinarello C A. The biological properties of interleukin-1. Eur Cytokine Netw 1994:5:517-31.

[17] Duewell P, Kono H, Rayner KJ, Sirois CM, Vladimer G, Bauernfeind FG, Abela GS, Franchi L, Nunez G, Schnurr M, EspevikT, Lien E, Fitzgerald KA, Rock KL, Moore KJ, Wright SD, Hornung V, Latz E. NLRP3 inflammasomes are required for atherogenesis and activated by cholesterol crystals. Nature 2010;464:1357-61.

Copyright (ㄷ) 2015 by the International Association for the Study of Pain. Unauthorized reproduction of this article is prohibited. 
[18] Ferreira SH. Peripheral analgesia: mechanism of the analgesic action of aspirin like drugs and opiate-antagonists. Br J Clin Pharmacol 1980;10 (suppl 2):237S-44S.

[19] Ferreira SH, Lorenzetti BB, Bristow AF, Poole S. Interleukin-1 beta as a potent hyperalgesic agent antagonized by a tripeptide analogue. Nature 1988;334:698-700.

[20] Franklin BS, Bossaller L, De Nardo D, Ratter JM, Stutz A, Engels G, Brenker C, Nordhoff M, Mirandola SR, Al-Amoudi A, Mangan MS, Zimmer S, Monks BG, Fricke M, Schmidt RE, Espevik T, Jones B, Jarnicki AG, Hansbro PM, Busto P, Marshak-Rothstein A, Hornemann S, Aguzzi A Kastenmüller W, LatzE. The adaptor ASC has extracellular and 'prionoid' activities that propagate inflammation. Nat Immunol 2014;15:727-37.

[21] Goldbach-Mansky R. Blocking interleukin-1 in rheumatic diseases. Ann N Y Acad Sci 2009:1182:111-23

[22] Guma M, Ronacher L, Liu-Bryan R, Takai S, Karin M, Corr M. Caspase 1independent activation of interleukin-1beta in neutrophil-predominan inflammation. Arthritis Rheum 2009;60:3642-50.

[23] Greten FR, Arkan MC, Bollrath J, Hsu LC, Goode J, Miething C, Göktuna SI Neuenhahn M, Fierer J, Paxian S, Van Rooijen N, Xu Y, O'Cain T, Jaffee BB Busch DH, Duyster J, Schmid RM, Eckmann L, Karin M. NF-kappaB is a negative regulator of $\mathrm{IL}-1$ beta secretion as revealed by genetic and pharmacological inhibition of IKKbeta. Cell 2007;130:918-31.

[24] Loppnow H, Guzik K, Pryjma J. The role of caspases in modulation of cytokines and other molecules in apoptosis and inflammation. Landes Biosci 2000;20.

[25] Hargreaves K, Dubner R, Brown F, Flores C, Joris J. A new and sensitive method for measuring thermal nociception in cutaneous hyperalgesia. PAIN 1988:1:77-88.

[26] Jamilloux Y, Pierini R, Querenet M, Juruj C, Fauchais AL, Jauberteau MO, Jarraud S, Lina G, Etienne J, Roy CR, Henry T, Davoust N, Ader F. Inflammasome activation restricts Legionella pneumophila replication in primary microglial cells through flagellin detection. Glia 2013:61:539-49.

[27] Jin XC, Gereau RW. Acute p38-mediated modulation of tetrodotoxinresistant sodium channels in mouse sensory neurons by tumor necrosis factor-alpha. J Neurosci 2006;26:246-55.

[28] Kawasaki Y, Xu ZZ, Wang X, Park JY, Zhuang ZY, Tan PH, Gao YJ, Roy K, Corfas G, Lo EH, Ji RR. Distinct roles of matrix metalloproteases in the early- and late-phase development of neuropathic pain. Nat Med 2008; 14:331-6.

[29] Kayagaki N, Warming S, Lamkanfi M, Vande Walle L, Louie S, Dong J, Newton K, Qu Y, Liu J, Heldens S, Zhang J, Lee W P, Roose-Girma M, Dixit $\mathrm{V}$ M. Non-canonical inflammasome activation targets caspase-11. Nature 2011;479:117-21.

[30] Kofoed EM, Vance RE. Innate immune recognition of bacterial ligands by NAIPs determines inflammasome specificity, Nature 2011:477:592-5.

[31] Kuida K, Lippke JA, Ku G, Harding MW, Livingston DJ, Su MS, Flavell RA Altered cytokine export and apoptosis in mice deficient in interleukinbeta converting enzyme. Science 1995;267:2000-3.

[32] Khasar SG, McCarter G, Levine JD. Epinephrine produces a betaadrenergic receptor-mediated mechanical hyperalgesia and in vitro sensitization of rat nociceptors. J Neurophysiol 1999;81:1104-12

[33] Lara-Tejero M, Sutterwala FS, Ogura Y, Grant EP, Bertin J, Coyle AJ, Flavell RA, Gala JE. Role of the caspase-1 inflammasome in Salmonella typhimurium pathogenesis. J Exp Med 2006;203:1407-12.

[34] Lee KM, Kang BS, Lee HL, Son SJ, Hwang SH, Kim DS, Park JS, Cho HJ. Spinal NF-kB activation induces COX-2 upregulation and contributes to inflammatory pain hypersensitivity. Eur J Neurosci 2004:19:3375-81.

[35] Li P, Allen H, Banerjee S, Franklin S, Herzog L, Johnston C, McDowell J, Paskind M, Rodman L, Salfeld J. Mice deficient in IL-1 beta-converting enzyme are defective in production of mature $\mathrm{IL}-1$ beta and resistant to endotoxic shock. Cell 1995;80:401-11.

[36] Li WW, Guo TZ, Liang D, Shi X, Wei T, Kingery WS, Clark JD. The NALP1 inflammasome controls cytokine production and nociception in a rat fracture model of complex regional pain syndrome. PAIN 2009;147: 277-86.

[37] Lightfield KL, Persson J, Brubaker SW, Witte CE, von Moltke J, Dunipace EA Henry T, Sun YH, Cado D, Dietrich WF, Monack DM, Tsolis RM, Vance RE. Critical function for Naip5 in inflammasome activation by a conserved carboxy-terminal domain of flagellin. Nat Immunol 2008 9:1171-8.

[38] Lightfield KL, Persson J, Trinidad NJ, Brubaker SW, Kofoed EM, Sauer JD, Dunipace EA, Warren SE, Miao EA, Vance RE. Differential requirements for NAIP5 in activation of the NLRC4 inflammasome. Infect Immun 2011; for NAIP5 in activ 14.

[39] Mariathasan S, Newton K, Monack DM, Vucic D, French DM, Lee WP Roose-Girma M, Erickson S, Dixit VM. Differential activation of the inflammasome by caspase-1 adaptors ASC and Ipaf. Nature 2004;430: 213-18.

[40] Mariathasan S, Weiss DS, Newton K, McBride J, O'Rourke K, RooseGirma M, Lee WP, Weinrauch Y, Monack DM, Dixit VM. Cryopyrin activates the inflammasome in response to toxins and ATP. Nature 2006; 440:228-32.

[41] Martinon F, Petrilli V, Mayor A, Tardivel A, Tschopp J. Gout-associated uric acid crystals activate the NALP3 inflammasome. Nature 2006;440: $237-41$.

[42] Martinon F, Mayor A, Tschopp J. The inflammasomes: guardians of the body. Annu Rev Immunol 2009;27:229-65.

[43] Millan MJ. The induction of pain: an integrative review. Prog Neurobio 1999;57:1-164.

[44] Pelegrin P. Surprenant A. Pannexin-1 couples to maitotoxin- and nigericin-induced interleukin-1 beta release through a dye uptakeindependent pathway. J Biol Chem 2007;282:2386-94.

[45] QuY, Misaghi S, Izrael-Tomasevic A, Newton K, Gilmour LL, Lamkanfi M, Louie S, Kayagaki N, Liu J, Komuves L, Cupp JE, Arnott D, Monack D, Dixit VM. Phosphorylation of NLRC4 is critical for inflammasome activation. Nature 2012;490:539-42.

[46] Romberg N, Al Moussawi K, Nelson-Williams C, Stiegler AL, Loring E, Choi M, Overton J, Meffre E, Khokha MK, Huttner AJ, West B, Podoltsev NA Boggon TJ, Kazmierczak BI, Lifton RP. Mutation of NLRC4 causes a syndrome of enterocolitis and autoinflammation. Nat Genet 2014;46: 1135-9.

[47] Samad TA, Moore KA, Sapirstein A, Billet S, Allchorne A, Poole S, Bonventre JV, Woolf CJ. Interleukin-1beta-mediated induction of Cox-2 in the CNS contributes to inflammatory pain hypersensitivity. Nature 2001; $410: 471-5$

[48] Souza GR, Talbot J, Lotufo CM, Cunha FQ, Cunha TM, Ferreira SH. Fractalkine mediates inflammatory pain through activation of satellite glial cells. Proc Natl Acad Sci U S A 2013;110:11193-8.

[49] Sutterwala FS, Ogura Y, Szczepanik M, Lara-Tejero M, Lichtenberger GS, Grant EP, Bertin J, Coyle AJ, Galan JE, Askenase PW, Flavell RA. Critica role for NALP3/CIAS1/Cryopyrin in innate and adaptive immunity through its regulation of caspase-1. Immunity 2006:24:317-27.

[50] SchönbeckU, Mach F, LibbyP. Generation of biologically active IL-1 beta by matrix metalloproteinases: a novel caspase-1-independent pathway of IL-1 beta processing. J Immunol 1998;161:3340-6.

[51] Schroder K, Tschopp J. The inflammasomes. Cell 2010;140:821-32.

[52] Valerio DA, Cunha TM, Arakawa NS, Lemos HP, Da Costa FB, Parada CA Ferreira SH, Cunha FQ, Verri WA Jr. Anti-inflammatory and analgesic effects of the sesquiterpene lactone budlein $A$ in mice: inhibition of cytokine production-dependent mechanism. Eur J Pharmacol 2007;562: 155-63.

[53] Verri WA Jr, Cunha TM, Parada CA, Poole JS, Cunha FQ, Ferreira SH Hypernociceptive role of cytokines and chemokines: targets for analgesic drug development? Pharmacol Ther 2006:112:116-38.

[54] Vigano E, Mortellaro A. Caspase-11: the driving factor for noncanonical inflammasomes. Eur J Immunol 2013;43:2240-5.

[55] Wang J, Lenardo MJ. Roles of caspases in apoptosis, development, and cytokine maturation revealed by homozygous gene deficiencies. $J$ Cel Sci 2000 Mar; 113:753-7.

[56] Wang J, Strong J, Xie W, Yang R, Dennis E, Dayna M, Ericka DD, Zhang JM. The chemokine CXCL1/growth related oncogene increases sodium currents and neuronal excitability in small diameter sensory neurons. Mol Pain 2008;4:38

[57] Zhao Y, Yang J, Shi J, Gong YN, Lu Q, Xu H, Liu L, Shao F. The NLRC4 inflammasome receptors for bacterial flagellin and type III secretion apparatus. Nature 2011;477:596-600.

Copyright (c) $\mathbf{2 0 1 5}$ by the International Association for the Study of Pain. Unauthorized reproduction of this article is prohibited. 